

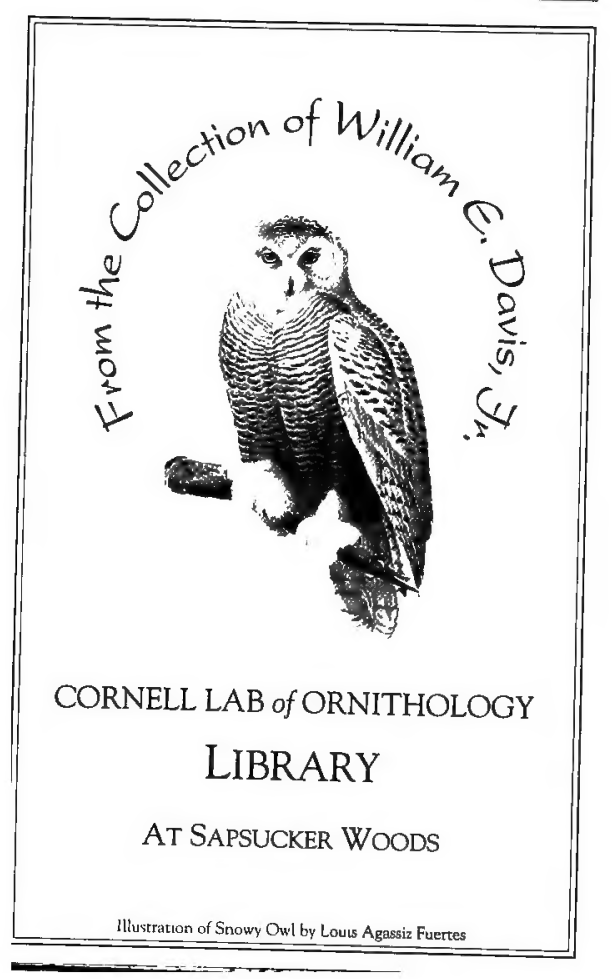




\section{DATE DUE}

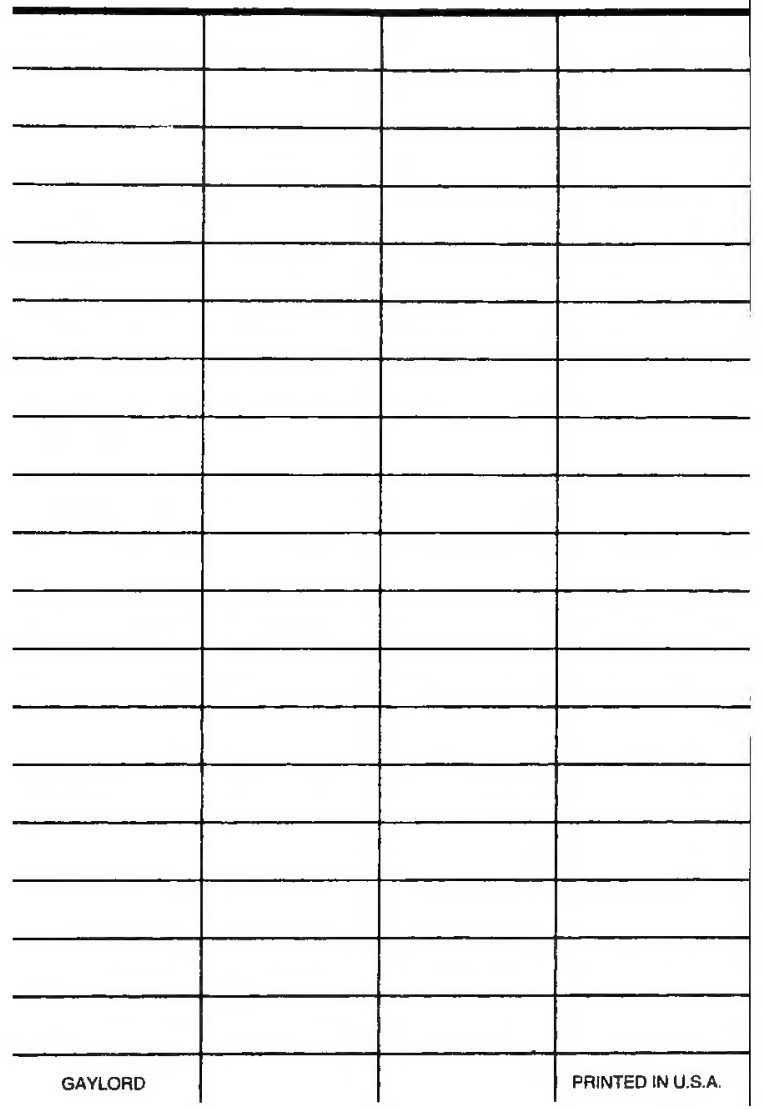




\section{Cornell University Library}

The original of this book is in the Cornell University Library.

There are no known copyright restrictions in the United States on the use of the text. 
CORNELL UNIVERSITY LIBAARY

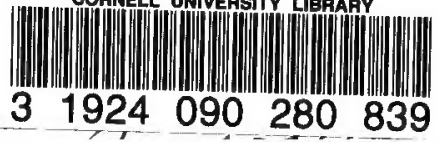






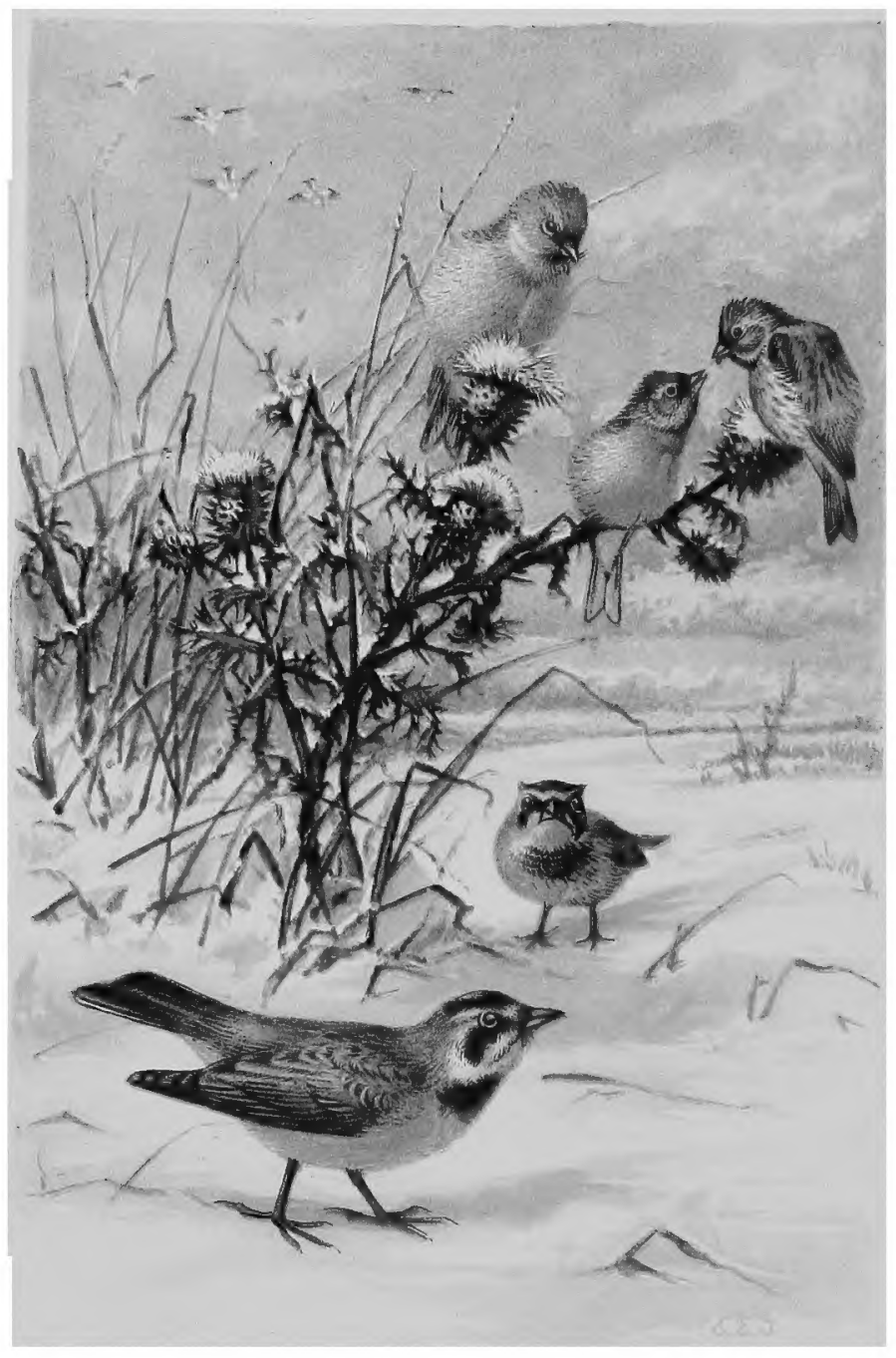






\title{
POPULAR HANDBOOK
}

OF THE

\section{ORNITHOLOGY}

OF THE

\section{UNITED STATES AND CANADA,}

Błasen on Nuttall's ftamual,

By MONTAGUE CHAMBERLAIN.

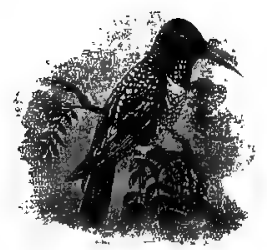

\section{STONY BROOK LIBRARY}

\author{
VOL. I.
}

THE LAND BIRDS.

BOSTON :

- LITTLE, BROWN, AND COMPANY.

I 89 . 


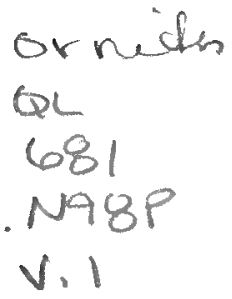

Copyright, 1891, By Little, Brown, and Company.

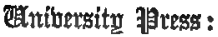

John Wilson and Son, Cambridge. 


\section{PREFACE.}

HIS work is practically an edition of "A Manual
of the Ornithology of the United States and of Canada," written by ThOMAS NUTTALL, though only as much of the original title has been retained as seemed consistent with the changed character of the text.

Nuttall's work has been out of print for several years; but its popularity and real value have kept it in demand, and the few copies recently offered for sale were disposed of at high prices. A new edition was thus called for; but it seemed unwise to issue the work in its original form, or to remodel it to the extent that would be required to arrange it in harmony with the new régime of affairs ornithological; for the science has advanced rapidly since the "Manual" was written, and the changes effected have been numerous and important. A new and entirely different system of classification has come in vogue; the nomenclature has been altered and trinomials introduced; and, indeed, little is left of American ornithology as Nuttall knew it, except the birds, - and even of these, two species have become extinct, and a large number of new forms have been discovered.

Thomas Nuttall came to this country from England in 1808 , and between 1825 and 1834 held the positions 
of Curator of the Botanic Garden and Lecturer on Natural History at Harvard University. In 1842 he returned to England, where he resided until his death in 1859 , at the age of seventy-three.

The first volume of the "Manual," containing an account of the Land Birds, was published in 1832 , and a second edition, with some additional matter, appeared in 1840 . The second volume, of which one edition only was issued, came out in 1834 .

The "Manual" was the first hand-book of the subject that had been published, and its delightful sketches of bird-life and its fragrance of the field and forest carried it into immediate favor. But Nuttall was more than a mere lover of Nature, he had considerable scientific attainment; and though he appears to have enjoyed the study of bird-life more than he did the musty side of ornithology, with its dried skins and drier technicalities, he had an eye trained for careful observation and a student's respect for exact statement. It was this rare combination that gave to Nuttall's work its real value; and these chapters of his are still valuable, - much too valuable to be lost; for if a great advance has been made in the study of scientific ornithology, - which term represents only the science of bird-skins, the names by which they are labelled, and the sequence of these names, in other words, the classification of birds, - if this science has advanced far beyond Nuttall's work, the study of bird-life, the real history of our birds, remains just about where Nuttall and his contemporaries left it. The present generation of working ornithologists have been too busy in hunting up new species and in variety-making 
to study the habits of birds with equal care and diligence, and it is to Wilson and Audubon and Nuttall that we are chiefly indebted even at this day for what we know of bird-life. I must not, however, be understood as implying that no additions have been made to this branch of knowledge, nor as undervaluing the importance of recent observations. But the field is large; and in comparison with the work accomplished by the older writers, and with that which is still unknown, the recent acquisitions must be termed slight.

It was suggested to me that the new might be combined with the old, - that an interesting and useful book might be prepared by taking Nuttall's biographies and inserting brief notes relating the results of recent determinations in distribution and habits. That is what I have attempted in the present work. The Introduction has been given exactly as it appeared in Nuttall's second edition, and the text of the biographical matter has been changed but little. My notes follow each chapter in a smaller type, that they may be readily distinguished. I have also rewritten the descriptions of plumage, and have endeavored to phrase these in such well-known and untechnical terms that they may be understood by unskilled readers. To these I have added a description of the nest and eggs of each species. In short, an effort has been made to prepare a work that will be useful to young students, as well as entertaining to those who are merely interested in birds.

The new matter has been selected with special regard for the needs of these classes of readers, for I 
have had another motive in the preparation of this work besides that of preserving Nuttall's biographies. Some time ago I made a promise to several Canadian friends to prepare a book treating of Canadian birds that would be scientifically correct and at the same time "popular" in its style. So while writing these pages I have kept Canadian readers constantly in mind, and have given here an account of every species that has been found within the Dominion east of the Manitoba plains, together with their Canadian distribution.

The limits of a "hand-book" demanding the most rigid economy of space, when treating of so extensive a subject I have been compelled to omit those species which occur only to the westward of the Mississippi. valley, though I have endeavored to make mention of every bird that has occurred within this Eastern Faunal Province, from the Gulf of Mexico to the Arctic Ocean, and to give their distribution and breeding area so far as these are known. Nuttall knew very little about the Western birds, and therefore only a few short chapters of his have been lost through restricting the scope of the present work to Eastern forms.

The nomenclature adopted is that of the "CheckList" issued by the American Ornithologists' Union. The sequence of species is that arranged by Nuttall, with some few trifling alterations; and being radically different from that of recent authors, the student must be referred to other works for guidance in classification as well as for diagnoses of the higher groups. Coues' "Key to North American Birds" is a useful work, and contains matter not obtainable elsewhere, though the 
system of classification now generally used is more clearly stated in Ridgway's "Manual of North American Birds." But the most complete work at present obtainable, and one which every student should have at hand, is "The History of North American Birds," by Baird, Brewer, and Ridgway. With that work and the "A. O. U. Check-List" to guide him, the student will be equipped for thorough study.

It only remains for me to thank many friends who have aided me. To Mr. William Brewster and Mr. Charles F. Batchelder, the president and the treasurer of the Nuttall Ornithological Club, I am particularly indebted for kind advice and assistance. Nor must I forget to mention the name of my fellow-worker, Ernest E. Thompson, of Toronto. A large number of the illustrations are from drawings made especially for this work by Mr. Thompson.

M. C.

Harvard University, Cambridge, Mass.

September, 1891. 



\section{ON T E N TS.}

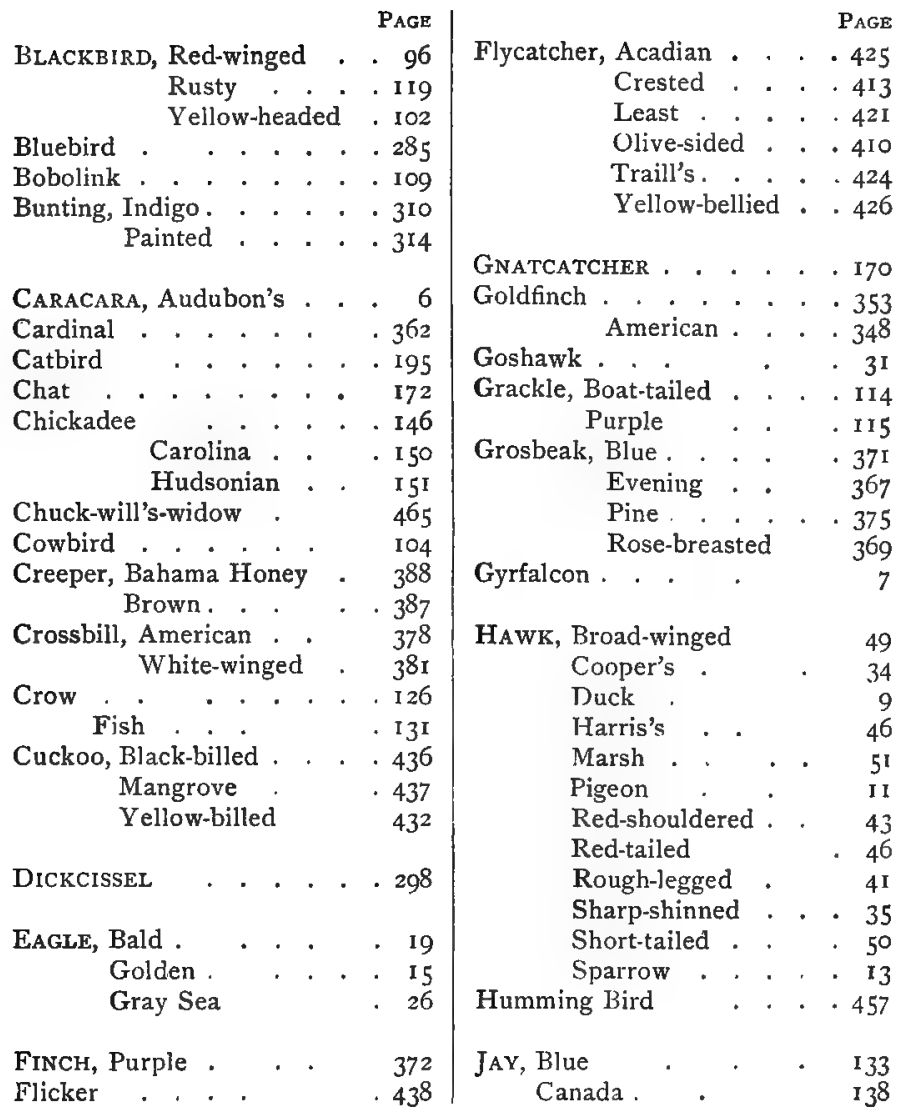




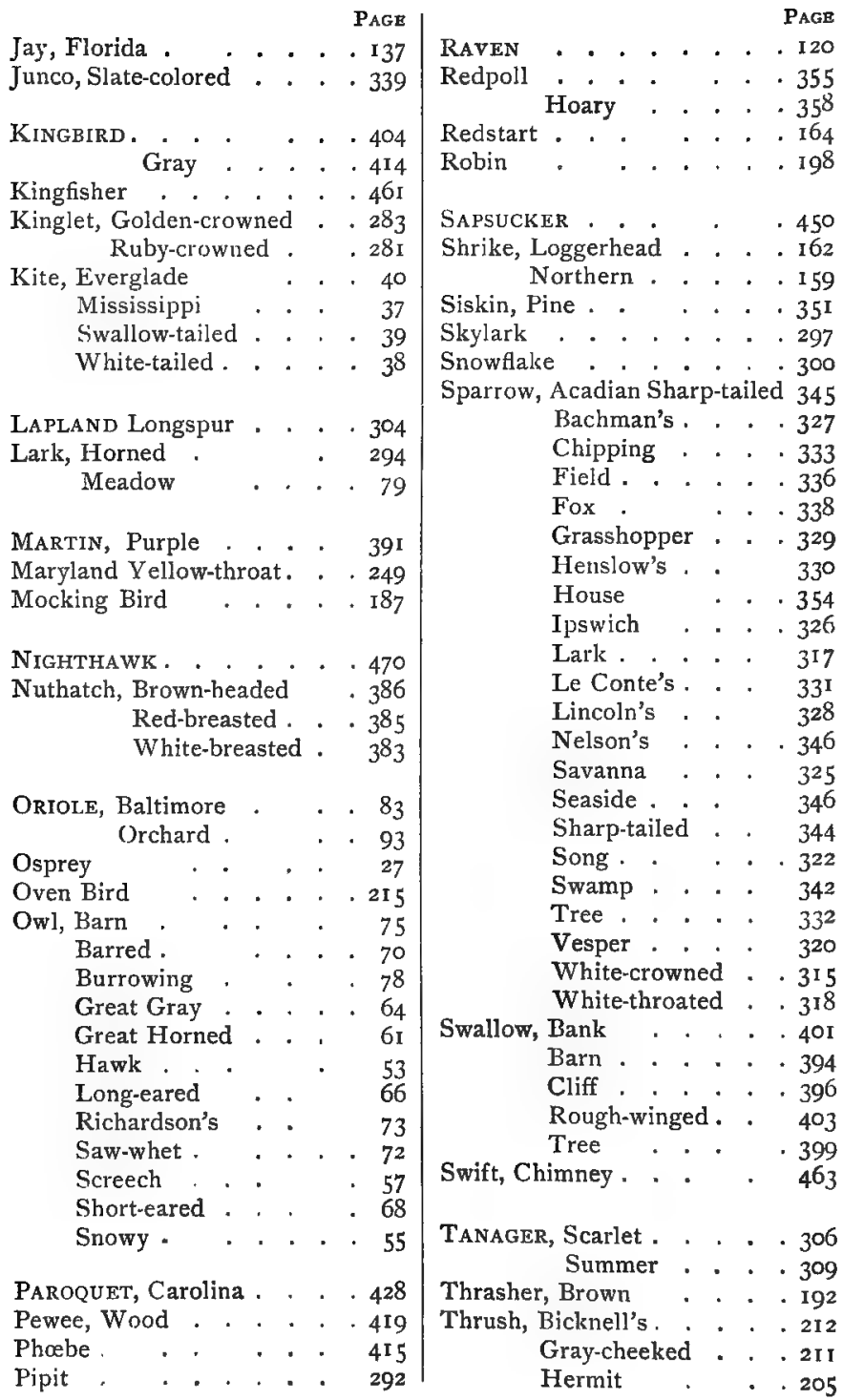




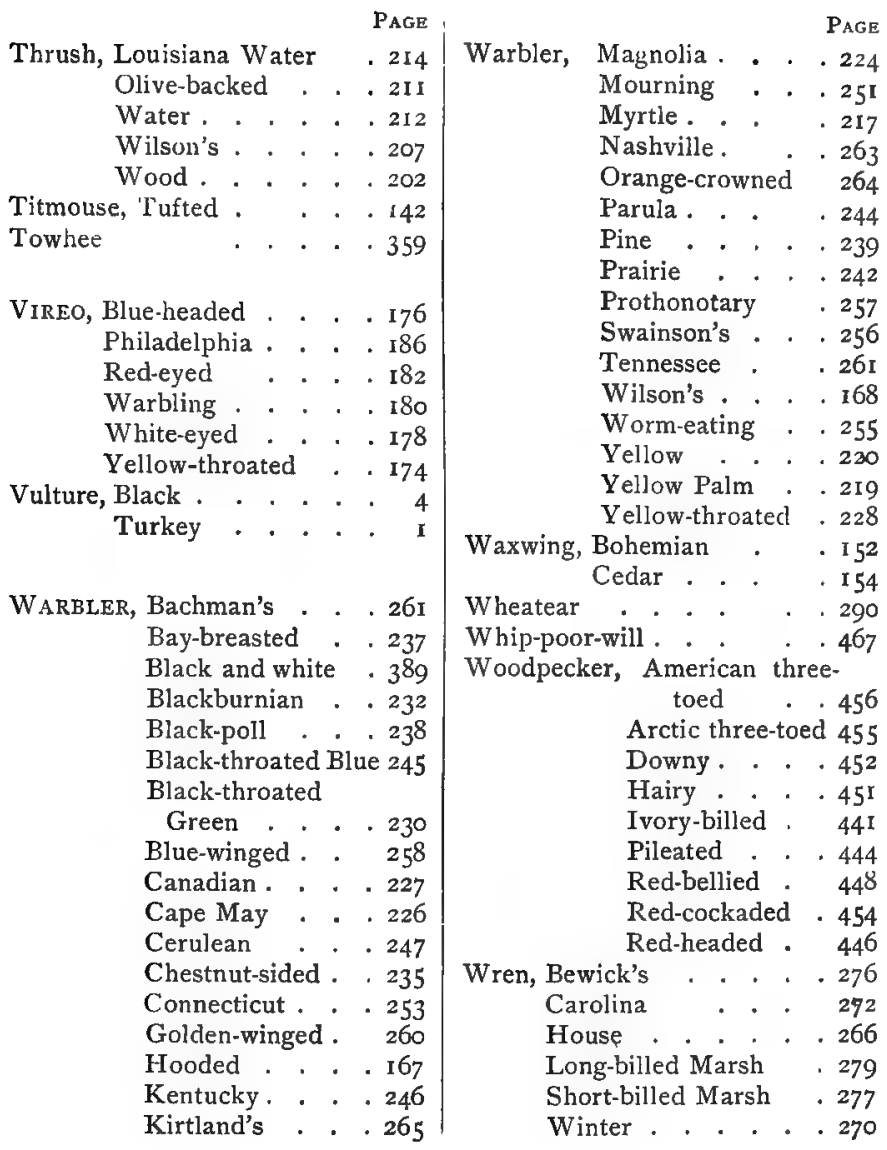





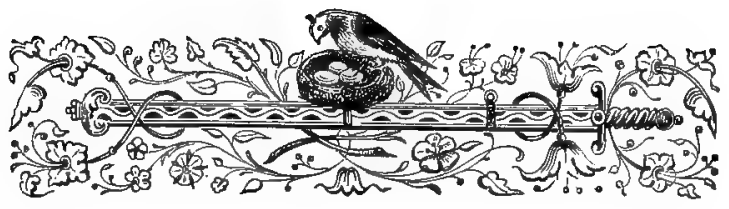

INTRODUCTION.

OF all the classes of animals by which we are surrounded in the ample field of Nature, there are none more remarkable in their appearance and habits than the feathered inhabitants of the air. They play around us like fairy spirits, elude approach in an element which defies our pursuit, soar out of sight in the yielding sky, journey over our heads in marshalled ranks, dart like meteors in the sunshine of summer, or, seeking the solitary recesses of the forest and the waters, they glide before us like beings of fancy. They diversify the still landscape with the most lively motion and beautiful association; they come and go with the change of the season; and as their actions are directed by an uncontrollable instinct of provident Nature, they may be considered as concomitant with the beauty of the surrounding scene. With what grateful sensations do we involuntarily hail the arrival of these faithful messengers of spring and summer, after the lapse of the dreary winter, which compelled them to forsake us for more favored climes. Their songs, now heard from the leafy groves and shadowy forests, inspire delight, or recollections of the pleasing past, in every breast. How volatile, how playfully capricious, how musical and happy, are these roving sylphs of Nature, to whom the air, the earth, and the waters are alike habitable! Their lives are spent in boundless action; and Nature, with an omniscient benevolence, has assisted and formed them for this wonderful display of perpetual life and vigor, in an element almost their own. 
If we draw a comparison between these inhabitants of the air and the earth, we shall perceive that, instead of the large head, formidable jaws armed with teeth, the capacious chest, wide shoulders, and muscular legs of the quadrupeds, they have bills, or pointed jaws destitute of teeth; a long and pliant neck, gently swelling shoulders, immovable vertebræ; the forearm attenuated to a point and clothed with feathers, forming the expansive wing, and thus fitted for a different species of motion; likewise the wide extended tail, to assist the general provision for buoyancy throughout the whole anatomical frame. For the same general purpose of lightness, exists the contrast of slender bony legs and feet. So that, in short, we perceive in the whole conformation of this interesting tribe, a structure wisely and curiously adapted for their destined motion through the air. Lightness and buoyancy appear in every part of the structure of birds : to this end nothing contributes more than the soft and delicate plumage with which they are so warmly clad; and though the wings (or great organs of aërial motion by which they swim, as it were, in the atmosphere) are formed of such light materials, yet the force with which they strike the air is so great as to impel their bodies with a rapidity unknown to the swiftest quadruped. The same grand intention of forming a class of animals to move in the ambient desert they occupy above the earth, is likewise visible in their internal structure. Their bones are light and thin, and all the muscles diminutive but those appropriated for moving the wings. The lungs are placed near to the back-bone and ribs; and the air is not, as in other animals, merely confined to the pulmonary organs, but passes through, and is then conveyed into a number of membranous cells on either side the external region of the heart, communicating with others situated beneath the chest. In some birds these cells are continued down the wings, extending even to the pinions, bones of the thighs, and other parts of the body, which can be distended with air at the pleasure or necessity of the animal. This diffusion of air is not only intended to assist in lightening and elevating the body, but also appears necessary to prevent the stoppage or 
interruption of respiration, which would otherwise follow the rapidity of their motion through the resisting atmosphere; and thus the Ostrich, though deprived of the power of flight, runs almost with the swiftness of the wind, and requires, as he possesses, the usual resources of air conferred on other birds. Were it possible for man to move with the rapidity of a Swallow, the resistance of the air, without some such peculiar provision as in birds, would quickly bring on suffocation. The superior vital heat of this class of beings is likewise probably due to this greater aëration of the vital fluid.

Birds, as well as quadrupeds, may be generally distinguished into two great classes from the food on which they are destined to subsist ; and may, consequently, be termed carnivorous and granivorous. Some also hold a middle nature, or partake of both. The granivorous and herbivorous birds are provided with larger and longer intestines than those of the carnivorous kinds. Their food, consisting chiefly of grain of various sorts, is conveyed whole into the craw or first stomach, where it is softened and acted upon by a peculiar glandular secretion thrown out upon its surface; it is then again conveyed into a second preparatory digestive organ; and finally transmitted into the true stomach, or gizzard, formed of two strong muscles connected externally with a tendinous substance, and lined internally with a thick membrane of great power and strength; and in this place the unmasticated food is at length completely triturated, and prepared for the operation of the gastric juice. The extraordinary powers of the gizzard in comminuting food, to prepare it for digestion, almost exceeds the bounds of credibility. Turkeys and common fowls have been made to swallow sharp angular fragments of glass, metallic tubes, and balls armed with needles, and even lancets, which were found broken and compressed, without producing any apparent pain or wounds in the stomach. The gravel pebbles swallowed by this class of birds with so much avidity, thus appear useful in bruising and comminuting the grain they feed on, and preparing it for the solvent action of the digestive organs.

Those birds which live chiefly on grain and vegetable subroL. I. $-b$ 
stances partake in a degree of the nature and disposition of herbivorous quadrupeds. In both, the food and the provision for its digestion are very similar. Alike distinguished for sedentary habits and gentleness of manners, their lives are harmlessly and usefully passed in collecting seeds and fruits, and ridding the earth of noxious and destructive insects; they live wholly on the defensive with all the feathered race, and are content to rear and defend their offspring from the attacks of their enemies. It is from this tractable and gentle race, as well as from the amphibious or aquatic tribes, that man has long succeeded in obtaining useful and domestic species, which, from their prolificacy and hardihood, afford a vast supply of wholesome and nutritious food. Of these, the Hen, originally from India; the Goose, Duck, and Pigeon of Europe; the Turkey of America ; and the Pintado, or Guineahen of Africa, are the principal: to which may also be added, as less useful, or more recently naturalized, the Peacock of India, the Pheasant of the same country, the Chinese and Canada Goose, the Muscovy Duck, and the European Swan.

Carnivorous birds by many striking traits evince the destiny for which they have been created; they are provided with wings of great length, supported by powerful muscles, which enable them to fly with energy and soar with ease at the loftiest elevations: They are armed with strong hooked bills and with the sharp and formidable claws of the tiger; they are also further distinguished by their large heads, short necks, strong muscular thighs in aid of their retractile talons, and a sight so piercing as to enable them, while soaring at the greatest height, to perceive their prey, upon which they sometimes descend, like an arrow, with undeviating aim. In these birds the stomach is smaller than in the granivorous kinds, and their intestines are shorter. Like beasts of prey, they are of a fierce and unsociable nature; and so far from herding together like the inoffensive tribes, they drive even their offspring from the eyry, and seek habitually the shelter of desert rocks, neglected ruins, or the solitude of the darkest forest, from whence 
they utter loud, terrific, or piercing cries, in accordance with the gloomy rage and inquietude of their insatiable desires.

Besides these grand divisions of the winged nations, there are others, which, in their habits and manners, might be compared to the amphibious animals, as they live chiefly on the water, and feed on its productions. To enable them to swim and dive in quest of their aquatic food, their toes are connected by broad membranes or webs, with which, like oars, they strike the water, and are impelled with force. In this way even the seas, lakes, and rivers, abounding with fish, insects, and seeds, swarm with birds of various kinds, which all obtain an abundant supply. There are other aquatic birds, frequenting marshes and the margins of lakes, rivers, and the sea, which seem to partake of an intermediate nature between the land and water tribes. Some of these feed on fishes and reptiles; others, with long and sensible bills and extended necks, seek their food in wet and muddy marshes. These birds are not made for swimming; but, familiar with water, they wade, and many follow the edge of the retiring waves of the sea, gleaning their insect prey at the recession of the tides: for this kind of life Nature has provided them with long legs, bare of feathers even above the knees; their toes, unconnected by webs, are only partially furnished with membranous appendages, just sufficient to support them on the soft and boggy grounds they frequent. To this tribe belong the Cranes, Snipes, Sandpipers, Woodcocks, and many others.

In comparing the senses of animals in connection with their instinct, we find that of sight to be more extended, more acute, and more distinct in birds, in general, than in quadrupeds. I say "in general," for there are some birds, such as the Owls, whose vision is less clear than that of quadrupeds; but this rather results from the extreme sensibility of the eye, which, though dazzled with the glare of full day, nicely distinguishes even small objects by the aid of twilight. In all birds the organ of sight is furnished with two membranes, - an external and internal, - additional to those which occur in the human subject. The former, membrana nictitans, or external mem- 
brane, is situated in the larger angle of the eye, and is, in fact, a second and more transparent eyelid, whose motions are directed at pleasure, and its use, besides occasionally cleaning and polishing the cornéa, is to temper the excess of light and adjust the quantity admitted to the extreme delicacy of the organ. The other membrane, situated at the bottom of the eye, appears to be an expansion of the optic nerve, which, receiving more immediately the impressions of the light, must be much more sensible than in other animals; and consequently the sight is in birds far more perfect, and embraces a wider range. Facts and observations bear out this conclusion; for a Sparrow-hawk, while hovering in the air, perceives a Lark or other small bird, sitting on the ground, at twenty times the distance that such an object would be visible to a man or dog. A Kite, which soars beyond the reach of human vision, yet distinguishes a lizard, field-mouse, or bird, and from this lofty station selects the tiny object of his prey, descending upon it in nearly a perpendicular line. But it may also be added that this prodigious extent of vision is likewise accompanied with equal accuracy and clearness; for the eye can dilate or contract, be shaded or exposed, depressed or made protuberant, so as readily to assume the precise form suited to the degree of light and the distance of the object; the organ thus answering, as it were, the purpose of a self-adjusting telescope, with a shade for examining the most luminous and dazzling objects; and hence the Eagle is often seen to ascend to the higher regions of the atmosphere, gazing on the unclouded sun as on an ordinary and familiar object.

The rapid motions executed by birds have also a reference to the perfection of their vision; for if Nature, while she endowed them with great agility and vast muscular strength, had left them as short-sighted as ourselves, their latent powers would have availed them nothing, and the dangers of a perpetually impeded progress would have repressed or extinguished their ardor. We may then, in general, consider the celerity with which an animal moves, as a just indication of the perfection of its vision. A bird, therefore, shooting swiftly 
through the air, must undoubtedly see better than one which slowly describes a waving tract. The weak-sighted bat, flying carefully through bars of willow, even when the eyes were extinguished, may seem to suggest an exception to this rule of relative velocity and vision; but in this case, as in that of some blind individuals of the human species, the exquisite auditory apparatus seems capable of supplying the defect of sight. Nor are the flickerings of the bat, constantly performed in a narrow circuit, at all to be compared to the distant and lofty soarings of the Eagle, or the wide wanderings of the smaller birds, who often annually pass and repass from the arctic circle to the equator.

The idea of motion, and all the other ideas connected with it, such as those of relative velocities, extent of country, the proportional height of eminences, and of the various inequalities that prevail on the surface, are therefore more precise in birds, and occupy a larger share of their conceptions, than in the grovelling quadrupeds. Nature would seem to have pointed out this superiority of vision, by the more conspicuous and elaborate structure of its organ; for in birds the eye is larger in proportion to the bulk of the head than in quadrupeds; it is also more delicate and finely fashioned, and the impressions it receives must consequently excite more vivid ideas.

Another cause of difference in the instincts of birds and quadrupeds is the nature of the element in which they live. Birds know better than man the degrees of resistance in the air, its temperature at different heights, its relative density, and many other particulars, probably, of which we can form no adequate conception. They foresee more than we, and indicate better than our weather-glasses, the changes which happen in that voluble fluid; for often have they contended with the violence of the wind, and still oftener have they borrowed the advantage of its aid. The Eagle, soaring above the clouds, can at will escape the scene of the storm, and in the lofty region of calm, far within the aërial boundary of eternal frost, ${ }^{1}$ enjoy a

1 The mean heights of eternal frost under the equator and at the latitude of $30^{\circ}$ and $60^{\circ}$ are, respectively, $15,207,1 \mathrm{I}, 484$, and 3,818 feet. 
serene sky and a bright sun, while the terrestrial animals remain involved in darkness and exposed to all the fury of the tempest. In twenty-four hours it can change its climate, and sailing over different countries, it will form a picture exceeding the powers of the pencil or the imagination. The quadruped knows only the spot where it feeds, - its valley, mountain, or plain; it has no conception of the expanse of surface or of remote distances, and generally no desire to push forward its excursions beyond the bounds of its immediate wants. Hence remote journeys and extensive migrations are as rare among quadrupeds as they are frequent among birds. It is this desire, founded on their acquaintance with foreign countries, on the consciousness of their expeditious course, and on their foresight of the changes that will happen in the atmosphere, and the revolutions of seasons, that prompts them to retire together at the powerful suggestions of an unerring instinct. When their food begins to fail, or the cold and heat to incommode them, their innate feelings and latent powers urge them to seek the necessary remedy for the evils that threaten their being. The inquietude of the old is communicated to the young; and collecting in troops by common consent, influenced by the same general wants, impressed with the approaching changes in the circumstances of their existence, they give way to the strong reveries of instinct, and wing their way over land and sea to some distant and better country.

Comparing animals with each other, we soon perceive that smell, in general, is much more acute among the quadrupeds than the birds. Even the pretended scent of the Vulture is imaginary, as he does not perceive the tainted carrion, on which he feeds, through a wicker basket, though its odor is as potent as in the open air. This choice also of decaying flesh is probably regulated by his necessities and the deficiency of his muscular powers to attack a living, or even tear in pieces a recent, prey. The structure of the olfactory organ in birds is obviously inferior to that of quadrupeds; the external nostrils are wanting, and those odors which might excite sensation have access only to the duct leading from the palate; and even 
in those, where the organ is disclosed, the nerves, which take their origin from it, are far from being so numerous, so large, or so expanded as in the quadrupeds. We may therefore regard touch in man, smell in the quadruped, and sight in birds, as respectively the three most perfect senses which exercise a general influence on the character.

After sight, the most perfect of the senses in birds appears to be hearing, which is even superior to that of the quadrupeds, and scarcely exceeded in the human species. We perceive with what facility they retain and repeat tones, successions of notes, and even words; we delight to listen to their unwearied songs, to the incessant warbling of their tuneful affection. Their ear and throat are more ductile and powerful than in other animals, and their voice more capacious and generally agreeable. A Crow, which is scarcely more than the thousandth part the size of an ox, may be heard as far, or farther; the Nightingale can fill a wider space with its music than the human voice. This prodigious extent and power of sound depend entirely on the structure of their organs; but the support and continuance of their song result solely from their internal emotions.

The windpipe is wider and stronger in birds than in any other class of animals, and usually terminates below in a large cavity that augments the sound. The lungs too have greater extent, and communicate with internal cavities which are capable of being expanded with air, and, besides lightening the body, give additional strength to the voice. Indeed, the formation of the thorax, the lungs, and all the organs connected with these, seems expressly calculated to give force and duration to their utterance.

Another circumstance, showing the great power of voice in birds, is the distance at which they are audible in the higher regions of the atmosphere. An Eagle may rise at least to the height of seventeen thousand feet, for it is there just visible. Flocks of Storks and Geese may mount still higher, since, notwithstanding the space they occupy, they soar almost out of sight; their cry will therefore be heard from an altitude of 
more than three miles, and is at least four times as powerful as the voice of men and quadrupeds.

Sweetness of voice and melody of song are qualities which in birds are partly natural and partly acquired. The facility with which they catch and repeat sounds, enables them not only to borrow from each other, but often even to copy the more difficult inflections and tones of the human voice, as well as of musical instruments. It is remarkable that in the tropical regions, where the birds are arrayed in the most glowing colors, their voices are hoarse, grating, singular, or terrific. Our sylvan Orpheus (the Mocking-bird), the Brown Thrush, the Warbling Flycatcher, as well as the Iinnet, the Thrush, the Blackbird, and the Nightingale of Europe, pre-eminent for song, are all of the plainest colors and weakest tints.

The natural tones of birds, setting aside those derived from education, express the various modifications of their wants and passions; they change even according to different times and circumstances. The females are much more silent than the males; they have cries of pain or fear, murmurs of inquietude or solicitude, especially for their young; but of song they are generally deprived. The song of the male is inspired by tender emotion, he chants his affectionate lay with a sonorous voice, and the female replies in feeble accents. The Nightingale, when he first arrives in the spring, without his mate, is silent; he begins his lay in low, faltering, and unfrequent airs; and it is not until his consort sits on her eggs that his enchanting melody is complete: he then tries to relieve and amuse her tedious hours of incubation, and warbles more pathetically and variably his amorous and soothing lay. In a state of nature this propensity for song only continues through the breeding season, for after that period it either entirely ceases, becomes enfeebled, or loses its sweetness.

Conjugal fidelity and parental affection are among the most conspicuous traits of the feathered tribes. The pair unite their labors in preparing for the accommodation of their expected progeny; and during the time of incubation their participation of the same cares and solicitudes continually augments 
their mutual attachment. When the young appear, a new source of care and pleasure opens to them, still strengthening the ties of affection; and the tender charge of rearing and defending their infant brood requires the joint attention of both parents. The warmth of first affection is thus succeeded by calm and steady attachment, which by degrees extends, without suffering any diminution, to the rising branches of the family.

This conjugal union, in the rapacious tribe of birds, the Eagles and Hawks, as well as with the Ravens and Crows, continues commonly through life. Among many other kinds it is also of long endurance, as we may perceive in our common Pewee and the Blue-bird, who year after year continue to frequent and build in the same cave, box, or hole in the decayed orchard tree. But, in general, this association of the sexes expires with the season, after it has completed the intentions of reproduction, in the preservation and rearing of the offspring. The appearance even of sexual distinction often vanishes in the autumn, when both the parents and their young are then seen in the same humble and oblivious dress. When they arrive again amongst us in the spring, the males in flocks, often by themselves, are clad anew in their nuptial livery; and with vigorous songs, after the cheerless silence in which they have passed the winter, they now seek out their mates, and warmly contest the right to their exclusive favor.

With regard to food, birds have a more ample latitude than quadrupeds ; flesh, fish, amphibia, reptiles, insects, fruits, grain, seeds, roots, herbs, - in a word, whatever lives or vegetates. Nor are they very select in their choice, but often catch indifferently at what they can most easily obtain. Their sense of taste appears indeed much less acute than in quadrupeds; for if we except such as are carnivorous, their tongue and palate are, in general, hard, and almost cartilaginous. Sight and scent can only direct them, though they possess the latter in an inferior degree. The greater number swallow without tasting; and mastication, which constitutes the chief pleasure in eating, is entirely wanting to them. As their horny jaws are unprovided 
with teeth, the food undergoes no preparation in the mouth, but is swallowed in unbruised and untasted morsels. Yet there is reason to believe that the first action of the stomach, or its preparatory ventriculus, affords in some degree the ruminating gratification of taste, as after swallowing food, in some insectivorous and carnivorous birds, the motion of the mandibles, exactly like that of ordinary tasting, can hardly be conceived to exist without conveying some degree of gratifying sensation.

The clothing of birds varies with the habits and climates they inhabit. The aquatic tribes, and those which live in northern regions, are provided with an abundance of plumage and fine down, - from which circumstance often we may form a correct judgment of their natal regions. In all climates, aquatic birds are almost equally feathered, and are provided with posterior glands containing an oily substance for anointing their feathers, which, aided by their thickness, prevents the admission of moisture to their bodies. These glands are less conspicuous in land birds, - - unless, like the fishing Eagles, their habits be to plunge in the water in pursuit of their prey.

The general structure of feathers seems purposely adapted both for warmth of clothing and security of flight. In the wings of all birds which fly, the webs composing the vanes, or plumy sides of the feather, mutually interlock by means of regular rows of slender, hair-like teeth, so that the feather, except at and towards its base, serves as a complete and close screen from the weather on the one hand, and as an impermeable oar on the other, when situated in the wing, and required to catch and retain the impulse of the air. In the birds which do not fly, and inhabit warm climates, the feathers are few and thin, and their lateral webs are usually separate, as in the Ostrich, Cassowary, Emu, and extinct Dodo. In some cases feathers seem to pass into the hairs, which ordinarily clothe the quadrupeds, as in the Cassowary, and others; and the base of the bill in many birds is usually surrounded with these capillary plumes.

'The greater number of birds cast their feathers annually, and appear to suffer much more from it than the quadrupeds do 
from a similar change. The best-fed fowl ceases at this time to lay. The season of moulting is generally the end of summer or autumn, and their feathers are not completely restored till the spring. The male sometimes undergoes, as we have already remarked, an additional moult towards the close of summer; and among many of the waders and web-footed tribes, as Sandpipers, Plovers, and Gulls, both sexes experience a moult twice in the year, so that their summer and winter livery appears wholly different.

The stratagems and contrivances instinctively employed by birds for their support and protection are peculiarly remarkable; in this way those which are weak are enabled to elude the pursuit of the strong and rapacious. Some are even screened from the attacks of their enemies by an arrangement of colors assimilated to the places which they most frequent for subsistence and repose : thus the Wryneck is scarcely to be distinguished from the tree on which it seeks its food; or the Snipe from the soft and springy ground which it frequents. The Great Plover finds its chief security in stony places, to which its colors are so nicely adapted that the most exact observer may be deceived. The same resort is taken advantage of by the Night Hawk, Partridge, Plover, and the American Quail, the young brood of which squat on the ground, instinctively conscious of being nearly invisible, from their close resemblance to the broken ground on which they lie, and trust to this natural concealment. The same kind of deceptive and protecting artifice is often employed by birds to conceal or render the appearance of their nests ambiguous. Thus the European Wren forms its nest externally of hay, if against a hayrick; covered with lichens, if the tree chosen is so clad; or made of green moss, when the decayed trunk in which it is built, is thus covered; and then, wholly closing it above, leaves only a concealed entry in the side. Our Hummingbird, by external patches of lichen, gives her nest the appearance of a moss-grown knot. A similar artifice is employed by our Yellow-breasted Flycatcher, or Vireo, and others. The 
Golden-crowned Thrush (Seiurus aurocapillus) makes a nest like an oven, erecting an arch over it so perfectly resembling the tussuck in which it is concealed that it is only discoverable by the emotion of the female when startled from its covert.

The Butcher-bird is said to draw around him his feathered victims by treacherously imitating their notes. The Kingfisher of Europe is believed to allure his prey by displaying the brilliancy of his colors as he sits near some sequestered place on the margin of a rivulet; the fish, attracted by the splendor of his fluttering and expanded wings, are detained while the wily fisher takes an unerring aim. ${ }^{1}$ The Erne, and our Bald Eagle, gain a great part of their subsistence by watching the success of the Fish Hawk, and robbing him of his finny prey as soon as it is caught. In the same way also the rapacious Burgomaster, or Glaucous Gull (Larus glaucus), of the North levies his tribute of food from all the smaller species of his race, who, knowing his strength and ferocity, are seldom inclined to dispute his piratical claims. Several species of Cuckoo, and the Cow Troopial of America, habitually deposit their eggs in the nests of other small birds, to whose deceived affection are committed the preservation and rearing of the parasitic and vagrant brood. The instinctive arts of birds are numerous; but treachery, like that which obtains in these parasitic species, is among the rarest expedients of nature in the feathered tribes, though not uncommon among some insect families.

The art displayed by birds in the construction of their temporary habitations, or nests, is also deserving of passing attention. Among the Gallinaceous tribe, including our land domestic species, as well as the aquatic and wading kinds, scarcely any attempt at a nest is made. The birds which swarm along the sea-coast often deposit their eggs on the bare ground, sand, or slight depressions in shelving rocks; governed alone by grosser wants, their mutual attachment is feeble or nugatory, and neither art nor instinct prompts attention to the construc-

1 The bright feathers of this bird enter often successfully, with others, into the composition of the most attractive artificial flies employed by anglers. 
tion of a nest, - the less necessary, indeed, as the young run or take to the water as soon as hatched, and early release themselves from parental dependence. The habits of the other aquatic birds are not very dissimilar to these; yet it is singular to remark that while our common Geese and Ducks, like domestic Fowls, have no permanent selective attachment for their mates, the Canadian Wild Goose, the Eider Duck, and some others, are constantly and faithfully paired through the season; so that this neglect of accommodation for the young in the fabrication of an artificial nest, common to these with the rest of their tribe, has less connection with the requisition of mutual aid than with the hardy and precocious habits of these unmusical, coarse, and retiring birds. It is true that some of them show considerable address, if little of art, in providing security for their young; in this way some of the Razor-bills (including the Common Puffin) do not trust the exposure of their eggs, like the Gulls, who rather rely on the solitude of their retreat, than art in its defence; but with considerable labor some of the Alcas form a deep burrow for the security of their brood.

Birds of the same genus differ much in their modes of nidification. Thus the Martin makes a nest within a rough-cast rampart of mud, and enters by a flat opening in the upper edge. The Cliff Swallow of Bonaparte conceals its warm and feathered nest in a receptacle of agglutinated mud resembling a narrow-necked purse or retort. Another species, in the Indian seas, forms a small receptacle for its young entirely of interlaced gelatinous fibres, provided by the mouth and stomach; these nests, stuck in clusters against the rocks, are collected by the Chinese, and boiled and eaten in soups as the rarest delicacy. The Bank Martin, like the Kingfisher, burrows deep into the friable banks of rivers to secure a depository for its scantily feathered nest. The Chimney Swallow, originally an inhabitant of hollow trees, builds in empty chimneys a bare nest of agglutinated twigs. The Woodpecker, Nuthatch, Titmouse, and our rural Bluebird, secure their young in hollow trees; and the first often gouge and dig through the solid wood with the success and industry of car- 
penters, and without the aid of any other chisel than their wedged bills.

But the most consummate ingenuity of ornithal architecture is displayed by the smaller and more social tribes of birds, who, in proportion to their natural enemies, foreseen by Nature, are provided with the means of instinctive defence. In this labor both sexes generally unite, and are sometimes occupied a week or more in completing this temporary habitation for their young. We can only glance at a few examples, chiefly domestic; since to give anything like a general view of this subject of the architecture employed by birds would far exceed the narrow limits we prescribe. And here we may remark that, after migration, there is no more certain display of the reveries of instinct than what presides over this interesting and necessary labor of the species. And yet so nice are the gradations betwixt this innate propensity and the dawnings of reason that it is not always easy to decide upon the characteristics of one as distinct from the other. Pure and undeviating instincts are perhaps wholly confined to the invertebral class of animals.

In respect to the habits of birds, we well know that, like quadrupeds, they possess, though in a lower degree, the capacity for a certain measure of what may be termed education, or the power of adding to their stock of invariable habits the additional traits of an inferior degree of reason. Thus in those birds who have discovered (like the faithful dog, that humble companion of man) the advantages to be derived from associating round his premises, the regularity of their instinctive habits gives way, in a measure, to improvable conceptions. In this manner our Golden Robin (Icterus baltimore), or Fiery Hang Bird, originally only a native of the wilderness and the forest, is now a constant summer resident in the vicinity of villages and dwellings. From the depending boughs of our towering elms, and other spreading trees, like the Oriole of Europe, and the Cassican of tropical America, he weaves his pendulous and purse-like nest of the most tenacious and durable materials he can collect. These naturally consist of the 
Indian hemp, flax of the silk-weed (Asclepias species), and other tough and fibrous substances; but with a ready ingenuity he discovers that real flax and hemp, as well as thread, cotton, yarn, and even hanks of silk, or small strings, and horse and cow hair, are excellent substitutes for his original domestic materials; and in order to be convenient to these accidental resources, - a matter of some importance in so tedious a labor, - he has left the wild woods of his ancestry, and conscious of the security of his lofty and nearly inaccessible mansion, has taken up his welcome abode in the precincts of our habitations. The same motives of convenience and comfort have had their apparent influence on many more of our almost domestic feathered tribes; the Bluebirds, Wrens, and Swallows, original inhabitants of the woods, are now no less familiar than our Pigeons. The Catbird often leaves his native solitary thickets for the convenience and refuge of the garden, and watching, occasionally, the motions of the tenant, answers to his whistle with complacent mimicry, or in petulant anger scolds at his intrusion. The Common Robin, who never varies his simple and coarse architecture, tormented by the parasitic Cuckoo or the noisy Jay, who seek at times to rob him of his progeny, for protection has been known fearlessly to build his nest within a few yards of the blacksmith's anvil, or on the stern timbers of an unfinished vessel, where the carpenters were still employed in their noisy labors. That sagacity obtains its influence over unvarying instinct in these and many other familiar birds, may readily be conceived when we observe that this venturous association with man vanishes with the occasion which required it; for no sooner have the Oriole and Robin reared their young than their natural suspicion and shyness again return.

Deserts and solitudes are avoided by most kinds of birds. In an extensive country of unvarying surface, or possessing but little variety of natural productions, and particularly where streams and waters are scarce, few of the feathered tribes are to be found. The extensive prairies of the West, and the gloomy and almost interminable forests of the North, as well as 
the umbrageous, wild, and unpeopled banks of the Mississippi, and other of the larger rivers, no less than the vast pine-barrens of the Southern States, are nearly without birds as permanent residents. In crossing the desolate piny glades of the South, with the exception of Creepers, Nuthatches, Woodpeckers, Pine Warblers, and flocks of flitting Larks (Sturnella), scarcely any birds are to be seen till we approach the meanders of some stream, or the precincts of a plantation. The food of birds being extremely various, they consequently congregate only where sustenance is to be obtained; watery situations and a diversified vegetation are necessary for their support, and convenient for their residence; the fruits of the garden and orchard, the swarms of insects which follow the progress of agriculture, the grain which we cultivate, - in short, everything which contributes to our luxuries and wants, in the way of subsistence, no less than the recondite and tiny enemies which lessen or attack these various resources, all conduce to the support of the feathered race, which consequently seek out and frequent our settlements as humble and useful dependents.

The most ingenious and labored nest of all the North American birds is that of the Orchard Oriole, or Troopial. It is suspended, or pensile, like that of the Baltimore Bird, but, with the exception of hair, constantly constructed of native materials, the principal of which is a kind of tough grass. The blades are formed into a sort of platted purse but little inferior to a coarse straw bonnet; the artificial labor bestowed is so apparent that Wilson humorously adds, on his showing it to a matron of his acquaintance, betwixt joke and earnest, she asked " if he thought it could not be taught to darn stockings." Every one has heard of the Tailor Bird of India (Sylizi sutoria); this little architect, by way of saving labor and gaining security for its tiny fabric, sometimes actually, as a seamstress, sews together the edges of two leaves of a tree, in which her nest, at the extremity of the branch, is then secured for the period of incubation. Among the Sylvias, or Warblers, there is a species, inhabiting Florida and the West Indies, the Sylvia pensilis, which forms its woven, covered nest to rock in 
the air at the end of two suspending strings, rather than trust it to the wily enemies by which it is surrounded; the entrance, for security, is also from below, and through a winding vestibule.

Our little cheerful and almost domestic Wren (Troglodytes fulvus), which so often disputes with the Martin and the Bluebird the possession of the box set up for their accommodation in the garden or near the house, in his native resort of a hollow tree, or the shed of some neglected out-house, begins his fabric by forming a barricade of crooked interlacing twigs, - a kind of chevaux-de-frise, - for the defence of his internal habitation, leaving merely a very small entrance at the upper edge. The industry of this little bird, and his affection for his mate, are somewhat remarkable, as he frequently completes his habitation without aid, and then searches out a female on whom to bestow it; but not being always successful, or the premises not satisfactory to his mistress, his labor remains sometimes without reward, and he continues to warble out his lay in solitude. The same gallant habit prevails also with our recluse Wren of the marshes. Wilson's Marsh Wren (Troglodytes palustris), instead of courting the advantages of a proximity to our dwellings, lives wholly among the reed-fens, suspending his mudplastered and circularly covered nest usually to the stalks of the plant he so much affects. Another marsh species inhabits the low and swampy mealows of our vicinity (Troglodytes brevirostris), and with ready address constructs its globular nest wholly of the intertwined sedge-grass of the tussock on which it is built; these two species never leave their subaquatic retreats but for the purpose of distant migration, and avoid and deprecate in angry twitterings every sort of society but their own.

Among the most extrnordinary habitations of birds, illustrative of their instinctive invention, may be mentioned that of the Bengal Grosbeak, whose pensile nest, suspended from the lofty boughs of the Indian fig-tree, is fabricated of grass, like cloth, in the form of a large bottle, with the entrance downwards; it consists also of two or three chambers, supposed to be occasionally illuminated by the fire-flies, which, however,

roL. I. $-c$ 
only constitute a part of the food it probably conveys for the support of its young. But the most extraordinary instinct of this kind known, is exhibited by the Sociable, or Republican Grosbeak (Ploceus socius, CLTIER), of the Cape of Good Hope. In one tree, according to Mr. Paterson, there could not be fewer than from eight hundred to one thousand of these nests, covered by one general roof, resembling that of a thatched house, and projecting over the entrance of the nest. Their common industry almost resembles that of bees. Beneath this roof there are many entrances, each of which forms, as it were, a regular street, with nests on either side, about two inches distant from each other. The material which they employ in this building is a kind of fine grass, whose seed, also, at the same time serves them for food.

That birds, besides their predilection for the resorts of men, are also capable of appreciating consequences to themselves and young, scarcely admits the shadow of a doubt; they are capable of communicating their fears and nicely calculating the probability of danger or the immunities of faror. We talk of the cunning of the Fox and the watchfulness of the Weasel; but the Eagle, Hawk, Raven, Crow, Pre, and Blackbird possess those traits of shrewdness and caution which would seem to arise from reflection and prudence. They well know the powerful weapons and wiles of civilized man. Without being able to smell pozider, - a vulgar idea, - the Crow and Blackbird at once suspect the character of the fatal gun; they will alight on the backs of cattle without any show of apprehension, and the Pye even hops upon them with insulting and garrulous playfulness; but he flies instantly from his human enemy, and seems, by his deprecating airs, aware of the proscription that affects his existence. A man on horseback or in a carriage is much less an object of suspicion to those wily birds than when alone; and I have been frequently both amused and surprised, in the Southern States, by the sagacity of the Common Blackbirds in starting from the ploughing field, with looks of alarm, at the sight of a white man, as distinct from and more dangerous than the black slave, whose furrow they closely and familiarly fol- 
lowed, for the insect food it afforded them, without betraying any appearance of distrust. Need we any further proof of the capacity for change of disposition than that which has so long operated upon our domestic poultry? - "those victims," as Buffon slightingly remarks, "which are multiplied without trouble, and sacrificed without regret." How different the habits of our Goose and Duck in their wild and tame condition! Instead of that excessive and timid cautiousness, so peculiar to their savage nature, they keep company with the domestic cattle, and hardly shuffle out of our path. Nay, the Gander is a very ban-dog, - noisy, gabbling, and vociferous, he gives notice of the stranger's approach, is often the terror of the meddling school-boy, in defence of his fostered brood; and it is reported of antiquity, that by their usual garrulity and watchfulness they once saved the Roman capitol. Not only is the disposition of these birds changed by domestication, but even their strong instinct to migration, or wandering longings, are wholly annihilated. Instead of joining the airy phalanx which wing their way to distant regions, they grovel contented in the perpetual abundance attendant on their willing slavery. If instinct can thus be destroyed or merged in artificial circumstances, need we wonder that this protecting and innate intelligence is capable also of another change by improvement, adapted to new habits and unnatural restraints? Even without undergoing the slavery of domestication, many birds become fully sensible of immunities and protection; and in the same aquatic and rude family of birds already mentioned we may quote the tame habits of the Eider Ducks. In Iceland and other countries, where they breed in such numbers as to render their valuable down an object of commerce, they are forbidden to be killed under legal penalty; and as if aware of this legislative security, they sit on their eggs undisturbed at the approach of man, and are entirely as familiar, during this season of breeding, as our tamed Ducks. Nor are they apparently aware of the cheat habitually practised upon them of abstracting the down with which they line their nests, though it is usually repeated until they make the third attempt at incubation. If, 
however, the last nest, with its eggs and down, to the lining of which the male is now obliged to contribute, be taken away, they sagaciously leave the premises, without return. The pious Storks, in Holland, protected by law for their usefulness, build their nests on the tops of houses and churches, often in the midst of cities, in boxes prepared for them, like those for our Martins; and, walking about the streets and gardens without apprehension of danger, perform the usual office of domestic scavengers.

That birds, like our morê sedentary and domestic quadrupeds, are capable of exhibiting attachment to those who feed and attend them, is undeniable. Deprived of other society, some of our more intelligent species, particularly the Thrushes, soon learn to seek out the company of their friends or protectors of the human species. The Brown Thrush and Mocking Bird become in this way extremely familiar, cheerful, and capriciously playful; the former, in particular, courts the attention of his master, follows his steps, complains when neglected, flies to him when suffered to be at large, and sings and reposes gratefully perched on his hand, - in short, by all his actions he appears capable of real and affectionate attachment, and is jealous of every rival, particularly any other bird, which he persecutes from his presence with unceasing hatred. His petulant dislike to particular objects of less moment is also displayed by various tones and gestures, which soon become sufficiently intelligible to those who are near him, as well as his notes of gratulation and satisfaction. His language of fear and surprise could never be mistaken, and an imitation of his guttural low tsherr, tsherr, on these occasions, answers as a premonitory warning when any danger awaits him from the sly approach of cat or squirrel. As I have now descended, as I may say, to the actual biography of one of these birds, which I raised and kept uncaged for some time, I may also add, that besides a playful turn for mischief and interruption, in which he would sometimes snatch off the paper on which I was writing, he had a good degree of curiosity, and was much surprised one day by a large springing beetle or Elater (E. ocellatius), 
which I had caught and placed in a tumbler. On all such occasions his looks of capricious surprise were very amusing; he cautiously approached the glass with fanning and closing wings, and in an under-tone confessed his surprise at the address and jumping motion of the huge insect. At length he became bolder, and perceiving it had a relation to his ordinary prey of beetles, he, with some hesitation, ventured to snatch at the prisoner between temerity and playfulness. But when really alarmed or offended, he instantly flew to his loftiest perch, forbid all friendly approaches, and for some time kept up his low and angry tsherr. My late friend, the venerable William Bartram, was also much amused by the intelligence displayed by this bird, and relates that one which he kept, being fond of hard bread-crumbs, found, when they grated his throat, a very rational remedy in softening them, by soaking in his vessel of water; he likewise, by experience, discovered that the painful prick of the wasps on which he fed, could be obviated by extracting their stings. But it would be too tedious and minute to follow out these glimmerings of intelligence, which exist as well in birds as in our most sagacious quadrupeds. The remarkable talent of the Parrot for imitating the tones of the human voice has long been familiar. The most extraordinary and well-authenticated account of the actions of one of the common ash-colored species is that of a bird which Colonel O'Kelly bought for a hundred guineas at Bristol. This individual not only repeated a great number of sentences, but answered many questions, and was able to whistle a variety of tunes. While thus engaged it beat time with all the appearance of science, and possessed a judgment, or ear so accurate, that if by chance it mistook a note, it would revert to the bar where the mistake was made, correct itself, and still beating regular time, go again through the whole with perfect exactness. So celebrated was this surprising bird that an obituary notice of 1ts death appeared in the "General Evening Post" for the 9 th of October, 1802 . In this account it is added, that besides her great musical faculties, she could express her wants articulately, and give her orders in a manner approaching to 
rationality. She was, at the time of her decease, supposed to be more than thirty years of age. The colonel was repeatedly offered five hundred guineas a year for the bird, by persons who wished to make a public exhibition of her; but out of tenderness to his favorite he constantly refused the offer.

The story related by Goldsmith of a parrot belonging to King Henry the Seventh, is very amusing, and possibly true. It was kept in a room in the Palace of Westminster, overlooking the Thames, and had naturally enough learned a store of boatmen's phrases; one day, sporting somewhat incautiously, Poll fell into the river, but had rationality enough, it appears, to make a profitable use of the words she had learned, and accordingly vociferated, "A boat! twenty pounds for a boat!" This welcome sound reaching the ears of a waterman, soon brought assistance to the Parrot, who delivered it to the king, with a request to be paid the round sum so readily promised by the bird; but his Majesty, dissatisfied with the exorbitant demand, agreed, at any rate, to give him what the bird should now award; in answer to which reference, Poll shrewdly cried, "Give the knave a groat!"

The story given by Locke, in his "Essay on the Human Understanding," though approaching closely to rationality, and apparently improbable, may not be a greater effort than could have been accomplished by Colonel O'Kelly's bird. This Parrot had attracted the attention of Prince Maurice, then governor of Brazil, who had a curiosity to witness its powers. The bird was introduced into the room, where sat the prince in company with several Dutchmen. On viewing them, the Parrot exclaimed, in Portuguese, "What a company of white men are here !" Pointing to the prince, they asked, "Who is that man?" to which the Parrot replies, "Some general or other." The prince now asked, "From what place do you come?" The answer was, "From Marignan." "To whom do you belong?" It answered, "To a Portuguese." "What do you do there?" To which the Parrot replied, "I look after chickens!" The prince, now laughing, exclaimed, "You look 
after chickens!" To which Poll pertinently answered, "Yes, $I$, - and I know well enough how to do it ; "clucking at the same instant in the manner of a calling brood-hen.

The docility of birds in catching and expressing sounds depends, of course, upon the perfection of their voice and hearing, - assisted also by no inconsiderable power of memory. The imitative actions and passiveness of some small birds, such as Goldfinches, Linnets, and Canaries, are, however, quite as curious as their expression of sounds. A Sieur Roman exhibited in England some of these birds, one of which simulated death, and was held up by the tail or claw without showing any active signs of life. A second balanced itself on the head, with its claws in the air. A third imitated a milkmaid going to market, with pails on its shoulders. A fourth mimicked a Venetian girl looking out at a window. A fifth acted the soldier, and mounted guard as a sentinel. The sixth was a cannonier, with a cap on its head, a firelock on its shoulder, and with a match in its claw discharged a small cannon. The same bird also acted as if wounded, was wheeled in a little barrow, as it were to the hospital; after which it flew away before the company. The seventh turned a kind of windmill ; and the last bird stood amidst a discharge of small fireworks, without showing any sign of fear.

A similar exhibition, in which twenty-four Canary birds were the actors, was also shown in London in 1820 , by a Frenchman named Dujon; one of these suffered itself to be shot at, and falling down, as if dead, was put into a little wheelbarrow and conveyed away by one of its comrades.

The docility of the Canary and Goldfinch is thus, by dint of severe education, put in fair competition with that of the dog; and we cannot deny to the feathered creation a share of that kind of rational intelligence exhibited by some of our sagacious quadrupeds, - an incipient knowledge of cause and effect far removed from the unimprovable and unchangeable destinies of instinct. Nature probably delights less in producing such animated machines than we are apt to suppose; and amidst the mutability of circumstances by which almost every animated 
being is surrounded, there seems to be a frequent demand for that relieving invention denied to those animals which are solely governed by inflexible instinct.

The velocity with which birds are able to travel in their aërial element has no parallel among terrestrial animals; and this powerful capacity for progressive motion is bestowed in aid of their peculiar wants and instinctive habits. The swiftest horse may perhaps proceed a mile in something less than two minutes; but such exertion is unnatural, and quickly fatal. An Eagle, whose stretch of wing exceeds seven feet, with ease and majesty, and without any extraordinary effort, rises out of sight in less than three minutes, and therefore must fly more than three thousand five hundred yards in a minute, or at the rate of sixty miles in an hour. At this speed a bird would easily perform a journey of six hundred miles in a day, since ten hours only would be required, which would allow frequent halts, and the whole of the night for repose. Swallows and other migratory birds might therefore pass from northern Europe to the equator in seven or eight days. In fact, Adanson saw, on the coast of Senegal, Swallows that had arrived there on the $9^{\text {th }}$ of October, or eight or nine days after their departure from the colder continent. A Canary Falcon, sent to the Duke of Lerma, returned in sixteen hours from Andalusia to the island of Teneriffe, - a distance of seven hundred and fifty miles. The Gulls of Barbadoes, according to Sir Hans Sloane, make excursions in flocks to the distance of more than two hundred miles after their food, and then return the same day to their rocky roosts.

If we allow that any natural powers come in aid of the instinct to migration, so powerful and uniform in birds, besides their vast capacity for motion, it must be in the perfection and delicacy of their vision, of which we have such striking examples in the rapacious tribes. It is possible that at times they may be directed principally by atmospheric phenomena alone; and hence we find that their appearance is frequently a concomitant of the approaching season, and the wild Petrel of the ocean is not the only harbinger of storm and coming change. The currents of the air, in those which make exten- 
sive voyages, are sedulously employed; and hence, at certain seasons, when they are usually in motion, we find their arrival or departure accelerated by a favorable direction of the winds. That birds also should be able to derive advantage in their journeys from the acuteness of their vision, is not more wonderful than the capacity of a dog to discover the path of his master, for many miles in succession, by the mere scent of his. steps. It is said, indeed, in corroboration of this conjecture, that the Passenger, or Carrying Pigeon, is not certain to return to the place from whence it is brought, unless it be conveyed in an open wicker basket admitting a view of the passing scenery. Many of our birds, however, follow instinctively the great valleys and river-courses, which tend towards their southern or warmer destination; thus the great valleys of the Connecticut, the Hudson, the Delaware, the Susquehanna, the Santee, and more particularly the vast Mississippi, are often, in part, the leading routes of our migrating birds. But, in fact, mysterious as is the voyage and departure of our birds, like those of all other countries where they remove at all, the destination of many is rendered certain, as soon as we visit the southern parts of the Union, or the adjoining countries of Mexico, to which they have retired for the winter; for now, where they were nearly or wholly unknown in summer, they throng by thousands, and flit before our path like the showering leaves of autumn. It is curious to observe the pertinacity of this adventurous instinct in those more truly and exclusively insectivorous species which wholly leave us for the mild and genial regions of the tropics. Many penetrate to their destination through Mexico overland; to these the whole journey is merely an amusing and varied feast. But to a much smaller number, who keep too far toward the sea-coast, and enter the ocean-bound peninsula of Florida, a more arduous aerial voyage is presented; the wide ocean must be crossed, by the young and inexperienced as well as the old and venturous, before they arrive either at the tropical continent or its scattered islands. When the wind proves propitious, however, our little voyagers wing their unerring way like prosperous 
fairies; but baffled by storms and contrary gales, they often suffer from want, and at times, like the Quails, become victims to the devouring waves. On such unfortunate occasions (as Mr. Bullock ${ }^{1}$ witnessed in a voyage near to Vera Cruz late in autumn), the famished travellers familiarly crowd the decks of the vessel, in the hope of obtaining rest and a scanty meal preparatory to the conclusion of their unpropitious flight.

Superficial observers, substituting their own ideas for facts, are ready to conclude, and frequently assert, that the old and young, before leaving, assemble together for mutual departure ; this may be true in many instances, but in as many more a different arrangement obtains. The young, often instinctively vagrant, herd together in separate flocks previous to their departure, and guided alone by the innate monition of Nature, seek neither the aid nor the company of the old; consequently in some countries flocks of young of particular species are alone observed, and in others, far distant, we recognize the old. From parental aid the juvenile company have obtained all that Nature intended to bestow, - existence and education; and they are now thrown ipon the world among their numerous companions, with no other necessary guide than self-preserving instinct. In Europe it appears that these bands of the young always affect even a warmer climate than the old; the aëration of their blood not being yet complete, they are more sensible to the rigors of cold. The season of the year has also its effect on the movements of birds; thus certain species proceed to their northern destination more to the eastward in the spring, and return from it to the south-westward in autumn.

The habitudes and extent of the migrations of birds admit of considerable variety. Some only fly before the inundating storms of winter, and return with the first dawn of spring; these do not leave the continent, and only migrate in quest of food when it actually begins to fail. Among these may be named our common Song Sparrow, Chipping Sparrow, Bluebird, Robin, Pewee, Cedar Bird, Blackbird, Meadow Lark, and many more. Others pass into warmer climates in the autumn,

1 Travels in Mexico. 
after rearing their young. Some are so given to wandering that their choice of a country is only regulated by the resources which it offers for subsistence; such are the Pigeons, Herons of several kinds, Snipes, wild Geese and Ducks, the wandering Albatros, and Waxen Chatterer.

The greater number of birds travel in the night; some species, however, proceed only by day, as the diurnal birds of prey, - Crows, Pies, Wrens, Creepers, Cross-bills, Larks, Bluebirds, Swallows, and some others. Those which travel wholly in the night are the Owls, Butcher Birds, Kingfishers, Thrushes, Flycatchers, Night Hawks, Whip-poor-wills, and also a great number of aquatic birds, whose motions are also principally nocturnal, except in the cold and desolate northern regions, where they usually retire to breed. Other birds are so powerfully impelled by this governing motive to migration that they stop neither day nor night; such are the Herons, Motacillas, Plovers, Swans, Cranes, Wild Geese, Storks, etc. When untoward circumstances render haste necessary, certain kinds of birds, which ordinarily travel only in the night, continue their route during the day, and scarcely allow themselves time to eat; yet the singing-birds, properly so called, never migrate by day, whatever may happen to them. And it may here be inquired, with astonishment, how these feeble but enthusiastic animals are able to pass the time, thus engaged, without the aid of recruiting sleep? But so powerful is this necessity for travel that its incentive breaks out equally in those which are detained in captivity, - so much so that although during the day they are no more alert than usual, and only occupied in taking nourishment, at the approach of night, far from seeking repose, as usual, they manifest great agitation, sing without ceasing in the cage, whether the apartment is lighted or not; and when the moon shines, they appear still more restless, as it is their custom, at liberty, to seek the advantage of its light for facilitating their route. Some birds, while engaged in their journey, still find means to live without halting, - the Swallow, while traversing the sea, pursues its insect prey; those who can subsist on fish without any serious effort, feed as they pass 
or graze the surface of the deep. If the Wren, the Creeper, and the Titmouse rest for an instant on a tree to snatch a hasty morsel, in the next they are on the wing, to fulfil their destination. However abundant may be the nourishment which presents itself to supply their wants, in general, birds of passage rarely remain more than two days together in a place.

The cries of many birds, while engaged in their aërial voyage, are such as are only heard on this important occasion, and appear necessary for the direction of those which fly in assembled ranks.

During these migrations it has been observed that birds fly ordinarily in the higher regions of the air, except when fogs force them to seek a lower elevation. This habit is particularly prevalent with Wild Geese, Storks, Cranes, and Herons, which often pass at such a height as to be scarcely distinguishable.

We shall not here enter into any detailed description of the manner in which each species conducts its migration, but shall content ourselves with citing the single remarkable example of the motions of the Cranes. Of all migrating birds, these appear to be endowed with the greatest share of foresight. They never undertake the journey alone; throughout a circle of several miles they appear to communicate the intention of commencing their route. Several days previous to their departure they call upon each other by a peculiar cry, as if giving warning to assemble at a central point; the favorable moment being, at length arrived, they betake themselves to flight, and, in military style, fall into two lines, which, uniting at the summit, form an extended angle with two equal sides. At the central point of the phalanx, the chief takes his station, to whom the whole troop, by their subordination, appear to have pledged their obedience. The commander has not only the painful task of breaking the path through the air, but he has also the charge of watching for the common safety; to avoid the attacks of birds of prey; to range the two lines in a circle at the approach of a tempest, in order to resist with more effect the squalls which menace the dispersion of the 
linear ranks; and, lastly, it is to their leader that the fatigued company look up to appoint the most convenient places for nourishment and repose. Still, important as is the station and function of the aerial director, its existence is but momentary. As soon as he feels sensible of fatigue, he cedes his place to the next in the file, and retires himself to its extremity. During the night their flight is attended with considerable noise; the loud cries which we hear, seem to be the marching orders of the chief, answered by the ranks who follow his commands. Wild Geese and several kinds of Ducks also make their aërial voyage nearly in the same manner as the Cranes. The loud call of the passing Geese, as they soar securely through the higher regions of the air, is familiar to all ; but as an additiona proof of their sagacity and caution, we may remark that when fogs in the atmosphere render their flight necessarily low, they steal along in silence, as if aware of the danger to which their lower path now exposes them.

The direction of the winds is of great importance to the migration of birds, not only as an assistance when favorable, but to be avoided when contrary, as the most disastrous of accidents, when they are traversing the ocean. If the breeze suddenly change, the aerial voyagers tack to meet it, and diverging from their original course, seek the asylum of some land or island, as is the case very frequently with the Quails, who consequently, in their passage across the Mediterranean, at variable times, make a descent in immense numbers on the islands of the Archipelago, where they wait, sometimes for weeks, the arrival of a propitious gale to terminate their journey. And hence we perceive the object of migrating birds, when they alight upon a vessel at sea: it has fallen in their course while seeking refuge from a baffling breeze or overwhelming storm, and after a few hours of rest they wing their way to their previous destination. That Nature has provided ample means to fulfil the wonderful instinct of these feeble but cautious wanderers, appears in every part of their economy. As the period approaches for their general departure, and the chills of autumn are felt, their bodies begin to be loaded with 
cellular matter, and at no season of the year are the true birds of passage so fat as at the approach of their migration. The Gulls, Cranes, and Herons, almost proverbially macilent, are at this season loaded with this reservoir of nutriment, which is intended to administer to their support through their arduous and hazardous voyage. With this natural provision, dormant animals also commence their long and dreary sleep through the winter, - a nutritious resource no less necessary in birds while engaged in fulfilling the powerful and waking reveries of instinct.

But if the act of migration surprise us when performed by birds of active power of wing, it is still more remarkable when undertaken by those of short and laborious flight, like the Coots and Rails, who, in fact, perform a part of their route on foot. The Great Penguin (Alca impennis), the Guillemot, and the Divers, even make their voyage chiefly by dint of swimming. The young Loons (Colymbus glacialis), bred in inland ponds, though proverbially lame (and hence the name of Lom, or Loon), without recourse to their wings, which are at this time inefficient, continue their route from pond to pond, floundering over the intervening land by night, until at length they gain some creek of the sea, and finally complete their necessary migration by water.

Birds of passage, both in the old and new continents, are observed generally to migrate southwest in autumn, and to pass to the northeast in spring. Parry, however, it seems, observed the birds of Greenland proceed to the southeast. This apparent aberration from the usual course may be accounted for by considering the habits of these aquatic birds. Intent on food and shelter, a part, bending their course over the cold regions of Norway and Russia, seek the shores of Europe; while another division, equally considerable, proceeding southwest, spread themselves over the interior of the United States and the coast and kingdom of Mexico.

This propensity to change their climate, induced by whatever cause, is not confined to the birds of temperate regions; it likewise exists among many of those who inhabit the tropics. 
Aquatic birds of several kinds, according to Humboldt, cross the line on either side about the time of the periodical rise of the rivers. Waterton, likewise, who spent much time in Demerara and the neighboring countries, observed that the visits of many of the tropical birds were periodical. Thus the wonderful Campanero, whose solemn voice is heard at intervals tolling like the convent-bell, was rare to Waterton, but frequent in Brazil, where it most probably retires to breed. The failure of particular food at any season, in the mildest climate, would be a sufficient incentive to a partial and overland migration with any species of the feathered race.

The longevity of birds is various, and, different from the case of man and quadrupeds, seems to bear but little proportion to the age at which they acquire maturity of character. A few months seems sufficient to bring the bird into full possession of all its native powers; and there are some, as our Marsh Titmouse or Chickadee, which, in fact, as soon as fledged, are no longer to be distinguished from their parents. Land animals generally live six or seven times as long as the period required to attain maturity; but in birds the rate is ten times greater. In proportion to their size, they are also far more vivacious and long-lived than other animals of the superior class. Our knowledge of the longevity of birds is, however, necessarily limited to the few examples of domesticated species which we have been able to support through life: the result of these examples is, that our domestic Fowls have lived twenty years; Pigeons have exceeded that period; Parrots have attained more than thirty years. Geese live probably more than half a century ; a Pelican has lived to eighty years ; and Swans, Ravens, and Eagles have exceeded a century. Even Linnets, in the unnatural restraints of the cage, have survived for fourteen or fifteen years, and Canaries twenty-five. To account for this remarkable tenacity of life, nothing very satisfactory has been offered; though Buffon is of opinion that the soft and porous nature of their bones contributes to this end, as the general ossification and rigidity of the system perpetually tends to abridge the boundaries of life. 
In a general way it may be considered as essential for the bird to fly as it is for the fish to swim or the quadruped to walk; yet in all these tribes there are exceptions to the general habits. Thus among quadrupeds the bats fly, the seals swim, and the beaver and otter swim better than they can walk. So also among birds, the Ostrich, Cassowary, and some others, incapable of flying, are obliged to walk ; others, as the Dippers, fly and swim but never walk. Some, like the Swallows and Humming Birds, pass their time chiefly on the wing. A far greater number of birds live on the water than of quadrupeds, for of the latter there are not more than five or six kinds furnished with webbed or oar-like feet, whereas of birds with this structure there are several hundred. The lightness of their feathers and bones, as well as the boat-like form of their bodies, contributes greatly to facilitate their buoyancy and progress in the water, and their feet serve as oars to propel them.

Thus in whatever way we view the feathered tribes which surround us, we shall find much both to amuse and instruct. We hearken to their songs with renewed delight, as the harbingers and associates of the season they accompany. Their return, after a long absence, is hailed with gratitude to the Author of all existence; and the cheerless solitude of inanimate Nature is, by their presence, attuned to life and harmony. Nor do they alone administer to the amusement and luxury of life; faithful aids as well as messengers of the seasons, they associate round our tenements, and defend the various productions of the earth, on which we so much rely for subsistence, from the destructive depredations of myriads of insects, which, but for timely riddance by unnumbered birds, would be followed by a general failure and famine. Public economy and utility, then, no less than humanity, plead for the protection of the feathered race; and the wanton destruction of birds, so useful, beautiful, and amusing, if not treated as such by law, ought to be considered as a crime by every moral, feeling, and reflecting mind. 


\section{ORNITHOLOGY}

OF THE

\section{UNITED STATES AND CANADA.}




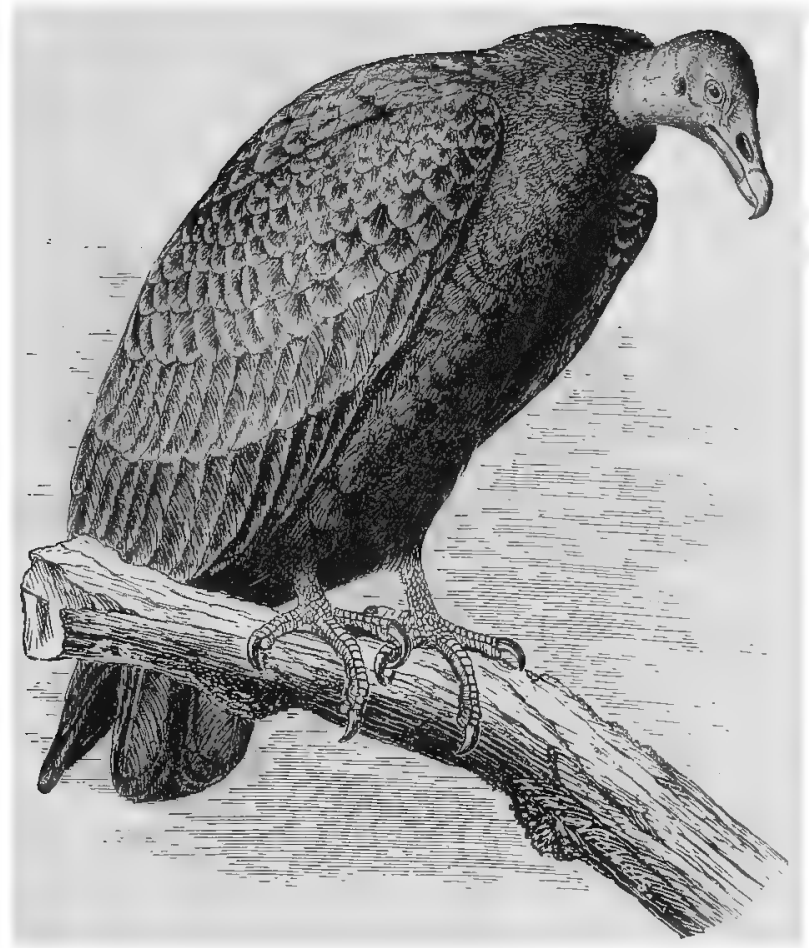

TURKEY VULTURE.

TURKEY BUZZARD.

Cathartes aURa.

CHAR. Brownish black; head bare of feathers and bright red; bill white; length about 2 feet.

Nest. In a stump, or cavity among rocks, without additional material.

$E_{\text {gggs, }}$; white, or with a tinge of green or yellow, spotted with brown and purple; $2.75 \times$ r.go.

This common Turkey-like Vulture is found abundantly in both North and South America, but seems wholly to avoid the Northeastern or New England States, a straggler being seldom seen as far as the latitude of $4 \mathrm{I}^{\circ}$. Whether this limit arises from some local antipathy, their dislike of the cold eastern storms which prevail in the spring till the time they usually

VOL. I. - I 
breed, or some other cause, it is not easily assignable; and the fact is still more remarkable, as they have been observed in the interior by Mr. Say as far as Pembino, in the 49th degree of north latitude, by Lewis and Clarke near the Falls of the Oregon, and they are not uncommon throughout that territory. They are, however, much more abundant in the warmer than in the colder regions, and are found beyond the equator, even as far or farther than the La Plata. All the West India islands are inhabited by them, as well as the tropical continent, where, as in the Southern States of the Union, they are commonly protected for their services as scavengers of carrion, which would prove highly deleterious in those warm and humid climates. In the winter they generally seek out warmth and shelter, hovering often like grim and boding spectres in the suburbs, and on the roofs and chimneys of the houses, around the cities of the Southern States. A few brave the winters of Maryland, Delaware, and New Jersey, but the greater part migrate south at the approach of cold weather.

The Turkey Buzzard has not been known to breed north of New Jersey in any of the Atlantic States. Here they seek out the swampy solitudes, and, without forming any nest, deposit two eggs in the stump of a hollow tree or log, on the mere fragments of rotten wood with which it is ordinarily strewed. Occasionally, in the Southern States, they have been known to make choice of the ruined chimney of a deserted house for this purpose. The eggs are larger than those of a Turkey, of a yellowish white, irregularly blotched with dark brown and blackish spots, chiefly at the larger end. The male often attends while the female is sitting; and if not materially disturbed, they will continue to occupy the same place for several years in succession.

The young are covered with a whitish down, and, in common with the habit of the old birds, will often eject, upon those who happen to molest them, the filthy contents of their stomachs.

In the cities of the South they appear to be somewhat gregarious, and as if aware of the protection afforded them, present themselves often in the streets, and particularly near the 
shambles. They also watch the emptying of the scavengers' carts in the suburbs, where, in company with the still more domestic Black Vultures, they search out their favorite morsels amidst dust, filth, and rubbish of all descriptions. Bits of cheese, of meat, fish, or anything sufficiently fotid, and easy of digestion, is greedily sought after, and eagerly eyed. When the opportunity offers they eat with gluttonous voracity, and fill themselves in such a manner as to be sometimes incapable of rising from the. ground. They are accused at times of attacking young pigs and lambs, beginning their assault by picking out the eyes. Mr. Waterton, however, while at Demerara watched them for hours together amidst reptiles of all descriptions, but they never made any attack upon them. He even killed lizards and frogs and put them in their way, but they did not appear to notice them until they attained the putrid scent. So that a more harmless animal, living at all upon flesh, is not in existence, than the Turkey Vulture.

At night they roost in the neighboring trees, but, I believe, seldom in flocks like the Black kind. In winter they sometimes pass the night in numbers on the roofs of the houses in the suburbs of the Southern cities, and appear particularly desirous of taking advantage of the warmth which they discover to issue from the chimneys. Here, when the sun shines, they and their black relatives, though no wise social, may be observed perched in these conspicuous places basking in the feeble rays, and stretching out their dark wings to admit the warmth directly to their chilled bodies. And when not engaged in acts of necessity, they amuse themselves on fine clear days, even at the coolest season of the year, by soaring, in companies, slowly and majestically into the higher regions of the atmosphere; rising gently, but rapidly, in vast spiral circles, they sometimes disappear beyond the thinnest clouds. They practise this lofty flight particularly before the commencement of thunder-storms, when, elevated above the war of elements, they float at ease in the ethereal space with outstretched wings, making no other apparent effort than the light balloon, only now and then steadying their sailing pinions as they spread 
them to the fanning breeze, and become abandoned to its accidental sports. In South America, according to Humboldt, they soar even in company with the Condor in his highest flights, rising above the summits of the tropical Andes.

Examples of this species still wander occasionally to New England and to Grand Menan, and in 1887 Mr. Philip Cox reported the capture of two near the mouth of the Miramichi River, on the Gulf of St. Lawrence, in latitude $47^{\circ}$. It occurs regularly on the St. Clair Flats, in Ontario.

The Vultures are not classed as the first of birds by the systematists of the present day. Now the singing-birds - the Oscines arc considered the most highly developed, and of these the Thrush family is given highest rank. The Vultures are classed as the lowest of the birds of prey; and this entire order has been moved down below the Swifts and the Woodpeckers.

\section{BLACK VULTURE.}

\section{CARRION CROW.}

\section{CathaRista ATRATA.}

CHAR. Dull black; head dusky and partially covered above with feathers. Length about 2 feet.

Nest. On the ground screened by bushes, or in a stump. (No attempt is made to build a nest or even to lay a cushion for the eggs.)

Eggs. I-3 (usually 2); bluish white, marked with several shades of brown; $3.10 \times 2.05$.

This smaller, black, and truly gregarious species of Vulture in the United States appears to be generally confined to the Southern States, and seems to be most numerous and familiar in the large maritime towns of North and South Carolina, Georgia, and Florida. They are also met with in several of the Western States, and as far up the Ohio as Cincinnati. In the tropical regions of America they are also very common, and extend at least as far as Chili. Like the former species, with which they associate only at meal-times, they are tacitly allowed a public protection for the service they render in ridding the earth of carrion and other kinds of filth. They are 
much more familiar in the towns than the preceding, delighting, during winter, to remain on the roofs of houses, catching the feeble rays of the sun, and stretching out their wings to admit the warm air over their foetid bodies. When the weather becomes unusually chilly, or in the mornings, they may be seen basking upon the chimneys in the warm smoke, which, as well as the soot itself, can add no additional darkness or impurity to such filthy and melancholy spectres. Here, or on the limbs of some of the larger trees, they remain in listless indolence till aroused by the calls of hunger.

Their flight is neither so easy nor so graceful as that of the Turkey Buzzard. They flap their wings and then soar horizontally, renewing the motion of their pinions at short intervals. At times, however, they rise to considerable elevations. In the cities of Charleston and Savannah they are to be seen in numbers walking the streets with all the familiarity of domestic Fowls, examining the channels and accumulations of filth in order to glean up the offal or animal matter of any kind which may happen to be thrown out. They appeared to be very regular in their attendance around the shambles, and some of them become known by sight. This was particularly the case with an old veteran who hopped upon one foot (having by some accident lost the other), and had regularly appeared round the shambles to claim the bounty of the butchers for about twenty years. In the country, where I have surprised them feeding in the woods, they appeared rather shy and timorous, watching my movements alertly like Hawks; and every now and then one or two of them, as they sat in the high boughs of a neighboring oak, communicated to the rest, as I slowly approached, a low bark of alarm, or waugh, something like the suppressed growl of a puppy, at which the whole flock by degrees deserted the dead hog upon which they happened to be feeding. Sometimes they will collect together about one carcase to the number of two hundred and upwards; and the object, whatever it may be, is soon robed in living mourning, scarcely anything being visible but a dense mass of these sable scavengers, who may often be 
seen jealously contending with each other, both in and out of the carcase, defiled with blood and filth, holding on with their feet, hissing and clawing each other, or tearing off morsels so as to fill their throats nearly to choking, and occasionally joined by growling dogs, - the whole presenting one of the most savage and disgusting scenes in nature, and truly worthy the infernal bird of Prometheus.

This species is very rarely seen north of the Carolinas, though a few examples have been taken in New England and at Grand Menan.

\section{AUDUBON'S CARACARA. \\ CARACARA EAGLE. KING BUZZARD.}

POLYBORUS CHERIWAY.

CHAR. General color brownish black; fore part of back and breast barred with white; tail white, with bars of black. Length $20 \frac{1}{2}$ to 25 inches.

Nest. On a low tree or bush; made of sticks and leaves.

Eggs. 2-4 (usually 2); brownish white or pale brown, blotched with deeper brown; $2.30 \times 1.75$.

This very remarkable and fine bird was first met with by $\mathrm{Mr}$. Audubon near St. Augustine, in East Florida. He afterwards also found it on Galveston Island, in Texas. From its general habits and graceful, sweeping flight, it was for some time mistaken for a Hawk. Though common in many parts of South America, it is within the limits of the United States merely an accidental visitor. It is said, however, to breed in Florida, in the highest branches of tall trees in the pine-barrens, making a rough nest of sticks like a Hawk. In Texas it breeds, according to Audubon, in the tops of bushes.

Since Nuttall wrote, the Caracara has been found in numbers in parts of Florida, and it is not uncommon in Texas, southern Arizona, and Lower California. 


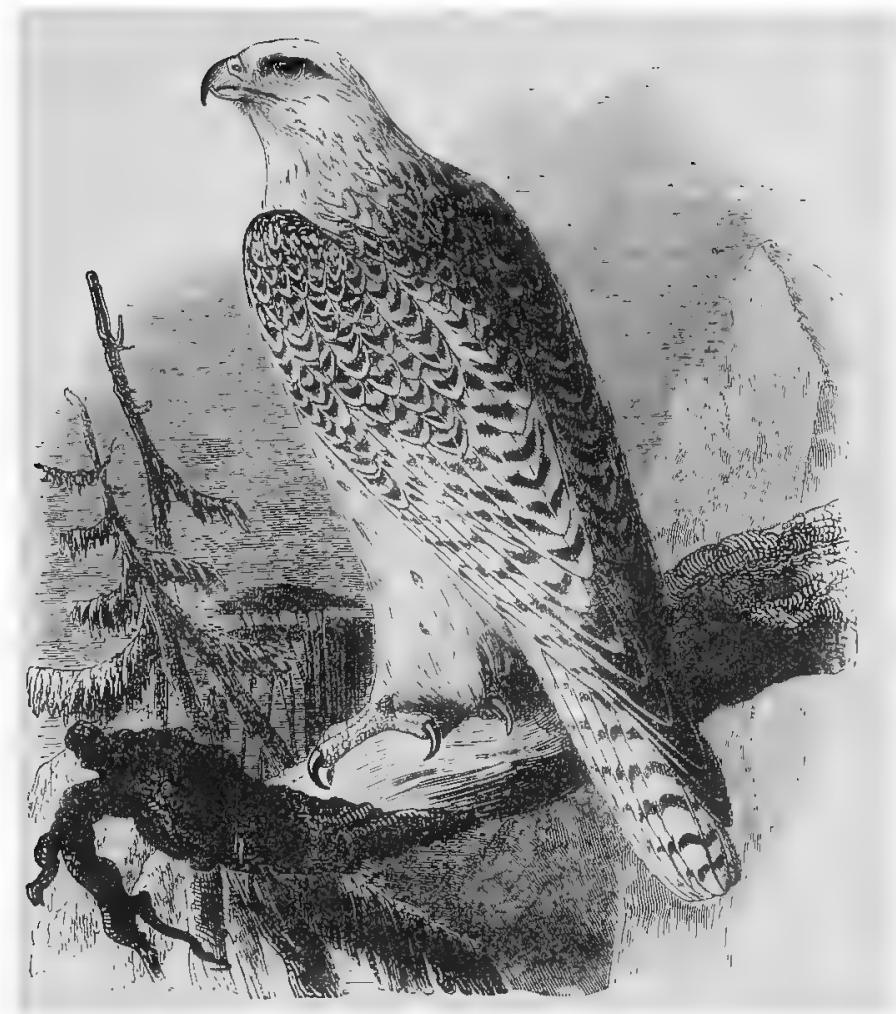

\section{WHITE GYRFALCON.}

FALCO ISLANDUS.

ChAR. Prevailing color white, often immaculate, but usually with dark markings. Legs partially feathered. A sharp tooth near point of upper mandible; the end of under mandible notched. Length 21 to 24 inches.

Nest. Usually on a cliff; roughly made of sticlss, - large dry twigs.

Eggs. 3-4; buff or brownish, marked with reddish brown; 2.25 $\times \mathbf{I} 25$.

\section{GRAY GYRFALCON.}

\section{Falco Rusticolus.}

ChAR. Prevailing color dull gray, with whitish and slaty-blue bands and spots; sometimes white prevails; thighs usually barred. 


\section{GYRFALCON. \\ Faico rusticolus gyrfalco.}

CHAR. Upper parts dull brownish (dusky), with bars of bluish gray; lower parts white, or mostly white marked with dusky; thighs heavily barred.

\section{BLACK GYRFALCON.}

\section{Falco RUSTiColus obsoletus.}

CHAR. Prevailing color brownish black; usually barred with lighter tints, but sometimes the bars are indistinct.

This elegant and celebrated Falcon is about two feet in length; the female two or three inches longer. They particularly abound in Iceland, and are found also throughout Siberia, and the North of Europe as far as Greenland; Mr. Hutchins, according to Pennant, saw them commonly about Fort Albany, at Hudson's Bay. Occasionally a pair is also seen in this vicinity in the depth of winter. They brave the coldest climates, for which they have such a predilection as seldom to leave the Arctic regions; the younger birds are commonly seen in the North of Germany, but very rarely the old, which are readily distinguished by the superior whiteness of their plumage, which augments with age, and by the increasing narrowness of the transverse stripes that ornament the upper parts of the body. The finest of these Falcons were caught in Iceland by means of baited nets. The bait was commonly a Ptarmigan, Pigeon, or common Fowl; and such was the velocity and power of his pounce that he commonly severed the head from the baited bird as nicely as if it had been done by a razor. These birds were reserved for the kings of Denmark, and from thence they were formerly transported into Germany, and even Turkey and Persia. The taste for the amusement of falconry was once very prevalent throughout Europe, and continued for several centuries; but at this time it has almost wholly subsided. The Tartars, and Asiatics generally, were also equally addicted to this amusement. A Sir 
Thomas Monson, no later than the reign of James the First, is said to have given a thousand pounds for a cast of Hawks.

Next to the Eagle, this bird is the most formidable, active, and intrepid, and was held in the highest esteem for falconry. It boldly attacks the largest of birds; the Swan, Goose, Stork, Heron, and Crane are to it easy victims. In its native regions it lives much on the hare and Ptarmigan; upon these it darts with astonishing velocity, and often seizes its prey by pouncing upon it almost perpendicularly. It breeds in the cold and desert regions where it usually dwells, fixing its nests amidst the most lofty and inaccessible rocks.

Nuttall treated the four forms as one, while I follow the A. O. U. in separating them; though I do not think that the present classification will be retained. The accessible material is very limited, but it appears to indicate that there is but one species with two, or possibly three, geographical races. The nests and eggs and the habits are similar, the difference being entirely that of plumage, - the prevalence of the dark or white color.

The White breeds chiefly in North Greenland and along the borders of the Arctic Ocean; the Gray breeds in South Greenland; the Black is restricted to Labrador; and the habitat of gyrfalco is given as "interior of Arctic America from Hudson's Bay to Alaska." Specimens of all four have been taken south of latitude $45^{\circ}$, and a few of the Black have been taken, in winter, as far south as southern New England and New York.

Note. - A few examples of the Prairie Falcon (Falco mexicanus) have accidentally wandered to the prairie districts of Illinois.

\section{DUCK HAWK.}

PEREGRINE FALCON. GREAT-FOOTED HAWK.

\section{FALCO PEREGRINUS ANATUM.}

CHAR. Above, bluish ash or brownish black, the edges of the feathers paler; below, ashy or dull tawny, with bars or streaks of brownish; a black patch on the cheeks. Bill of bluish color, and toothed and notched, as in all true Falcons; cere yellow. Wing long, thin, and pointed. Length 17 to 19 inches. 
Nest. On tree or cliff; a loosely arranged platform of dry sticks, sometimes partially lined with grass, leaves, or moss.

Eggs. 2-4; reddish brown - sometimes of bright tint - marked with dull red and rich brown; $2.10 \times 1.60$.

The celebrated, powerful, and princely Falcon is common both to the continent of Europe and America. In the former they are chiefly found in mountainous regions, and make their nests in the most inaccessible clefts of rocks, and very rarely in trees, laying 3 or 4 eggs of a reddish-yellow, with brown spots. In Europe they seldom descend to the plains, and avoid marshy countries. The period of incubation lasts but a short time, and commences in winter, or very early in the spring, so that the young acquire their full growth by the middle of May. They are supposed to breed in the tall trees of the desolate cedar swamps in New Jersey. Audubon, however, found them nesting on shelving rocks on the shores of Labrador and Newfoundland, laying from 2 to 5 eggs of a rusty yellowish brown, spotted and blotched with darker tints of the same color. They also breed on shelving rocks in the Rocky Mountains, where Mr. Townsend obtained a specimen on Big Sandy River of the Colorado of the West in the month of July. When the young have attained their growth, the parents drive them from their haunts, with incessant and piercing screams and complaints, - an unnatural propensity which nothing but dire necessity, the difficulty of acquiring sustenance, can palliate.

In strength and temerity the Falcon is not exceeded by any bird of its size. He soars with easy and graceful motions amidst the clouds or clear azure of the sky; from this lofty elevation he selects his victim from among the larger birds, Grouse, Pheasants, Pigeons, Ducks, or Geese. Without being perceived, he swiftly descends, as if falling from the clouds in a perpendicular line, and carries terror and destruction into the timid ranks of his prey. Instead of flying before their relentless enemy, the Partridge and Pheasant run and closely hide in the grass, the Pigeons glance aside to avoid the fatal blow which is but too sure in its aim, and the Water Fowls seek 
a more certain refuge in diving beneath their yielding element. If the prey be not too large, the Falcon mounts into the air, bearing it off in his talons, and then alights to gorge himself with his booty at leisure. Sometimes he attacks the Kite, another fellow-plunderer, either in wanton insult, or more probably to rob him of his quarry.

The Peregrine is very generally distributed throughout America, but excepting on the Atlantic coast of Labrador, and possibly on Newfoundland, it is nowhere common in this faunal province. It is a winter visitor chiefly in Ohio and southern Ontario, but it is known to breed on isolated cliffs in the Maritime Provinces and the New England States, and it is said that nests have been found in Pennsylvania and Maryland. The report of its building in a swamp in New Jersey has not been confirmed.

\section{PIGEON HAWK.}

\section{Falco columbarius.}

CHAR. Generally the prevailing color, above, is blackish brown, though the older birds assume a dull tint approaching bluish gray; wings, back, and tail streaked and barred with buffy or recldish brown. Tail tipped with white; the middle tail-feathers in male with four bands of blackish, and in female about six pale bands. Below, dull, pale reddish brown, lighter on breast and throat. Length I $\mathrm{I}$ to $\mathrm{I} 3$ inches.

$N_{i s t}$. Usually on branches of trees, though found sometimes in cavities of dead trees and on cliffs; loosely built of twigs, and lined with grass and leaves.

Eggs. 3-6; buffy or pale reddish-brown ground color, blotched with dull red and brown; $1.30 \times \mathbf{1 . 5 5}$.

This species is a little larger than the following, but by no means so abundant; though met with in latitude forty-eight degrees by Long's Northwestern Expedition, and occasionally extending its migrations from Texas to Hudson's Bay, and rearing its young in the interior of Canada. Its nest was also observed by Audubon in Labrador in the low fir-trees, and contained five eggs, laid about the ist of June. It is shy, skulking, and watchful, seldom venturing beyond the unreclaimed forest, and flies rapidly, but, I believe, seldom soars or hovers. 
Small birds and mice constitute its principal food; and according to Wilson, it follows often in the rear of the gregarious birds, such as the Blackbirds and Reedbirds, as well as after the flitting flocks of Pigeons and Robins, picking up the stragglers, the weak and unguarded, as its legitimate prey. Sometimes, when shot at without effect, it will fly in circles around the gunner and utter impatient shrieks, - probably in apprehension for the safety of the mate, or to communicate a cry of alarm.

The Pigeon Hawk is not a common bird in Massachusetts, though a few pairs breed in the State; and it has been found in summer in Connecticut, as well as in Illinois and Ohio, though McIlwraith considers it a migrant only in southern Ontario. It breeds sparingly in the northern portions of New England, the Maritime Provinces of Canada and north to the lower fur countries, and in winter ranges to the Southern States.

Note. - One example of the European Merlin (Falco regulus) has been captured off the coast of Greenland. 


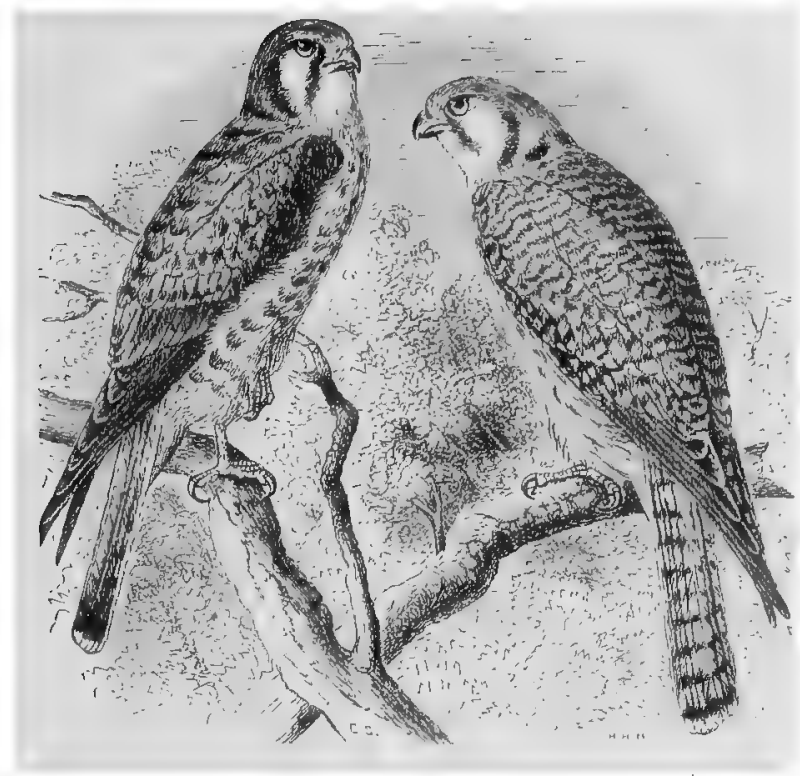

\section{AMERICAN SPARROW HAWK.}

\section{FaLCo SPARVERIUS.}

CHAR. Adult male : head bluish ash, with reddish patch on crown, and black patch on sides and nape; back rufous; wings bluish and black in bars; tail tawny, with black band, and tipped with white; below, buffish or tawny. Female: rufous and black, more streaked than the male; the tail tawny, with several blackish bars. Length to to II inches.

Nest. Usually in cavities of trees, often in Woodpecker's holes, sometimes in deserted nest of a Crow.

Eggs. 5-7; buffish, occasionally white, blotched with dull red and brown; I.33 X I.12.

This beautiful and singularly marked bird appears to reside principally in the warmer parts of the United States. They are particularly abundant in the winter throughout South Carolina, Georgia, Alabama, and Florida, whither they assemble from the remote interior of the Northern States, wandering in summer as far as the Rocky Mountains, and were even seen by Dr. Richardson in the remote latitude of $53^{\circ}$; these appear, however, to be only stragglers, nor do they seem at all to visit 
the maritime districts of New England. As they were seen in St. Domingo; by Veillot, abundantly in April and May, the breeding-season, we may naturally conclude that this species has a much greater predilection for the warm than the cold climates. On the south side of the equator, even in Cayenne and Paraguay, they are still found, in all of which countries they probably breed.

According to the habits of this tribe of rapacious birds it appears that the nest is built in a hollow, shattered, or decayed tree at a considerable elevation.

Its motions appear somewhat capricious; it occasionally hovers with beating wings, reconnoitring for prey, and soon impatiently darts off to a distance to renew the same manœuvre. In the winter, however, it is most commonly seen perched on some dead branch, or on a pole or stalk in the fields, often at a little distance from the ground, keeping up a frequent jerking of the tail, and attentively watching for some such humble game as mice, grasshoppers, or lizards. At this time it is likewise so familiar as to enter the garden, orchard, or premises near to the house, and shows but little alarm on being approached. It is, however, by no means deficient in courage, and, like the larger Falcons, often makes a fatal and rapid sweep upon Sparrows or those small birds which are its accustomed prey.

Instead of being a mere straggler outside the warmer portions of the United States, as Nuttall appears to have considered this Falcon, it is quite common throughout most of the continent, and not only breeds in New England, but winters there. It breeds also throughout Canada, north to the lower fur countries, and retires to the Southern States during the cold weather.

Note. - The Cuban SPARrow Hawk (Falco sparverioides) has been found in Florida; and two examples of the Kestrel (Falco tinunculus) bave been captured on this side of the Atlantic, - one off the coast of Greenland, and the other at Nantasket, Mass., in 1887. 


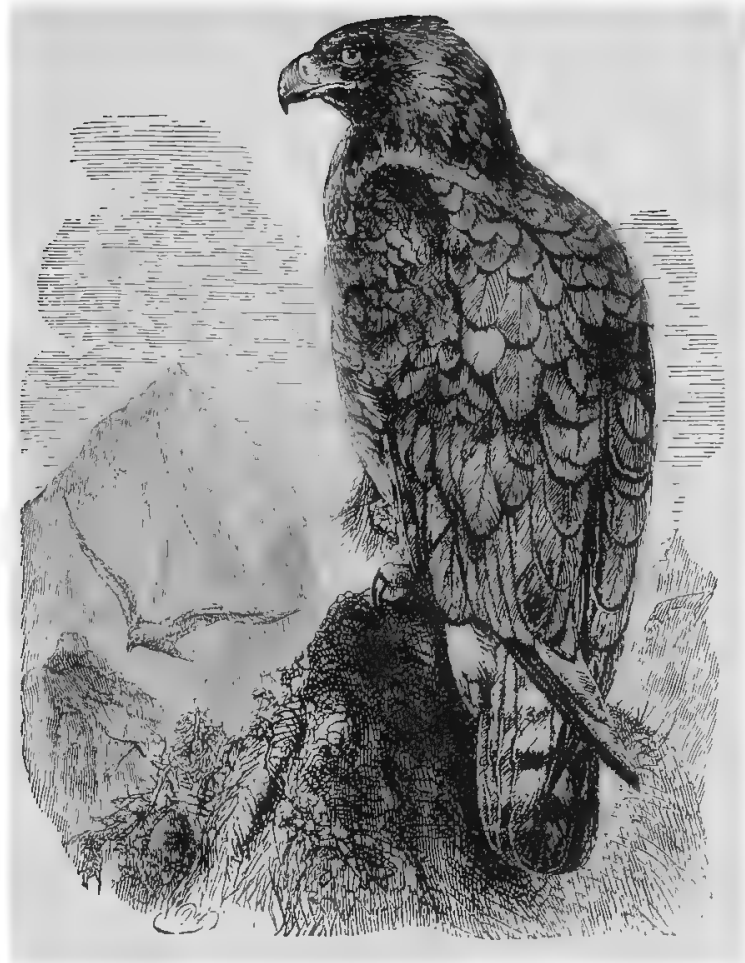

\section{GOLDEN EAGLE.}

\section{Aquila CHRYSAËTOS.}

ChAR. Dark brown, head and neck tawny brown; legs feathered to the toes; in the young, tail whitish, with broad terminal band of black.

Nest. On a tree, sometimes on a high cliff; loosely built of dry sticks, lined with twigs, grass, moss, leaves, and feathers.

Eggs. 2-3 (usually 2); dull white or pale buff, spotted and blotched more or less thickly with reddish brown and lavender; $3.00 \times 2.30$.

This ancient monarch of the birds is found in all the cold and temperate regions of the northern hemisphere, taking up his abode by choice in the great forests and plains, and in wild, desert, and mountainous regions. His eyry, commonly formed of an extensive set of layers of large sticks, is nearly horizontal, and occasionally extended between some rock and adjoining 
tree, as was the one described by Willughby in the Peak of Derbyshire. About thirty miles inland from the Mandan Fort on the Missouri I once had occasion to observe the eyry of this noble bird, which here consisted of but a slender lining of sticks conveyed into a rocky chasm on the face of a lofty hill rising out of the grassy, open plain. It contained one young bird, nearly fledged, and almost of the color of the Gyrfalcon. Near their rocky nests they are seen usually in pairs, at times majestically soaring to a vast height and gazing on the sun, towards which they ascend until they disappear from view. From this sublime elevation they often select their devoted prey, - sometimes a kid or a lamb from the sporting flock, or the timid rabbit or hare crouched in the furrow or sheltered in some bush. The largest birds are also frequently their victims; and in extreme want they will not refuse to join with the alarmed Vulture in his cadaverous repast. After this gorging meal the Eagle can, if necessary, fast for several days. The precarious nature of his subsistence and the violence by which it is constantly obtained seem to produce a moral effect on the disposition of this rapacious bird: though in pairs, they are never seen associated with their young; their offspring are driven forth to lead the same unsocial, wandering life as their unfeeling progenitors. This harsh and tyrannical disposition is strongly displayed.even when they lead a life of restraint and confinement. The weaker bird is never willingly suffered to eat a single morsel; and though he may cower and quail under the blow with the most abject submission, the same savage deportment continues towards him as long as he exists. Those which I have seen in confinement frequently uttered hoarse and stridulous cries, sometimes almost barkings, accompanied by vaporous breathings, strongly expressive of their ardent, unquenchable, and savage appetites. Their fire-darting eyes, lowering brows, flat foreheads, restless disposition, and terrific plaints, together with their powerful natural weapons, seem to assimilate them to the tiger rather than the timorous bird. Yet it would appear that they may be rendered docile, as the Tartars (according to Marco Polo in 1269 ) were said to train 
this species to the chase of hares, foxes, wolves, antelopes, and other kinds of large game, in which it displayed all the docility of the Falcon. The longevity of the Eagle is as remarkable as its strength; it is believed to subsist for a century, and is about three years in gaining its complete growth and fixed plumage. This bird was held in high estimation by the ancients on account of its extraordinary magnitude, courage, and sanguinary habits. The Romans chose it as an emblem for their imperial standard; and from its aspiring flight and majestic soaring it was fabled to hold communication with heaven and to be the favorite messenger of Jove. The Tartars have a particular esteem for the feathers of the tail, with which they superstitiously think to plume invincible arrows. It is no less the venerated War-Eagle of our Northern and Western aborigines; and the caudal feathers are extremely valued for talismanic head-dresses and as sacred decorations for the Pipe of Peace.

The Eagle appears to be more abundant around Hudson's Bay than in the United States; but they are not unfrequent in the great plains of the Mississippi and Missouri, as appears from the frequent use of the feathers by the natives. The wilderness seems their favorite resort, and they neither crave nor obtain any advantage from the society of man. Attached to the mountains in which they are bred, it is a rare occurrence to see the Eagle in this vicinity; and, as with some other birds, it would appear that the young only are found in the United States, while the old remain in Labrador and the northern regions. The lofty mountains of New Hampshire afford suitable situations for the eyry of the Eagle, over whose snow-clad summits he is seen majestically soaring in solitude and grandeur. A young bird from this region, which $I$ have seen in a state of domestication, showed considerable docility. He had, however, been brought up from the nest, in which he was found in the month of August; he appeared even playful, turning his head about in a very antic manner, as if desirous to attract attention, - still, his glance was quick and fiery. When birds were given to him, he plumed them very clean before he began his meal, and picked the subject to a perfect skeleton.

VOL. I. - 2 
The ferocious and savage nature of the Eagle, in an unreclaimed state, is sometimes displayed in a remarkable manner. A peasant attempted to rob an eyry of this bird situated at the Lake of Killarney: for this purpose he stripped and swam over to the spot in the absence of the old birds; but on his return, while yet up to the chin in water, the parents arrived, and missing their young, instantly fell on the unfortunate plunderer and killed him on the spot.

There are several well-authenticated instances of their carrying off children to their nests. In 1737 , in the parish of Norderhougs, in Norway, a boy over two years old, on his way from the cottage to his parents, at work in the fields at no great distance, fell into the pounce of an Eagle, who flew off with the child in their sight, and was seen no more. Anderson, in his history of Iceland, says that in that island children of four or five years of age have occasionally been borne away by Eagles; and Ray relates that in one of the Orkneys a child of a year old was seized in the talons of this ferocious bird and carried about four miles to its nest, but the mother, knowing the place of the eyry, followed the bird, and recovered her child yet unhurt.

The Common, or Ring-tailed Eagle, is now found to be the young of the Golden Eagle. These progressive changes have been observed by Temminck on two living subjects which he kept for several years.

The Golden Eagle is generally considered to be a rare bird in New England and Canada, and, indeed, throughout the settled districts everywhere; though examples have been taken the continent over, from Greenland to Mexico, and west to the Pacific. 


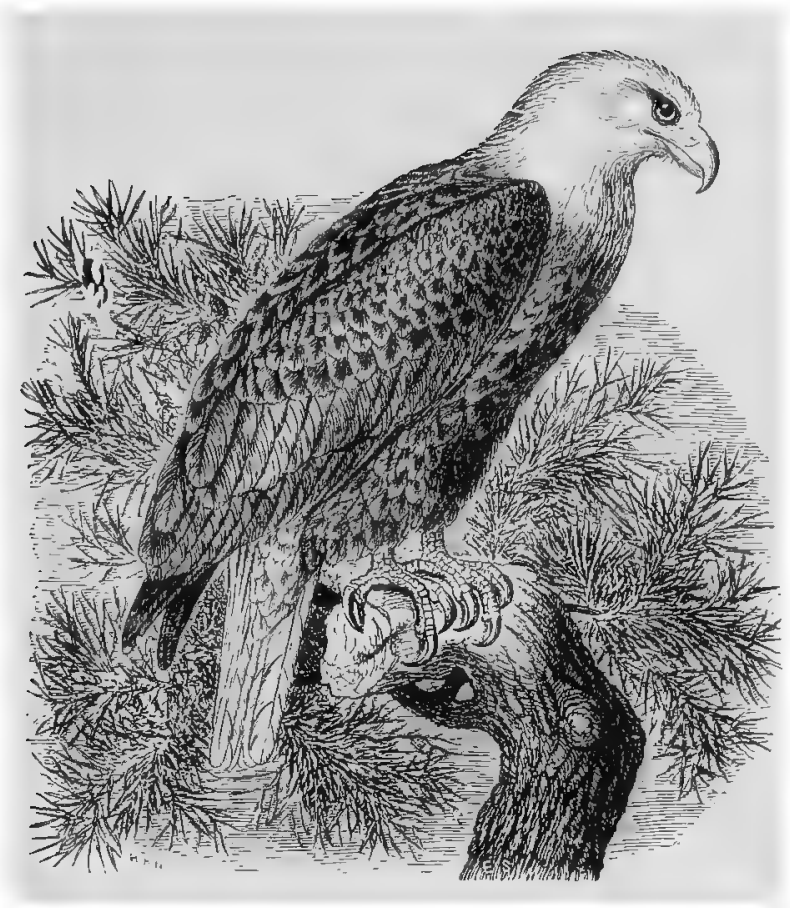

BALD EAGLE.

\section{WASHINGTON EAGLE.}

\section{Halieetus leucocephalus.}

CHar. Adult : blackish brown, paler on margin of feathers; head and tail white after third year; bill and feet yellow; legs bare of feathers. Young: darker than the adult; no white on head or tail (or concealed by contour feathers); bill and feet brownish.

Length 30 to 40 inches. (The young are larger than the adult birds, and are very similar to the young of the Golden Eagle, though the latter are easily distinguished by their feathered legs.)

Nest. On a high tree, usually in a crotch, seldom on a dead tree, sometimes on a cliff; made of dry sticks loosely arranged, and occasionally weed-stems and coarse grass are added; but there israrely any attempt at a lining.

Eggs. 2-3; white or pale buff ; $2.90 \times 2.25$. 
The Washington Ecgle. - It is to the indefatigable Audubon that we owe the distinct note and description of this noble Eagle, which first drew his attention while voyaging far up the Mississippi, in the month of February, I8 I4. At length he had the satisfaction of discovering its eyry, in the high cliffs of Green River, in Kentucky, near to its junction with the Ohio: two young were discovered loudly hissing from a fissure in the rocks, on the approach of the male, from whom they received a fish. The female now also came, and with solicitous alarm for the safety of her young, gave a loud scream, dropped the food she had brought, and hovering over the molesting party, kept up a growling and threatening cry by way of intimidation; and in fact, as our disappointed naturalist soon discovered, she from this time forsook the spot, and found means to convey away her young. The discoverer considers the species as rare, - indeed, its principal residence appears to be in the northern parts of the continent, particularly the rocky solitudes around the Great Northwestern Lakes, where it can at all times collect its finny prey and rear its young without the dread of man. In the winter season, about January and February, as well as at a later period of the spring, these birds are occasionally seen in this vicinity (Cambridge, Mass.),-rendered perhaps bolder and more familiar by want, as the prevalence of the ice and cold at this season drives them to the necessity of wandering farther than usual in search of food. At this early period Audubon observed indications of the approach of the breeding-season. They are sometimes seen contending in the air, so that one of the antagonists will suddenly drop many feet downwards, as if wounded or alarmed. My friend Dr. Hayward, of Boston, had in his possession one of these fine, docile Eagles for a considerable time; but desirous of devoting it to the then Linnæan Museum, he attempted to poison it by corrosive sublimate of mercury: several times, however, doses even of two drams were given to it, concealed in fish, without producing any injurious effect on its health.

The Washington Eagle, bold and vigorous, disdains the piratical habits of the Bald Eagle, and invariably obtains his 
own sustenance without molesting the Osprey. The circles he describes in his flight are wicler than those of the Whiteheaded Eagle; he also flies nearer to the land or the surface of the water; and when about to dive for his prey, he descends in circuitous, spiral rounds, as if to check the retreat of the fish, on which he darts only when within the distance of a few yards. When his prey is obtained, he flies out at a low elevation to a considerable distance to enjoy his repast at leisure. The quantity of food consumed by this enormous bird is very great, according to the account of those who have had them in confinement. Mr. Audubon's male bird weighed fourteen and one half pounds avoirdupois. One in a small museum in Philadelphia (according to the account of my friend Mr. C. Pickering), also a male, weighed much more, -- by which difference it would appear that they are capable of becoming exceedingly fat; for the length of this bird was about the same as that of Audubon, - three feet six or seven inches. The width, however, was only about seven feet, - agreeing pretty nearly with a specimen now in the New England Museum. The male of the Golden Eagle, the largest hitherto known, is seldom more than three feet long.

That this bird is not the White-tailed Eagle (Falco albicilla), or its young, the Sea Eagle ( $F$. ossifragus), is obvious from the difference in size alone, the male of that bird being little over two feet four inches in length, or a little less even than the Bald Eagle. The female of the Washington Eagle must, of course, be six or eight inches longer, which will give a bird of unparalleled magnitude amongst the whole Eagle race. This measurement of the Sea Eagle is obtained from Temminck's "Manual of Ornithology," who has examined more than fifty individuals. At the same time I have a suspicion that the Washington Eagle, notwithstanding this, exists also in Europe; as the great Sea Eagle of Brisson is described by this author as being three feet six inches in length from the point of the bill to the end of the tail, and the stretch of the wings about seven feet! These measurements also are adopted by Buffon; but the individuals were evidently in young 
plumage, in which state, as described by Brisson, they again approach the present species. Nor need it be considered as surprising if two different species be confounded in the Sea Eagle of Europe, as the recently established Imperial Eagle had ever been confounded with the Golden. Another distinguishing trait of the Washington Eagle is in the length of the tail, which is one and one half inches longer than the folded wings. In the White-tailed species this part never extends beyond the wings.

The White-headed or Bald Eagle. - This noble and daring Eagle is found along the sea-coasts, lakes, and rivers throughout the northern regions, being met with in Asia, Europe, and America, where they extend to the shores of the Pacific, and as far as the confines of California. In Behring's Isle, Mackenzie's River, and Greenland, they are not uncommon. But while they are confined in the Old World to this cheerless region so constantly that only two instances are known of their appearance in the centre of Europe, in the United States they are most abundant in the milder latitudes, residing, breeding, and rearing their young in all the intermediate space from Nova Scotia or Labrador to the shores of the Gulf of Mexico. The rocky coast of this part of New England (Massachusetts) is, however, seldom tenanted by this species, though they are occasionally seen in the spring and about the commencement of winter. In the United States it is certain that they show a decided predilection for the milder climates. It is probable that in Europe they are deterred in their migrations by the tyrannical persecution of the White-tailed Eagle ( $F$. albicilla), which abounds in that country, living also principally on fish, and therefore selecting the same maritime situations as our Eagle. In the United States he sways almost without control the whole coast of the Atlantic, and has rendered the rival Osprey his humble tributary, proscribing, in his turn, the appearance of the Sea Eagle, which, if it exist at all with us, is equally as rare as the present species appears to be in Europe. Though on Behring's Isle the Bald Eagle is said to nest on 
cliffs, as the only secure situation that probably offers, in the United States he usually selects, near the sea-coast, some lofty pine or cypress tree for his eyry; this is built of large sticks, several feet in length, forming a floor, within and over which are laid sods of earth, hay, moss, dry reeds, sedge-grass, pinetops, and other coarse materials, piled after several incubations to the height of 5 or 6 feet, and 4 or 5 feet in breadth. On this almost level bed the female early in February deposits two dull white eggs, one of which is said sometimes to be laid after an interval so considerable that the young are hatched at different periods. Lawson, however, says that they breed so often as to commence laying again under their callow young, whose warmth assists the hatching of the eggs. This eyry or breeding-place continues to be perpetually occupied and repaired as long as the tree endures, - indeed their attachment to particular places is so strong that after their habitation has been demolished, by the destruction of the tree that supported it, they have very contentedly taken possession of an adjoining one. Nor is the period of incubation the only time spent in the nest by this species; it is a shelter and common habitation at all times and seasons, being a home like the hut to the savage, or the cottage to the peasant.

The helpless young, as might be supposed, are fed with great attention, and supplied with such a superfluity of fish and other matters that they often lie scattered around the tree, producing the most putrid and noisome effluvia. The young are at first clothed with a whitish down; they gradually become gray, and continue of a brownish gray until the third year, when the characteristic white of the head and tail becomes perfectly developed. As their food is abundant, the young are not forcibly driven from the nest, but fed for some time after they have left it. They are by no means shy or timorous, will often permit a near approach, and sometimes even bristle up their feathers in an attitude of daring defence. Their cry is sonorous and lamentable, like that of the Great Eagle, and when asleep they are said to make a very audible snoring sound. 
The principal food of the Bald Eagle is fish; and though he possesses every requisite of alertness and keenness of vision for securing his prey, it is seldom that he obtains it by any other means than stratagem and rapine. For this habitual daring purpose he is often seen perching upon the naked limb of some lofty tree which commands an extensive view of the ocean. In this attitude of expectation he heedlessly surveys the active employment of the feathered throng, which course along the wavy strand, or explore the watery deep with beating wing, until from afar he attentively scans the motions of his provider, the ample-winged and hovering Osprey. At length the watery prey is espied, and the feathered fisher descends like a falling rock; cleaving the wave, he now bears his struggling victim from the deep, and mounting in the air, utters an exulting scream. At this signal the Eagle pirate gives chase to the fortunate fisher, and soaring above him, by threatening attitudes obliges him to relinquish his prey; the Eagle, now poising for a surer aim, descends like an arrow, and snatching his booty before it arrives at the water, retires to the woods to consume it at leisure. These perpetual depredations on the industrious Osprey sometimes arouse him to seek for vengeance, and several occasionally unite to banish their tyrannical invader. When greatly pressed by hunger, the Bald Eagle has sometimes been observed to attack the Vulture in the air, obliging him to disgorge the carrion in his craw, which he snatches up before it reaches the ground. $\mathrm{He}$ is sometimes seen also to drive away the Vultures, and feed voraciously on their carrion. Besides fish, he preys upon Ducks, Geese, Gulls, and other sea-fowl; and when the resources of the ocean diminish, or fail from any calse, particularly on the southern migration of the Osprey, his inland depredations are soon notorious, young lambs, pigs, fawns, and even deer often becoming his prey. So indiscriminate indeed is the fierce appetite of this bold bird that instances are credibly related of their carrying away infants. An attempt of this kind, according to Wilson, was made upon a child lying by its mother as she was weeding a garden at Great Egg- 
Harbor, in New Jersey; but the garment seized upon by the Eagle giving way at the instant of the attempt, the life of the child was spared. I have heard of another instance, said to have happened at Petersburgh, in Georgia, near the Savannah River, where an infant, sleeping in the shade near the house, was seized and carried to the eyry near the edge of a swamp five miles distant, and when found, almost immediately, the child was dead. The story of the Eagle and child, in "The History of the House of Stanley," the origin of the crest of that family, shows the credibility of the exploit, as supposed to have been effected by the White-tailed Eagle, so nearly related to the present. Indeed, about the year I 745 some Scotch reapers, accompanied by the wife of one of them with an infant, repaired to an island in Loch Lomond; the mother laid down her child in the shade at no great distance from her, and while she was busily engaged in labor, an Eagle of this kind suddenly darted upon the infant and immediately bore it away to its rocky eyry on the summit of Ben Lomond. The alarm of this shocking event was soon spread; and a considerable party, hurrying to the rescue, fortunately succeeded in recovering the child alive.

The Bald Eagle, like most of the large species, takes wide circuits in its flight, and soars at great heights. In these sublime attitudes he may often be seen hovering over waterfalls and lofty cataracts, particularly that of the famous Niagara, where he watches for the fate of those unfortunate fish and other animals that are destroyed in the descent of the tumultuous waters.

All ornithologists of the present day agree in the opinion that Audubon's "Bird of Washington" was an immature Bald Eagle, - the difference in size and coloration accounting for the error.

Nuttall, following Audubon, wrote of the two phases as of distinct species; for it was not until about 1870 that reashingtoni was dropped from the lists. I have given the two biographies as they appeared in the original work, for together they form a good history of the bird's distinctive habits. The difference in habits noted is not due to difference of age, as might be supposed, but to the different conditions under which the birds chanced to be observed. 
I will take this opportunity of protesting against the perpetuation of an idea, still current, which originated with the older writers, concerning the "nobility" of the Falconida, under which family name are grouped the Eagles, Falcons, Kites, and Hawks. They were until quite recently classed among the first of the feathered race; but the systematists now place them below the Woodpeckers, and next above the Grouse and Pigeons.

The majority of the Falconille have an attractive physique and superior strength, as well as a haughty bearing. They are handsome, stalwart ruffians, but they are nothing more. They are neither the most intelligent nor most enterprising of birds, nor the bravest. They are not even the swiftest, or most dexterous on the wing; and in bearing, proudly as they carry themselves, are not supreme.

It is now considered probable that the tales of Eagles carrying off children are myths.

\section{GRAY SEA EAGLE.}

WHITE-TAILED EAGLE.

\section{HALIAETUS ALBICILLA.}

CHAR. General color, grayish-brown (paler on margin of feathers); head and neck gray, - paler in old birds; tail white; legs bare.

Length: male, 33 inches; female, $3^{8}$ inches.

$N^{\top}$ est. In a tree or on a rock, sometimes on the ground; made of dry sticks loosely arranged and often piled to considerable height.

Eggs. I-3 (usually 2); dull white; $2.85 \times 2.25$.

Mr. Hagerup reports that this European bird breeds in southern Greenland and is quite common there. It feeds principally on fish, but will eat any kind of meat or carrion, being particularly partial to water fowl, and is much more enterprising than is its congener, the Bald Eagle. 


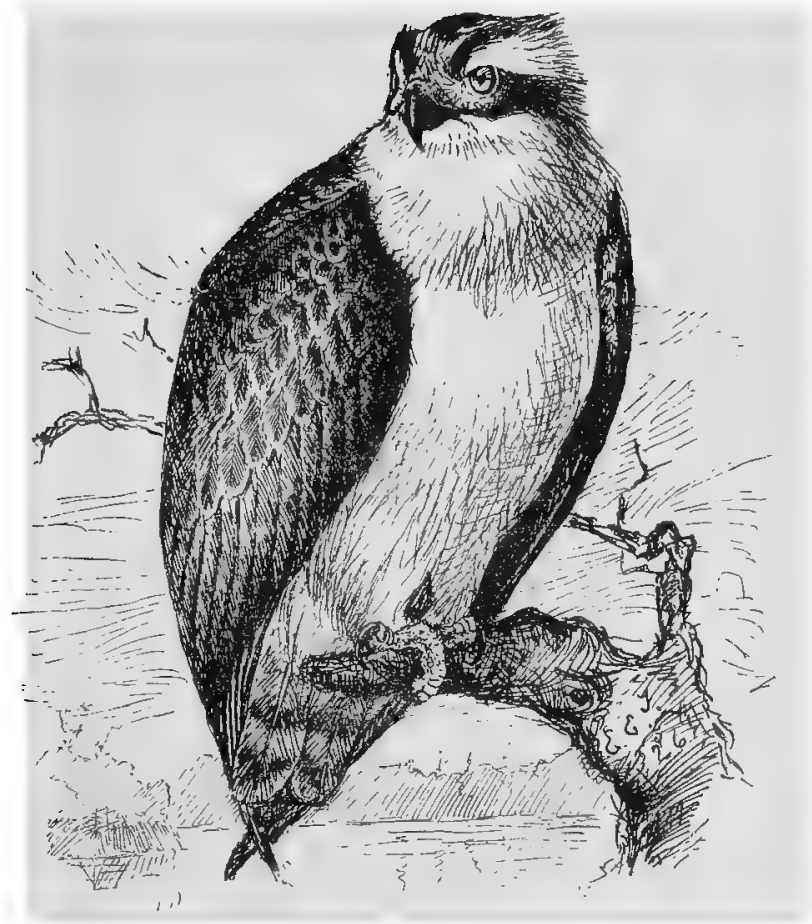

\section{AMERICAN OSPREY.}

FISH HAWK.

\section{Pandion haliaËtus CaRolinensis.}

Char. Above, dark brown; head and neck white, with dark stripe on side of the head; tail grayish, with several narrow dark bars, and tipped with white; under-parts white or buffish, sometimes (in female) streaked with brown. Feet and claws large and strong. Hook of the bill long. Length 21 to 25 inches.

Nest. Of loosely arranged sticks on top of high tree, - generally a dead tree is selected; usually near water.

Eggs. 2 to 4 ; variable in shape, color, size, and markings; ground color generally whitish, with yellow or red tint, blotched with reddish brown of various shades. Size about $2.50 \times 1.75$.

This large and well-known species, allied to the Eagles, is found near fresh and salt water in almost every country in the 
world. In summer it wanders into the Arctic regions of Europe, Asia, and America; it is also equally prevalent in the milder parts of both continents, as in Greece and Egypt. In America it is found in the summer from Labrador, and the interior around Hudson's Bay, to Florida; and according to Buffon, it extends its residence to the tropical regions of Cayenne.

Its food being almost uniformly fish, it readily acquires subsistence as long as the waters remain unfrozen; but at the commencement of cool weather, even as early as the close of September, or at farthest the middle of October, these birds leave New York and New Jersey and go farther south. This early period of departure is, in all probability, like their arrival towards the close of March, wholly regulated by the coming and going of the shoals of fish on which they are accustomed to feed. Towards the close of March or beginning of April they arrive in the vicinity of Boston with the first shoal of alewives or herrings; but yet are seldom known to breed along the coast of Massachusetts. Their arrival in the spring is welcomed by the fisherman as the sure indication of the approach of those shoals of shad, herring, and other kinds of fish which now begin to throng the bays, inlets, and rivers near the ocean; and the abundance with which the waters teem affords ample sustenance for both the aërial and terrestrial fishers, as each pursues in peace his favorite and necessary employment. In short, the harmless industry of the Osprey, the familiarity with which he rears his young around the farm, his unexpected neutrality towards all the domestic animals near him, his sublimely picturesque flight and remarkable employment, with the strong affection displayed towards his constant mate and long helpless young, and the wrongs he hourly suffers from the pirate Eagle, are circumstances sufficiently calculated, without the aid of ready superstition, to ensure the public favor and tolerance towards this welcome visitor. Driven to no harsh necessities, like his superiors the Eagles, he leads a comparatively harmless life; and though unjustly doomed to servitude, his address and industry raise him greatly above his oppressor, so that he supplies himself and his young with a plentiful 
sustenance. His docility and adroitness in catching fish have also sometimes been employed by man for his advantage.

Intent on exploring the sea for his food, he leaves the nest and proceeds directly to the scene of action, sailing round in easy and wide circles, and turning at times as on a pivot, apparently without exertion, while his long and curving wings seem scarcely in motion. At the height of from one hundred to two hundred feet he continues to survey the bosom of the deep. Suddenly he checks his course and hovers in the air with beating pinions; he then descends with rapidity, but the wily victim has escaped. Now he courses near the surface, and by a dodging descent, scarcely wetting his feet, he seizes a fish, which he sometimes drops, or yields to the greedy Eagle; but, not discouraged, he again ascends in spiral sweeps to regain the higher regions of the air and renew his survey of the watery expanse. His prey again espied, he descends perpendicularly like a falling plummet, plunging into the sea with a loud, rushing noise.and with an unerring aim. In an instant he emerges with the struggling prey in his talons, shakes off the water from his feathers, and now directs his laborious course to land, beating in the wind with all the skill of a practised seaman. The fish which he thus carries may be sometimes from six to eight pounds; and so firm sometimes is the penetrating grasp of his talons that when by mistake he engages with one which is too large, he is dragged beneath the waves, and at length both fish and bird perish.

From the nature of its food, the flesh, and even the eggs, are rendered exceedingly rank and nauseous. Though its prey is generally taken in the bold and spirited manner described, an Osprey sometimes sits on a tree over a pond for an hour at a time, quietly waiting its expected approach.

Unlike other rapacious birds, these may be almost considered gregarious, breeding so near each other that, according to Mr. Gardiner, there were on the small island on which he resided, near to the eastern extremity of Long Island (New York), no less than three hundred nests with young. Wilson observed twenty of their nests within half a mile. I have seen them nearly as thick about Rehoboth Bay in Dela- 
ware. Here they live together at least as peaceably as rooks; and so harmless are they considered by other birds that, according to Wilson, the Crow Blackbirds, or Grakles, are sometimes allowed refuge by the Ospreys, and construct their nests in the very interstices of their eyry. It would appear sometimes that, as with Swallows, a general assistance is given in the constructing of a new nest; for previous to this event, a flock have been seen to assemble in the same tree, squealing as is their custom when anything materially agitates them. At times they are also seen engaged in social gambols high in the air, making loud vociferations, suddenly darting down, and then sailing in circles; and these innocent recreations, like many other unmeaning things, are construed into prognostications of stormy or changing weather. Their common friendly call is a kind of shrill whistle, 'phew, 'phew, 'phew, repeated five or six times, and somewhat similar to the tone of a fife. Though social, they are sometimes seen to combat in the air, instigated probably more by jealousy than a love of rapine, as their food is always obtained from an unfailing source.

Early in May the Osprey commences laying, and has from two to four eggs. They are a little larger than those of the Common Fowl, and are from a reddish or yellowish cream-color to nearly white, marked with large blotches and points of reddish brown. During the period of incubation the male frequently supplies his mate with food, and she leaves her eggs for very short intervals.

The young appear about the last of June, and are most assiduously attended and supplied. On the approach of any person towards the nest, the parent utters a peculiar plaintive, whistling note, which increases as it takes to wing, sailing round, and at times making a quick descent, as if aiming at the intruder, but sweeping past at a short distance. On the nest being invaded, either while contaming eggs or young, the male displays great courage and makes a violent and dangerous opposition. The young remain a long time in the nest, so that the old are sometimes obliged to thrust them out and encourage them to fly; but they still, for a period, continue to feed them in the air. 


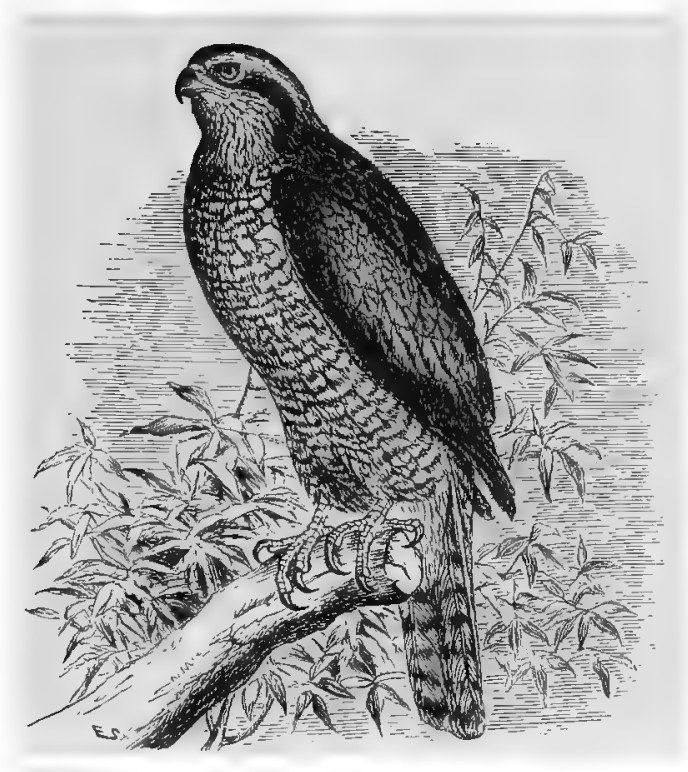

\section{AMERICAN GOSHAWK.}

BLUE HEN HAWK.

\section{ACCIPITER ATRICAPILLUS.}

CHAR. Above, dark bluish gray; top of head black, the feathers beneath the surface white; white stripe over the eye: tail with four dark bands; below, white barred and streaked with narrow dark lines. Young very different; above, brown, edges of feathers buffish; tail lighter, tipped with white and crossed by four or five dark bands; below, buffish, streaked with brown. Length 22 to 24 inches.

Nest. In a tree; made of twigs.

Eggs. 3-4; bluish white, with buff or reddish brown markings; 2.30 $\times 1.75$.

The foreign representative of this elegant and spirited species of Hawk appears to be common in France, Germany, the northern parts of Great Britain, Russia, and Siberia, and extends into Chinese Tartary. Our species, so nearly related to the European bird, is very rare, migrating to the South apparently at the approach of winter. On the 26 th of October, I830. I received one of these birds from the proprietor of 
Fresh Pond Hotel, in the moult, having the stomach crammed with moles and mice, and it was shot in the act of devouring a Pigeon.

The Goshawk was held in considerable esteem for falconry, and, according to Bell, was employed for this amusement by the emperor of China, who moved sometimes to these excursions in great state, often bearing a Hawk on his hand, to let fly at any game that might be raised, which was usually Pheasants, Partridges, Quails, or Cranes. In I269 Marco Polo witnessed this diversion of the emperor, which probably had existed for many ages previous. The falconers distinguished these birds of sport into two classes, - namely, those of falconry properly so called, and those of hawking; and in this second and inferior class were included the Goshawk, the Sparrow Hawk, Buzzard, and Harpy. This species does not soar so high as the longer-winged Hawks, and darts upon its quarry by a side glance, not by a direct descent, like the true Falcon. These birds were caught in nets baited with live Pigeons, and reduced to obedience by the same system of privation and discipline as the Falcon.

A pair of Goshawks were kept for a long time in a cage by Buffon; he remarks that the female was at least a third larger than the male, and the wings, when closed, did not reach within six inches of the end of the tail. The male, though smaller, was much more fierce and untamable. They often fought with their claws, but seldom used the bill for any other purpose than tearing their food. If this consisted of birds, they were plucked as neatly as by the hand of the poulterer; but mice were swallowed whole, and the hair and skin, and other indigestible parts, after the manner of the genus, were discharged from the mouth rolled up in little balls. Its cry was raucous, and terminated by sharp, reiterated, piercing notes, the more disagreeable the oftener they were repeated; and the cage could never be approached without exciting violent gestures and screams. Though of different sexes, and confined to the same cage, they contracted no friendship for each other which might soothe their imprisonment, and finally, 
to end the dismal picture, the female, in a fit of indiscriminate rage and violence, murdered her mate in the silence of the night, when all the other feathered race were wrapped in repose. Indeed, their dispositions are so furious that a Goshawk, left with any other Falcons, soon effects the destruction of the whole. Their ordinary food is young rabbits, squirrels, mice, moles, young Geese, Pigeons, and small birds, and, with a cannibal appetite, they sometimes even prey upon the young of their own species.

The Goshawk is not so rare in America as the older naturalists supposed; indeed, it is quite a common bird in the maritime Prov. inces of Canada and in northern New England, where it is found during the entire year. It occurs also west to Manitoba (though apparently rare in the Lake Superior region), and ranges, in winter, south to Maryland, Kentucky, and Ohio.

Its usual breeding area is from about latitude $45^{\circ}$ to the fur countries; though a few pairs probably build every year in southern New England. So few, comparatively, of the older and full-plumaged birds are seen that the species is not well known, the younger brown birds being almost indistinguishable from the young of several other Hawks.

There are several species that receive the name of "Hen Hawk" from the farmer; but none is so much dreaded as the "Blue Hawk," - and for good reason. With a boldness, strength, and dexterity of flight that is rivalled only by the Peregrine, the Goshawk combines a spirit of enterprise worthy of the Osprey, and a ferocity and cunning that are unmatched by any of the tribe. I have seen one swoop into a farmyard while the fowls were being fed, and carry off a half-grown chick without any perceptible pause in the flight.

$$
\text { VOL. I. }--3
$$




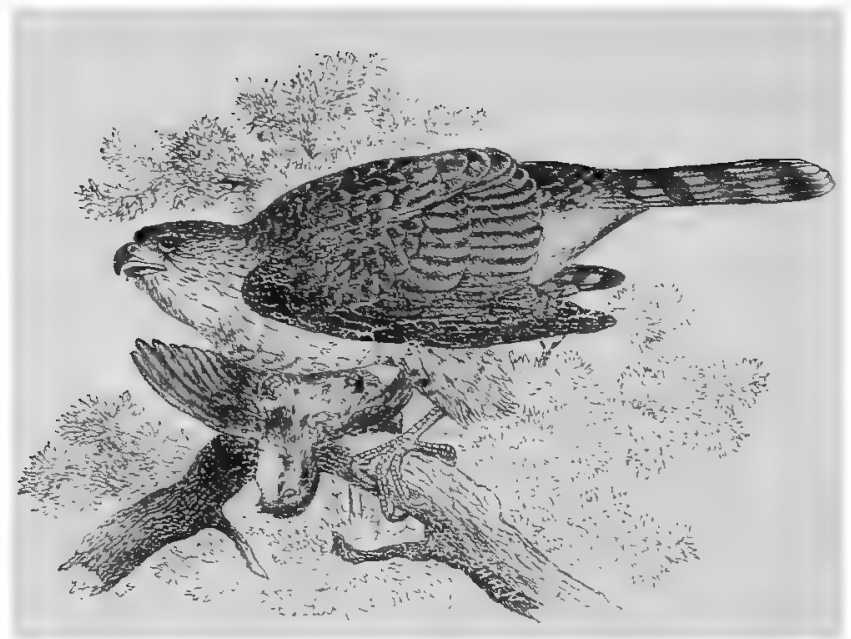

\section{COOPER'S HAWK.}

\section{ACCIPITER COOPERI.}

CHAR. Adult bluish gray or almost bluish ash, head darker; below, whitish, breast and belly thickly streaked with reddish brown, sides with a bluish tinge; wings and tail barred with dark brown, tail tipped with white. Length about 16 inches (female 2 to 3 inches longer).

Nest. In a tree, near the trunk; made of twigs, lined with grass.

Egss. 3-4; bluish white spotted with reddish brown (sometimes immaculate); $1.90 \times 1.50$.

This fine species of Hawk is found in considerable numbers in the Middle States, particularly New York and New Jersey, in the autumn and at the approach of winter. It is also seen in the Oregon territory to the shores of the Pacific. Its food appears principally to be birds of various kinds; from the Sparrow to the Ruffed Grouse, all contribute to its rapacious appetite. I have also seen this species as far south as the capital of Alabama, and, in common with the preceding, its depredations among the domestic fowls are very destructive. Mr. Cooper informs me that the plumage of the adult male bears the same analogy to the adult of $F$. fuscus as the young of that species does to the present, excepting that the rufous 
tints are paler. The difference in size between the two is as 2 , or even 3 , to $\mathbf{I}$.

Cooper's Hawk is generally distributed throughout North America from the fur countries to Mexico (in winter), though most abundant in the southern portions of New England and in the Middle States.

It is called "Chicken Hawk" by the Northern farmers.

\section{SHARP-SHINNED HAWK.}

\section{ACCIPITER VELOX.}

CHAR. The adult may be best described as a small edition of Cooper's Hawk, which it resembles in almost everything but size. The top of the head is bluish, and the cheeks have a reddish tinge. Length of male about I inches; female some 2 inches longer.

Nest. In a tree : made of twigs, and lined with leaves and grass.

Eggs. 3-5; bluish white or greenish white blotched with brown; I.45 $\times$ I.I 5 .

This bold and daring species possesses all the courageous habits and temerity of the true Falcon; and if the princely amusement to which. these birds were devoted was now in fashion, few species of the genus would be found more sanguinary and pugnacious than the present. The young bird is described by Pennant under the name of the Dubious Falcon, and he remarks its affinity to the European Sparrow Hawk. It is, however, somewhat less, differently marked on the head, and much more broadly and faintly barred below. The nest of our species, according to Audubon, is made in a tree, and the eggs are four or five, grayish white, blotched with dark brown; they lay about the beginning to the middle of March. The true Sparrow Hawk shows considerable docility, is easily trained to hunt Partridges and Quails, and makes great destruction among Pigeons, young poultry, and small birds of all kinds. In the winter they migrate from Europe into Barbary and Greece, and are seen in great numbers out at sea, making such havoc among the birds of passage they happen to meet in their way that the sailors in the Mediterranean call them Corsairs. Wilson observed the female of our species descend 
upon its prey with great velocity in a sort of zig-zag pounce, after the manner of the Goshawk. Descending furiously and blindly upon' its quarry, a young Hawk of this species broke through the glass of the greenhouse at the Cambridge Botanic Garden, and fearlessly passing through a second glass partition, he was only brought up by the third, and caught, though little stunned by the effort. His wing-feathers were much torn by the glass, and his flight in this way so impeded as to allow of his being approached. This species feeds principally upon mice, lizards, small birds, and sometimes even squirrels. In the thinly settled States of Georgia and Alabama this Hawk seems to abound, and proves extremely destructive to young chickens, a single bird having been known regularly to come every day until he had carried away between twenty and thirty. At noon-day, while I was conversing with a planter, one of these Hawks came down, and without any ceremony, or heeding the loud cries of the housewife, who most reluctantly witnessed the robbery, snatched away a chicken directly before us. At another time, near Tuscaloosa, in Alabama, I observed a pair of these birds furiously attack the large Red-tailed Hawk, squalling very loudly, and striking him on the head until they had entirely chased him out of sight. This enmity appeared to arise from a suspicion that the Buzzard was prowling round the farm-house for the poultry, which these Hawks seemed to claim as their exclusive perquisite. As this was, however, the I $3^{\text {th }}$ of February, these insulting marauders might possibly be already preparing to breed, and thus be incited to drive away every suspicious intruder approaching their nest. In fine weather I have observed this species soar to a great elevation, and ascend above the clouds. In this exercise, as usual, the wings seem but little exercised, the ascent being made in a sort of swimming gyration; though while near the surface of the earth the motion of the wings in this bird is rapid and continuous.

The Sharp-shinned is the commonest Hawk throughout New England and the settled portions of Canada. In winter it ranges south to Panama. 


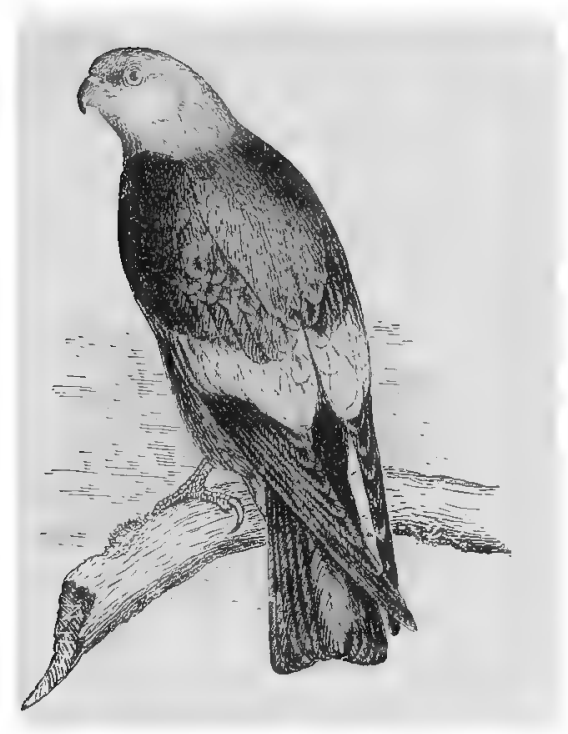

MISSISSIPPI KITE.

BLUE KITE.

ICTina Mississippiensis.

Char. General color bluish-gray, lighter on the head and secondaries, darker on prinaries and tail. Length, 13 to $15 \frac{1}{2}$ inches.

Nest. On a tree; of small sticks, lined with moss and leaves.

Eggs. 2-3; bluish white; size variable, averaging 1.65 $\times$ I.35.

This remarkably long-winged and beautiful Hawk does not appear to extend its migrations far within the United States. Wilson observed it rather plentiful about and below Natchez in the summer season, sailing in easy circles, sometimes at a great elevation, so as to keep company with the Turkey Buzzards in the most elevated regions of the air ; at other times they were seen among the lofty forest trees, like Swallows sweeping along, and collecting the locusts (Cicadce) which swarmed at this season. My friend Mr. Say observed this species pretty far up the Mississippi, at one of Major Long's cantonments. But except on the banks of this great river, it is rarely seen even in the most southern States. Its food, 
no doubt, abounds more along the immense valley of the Mississippi than in the interior regions, and, besides large insects, probably often consists of small birds, lizards, snakes, and other reptiles, which swarm in these their favorite resorts. On the failure of food these birds migrate by degrees into the Mexican and South American provinces, and were observed by D'Azara in Guiana, about the latitude of $7^{\circ}$. According to Audubon, this Kite breeds in the Southern States as well as in Texas, selecting the tall magnolias and white-oaks. From the narrow limits within which this bird inhabits in the United States, it is more than probable that the principal part of the species are constant residents in the warmer parts of the American continent. They begin to migrate early in August.

The range of this species is given as "southern United States soutbward from South Carolina, and Wisconsin and Iowa to Mexico."

\section{WHITE-TAILED KITE.}

\section{BLACK-SHOULDERED KITE.}

\section{ELANUS LEUCURUS.}

CHAR. General color bluish gray fading to white on head and tail ; a large patch of black on shoulder; lower parts white. Length 15 to $163 / 4$ inches.

Nest. In a tree, loosely built of sticks and leaves.

Eggs. 2-4; dull white, heavily blotched with brown, I.60 $\times$ I.25.

This beautiful Hawk, scarcely distinguishable from a second African species of this section, chiefly inhabits the continent of South America as far as Paraguay. In the United States it is only seen occasionally in the peninsula of East Florida, confining its visits almost to the southern extremity of the Union. It appears to be very shy and difficult of approach; flying in easy circles at a moderate elevation, or at times seated on the deadened branches of the majestic live-oak, it attentively watches the borders of the salt-marshes and watery situations 
for the field-mice of that country, or unwary Sparrows, that approach its perch. 'The bird of Africa and India is said to utter a sharp and piercing cry, which is often repeated while the bird moves in the air. It builds, in the forks of trees, a broad and shallow nest, lined internally with moss and feathers. A pair have been known to breed on the Santee River in the month of March, according to Audubon.

This Kite occurs regularly in the Southern States, north to South Carolina, and Mr. Ridgway bas met with it in southern Illinois. It extends its range westward to California.

\section{SWALLOW-TAILED KITE.}

FORK-TAILED KITE.

Elanoides forficatus.

CHAR. Head, neck, rump, and lower parts white, ofher parts black; tail deeply forked. Length $191 / 2$ to $25 \mathrm{I} / 2$ inches.

Nest. In a tree; of sticks and moss, lined with grass and leaves.

Eggs. 2-3; white, with buff or green tinge, spotted with various shades of brown ; $1.85 \times 1.50$.

This beautiful Kite breeds and passes the summer in the warmer parts of the United States, and is also probably resident in all tropical and temperate America, migrating into the southern as well as the northern hemisphere. In the former, according to Viellot, it is found in Peru and as far as Buenos Ayres; and though it is extremely rare to meet with this species as far as the latitude of $40^{\circ}$ in the Atlantic States, yet, tempted by the abundance of the fruitful valley of the Mississippi, individuals have been seen along that river as far as the Falls of St. Anthony, in the 44th degree of north latitude. Indeed, according to Fleming two stragglers have even found their devious way to the strange climate of Great Britain.

These Kites appear in the United States about the close of April or beginning of May, and are very numerous in the Mis- 
sissippi territory, twenty or thirty being sometimes visible at the same time; often collecting locusts and other large insects, which they are said to feed on from their claws while flying, at times also seizing upon the nests of locusts and wasps, and, like the Honey Buzzard, devouring both the insects and their larvæ. Snakes and lizards are their common food in all parts of America. In the month of October they begin to retire to the South, at which season Mr. Bartram observed them in great numbers assembled in Florida, soaring steadily at great elevations for several days in succession, and slowly passing towards their winter quarters along the Gulf of Mexico. From the other States they migrate early in September.

This species is most abundant in the western division of the Gulf States, but is irregularly distributed over the Southern, Western, and Middle States. It has occasionally visited New England, and examples have been seen in Manitoba and near London and Ottawa in Ontario.

\section{EVERGLADE KITE.}

\section{BLACK KITE, HOOK-BILL KITE. SNAIL HAWK.}

\section{RostrhaniUS SOCIABILIS.}

ChaR. Prevailing color dull bluish ash, darker on tail, wings, and anterior portion of head; rump white, with terminal bar of light brown; bill black; feet orange. Length 16 to 18 inches.

Nest. A platform with a slight depression, composed of sticks or dried grass, built in a low bush or amid tall grass.

Eggs. 2-3; brownish white blotched with various shades of brown; I. $70 \times 1.45$.

This is a tropical species that occurs in Florida. Mr. W. E. D. Scott reports finding it abundant at Panasofkee Lake, and says : "Their food at this point apparently consists of a kind of large fresh-water snail which is very abundant. . . . They fish over the shallow water, reminding one of gulls in their motions; and having secured a snail by diving, they immediately carry it to the nearest available perch, when the animal is dexterously taken from the shell, without injury to the latter." 


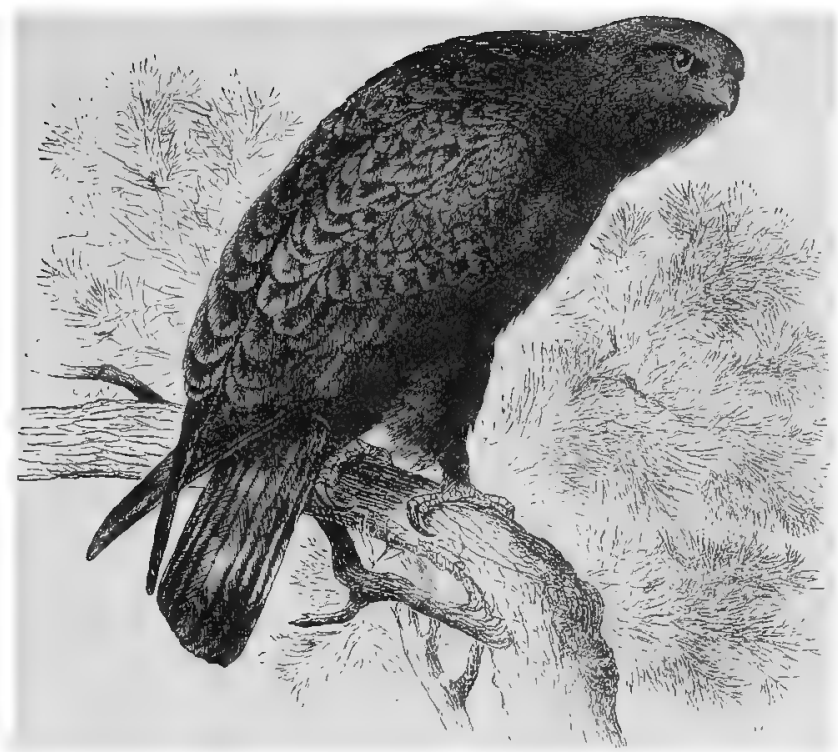

\section{AMERICAN ROUGH-LEGGED HAWK.}

BLACK HAWK.

\section{ARCHIBUTEO LAGOPUS SANCTI-JOHANNIS.}

CHAR. General color variable, - dark or light brown, or brownish gray, sometimes black; all the feathers edged with lighter color, producing an appearance of streaks. The absence of these streaks on the belly forms a dark band. Tail with dark and light bars, and whitish at its base. Easily distinguished from any other Hawk by the feathered shank. Length $19 \frac{1}{2}$ to 22 inches.

Nest. In a large tree, or on rocks : of sticks lined with grass, dry moss, and feathers.

Egrgs. 2-3; white or creamy, more or less spotted with brown; 1.90 $\times 1.55$.

This remarkable species of Buzzard appears to take up its residence chiefly in the northern and western wilds of America. My friend Mr. Townsend found its nest on the banks of Bear River, west of the Rocky Mountains. The nest, formed of large sticks, was in a thick willow bush about ten feet from the ground, and contained two young almost fledged. It is 
said to. lay four eggs, clouded with reddish. It is common also to the north of Europe, if not to Africa. The usual station of these birds is on the outskirts of woods, in the neighborhood of marshes, - situations suited for supplying them with their usual humble prey of frogs, mice, reptiles, and straggling birds, for which they patiently watch for hours together, from daybreak to late twilight. When prey is perceived, the bird takes a cautious, slow, circuitous course near the surface, and sweeping over the spot where the object of pursuit is lurking, he instantly grapples it, and flies off to consume it at leisure. Occasionally they feed on crabs and shell-fish. The inclement winters of the high northern regions, where they are usually. bred, failing to afford them food, they are under the necessity of making a slow migration towards those countries which are less severe. According to Wilson, no less than from twenty to thirty young individuals of this species continued regularly to take up their winter quarters in the low meadows below Philadelphia. They are never observed to soar, and when disturbed, utter a loud, squealing note, and only pass from one neighboring tree to another.

The great variation in the plumage of this Hawk has been the cause of considerable controversy. Wilson wrote of the black and the brown phases as of two species, giving them distinct habits. Nuttall, following Audubon, considered the changes from light to dark due only to age. Spencer Baird (in 1858), Cassin, and Dr. Brewer agreed with Wilson. Later authorities, however, with more material to aid them, have pronounced both views incorrect, and have decided that there is but one species, - that the black is but a melanistic phase. Our systematists now separate the American from the European form, giving to the former varietal rank, as its "trinomial appellation" denotes.

Nuttall does not mention the occurrence of this bird in Massachusetts, though Dr. Brewer states that at one time it was abundant near Boston, and within more recent years numbers have been captured by Mr. E. O. Damon on the Holyoke Hills, near Springfield. It occurs within the United States principally as a winter visitor, its chief breeding-ground lying in the Labrador and Hudson Bay district. 


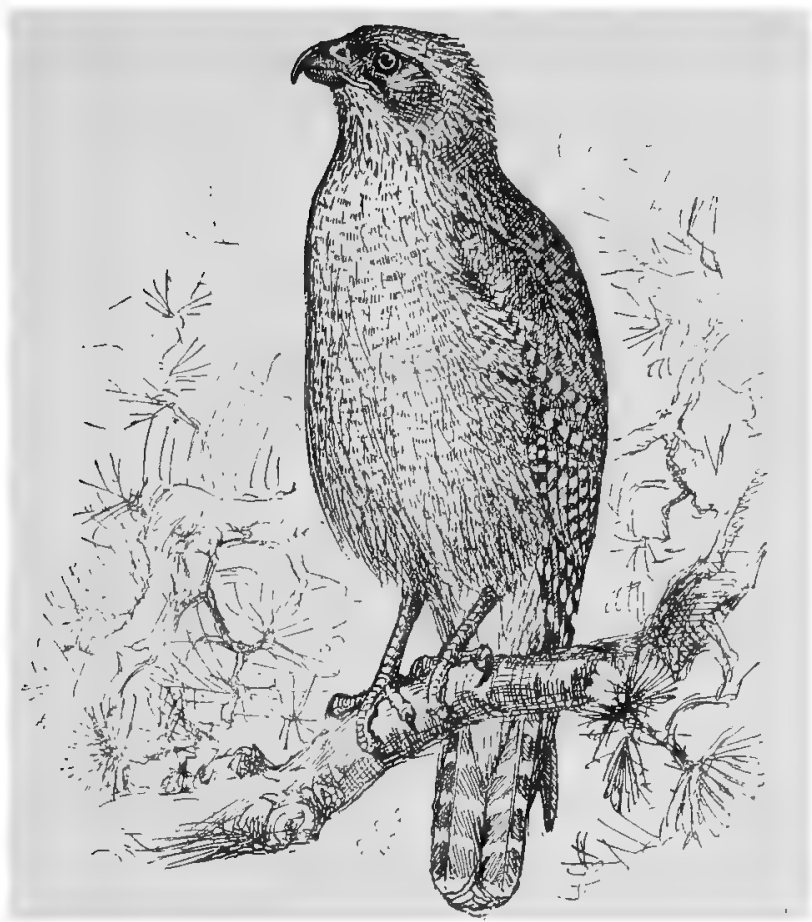

\section{RED-SHOULDERED HAWK.}

WINTER HAWK.

BUTEO LiNEATUS.

CHAR. Adult : general color dark reddish brown; head and neck rufous: below, lighter, with dark streaks and light bars; wings and tail black with white bars; lesser wing-coverts chestnut. Young, with little of the rufous tinge, below, buffy with dark streaks, Length ig to 22 inches.

Nest. In a tree; of loosely arranged twigs, lined with grass and feathers.

Eggs. 2-4: bluish white or buffy blotched with brown; $2.20 \times 1.70$.

This very elegant Hawk does not migrate or inhabit very far to the north. It is never seen in Massachusetts, nor perhaps much farther than the State of Pennsylvania. In the Southern States, during winter, these birds are very common in swampy situations, where their quailing cry of mutual recognition may be heard from the deptbs of the dark forest almost 
every morning of the season. This plaintive echoing note resembles somewhat the garrulous complaint of the Jay, keé-ó, $k e \dot{e}-o \dot{o}, k e \hat{e}-o \dot{o}$, continued with but little intermission sometimes for near twenty minutes. At length it becomes loud and impatient; but on being distantly answered by the mate, the sound softens and becomes plaintive like $k \bar{e} e \dot{e}-00$. This morning call is uttered most loudly and incessantly by the male, inquiring for his adventurous mate, whom the uncertain result of the chase has perhaps separated from him for the night. As this species is noways shy, and very easily approached, I have had the opportunity of studying it closely. At length, but in no haste, I observed the female approach and take her station on the same lofty, decayed limb with her companion, who, grateful for this attention, plumed the feathers of his mate with all the assiduous fondness of a Dove. Intent upon her meal, however, she soon flew off to a distance, while the male still remained on his perch, dressing up his beautiful feathers for near half an hour, often shaking his tail, like some of the lesser birds, and occasionally taking an indifferent survey of the hosts of small chirping birds which surrounded him, who followed without alarm their occupation of gleaning seeds and berries for subsistence. I have occasionally observed them perched on low bushes and stakes in the rice-fields, remaining thus for half an hour at a time, and then darting after their prey as it comes in sight. I saw one descend upon a Plover, as I thought, and Wilson remarks their living on these birds, Larks, and Sandpipers. The same pair that I watched also hung on the rear of a flock of cow-buntings which were feeding and scratching around them. They sometimes attack squirrels, as I have been informed, and Wilson charges them with preying also upon Ducks.

I never observed them to soar, at least in winter, their time being passed very much in indolence and in watching for their game. Their flight is almost as easy and noiseless as that of the Owl. In the early part of the month of March they were breeding in West Florida, and seemed to choose the densest thickets and not to build at any great height from 
the ground. On approaching these places, the $k e e^{-}-o \dot{o}$ became very loud and angry.

Winter Hawk. - This large American Buzzard is not uncommon in this vicinity, as well as in the neighborhood of Philadelphia, where Wilson met with it along the marshes and meadows, feeding almost wholly upon frogs. It is abundant toward winter. It appears to have very much the manners of the European Buzzard, remaining inactive for hours together on the edges of wet meadows, perched upon the larger limbs of trees, and at times keeping up a regular quailing and rather hoarse keigh-oo, keigh-oo, which at intervals is answered by the mate. When approached, it commonly steals off to some other tree at no great distance from the first; but if the pursuit be continued, it flies out and hovers at a considerable height. It is also an inhabitant of Hudson's Bay and Newfoundland.

Nuttall regarded the old and young as distinct species, giving to them not only distinctive names, but a different distribution. Taken together, lis two biographies tell about all that is yet known of the habits and range of the species. It is found throughout this faunal province, from the Gulf States to the southern border of the fur countries, has been taken at York Factory on Hudson's Bay, and is common in Manitoba.

Note. - The Florida Red-Shouldered Hawk (Buteo lineatus alleni) is a Southern form restricted to Florida and Texas. It differs from true lineatus in having the rufous tinge on the head and neck replaced by brownish gray. 


\section{HARRIS'S HAWK.}

\section{PaRABUTEO UNICINCTUS HARRISI.}

CHAR. Prevailing color black, sometimes chocolate brown, tinged with chestnut on the rump; shoulders and lining of wings chestnut; tail-coverts, base of tail, and terninal band, white. Length about 20 inches.

Nest. On a cliff or in a tree, - usually the latter; a mere platform of twigs and roots, lined with grass.

Eggrs. 2-5 (usually 3); white, tinged with yellow, sometimes marked with brown or lavender, or both, $2.15 \times 1.65$.

Harris's Hawk is abundant in parts of Texas and in Mexico, and occurs in small numbers in the southern part of Mississippi. It is usually represented as a rather sluggish bird, associating with the Vultures and joining in their feasts of carrion, but sometimes preying upon the small reptiles that infest the banks of streams and pools. Mr. Sennett, however, describes those he saw along the lower Rio Grande as more active, feeding chiefly on birds, mice, and gophers.

\section{RED-TAILED HAWK.}

\section{BUTEO BOREALIS.}

Char. Above, dull brown streaked with rufous and grayish; below, whitish or tawny streaked with brown; tail chestnut abore and gray beneath, with a land of black near the end and tipped with white. In the young the tail is grayish brown crossed by some nine dark bars, and the underparts are white with brown streaks. Length $191 / 2$ to 23 inches.

Nest. In a high tree; of sticks, lined with grass, sometimes with feathers.

Egos. 2-4; whitish or bluish white, usually heavily spotted or blotched with reddish brown; $230 \times 1.80$.

This beautiful Buzzard inhabits most parts of the United States, being observed from Canada to Florida; also, far westward up the Missouri, and even on the coasts of the northern Pacific Ocean, by Lewis and Clarke. Wilson found the young to be fully grown in the month of May, about latitude $3 \mathrm{I}^{\circ}$ on the banks of the Mississippi; at this period they were very noisy and clamorous, keeping up an incessant squealing. It also occasionally nests and breeds in large 
trees in the secluded forests of this part of Massachusetts. The young birds soon becume very submissive, and allow themselves to be handled with impunity by those who feed them. The older birds sometimes contest with each other in the air about their prey, and nearly or wholly descend to the earth grappled in each other's talons. Though this species has the general aspect of the Buzzard, its manners are very similar to those of the Goshawk; it is equally fierce and predatory, prowling around the farm often when straitened for food, and seizing, now and then, a hen or chicken, which it snatches by making a lateral approach: it sweeps along near the surface of the ground, and grasping its prey in its talons, bears it away to devour in some place of security. These depredations on the farm-yard happen, however, only in the winter; at all other seasons this is one of the shyest and most difficult birds to approach. It will at times pounce upon rabbits and considerable-sized birds, particularly Larks, and has been observed in the Southern States perseveringly to pursue squirrels from bough to bough until they are overtaken and seized in the talons. It is frequently seen near wet meadows where mice, moles, and frogs are prevalent, and also feeds upon lizards, - appearing, indeed, often content with the most humble game.

They usually associate in pairs, and seem much attached to each other; yet they often find it convenient and profitable to separate in hunting their prey, about which they would readily quarrel if brought into contact. Though a good deal of their time passes in indolence, while perched in some tall and deadened tree, yet at others they may be seen beating the ground as they fly over it in all directions in quest of game. On some occasions they amuse themselves by ascending to a vast elevation, like the aspiring Eagle. On a fine evening, about the middle of January, in South Carolina, I observed one of these birds leave its withered perch, and soaring aloft over the wild landscape, in a mood of contemplation, begin to ascend towards the thin skirting of elevated clouds above him. At length he passed this sublime boundary, and was now per- 
ceived and soon followed by his ambitious mate, and in a little time, by circular ascending gyrations, they both disappeared in the clear azure of the heavens; and though I waited for their re-appearance half an hour, they still continued to be wholly invisible. This amusement, or predilection for the cooler regions of the atmosphere, seems more or less common to all the rapacious birds. In numerous instances this exercise must be wholly independent of the inclination for surveying their prey, as few of them besides the Falcon descend direct upon their quarry. Many, as well as the present species, when on the prowl fly near to the surface of the ground, and often wait and watch so as to steal upon their victims before they can take the alarm. Indeed the Condor frequents and nests upon the summit of the Andes, above which they are seen to soar in the boundless ocean of space, enjoying the invigorating and rarefied atmosphere, and only descending to the plains when impelled by the cravings of hunger.

The Eastern variety of the Red-tail is a common bird throughout eastern North America north to about latitude $49^{\circ}$, and was taken by Dr. Bell at Fort Churchill, on Hudson's Bay. It ranges westward to the Great Plains, where it is replaced by the subspecies krideri. From the Rocky Mountains to the Pacific it is represented by calurus, and examples of this latter variety have been taken, occasionally, as far east as Illinois. The Red-tail is a summer resident only of the Maritime Provinces, but a few are found in winter in southern Ontario and New England.

Note. - Mr. Ridgway now considers HarLan's Hawk to be a variety of the Red-tail, and he proposes to name it Buteo borealis harlani. Its usual habitat is along the lower Mississippi ; but exam. ples have been taken in Illinois, Iowa, Pennsylvania, and Georgia.

Two examples of SwAINSON's HAWK (Buteo swainsoni), a Western species, have been taken in Massachusetts, - one at Wayland in 1876 , and the other near Salem in 1878 . 


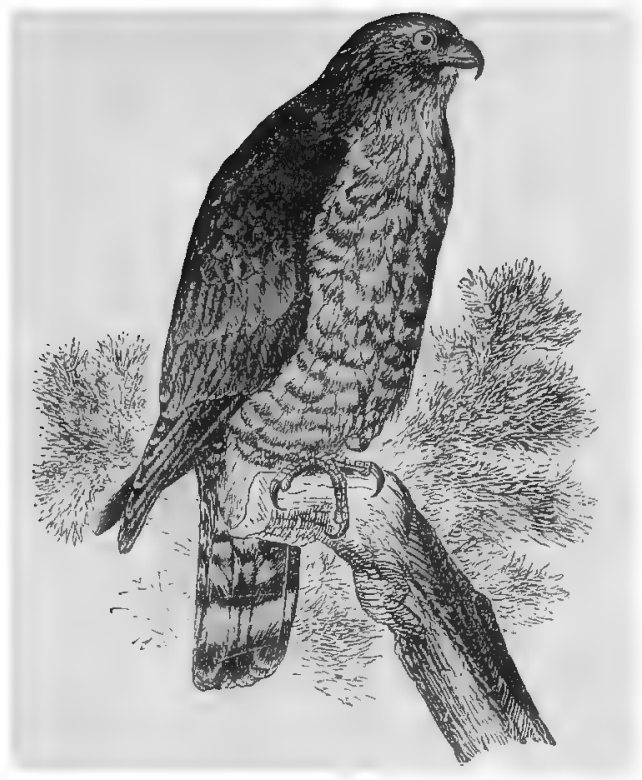

\section{BROAD-WINGED HAWK.}

\section{BUteo latissimus.}

CHAR. Above, dull brown, the feathers with paler edges; tail brown with four light bars and tipped with white; below, buffish or tawny, barred and streaked with rufous; wings short and broad Length $13 \% / 2$ to 15 inches.

Nest. In a tree; loosely built of twigs, and lined with leaves and feathers.

Eggs. 2-4; buffish, blotched with reddish brown of various shades; I.90 $\times 1.55$.

This species was obtained by Wilson, in the vicinity of Philadelphia, in the act of feeding on a meadow-mouse. On being approached, it uttered a whining whistle and flew to another tree, where it was shot. Its great breadth of wing, as well as of the head and body, compared with its length, appears remarkably characteristic. The following day the mate was observed sailing in wide circles, the wings scarcely moving, and presenting almost a semi-circular outline. These two individuals appear to be all that were known to Wilson of this

VOL. I. -4 
species. Audubon considers it by no means a rare species in Virginia, Maryland, and all the States to the eastward of these. Its usual prey is small birds, very young poultry, small quadrupeds, and insects.

The Broad-wing occurs throughout this eastern faunal province, but is somewhat local in distribution. In portions of the Maritime Provinces it is abundant, though in general it is rather uncommon. Mr. John Neilson considers it common near the city of Quebec, but Mr. Ernest Wintle reports it rare at Montreal, while Mr. William L. Scott thinks it the commonest Hawk in the Ottawa valley. $\mathrm{Mr}$. Thomas McIlwraith gives it as a "casual visitor" to the southern portions of Ontario, and $\mathrm{Mr}$. Ernest Thompson found it abundant in the Muskoka district. Thompson also reports it common in Manitoba.

In the more northern portions of New England it is a fairly common summer visitor, while it is found in Massachusetts and Connecticut throughout the year, but is rather rare. It occurs also in more or less abundance in all the Middle, Western, and Southern States.

My observations in New Brunswick have led me to form a different opinion of the characteristics of this Hawk from those expressed by several writers. The examples I met with were not peculiarly void of either boldness or vigor in pursuit of their prey, nor peculiarly spiritless when wounded. They did, of course, like others of the tribe, pursue weak prey, and displayed little true bravery; but bravery is not a characteristic of the Hawks. A wounded Broad-wing, however, acts just as cloes the boldest of them, - he turns on his back and hits out with claws, beak, and wings; and the gunner who thinks he has a meek or spiritless bird to handle may regret the thought.

\section{SHORT-TAILED HAWK.}

\section{BUTEO BRACHYURUS.}

Char. Above, brownish black or blackish brown; forehead and cheeks white; tail brownish gray barred with black and tipped with white; beneath, pure white, a patch of rufous on side of chest. Length 16 inches.

Nest. In a tall tree; made of dry twigs, lined with fresh twigs of cypress.

Eggs. I-3; dull white, spotted on large end with reddish brown. 
The black and brown phases of plumage worn by this bird have caused the scientific ornithologists no little perplexity, and been the subject of some controversy; so a brief summary of the various opinions held may serve as an illustration of the evolution of many scientific names.

The species was first described from a specimen in brown plumage and given the name it now bears; then a young bird came into the hands of another systematist, and supposing it to be a new species, he named it $B$. oxypterus; and afterwards an example in black was taken by still another, who supposed it to be something new, so he wrote it down $B$. fuliginosus. These two last-mentioned were disposed of by other writers as synonyms of swainsoni, oxypterus being considered the young plumage, and fuliginosus a melanistic phase, while in several more recent works the latter, as the Little Black Hawk, was restored to specific rank. These opinions have recently been abandoned for that which has been held for a long time by the few, - that both fuliginosus and oxypterus are synonyms of the present species.

It cannot, however, be said that the matter is finally adjusted, for the black color still presents this problem: Is it individual or sexual, - a melanistic phase, or the normal color of the adult male?

The bird is entirely tropical in its range, and is found within the United States only in the tropical portions of Florida. It was supposed formerly to occur there merely as a casual or accidental straggler; but recent observations have proved it to be a regular though uncommon visitor, and breeding there.

\section{MARSH HAWK.}

\section{MARSH HARRIER. BLUE HAWK.}

Circus hudsonius.

Char. Adult male: above, bluish gray; tail with dark bands; rump white; beneath white. Adult female and young: above, dark brown streaked with rufous; tail with dark bands; rump white ; beneath, tawny with dark streaks. Length 19 to 24 inches.

Nest. On the ground, in damp meadow or cedar swamp; a loosely arranged platform of dried grass some four to six inches high, with little depression, occasionally lined with softer material.

Eggs. 3-8; bluish white, sometimes spotted with buffish or brown; $\mathrm{I} .80 \times \mathrm{I} .40$. 
This species is common to the northern and temperate, as well as the warmer parts of the old and new continents, being met with in Europe, Africa, South America, and the West Indies. In the winter season it extends its peregrinations from Hudson's Bay to the Oregon territory and the southern parts of the United States, frequenting chiefly open, low, and marshy situations, over which it sweeps or skims along, at a little distance usually from the ground, in quest of mice, small birds, frogs, lizards, and other reptiles, which it often selects by twilight as well as in the open day; and at times, pressed by hunger, it is said to join the Owls and seek out its prey even by moonlight. Instances have been known in England in which this bird has carried its temerity so far as to pursue the same game with the armed fowler, and even snatch it from his grasp after calmly waiting for it to be shot, and without even betraying timidity at the report of the gun. The nest of this species is made on the ground, in swampy woods or among rushes, occasionally also under the protection of rocky precipices, and is said to be formed of sticks, reeds, leaves, straw, and similar materials heaped together, and finished with a lining of feathers, hair, or other soft substances. In the $F$. cineraceus, so nearly related to this species, the eggs are of a pure white. When their young are approached, the parents, hovering round the intruder and uttering a sort of uncouth syllable, like geg geg gag, or ge ge ne ge ge, seem full of afright and anxiety. The Crows, however, are their greatest enemies, and they often succeed in demolishing the nests. The young are easily tamed, and feed almost immediately without exhibiting any signs of fear.

Nuttall has told about all that more modern observers have to tell of this species. The authorities differ chiefly in descriptions of the structure of the nest and the markings on the eggs. The nests that I have examined have been composed entirely of coarse grass, without lining, though the softest of the grass was laid on top. The eggs were unspotted. 


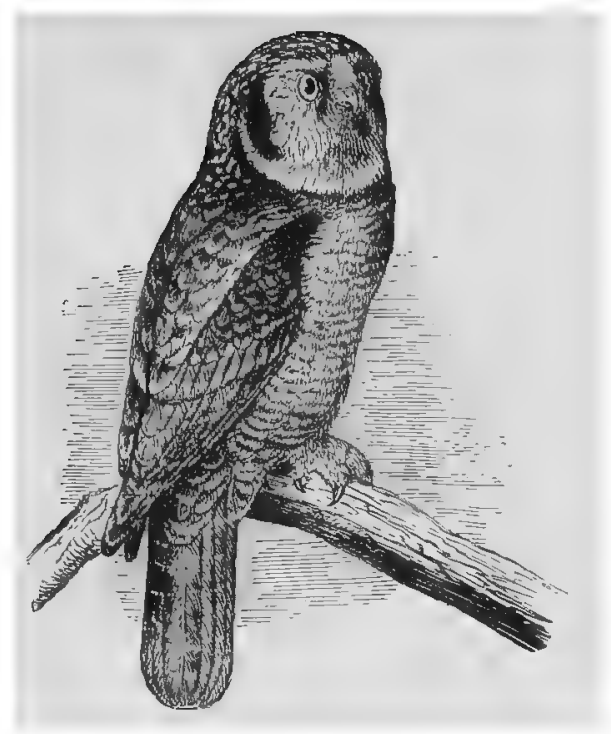

HAWK OWL.

SuRNia Ulula CAPAROCH.

Char. Above, dull blackish brown, spotted with white; crown without spots; dark patch on the cheeks; face white, the feathers with dark margins; tail and wing with white bars; below, white with dark bars. Length $14 \% \frac{3}{4}$ to $17 \frac{1}{2}$ inches.

Nest. On a tree; of twigs lined with feathers.

Eggs. 2-7; dull white; $1.55 \times 1.25$.

This remarkable species, forming a connecting link with the preceding genus of the Hawks, is nearly confined to the Arctic wilds of both continents, being frequent in Siberia and the fur countries from Hudson's Bay to the Pacific. A few stragglers, now and then, at distant intervals and in the depths of winter, penetrate on the one side into the northern parts of the United States, and on the other they occasionally appear in Germany, and more rarely in France. At Hudson's Bay they are observed by day flying high and preying on the White Grouse and other birds, sometimes even attending the hunter like a Falcon, and boldly taking up the wounded game as it 
flutters on the ground. They are also said to feed on mice and insects, and (according to Meyer) they nest upon trees, laying two white eggs. They are said to be constant attendants on the Ptarmigans in their spring migrations towards the North, and are observed to hover round the camp-fires of the natives, in quest probably of any offal or rejected game.

In Massachusetts and the more southern portions of New England the Hawk Owl is only an occasional winter visitor; but in northern New England and the Maritime Provinces it occurs regularly, though of varying abundance, in some seasons being quite rare. It is fairly common near Montreal, and rare in Ontario and in Ohio. Thompson reports it abundant in Manitoba, but only one example has been taken in Illinois (Ridgrway). It breeds in Newfoundland and the Magdalen Islands, and north to sub-arctic regions. 


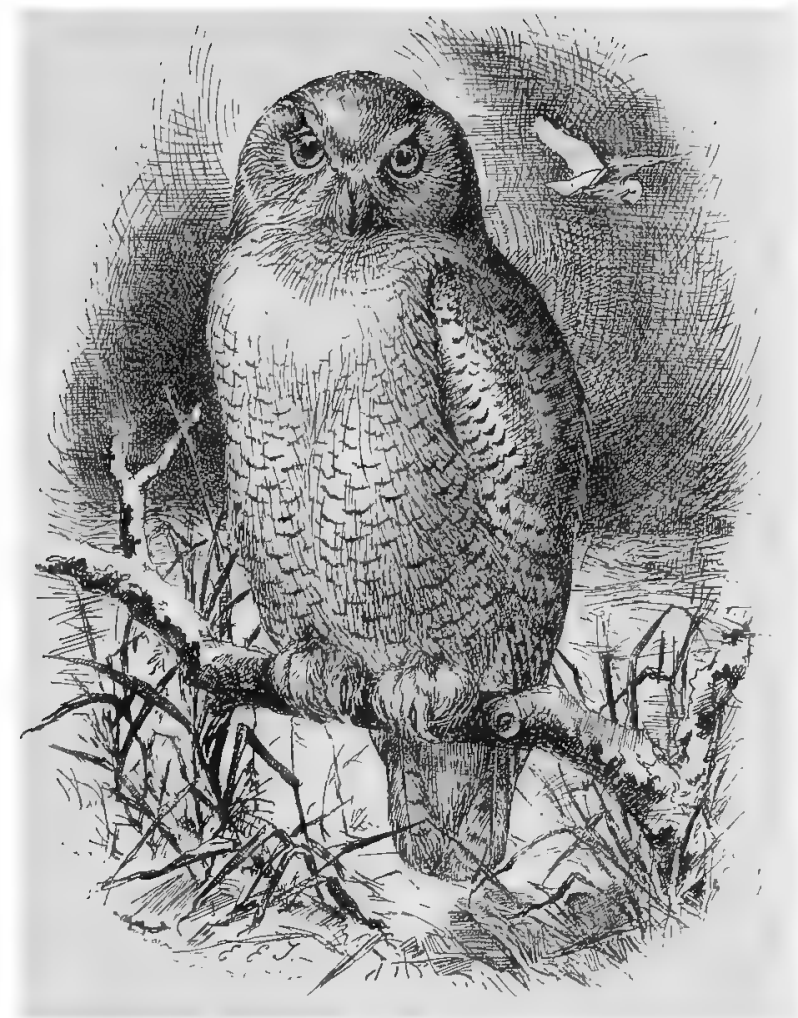

\section{SNOWY OWL.}

\section{Nyctea NYCTEA.}

CHAR. General color pure white, with markings of dull brown or brownish black, the abundance and shade of the spots varying with age. A large, stout bird. Length 23 to 27 inches.

Nest. On the ground, of twigs and.grass, lined with feathers.

Eggs. 5 to 10; white; $2.55 \times$ x.g0.

This very large and often snow-white species of Owl is almost an exclusive inhabitant of the Arctic regions of both continents, being common in Iceland, the Shetland Islands, Kamtschatka, Lapland, and Hudson's Bay. In these dreary wilds, surrounded by an almost perpetual winter, he dwells, breeds, and obtains his subsistence. His white robe renders 
him scarcely discernible from the overwhelming snows, where he reigns, like the boreal spirit of the storm. His loud, hollow, barking growl, 'whozeh, 'zohowh, 'whowh hăh, hăh, hăh, $h \breve{a} h,{ }^{1}$ and other more dismal cries, sound like the unearthly ban of Cerberus; and heard amidst a region of cheerless solitude, his lonely and terrific voice augments rather than relieves the horrors of the scene.

Clothed with a dense coating of feathers, which hide even the nostrils, and leave only the talons exposed, he ventures abroad boldly at all seasons, and, like the Hawks, seeks his prey by daylight as well as dark, skimming aloft and reconnoitring his prey, which is commonly the White Grouse or some other birds of the same genus, as well as hares. On these he darts from above, and rapidly seizes them in his resistless talons. At times he watches for fish, and condescends also to prey upon rats, mice, and even carrion.

These birds appear to have a natural aversion to settled countries; for which. reason, perhaps, and the severity of the climate of Arctic America, they are frequently known to wander in the winter south through the thinly settled interior of the United States. They migrate probably by pairs; and according to Wilson, two of these birds were so stupid, or dazzled, as to alight on the roof of the court-house in the large town of Cincinnati. In South Carolina Dr. Garden saw them occasionally, and they were, in this mild region, observed to hide themselves during the day in the palmetto-groves of the seacoast, and only sallied out towards night in quest of their prey. Their habits, therefore, seem to vary considerably, according to circumstances and climate.

This species is a regular winter visitor to the Northern and Middle States, and during some seasons has been quite abundant. A few pairs have been seen in summer in northern Maine, New Brunswick, and Nova Scotia; but the usual breeding-ground is from about latitude $50^{3}$ to the Arctic regions.

While in their more southern resorts they are rarely found far from the forest districts.

1 These latter syllables with the usual quivering sound of the Owl. 


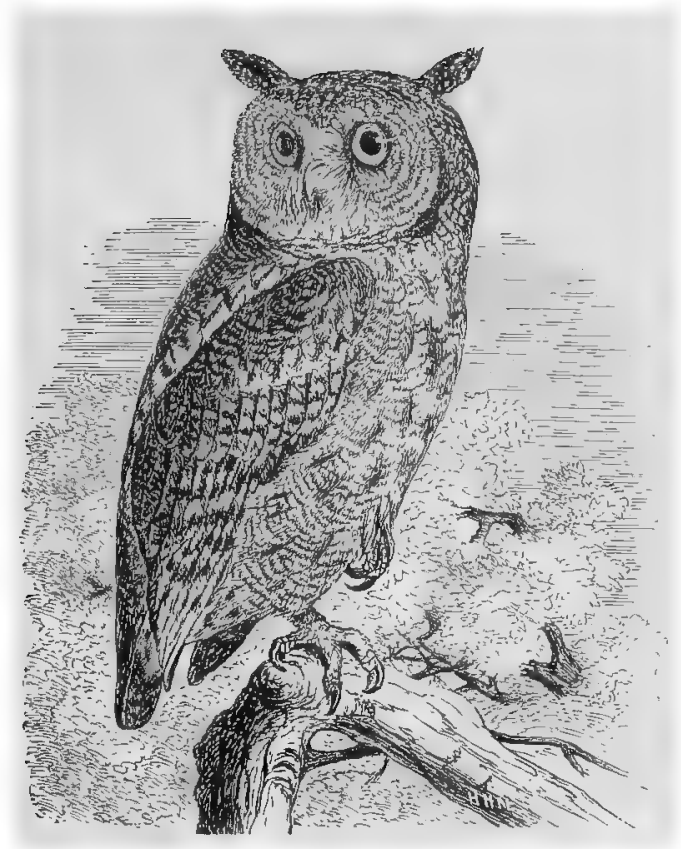

\section{SCREECH OWL. \\ MOTTLED OWL. RED OWL. \\ Megascops asio.}

CHAR. Above, varying greatly from brownish gray to brownish red, spotted (mottled) with darker shades of the same tint and with blackish; below, dull whitish or with a rufous tint and heavily marked with dull brown or blackish. In highly colored red examples the spots are less trequent. Large ear tufts; wings and tail barred with the light and darls colors; legs feathered and toes bristled. Length 7 to ro inches.

Nest. In a hollow tree or stump; the bottom of the hole slightly lined with leaves or feathers.

Eggos. 4-8; white, nearly round; I.35 $\times$ I.20.

Mottled Owl.-This common, small, and handsome species, known as the Little Screech Owl, is probably resident in every part of the United States, and, in fact, inhabits from Greenland to Florida, and westward to the Oregon. It appears more abundant in autumn and winter, as at those seasons, food fail- 
ing, it is obliged to approach habitations and barns, in which the mice it chiefly preys on now assemble; it also lies in wait for small birds, and feeds on beetles, crickets, and other insects. The nest is usually in the hollow of an old orchard tree, about the months of May or June; it is lined carelessly with a little hay, leaves, and feathers, and the eggs are commonly four to six, white, and nearly round. Aldrovandus remarks that the Great Horned Owl provides so plentifully for its young that a person might obtain some dainties from the nest, and yet leave a sufficiency for the Owlets besides. The same remark may also apply to this species, as in the hollow stump of an apple-tree, which contained a brood of these young Owls, were found several Bluebirds, Blackbirds, and Song Sparrows, intended as a supply of food.

During the day these birds retire into hollow trees and unfrequented barns, or hide in the thickest evergreens. At times they are seen abroad by day, and in cloudy weather they wake up from their diurnal slumbers a considerable time before dark. In the day they are always drowsy, or, as if dozing, closing, or scarcely half opening their heavy eyes, presenting the very picture of sloth and nightly dissipation. When perceived by the smaller birds, they are at once recognized as their insidious enemies; and the rareness of their appearance, before the usual roosting-time of other birds, augments the suspicion they entertain of these feline hunters. From complaints and cries of alarm, the Thrush sometimes threatens blows; and though evening has perhaps set in, the smaller birds and cackling Robins re-echo their shrill chirpings and complaints throughout an extensive wood, until the nocturnal monster has to seek safety in a distant flight. Their notes are most frequent in the latter end of summer and autumn, crying in a sort of wailing quiver, not very unlike the whining of a

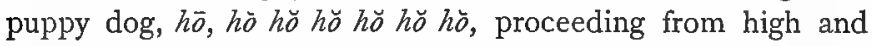
clear to a low guttural shake or trill. These notes, at little intervals, are answered by some companion, and appear to be chiefly a call of recognition from young of the same brood, or pairs who wish to discover each other after having been sepa- 
rated while dozing in the day. On moonlight evenings this slender wailing is kept up nearly until midnight.

Red Owl. - From the very satisfactory and careful observations of Dr. Ezra Michener, of New Garden, Chester County, Pennsylvania, published in the eighth volume of the Journal of the Academy of Natural Sciences of Philadelphia, it appears certain that the Red and Gray "Screech Owls " of the United States are specifically distinct; he has observed that the Red Owls rear young of the same color, and that the Gray Owls of the preceding species have also young which are gray and mottled from the very nest. Still different as they are in plumage, the habits of the species are nearly alike. The present inhabits and breeds in most parts of the United States. In Pennsylvania they are hatched by the latter end of May, breeding in hollow trees. The eggs are about four.

I have had an opportunity of verifying all that Wilson relates of the manners of this species in a Red or young Owl, taken out of a hollow apple-tree, which I kept for some months. A dark closet was his favorite retreat during the day. In the evening he became very lively and restless, gliding across the room in which he was confined, with a sidelong, noiseless flight, as if wafted by the air alone. At times he clung to the wainscot, and, unable to turn, he brought his head round to his back, so as to present, by the aid of his brilliant eyes, a most spectral and unearthly appearance. As the eyes of all the Owls, according to Wilson, are fixed immovably in the socket by means of a many cleft capsular ligament, this provision for the free versatile motion of the head appears necessary. When approached towards evening, he appeared strongly engaged in reconnoitring the object, blowing with a hissing noise (shay, shay', shay), common to other species, and stretching out his neck with a waving, lateral motion, in a threatening attitude, and, on a nearer approach, made a snapping with the bill, produced by striking together both mandibles, as they are equally movable. He was a very expert mouse-catcher, swallowed his prey whole, and then, after some time, ejected from the bill the bones, skin, and 
hair, in pellets. He also devoured large flies, which at this time came into the room in great numbers; and even the dry parts of these were also ejected from the stomach without digestion. A pet of this species, which Dr. Michener had, drank frequently, and was accustomed to wash every day in a basin of cold water during the heat of summer.

Nuttall, following Wilson and Audubon, treated the gray and red phases of this bird as two distinct species, and wrote separate biographies, which I insert in full. Some ornithologists have supposed that the gray specimens were the young birds; but it has been proved beyond question that the two phases are simply individual variations of the same species. Gray and red birds have been found in one nest, with both parents gray, or both red, or with one of each color.

NoтE. - A smaller and darker race is found in South Carolina, Georgia, and Florida. It is named Florida SCREECH OWL ( $M$. asio floridanus). In this race the reddish feathers wear a richer rufous tint, and the gray are more deeply tinged with brown. 


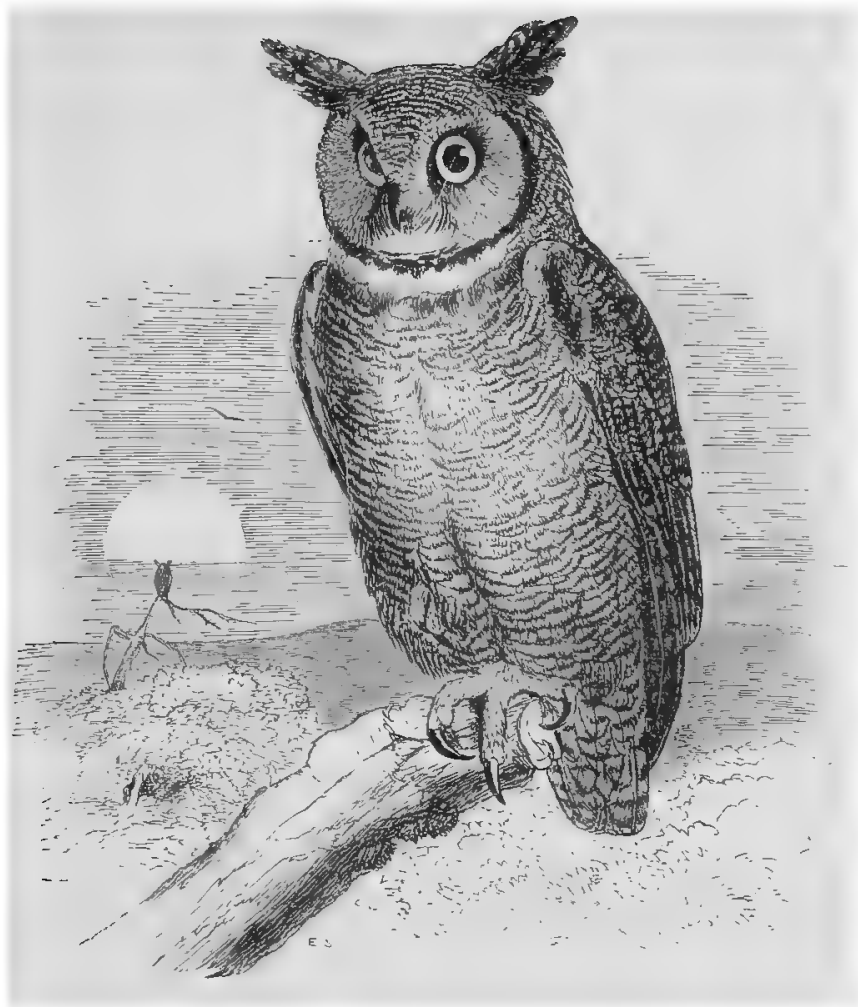

\section{GREAT HORNED OWL.}

\section{CAT OWL.}

\section{BUBo VIRGINIANUS.}

Char. Plumage very variable, of mottled black, light and dark brown, buff, and tawny. A white band on the throat, and a white stripe down the breast, - the latter sometimes obscure. Ear-tufts large and conspicuous; legs and toes feathered. Length IS to 25 inches.

Nest. Sometimes within a hollow tree, but usually on an upper limb. A deserted nest of Crow or Hawk is often used, and then it is a clumsy, bulky affair of sticks, lined with feathers.

Eggs. 2-3; white and nearly spherical; $2.20 \times 1.80$.

This species, so nearly related to the Great Eared Owl of Europe, is met with occasionally from Hudson's Bay to 
Florida, and in Oregon; it exists even beyond the tropics, being very probably the same bird described by Marcgrave as inhabiting the forests of Brazil. All climates are alike to this Eagle of the night, the king of the nocturnal tribe of American birds. The aboriginal inhabitants of the country dread his boding howl, dedicating his effigies to their solemnities, and, as if he were their sacred bird of Minerva, forbid the mockery of his ominous, dismal, and almost supernatural cries. His favorite resort, in the dark and impenetrable swampy forests, where he dwells in chosen solitude secure from the approach of every enemy, agrees with the melancholy and sinister traits of his character. To the surrounding feathered race he is the Pluto of the gloomy wilderness, and would scarcely be known out of the dismal shades where he hides, but to his victims, were he as silent as he is solitary. Among the choking, loud, guttural sounds which he sometimes utters in the dead of night, and with a suddenness which always alarms, because of his noiseless approach, is the 'waugh ho' 'waugh ho! which, Wilson remarks, was often uttered at the instant of sweeping down around his camp-fire. Many kinds of Owls are similarly dazzled and attracted by fire-lights, and occasionally finding, no doubt, some offal or flesh thrown out by those who encamp in the wilderness, they come round the nocturnal blaze with other motives than barely those of curiosity. The solitary travellers in these wilds, apparently scanning the sinister motive of his visits, pretend to interpret his address into "Who 'cooks for you a all!" and with a strong guttural pronunciation of the final syllable, to all those who have heard this his common cry, the resemblance of sound is well hit, and instantly recalls the ghastly serenade of his nocturnal majesty in a manner which is not easily forgotten. The shorter cry which we have mentioned makes no inconsiderable approach to that uttered by the European brother of our species, as given by Buffon, namely, 'he-hoo, 'hoo-hoo, boo-hoo, etc. The Greeks called this transatlantic species Byas, either from its note or from the resemblance this bore to the bellowing of the ox. The Latin name $B u b o$ has also reference to the same note of this noc- 
turnal bird. According to Frisch, who kept one of these birds alive, its cries varied according to circumstances; when hungry it had a muling cry like $P u ́ h u$. I have remarked the young, probably, of our species utter the same low, quailing cry, while yet daylight, as it sat on the low branch of a tree; the sound of both is, at times, also not unlike that made by the Hawks or diurnal birds of prey. Indeed, in gloomy weather I have seen our species on the alert, flying about many hours before dark, and uttering his call of ' $k o k o, k o k o b$ ho. Their usual prey is young rabbits, squirrels, rats, mice, Quails, and small birds of various kinds; and when these resources fail or diminish, they occasionally prowl pretty boldly around the farm-yard in quest of Chickens, which they seize on the roost. Indeed the European Horned Owl frequently contends with the Buzzard for its prey, and generally comes off conqueror; blind and infuriate with hunger, one of these has been known to dart even upon a man, as if for conflict, and was killed in the encounter. My friend Dr. Boykin, of Milledgeville, in Georgia, assured me that one of our own daring nocturnal adventurers, prowling round his premises, saw a cat dozing on the roof of a smoke-house, and supposing grimalkin a more harmless, rabbit-like animal than appeared in the sequel, blindly snatched her up in his talons; but finding he had caught a Tartar, it was not long before he allowed puss once more to tread the ground. In England the same error was committed by an Eagle, who, after a severe conflict with a cat he had carried into the air, was at length brought to the ground before he could disengage himself from the feline grasp.

An Owl of this species, which I have observed in a cage, appeared very brisk late in the morning, hissed and blew when approached with a stick, and dashed at it very heedlessly with his bill; he now and then uttered a 'ko-koh, and was pretty loud in his call at an earlier hour. When approached, he circularly contracted the iris of the eyes to obtain a clearer view of the threatened object; he also listened with great quickness to any sound which occurred near his prison, and eyed the flying Pigeons, which passed by at some distance, with a scruti- 
nizing and eager glance. When fed he often had the habit of hiding away his superfluous provision.

As far as I have been able to observe the retiring manners of this recluse, he slumbers out the day chiefly in the dark tops of lofty trees. In these, according to Wilson, he generally begins to build in the month of May, though probably earlier in the Southern States. The nest is usually placed in the fork of a tree, made of a considerable pile of sticks, and lined with dry leaves and some feathers; and, as a saving of labor, sometimes they select a hollow tree for the purpose.

This Owl is usually found in woods of rather large growth; but Nuttall slightly exaggerated in naming the "dark and impenetrable swampy forest" as its "favorite resort." Throughout the Maritime Provinces it is found on the outskirts of settlements, as well as in the wilderness.

An interesting account of the habits of this species in captivity, from the note-book of Mr. James W. Banks, of St. John, N. B., appeared in "The Auk" for April, I884.

Note. - There are two geographical races of this species that should be named here. The Dusky Horned OWL ( $B$. viryinianus saturatus), an extremely dark form, occurs in Labrador, and is found also on the coast of the Northwest. The Western HorNed OWL ( $B$. virginianus subarcticus), a light-gray form, is usually restricted to the middle faunal province, but has been taken in Illinois and Wisconsin.

\section{GREAT GRAY OWL.}

\section{ULULA CINEREA.}

CHAR. Above, sooty brown mottled with irregular bars of dull gray; below, paler tints of same colors in wavy stripes. No ear-tufts. The largest of the Owls. Length, 23 to 30 inches.

Nest. In a tree.

Eggs. 2-3; white; 2.I $5 \times$ I.70.

This is the largest American species known, and if the $S$. lapponica, common also to the Arctic circle, and seldom leaving it, being only accidental about Lake Superior, and occa- 
sionally seen in Massachusetts in the depth of severe winters. One was caught perched on a wood-pile, in a state of listless. inactivity, in the morning after daylight, at Marblehead, in February, I83r. This individual survived for several months, and showed a great partiality for fish and birds. At times he uttered a tremulous cry or hŏ hŏ hŏ hŏ hoo, not very dissimilar to that of the Mottled Owl. At Hudson's Bay and Labrador these Owls reside the whole year, and were found in the Oregon territory by Mr. Townsend. They associate in pairs, fly very low, and feed on mice and hares, which they seize with such muscular vigor as sometimes to sink into the snow after them a foot deep. With ease they are able to carry off the alpine hare alive in their talons. In Europe the species appears wholly confined to the desert regions of Lapland, two or three stragglers being all that have been obtained out of that country by naturalists.

Dr. Richardson says that it is by no means a rare bird in the fur countries, being an inhabitant of all the woody districts lying between Lake Superior and latitudes $67^{\circ}$ or $68^{\circ}$ and between Hudson's Bay and the Pacific. It is common on the borders of Great Bear Lake; and there, and in the higher parallels of latitude, it must pursue its prey, during the summer months, by daylight. It keeps, however, within the woods, and does not frequent the barren grounds, like the Snowy Owl, nor is it so often met with in broad daylight as the Hawk Owl, but hunts principally when the sun is low, - indeed, it is only at such times, when the recesses of the woods are deeply shadowed, that the American hare and the marine animals on which the Cinereous Owl chiefly preys, come forth to feed. On the $23 \mathrm{~d}$ of May I discovered a nest of this Owl, built on the top of a lofty balsam poplar, of sticks, and lined with feathers. It contained three young, which were covered with a whitish down.

The capture in New England of several examples of this species has been recorded. During the winter of $1889-90$, a number were seen along the northern border of these States and in the southern portions of Canada. Mr. McIlwraith reported that a large number had been taken near Hamilton.

VOL. I. -5 


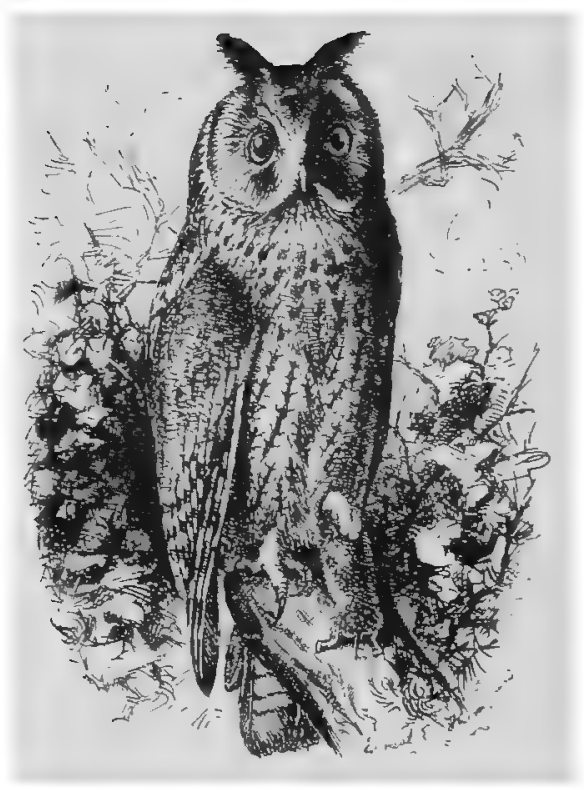

\section{LONG-EARED OWL.}

\section{ASIO WILSONIANUS.}

Char. Above, finely mottled with dark brown, dull buff, and gray; breast similar, but of reddish tint; belly paler, with dark markings. Eartufts large; toes feathered. Length 15 inches.

Nest. Usually in a tree; of twigs, lined with grass and feathers. Sometinies a deserted Crow's or Hawk's nest is used.

Eggs. 3-6; white and oval; $1.65 \times 1.30$.

This species, like several others of the genus, appears to be almost a denizen of the world, being found from Hudson's Bay to the West Indies and Brazil, throughout Europe, in Africa, northern Asia, and probably China, in all which countries it appears to be resident, but seems more abundant in certain places in winter, following rats and mice to their retreats in or near houses and barns. It also preys upon small birds, and in summer destroys beetles. It commonly lodges in ruined buildings, the caverns of rocks, or in hollow trees. It defends 
itself with great spirit from the attacks of larger birds, making a ready use of its bill and talons, and when wounded is dangerous and resolute.

The Long-Eared Owl seldom, if ever, takes the trouble to construct a nest of its own; it seeks shelter amidst ruins and in the accidental hollows of trees, and rests content with the dilapidated nursery of the Crow, the Magpie, that of the Wild Pigeon, of the Buzzard, or even the tufted retreat of the squirrel. True to these habits, Wilson found one of these Owls sitting on her eggs in the deserted nest of the Qua Bird, on the $25^{\text {th }}$ of April, six or seven miles below Philadelphia, in the midst of the gloomy enswamped forest which formed the usual resort of these solitary Herons. So well satisfied was she in fact with her company, and so peaceable, that one of the Quas had a nest in the same tree with the Owl. The young, until nearly fully grown, are grayish white, and roost close together on a large branch during the day, sheltered and hid amidst the thickest foliage ; they acquire their natural color in about fifteen days. Besides mice and rats, this species also preys on fieldmice, moles, and beetles. The plaintive cry or hollow moaning made by this bird, "clowe cloud," incessantly repeated during the night, so as to be troublesome where they frequent, is very attractive to the larger birds, who out of curiosity and for persecution assemble around this species when employed as a decoy, and are thus shot or caught by limed twigs.

This Owl occurs throughout temperate North America, and is a common resident everywhere excepting along the northern limit of its range, where it is less abundant, and appears in summer only. 


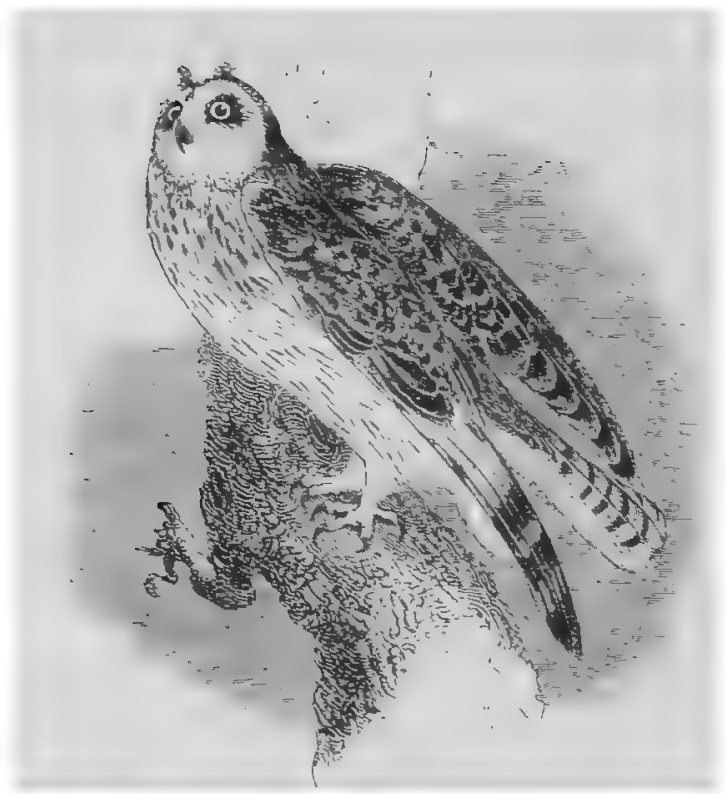

\section{SHORT-EARED OWL.}

ASIO ACCIPITRINUS.

Char. Above, mottled with dark brown, tawny, and buffish white; below, paler; feet feathered; ear-tufts inconspicuous. Some examples are much paler, as if the colors had faded. Length about 15 inches.

Vest. On the ground amid tall grass, and composed of a few twigs and a few feathers.

Eggs. 3-6; white and oval ; 1.60 $\times 1.20$.

This is another of those nocturnal wanderers which now and then arrive amongst us from the northern regions, where they usually breed. It comes to Hudson's Bay from the South about May, where it makes a nest of dry grass on the ground, and, as usual, has white eggs. After rearing its brood it departs for the South in September, and in its migrations has been met with as far as New Jersey, near Philadelphia, where, according to Wilson, it arrives in November and departs in April. Pennant remarks that it has been met with in the 
southern continent of America at the Faikland Islands. It is likewise spread through every part of Europe, and is common in all the forests of Siberia; it also visits the Orkney Islands and Iceland, and we have observed it at Atooi, one of the Sandwich Islands, in the Pacific, as well as in the territory of Oregon. In England it appears and disappears with the migrations of the Woodcock. Its food is almost exclusively mice, for which it watches, seated on a stump, with all the vigilance of a cat, listening attentively to the low squeak of its prey, to which it is so much alive as to be sometimes brought in sight by imitating the sound. It is readily attracted by the blaze of nocturnal fires, and on such occasions has sometimes had the blind temerity to attack men, and come so close to combat as to be knocked down with sticks. When wounded it also displays the same courageous ferocity, so as to be dangerous to approach. In dark and cloudy weather it sometimes ventures abroad by daylight, takes short flights, and when sitting and looking sharply round, it erects the short, earlike tufts of feathers on the head which are at other times scarcely visible. Like all other migrating birds, roving indifferently over the country in quest of food alone, these Owls have sometimes been seen in considerable numbers together; Bewick even remarks that 28 of them had been counted at once in a turnip-field in England. They are also numerous in Holland in the months of September and October, and in all countries are serviceable for the destruction they make among house and field mice, their principal food. Although they usually breed in high ground, they have also been observed in Europe to nest in marshes, in the middle of the high herbage, - a situation chosen both for safety and solitude.

This is one of the commonest of the New England Owls, and breeds in all the suitable marsh land along the coast. It ranges north to the fur countries, south to the Gulf States and beyond, and west to the Pacific. 


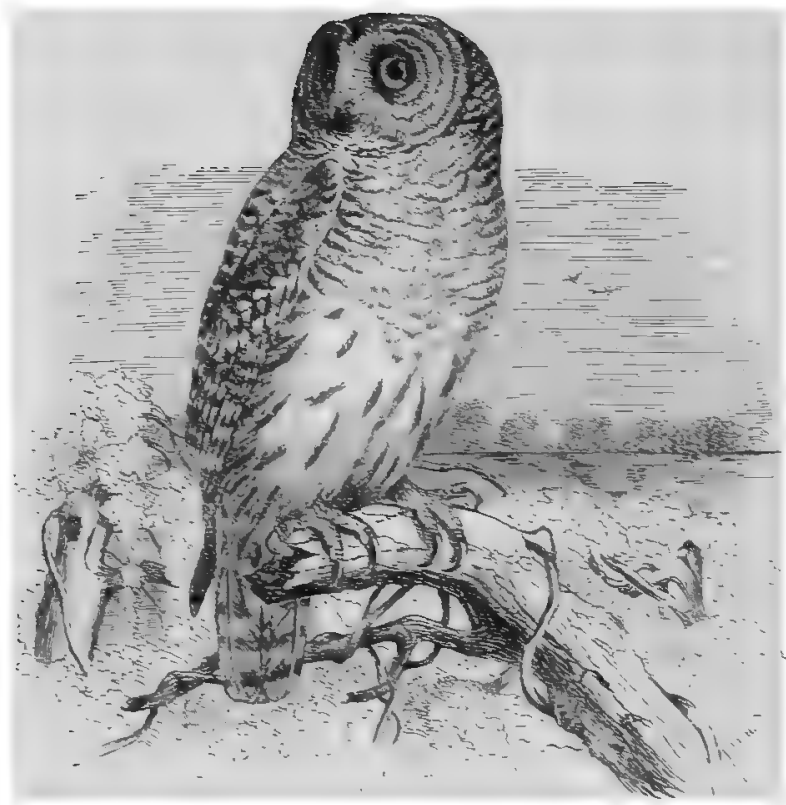

\section{BARRED OWL.}

HOOT OWL.

\section{Siritia sebtlostar.}

Char. Above, brown barred, spotted, and striped with dull gray or tawny; below, similar colors of paler tints; face, gray stripes; tail barred; iris brownish black; bill yellow. Length $19^{3}+$ to 24 inches.

Easily distinguished from all other species by its dark eyes.

Viest. ['sually in a hollow tree, but often a deserted nest of Crow or Hawk is re-lined and used.

Eggs. 2-4; white and nearly spherical; $1.95 \times 1.65$.

This species inhabits the northern regions of both the old and new continent, but with this difference, as in the Bald Eagle, that in the ancient continent it seldom wanders beyond the Arctic circle, being found no farther to the south than Sweden and Norway; while in America it drells and breeds at least in all the intermediate region from Hudson's Bay to Florida, being considerably more numerous even than other species throughout the swamps and dark forests of the South- 
ern States. Its food is principally rabbits, squirrels, Grouse, Quails, rats, mice, and frogs. From necessity, as well as choice, these birds not unfrequently appear around the farm-house and garden in quest of the poultry, particularly young chickens. At these times they prowl abroad towards evening, and fly low and steadily about, as if beating for their prey. In Alabama, Georgia, West Florida, and Louisiana, where they abound, they are often to be seen abroad by day, particularly in cloudy weather, and at times even soar and fly with all the address of diurnal birds of prey. Their loud guttural call of ' $k o h$ ' $k o h$ ' $k o$ $k \grave{o}, h \dot{s}$, or 'whah 'whah 'whah 'whah-aa, may be heard occasionally both by day and night, and as a note of recognition, is readily answered when mimicked, so as to decoy the original towards the sound. One which I received, in the month of December (1830), was hovering over a covey of Quails in the day-time; and though the sportsman had the same aim, the Owl also joined the chase, and was alone deterred from his sinister purpose by receiving the contents of the gun intended only for the more favorite game. When the young leave the nest they still keep together for mutual warmth and safety in the high, shaded branches of the trees where they have probably been hatched. On being approached by the parents, they utter a hissing call audible for some distance. According to Audubon, when kept in captivity they prove very useful in catching mice. Their flesh is also eaten by the creoles of Louisiana, and considered as palatable.

An interesting article, containing the most valuable information regarding the habits of this Owl that has yet been published, appeared in "The Auk" for April, r8go. The wtiter, Mr. Frank Bolles, kept a pair for several years ; and one of these, having broken its wing, was reduced to such subjection that $\mathrm{Mr}$. Bolles was enabled to make use of it in hunting for other birds, and thus gained an insight into the bird's methods that no other naturalist has equalled.

Note. - The Florida BARRed OWL (S. nebulosum alleni), a somewhat darker variety, is restricted to the Gulf States and Florida. 


\title{
SAW-WHET OWL.
}

\author{
ACADIAN OWL.
}

Nyctala aCADica.

CHAR. Above, dark grayish brown spotted with white; below, white, spotted with reddish brown; tail short, with three narrow bands of white spots. Young almost solid brown of reddish tint, and face with white markings. Length $7 \frac{1}{4}$ to $8 \% / 2$ inches.

Nest. A hole in a tree (often in a hole that has been deserted by Wood. peckers), lined with feathers.

Eggs. 3-6 (usually 4); white; 1.20 X 1.00.

This very small species is believed to be an inhabitant of the northern regions of both continents, from which in Europe it seldom wanders, being even very rare in the North of Germany. In the United States it is not uncommon as far to the south as Pennsylvania and New Jersey, where it is resident, having apparently a predilection for the sea-coast, living and nesting in the pine-trees or in the clefts of rocks, and laying 4 or 5 white eggs. It is generally nocturnal; and if accidentally abroad by day, it flies quickly to some shelter from the light. It is very solitary in its habits, living wholly in the evergreen forests, and coming out only towards night or early in the morning in search of mice, beetles, moths, and grasshoppers.

The note of this species is very different from that of the Strix passerina, or Little Owl, to which it is nearly related. This latter kind has a reiterated cry, when flying, like poŏpor poŏpŏ. Another note, which it utters sitting, appears so much like the human voice calling out $a \bar{\imath} m \breve{e}, h \bar{e} m \breve{e}, \bar{e} d m \breve{e}$, that according to Buffon, it deceived one of his servants, who lodged in one of the old turrets of the castle of Montbard; and waking him up at three o'clock in the morning, with this singular cry, he opened the window and called out, "Who's there below? My name is not EDMe, but Peter!"

The Saw-whet - called so from its note, which resembles the filing of a saw - breeds from the Middle States northward to about latitude $50^{\circ}$, but is not an abundant bird anywhere. 


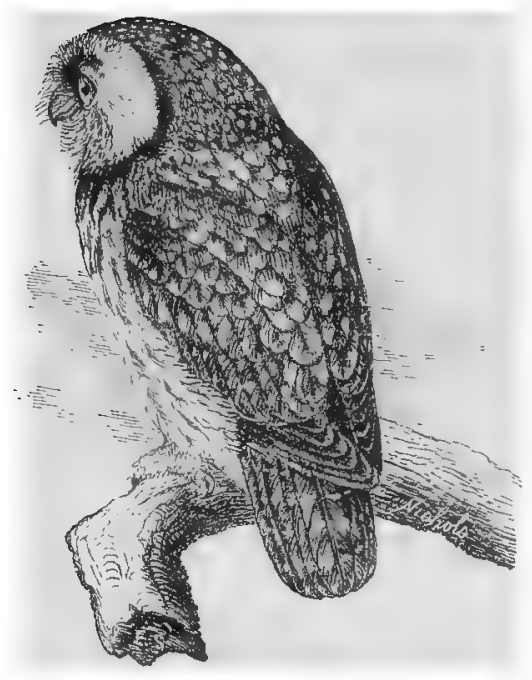

\section{RICHARDSON'S OWL.}

SPARROW OWL.

\section{NyCTALA TENGMALMI RICHARDSONI.}

CHAR. Above, dark brown spotted with white; beneath, white streaked with brown; legs and feet buffy, sometimes spotted. Similar to the Sawwhet, but with more white on head and neck. Length 9 to 12 inches.

Nest. In a tree; of grass and leaves.

Eggs. 2-4; white; I.35 X I.I5-

This is a small and nocturnal species, and so much so that when it accidentally wanders abroad by day it is so much dazzled by the light as to be rendered unable to make its escape when surprised, and may then be readily caught by the hand. Its nocturnal cry consists of a single melancholy note repeated at the long intervals of a minute or two: and it is one of the superstitious practices of the Indians to whistle when they hear it; and if the bird remains silent after this interrogatory challenge, the speedy death of the inquirer is augured; and hence among the Crees it has acquired the omnious appellation of the Bird of Death (Cheepomeseees). According to M. Hutchins, it builds a nest of grass half way up a pine-tree, and lays 
2 eggs in the month of May. It feeds on mice and beetles. It probably inhabits all the forests of the fur countries from Great Slave Lake to the United States. On the banks of the Saskatchewan it is so common that its voice is heard almost every night by the traveller wherever he may select his camp. It inhabits the woods along the streams of the Rocky Mountains down to the Oregon, and betrays but little suspicion when approached.

Richardson's Owl is usually a rare winter visitor to the Maritime Provinces; but Mr. C. B. Cory found it common and breeding on the Magdalene Islands, and a few examples have been taken in New Brunswick in summer.

It is common on the north shore of the Gulf of St. Lawrence, though rare near the city of Quebec; it occurs sparingly in winter along the northern border of New England and in southern Ontario, and occasionally straggles to Massachusetts and Connecticut. Thompson reports it common in Manitoba. 


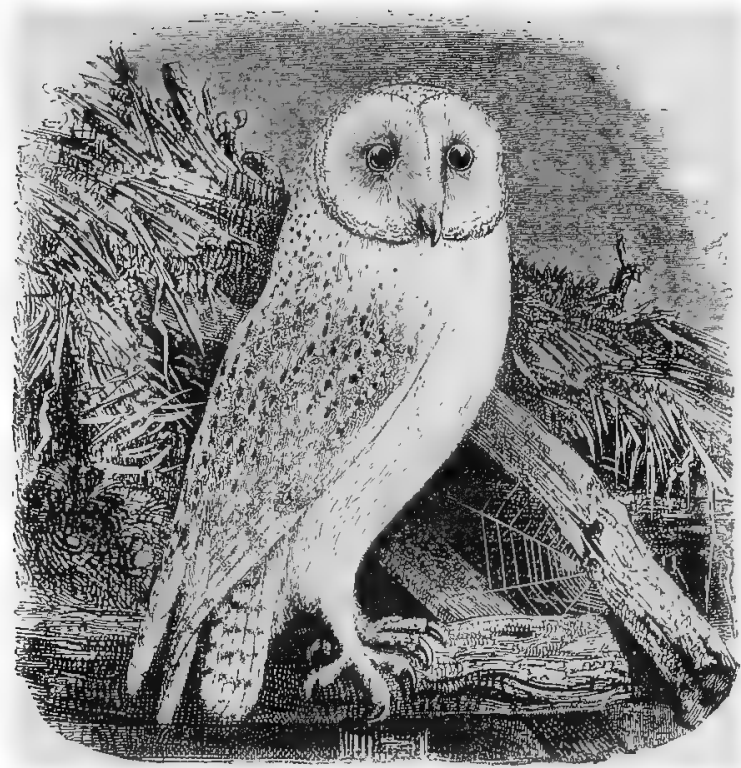

\section{BARN OWL.}

\section{STRIX PRATINCOLA.}

Char. Colors extremely variable. Above, usually yellowish tawny or orange brown, clouded with darker tints and spotted with white; beneath, buffish with dark spots; face white, tinged with tawny; bill whitish. Some examples have but little marking on the back, and the face and lower parts are pure white. Easily distinguished from other $\mathrm{O}$ wls by peculiar facial disc. Length 15 to $2 \mathrm{I}$ inches.

Nest. In barn or church tower or hollow tree, - usually the last. The eggs are laid upon a mat of loosely laid twigs and weed-stems or grass.

Eggs. 3-II ; white ; $1.75 \times 1.30$.

There is scarcely any part of the world in which this common species is not found; extending even to both sides of the equator, it is met with in New Holland, India, and Brazil. It is perhaps nowhere more rare than in this part of the United States, and is only met with in Pennsylvania and New Jersey in cold and severe winters. Nor is it ever so familiar as in Europe, frequenting almost uniformly the hollows of trees. 
In the old continent it is almost domestic, inhabiting even populous towns, and is particularly attached to towers, belfries, the roofs of churches, and other lofty buildings, which afford it a retreat during the day. The elegant, graphic lines of Gray, describing its romantic haunt, are in the recollection of every one, -

"From yonder ivy-mantled tower

The moping Owl does to the moon complain

Of such as, wandering near her secret bower,

Molest her ancient solitary reign."

Superstition laid aside, these Owls render essential service to the farmer by destroying mice, rats, and shrews, which infest houses and barns; they also catch bats and beetles. They likewise clear churches of such vermin, and now and then, pressed by hunger, they have been known to sip, or rather eat, the oil from the lamps when congealed by cold. A still more extraordinary appetite, attributed to them, is that of catching fish, on which they fed their voracious young. In autumn also they have been known to pay a nightly visit to the places where springes were laid for Woodcocks and Thrushes. The former they killed and ate on the spot; but sometimes carried off the Thrushes and smaller birds, which, like mice, they either swallowed entire, rejecting the indigestible parts by the bill, or if too large, they plucked off the feathers and then bolted them whole, or only took them down piecemeal.

In fine weather they venture out into the neighboring woods at night, returning to their usual retreat at the approach of morning. When they first sally from their holes, their eyes hardly well opened, they fly tumbling along almost to the ground, and usually proceed side-ways in their course. In severe seasons, 5 or 6 , probably a family brood, are discovered in the same retreat, or concealed in the fodder of the barn, where they find shelter, warmth, and food. The Barn Owl drops her eggs in the bare holes of walls, in the joists of houses, or in the hollows of decayed trees, and spreads no lining to receive them; they are 3 to 5 in number, of a whitish color, and rather long than round. 
When out abroad by day, like most of the other species, they are numerously attended by the little gossiping and insulting birds of the neighborhood; and to add to their distraction, it is not an uncommon practice, in the North of England, for boys to set up a shout and follow the Owl, who becomes so deafened and stunned as at times nearly to fall down, and thus become an easy prey to his persecutors. And the probability of stich an effect will not be surprising when we consider the delicacy and magnitude of the auditory apparatus of this bird, the use of which is probably necessary to discover the otherwise silent retreats of their tiny prey. When taken captive, according to Buffon, they do not long survive the loss of liberty, and pertinaciously refuse to eat, - a habit very different from that of the young Red Owl, who allowed himself to feed from my hand, and tugged greedily and tamely at the morsel held out to him until he got it in his possession; small birds also he would instantly grasp in his talons, and hiss and shaié, shaie, when any attempt was made to deprive him of his booty.

The young of this species, when they have just attained their growth, are, in France, considered good food, as they are then fat and plump. When first hatched they are so white and downy as almost entirely to resemble. a powder puff. At Hudson's Bay a large Owl, resembling the cinereous, is likewise eaten, and esteemed a delicacy, according to Pennant.

The Barn Owl occurs regularly from the Middle States southward, though it is not abundant north of South Carolina. A few examples have been taken in Connecticut and Massachusetts, and Mr. McIlwraith reports that four have been taken in Ontario. 


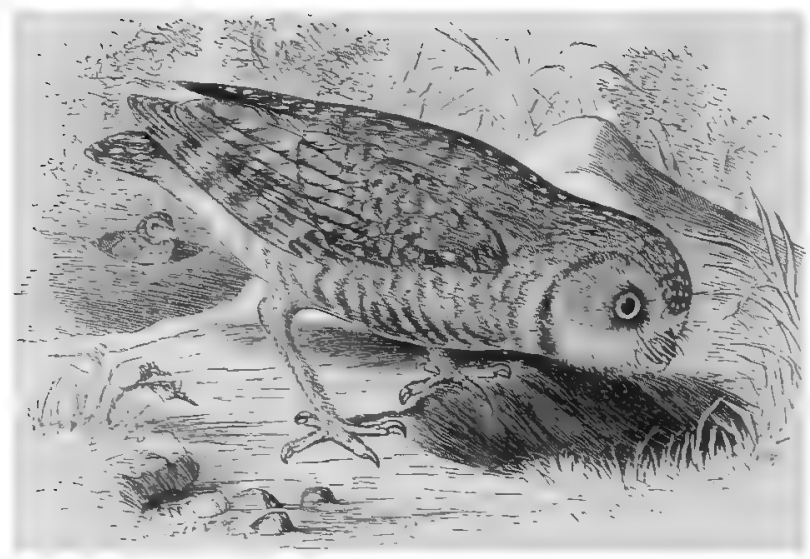

\section{FLORIDA BURROWING OWL.}

\section{SPEOTYTO CUNICULARLA FLORIDANA.}

Char. Above, grayish brown spotted and barred with white; below, pale buffish barred with brown; a patch of white on the breast; legs long and slender, and covered with buffish bristles. Length about to inches.

Nest. At the end of a burrow in the ground, lined with grass and feathers.

Eggss. 4-to; white, varying in shape, usually nearly round; I.25 $\times$ r.oo.

This variety, which is found in Florida only, is smaller and lightercolored than is the well-known bird of the prairies. In habits the two differ little, the Florida birds living in communities, - sometimes several pairs in one burrow, - and feeding on mice and small birds. The tales related of Burrowing Owls and rattlesnakes occupying the same burrow are "hunter's tales," and lack confirmation.

Note. - The Western form of the Burrowing OwL (S. cmicularia hypogaa, has been taken in Massachusetts; but its occurrence to the eastward of the Great Plains is accidental. 


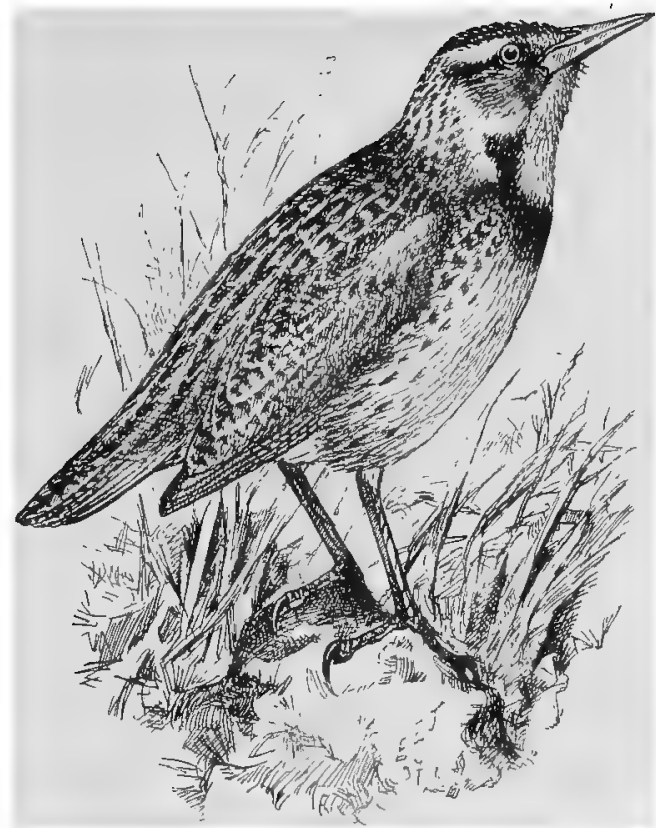

\section{MEADOW LARK.}

FIELD LARK.

STURNELla MAGNA.

Char. Above, grayish brown barred with black; crown with medial stripe of buff; lateral tail-feathers white; below yellow, sides darker and spotted with brown; black crescent on the breast. Length about Io inches.

Nest. Made of dry grass and placed amid a tuft of long grass in a meadow; often covered, and the opening placed at the side.

Eggs. 4-6; white, thickly spotted with reddish brown and lilac; I.1 $5 \times .80$.

'This well-known harmless inhabitant of meadows and old fields is not only found in every part of the United States, but appears to be a resident in all the intermediate region, from the frigid latitude of $53^{\circ}$ and the territory of Oregon, to the mild table-land of Mexico and the savannahs of Guiana. In the winter these birds abound in Alabama and Western 
Florida; so that in some degree, like the Jays and the legitimate Starlings, they partially migrate in quest of food during the severity of the weather in the colder States. It is not, however, improbable but that most of the migrating families of these birds, which we find at this season, have merely travelled eastward from the cold Western plains that are annually covered with snow. They are now seen in considerable numbers in and round the salt-marshes, roving about in flocks of ten to thirty or more, seeking the shelter of the sea-coast, though not in such dense flocks as the true Starlings; these, in the manner of our common Blackbirds, assemble in winter like dark clouds; moving as one body, and when about to descend, perform progressive circular evolutions in the air like a phalanx in the order of battle; and when settled, blacken the earth with their numbers, as well as stun the ears with their chatter. Like Crows also, they seek the shelter of reed-marshes to pass the night, and in the day take the benefit of every sunny and sheltered covert.

Our Starling, like the American Quail, is sociable, and somewhat gregarious; and though many, no doubt, wander some distance after food, yet a few, in Pennsylvania as well as in this rigorous climate, may be seen in the market after the ground is covered with snow. Wilson even observed them in the month of February, during a deep snow, among the heights of the Alleghanies, gleaning their scanty pittance on the road, in company with the small Snow Birds.

The flesh of our bird is white, and for size and delicacy it is considered little inferior to the Partridge ; but that of the European species is black and bitter.

The flight of these Larks is laborious and steady, like that of the Quail, with the action of the wings renewed at short intervals. They often alight on trees, and select usually the main branches or topmost twigs on which to perch, though their food is commonly collected from the ground. At various times of the day, and nearly through the winter, in the milder States, their very peculiar lisping, long, and rather melancholy note is heard at short intervals; and without the variations, which are 
not inconsiderable, bears some resemblance to the slender sing-

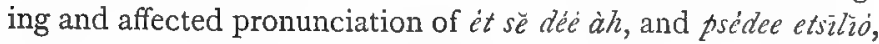
or tat sedzizo in a slow, wiry, shrill tone, and sometimes differently varied and shortened. The same simple ditty is repeated in the spring, when they associate in pairs; the female also, as she rises or descends, at this time frequently gives a reiterated guttural chirp, or hurried twitter, like that of the female Redwinged Blackbird. I have likewise at times heard them utter notes much more musical and vigorous, not very unlike the fine tones of the Sky Lark; but I can by no means compare our lisping songster with that blithe "harbinger of day." There is a monotonous affectation in the song of our Lark which appears indeed somewhat allied to the jingling, though not unpleasant, tune of the Starling. The Stare, moreover, had the faculty of imitating human speech (which ours has not, as far as we yet know), and could indifferently speak even French, English, German, Latin, and Greek, or any other language within his hearing, and repeat short phrases; so that " ' $I$ can't get out, I can't get out,' says the Starling," which accidentally afforded Sterne such a beautiful and pathetic subject for his graphic pen, was probably no fiction.

At the time of pairing, our Lark exhibits a little of the jealous disposition of his tribe; and having settled the dispute which decicles his future condition, he retires from his fraternity, and, assisted by his mate, selects a thick tuft for the reception of his nest, which is pretty compact, made of dry, wiry grass, and lined with finer blades of the same. It is usually formed with a covered entrance in the surrounding withered grass, through which a hidden and almost winding path is made, and generally so well concealed that the nest is only to be found when the bird is flushed.

The eggs are four or five, white, with a very faint tint of blue, almost round, and rather large, for the size of the bird, marked with numerous small reddish-brown spots, more numerous at the greater end, blended with other lighter and darker points and small spots of the same. They probably often raise two broods in the season. About the time of voL. I. -6 
pairing, in the latter end of the month of April, they have a call, like 'tship, twee, the latter syllable in a fine and slender tone, - something again allied to the occasional notes of the Red-winged Blackbird, to which genus (Ictirns) our Sturnella is not very remotely allied. Towards the close of June little else is heard from the species but the noisy twitter of the female, preceded by a hoarse and sonorous ' $j$ 'imp or ' $j$ 'ip, accompanied by an impatient raising and lowering of the wings, and, in short, all the unpleasant and petulant actions of a brood-hen, as she is now assiduously engaged in fostering and supporting her helpless and dependent offspring.

Their food consists of the larvæ of various insects, as well as worms, beetles, and grass-seeds, to assist the digestion of which they swallow a considerable portion of gravel. It does not appear that these birds add berries or fruits of any kind to their fare, like the Starling, but usually remain the whole summer in moist meadows, and in winter retire to the open grassy woods, having no inclination to rob the orchard or garden, and, except in winter, are of a shy, timid, and retiring disposition.

In the East the Meaclow Lark seldom ranges north of latitude $45^{\circ}$. I met with but one example in New Brunswick, and learn that it is rare near Montreal. It is common around Ottawa and throughout southern Ontario.

Note. - A larger and paler form, named the Western MeADOW LARK ( $S$. magna neglecta), occurs in Wisconsin, Illinois, and Iowa; and Mr. W. E. D. Scott has lately announced that the birds found in southwestern Florida should be referred to mexicana, the Mrxican Meadow LaRK, which is the smallest of the three.

A stray Starling (Sturnues rulgaris) is said to have wandered from Europe to Greenland; and a TROUPIAL (Icterus icterus), a South American bird, was taken by Audubon near Charleston, S. C. 


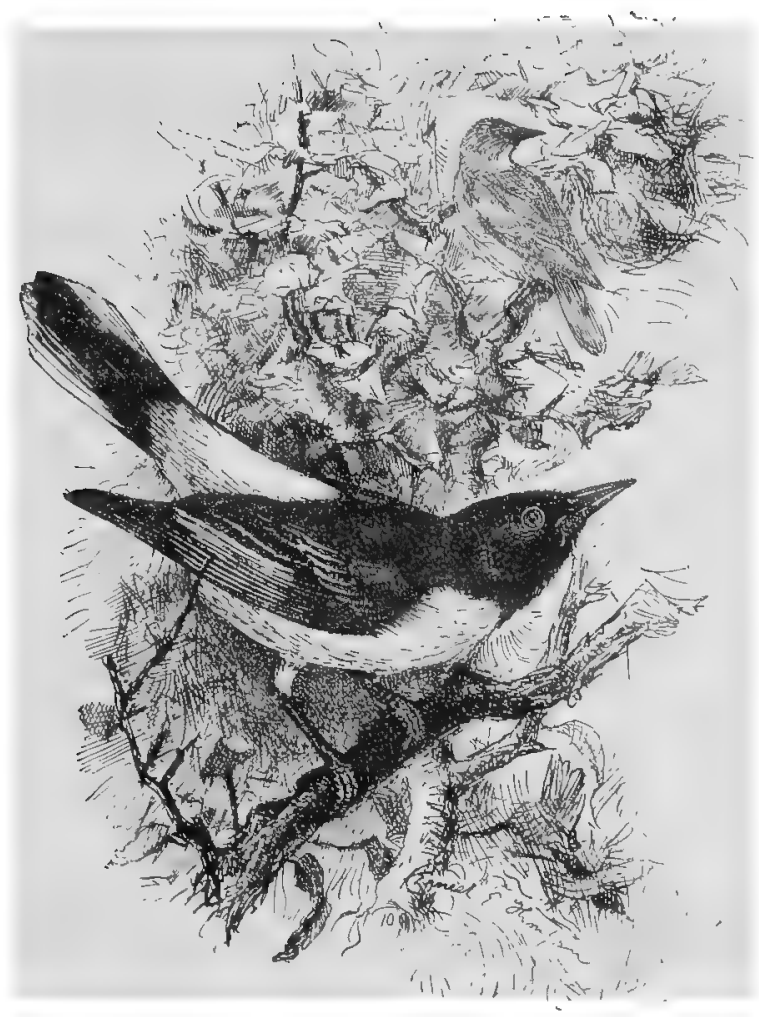

BALTIMORE ORIOLE.

GOLDEN ROBIN. HANG-NEST. FIRE BIRD.

ICTERUS GALBULA.

CHAR. Male : head, neck, throat, back, wings, and greater part of tail black; wing-coverts and secondaries tipped with white; other parts orange. Bill and feet blue black. Female: smaller and paler, sometimes the black replaced by olive or grayish. Young similar to female. Length 7 to 8 inches.

Nest. Pensile and purse-shaped, 6 to 8 inches deep, suspended from extremity of branch to to 50 feet from the ground, composed of yarn, string, horsehair, grass, etc., woven into a compact texture.

Eggs. 4-6; dull white, blotched irregularly with dark brown; .90 $\times .60$. 
These gay, lively, and brilliant strangers, leaving their hibernal retreat in South America, appear in New England about the first week in May, and more than a month earlier in Louisiana, according to the observations of Audubon. They were not seen, however, in West Florida by the middle of March, although vegetation had then so far advanced that the oaks were in leaf, and the white flowering cornel was in full blossom.

It is here that they pass the most interesting period of their lives; and their arrival is hailed as the sure harbinger of approaching summer. Full of life and activity, these fiery sylphs are now seen vaulting and darting incessantly through the lofty boughs of our tallest trees; appearing and vanishing with restless inquietude, and flashing at quick intervals into sight from amidst the tender waving foliage, they seem like living gems intended to decorate the verdant garment of the new-clad forest. But the gay Baltimore is neither idle nor capricious; the beautiful small beetles and other active-winged insects on which he now principally feeds are in constant motion, and require perpetual address in their capture. At first the males only arrive, but without appearing in flocks; their mates are yet behind, and their social delight is incomplete. They appear to feel this temporary bereavement, and in shrill and loud notes they fife out their tender plaints in quick succession, as they pry and spring through the shady boughs for their tiny and eluding prey. They also now spend much time in the apple-trees, often sipping honey from the white blossoms, over which they wander with peculiar delight, continually roving amidst the sweet and flowery profusion. The mellow whistled notes which they are heard to trumpet from the high branches of our tallest trees and gigantic elms resemble, at times, 'tshippe-tshayia too too, and sometimes 'tshippee 'tshippee (lispingly), too too (with the two last syllables loud and full). These notes are also varied by some birds so as to resemble 'tsh 'tsh 'tsheetshoo tshoo tshoo,' also 'tsh 'tsheefä 'tsheefă 'tsheefä

1 The first three of these notes are derived from the Summer Yellow Bird, though not its most usual tones. 
tshoo and ' $k$ 'túf $\breve{a}$ túf $\breve{a}$ tüf a téa kĕrry, ${ }^{1}$ another bird I have occasionally heard to call for hours, with some little variation, thí těo tĕo tĕo teo too, in a loud, querulous, and yet almost ludicrously merry strain. At other intervals the sensations of solitude seem to stimulate sometimes a loud and interrogatory note, echoed forth at intervals, as k'rry kerry? and terminating plaintively k'rry k'rry k'rry, tū ; the voice falling off very slenderly in the last long syliable, which is apparently an imitation from the Cardinal Grosbeak, and the rest is derived from the Crested Titmouse, whom they have already heard in concert as they passed through the warmer States. Another interrogatory strain which I heard here in the spring of I 830 was precisely, 'yip k'rry, 'yip, 'yip k'rry, very loud and oft repeated. Another male went in his ordinary key, tshĕrry tshêrry, tshipee tsh'rry, — notes copied from the exhaustless stock of the Carolina Wren (also heard on his passage), but modulated to suit the fancy of our vocalist. The female likewise sings, but less agreeably than the male. One which I had abundant opportunity of observing, while busied in the toil of weaving her complicated nest, every now and then, as a relief from the drudgery in which she was solely engaged, sung, in a sort of querulous and rather plaintive strain, the strange, un-

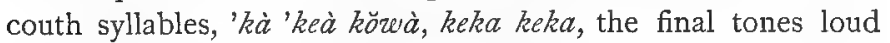
and vaulting, which I have little doubt were an imitation of the discordant notes of some South American bird. For many days she'continued this tune at intervals without any variation. The male, also while seeking his food in the same tree with his mate, or while they are both attending on their unfledged brood, calls frequently in a low, friendly whisper, 'twait, two'it. Indeed, all the individuals of either sex appear pertinaciously to adhere for weeks to the same quaint syllables which they have accidentally collected.

This bird then, like the Starling, appears to have a taste for mimicry, or rather for sober imitation. A Cardinal Grosbeak happening, very unusually, to pay us a visit, his harmonious

I The last phrase loud and ascending, the tea plaintive, and the last syllable tender and echoing. 
and bold whistle struck upon the ear of a Baltimore with great delight; and from that moment his ordinary notes were laid aside for 'woit, 'woit, teú, and other phrases previously foreign to him for that season. I have likewise heard another individual exactly imitating the soft and somewhat plaintive vizt y'u, vist yiu of the same bird, and in the next breath the perit, or call of Wilson's Thrush; also at times the earnest song of the Robin. Indeed his variations and imitations have sometimes led me to believe that I heard several new and melodious birds, and I was only undeceived when I beheld his brilliant livery. So various, in fact, are the individual phrases chanted by this restless and lively bird that it is scarcely possible to fix on any characteristic notes by which he may be recognized; his singular, loud, and almost plaintive tone, and a fondness for harping long on the same string, are perhaps more peculiar than any particular syllables which he may be heard to utter. When alarmed or offended at being too closely watched or approached, both male and female utter an angry, rattling tsher tsh'r, or hiss, tsh' tsh' tsh' 'tsh.

The beautiful Baltimore bird is only one of the tribe of true Icteri, which, except the present and two following species, remain within the tropical regions, or only migrate to short distances in the rainy season. Ours wing their way even into Canada as far as the $55^{\text {th }}$ degree, and breed in every intermediate region to the table-land of Mexico. A yellow Brazilian species of the section of this genus, called cassicus, according to Waterton inhabits also Demerara, where, like our bird, he familiarly weaves his pendulous nest near the planter's house, suspending it from the drooping branches of trees, and so low that it may be readily looked into even by the incurious. Omnivorous like the Starling, he feeds equally on insects, fruits, and seeds. He is called the Mocking Bird, and for hours together, in gratitude as it were for protection, he serenades the inhabitants with his imitative notes. His own song, though short, is sweet and melodious. But hearing perhaps the yelping of the Toucan, he drops his native strain to imitate it, or place it in ridicule by contrast. Again, he gives the cackling 
cries of the Woodpecker, the bleating of the sheep; an interval of his own melody, then probably a puppy dog or a Guineafowl receives his usual attention: and the whole of this mimicry is accompanied by antic gestures indicative of the sport and company which these vagaries afford him. Hence we see that the mimicking talent of the Stare is inherent in this branch of the gregarious family, and our own Baltimore, in a humbler style, is no less delighted with the notes of his feathered neighbors.

There is nothing more remarkable in the whole instinct of our Golden Robin than the ingenuity displayed in the fabrication of its nest, which is, in fact, a pendulous cylindric pouch of five to seven inches in depth, usually suspended from near the extremities of the high, drooping branches of trees (such as the elm, the pear or apple tree, wild-cherry, weeping-willow, tulip-tree, or buttonwood). It is begun by firmly fastening natural strings of the flax of the silk-weed, or swamp-holyhock, or stout artificial threads, round two or more forked twigs, corresponding to the intended width and depth of the nest. With the same materials, willow down, or any accidental ravellings, . strings, thread, sewing-silk, tow, or wool, that may be lying near the neighboring houses, or round the grafts of trees, it interweaves and fabricates a sort of coarse cloth into the form intended, towards the bottom of which is placed the real nest, made chiefly of lint, wiry grass, horse and cow hair, sometimes, in defect of hair, lining the interior with a mixture of slender strips of smooth vine-bark, and rarely with a few feathers, the whole being of a considerable thickness, and more or less attached to the external pouch. Over the top, the leaves, as they grow out, form a verdant and agreeable canopy, defending the young from the sun and rain. There is sometimes a considerable difference in the manufacture of these nests, as well as in the materials which enter into their composition. Both sexes seem to be equally adepts at this sort of labor, and I have seen the female alone perform the whole without any assistance, and the male also complete this laborious task nearly without the aid of his consort, - who, how- 
ever, in general, is the principal worker. I have observed a nest made almost wholly of tow, which was laid out for the convenience of a male bird, who with this aid completed his labor in a very short time, and frequently sang in a very ludicrous manner while his mouth was loaded with a mass larger than his head. So eager are these birds to obtain fibrous materials that they will readily tug at and even untie hard knots made of tow. In Audubon's magnificent plates a nest is represented as formed outwardly of the long-moss; where this abounds, of course, the labor of obtaining materials must be greatly abridged. The author likewise remarks that the whole fabric consists almost entirely of this material, loosely interwoven, without any warm lining, - a labor which our ingenious artist seems aware would be superfluous in the warm forests of the lower Mississippi. A female, which I observed attentively, carried off to her nest a piece of lamp-wick ten or twelve feet long. This long string, and many other shorter ones, were left hanging out for about a week before both the ends were wattled into the sides of the nest. Some other little birds, making use of similar materials, at times twitched these flowing ends, and generally brought out the busy Baltimore from her occupation in great anger.

The haste and eagerness of one of these airy architects, which I accidentally observed on the banks of the Susquehanna, appeared likely to prove fatal to a busy female who, in weaving, got a loop round her neck; and no sooner was she disengaged from this snare than it was slipped round her feet, and thus held her fast beyond the power of escape! The male came frequently to the scene, now changed from that of joy and hope into despair, but seemed wholly incapable of comprehending or relieving the distress of his mate. In a second instance $I$ have been told that a female has been observed dead in the like predicament.

The eggs of this species are usually four or five, white, with a faint, indistinct tint of bluish, and marked, chiefly at the greater end, though sometimes scatteringly, with straggling, serpentine, dark-brown lines and spots, and fainter hair streaks, 
looking sometimes almost like real hair, and occasionally lined only, and without the spots. The period of incubation is fourteen days. In Louisiana, according to Audubon, they frequently raise two broods in the season, arriving in that country with the opening of the early spring. Here they raise but a single brood, whose long and tedious support in their lofty cradle absorbs their whole attention; and at this interesting period they seem, as it were, to live only to protect, cherish, and educate their young. The first and general cry which the infant brood utter while yet in the nest, and nearly able to take wing, as well as for some days after, is a kind of té-did té-

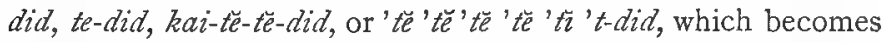
clamorous as the parents approach them with food. They soon also acquire the scolding rattle and short notes which they probably hear around them, such as peet-weet, the cry of the spotted Sandpiper, and others, and long continue to be assiduously fed and guarded by their very affectionate and devoted parents. Unfortunately, this contrivance of instinct to secure the airy nest from the depredations of rapacious monkeys, and other animals which frequent trees in warm or mild climates, is also occasionally attended with serious accidents, when the young escape before obtaining the perfect use of their wings. They cling, however, with great tenacity either to the nest or neighboring twigs; yet sometimes they fall to the ground, and, if not killed on the spot, soon become a prey to numerous enemies. On such occasions it is painful to hear the plaints and wailing cries of the parents. And when real danger offers, the generous and brilliant male, though much the less querulous of the two, steps in to save his brood at every hazard; and I have known one so bold in this hopeless defence as to suffer himself to be killed, by a near approach with a stick, rather than desert his offspring. Sometimes, after this misfortune, or when the fell cat has devoured the helpless brood, day after day the disconsolate parents continue to bewail their loss. They almost forget to eat amidst their distress, and after leaving the unhappy neighborhood of their bereavement, they still come, at intervals, to visit and lament over the fatal spot, as if 
spell-bound by despair. If the season be not too far advanced, the loss of their eggs is generally soon repaired by constructing a second nest, in which, however, the escrs are fewer.

The true Oriole $\left(O . s_{\text {s }}\right.$ ibula), which migrates into Africa, and passes the breeding season in the centre of Europe, also makes a pendulous nest, and displays great courage in the defence of its young, being so attached to its progeny that the female has been taken and conveyed to a cage on her eggs, on which, with resolute and fatal instinct, she remained faithfully sitting until she expired.

The Baltimore bird, though naturally shy and suspicious, probably for greater security from more dangerous enemies, generally chooses for the nest the largest and tallest spreading trees near farm-houses, and along frequented lanes and roads; and trusting to the inaccessibleness of its ingenious mansion, it rorks fearlessly and scarcely studies concealment. But as soon as the young are hatched, here, towards the close of June, the whole family begin to leave the immediate neighborhood of their cares, flit through the woods, - a shy. roving, and nearly silent train; and when ready for the distant journey before them, about the end of August or beginning of September, the whole at once disappear, and probably arrive, as with us, amidst the forests of South America in a scattered flock, and continue, like Starlings. to pass the winter in celibacy, wholly engaged in gleaning a quiet subsistence until the return of spring. Then, incited by instinct to prepare for a more powerful passion, they again wing their way to the regions of the north, where, but for this wonderful instinct of migration, the whole race would perish in a single season. As the sexes usually arrive in different flocks, it is evident that the conjugal tie ceases at the period of migration, and the choice of mates is renewed with the season; during which the males, and sometimes also the females, carry on their jealous disputes with much obstinacy.

That our Oriole is not familiar with us, independent of the all-powerful natural impulse which he obeys, is sufficiently obvious when he nests in the woods. Two of these solitary 
and retiring pairs had this summer, contrary to their usual habits, taken up their abode in the lofty branches of a gigantic Buttonwood in the forest. As soon as we appeared they took the alarm, and remained uneasy and irritable until we were wholly out of sight. Others, again, visit the heart of the populous city, and pour forth their wild and plaintive songs from the trees which decorate the streets and gardens, amid the din of the passing crowd and the tumult of incessant and noisy occupations. Audubon remarks that their migrations are performed singly and during the day, and that they proceed high, and fly straight and continuous.

The food of the Baltimore appears to be small caterpillars, sometimes those of the apple-trees, - some uncommon kinds of beetles, cimices, and small flies, like a species of cynips. Occasionally I have seen an individual collecting Cicindeli by the sides of sandy and gravelly roads. They feed their young usually with soft caterpillars, which they swallow, and disgorge on arriving at the nest; and in this necessary toil both sexes assiduously unite. They seldom molest any of the fruits of our gardens, except a few cherries and mulberries, and are the most harmless, useful, beautiful, and common birds of the country. They are, however, accused of sometimes accompanying their young to the garden peas, which they devour while small and green; and being now partly gregarious, the damage they commit is at times rendered visible. Occasionally they are seen in cages, being chiefly fed on soaked bread, or meal and water; they appear also fond of cherries, strawberries, currants, raisins, and figs, so that we may justly consider them, like the Cassicans and Starlings, as omnivorous, though in a less degree. They sing and appear lively in confinement or domestication, and become very docile, playful, and friendly, even going in and out of the house, and sometimes alighting at a whistle on the hand of their protector. The young for a while require to be fed on animal food alone, and the most suitable appears to be fresh minced meat, soaked in new milk. In this way they may be easily raised almost from the first hatching; but at this time vegetable substances 
appear to afford them no kind of nutrition, and at all times they will thrive better if indulged with a little animal food or insects, as well as hard-boiled eggs.

The summer range of this beautiful bird in the fur countries extends to the $55^{\text {th }}$ degree of latitude, arriving on the plains of the Saskatchewan, according to Richardson, about the Ioth of May, or nearly as early as their arrival in Massachusetts. Those which thus visit the wilds of Canada in all probability proceed at once from Mexico, or ascend the great valley of the Mississippi and Missouri.

I have had a male bird in a state of domestication raised from the nest very readily on fresh minced meat soaked in milk. When established, his principal food was scalded Indian cornmeal, on which he fed contentedly, but was also fond of sweet cakes, insects of all descriptions, and nearly every kind of fruit. In short, he ate everything he would in a state of nature, and did not refuse to taste and eat of everything but the condiments which enter into the multifarious diet of the human species: he was literally omnivorous.

No bird could become more tame, allowing himself to be handled with patient indifference, and sometimes "with playfulness. The singular mechanical application of his bill was remarkable, and explains at once the ingenious art employed by the species in weaving their nest. If the folded hand was presented to our familiar Oriole, he endeavored to open it by inserting his pointed and straight bill betwixt the closed fingers, and then by pressing open the bill with great muscular force, in the manner of an opening pair of compasses, he contrived, if the force was not great, to open the hand and examine its contents. If brought to the face he did the same with the mouth, and would try hard to open the closed teeth. In this way, by pressing open any yielding interstice, he could readily insert the threads of his nest, and pass them through an infinity of openings, so as-to form the ingenious net-work or basis of his suspensory and procreant cradle.

This is a familiar bird throughout the greater part of this faunal province north to the southern portions of Ontario and Quebec, 
and it occurs sparingly in New Brunswick and Nova Scotia. It winters southward to Panama.

Note. - A single example of Bullock's Oriole (Icterus bullocki), which was shot near Bangor, Maine, in I889, gives this species a right to be mentioned here. The usual habitat of this species is between the eastern base of the Rockies and the Pacific coast.

\section{ORCHARD ORIOLE.}

\section{ICTERUS SPURIUS.}

CHAR. Male : head, neck, back, wings, and tail black; other parts chestnut, deepest on breast. Female: yellowish olive inclining to brown; wings dusky brown with 2 white bands; beneath, olive yellow. Young similar to female. Length 6 to $7 \frac{1}{4}$ inches.

Nest. A handsome basket-like structure, about 4 inches in depth, composed of grasses woven into a smorth firm fabric, and lined with feathers or other soft material. It is sometimes partly supported in the forks of small twigs, and often entirely pendent. Usually about 10 feet from the ground and near the end of the branch.

Eggs. 3-6 (generally 4); white with blue or green tint, irregularly marked with lilac and brown; $.80 \times .60$.

This smaller and plainer species has many of the habits of the Baltimore bird, and arrives in Pennsylvania about a week later. They enter the southern boundary of the United States early in March, and remain there until October. They do not however, I believe, often migrate farther north and east than the State of Connecticut. I have never seen or heard of them in Massachusetts, any more than my scientific friend, and close observer, Mr. C. Pickering. Their stay in the United States, it appears from Wilson, is little more than four months, as they retire to South America early in September, or at least do not winter in the Southern States. According to my friend Mr. Ware, they breed at Augusta, in Georgia; and Mr. Say observed the Orchard Oriole at Major Long's winter quarters on the banks of the Missouri. Audubon has also observed the species towards the sources of the Mississippi, as well as in the State of Maine. The same author likewise remarks that their 
northern migrations, like those of the Baltimore bird, are performed by day, and that the males arrive a week or ten days sooner than their mates. They appear to affect the elevated and airy rezions of the Alleghany mountains, where they are much more numerous than the Baltimore.

The Orchard Oriole is an exceedingly active, sprightly, and restless bird; in the same instant almost, he is on the ground after some fallen insect, fluttering amidst the foliage of the trees. prying and springing after his lurking prey, or flying and tuning his lively notes in a manner so hurried. rapid, and seemingly confused that the ear is scarce able to thread out the shrill and lirely tones of his agitated dittr. Between these hurried attempts he also gives others, which are distinct and agreeable, and not unlike the sweet warble of the Red-Breasted Grosbeak, though more brief and less varied. In choosing the situation of his nest he is equally familiar with the Baltimore Oriole, and seems to enjur the general society of his species. suspending his most ingenious and pensile fabric from the bending twig of the apple-tree, which, like the nest of the other, is constructed in the form of a pouch from three to nive inches in depth, according to the strength or flexibiility of the tree on which he labors; so that in a weeping-willow, according to Wilson, the nest is one or two inches deeper than if in an apple-tree, to obriate the danger of throwing out the eggs and young by the sweep of the long, pendulous branches. It is likewise slighter, as the cromding leaves of that tree afford a natural shelter of considerable thickness. That economy of this kind should be studied by the Orchard Oriole will scarcelysurprise so much as the laborious ingenuity and beautiful tissue of its nest. It is made exteriorly of a fine woren mat of long, tough, and flexible grass, as if darned with a needle. The form is hemispherical, and the inside is lined with downy substances, - sometimes the wool of the seeds of the Buttonwood, - forming thus a commodious and soft bed for the young. This precaution of a warm lining, as in the preceding species, is, according to Audubon, dispensed with in the warm climate of Louisiana. The eggs are 4 or 5, of a rery pale bluish 
tint, with a few points of brown, and spots of dark purple, chiefly disposed at the greater end. The female sits about $x+$ days, and the young continue in the nest io days before they become qualified to flit along with their parents; but they are generally seen abroad about the middle of June. Previously to their departure, the young, leaving the care of their parents, become gregarious, and assemble sometimes in flocks of separate sexes, from 30 to 40 or upwards, - in the South frequenting the savannahs, feeding much on crickets, grasshoppers, and spiders; and at this season their flesh is much esteemed by the inhabitants. Wilson found them easy to raise from the nest, but does not say on what they were fed, though they probably require the same treatment as the Baltimore Oriole. According to Audubon, they sing with great liveliness. in cages, being fed on rice and dry fruits when fresh cannot be procured. Their ordinary diet, it appears, is caterpillars and insects, of which they destroy great quantities. In the course of the season they likewise feed on various kinds of juicy fruits and berries; but their depredations on the fruits of the orchard are very unimportant.

This is a summer visitor throughout the Eastern States, though not common north of the Connecticut valley. It occurs regularly in Massachusetts and southern Ontario, and has been taken in Maine and New Brunswick. 


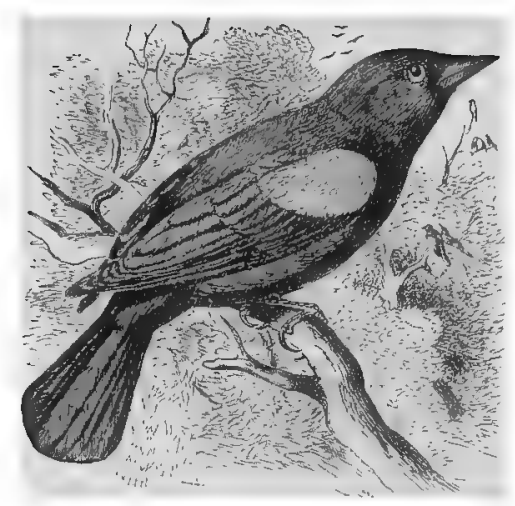

\section{RED-WINGED BLACKBIRD.}

\section{Agelaius PHCNiceus.}

CHAR. Male: black; lesser wing-coverts vermilion, bordered with buff. Female: above, blackish brown streaked with paler and grayish; lower parts dusky white streaked with reddish brown; sometimes wingcoverts have a reddish tinge, Young like female, but colors deeper. Length $7 \pi / 2$ to ro inches.

Nest. In a tuft of grass or on a bush; composed of grass, leaves, and mud, lined with soft grass.

Eggs, 3-5; color varies from bluish white to greenish blue, blotched. streaked, and spotted with lilac and dark brown; size variable, average about I.00 X.90.

The Red-Winged Troopial in summer inhabits the whole of North America from Nova Scotia to Mexico, and is found in the interior from the $53 \mathrm{~d}$ degree across the whole continent to the shores of the Pacific and along the coast as far as Cali. fornia. They are migratory north of Maryland, but pass the winter and summer in great numbers in all the Southern States, frequenting chiefly the settlements and rice and corn fields; towards the sea-coast, where they move about like blackening clouds, rising suddenly at times with a noise like thunder, and exhibiting amidst the broad shadows of their funereal plumage the bright flashing of the vermilion with which their wings are so singularly decorated. After whirling and waving a little distance like the Starling, they descend as a torrent, and, dark- 
ening the branches of the trees by their numbers, they commence a general concert that may be heard for more than two miles. This music seems to be something betwixt chattering and warbling, --jingling liquid notes like those of the Bobolink, with their peculiar kong-querr-ree and $b o b \breve{a} l e, o-b o b \vec{a}$ lee ; then complaining chirps, jars, and sounds like saw-filing, or the motion of a sign-board on its rusty hinge; the whole constituting a novel and sometimes grand chorus of discord and harmony, in which the performers seem in good earnest, and bristle up their feathers as if inclined at least to make up in quantity what their show of music may lack in quality.

When their food begins to fail in the fields, they assemble with the Purple Grakles very familiarly around the corn-cribs and in the barn-yards, greedily and dexterously gleaning up everything within their reach. In the month of March Mr. Bullock found them very numerous and bold near the city of Mexico, where they followed the mules to steal a tithe of their barley.

From the beginning of March to April, according to the nature of the season, they begin to visit the Northern States in scattered parties, flying chiefly in the morning. As they wing their way they seem to relieve their mutual toil by friendly chatter, and being the harbingers of spring, their faults are forgot in the instant, and we cannot help greeting them as old acquaintances in spite of their predatory propensities. Selecting their accustomed resort, they make the low meadows resound again with their notes, particularly in the morning and evening before retiring to or leaving the roost; previous to settling themselves for the night, and before parting in the day, they seem all to join in a general chorus of liquid warbling tones, which would be very agreeable but for the interruption of the plaints and jarring sounds with which it is blended. They continue to feed in small parties in swamps and by slow streams and ponds till the middle or close of April, when they begin to separate in pairs. Sometimes, however, they appear to be partly polygamous, like their cousins the Cow Troopials; as amidst a number of females engaged in

vOL. I. -7 
incubation, but few of the other sex appear associated with them; and as among the Bobolinks, sometimes two or three of the males may be seen in chase of an individual of the other sex, but without making any contest or show of jealous feud with each other, as a concubinage rather than any regular mating seems to prevail among the species.

Assembled again in their native marshes, the male perched, upon the summit of some bush surrounded by water, in company with his mates, now sings out, at short intervals, his guttural kong-quěr-ree, sharply calls t'tshéah, or when disturbed, plaintively utters 'ttsh $\bar{a} y$; to which his companions, not insensible to these odd attentions, now and then return a gratulatory cackle or reiterated chirp, like that of the native Meadow Lark. As a pleasant and novel, though not unusual, accompaniment, perhaps the great bull-frog elevates his green head and brassy eyes from the stagnant pool, and calls out in a loud and echoing bellow, 'w' rroo, 'warroo, 'worrŏrroo, 'boăroo, which is again answered, or, as it were, merely varied by the creaking or cackling voice of his feathered neighbors. This curious concert, uttered as it were from the still and sable waters of the Styx, is at once both ludicrous and solemn.

About the end of April or early in May, in the middle and northern parts of the Union, the Red-Winged Blackbirds commence constructing their nests. The situation made choice of is generally in some marsh, swamp, or wet meadow, abounding with alder (Alnus) or button-bushes (Cephalanthus) ; in these, commonly at the height of five to seven feet from the ground, or sometimes in a detached bush or tussock of rank grass in the meadow, the nest is formed. Outwardly it is composed of a considerable quantity of the long dry leaves of sedge-grass (Carex), or other kinds collected in wet situations, and occasionally the slender leaves of the flag (Iris) carried round all the adjoining twigs of the bush by way of support or suspension, and sometimes blended with strips of the lint of the swamp Asclepias, or silk-weed (Asclepias incarnata). The whole of this exterior structure is also twisted in and out, and carried in loops from one side of the nest to the other, pretty 
much in the manner of the Orioles, but made of less flexible and handsome materials. The large interstices that remain, as well as the bottom, are then filled in with rotten wood, marshgrass roots, fibrous peat, or mud, so as to form, when dry, a stout and substantial, though concealed shell, the whole very well lined with fine dry stalks of grass or with slender rushes (Scirpi). When the nest is in a tussock, it is also tied to the adjoining stalks of herbage; but when on the ground this precaution of fixity is laid aside. The eggs are from 3 to 5 , white, tinged with blue, marked with faint streaks of light purple, and long, straggling, serpentine lines and dashes of very dark brown; the markings not very numerous, and disposed almost wholly at the greater end. They raise two broods commonly in the season. If the nest is approached while the female is sitting, or when the young are hatched, loud cries of alarm are made by both parties, but more particularly by the restless male, who flies to meet the intruder, and generally brings together the whole sympathizing company of his fellows, whose nests sometimes are within a few yards of each other. The female cries 'queàh, 'pueà, and at length, when the mischief they dreaded is accomplished, the louder notes give way to others which are more still, slow, and mournful; one of which resembles $t^{\prime} a i, t^{\prime} a i$, or t' $a$ and $t^{\prime} t s^{\prime} \dot{a} h$. When the young are taken or destroyed, the-pair continue restless and dejected for several days; but from the force of their gregarious habit they again commence building, usually soon after, in the same meadow or swamp with their neighbors. In the latter part of July and August the young birds, now resembling the female, begin to fly in flocks and release themselves partly from dependence on their parents, whose cares up to this time are faithful and unremitting; a few males only seem inclined to stay and direct their motions.

About the beginning of September these flocks, by their formidable numbers, do great damage to the unripe corn, which is now a favorite repast; and they are sometimes seen whirling and driving over the devoted cornfields and meadows so as to darken the air with their numbers. The destruction 
at this time made among them by the gun and the Hawks produces but little effect upon the remainder, who continue fearlessly, and in spite of all opposition, from morning to night to ravage the cornfields while anything almost remains to be eaten. The farms near the sea-coast, or alluvial situations, however, are their favorite haunts; and towards the close of September, the corn becoming hard, it is at length rejected for the seeds of the wild rice (Zizania aquatica) and other aquatic plants, which now begin to ripen, and afford a more harmless and cheap repast to these dauntless marauders. At this time, also, they begin to roost in the reeds, whither they repair in large flocks every evening from all the neighboring quarters of the country; upon these they perch or cling, so as to obtain a support above the surrounding waters of the marsh. When the reeds become dry, advantage is taken of the circumstance to destroy these unfortunate gormandizers by fire; and those who might escape the flames are shot down in vast numbers as they hover and scream around the spreading conflagration. Early in November they generally leave the Northern and colder States, with the exception of straggling parties, who still continue to glean subsistence, in the shelter of the seacoast, in Delaware, Maryland, and even in the cold climate of the State of Massachusetts. ${ }^{1}$

To those who seem inclined to extirpate these erratic depredators, Wilson justly remarks, as a balance against the damage they commit, the service they perform in the spring season, by the immense number of insects and their larvæ which they destroy, as their principal food, and which are of kinds most injurious to the husbandman. Indeed, Kalm remarked that after a great destruction made among these and the common Blackbirds for the legal reward of 3 pence a dozen, the Northern States, in 1749 , experienced a complete loss of the grass and grain crops, which were now devoured by insects.

Like the Troopial (Oriolus icterus, LATH.), the Redwing shows attachment and docility in confinement, becoming, like

1 My friend Mr. S. Green, of Boston, assures me that he has seen these birds near Newton, in a ceclar-swamp, in January. 
the Starling, familiar with those who feed him, and repaying the attention he receives, by singing his monotonous ditty pretty freely, consisting, as we have already remarked, of various odd, grating, shrill, guttural, and sometimes warbling tones, which become at length somewhat agreeable to the ear; and instances are said to have occurred of their acquiring the power of articulating several words pretty distinctly.

The flesh of this bird is but little esteemed except when young, being dark and tough like that of the Starling; yet in some of the markets of the United States they are at times exposed for sale.

The Red-wing is a common summer visitor to the Eastern States and Canada, breeding as far north as latitude $50^{\circ}$. In the West it ranges through the Saskatchewan valley to Great Slave Lake. It winters south to Mexico; but a few individuals have been known to brave a New England winter. During the winter of I889-90, a male was seen about the Fresh Pond marshes by several members of the Nuttall Club of Cambridge.

Note. = The BaHAMAN RED-Wing ( $A$. phanicus bryanti), a smaller, darker race, is found on the Bahama Islands and in southern Florida. 


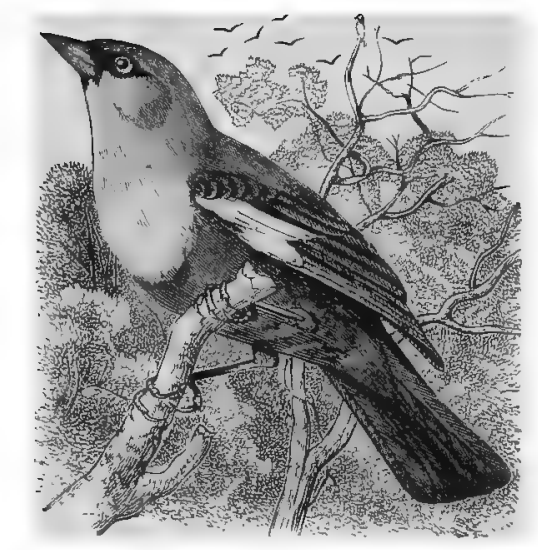

\section{YELLOW-HEADED BLACKBIRD.}

Xanthocephalus Xanthocephalus.

CHAR. Male: head, neck, and breast yellow; large patch on wing white; other parts black. Female and young: general color blackish brown; wings without the white spot; throat and breast dull yellow. Length 9 to II inches.

Nest. - Of dried grass, firmly woven and fastened to twigs of a bush or stalks of rushes, in a marsh or swampy meadow.

Eggs. - 2-6; grayish white, sometimes with a green tint, irregularly marked with brown; $1.05 \times 0.70$.

The Yellow-headed Troopial, though long known as an inhabitant of South America, was only recently added to the fauna of the United States by Major Long's expedition. It was seen in great numbers near the banks of the River Platte, around the villages of the Pawnees, about the middle of May; and the different sexes were sometimes observed associated in separate flocks, as the breeding season had not yet probably commenced. The range of this fine species is, apparently, from Cayenne, in tropical America, to the banks of the River Missouri, where Mr. Townsend and myself observed examples not far from the settled line of Missouri State. It has been seen by Dr. Richardson, in summer, as far as the $5^{8 \text { th }}$ parallel. Its visits in the United States are yet wholly confined to 
the west side of the Mississippi, beyond which, not even a straggler has been seen. These birds assemble in flocks, and in all their movements, aërial evolutions, and predatory character, appear as the counterpart of their Red-winged relatives. They are also seen to frequent the ground in search of food, in the manner of the Cow-Bunting, or Troopial. In the spring season they wage war upon the insect tribes and their larvæ, like the Red-wings, but in autumn they principally depend on the seeds of vegetables. At Demerara, Waterton observed them in flocks, and, as might have been suspected from their habits, they were very greedy after Indian corn.

On the $2 \mathrm{~d}$ of May, in our western tour across the continent, around the Kansa Indian Agency, we now saw abundance of the Yellow-headed Troopial, associated with the Cowbird. They kept wholly on the ground in companies, the males, at this time, by themselves. In loose soil they dig into the earth with their bills in quest of insects and larvæ, are very active, straddle about with a quaint gait, and now and then, in the manner of the Cowbird, whistle out with great effort a chuckling note sounding like ko-kukkle-'ăit, often varying into a straining squeak, as if using their utmost endeavor to make some kind of noise in token of sociability. Their music is, however, even inferior to the harsh note of the Cowbird. In the month of June, by the edge of a grassy marsh, in the open plain of the Platte, several hundred miles inland, $\mathrm{Mr}$. Townsend found the nest of this species built under a tussock formed of fine grasses and canopied over like that of the Sturnella, or Meadow Lark.

While essentially a bird of the prairie, this species occurs regularly and in abundance in Wisconsin and Illinois. It has been observed occasionally in southern Ontario, and examples have been taken at Point des Monts, on the Gulf of St. Lawrence, and in Massachusetts, Pennsylvania, South Carolina, and Florida. 


\section{COWBIRD.}

\section{COW BLACKBIRD.}

MOLOTHRUS ATER.

CHAR. Male: head and neck dull brown; other parts glossy black. Feinale and young: brownish gray, paler below, with dark streaks. Length 7 to 8 inches.

Nest. Does not build any, but lays its eggs in nests of other species, usually of smaller birds, such as the Yellow Warbler, Chipping Sparrow, or one of the Vireos.

Eggs. - ? (number unknown, probably 4); dull white, sometimes with green or buff tint, irregularly marked with various shades of brown; $085 \times 0.65$.

The Cow-pen Bird, perpetually gregarious and flitting, is observed to enter the Middle and Northern States in the latter end of March or the beginning of April. They make their migration now chiefly under cover of the night, or early dawn; and as the season becomes milder they pass on to Canada, and perhaps follow the Warblers and other small birds into the farthest regions of the north, for they are seen no more after the middle of June until the return of autumn, when, with the colds of October, they again reappear in numerous and augmented flocks, usually associated with their kindred Red-wings, to whom they bear a sensible likeness, as well as a similarity in notes and manners. They pass the winter in the warmer parts of America as well as in the Southern States, where I have observed them in the ploughed fields, gleaning along with the Red-wings and the common Blackbirds. They are also very familiar around the cattle, picking up insects which they happen to disturb, or that exist in their ordure. When on the ground, they scratch up the soil and appear very intent after their food. Sometimes even, infringing on the rights of the Plover, individuals, in the winter, frequent the margins of ponds in quest of aquatic insects and small shell-fish; and they may be seen industriously occupied in turning over the leaves of the water-plants to which they adhere. They also frequent 
occasionally the rice and corn fields, as well as their more notorious associates, but are more inclined to native food and insects at all times, so that they are more independent and less injurious to the farmer. As they exist in Mexico and California, it is probable that they are also bred in the higher table-lands, as well as in the regions of the north. In Louisiana, however, according to Audubon, they are rare visitors at any season, seeming more inclined to follow their route through the maritime districts. Over these countries, high in the air, in the month of October, they are seen by day winging their way to the remoter regions of the south.

We have observed that the Red-wings separate in parties, and pass a considerable part of the summer in the necessary duties of incubation. But the Cow-pen Birds release themselves from all hindrance to their wanderings. The volatile disposition and instinct which prompt birds to migrate, as the seasons change and as their food begins to fail, have only a periodical influence; and for a while they remain domestic, passing a portion of their time in the cares and enjoyments of the conjugal state. But with our bird, like the European Cuckoo, this season never arrives; the flocks live together without ever pairing. A general concubinage prevails among them, scarcely exciting any jealousy, and unaccompanied by any durable affection. From the commencement of their race they have been bred as foundlings in the nests of other birds, and fed by foster-parents under the perpetual influence of delusion and deception, and by the sacrifice of the concurrent progeny of the nursing birds. Amongst all the feathered tribes hitherto known, this and the European Cuckoo, with a few other species indigenous to the old continent, are the only kinds who never make a nest or hatch their young. That this character is not a vice of habit, but a perpetual instinct of nature, appears from various circumstances, and from none more evidently than from this, that the eggs of the Cow Troopial are earlier hatched than those of the foster-parent, - a singular and critical provision, on which perhaps the existence of the species depends; for did the natural brood of the deceived parent come first into exis- 
tence, the strange egg on which they sat would generally be destroyed.

When the female is disposed to lay, she appears restless and dejected, and separates from the unregarding flock. Stealing through the woods and thickets, she pries into the bushes and brambles for the nest that suits her, into which she darts in the absence of its owner, and in a few minutes is seen to rise on the wing, cheerful, and relieved from the anxiety that oppressed her, and proceeds back to the flock she had so reluctantly forsaken. If the egg be deposited in the nest alone, it is uniformly forsaken; but if the nursing parent have any of her own, she immediately begins to sit. The Red-eyed Flycatcher, in whose beautiful basket-like nests I have observed these eggs, proves a very affectionate and assiduous nurse to the uncouth foundling. In one of these I found an egg of each bird, and the hen already sitting. I took her own egg and left the strange one; she soon returned, and as if sensible of what had happened, looked with steadfast attention, and shifted the egg about, then sat upon it, but soon moved off, again renewed her observation, and it was a considerable time before she seemed willing to take her seat; but at length I left her on the nest. 'Two or three days after, I found that she had relinquished her attention to the strange egg and forsaken the nest. Another of these birds, however, forsook the nest on taking out the Cowbird's egg, although she had still two of her own left. The only example, perhaps, to the contrary of deserting the nest when solely occupied by the stray egg, is in the Bluebird, who, attached strongly to the breeding-places in which it often continues for several years, has been known to lay, though with apparent reluctance, after the deposition of the Cowbird's egg. My friend Mr. C. Pickering found two nests of the Summer-yellow Bird, in which had been deposited an egg of the Cowbird previously to any of their own; and unable to eject it, they had buried it in the bottom of the nest and built over it an additional story! I also saw, in the summer of $\mathrm{r} 83^{\circ}$, a similar circumstance with the same bird, in which the Cowbird's egg, though incarcerated, was still visible 
on the upper edge, but could never have been hatched. At times I think it probable that they lay in the nests of larger birds, who throw out the egg, or that they drop their eggs on the ground without obtaining a deposit, as I have found an egg of this kind thus exposed and broken. On placing an egg of this bird in the Catbird's nest it was almost instantly ejected; and this would probably be the usual fate of the strange egg if the diminutive nurses, thus wisely chosen, were capable of removing it.

The most usual nurse of this bird appears to be the Redeyed Vireo, who commences sitting as soon as the Cowbird's egg is deposited. On these occasions I have known the Vireo to begin her incubation with only an egg of each kind, and in other nests I have observed as many as 3 of her own, with that of the intruder. From the largeness of the strange egg, probably the nest immediately feels filled, so as to induce the nurse directly to sit. This larger egg, brought nearer to the body than her own, is consequently better warmed and sooner hatched; and the young of the Cowbird, I believe, appears about the $\mathbf{2}^{2}$ th or $13^{\text {th }}$ day of sitting. The foundling is very faithfully nursed by the affectionate Vireo, along with her own brood, who make their appearance about a day later than the Troopial. From the great size of the parasite, the legitimate young are soon stifled, and, when dead, are conveyed, as usual, by the duped parent to a distance before being dropped; but they are never found immediately beneath the nest, as would invariably happen if they were ejected by the young Troopial. In the summer of 1839 I actually saw a Chipping Sparrow carrying out to a distance one of its dead young thus stifled; and a second nest of the same species in which 3 of its own brood were hatched soon after the Cow Troopial: these survived 2 or 3 days, and as they perished were carried away by the parent bird. As far as I have had opportunity of observing, the foundling shows no hostility to the natural brood of his nurses, but he nearly absorbs their whole attention, and early displays his characteristic cunning and self-possession. When fully fledged, they quickly desert their foster-parent, and skulk 
about in the woods until, at length, they instinctively join company with those of the same feather, and now becoming more bold, are seen in parties of 5 or 6 , in the fields and lanes, gleaning their accustomed subsistence. They still, however, appear shy and watchful, and seem too selfish to study anything more than their own security and advantage.

The song of the Cowbird is guttural and unmusical, uttered with an air of affectation, and accompanied by a bristling of the feathers and a swelling of the body in the manner of the Turkey. These are also all the notes of the species in the season of their attachment; so that their musical talent rates lower than that of any other bird perhaps in the genus. Sometimes the tones of the male resemble the liquid clinking of the Bobolink and Red-winged Blackbird. Sitting on the summit of a lofty branch, he amuses himself perhaps for an hour with an occasional ' $k$ luck 'tse $\vec{e}$, the latter syllable uttered in a drawling hiss like that of the Red-wing. Accompanied by his mates, he also endeavors to amuse them by his complaisant chatter; and watching attentively for their safety, they flit together at the instant he utters the loud tone of alarm; and they are always shy and suspicious of the designs of every observer. On a fine spring morning, however, perched towards the summit of some tree in the forest where they seek rest after their twilight wanderings, small and select parties may be seen gratefully basking in the mild beams of the sunshine. The male on such occasions seems as proud of his uncouth jargon, and as eager to please his favorite companions, as the tuneful Nightingale with his pathetic and varied lay.

The Cowbird is a common summer resident of New England, though of rather local distribution. Dr. Wheaton reported it as abundant in Ohio during the summer months, and Mr. McIlwraith made a similar report for Ontario. It is rather uncommon in the Maritime Provinces, but ranges as far northward as the 5oth parallel. In January, I883, two specimens were taken near Cambridge, Mass., by Mr. William Brewster and Mr. Henry M. Spellman. 


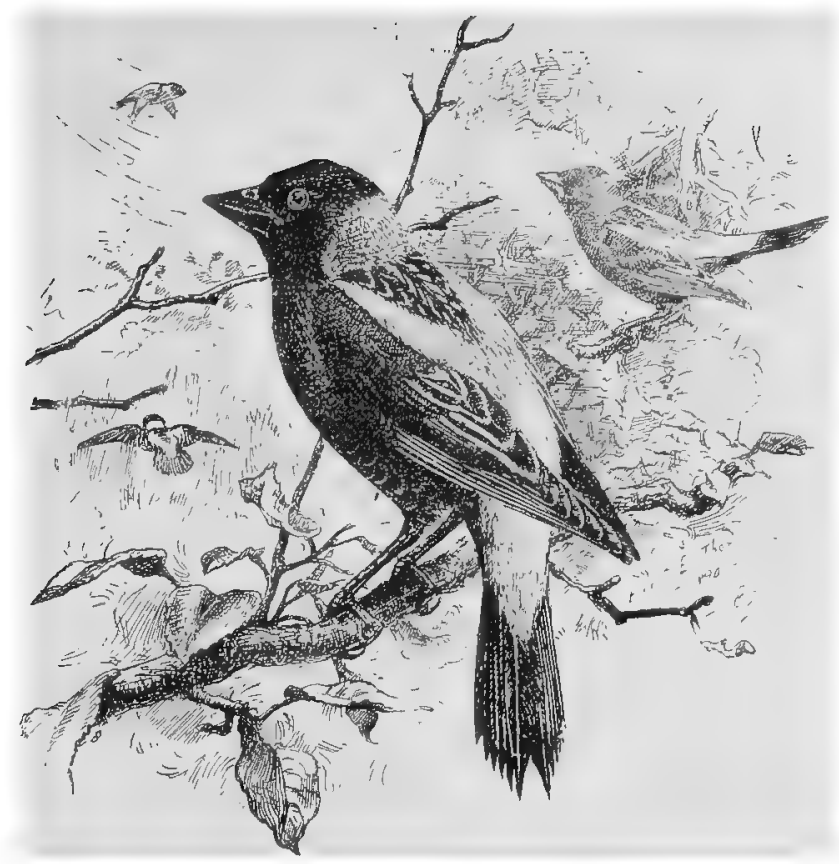

BOBOLINK.

RICE BIRD. SKUNK BLACKBIRD. MEADOW-WINK.

DOLICHONYX ORYZIVORUS.

-CHAR. Male in summer - black; back of head and hind-neck buff; scapulars, rump, and upper tail-coverts ashy white. Male in winter, female, and young: above, yellowish brown, beneath paler, more buffy; light stripe on crown. Length $61 / 2$ to $71 / 2$ inches.

Nest. In a meadow ; made of dried grass.

Eggs. 4-6; white with green or buff tint, irregularly marked with lilac and brown; $0.85 \times 0.60$.

The whole continent of America, from Labrador to Mexico, and the Great Antilles, are the occasional residence of this truly migratory species. About the middle of March or beginning of April the cheerful Bobolink makes his appearance in the southern extremity of the United States, becoming gradually arrayed in his nuptial livery, and accompanied by troops of his companions, who often precede the arrival of their more tardy 
mates. According to Richardson it is the beginning of June when they arrive at their farthest boreal station in the 54th degree. We observed them in the great western plains to the base of the Rocky Mountains, but not in Oregon. Their wintering resort appears to be rather the West Indies than the tropical continent, as their migrations are observed to take place generally to the east of Louisiana, where their visits are rare and irregular. At this season also they make their approaches chiefly by night, obeying, as it were, more distinctly, the mandates of an overruling instinct, which prompts them to seek out their natal regions; while in autumn, their progress, by day only, is alone instigated by the natural quest of food. About the Ist of May the meadows of Massachusetts begin to re-echo their lively ditty. At this season, in wet places, and by newly ploughed fields, they destroy many insects and their larvæ. According to their success in obtaining food, parties often delay their final northern movement as late as the middle of May, so that they appear to be in no haste to arrive at their destination at any exact period. The principal business of their lives, however, the rearing of their young, does not take place until they have left the parallel of the 4 oth degree. In the savannahs of Ohio and Michigan, and the cool grassy meadows of New York, Canada, and New England, they fix their abode, and obtain a sufficiency of food throughout the summer without molesting the harvest of the farmer, until the ripening of the latest crops of oats and barley, when, in their autumnal and changed dress, hardly now known as the same species, they sometimes show their taste for plunder, and flock together like the greedy and predatory Blackbirds. Although they devour various kinds of insects and worms on their first arrival, I have found that their frequent visits among the grassy meadows were often also for the seeds they contain; and they are particularly fond of those of the dock and dandelion, the latter of which is sweet and oily. Later in the season, and previously to leaving their native regions, they feed principally on various kinds of grass-seeds, particularly those of the Panicums, which are allied to millet. They also devour crickets and grasshoppers, as well as beetles and spiders. Their nest is fixed on 
the ground in a slight depression, usually in a field of meadow grass, either in a dry or moist situation, and consists merely of a loose bedding of withered grass, so inartificial as scarcely to be distinguishable from the rest of the ground around it. The eggs are 5 or 6 , of a dull white, inclining to olive, scattered all over with small spots and touches of lilac brown, with some irregular blotches of dark rufous brown, chiefly disposed towards the larger end.

The males, arriving a little earlier than the other sex, now appear very vigorous, lively, and familiar. Many quarrels occur before the mating is settled; and the females seem at first very coy and retiring. Emulation fires the Bobolink at this period, and rival songsters pour out their incessant strains of enlivening music from every fence and orchard tree. The quiet females keep much on the ground; but as soon as they appear, they are pursued by the ardent candidates for their affection, and if either seems to be favored, the rejected suitor is chased off the ground, as soon as he appears, by his more fortunate rival. The song of the male continues with little interruption as long as the female is sitting, and his chant, at all times very similar, is both singular and pleasant. Often, like the Skylark, mounted, and hovering on the wing, at a small height above the field, as he passes along from one tree-top or weed to another, he utters such a jingling medley of short, variable notes, so confused, rapid, and continuous, that it appears almost like the blending song of several different birds. Many of these tones are very agreeable; but they are delivered with such rapidity that the ear can scarcely separate them. The general effect, however, like all the simple efforts of Nature, is good, and when several are chanting forth in the same meadow, the concert is very cheerful, though monotonous, and somewhat quaint. Among the few phrases that can be distinguished, the liquid sound of $b o b$-o-lee bob-o-link bob-o-linké, is very distinct. To give an idea of the variable extent of song, and even an imitation, in some measure, of the chromatic period and air of this faniliar and rather favorite resident, the boys of this part of New England make him spout, among others, the following 
ludicrous dunning phrase, as he rises and hovers on the wing

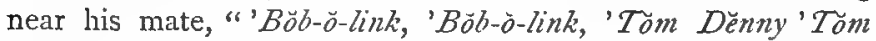
Dĕnny. - 'Come păy' me the twŏ ănd six pence y'ul've owed more than a l'cur ănd ă half ago! - 'tshĕ 'tshè 'tshĕ, 'tsh 'tsh 'tshe," modestly diving at the same instant down into the grass as if to avoid altercation. However puerile this odd phrase may appear, it is quite amusing to find how near it approaches to the time and expression of the notes, when pronounced in a hurried manner. It would be unwise in the naturalist to hold in contempt anything, however trifling, which might tend to elucidate the simple truth of nature; I therefore give the thing as I find it. This relish for song and merriment, confined wholly to the male, diminishes as the period of incubation advances; and when the brood begin to flutter around their parents and protectors, the song becomes less frequent, the cares of the parents more urgent, and any approach to the secret recess of their helpless family is deplored with urgent and incessant cries as they hover fearfully around the intentional or accidental intruder. They appear sometimes inclined to have a second brood, for which preparation is made while they are yet engaged in rearing the first; but the male generally loses his musical talent about the end of the first week in July, from which time his nuptial or pied dress begins gradually to be laid aside for the humble garb of the female. The whole, both young and old, then appear nearly in the same songless livery, uttering only a chink of alarm when surprised in feeding on the grass seeds, or the crops of grain which still remain abroad. When the voice of the Bobolink begins to fail, with the progress of the exhausting moult, he flits over the fields in a restless manner, and merely utters a broken 'bobl'lic', 'böb'lee, or with his songless mate, at length, a 'weet 'weet, b'leet b'leet, and a noisy and disagreeable cackling chirp. At the early dawn of day, while the tuneful talent of the species is yet unabated, the effect of their awakening and faltering voices from a wide expanse of meadows, is singular and grand. The sounds mingle like the noise of a distant torrent, which alternately subsides and rises on the breeze as 
the performers awake or relapse into rest; it finally becomes more distinct and tumultuous, till with the opening day it assumes the intelligible character of their ordinary song. The young males, towards the close of July, having nearly acquired their perfect character, utter also in the morning, from the trees which border their favorite marshy meadows, a very agreeable and continuous low warble, more like that of the Yellow Bird than the usual song of the species; in fact, they appear now in every respect as Finches, and only become jingling musicians when robed in their pied dress as Icteri.

About the middle of August, in congregating numbers, divested already of all selective attachment, vast foraging parties enter New York and Pennsylvania, on their way to the South. Here, along the shores of the large rivers, lined with floating fields of the wild rice, they find an abundant means of subsistence during their short stay; and as their flesh, now fat, is little inferior to that of the European Ortolan, the Reed or Rice Birds, as they are then called in their Sparrow-dress, form a favorite sport for gunners of all descriptions, who turn out on the occasion and commit prodigious havoc among the almost silent and greedy roosting throng. The markets are then filled with this delicious game, and the pursuit, both for success and amusement, along the picturesque and reedy shores of the Delaware and other rivers is second to none but that of Railshooting. As soon as the cool nights of October commence, and as the wild rice crops begin to fail, the Reed Birds take their departure from Pennsylvania and New Jersey, and in their farther progress through the Southern States they swarm in the rice fields; and before the crop is gathered they have already made their appearance in the islands of Cuba and Jamaica, where they also feed on the seeds of the Guinea grass, become so fat as to deserve the name of "Butter-birds," and are in high esteem for the table.

Near the Atlantic coast the Bobolink is not common north of the 45th parallel; but in the West it ranges to much higher latitudes. A few examples have been observed on the New Brunswick shore of the Gulf of St. Lawrence.

vor.. I. -8 


\title{
BOAT-TAILED GRACKLE.
}

\author{
JACKDAW.
}

Qutscalus Major.

CHAR. Extremely long, wedge-shaped tail, less conspicuous in female. Male : black, with metallic tints of green, blue, and purple. Length 15 to I $7 \frac{1}{2}$ inches. Female : above, brown; beneath, grayish brown, changing to reddish and buffy on breast and throat. Length, II I $1 / 2$ to 13 inches.

Nest. A bulky structure of dried grass and strips of bark, cemented with mud and lined with fine grass; placed in a tree in swamp or near a marsh, sometimes fastened to rushes.

Eggs. 3-5; grayish drab with tints of green or blue, marked with black and brown blotches and lines; $1.25 \times 0.90$.

This large and Crow-like species, sometimes called the Jackdaw, inhabits the southern maritime parts of the Union only, particularly the States of Georgia and Florida, where they are seen as early as the close of January or beginning of February, but do not begin to pair before March, previously to which season the sexes are seen in separate flocks. But about the latter end of November they quit even the mild climate of Florida, generally, and seek winter-quarters probably in the West Indies, where they are known to be numerous, as well as in Mexico, Louisiana, and Texas; but they do not ever extend their northern migrations as far as the Middle States. Previous to their departure, at the approach of winter, they are seen to assemble in large flocks, and every morning flights of them, at a great height, are seen moving away to the south.

Like most gregarious birds, they are of a very sociable disposition, and are frequently observed to mingle with the common Crow Blackbirds. They assemble in great numbers among the sea islands, and neighboring marshes on the mainland, where they feed at low water on the oyster-beds and sandflats. Like Crows, they are omnivorous, their food consisting of insects, small shell-fish, corn, and small grain, so that by turns they may be viewed as the friend or plunderer of the planter. 
The note of this species is louder than that of the common kind, according to Audubon resembling a loud, shrill whistle, often accompanied by a cry like crick crick cree, and in the breeding-season changing almost into a warble. They are only heard to sing in the spring, and their concert, though inclining to sadness, is not altogether disagreeable. Their nests are built in company, on reeds and bushes, in the neighborhood of salt-marshes and ponds. They begin to lay about the beginning of April; soon after which the males leave their mates, not only with the care of incubation, but with the rearing of the young, moving about in separate flocks like the Cowbirds, without taking any interest in the fate of their progeny.

This species is rarely found north of Virginia. Several instances of its occurrence in New England have been reported; but the correctness of these reports has been challenged, and $\mathrm{Mr}$. Allen omitted the species from his list of Massachusetts birds issued in I 886.

\section{PURPLE GRACKLE.}

\section{CROW BLACKBIRD.}

QUISCALUS QUISCLLA.

Char. Black, with rich metallic tints of steel blue and purple, the female somewhat duller. Length, II to $13 \frac{1}{2}$ inches.

Nest. On the branch of a tree or in a hollow stub; large and roughly made of coarse grass and twigs, and lined with finer grass, sometimes cemented with mud.

Eggs. 4-6; extremely variable in shape, color, and size; ground color greenish white to reddish brown, with irregular markings of dark brown; I. $25 \times 0.90$.

This very common bird is an occasional or constant resident in every part of America, from Hudson's Bay and the northern interior to the Great Antilles, within the tropic. In most parts of this wide region they also breed, at least from Nova Scotia to Louisiana, and probably farther south. Into the States north of Virginia they begin to migrate from the beginning of March 
to May, leaving those countries again in numerous troops about the middle of November. Thus assembled from the North and West in increasing numbers, they wholly overrun, at times, the warmer maritime regions, where they assemble to pass the winter in the company of their well-known cousins the Redwinged Troopials or Blackbirds; for both, impelled by the same predatory appetite, and love of comfortable winter quarters, are often thus accidentally associated in the plundering and gleaning of the plantations. The amazing numbers in which the present species associate are almost incredible. Wilson relates that on the zoth of January, a few miles from the banks of the Roanoke in Virginia, he met with one of those prodigious armies of Blackbirds, which, as he approached, rose from the surrounding fields with a noise like thunder, and descending on the stretch of road before him, covered it and the fences completely with black; rising again, after a few evolutions, they descended on the skirt of a leafless wood, so thick as to give the whole forest, for a considerable extent, the appearance of being shrouded in mourning, the numbers amounting probably to many hundreds of thousands. Their notes and screams resembled the distant sound of a mighty cataract, but strangely attuned into a musical cadence, which rose and fell with the fluctuation of the breeze, like the magic harp of Æolus.

Their depredations on the maize crop or Indian corn commence almost with the planting. The infant blades no sooner appear than they are hailed by the greedy Blackbird as the signal for a feast; and without hesitation, they descend on the fields, and regale themselves with the sweet and sprouted seed, rejecting and scattering the blades around as an evidence of their mischief and audacity. Again, about the beginning of August, while the grain is in the milky state, their attacks are renewed with the most destructive effect, as they now assemble as it were in clouds, and pillage the fields to such a degree that in some low and sheltered situations, in the vicinity of rivers, where they delight to roam, one fourth of the crop is devoured by these vexatious visitors. The gun, also, notwith- 
standing the havoc it produces, has little more effect than to chase them from one part of the field to the other. In the Southern States, in winter, they hover round the corn-cribs in swarms, and boldly peck the hard grain from the cob through the air openings of the magazine. In consequence of these reiterated depredations, they are detested by the farmer as a pest to his industry; though on their arrival their food for a long time consists wholly of those insects which are calculated to do the most essential injury to the crops. They at this season frequent swamps and meadows, and familiarly following the furrows of the plough, sweep up all the grub-worms and other noxious animals as soon as they appear, even scratching up the loose soil, that nothing of this kind may escape them. Up to the time of harvest I have uniformly, on dissection, found their food to consist of these larvæ, caterpillars, moths, and beetles, of which they devour such numbers that but for this providential economy the whole crop of grain, in many places, would probably be destroyed by the time it began to germinate. In winter they collect the mast of the beech and oak for food, and may be seen assembled in large bodies in the woods for this purpose. In the spring season the Blackbirds roost in the cedars and pine-trees, to which in the evening they retire with friendly and mutual chatter. On the tallest of these trees, as well as in bushes, they generally build their nests, - which work, like all their movements, is commonly performed in society, so that Io or $\mathrm{I}_{5}$ of them are often seen in the same tree; and sometimes they have been known to thrust their nests into the interstices of the Fish Hawk's eyry, as if for safety and protection. Occasionally they breed in tall poplars near to habitations, and if not molested, continue to resort to the same place for several years in succession. The nest is composed of mud, mixed with stalks and knotty roots of grass, and lined with fine dry grass and horse-hair. According to Audubon, the same species in the Southern States nests in the hollows of decayed trees, after the manner of the Woodpecker, lining the cavity with grass and mud. They seldom produce more than a single brood in the season. In the autumn, and at the approach 
of winter, numerous flocks, after foraging through the day, return from considerable distances to their general roosts among the reeds. On approaching their station, each detachment, as it arrives, in straggling groups like crows, sweeps round the marsh in waving flight, forming circles; amidst these bodies, the note of the old reconnoitring leader may be heard, and no sooner has he fixed upon the intended spot than they all descend and take their stations in an instant. At this time they are also frequently accompanied by the Ferruginous species, with which they associate in a friendly manner.

The Blackbird is easily tamed, sings in confinement, and may be taught to articulate some few words pretty distinctly. Among the variety of its natural notes, the peculiarly affected sibilation of the Starling is heard in the reottitshee, wottitshee, and whistle, which often accompanies this note.

In Nuttall's day variety making had not come in fashion, and the systematists were content to treat the Crow Blackbirds of eastern North America as of one form. Now we have three forms, with three "distinctive scientific appellations." It is somewhat difficult to distinguish these forms, except in extreme phases of plumage, for many specimens of the Northern variety have the diagnostic characters of the Southern birds. The present race is said to occur only on "the Atlantic coast of the United States, north to Massachusetts and west to eastern Tennessee."

The BRONZE GRACKLE (Q. quiscula aneus) lacks the purple metallic tint on the body, that being replaced by a tint of bronze; the purple and blue tints are restricted to the head and neck. The wings and tail are purple. This form is abundant throughout the New England States and Canada, and ranges north to Hudson's Bay and west to the Great Plains. I have seen nests of these birds placed on the beams of barns in New Brunswick. The farmers along the St. John and Kenebecasis rivers erect barns on the marshy islands and "intervales" to store their hay until it can be carried to the mainland on the ice; and these barns, being unused during the breeding season, offer excellent building sites for colonies of Crow Blackbirds and Swallows. The nests are fastened to the beams with mud in much the same method as that adopted by Robins.

A smaller race with a larger tail is restricted to southern Florida. It is named the Florida GRACKLE ( $Q$. quiscula aglaus). 


\section{RUSTY BLACKBIRD.}

\section{SCOLECOPHAGUS CAROLINUS.}

ChAR. Male in summer . glossy black, generally more or less feathers edged with reddish brown. Male in winter: the brown more conspicuous, the lower parts marked with buffy. Female and young: dull rusty brown above, rusty and ashy beneath. Length $8 \frac{1}{4}$ to $93 / 4$ inches.

Nest. In a spruce-tree or alder; a large but solid structure of twigs and vines, sometimes cemented with mud, lined with grass and leaves.

Eggs. 4-7; grayish green to pale green, thickly blotched with light and dark brown and purple; $1.00 \times 0.76$.

This species, less frequent than the preceding, is often associated with it or with the Red-winged Troopial or the Cowpen Bird; and according to the season, they are found throughout America, from Hudson's Bay to Florida, and westward to the Pacific Ocean. Early in April, according to Wilson, they pass hastily through Pennsylvania, on their return to the North to breed. Iin the month of March he observed them on the banks of the Ohio, near Kentucky River, during a snow-storm. They arrive in the vicinity of Hudson's Bay about the beginning of May, and feed much in the manner of the common Crow Blackbird on insects which they find on or near the ground. Dr. Richardson saw them in the winter as far as the latitude of $53^{\circ}$, and in summer they range to the 68 th parallel or to the extremity of the wooded region. They sing in the pairing season, but become nearly silent while rearing their young; though when their brood release them from care, they again resume their lay, and may occasionally be heard until the approach of winter. Their song is quite as agreeable and musical as that of the Starling, and greatly surpasses that of any of the other species. I have heard them singing until the middle of October.

They are said to build in trees and bushes at no great distance from the ground, making a nest similar to the other species, and lay five eggs, of a pale blue spotted with black. The young and old, now assembling in large troops, retire from the northern regions in September. From the beginning of 
October to the middle of November, they are seen in flocks through the Eastern States. During their stay in this vicinity they assemble towards night to roost in or round the reedmarshes of Fresh Pond, near Cambridge. Sometimes they select the willows by the water for their lodging, in preference to the reeds, which they give up to their companions the Crow Blackbirds. Early in October they feed chiefly on grasshoppers and berries, and at a later period pay a transient visit to the corn-fields. They pass the winter in the Southern States, and, like their darker relatives, make familiar visits to the barn-yard and corn-cribs. Wilson remarks that they are easily domesticated, and in a few days become quite familiar, being reconciled to any quarters while supplied with plenty of food.

The Rusty Blackbird breeds from about the $45^{\text {th }}$ parallel to the lower fur countries. It is fairly common near the Atlantic, but is more abundant in the interior, and $\mathrm{Mr}$. Thompson reports it commonly abundant in Manitoba. In this region it does not always select an alder swamp for a nesting site, as some authors have stated. A nest discovered by my friend Banks was amid the upper branches of a good sized spruce on a dry hillside in Mr. William Jack's park, near St. John.

\section{NORTHERN RAVEN. \\ CORVUS CORAX PRINCTPALIS.}

CHAR. Black with bluish purple gloss. Length 22 to $261 / 2$ inches.

Nist. On a cliff or in a tree; made of sticks carefully and compactly arranged, lined with grass or wool, - repaired year after year, and thus increased to considerable bulk.

Eggs. 2-7; pale olive, marked with olive-brown blotches and streaks ; $2.00 \times$ I. 40 .

The sable Raven has been observed and described from the earliest times, and is a resident of almost every country in the world; but is more particularly abundant in the western than the eastern parts of the United States, where it extends along the Oregon to the shores of the Pacific. This ominous bird 
has been generally despised and feared by the superstitious even more than the nocturnal Owl, though he prowls abroad in open day. He may be considered as holding a relation to the birds of prey, feeding not only on carrion, but occasionally seizing on weakly lambs, young hares or rabbits, and seems indeed to give a preference to animal food; but at the same time, he is able to live on all kinds of fruits and grain, as well as insects, earth-worms, even dead fish, and in addition to all, is particularly fond of eggs, so that no animal seems more truly omnivorous than the Raven.

If we take into consideration his indiscriminating voracity, sombre livery, discordant, croaking cry, with his ignoble, wild, and funereal aspect, we need not be surprised that in times of ignorance and error he should have been so generally regarded as an object of disgust and fear. He stood pre-eminent in the list of sinister birds, or those whose only premonition was the announcing of misfortunes; and, strange to tell, there are many people yet in Europe, even in this enlightened age, who tremble and become uneasy at the sound of his harmless croaking. According to Adair, the Southern aborigines also invoke the Raven for those who are sick, mimicking his voice; and the natives of the Missouri, assuming black as their emblem of war, decorate themselves on those occasions with the plumes of this dark bird. But all the knowledge of the future, or interest in destiny, possessed by the Raven, like that of other inhabitants of the air, is bounded by an instinctive feeling of the changes which are about to happen in the atmosphere, and which he has the faculty of announcing by certain cries and actions produced by these external impressions. In the southern provinces of Sweden, as Linnæus remarks, when the sky is serene the Raven flies very high and utters a hollow sound, like the word clong, which is heard to a great distance. Sometimes he has been seen in the midst of a thunder-storm with the electric fire streaming from the extremity of his bill, - a natural though extraordinary phenomenon, sufficient to terrify the superstitious and to stamp the harmless subject of it with the imaginary traits and attributes of a demon. 
In ancient times, when divination made a part of religion, the Raven, though a bad prophet, was yet a very interesting bird; for the passion for prying into future events, even the most dark and sorrowful, is an original propensity of human nature. Accordingly, all the actions of this sombre bird, all the circumstances of its flight, and all the different intonations of its discordant voice, of which no less than sixty-four were remarked, had each of them an appropriate signification; and there were never wanting impostors to procure this pretended intelligence, nor people simple enough to credit it. Some even went so far as to impose upon themselves, by devouring the heart and entrails of the disgusting Raven, in the strange hope of thus appropriating its supposed gift of prophecy.

The Raven indeed not only possesses a great many natural inflections of voice corresponding to its various feelings, but it has also a talent for imitating the cries of other animals, and even mimicking language. According to Buffon, colas is a word which he pronounces with peculiar facility. Connecting circumstances with his wants, Scaliger heard one, which when hungry, learnt very distinctly to call upon Conrad the cook. The first of these words bears a great resemblance to one of the ordinary cries of this species, kówallah, kówallah. Besides possessing in some measure the faculty of imitating human speech, they are at times capable of manifesting a durable attachment to their keeper, and become familiar about the house.

The sense of smell, or rather that of sight, is very acute in the Raven, so that he discerns the carrion, on which he often feeds, at a great distance. Thucydides even attributes to him the sagacity of avoiding to feed on animals which had died of the plague. Pliny relates a singular piece of ingenuity employed by this bird to quench his thirst: he had observed water near the bottom of a narrow-necked vase, to obtain which, he is said to have thrown in pebbles, one at a time, until the pile elevated the water within his reach. Nor does this trait, singular as it is, appear to be much more sagacious than that of carrying up nuts and shell-fish into the air, and 
dropping them on rocks, for the purpose of breaking them to obtain their contents, otherwise beyond his reach, - facts observed by men of credit, and recorded as an instinct of the Raven by Pennant and Latham. It is, however, seldom that these birds, any more than the rapacious kinds, feel an inclination for drinking, as their thirst is usually quenched by the blood and juices of their prey. The Ravens are also more social than the birds of prey, - which arises from the promiscuous nature and consequent abundance of their food, which allows a greater number to subsist together in the same place, without being urged to the stern necessity of solitude or famine, - a condition to which the true rapacious birds are always driven. The habits of these birds are much more generally harmless than is usually imagined; they are useful to the farmer in the destruction they make of moles and mice, and are often very well contented with insects and earth-worms.

Though spread over the whole world, they are rarely ever birds of passage, enduring the winters even of the Arctic circle, or the warmth of Mexico, St. Domingo, and Madagascar. They are particularly attached to the rocky eyries where they have been bred and paired. Throughout the year they are observed together in nearly equal numbers, and they never entirely abandon this adopted home. If they descend into the plain, it is to collect subsistence; but they resort to the low grounds more in winter than summer, as they avoid the heat and dislike to wander from their cool retreats. They never roost in the woods, like Crows, and have sufficient sagacity to choose in their rocky retreats a situation defended from the winds of the north, - commonly under the natural vault formed by an extending ledge or cavity of the rock. Here they retire during the night in companies of $I_{5}$ to 20 . They perch upon the bushes which grow straggling in the clefts of the rocks; but they form their nests in the rocky crevices, or in the holes of the mouldering walls, at the summits of ruined towers; and sometimes upon the high branches of large and solitary trees. After they have paired, their fidelity appears to continue through life. The male expresses his attachment by a particu- 
lar strain of croaking, and both sexes are observed caressing, by approaching their bills, with as much semblance of affection as the truest turtle-doves. In temperate climates the Raven begins to lay in the months of February or March. The eggs are 5 or 6 , of a pale, muddy bluish green, marked with numerous spots and lines of dark olive brown. She sits about 20 days, and during this time the male takes care to provide her with abundance of nourishment. Indeed, from the quantity of grain, nuts, and fruits which have been found at this time in the environs of the nest, this supply would appear to be a store laid up for future occasions. Whaterer may be their forethought regarding food, they have a well-known propensity to hide things which come within their reach, though useless to themselves, and appear to give a preference to pieces of metal, or anything which has a brilliant appearance. At Erfurt, one of these birds had the patience to carry and hide, one by one, under a stone in the garden, a quantity of small pieces of money, which amounted, when discovered, to 5 or 6 florins; and there are few countries which cannot afford similar instances of their domestic thefts.

Of the perseverance of the Raven in the act of incubation, Mr. White has related the following remarkable anecdote: In the centre of a grove near Selborne there stood a tall and shapeless oak which bulged out into a large excrescence near the middle of the stem. On this tree a pair of Ravens had fixed their residence for such a series of years that the oak was distinguished by the title of "The Raven Tree." Many were the attempts of the neighboring youths to get at this nest. The difficulty whetted their inclinations, and each was ambitious of accomplishing the arduous task; but when they arrived at the swelling, it jutted out so in their way, and was so far beyond their grasp, that the boldest lads were deterred, and acknowledged the undertaking to be too hazardous. Thus the Ravens continued to build, and rear their young in security, until the fatal day on which the wood was to be levelled. This was in the month of February, when these birds usually begin to sit. The saw was applied to the trunk, the wedges 
were driven, the woods echoed to the heavy blows of the beetle or mallet, and the tree nodded to its fall; but still the devoted Raven sat on. At last, when it gave way, she was flung from her ancient eyry; and a victim to parental affection, was whipped down by the twigs, and brought lifeless to the ground.

The young, at first more white than black, are fed by food previously prepared in the craw of the mother and then disgorged by the bill, nearly in the manner of pigeons. The male at this time, doubly vigilant and industrious, not only provides for, but defends his family vigorously from every hostile attack, and shows a particular enmity to the Kite when he appears in his neighborhood, pouncing upon him and striking with his bill until sometimes both antagonists descend to the ground. The young are long and affectionately fed by the parents; and though they soon leave the nest, they remain perching on the neighboring rocks, yet unable to make any extensive flight, and pass the time in continual complaining cries till the approach of the parent with food, when their note changes into craw, craw, crawe. Now and then as they gain strength they make efforts to fly, and then return to their rocky roost. About I 5 days after leaving the nest, they become so well prepared for flight as to accompany the parents out on their excursions from morning to night; and it is amusing to watch the progress of this affectionate association, the young continuing the whole summer to go out with the old in the morning, and as regularly return with them again in the evening, so that however we may despise the appetite of the Raven, we cannot but admire the instinctive morality of his nature.

Like birds of prey, the Ravens reject from the stomach, by the bill, the hard and indigestible parts of their food, as the stones of fruit and the bones of small fish which they sometimes eat.

The Northern Raven has been separated lately from the "Mexican" race (for which latter the name of sinuatus has been retained); but the limits of their distribution have not been determined. The northern form occurs throughout Canada north to the Arctic Ocean 
and west to the Pacific; but to which form the birds found in the Eastern States are to be referred, has not been settled by the authorities.

Of late years the Raven has almost forsaken the New England shores, though it is still numerous around the Bay of Fundy, and occurs locally in small numbers along the entire coast of the Atlantic, and throughout this faunal province. It is more abundant to the westward of the Mississippi.

\section{CROW.}

\section{CORVUS AMERICANUS.}

Char. Black, with gloss of purple tinge. Length $\mathbf{I} 7$ to $2 \mathbf{I}$ inches.

Nest. In a tree; made of sticks and twigs, lined with grass and leaves. Egys. $4^{-6}$; sea-green to dull olive, blotched with brown; $1.70 \times 1.20$.

The Crow, like the Raven, which it greatly resembles, is a denizen of nearly the whole world. It is found even in New Holland and the Philippine Islands, but is rare in Sweden, where the Raven abounds. It is also common in Siberia, and plentiful in the Arctic deserts beyond the Lena.

The native Crow is a constant and troublesomely abundant resident in most of the settled districts of North America, as well as an inhabitant of the Western wilds throughout the Rocky Mountains, to the banks of the Oregon and the shores of the Pacific. These birds only retire into the forests in the breeding season, which lasts from March to May. At this time they are dispersed through the woods in pairs, and roost in the neighborhood of the spot which they have selected for their nest; and the conjugal union, once formed, continues for life. They are now very noisy, and vigilant against any intrusion on their purpose, and at times appear influenced by mutual jealousy, but never proceed to any violence. The tree they select is generally lofty, and preference seems often given to some dark and concealing evergreen. The nest is formed externally of small twigs coarsely interlaced together, plastered and matted with earth, moss, and long horse-hair, 
and thickly and carefully lined with large quantities of the last material, wool, or the finest fibres of roots, so as to form a very comfortable bed for the helpless and naked young.

The male at this season is extremely watchful, reconnoitring the neighborhood, and giving an alarm as any person happens to approach towards their nest, when both retire to a distance till the intruder disappears; and in order the better to conceal their brood, they remain uncommonly silent until these are in a situation to follow them on the wing. The male also carries food to his mate while confined to her eggs, and at times relieves her by sitting in her absence. In Europe, when the Raven, the Buzzard, or the Kestrel makes his appearance, the pair join instantly in the attack, and sometimes, by dint of furious blows, destroy their enemy; yet the Butcher Bird, more alert and courageous, not only resists, but often vanquishes the Crows and carries off their young. Like the Ravens, endued with an unrestrained and natural affection, they continue the whole succeeding summer to succor and accompany their offspring in all their undertakings and excursions.

The Crow is equally omnivorous with the Raven; insects, worms, carrion, fish, grain, fruits, and in short everything digestible by any or all the birds in existence, being alike acceptable to this gormandizing animal. Its destruction of bird-eggs is also very considerable. In Europe Crows are often detected feeding their voracious young with the precious eggs of the Partridge; which they very sagaciously convey by carefully piercing and sticking them expertly on the bill. They also know how to break nuts and shell-fish by dropping them from a great height upon the rocks below. They visit even the snares and devour the birds which they find caught, attacking the weak and wounded game. They also sometimes seize on young chickens and Ducks, and have even been observed to pounce upon Pigeons in the manner of Hawks, and with almost equal success. So familiar and audacious are they in some parts of the Levant that they will frequent the courts of houses, and, like Harpies, alight boldly on the dishes, as the servants are conveying in the dinner, and carry off the meat, if not driven 
away by blows. In turn, however, the Crow finds enemies too powerful for him to conquer, such as the Kite and Eagle Owl, who occasionally make a meal of this carrion bird, - a voracious propensity which the Virginian Owl also sometimes exhibits towards the same species. Wherever the Crow appears, the smaller birds take the alarm, and vent upon him their just suspicions and reproaches. But it is only the redoubtable King Bird who has courage for the attack, beginning the onset by pursuing and diving on his back from above, and harassing the plunderer with such violence that he is generally glad to get out of the way and forego his piratical visit; in short, a single pair of these courageous and quarrelsome birds are sufficient to clear the Crows from an extensive cornfield.

The most serious mischief of which the Crow is guilty is that of pillaging the maize-field. He commences at the planting-time by picking up and rooting out the sprouting grain, and in the autumn, when it becomes ripe, whole flocks, now assembled at their roosting-places, blacken the neighboring fields as soon as they get into motion, and do extensive damage at every visit, from the excessive numbers who now rush to the inviting feast.

Their rendezvous or roosting-places are the resort in autumn of all the Crows and their families for many miles round. The blackening silent train continues to arrive for more than an hour before sunset, and some still straggle on until dark. They never arrive in dense flocks, but always in long lines, each falling into the file as he sees opportunity. This gregarious inclination is common to many birds in the autumn which associate only in pairs in the summer. The forests and groves, stripped of their agreeable and protecting verdure, seem no longer safe and pleasant to the feathered nations. Exposed to the birds of prey, which daily augment in numbers; penetrated by the chilling blasts, which sweep without control through the naked branches, - the birds, now impelled by an overruling instinct, seek in congregated numbers some general, safer, and more commodious retreat. Islands of reeds, dark and solitary thickets, and neglected swamps, are the situations chosen for 
their general diurnal retreats and roosts. Swallows, Blackbirds, Rice Birds, and Crows seem always to prefer the low shelter of reed-flats. On the River Delaware, in Pennsylvania, there are two of these remarkable Crow-roosts. The one mentioned by Wilson is an island near Newcastle called the Pea-Patch, - a low, flat, alluvial spot, just elevated above high-water mark, and thickly covered with reeds, on which the Crows alight and take shelter for the night. Whether this roost be now occupied by these birds or not, I cannot pretend to say; but in December, I829, I had occasion to observe their arrival on Reedy Island, just above the commencement of the bay of that river, in vast numbers; and as the wind wafted any beating vessel towards the shore, they rose in a cloud and filled the air with clamor. Indeed, their vigilant and restless careing continued till after dark.

Creatures of mere instinct, they foresee no perils beyond their actual vision; and thus, when they least expect it, are sometimes swept away by an unexpected destruction. Some years ago, during the prevalence of a sudden and violent northeast storm accompanied by heavy rains, the Pea-Patch Island was wholly inundated in the night; and the unfortunate Crows, dormant and bewildered, made no attempts to escape, and were drowned by thousands, so that their bodies blackened the shores the following day for several miles in extent.

The Crows, like many other birds, become injurious and formidable only in the gregarious season. At other times they live so scattered, and are so shy and cautious, that they are but seldom seen. But their armies, like all other great and terrific assemblies, have the power, in limited districts, of doing very sensible mischief to the agricultural interests of the community; and in consequence, the poor Crows, notwithstanding their obvious services in the destruction of a vast host of insects and their larva, are proscribed as felons in all civilized countries, and, with the wolves, panthers, and foxes, a price is put upon their heads. In consequence, various means of ensnaring the outlaws have been had recourse to. Of the gun they are very cautious, and suspect its appearance at the VOL. I. -9 
first glance, perceiving with ready sagacity the wily manner of the fowler. So fearful and suspicious are they of human artifices that a mere line stretched round a field is often found sufficient to deter these wily birds from a visit to the cornfield. Against poison they are not so guarded, and sometimes corn steeped in hellebore is given them, which creates giddiness and death.

Another curious method is that of pinning a live Crow to the ground by the wings, stretched out on his back, and retained in this posture by two sharp, forked sticks. In this situation, his loud cries attract other Crows, who come sweeping down to the prostrate prisoner, and are grappled in his claws. In this way each successive prisoner may be made the innocent means of capturing his companion. The reeds in which they roost, when dry enough, are sometimes set on fire also to procure their destruction; and to add to the fatality produced by the flames, gunners are also stationed round to destroy those that attempt to escape by flight. In severe winters they suffer occasionally from famine and cold, and fall sometimes dead in the fields. According to Wilson, in one of these severe seasons, more than 600 Crows were shot on the carcase of a dead horse, which was placed at a proper shooting distance from a stable. The premiums obtained for these, and the price procured for the quills, produced to the farmer nearly the value of the horse when living, besides affording feathers sufficient to fill a bed.

The Crow is easily raised and domesticated, and soon learns to distinguish the different members of the fimily with which he is associated. He screams at the approach of a stranger; learns to open the door by alighting on the latch; attends regularly at meal times; is very noisy and loquacious; imitates the sounds of various words which he hears; is very thievish, given to hiding curiosities in holes and crevices, and is very fond of carrying off pieces of metal, corn, bread, and food of all kinds; he is also particularly attached to the society of his master, and recollects him sometimes after a long absence.

It is commonly believed and asserted in some parts of this 
country that the Crows engage at times in general combat; but it has never been ascertained whether this hostility arises from civil discord, or the opposition of two different species contesting for some exclusive privilege of subsisting ground. lt is well known that Rooks often contend with each other, and drive away by every persecuting means individuals who arrive among them from any other rookery.

Note. - The Florida CROW (C. americanus foridanus) differs from true americanus in having the wings and tail shorter, and the bill and feet larger. It is restricted to southern Florida.

\section{FISH CROW.}

\section{CORVUS OSSIFRAGUS.}

Char. Black glossed with steel-blue. Length 15 to $171 / 2$ inches.

$N^{\top}{ }^{\prime} s t . \quad$ On a tree ; of sticks and twigs firmly laid, lined with leaves.

Eggs. 5-7; sea-green or olive, blotched and spotted with brown; I. $50 \times 1.05$.

Wilson was the first to observe the distinctive traits of this smaller and peculiar American species of Crow along the seacoast of Georgia. It is met with as far north as the coast of New Jersey; and although we did not see it in the western interior of the continent, it is common on the banks of the Oregon, where it was nesting in the month of April. It keeps apart from the common species, and instead of assembling to roost among the reeds at night, retires, towards evening, from the shores which afford it a subsistence, and perches in the neighboring woods. Its notes, probably various, are at times hoarse and guttural, at others weaker and higher. These Crows pass most of their time near rivers, hovering over the stream to catch up dead and perhaps living fish, or other animal matters which float within their reach; at these they dive with considerable celerity, and seizing them in their claws, convey them to an adjoining tree, and devour the fruits of their predatory industry at leisure. They also snatch up water- 
lizards in the same manner, and feed upon small crabs; at times they are seen even contending with the Gulls for their prey. It is amusing to see with what steady watchfulness they hover over the water in search of their precarious food, having, in fact, all the traits of the Gull; but they subsist more on accidental supplies than by any regular system of fishing. On land they have sometimes all the familiarity of the Magpie, hopping upon the backs of cattle, in whose company they no doubt occasionally meet with a supply of insects when other sources fail. They are also regular in their attendance on the fishermen of New Jersey for the purpose of gleaning up the refuse of the fish. They are less shy and suspicious than the common Crow, and showing no inclination for plundering the cornfields, are rather friends than enemies to the farmer. They appear near Philadelphia from the middle of March to the beginning of June, during the season of the shad and herring fishery.

The habitat now accorded to this species is "the Atlantic and Gulf States north to Long Island and west to Louisiana." It probably occurs occasionally along the Connecticut shore, and may straggle into Massachusetts; though Mr. Allen has omitted it from his list.

On the Pacific coast it is replaced by $C$. caurinus.

All Crows are more or less fish-eaters, and in some localities fish forms their staple diet. On the shores of Cape Breton, near the coal districts, the fish-eating Crows are separated by the natives from the common sort. It is said that the flight and voice of these birds can be readily distinguished. Some miners working at Lepreaux, in New Brunswick, who were familiar with the fisheating Crows of Cape Breton, drew my attention to a flock of apparently small and peculiar-voiced Crows gleaning along the shores; but though easily trapped by a fish bait, they proved to be nothing more than rather small common Crows.

Note. - The American Magpte (Pica pica hudsonica) is a Western and Northwestern bird, and occurs as a straggler only east of the Mississippi. It has been taken in Michigan, northern Illinois, and western Ontario; also at Chambly, near Montreal. 


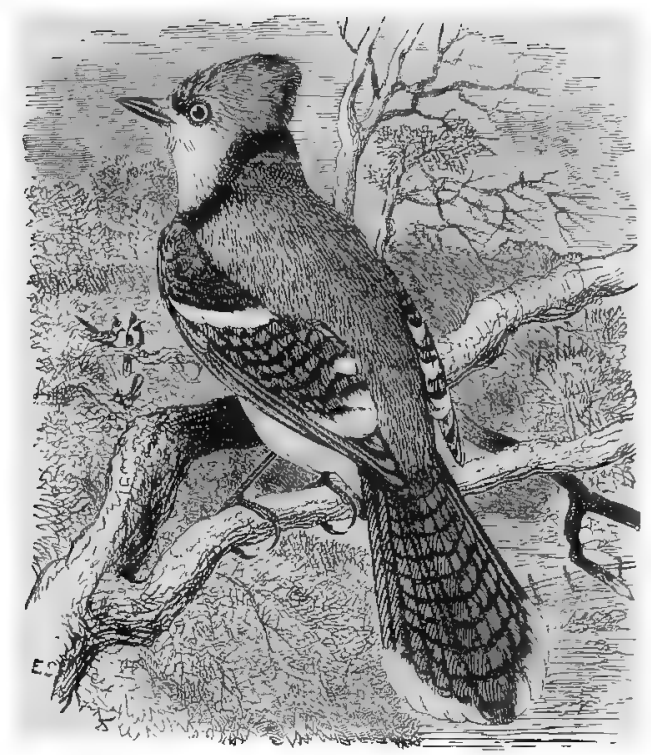

\section{BLUE JAY.}

\section{Cyanocitta cristata.}

Char. Above, purplish blue; below, pale purplish gray, lighter on throat and tail-coverts : wings and tail bright blue barred with black; wing. coverts, secondaries, and most of tail-feathers broadly tipped with white. Head conspicuously crested; tail wedge-shaped. Length I I to I $2 \frac{1}{2}$ inches.

Nest. In a small conifer, about 20 feet from the ground, situated in deep forest or near a settlement; roughly but firmly constructed of twigs and roots, and lined with fine roots.

Eggs. 4-5; pale olive or buff, spotted with yellowish brown; I. Io $\times 0.85$.

This elegant and common species is met with in the interior, from the remote northwestern regions near Peace River, in the $54^{\text {th }}$ to the $5^{6 \text { th }}$ degree, Lake Winnipeg in the $49^{\text {th }}$ degree, the eastern steppes of the Rocky Mountains, and southwestward to the banks of the Arkansas; also along the Atlantic regions from the confines of Newfoundland to the peninsula of Florida and the shores of the Gulf of Mexico. 
The Blue Jay is a constant inhabitant both of the wooded wilderness and the vicinity of the settled farm, though more familiar at the approach of winter and early in spring than at any other season. These wanderings or limited migrations are induced by necessity alone; his hoards of grain,.nuts, and acorns either have failed or are forgotten: for, like other misers, he is more assiduous to amass than to expend or enjoy his stores, and the fruits of his labors very frequently either devolve to the rats or squirrels, or accidentally assist in the replanting of the forest. His visits at this time are not unfrequent in the garden and orchard, and his usual petulant address of $d j a j y, j a y y, j a y$, and other harsh and trumpeting articulations, soon make his retreat known to all in his neighborhood. So habitual is this sentinel cry of alarm, and so expressive, that all the birds within call, as well as other wild animals, are instantly on the alert, so that the fowler and hunter become generally disappointed of their game by this his garrulous and noisy propensity; he is therefore, for his petulance, frequently killed without pity or profit, as his flesh, though eaten, has but little to recommend it. His more complaisant notes, when undisturbed, though guttural and echoing, are by no means unpleasant, and fall in harmoniously with the cadence of the feathered choristers around him, so as to form a finishing part to the general music of the grove. His accents of blandishment, when influenced by the softer passions, are low and musical, so as to be scarcely heard beyond the thick branches where he sits concealed; but as soon as discovered he bursts out into notes of rage and reproach, accompanying his voice by jerks and actions of temerity and defiance. Indeed the Jay of Europe, with whom our beau agrees entirely in habits, is so irascible and violent in his movements as sometimes to strangle himself in the narrow fork of a branch from which he has been found suspended. Like the European species, he also exhibits a great antipathy to the Owl, and by his loud and savage vociferation soon brings together a noisy troop of all the busy birds in the neighborhood. To this garrulous attack the night wanderer has no reply but a threatening stare 
of indifference; and as soon as opportunity offers, he quietly slips from his slandering company. Advantage in some countries is taken of this dislike for the purpose of catching birds; thus the Owl, being let out of a box, sometimes makes a hoot, which instantly assembles a motley group, who are then caught by liming the neighboring twigs on which they perch. In this gossip the Jay and Crow are always sure to take part if within sight or hearing of the call, and are thus caught or destroyed at will. The common Jay is even fond of imitating the harsh voice of the Owl and the noisy Kestrel. I have also heard the Blue Jay mock with a taunting accent the ké oo, ké oo, or quailing, of the Red-shouldered Hawk. Wilson likewise heard him take singular satisfaction in teasing and mocking the little American Sparrow Hawk, and imposing upon him by the pretended plaints of a wounded bird; in which frolic several would appear to join, until their sport sometimes ended in sudden consternation, by the Hawk, justly enough, pouncing on one of them as his legitimate and devoted prey.

His talent for mimicry when domesticated is likewise so far capable of improvement as to enable him to imitate human speech, articulating words with some distinctness; and on hearing voices, like a Parrot, he would endeavor to contribute his important share to the tumult. Bewick remarks of the common Jay of Europe that he heard one so exactly counterfeit the action of a saw that, though on a Sunday, he could scarcely be persuaded but that some carpenter was at work. Another, unfortunately, rendered himself a serious nuisance by learning to hound a cur dog upon the domestic cattle, whistling and calling him by name, so that at length a serious accident occurring in consequence, the poor Jay was proscribed.

One which I have seen in a state of domestication behaved with all the quietness and modest humility of Wilson's caged bird with a petulant companion. He seldom used his voice, came in to lodge in the house at night in any corner where he was little observed, but unfortunately perished by an accident before the completion of his education.

The favorite food of this species is chestnuts, acorns, and 
Indian corn or maize, the latter of which he breaks before swallowing. He also feeds occasionally on the larger insects and caterpillars, as well as orchard fruits, particularly cherries, and does not even refuse the humble fare of potatoes. In times of scarcity he falls upon carrion, and has been known to venture into the barn, through accidental openings; when, as if sensible of the danger of purloining, he is active and silent, and if surprised, postponing his garrulity, he retreats with noiseless precipitation and with all the cowardice of a thief. The worst trait of his appetite, however, is his relish for the eggs of other birds, in quest of which he may frequently be seen prowling; and with a savage cruelty he sometimes also devours the callow young, spreading the plaint of sorrow and alarm wherever he flits. The whole neighboring community of little birds, assembled at the cry of distress, sometimes, how. ever, succeed in driving off the ruthless plunderer, who, not always content with the young, has been seen to attack the old, though with dubious success; but to the gallant and quarrelsome King Bird he submits like a coward, and driven to seek shelter, even on the ground, from the repeated blows of his antagonist, sneaks off well contented to save his life.

Although a few of these birds are seen with us nearly through the winter, numbers, no doubt, make predatory excursions to milder regions, so that they appear somewhat abundant at this season in the Southern States; yet they are known to rear their young from Canada to South Carolina, so that their migrations may be nothing more than journeys from the highlands towards the warmer and more productive sea-coast, or eastern frontier.

East of the Mississippi the Blue Jay has been rarely seen north of the 50 th parallel.

Note. - A smaller race, which differs also from true cristata in having less white on the tips of the secondaries and tail-feathers, has been named the FLORIDA BLUE JAY (C. cristata florincola). It is found in Florida only. 


\section{FLORIDA JAY.}

\section{APHELOCOMA FLORIDANA.}

Char. Above, dull azure blue; back with patch of brownish gray; throat and chest grayish white streaked with ashy; belly, brownish gray. No crest; tail longer than wing. Length $101 / 2$ to $121 / 2$ inches.

Nest. In low tree or thicket of bushes; made of twigs and roots, lined with fine roots and moss.

Eggs. 4-5; pale green or bluish gray, spotted with rufous and black; I $10 \times 0.80$.

This elegant species is, as far as yet known, almost wholly confined to the interior of the mild peninsula of East Florida. In a tour through the lower parts of Georgia and West Florida, protracted to the middle of March, I saw none of these birds ; and at the approach of winter they even retire to the south of St. Augustine, as Mr. Ord did not meet with them until about the middle of February; from that time, however, they were seen daily, flying low and hopping through the luxuriant thickets, or peeping from the dark branches of the live-oaks which adorn the outlet of the St. Juan. 'These birds appear to possess the usual propensities of their tribe, being quarrelsome, active, and garrulous. Their voice is less harsh than that of the common Blue Jay, and they have a variety of notes, some of which, probably imitations, are said to have a resemblance to the song of the Thrush and the call of the common Jay.

Only a single brood is raised in the season. Its food is very similar to that of the other species; namely, berries, fruits, mast, and insects. It likewise collects snails from the marshy grounds, feeds largely on the seeds of the sword-palmetto; and, in the manner of the Titmouse, it secures its food between its feet, and breaks it into pieces previous to swallowing. Like other species of the genus, it destroys the eggs and young of small birds, despatching the latter by repeated blows on the head. It is also easily reconciled to the cage, and feeds on fresh or dried fruits and various kinds of nuts. Its attempts at mimicry in this state are very imperfect. 


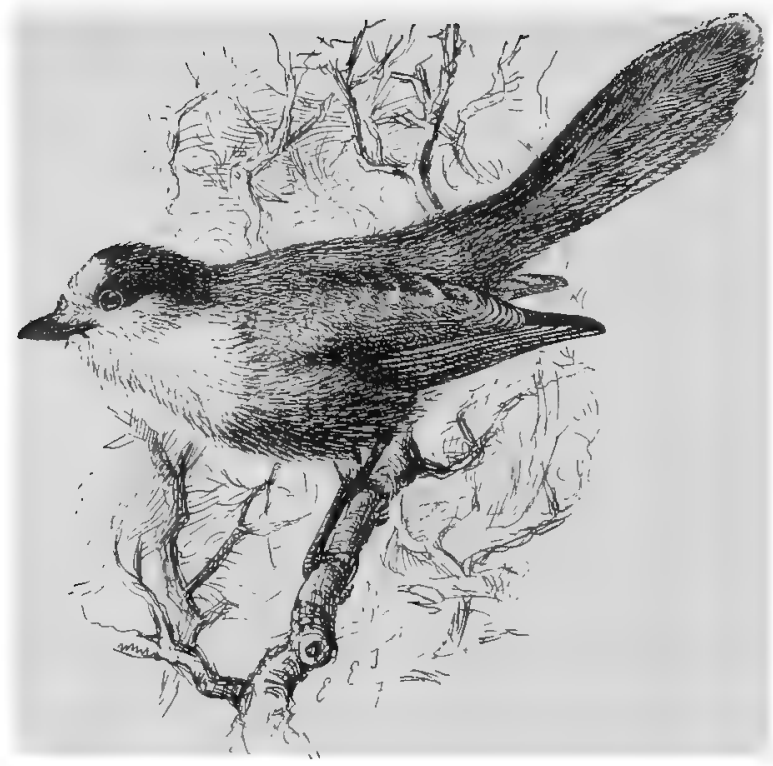

CANADA JAY.

WHISKEY JACK. MOOSE BIRD.

Perisoreus canadensis.

CHAR. Above, ashy gray; head and nape smoky black; forehead and lower parts whitish gray; breast brownish gray; wings and tail dark ashy, tipped obscurely with white. Young: uniform dull smoky black, paler beneath. Length, II to 12 inches.

Nest. In a coniferous tree; a bulky but compact structure of dried twigs, shreds of bark and moss thickly lined with feathers.

Eggs. 4-5; of light gray or buffish, spotted with dark gray, lilac gray, and pale brown; $1.15 \times 0.80$.

This species, with the intrusive habits and plain plumage of the Pie, is almost confined to the northern regions of America, being met with around Hudson's Bay, but becoming rare near the St. Lawrence, and in winter only straggling along the coast as far as Nova Scotia. Westward, occasionally driven by the severity of the weather and failure of food, they make their appearance in small parties in the interior of Maine and north- 
ern parts of Vermont, where, according to Audubon, they are frequently known to breed. They also descend into the State of New York as far as the town of Hudson and the banks of the Mohawk. In the month of May I observed a wandering brood of these birds, old and young, on the shady borders of the Wahlamet, in the Oregon territory, where they had probably been bred. They descended to the ground near a spring in quest of insects and small shells.

According to Mr. Hutchins, like the Pie, when near the habitations and tents of the inhabitants and natives, it is given to pilfering everything within reach, and is sometimes so bold as to venture into the tents and snatch the meat from the dishes even, whether fresh or salt. It has also the mischievous sagacity of watching the hunters set their traps for the Martin, from which it purloins the bait. Its appetite, like that of the Crow, appears omnivorous. It feeds on worms, various insects, and their larvæ, and on flesh of different kinds; lays up stores of berries in hollow trees for winter; and at times, with the reindeer, is driven to the necessity of feeding on lichens. The severe winters of the wilds it inhabits, urges it to seek support in the vicinity of habitations. Like the common Jay, at this season it leaves the woods to make excursions after food, trying every means for subsistence; and tamed by hunger, it seeks boldly the society of men and animals. These birds are such praters as to be considered Mocking Birds, and are superstitiously dreaded by the aborigines. They commonly fly in pairs or rove in small families, are no way difficult to approach, and keep up a kind of friendly chattering, sometimes repeating their notes for a quarter of an hour at a time, immediately before snow or falling weather. When caught, they seldom long survive, though they never neglect their food. Like most of their genus, they breed early in the spring, building their nests, which are formed of twigs and grass in the pinetrees. They lay 4 to 6 light-grayish eggs, faintly marked with brown spots. The young brood, at first, are perfect Crows, or nearly quite black, and continue so for some time.

According to Richardson, this inelegant but familiar bird 
inhabits all the woody districts of the remote fur countries from the $65^{\text {th }}$ parallel to Canada, and now and then in severe winters extends his desultory migrations within the northern limits of the United States. Scarcely has the winter traveller in those cold regions chosen a suitable place of repose in the forest, cleared away the snow, lighted his fire, and prepared his tent, when Whiskey Jack insidiously pays him a visit, and boldly descends into the social circle to pick up any crumbs of frozen fish or morsels of dry meat that may have escaped the mouths of the weary and hungry sledge-dogs. This confidence is almost the only recommendation of our familiar intruder. There is nothing pleasing in his voice, plumage, or attitudes. But this dark, sinister dwarf of the North is now the only inhabitant of those silent and trackless forests, and trusting from necessity in the forbearance of man, he fearlessly approaches, and craves his allowed pittance from the wandering stranger who visits his dreary domain. At the fur posts and fishing stations he is also a steady attendant, becoming so tamed in the winter by the terrible inclemency of the climate as to eat tamely from the offered hand; yet at the same time, wild and indomitable under this garb of humility, he seldom survives long in confinement, and pines away with the loss of his accustomed liberty. He hops with activity from branch to branch, but when at rest, sits with his head drawn in, and with his plumage loose. The voice of this inelegant bird is plaintive and squeaking, though he occasionally makes a low chattering, especially when his food appears in view. Like our Blue Jay, he has the habit of hoarding berries, morsels of meat, etc., in the hollows of trees or beneath their bark. These magazines prove useful in winter, and enable him to rear his hardy brood even before the disappearance of the snow from the ground, and long before any other bird indigenous to those climates. The nest is concealed with such care that but few of the natives have seen it.

Whiskey Jack has evidently moved somewhat southward since Nuttall made his observations, for the species is now a fairly common resident of the Maritime Provinces of Canada, as well as of the northern portions of Maine, New Hampshire, Vermont, New 
York, and Michigan. Near Ottawa, and in the Muskoka district of Ontario, it occurs regularly, though it is not abundant. In October, I889, one example was taken at Arlington Heights, near Boston.

I examined a nest taken near Edmundston, New Brunswick, on April 7,1883 , at which date the country there was covered with snow and ice. The nest was placed on a small tree near the main highway, and not many hundred yards from the railroad station. As the cold in that region is intense, the temperature often being at $-30^{\circ}$ to $-40^{\circ} \mathrm{F}$. in midwinter, it is surprising that the eggs are ever hatched. But the nest is made very warm, and the birds sit close, and when one parent steps off the other at once steps on.

By the first of June the young are in full feather and taking care of themselves.

Nuttall's opinion that these birds appear bold and familiar only when pressed by the hunger of winter, has not found support in my experience. Frequently when camping in the New Brunswick woods during the summer vacation I have seen numbers of these birds gather about my camp-fire within a few minutes after it has been lighted; and they did not hesitate to pick up a piece of meat thrown toward them. Several other observers, however, have recorded a similar opinion to Nuttall's ; and it may be that the fearless birds are restricted to localities where they are not disturbed.

The Canadian hunters and lumbermen have a superstitious respect for these birds, fearing the ill-luck that is said to result from killing one, and Whiskey Jack may have discovered that.

NOTE. - The Labrador JAY ( $S$. canadensis nigricapilus) differs from true canadensis in being darker in general coloration. It is restricted to the coast region of Labrador. 


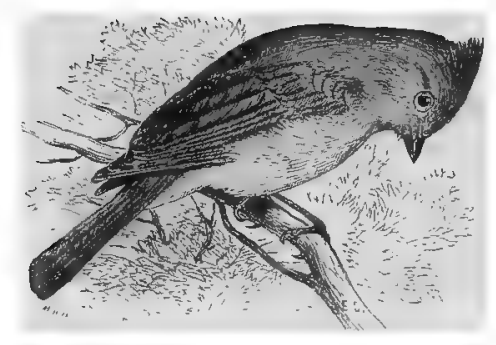

\section{TUFTED TITMOUSE.}

PARUS BICOLOR.

CHAR. Above, bluish ash; beneath, dull white; flanks tinged with yellowish brown; forehead black; head conspicuously crested. Length $5 \frac{3}{4}$ to $61 / 2$ inches.

Nest. In a cavity of a tree or stump; composed of leaves, moss, or woollen material, lined with feathers.

Eggs. 5-8; white or pale cream, spotted with reddish brown; 0.75 $\times 0.55$.

From the geographic limits of this species, as it occurs to me, I am inclined to believe that the bird seen in Greenland may be different from the present, as it scarcely appears to exist north beyond the States of Pennsylvania or New York. They are seldom, if ever, seen or heard in this part of Massachusetts, and instead of being more abundant to the north, as believed by Wilson, they are probably not known there at all. In the Southern States, at least in winter and spring, they are very common, and present all the usual habits and notes of the genus. The numbers which I saw in the Southern States from January to March would seem to indicate a migratory habit; but whether they had arrived from the Northeast, or from the great forests of the West, could not be conjectured.

The Peto, as I may call this bird from one of his characteristic notes, and the Carolina Wren, were my constant and amusing companions during the winter as I passed through the dreary solitudes of the Southern States. The sprightliness, caprice, and varied musical talent of this species are quite interesting, and more peculiarly so when nearly all the other vocal tenants of the forest are either absent or silent. To 
hear in the middle of January, when at least the leafless trees and dark cloudy skies remind us of the coldest season, the lively, cheering, varied pipe of this active and hardy bird, is particularly gratifying; and though his voice on paper may appear to present only a list of quaint articulations, yet the delicacy, energy, pathos, and variety of his simple song, like many other things in Nature, are far beyond the feeble power of description; and if in these rude graphic outlines of the inimitable music of birds I am able to draw a caricature sufficient to indicate the individual performer, I shall have attained all the object to be hoped for in an attempt at natural delineation.

The notes of the Peto generally partake of the high, echoing, clear tone of the Baltimore Bird. Among his more extraordinary expressions I was struck with the call of 'whip-tomkülly kìlly, and now and then 'rehip tom killy', with occasionally some variation in the tone and expression, which was very lively and agreeable. The middle syllable $(t \bar{o} m)$ was pronounced in a hollow reverberating tone. In a few minutes after the subject and its variations were finished, in the estimation of the musical performer, he suddenly twisted himself round the branch on which he had sat, with a variety of odd and fantastic motions; and then, in a lower, hoarser, harsh voice, and in a peevish tone, exactly like that of the Jay and the Chickadee, went $d \bar{a} y-d \bar{a} y^{\prime}-d \bar{a} y-d \bar{a} y$, and $d a y-d \bar{a} y^{\prime}-d l a y y-d a y-$ ddit; sometimes this loud note changed into one which became low and querulous. On some of these occasions he also called 'tshica dee-dee. The jarring call would then change occasionally into kai-tee-did did-tlit-did. These peevish notes would often be uttered in anger at being approached; and then again would perhaps be answered by some neighboring rival, against whom they appeared levelled in taunt and ridicule, being accompanied by extravagant gestures.

Later in the season, in February, when in the lower part of Alabama the mild influence of spring began already to be felt, our favorite, as he gayly pursued the busy tribe of insects, now his principal food, called, as he vaulted restlessly from branch to branch, in an echoing rapid voice, at short intervals, petö- 
petö-petö-petă. This tender call of recognition was at length answered, and continued at intervals for a minute or two; they then changed their quick call into a slower péto pétó pétó; and now the natural note passed into the plaintive key, sounding like que-āh que- $\bar{a} h$; then in the same breath a jarring note like that of the Catbird, and in part like the sound made by putting the lower lip to the upper teeth, and calling ' $t s h$ ' $v a h$, ' $t s h$ ' vah. After this the call of kerry-kerry-kerry-kerry struck up with an echoing sound, heightened by the hollow bank of the river whence it proceeded. At length, more delicately than at first, in an under tone, you hear anew, and in a tender accent, peto peto peto. In the caprice and humor of our performer, tied by no rules but those of momentary feeling, the expression will perhaps change into a slow and full peet-peet-a-peet-a-peet, then a low and very rapid ker-ker-ker-ker-ker-kerry, sometimes so quick as almost to resemble the rattle of a watchman. At another time his morning song commences like the gentle whispers of an aërial spirit, and then becoming high and clear like the voice of the nightingale, he cries keeva keeva kéevia keeva, but soon falling into the querulous, the day-day-day-dayday-dait of the Chickadee terminates his performance Imitative, as well as inventive, I have heard the Peto also sing something like the lively chatter of the Swallow, leta-leta-letaletalit, and then vary into pèto-péto-pĕto-pèto-peto extremely quick. Unlike the warblers, our cheerful Peto has no trill, or any other notes than these simple, playful, or pathetic calls; yet the compass of voice and the tone in which they are uttered, their capricious variety and their general effect, at the season of the year when they are heard, are quite as pleasing to the contemplative observer as the more exquisite notes of the summer songsters of the verdant forest.

The sound of 'whip-tom-kelly, which I heard this bird utter, on the 17 th of January, I830, near Barnwell, in South Carolina, is very remarkable, and leads me to suppose that the species is also an inhabitant of the West India Islands, where Sloane attributes this note to the Red-eyed Flycatcher; but it is now known to be the note of a tropical species, the vireo longiros- 
tris, and which our bird had probably heard and mimicked in its distant clime.

The Peto, besides insects, like the Jay, to which he is allied, chops up acorns, cracks nuts and hard and shelly seeds to get at their contents, holding them meanwhile in his feet. $\mathrm{He}$ also searches and pecks decayed trees and their bark with considerable energy and industry in quest of larvæ; he often also enters into hollow trunks, prying after the same objects. In these holes they commonly roost in winter, and occupy the same secure situations, or the holes of the small Woodpecker, for depositing and hatching their eggs, which takes place early in April or in May, according to the different parts of the Union they happen to inhabit. Sometimes they dig out a cavity for themselves with much labor, and always line the hollow with a variety of warm materials. Their eggs, about six to eight, are white with a few small specks of brownish red near the larger end. The whole family, young and old, may be seen hunting together throughout the summer and winter, and keeping up a continued mutual chatter.

According to the observations of Wilson it soon becomes familiar in confinement, and readily makes its way out of a wicker cage by repeated blows at the twigs. It may be fed on hemp-seed, cherry-stones, apple-pippins, and hickory nuts, broken and thrown in to it. In its natural state, like the rest of its vicious congeners, it sometimes destroys small birds by blows on the skull.

This species belongs to the Carolinian faunal area, and occurs regularly only from about the 4oth parallel southward; north of that it is but an accidental straggler. 


\section{CHICKADEE.}

\section{PARUS ATRICAPILlUS.}

CHAR. Above, ashy gray; below, grayish white; flanks buffy; crown and throat black; cheek white. Length $4 \frac{3}{4}$ to $5 \frac{3}{4}$ inches.

$N_{i s t}$. In a cavity made in a decayed stump, entering from the top or side; composed of wool or inner fur of small mammals firmly and compactly felted. Sometimes moss and hair are used, and a lining of feathers.

Eggs. 5-8; white speckled with reddish brown, $0.60 \times 0.50$.

This familiar, hardy, and restless little bird chiefly inhabits the Northern and Middle States as well as Canada, in which it is even resident in winter around Hudson's Bay, and has been met with at $62^{\circ}$ on the northwest coast. In all the Northern and Middle States, during autumn and winter, families of these birds are seen chattering and roving through the woods, busily engaged in gleaning their multifarious food, along with Nuthatches and Creepers, the whole forming a busy, active, and noisy group, whose manners, food, and habits bring them together in a common pursuit. Their diet varies with the season; for besides insects, their larvæ and eggs, of which they are more particularly fond, in the month of September they leave the woods and assemble familiarly in our orchards and gardens, and even enter the thronging cities in quest of that support which their native forests now deny them. Large seeds of many kinds, particularly those which are oily, as the sunflower and pine and spruce kernels, are now sought after. These seeds, in the usual manner of the genus, are seized in the claws and held against the branch until picked open by the bill to obtain their contents. Fat of various kinds is also greedily eaten, and they regularly watch the retreat of the hogkillers in the country, to glean up the fragments of meat which adhere to the places where the carcases have been suspended. At times they feed upon the wax of the candle-berry myrtle (Myrica cerifera) ; they likewise pick up crumbs near the houses, and search the weather-boards, and even the window-sills, 
familiarly for their lurking prey, and are particularly fond of spiders and the eggs of destructive moths, especially those of the canker-worm, which they greedily destroy in all its stages of existence. It is said that they sometimes attack their own species when the individual is sickly, and aim their blows at the skull with a view to eat the brain; but this barbarity I have never witnessed. In winter, when satisfied, they will descend to the snow-bank beneath and quench their thirst by swallowing small pieces; in this way their various and frugal meal is always easily supplied; and hardy, and warmly clad in light and very downy feathers, they suffer little inconvenience from the inclemency of the seasons. Indeed in the winter, or about the close of October, they at times appear so enlivened as already to show their amorous attachment, like our domestic cock, the male approaching his mate with fluttering and vibrating wings; and in the spring season, the males have obstinate engagements, darting after each other with great velocity and anger. Their roost is in the hollows of decayed trees, where they also breed, making a soft nest of moss, hair, and feathers, and laying from six to twelve eggs, which are white, with specks of brown-red. They begin to lay about the middle or close of April ; and though they commonly make use of natural or deserted holes of the Woodpecker, yet at times they are said to excavate a cavity for themselves with much labor. The first brood take wing about the $7^{\text {th }}$ or Ioth of June, and they have sometimes a second towards the end of July. The young, as soon as fledged, have all the external marks of the adult, the head is equally black, and they chatter and skip about with all the agility and self-possession of their parents, who appear nevertheless very solicitous for their safety. From this time the whole family continue to associate together through the autumn and winter. They seem to move by concert from tree to tree, keeping up a continued 'tshe-de-de-de-de, and 'tshede-de-de-dait, preceded by a shrill whistle, all the while busily engaged picking round the buds and branches hanging from their extremities and proceeding often in reversed postures, head downwards, like so many tumblers, prying into every 
crevice of the bark, and searching around the roots and in every possible retreat of their insect prey or its larvæ. If the object chance to fall, they industriously descend to the ground and glean it up with the utmost economy.

On seeing a cat or other object of natural antipathy, the Chickadee, like the peevish Jay, scolds in a loud, angry, and hoarse note, like 'tshe daigh dáigh dáigh. Among the other notes of this species I have heard a call like tshe-de-jay, tshede-jay, the two first syllables being a slender chirp, with the jay strongly pronounced. Almost the only note of this bird which may be called a song is one which is frequently heard at intervals in the depth of the forest, at times of the day usually when all other birds are silent. We then may sometimes hear in the midst of this solitude two feeble, drawling, clearly whistled, and rather melancholy notes, like 'te-děrry, and sometimes 'yeperrrit, and occasionally, but much more rarely, in the same wiry, whistling, solemn tone, 'pēhbé. The young, in winter, also sometimes drawl out these contemplative strains. In all cases the first syllable is very high and clear, the second word drops low and ends like a feeble plaint. This is nearly all the quaint song ever attempted by the Chickadee, and is perhaps the two notes sounding like the whetting of a saw, remarked of the Marsh Titmouse in England by Mr. White, in his "Natural History of Selborne." On fine days, about the commencement of October, I have heard the Chickadee sometimes for half an hour at a time attempt a lively, petulant warble very different from his ordinary notes. On these occasions he appears to flit about, still hunting for his prey, but almost in an ecstasy of delight and vigor. But after a while the usual drawling note again occurs. These birds, like many others, are very subject to the attacks of vermin, and they accumulate in great numbers around that part of the head and front which is least accessible to their feet.

The European bird, so very similar to ours, is partial to marshy situations. Ours has no such predilection, nor do the American ones, that I can learn, ever lay up or hide any'store of seeds for provision, - a habit reported of the foreign family. 
In this fact, with so many others, we have an additional evidence of affinity between the Titmouse and Jay, particularly that short-billed section which includes the Garrulus canadensis and $G$. infaustus. Even the blue color, so common with the latter, is possessed by several species of this genus. Indeed, from their aggregate relation and omnivorous habit we see no better place of arrangement for these birds than succinctly after the Garruli, or Jays.

Following the authority of Temminck and Montagu, I considered this bird the same as the European Marsh Titmouse. I have since seen the bird of Europe in its native country, and have good reason to believe it wholly different from our lively and familiar Chickadee. Unlike our bird, it is rather shy, seldom seen but in pairs or solitary, never in domestic premises, usually and almost constantly near streams or watercourses, on the willows, alders, or other small trees impending over streams, and utters now and then a feeble complaining or querulous call, and rarely if ever the chicka dee-dee. It also makes a noise in the spring, as it is said, like the whetting of a saw, which ours never does. The Chickadee is seldom seen near waters; often, even in summer, in dry, shady, and secluded woods; but when the weather becomes cold, and as early as October, roving families, pressed by necessity and the failure of their ordinary insect fare, now begin to frequent orchards and gardens, appearing extremely familiar, hungry, indigent, but industrious, prying with restless anxiety into every cranny of the bark or holes in decayed trees after dormant insects, spiders, and larvæ, descending with the strictest economy to the ground in quest of every stray morsel of provision which happens to fall from their grasp. Their quaint notes and jingling warble are heard even in winter on fine days when the weather relaxes in its severity; and, in short, instead of being the river hermit of its European analogue, it adds by its presence, indomitable action and chatter, an air of cheerfulness to the silent and dreary winters of the coldest parts of America. 


\section{CAROLINA CHICKADEE.}

\section{Parus Carolinensis.}

CHAR. Above, ashy gray tinged with dull brown; head and throat black; cheek white; beneath, brownish white; flanks buffish. Length $4 \frac{1}{4}$ to $43 / 4$ inches.

Nest. In a cavity of decayed stump, composed of grass or shreds of bark, and lined with feathers. Sometimes composed entirely of fur or fine wool felted compactly.

Eggs. 5-8; white often spotted with reddish brown; $0.60 \times 0.50$.

This species, detected by Mr. Audubon, is a constant inhabitant of the Southern and Middle States from the borders of New Jersey to East Florida. It has a predilection for the borders of ponds, marshes, and swamps, and less gregarious than the preceding, seldom more than a pair or family are seen together. It is also shy and retiring; inhabiting at all times a mild and genial clime, it never seeks out domestic premises, nor even the waysides, but, like the European Marsh Titmouse, it remains throughout the year in the tangled woods and swamps which gave it birth. In the wilds of Oregon late in autumn we frequently saw small roving restless flocks of these birds associated often with the Chestnut-Backed species. At such times both parties were querulous and noisy; but the tshe te de de is comparatively feeble, uttered in a slender, wiry tone. At such times intently gleaning for insects, they show very little fear, but a good deal of sympathy for their wounded companions, remaining round them and scolding in a petulant and plaintive tone. At the approach of winter those in the Atlantic region retire farther to the south, and on the Pacific border they are to be seen in winter in the woods of Upper California ; but in no instance did we see them approach the vicinity of the trading posts or the gardens.

A nest of this species discovered by Dr. Bachman was in a hollow stump about four feet from the ground; it was rather shallow, composed of fine wool, cotton, and some fibres of plants, the whole fitted together so as to be of an uniform thickness throughout, and contained pure white eggs. 


\section{HUDSONIAN CHICKADEE.}

\section{PARUS hUdSONICUS.}

CHAR. Above, pale dull brown, darker on crown; cheeks white; below, grayish white; flanks rusty; thruat brownish black. Length 5 to $5 \frac{3 \%}{4}$.

Nest. In an excavation in a decayed stump, usually entering from the top. On the bottom of the cavity is placed a platform of dried moss, and on this another of felted fur, and upon this latter is set the graceful pouchshaped nest of firm felt, made of the inner fur of small mammals.

Eggs. 6-10; creamy white with brown spots in a circle around the larger end $; 0.5^{8} \times 0.5^{8}$.

This more than usually hardy species continues the whole year about Severn River, braving the inclemency of the winters, and frequents the juniper-bushes on the buds of which it feeds. In winter, like the common species, it is seen roving about in small flocks, busily foraging from tree to tree. It is said to lay five eggs. Mr. Audubon met with it on the coast of Labrador, where it was breeding, about the middle of July. $\mathrm{He}$ describes the nest as being placed at the height of not more than three feet from the ground, in the hollow of a decayed low stump scarcely thicker than a man's leg, the whole so rotten that it crumbled to pieces on being touched. It was shaped like a purse, eight inches in depth, two in diameter inside, its sides about a half an inch thick. It was composed of the finest fur of different quadrupeds, so thickly matted throughout that it looked as if it had been felted by the hand of man. On the nest being assailed, the male flew at the intruder, uttering an angry te-te-te-tee.

The Hudson Bay Chickadee is fairly common in the Maritime Provinces, though more abundant in winter than in summer. It has been found breeding, also, in the northern parts of Maine, New Hampshire, New York, and Michigan, and in the Muskoka districts of Ontario. Mr. Walter Faxon considers it a rare though regular migrant to the eastern part of Massachusetts, but thinks it occurs in numbers in winter amid the Berkshire hills.

One example has been taken in Connecticut, and one in Rhode Island. 


\section{BOHEMIAN WAXWING.}

\section{AMIPELIS GARRULLS.}

CHAR. Prevailing color cimnamon brown or fawn color, darker on front head and cheeks, changing to ashy on rump; chin and line across forehead and through the eyes, rich black; wings and tail slaty; tail tipped with yellow; primaries tipped with white, secondaries with appendages like red sealing-wax. Head with long pointed crest. Length $71 / 2$ to $\mathrm{S}^{3}+$ inches. Easily distinguished from the Cedar Bird by its larger size and darker color.

lest. In a tree, a bulky structure of twigs and roots, lined with feathers.

Eggs. 3-5; bluish white spotted with lilac and brown; $1.00 \times 0.70$.

The Waxwing, of which stragglers are occasionally seen in Nova Scotia, Massachusetts, Long Island, and the vicinity of Philadelphia, first observed in America in the vicinity of the Athabasca River, near the region of the Rocky Mountains, in the month of March, is of common occurrence as a passenger throughout the colder regions of the whole northern hemisphere. Like our Cedar Birds, they associate in numerous flocks, pairing only for the breeding season; after which the young and old give way to their gregarious habits, and collecting in numerous companies, they perform extensive journeys, and are extremely remarkable for their great and irregular wanderings. The circumstances of incubation in this species are wholly unknown. It is supposed that they retire to the remote regions to breed; yet in Norway they are only birds of passage, and it has been conjectured that they pass the summer in the elevated table-land of Central Asia. Wherever they dwell at this season, it is certain that in spring and late autumn they visit northern Asia or Siberia and eastern Europe in vast numbers, but are elsewhere only uncertain stragglers, whose appearance, at different times, has been looked upon as ominous of some disaster by the credulous and ignorant.

The Waxen Chatterers, like our common Cedar Birds, appear destitute of song, and only lisp to each other their usual low, reiterated call of zé zé re, which becomes more audible 
when they are disturbed and as they take to wing. They are also very sociable and affectionate to their whole fraternity, and sit in rows often on the same branch, when not employed in collecting their food, which is said to consist of juicy fruits of various kinds, particularly grapes; they will also eat juniper and laurel berries, as well as apples, currants, and figs, and are often seen to drink.

Dr. Richardson informs us that this bird appears in flocks at Great Bear Lake about the 24th of May, when they feed on the berries of the alpine arbutus, marsh vaccinium, and other kinds exposed again to the surface after the spring thaw. Another flock of three or four hundred individuals was seen on the banks of the Saskatchewan, at Carlton House, early in the same month. In their usual manner they all settled together on one or two trees, and remained together about the same place for an hour in the morning, making a loud twittering noise, and were too shy to be approached within gunshot. Their stay at most did not exceed a few days, and none of the Indians knew of their nests; though the doctor had reason to believe that they retired in the breeding season to the broken and desolate mountain-limestone districts in the $67^{\text {th }}$ or 68 th parallels, where they find means to feed on the fruit of the common juniper, so abundant in that quarter. Neither $\mathrm{Mr}$. Townsend nor myself observed this bird either in the Columbia River district or on the Rocky Mountains.

The Bohemian is still a rover of uncertain and irregular habits, occasionally in winter appearing along the northern border of the United States and through the settled portions of Canada in large flocks, but sometimes absent for several seasons. Colonel Goss found a nest in Labrador, and several have been taken in the Northwest. 


\section{CEDAR WAXWING. \\ CEDAR BIRD. CHERRY BIRD. \\ AMPELIS CEDRORUM.}

Char. Prevailing color cinnamon brown or fawn color, changing to ashy un rump; chin and line across forehead and through eyes, rich black; wings and tail slaty; tail tipped with yellow; secondaries sometimes with red, wax-like appendages. Head with long, pointed crest. Length $6 / / 2$ to $7 \frac{1}{2}$ inches.

West. In a tree; large and loosely made of twigs and grass, lined with grass, hair, or feathers.

Eggs. $3-5$; bluish white spotted with lilac and brown; $0.85 \times 0.60$.

This common native wanderer, which in summer extends its migrations to the remotest unpeopled regions of Canada, is also found throughout the American continent to Mexico, and parties even roam to the tropical forests of Cayenne. In all this extensive geographical range, where great elevation or latitude tempers the climate so as to be favorable to the production of juicy fruits, the Cedar Bird will probably be found either almost wholly to reside, or to pass the season of reproduction. Like its European representative (the Waxen Chatterer), it is capable of braving a considerable degree of cold; for in Pennsylvania and New Jersey some of these birds are seen throughout the winter, where, as well as in the early part of the summer and fall, they are killed and brought to market, generally fat, and much esteemed as food. Silky softness of plumage, gentleness of disposition, innocence of character, extreme sociability, and an innate, inextinguishable love of freedom, accompanied by a constant desire of wandering, are characteristic traits in the physical and moral portrait of the second as well as, the preceding species of this peculiar and extraordinary genus.

Leaving the northern part of the continent, situated beyond the 4oth degree, at the approach of winter, they assemble in companies of twenty to a hundred, and wander through the Southern States and Mexico to the confines of the equator, in 
all of which countries they are now either common or abundant. As observed by Audubon, their flight is easy, continued, and often performed at a considerable height; and they move in flocks or companies, making several turns before they alight. As the mildness of spring returns, and with it their favorite food, they reappear in the Northern and Eastern States about the beginning of April, before the ripening of their favorite fruits, the cherries and mulberries. But at this season, to repay the gardener for the tithe of his crop, their natural due, they fail not to assist in ridding his trees of more deadly enemies which infest them, and the small caterpillars, beetles, and various insects now constitute their only food; and for hours at a time they may be seen feeding on the all-despoiling cankerworms which infest our apple-trees and elms. On these occasions, silent and sedate, after plentifully feeding; they sit dressing their feathers in near contact on the same branch to the number of 5 or 6 ; and as the season of selective attachment approaches, they may be observed pluming each other, and caressing with the most gentle fondness, - a playfulness in which, however, they are even surpassed by the contemned Raven, to which social and friendly family our Cedar Bird, different as he looks, has many traits of alliance. But these demonstrations of attachment, which in a more vigorous kind would kindle the feud of jealousy, apparently produce in this bird scarcely any diminution of the general social tie; and as they are gregarious to so late a period of the inviting season of incubation, this affection has been supposed to be independent of sexual distinction. This friendly trait is carried so far that an eye-witness assures me he has seen one among a row of these birds seated upon a branch dart after an insect, and offer it to his associate when caught, who very disinterestedly passed it to the next, and each delicately declining the offer, the morsel has proceeded backwards and forwards before it was appropriated. Whatever may be the fact, as it regards this peculiar sociability, it frequently facilitates the means of their destruction with the thoughtless and rapacious sportsman, who, because many of these unfortunate birds can be killed in an 
instant, sitting in the same range, thinks the exercise of the gun must be credited only by the havoc which it produces against a friendly, useful, and innocent visitor.

Towards the close of May or beginning of June the Cherry Birds, now paired, commence forming the cradle of their young; yet still so sociable are they that several nests may be observed in the same vicinity. The materials and trees chosen for their labors are various, as well as the general markings of their eggs. Two nests, in the Botanic Garden at Cambridge, were formed in small hemlock-trees, at the distance of 16 or 18 feet from the ground, in the forks of the main branches. One of these was composed of dry, coarse grass, interwoven roughly with a considerable quantity of dead hemlock sprigs, further connected by a small quantity of silk-weed lint, and lined with a few strips of thin grape-vine bark, and dry leaves of the silver fir. In the second nest the lining was merely fine rootfibres. On the $4^{\text {th }}$ of June this nest contained 2 eggs, - the whole number is generally about 4 or 5 ; these are of the usual form (not remarkable for any disproportion of the two ends), of a pale clay white, inclining to olive, with a few well-defined black or deep umber spots at the great end, and with others seen, as it were, beneath the surface of the shell. Two or three other nests were made in the apple-trees of an adjoining orchard, one in a place of difficult access, the other on a depending branch easily reached by the hand. These were securely fixed horizontally among the ascending twigs, and were formed externally of a mass of dry, wiry weeds, the materials being firmly held together by a large quantity of cudweed down, in some places softened with glutinous saliva so as to be formed into coarse, connecting shreds. The round edge of the nest was made of coils of the wiry stolons of a common Cinquefoil then lined with exceedingly fine root-fibres; over the whole, to give elasticity, were laid fine stalks of a slender juncus, or minute rush. In these nests the eggs were, as described by Wilson (except as to form), marked with smaller and more numerous spots than the preceding. From the lateness of the autumn, at which period incubation is still going 
on, it would appear that this species is very prolific, and must have at least two hatches in the season; for as late as the $7^{\text {th }}$ of September a brood, in this vicinity, were yet in the nest. The period of sitting is about 15 or 16 days; and while the young are still helpless, it is surprising to witness the silence of the parents, uttering no cries, nor making any approaches to those who may endanger or jeopard the safety of their brood; still, they are flying round, and silently watching the dreaded result, and approach the nest the moment the intruder disappears. They feed the young, at first, with insects and smooth caterpillars; but at the end of the $3 \mathrm{~d}$ or 4 th day they are fed, like the old ones, aimost exclusively on sweet and juicy fruits, such as whortle and service berries, wild and cultivated cherries, etc. A young bird from one of the nests described, in the hemlock, was thrown upon my protection, having been by some means ejected from his cradle. In this critical situation, however, he had been well fed, or rather gorged, with berries, and was merely scratched by the fall he had received. Fed on cherries and mulberries, he was soon well fledged, while his mate in the nest was suffered to perish by the forgetfulness of his natural protectors. Coeval with the growth of his wingfeathers were already seen the remarkable red waxen appendages, showing that their appearance indicates no particular age or sex; many birds, in fact, being without these ornaments during their whole lives. I soon found my interesting protégé impatient of the cage and extremely voracious, gorging himself to the very mouth with the soft fruits on which he was often fed. The throat, in fact, like a craw, admits of distention, and the contents are only gradually passed off into the stomach. I now suffered the bird to fly at large, and for several days he descended from the trees, in which he perched, to my arm for food; but the moment he was satisfied, he avoided the cage, and appeared unable to survive the loss of liberty. He now came seldomer to me, and finally joined the lisping muster-cry of tze tze tzé, and was enticed away by more attractive associates. When young, nature provided him with a loud, impatient vòice, and $t \dot{e}-d i d$, té-did, kati-tédid (often also the clamorous cry of 
the young Baltimore), was his deafening and almost incessant call for food. Another young bird of the first brood, probably neglected, cried so loud and plaintively to a male Baltimore Bird in the same tree that he commenced feeding it. $\mathrm{Mr}$. Winship, of Brighton, informs me that one of the young Cedar Birds, who frequented the front of his house in quest of honeysuckle berries, at length, on receiving food (probably also abandoned by his roving parents), threw himself wholly on his protection. At large day and night, he still regularly attended the dessert of the dinner-table for his portion of fruit, and remained steadfast in his attachment to Mr. W. till killed by an accident, being unfortunately trodden under foot.

Though harmless, exceedingly gentle and artless, they make some show of defence when attacked; as a second bird which I brought up, destitute of the red appendages on the wings, when threatened elevated his crest, looked angry, and repeatedly snapped with his bill.

Almost all kinds of sweet berries are sought for food by the American Waxen-wing. In search of whortle-berries, they retire in Pennsylvania to the western mountain-chains of the Alleghany range ; and in autumn, until the approach of winter, they are equally attached to the berries of the Virginia juniper, as well as those of the sour-gum tree and the wax-myrtle. They also feed late in the season on ripe persimmons, small winter-grapes, bird-cherries, the fruit of the pride of China, and other fruits. The kernels and seeds of these, uninjured by the action of the stomach, are strewed about, and thus accidentally planted in abundance wherever these birds frequent. - Like their prototype, the preceding species, the migrations, and time and place of breeding, are influenced by their supply of food. In the spring of $183_{1}$ they arrived in this vicinity as usual; but in consequence of the failure of cherries, scarcely any were bred, and very few were either to be heard or seen in the vicinity. In parts of New England this bird is known by the name of the Canada Robin; and by the French Canadians it is fancifully called Recollet, from the color of its crest resembling that of the hood of this religious order. 


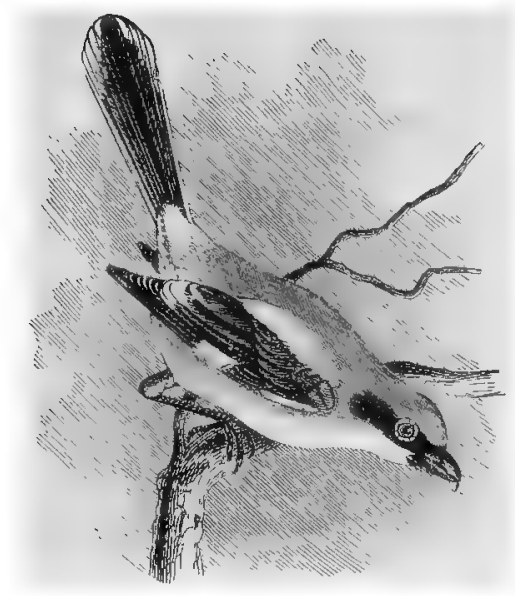

\section{NORTHERN SHRIKE.}

BUTCHER BIRD.

\section{LANIUS BOREALIS.}

Char. Above, bluish ash, paler on rump; under parts dull white, with fine wavy lines of brownish gray; bar on side of head black; wings and tail black tipped with white; white patch on wing; outer tail feathers white. Length $9 \frac{1}{4}$ to $103 / 4$ inches.

Nest. In a tree or low bush; large and roughly made of sticks and grass, lined with leaves or feathers.

Esgs. 4-6; dull gray with green tint, spotted with lilac and brown; $1.05 \times 0.75$.

This little wary Northern hunter is most commonly seen in this part of the continent at the commencement of winter, a few remaining with us throughout that season. They extend their wanderings, according to Audubon, as far as Natchez, and are not uncommon in Kentucky in severe winters. In March they retire to the North, though some take up their summer abode in the thickest forests in Pennsylvania and New England. The nest is said to be large and compact, in the fork of a small tree, and sometimes in an apple-tree, composed externally of dried grass, with whitish moss, and well lined with feathers. The eggs are about 6 , of a pale cinereous white, 
thickly marked at the greater end with spots and streaks of rufous. The period of sitting is about ${ }_{5} 5$ days. The young appear early in June or the latter end of May.

The principal food of this species is large insects, such as grasshoppers, crickets, and spiders. With the surplus of the former, as well as small birds, he disposes in a very singular manner, by impaling them upon thorns, as if thus providing securely for a future supply of provision. In the abundance, however, which surrounds him in the ample store-house of Nature, he soon loses sight of this needless and sportive economy, and, like the thievish Pie and Jay, he suffers his forgotten store to remain drying and bleaching in the elements till no longer palatable or digestible. As this little Butcher, like his more common European representative, preys upon birds, these impaled grasshoppers were imagined to be lures to attract his victims; but his courage and rapacity render such snares both useless and improbable, as he has been known, with the temerity of a Falcon, to follow a bird into an open cage sooner than lose his quarry. Mr. J. Brown, of Cambridge, informs me that one of these birds had the boldness to attack two Canaries in a cage, suspended one fine winter's day at the window. The poor songsters in their fears fluttered to the side of the cage, and one of them thrust his head through the bars of his prison; at this instant the wily Butcher tore off his head, and left the body dead in the cage. The cause of the accident seemed wholly mysterious, till on the following day the bold hunter was found to have entered the room, through the open window, with a view to despatch the remaining victim; and but for timely interference it would have instantly shared the fate of its companion. On another occasion, while a Mr. Lock in this vicinity was engaged in fowling, he wounded a Robin, who flew to a little distance and descended to the ground; he soon heard the disabled bird uttering unusual cries, and on approaching found him in the grasp of the Shrike. He snatched up the bird from its devourer; but having tasted blood, it still followed, as if determined not to relinquish its proposed prey, and only desisted from the quest on receiving a mortal wound. 
The propensity for thus singularly securing its prey is also practised on birds, which it impales in the same manner, and afterwards tears them to pieces at leisure.

From his attempts to imitate the notes of other small birds, in Canada and some parts of New England he is sometimes called a Mocking Bird. His usual note, like that of the following species, resembles the discordant creaking of a sign-board hinge; and my friend Mr. Brown has heard one mimicking the quacking of his Ducks, so that they answered to him as to a decoy fowl. They also imitate other birds, and I have been informed that they sing pretty well themselves at times, or rather chatter, and mimic the songs of other birds, as if with a view to entice them into sight, for the purpose of making them their prey. This fondness for imitation, as in the Pies, may however be merely the result of caprice.

So complete at times is the resemblance between the Mocking Bird (Mimus pollyglottus) and this species of Lanius, that it is difficult to distinguish them apart. I have lately heard one (November Ioth, 1833 ), employed in a low and soft warble resembling that of the Song Sparrow at the present season, and immediately after his note changed to that of the Catbird. Like that pre-eminent minstrel, the Orpheus, he also mounts to the topmost spray of some lofty tree to display his deceptive talent and mislead the small birds so as to bring them within his reach. His attitudes are also light and airy, and his graceful, flowing tail is kept in fantastic motion.

The parents and their brood move in company in quest of their subsistence, and remain together the whole season. The male boldly attacks even the Hawk or the Eagle in their defence, and with such fury that they generally decline the onset.

The Butcher Bird breeds from about latitude $50^{\circ}$ northward, migrating in winter south to the Potomac and Ohio valleys.

Dr. Arthur Chadbourne, of Cambridge, reports that he has heard a female sing, and describes her as "an unusually fine singer and quite a mimic." 


\section{LOGGERHEAD SHRIKE.}

\section{- Lanius ludovicianus.}

Char. Above, bluish ash, generally not much paler on rump; underparts pure white, rarely any lines of gray; flanks tinged with gray; forehead and side of head black; wings and tail black tipped with white; white patch on wings; outer tail feathers white. Length $81 / 2$ to $9 \pi / 2$ inches.

Distinguished from borealis by smaller size and by the black forehead and white under-parts.

Nest. In a tree; roughly made of twigs and grass, lined with leaves and feathers.

$E_{\text {Eg gs. }}$ 4-6; dull gray with green tint spotted with lilac and brown; $0.95 \times 0.70$.

This species principally inhabits the warmer parts of the United States, residing and breeding from North Carolina to Florida, where I have observed it likewise in winter. It was also seen in the table-land of Mexico by that enterprising naturalist and collector, Mr. Bullock, and my friend Mr. T. Townsend found it in the Rocky Mountain range and in the territory of Oregon. According to Audubon it affects the low countries, being seldom met with in the mountainous districts.

Its habits are shy and retiring, and it renders itself useful, and claims protection by destroying mice around the plantation, for which it sits and watches near the rice-stacks for hours together, seldom failing of its prey as soon as it appears. Like most of the genus, it is also well satisfied with large insects, crickets, and grasshoppers, which like the preceding species it often impales. In the breeding-season, according to Dr. Bachman, it has a song which bears some resemblance to that of the young Brown Thrush; and though very irregular, the notes are not unpleasing. At other times its discordant call may almost be compared to the creaking of a sign-board in windy weather; it probably has also the usual talent for mimicry. The pairs mate about March, at which time the male frequently feeds the female, and shows great courage in defending his nest from the intrusion of other birds. The nest 
is, according to Dr. Bachman, usually made in the outer limbs of a tree such as the live-oak or sweet-gum, and often on a cedar I 5 to 30 feet from the ground. It is coarsely made of dry crooked twigs, and lined with root-fibres and slender grass. The eggs, 3 to 5, are greenish white. Incubation is performed by both sexes in turn, but each bird procures its own food in the intervals. They rear two broods in the season. Its manners resemble those of a Hawk; it sits silent and watchful until it espies its prey on the ground, when it pounces upon it, and strikes first with the bill, in the manner of small birds, seizing the object immediately after in its claws; but it seldom attacks birds except when previously wounded.

The Loggerhead is now said to be restricted to the southern portion of the Eastern States north to Ohio and southern Illinois; but birds have been found breeding in Vermont, Maine, and New Brunswick that resembled true ludovicianus more than excubitorides, to which variety some authorities have referred them.

Note. - The White-RUMPed Shrike (L. ludoricianus excubitorides) is a pale form, usually restricted to the Western plains, but ranging occasionally through the region of the Great Lakes, east to northern New England and the Maritime Provinces of Canada. 


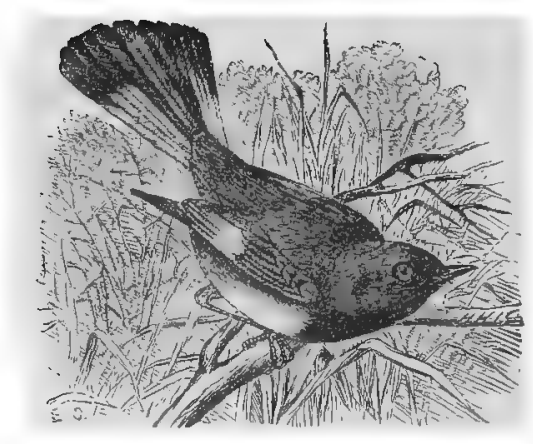

\section{REDSTART.}

\section{SETOPHAGa RUTICILla.}

CHAR. Male: lustrous blue-black; belly white; patch on sides of breast, basal half of wing-quills and of tail, orange red. Female: the black of the male replaced by olive brown, the red replaced by dull yellow. Young males like female, but gradually changing to full plumage. bill and feet black. Length 5 to $5 \frac{\mathrm{I} / 2}{2}$ inches.

Nest. An exceedingly graceful and compact structure saddled on a branch, or supported by forked twigs of a sapling, from 5 to 20 feet from the ground. It is composed of a variety of materials, in this region most commonly of grass and vegetable fibres lined with fine grass or horse-hair.

Eggs. 4-5; dull white, spotted chielly around the larger end with brown and lilac; $0.65 \times 0.50$

This beautiful and curious bird takes up its summer residence in almost every part of the North American continent, being found in Canada, in the remote interior near Red River in the latitude of 49 degrees, throughout Louisiana, Arkansas, and the maritime parts of Mexico; in all of which vast countries it familiarly breeds and resides during the mild season, withdrawing early in September to tropical America, where, in. the perpetual spring and summer of the larger West India islands, the species again find means of support. At length, instigated by more powerful feelings than those of ordinary want, the male, now clad in his beautiful nuptial livery, and accompanied by his mate, seeks anew the friendly but far distant natal regions of his race. In no haste, the playful 
Redstart does not appear in Pennsylvania until late in April. The month of May, about the close of the first week, ushers his arrival into the States of New England; but in Louisiana he is seen as early as the beginning of March. He is no pensioner upon the bounty of man. Though sometimes seen, on his first arrival, in the darkest part of the orchard or garden, or by the meandering brook, he seeks to elude observation, and now, the great object of his migrations having arrived, he retires with his mate to the thickest of the sylvan shade. Like his relative Sylvias, he is full of life and in perpetual motion. He does not, like the loitering Pewee, wait the accidental approach of his insect prey, but carrying the war amongst them, he is seen flitting from bough to bough, or at times pursuing the flying troop of winged insects from the top of the tallest tree in a zig-zag, hawk-like, descending flight, to the ground, while the clicking of the bill declares distinctly both his object and success. Then alighting on some adjoining branch, intently watching with his head extended, he runs along upon it for an instant or two, flirting like a fan his expanded, brilliant tail from side to side, and again suddenly shoots off like an arrow in a new direction, after the fresh game he has discovered in the distance, and for which he appeared to be reconnoitring. At first the males are seen engaged in active strife, pursuing each other in wide circles through the forest. The female seeks out her prey with less action and flirting, and in her manners resembles the ordinary Sylvias.

The notes of the male, though not possessed of great compass, are highly musical, and at times sweet and agreeably varied like those of the Warblers. Many of these tones, as they are mere trills of harmony, cannot be recalled by any words. Their song on their first arrival is however nearly uniform, and greatly resembles the 'tsh' $t s h$ tsh tshee, tshè, tshe, tshe tshea, or 'tsh 'tsh'tsh'tshitshee of the summer Yellow Bird (Sylvia cestiva), uttered in a piercing and rather slender tone; now and then also agreeably varied with a somewhat plaintive flowing 'tshe tshé tshe, or a more agreeable 'tshit 'tshit a 'tshee, given almost in the tones of the common Yellow Bird (Fringilla tristis). I 
have likewise heard individuals warble out a variety of sweet and tender, trilling, rather loud and shrill notes, so superior to the ordinary lay of incubation that the performer would scarcely be supposed the same bird. On some occasions the male also, when angry or alarmed, utters a loud and snapping chirp.

The nest of this elegant Sylvan Flycatcher is very neat and substantial, fixed occasionally near the forks of a slender hickory or beech sapling, but more generally fastened or agglutinated to the depending branches or twigs of the former; sometimes securely seated amidst the stout footstalks of the waving foliage in the more usual manner of the delicate cradle of the Indian Tailor Bird, but in the deep and cool shade of the forest, instead of the blooming bower. Both parents, but particularly the male, exhibit great concern for the safety of their nest, whether containing eggs only or young, and on its being approached, the male will flit about within a few feet of the invader, regardless of his personal safety, and exhibiting unequivocal marks of distress. The parents also, in their solicitude and fear, keep up an incessant 'tship when their infant brood are even distantly approached.

Nuttall classed the Redstart with the Flycatchers, as some of its habits - such as darting from a perch, and capturing insects while on the wing - are typical of that family; but the more modern systematists class it with the Wood Warblers. It is an abundant summer resident of this eastern province, breeding from about the valley of the Potomac to southern Labrador. 


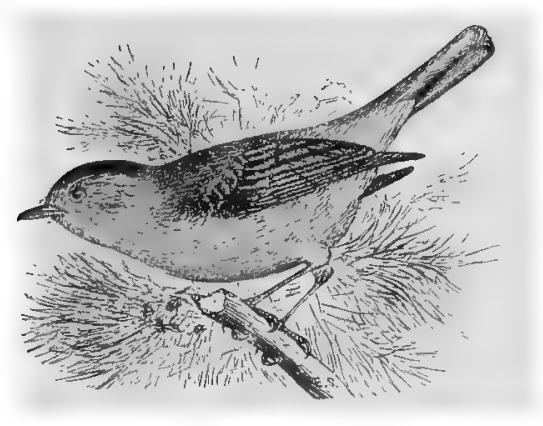

HOODED WARBLER.

SyLVANIA MitRATA.

ChAR. Male: above, yellow olive; beneath, rich yellow; sides shaded with pale olive; head and neck black, enclosing a wide band of yellow across forehead and through eyes; tail with patch of white on two or three outer tail-feathers. Bill black, feet flesh-color. Female: similar to male, but sometimes lacking the black, in which specimens the crown is olive and the throat yellow.

Nest. In a low bush; made of leaves and vegetable fibre, lined with grass or horse-hair.

Eggs. 4-5; creamy white, spotted chiefly around the larger end with brown and lilac; $0.70 \times 0.53$.

This beautiful and singularly marked summer species, common in the South, is rarely seen to the north of the State of Maryland. It retires to Mexico or the West Indies probably to pass the winter. At Savannah, in Georgia, it arrives from the South about the zoth of March, according to Wilson. It is partial to low and shady situations darkened with underwood, is frequent among the cane-brakes of Tennessee and Mississippi, and is exceedingly active, and almost perpetually engaged in the pursuit of winged insects. While thus em. ployed, it now and then utters three loud, and not unmusical, very lively notes, resembling the words, twee twee 'twittshe. In its simple song and general habits it therefore much resembles the summer Yellow Bird. Its neat and compact nest is generally fixed in the fork of a small bush, formed outwardly of moss and flax, lined with hair, and sometimes feathers; the 
eggs, about 5 , are grayish white, with reddish spots towards the great end.

The Hooded Warbler is a Southern species, but is a regular summer resident of the Connecticut valley, and has been found breeding near Cleveland, Ohio, and in southern Michigan. It is said to be more abundant in South Carolina than elsewhere.

Note. - The Smald-headed Flycatcher (Wilsonia minuta and Sylvia minuta of Wilson and Audubon) was given a place in the "Manual" by Nuttall, who alleged to have seen the species. Not having been found by any of the more modern observers, it has been omitted from many recent works. It was placed on the "hypothetical list" by the A. O. A. committee, but has been again brought forward by Ridgeway, in his "Manual." Wilson stated that he saw it in New Jersey; Audubon said he shot one in Kentucky; and Nuttall's examples were in Massachusetts. As the birds were seen by Nuttall only "at the approach of winter," it is probable they were the young of the year of some of the more northern breeding species.

\title{
WILSON'S WARBLER.
}

\author{
WILSON'S BLACK CAP.
}

\section{SYLVANIA PUSILLA.}

ChAR. Above, olive; crown black; forehead, cheeks, and entire under parts yellow. Female and young duller, and black cap often obscure, sometimes lacking. Length, $4^{1 / 4}$ to 5 inches.

Nest. On the ground, in a bushy swamp, or on branch of low bush; of twigs and vegetable fibre lined with moss or fine grass.

Eggs. 4-6; white spotted with brown and lavender; $0.60 \times 0.50$.

This remarkable species of sylvan Flycatcher was first observed by Wilson in New Jersey and Delaware as a transitory bird of passage. Audubon has noticed it in Labrador and Newfoundland, where it was breeding, and it is not uncommon in the State of Maine. He also saw it in his way to Texas early in April. It begins to migrate from Newfoundland about the middle of August, and is seen in Maine in October. Mr. Townsend and myself had the pleasure of observing the 
arrival of the little cheerful songsters in the wilds of Oregon about the first week of May, where these birds commonly take up their summer residence, and seem almost the counterpart of our brilliant and cheerful Yellow Birds (Sylvia astiva), tuning their lay to the same brief and lively ditty, like ' $t s h$ ' $t s h$ ' $t s h$ tshea, or something similar; their call, however, is more brief and less loud. They were rather familiar and unsuspicious, kept in bushes more than trees, particularly in the thickets which bordered the Columbia, busily engaged collecting their insect fare, and only varying their employment by an occasional and earnest warble. By the $\mathrm{I} 2$ th of May they were already feeding their full-fledged young, though I also found a nest on the I 6th of the same month, containing 4 eggs, and just commencing incubation. The nest was in the branch of a small service bush, laid very adroitly as to concealment upon an accidental mass of old moss (Usnea) that had fallen from a tree above. It was made chiefly of ground moss (Hypnum), with a thick lining of dry, wiry, slender grass. The female, when approached, went off slyly, running along the ground like a mouse. The eggs are very similar to those of the summer Yellow Bird, sprinkled with spots of pale olive brown, inclined to be disposed in a ring at the greater end, as observed by $\mathrm{Mr}$. Audubon in a nest which he found in Labrador made in a dwarf fir, also made of moss and slender fir-twigs.

WiLson's BLACK CAP is a regular, though not common, summer resident of northern New England, breeding chiefly north of the United States. It is not uncommon in the Maritime Provinces, and fairly common as a migrant about Montreal, but is rarely seen in Ontario, though abundant in Ohio. 


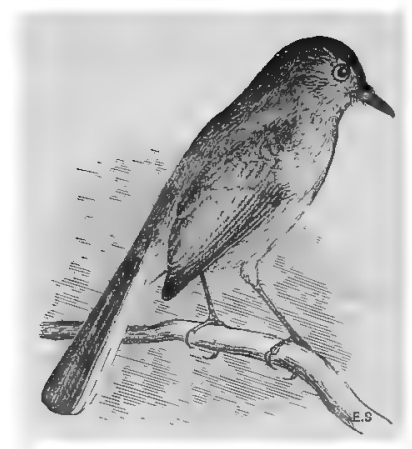

\section{BLUE-GRAY GNATCATCHER.}

POLIOPTILA CERULEA.

Char. Male : above, bluish gray, darker on head, paler on rump; forehead and line over the eye black; beneath, pale bluish white; wings dusky; tail longer than the body, the outer feathers partly white. Female: similar to the male, but lacking the black on head. Length $4 \frac{3}{2}$ to 5 inches.

Nest. A graceful, cup-shaped structure, saddled on limb of a tree I5 or 20 feet from the ground; composed of felted plant fibre ornamented externally with lichens and lined with feathers.

Eggs. 3-5; bluish white, speckled with bright brown; $0.55 \times 0.45$.

But for the length of the tail, this would rank among the most diminutive of birds. It is a very dexterous, lively insecthunter, and keeps commonly in the tops of tall trees; its motions are rapid and incessant, appearing always in quest of its prey, darting from bough to bough with hanging wings and elevated tail, uttering only at times a feeble song of tsee tsee tsee, scarcely louder than the squeak of a mouse. It arrives in the State of Pennsylvania from the South about the middle of April, and seldom passes to the north of the States of New York and Ohio, though others, following the course of the large rivers, penetrate into Kentucky, Indiana, and Arkansas. Its first visits are paid to the blooming willows along the borders of watercourses, and besides other small insects it now preys on the troublesome mosquitoes. About the beginning of May it forms its nest, which is usually fixed among twigs, at the height of Io, or sometimes even 50 , feet from the ground, near the summit 
of a forest tree. It is formed of slight materials, such as the scales of buds, stems and parts of fallen leaves, withered blossoms, fern down, and the silky fibres of various plants, lined with a few horsehairs, and coated externally with lichens. In this frail nest the Cow Troopial sometimes deposits her egg, and leaves her offspring to the care of these affectionate and pigmy nurses. In this case, as with the Cuckoo in the nest of the Yellow Wren and that of the Red-tailed Warbler, the egg is probably conveyed by the parent, and placed in this small and slender cradle, which would not be able to sustain the weight or receive the body of the intruder.

Though classed with the Flycatchers by Nuttall and other writers of his day, this species is now ranked as one of the highest types of the Oscines, or Singing Birds, and a sub-family has been made for this and the two Western forms. Mr. William Saunders finds the present species fairly common near London, Ontario, but it is only casual in Massachusetts, and is rarely seen north of latitude $42^{\circ}$. It winters in the Gulf States and southward. 


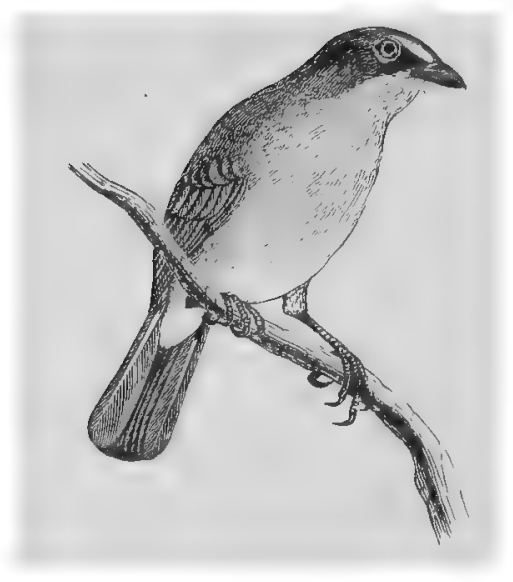

YELLOW-BREASTED CHAT.

ICTERIA VIRENS.

CHAR. Above, olive; lores black; throat and breast rich yellow; belly white. Length 7 to 8 inches.

Nest. In a thicket 2 or 3 feet from the ground; of dried leaves, strips of bark, or grass lined with fine grass or fibres.

Eggs. 3-4; white, with pink tint, spotted with brown and lilac; 0.90 $\times 0.70$.

This remarkable bird is another summer resident of the United States which passes the winter in tropical America, being found in Guiana and Brazil, so that its migrations probably extend indifferently into the milder regions of both hemispheres. Even the birds essentially tropical are still known to migrate to different distances on either side the equator, so essential and necessary is this wandering habit to almost all the feathered race.

The Icteria arrives in Pennsylvania about the first week in May, and does not usually appear to proceed farther north and east than the States of New York or Connecticut. To the west it is found in Kentucky, and ascends the Ohio to the borders of Lake Erie. In the distant interior, however, near the Rocky Mountains, towards the sources of the Arkansas, this bird was observed by Mr. Say, and Mr. Townsend saw it 
at Walla-Walla, on the Columbia, breeding in the month of June. It retires to the south about the middle of August, or as soon as the only brood it raises are fitted to undertake their distant journey.

The males, as in many other migrating birds, who are not continually paired, arrive several days before the females. As soon as our bird has chosen his retreat, which is commonly in some thorny or viny thicket where he can obtain concealment, he becomes jealous of his assumed rights and resents the least Intrusion, scolding all who approach in a variety of odd and uncouth tones very difficult to describe or imitate, except by a whistling, in which case the bird may be made to approach, but seldom within sight. His responses on such occasions are constant and rapid, expressive of anger and anxiety; and still unseen, his voice shifts from place to place amidst the thicket. Some of these notes resemble the whistling of the wings of a flying duck, at first loud and rapid, then sinking till they seem to end in single notes. A succession of other tones are now heard, some like the barking of young puppies, with a variety of hollow, guttural, uncommon sounds frequently repeated, and terminated occasionally by something like the mewing of a cat, but hoarser, - a tone to which all our Vireos, particularly the young, have frequent recurrence. All these notes are uttered with vehemence, and with such strange and various modulations as to appear near or distant, like the mancuvres of ventriloquism. In mild weather also, when the moon shines, this exuberant gabbling is heard nearly throughout the night, as if the performer was disputing with the echoes of his own voice.

Soon after their arrival, or about the middle of May, the Icterias begin to build, fixing the nest commonly in a bramblebush, in an interlaced thicket, a vine, or small cedar, 4 or 5 feet from the ground. The young are hatched in the short period of $\mathrm{I} 2$ days, and leave the nest about the second week in June. While the female is sitting, the cries of the male are still more loud and incessant. He now braves concealment, and at times mounts into the air almost perpendicularly $3^{\circ}$ 
or 40 feet, with his legs hanging down, and descending as he rose, by repeated jerks, he seems to be in a paroxysm of fear and anger. The usual mode of flying is not, however, different from that of other birds.

The food of the Icteria consists of beetles and other shelly insects; and as the summer advances, they feed on various kinds of berries, like the Flycatchers, and seem particularly fond of whortleberries. They are frequent through the Middle States, in hedges, thickets, and near rivulets and watery situations.

This Chat is now found regularly in Connecticut and northern Ohio, and sparingly in Massachusetts. A few examples have been taken in New Hampshire and southern Ontario.

\section{YELLOW-THROATED VIREO.}

\section{VIREO FLAVIFRONS.}

CHAR. Above, rich olive, shading to ashy gray on the rump; line acruss the forehead and around the eyes yellow; throat and breast rich yellow; belly white, sides shaded with pale olive; wings dusky with two white bars; tail dusky, the feathers edged with white. Length 5 to 6 inches.

Nest. In woods or orchard; suspended from fork of branch 5 to 30 feet from the ground (usually about Io feet); a graceful and compact structure of grass and strips of bark covered with lichens and lined with grass or pine needles.

Eggs. 3-5; white with roseate tint, thickly spotted around the large end with shades of brown; $0.80 \times 0.60$.

This species of Vireo, or Warbling Flycatcher, visits the Middle and Northern States of the Union about the beginning of May or as soon as his insect food allows him a means of subsistence. He resides chiefly in the forests, where he hunts his tiny prey among the high branches; and as he shifts from twig to twig in restless pursuit, he often relieves his toil with a somewhat sad and indolent note, which he repeats, with some variation, at short intervals. This song appears like 'preea 'preeá, etc., and it sometimes finishes with a complaining call 
of recognition, 'prréaigh 'prréaigh. These syllables rise and fall in different tones as they are repeated, but though usually sweet and impressive, are delivered too slow and solemn to be generally pleasing. In other respects they considerably resemble the song of the Red-Eyed Warbling Flycatcher, in whose company it is often heard, blending its deep but languid warble with the loud, energetic notes of the latter; and their united music, uttered during summer, even at noonday, is rendered peculiarly agreeable, as nearly all the songsters of the grove are now seeking a silent shelter from the sultry heat. In the warmest weather the lay of this bird is indeed peculiarly strong and lively; and his usually long-drawn, almost plaintive notes, are now delivered in fine succession, with a peculiar echoing and impressive musical cadence, appearing like a romantic and tender revery of delight. The song, now almost incessant, heard from this roving sylvan minstrel is varied in bars nearly as follows: preă preá preoi, preait preoit p' rrĭzeet preeai, pewai praiou, preeai preeō praoŭt, preeo prëăwit preeoo. When irritated, he utters a very loud and hoarse mewing praigh praigh. As soon, however, as the warm weather begins to decline, and the business of incubation is finished, about the beginning of August, this sad and slow but interesting musician nearly ceases his song, a few feeble farewell notes only being heard to the first week in September.

This species, like the rest of the genus, constructs a very beautiful pendulous nest about 3 inches deep and $2 \frac{\mathrm{T}}{2}$ in diameter. One, which I now more particularly describe, is suspended from the forked twig of an oak in the near neighborhood of a dwelling-house in the country. It is attached firmly all round the curving twigs by which it is supported; the stoutest external materials or skeleton of the fabric is formed of interlaced folds of thin strips of red cedar bark, connected very intimately by coarse threads and small masses of the silk of spiders' nests and of the cocoons of large moths. These threads are moistened by the glutinous saliva of the bird. Among these external materials are also blended fine blades of dry grass. The inside is thickly bedded with this 
last material and fine root-fibres; but the finishing layer, as if to preserve elasticity, is of rather coarse grass-stalks. Externally the nest is coated over with green lichen, attached very artfully by slender strings of caterpillars' silk, and the whole afterwards tied over by almost invisible threads of the same, so as to appear as if glued on; and the entire fabric now resembles an accidental knot of the tree grown over with moss.

The food of this species during the summer is insects, but towards autumn they and their young feed also on various small berries. About the middle of September the whole move off and leave the United States, probably to winter in tropical America.

Nuttall followed the older authors in naming the forest as the favorite haunt of this species. Later observers consider that it frequents orchards and fields quite as much as the woods, and it is reported as common in the gardens near Boston.

It occurs throughout the New England and Middle States as far west as Iowa, and in Manitoba, where it is common. It has not been found in the Maritime Provinces, but is common near Montreal and in Ontario.

\section{BLUE-HEADED VIREO.}

SOLITARY VIREO.

\section{VIREO SOLITARIUS.}

CHAR. Above, bright olive; line from nostril to and around the eyes whitish; crown and sicles of head bluish ash; beneath, white, sides and flanks shaded with olive and yellow; wings dusky with two bars of yellowish white; tail dusky, feathers edged with white. Length 5 to 6 juches.

Nest. Suspended from fork of branch of low tree or bush; composed of grass or vegetable fibre, ornamented with moss or lichens, lined with grass and plant down.

Eggs. Creamy white, spotted, in wreath around larger end, with bright brown; $0.80 \times 0.50$.

This is one of the rarest species of the genus, and from Georgia to Pennsylvania seems only as a straggler or accidental visitor. 
It possesses all the unsuspicious habits of the genus, allowing a near approach without alarm. It seldom rises beyond the tops of the canes or low bushes amidst which it is commonly seen hopping in quest of its subsistence, which consists of insects and berries. Its flight is generally tremulous and agitated. According to Dr. Bachman, "it is every year becoming more abundant in South Carolina, where it remains from about the middle of February to that of March, keeping to the woods. It has a sweet and loud song of half a dozen notes, heard at a considerable distance."

About the beginning of May, in the oaks already almost wholly in leaf, on the banks of the Columbia, we heard around us the plaintive deliberate warble of this species, first noticed by Wilson. Its song seems to be intermediate between that of the Red-eyed and Yellow-breasted species, having the preai, preai, etc., of the latter, and the fine variety of the former in its tones. It darted about in the tops of the trees, incessantly engaged in quest of food, now and then disputing with some rival. The nest of this bird is made much in the same manner as that of the Vireo olivaceus. One which I examined was suspended from the forked twig of the wild crab-tree, at about ten feet from the ground. The chief materials were dead and whitened grass leaves, with some cobwebs agglutinated together, externally scattered with a few shreds of moss. (Hypnum), to resemble the branch on which it was hung; here and there were also a few of the white paper-like capsules of the spider's nest, and it was lined with fine blades of grass and slender root-fibres. The situation, as usual, was open but shady.

This is a fairly common summer resident of northern New England, and it breeds sparingly south to the Middle States, and north to Hudson's Bay. It is a rare bird in the Maritime Provinces and in Quebec, though common in parts of Ontario.

Note. - The Mountain Solitary Vireo ( $V$. solitarius alticola), lately discovered by Mr. William Brewster in western . North Carolina, is described as "nearly uniform blackish plumbeous, with only a faint tinge of green on the back."

voL. r. -12 


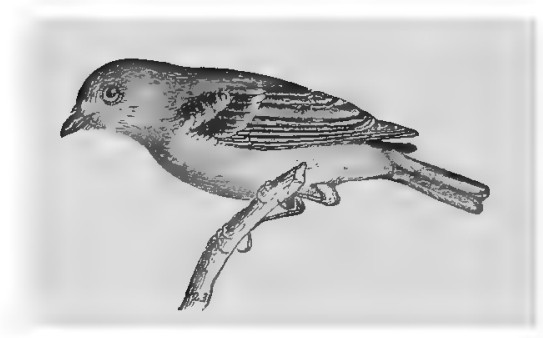

\section{WHITE-EYED VIREO.}

\section{VIREO NOVEBORACENSIS.}

CHAR. Above, olive, shading to ash on hind neck and rump; line from nostril to and around eyes, yellow; beneath, white, duller on throat and breast; sides shaded with yellow; wings and tail dusky; wing-bars yellow. Length about 5 inches.

Nest. Suspended from forked twig of low bush in a thicket, sometimes on edge of swamp; composed of various materials, - grass, twigs, etc., - ornamented with moss and lichens, and lined with grass, etc.

Eggs. 3-5; white, spotted around larger end with brown; $0.75 \times 0.55$.

This interesting little bird appears to be a constant resident within the limits of the United States; as, on the I 2 th of January, I saw them in great numbers near Charleston, S. C., feeding on the wax-myrtle berries, in company with the YellowRumped Sylvias. At this season they were silent, but very familiar, descending from the bushes when whistled too, and peeping cautiously, came down close to me, looking about with complacent curiosity, as if unconscious of any danger. In the last week of February, Wilson already heard them singing in the southern parts of Georgia, and throughout that month to March, I saw them in the swampy thickets nearly every day, so that they undoubtedly reside and pass the winter in the maritime parts of the Southern States. The arrival of this little unsuspicious warbler in Pennsylvania and New England is usually about the middle of April or earlier. On the I ath of March I first heard his voice in the low thickets of West Florida. His ditty was now simply $s s^{\prime} t$ (with a whistle) wá witte wrtte we-erá (the first part very quick). As late as in the first week in May I observed a few stragglers in this vicinity 
peeping through the bushes; and in the latter end of the month a pair had taken up their abode in the thickets of Fresh Pond, so that those which first arrive leave us and proceed farther to the north. On the $22 \mathrm{~d}$ of June I heard the male in full song, near his nest in our neighborhood, where incubation was going on. His warble was very pleasing, though somewhat monotonous and whimsical. This affectionate note, often repeated near to his faithful mate while confined to her nest, was like 'tshippewuee-wá-say, tshìppewee-wée-zus-say, sweetly whistled, and with a greater compass of voice and loudness than might have been expected from the size of the little vocalist. The song is sometimes changed two or three times in the course of twenty minutes; and I have heard the following phrases: 'att tshippewat'wurr, tshippewat'wurr; at another time, 'tshipeway 'tshe ŏ et 'tsherr. On another visit the little performer had changed his song to 'pip te waigh $\vec{a}$ tshewa, with a guttural trill, as usual, at the last syllable. He soon, however, varied his lay to 'whip te woz wee, the last syllable but one considerably lengthened and clearly whistled. Such were the captious variations of this little quaint. and peculiarly earnest musician, whose notes are probably almost continually varied. On the 6 th of October I still heard one of these wandering little minstrels, who at intervals had for several weeks visited the garden, probably in quest of berries. His short, quaint, and more guttural song was now atshĕe-vaŭt (probably the attempt of a young bird). As late as the 3 oth of October the White-Eyed Vireo still lingered around Cambridge, and on the margin of a pond, surrounded by weeds and willows, he was actively employed in gleaning up insects and their larvæ; and now, with a feebler tone of voice, warbled with uncommon sweetness wholly different from his usual strain, sounding something like the sweet whisperings of the Song Sparrow at the present season, and was perhaps an attempt at mimickry. Occasionally, also, he blended in his harsher, scolding, or querulous mewing call.

This species, like the rest, build commonly a pensile nest suspended by the upper edge of the two sides on the circular 
bend, often of the smilax or green briar vine. In the Middle States they often raise 2 broods in the season, generally make choice of thorny thickets for their nest, and show much concern when it is approached, descending within a few feet of the intruder, looking down and hoarsely mewing and scolding with great earnestness. This petulant display of irritability is also continued when the brood are approached, though as large and as active as their vigilant and vociferous parents. In the Middle States this is a common species, but in Massachusetts rather rare. Its food, like the rest of the Vireos, is insects and various kinds of berries, for the former of which it hunts with great agility, attention, and industry.

"Eastern United States, west to the Rockies, south in winter to Guatemala," is usually given as the habitat of this species. It has been seen rarely north of southern New England, and only one example has been taken in New Brunswick, though Mr: J. M. Jones considers it fairly common in portions of Nova Scotia. There is no authentic report of its occurrence in Ontario, but Mr. McIlwraith thinks it may yet be found there.

Note. - Mr. William Brewster has lately described the KeY WEST VIREo ( $V$. noveboracensis maynardi) as a larger bird than the type and of duller color, the yellow paler.

BELL's Vireo (Vireo bellii), a bird of much the same appearance and habits as the White-eyed, is found in the prairie districts of Illinois and Iowa. It ranges thence to the eastern base of the Rockies.

\section{WARBLING VIREO.}

VIREO GILVUS.

Char. Above, grayish olive brighter on the rump, shading to ashy on the head; beneath, buffy white, flanks and sides tinged with olive yellow. Length 5 to $5^{1 / 2}$ inches.

Nest. In open pasture or shaded street, suspended from fork of a high branch; composed of grass and vegetable fibre, and lined with fine grass.

Eggs. 3-4; white, spotted, chiefly about the larger end, with brown; $0.75 \times 0.55$. 
This sweetest and most constant warbler of the forest, extending his northern migrations to the confines of Canada and along the coast of the Pacific to the Oregon, arrives from tropical America in Pennsylvania about the middle of April, and reaches this part of New England early in May. His livery, like that of the Nightingale, is plain and unadorned; but the sweet melody of his voice, - surpassing, as far as Nature usually surpasses art, the tenderest airs of the flute, — poured out often from the rising dawn of day to the approach of evening, and vigorous even during the sultry heat of noon, when most other birds are still, gives additional interest to this little vocalist. While chanting forth his easy, flowing, tender airs, apparently without effort, so contrasted with the interrupted emphatical song of the Red-Eye, he is gliding along the thick and leafy branches of our majestic elms and tallest trees busied in quest of his restless insect prey. With us, as in Pennsylvania, the species is almost wholly confined to our villages, and even cities. It is rarely ever observed in the woods; but from the tall trees which decorate the streets and lanes, the almost invisible musician, secured from the enemies of the forest, is heard to cheer the house and cottage with his untiring song. As late as the $2 \mathrm{~d}$ of October I still distinguished his tuneful voice from amidst the yellow fading leaves of the linden, near which he had passed away the summer. The approaching dissolution of those delightful connections which had been cemented by affection and the cheerless stillness of autumn, still called up a feeble and plaintive revery. Some days after this late period, warmed by the mild rays of the morning sun, I heard, as it were, faintly warbled, a parting whisper; and about the middle of this month our vocal woods and fields were once more left in dreary silence.

When offended or irritated, our bird utters an angry 'tshay 'tshay, like the Catbird and the other Vireos, and sometimes makes a loud snapping with his bill. The nest of the Warbling Vireo is generally pendulous, and ambitiously and securely suspended at great elevations. In our elms I have seen one of these airy cradles at the very summit of one of the most gigan- 
tic, more than 100 feet from the ground. At other times they are not more than 50 to 70 feet high. The only nest $I$ have been able to examine was made externally of flat and dry sedge-grass blades, for which, as I have observed, are occasionally substituted strings of bass. These dry blades and strips are confined and tied into the usual circular form by caterpillars' silk, blended with bits of wool, silk-weed lint, and an accidental and sparing mixture of vernal grass tops and old apple-blossoms. It was then very neatly lined with the small flat blades of the meadow grass called Poa compressa.

This species is rather uncommon in the Maritime Provinces excepting near the Maine border in New Brunswick, and in the more southern portions of Nova Scotia. It is fairly common in southern Quebec, and abundant in Ontario. In the New England and Middle States it is an abundant summer resident. At the West it ranges north to the fur countries.

\section{RED-EYED VIREO.}

VIREO OLIVACEOU'S.

CHar. Above, bright olive, crown ashy ; beneath, white faintly tinged with dull olive on sides; wings and tail dusky. Length $5^{1 / 2}$ to $61 / 2$ inches.

Nest. In an open pasture or along margin of field; suspended from fork of an upper branch; composed of grass and vegetable fibre, and lined with fine grass, etc.

Eggs. 3-5; white (sometimes with a faint pink tint) spotted sparingly, around larger end, with dull brown; $0.80 \times 0.55$.

These common and indefatigable songsters appear to inhabit every part of the American continent, from Labrador to the large tropical islands of Jamaica and St. Domingo; they are likewise resident in the mild tableland of Mexico. Those individuals who pass the summer with us, however, migrate to the warmer regions at the commencement of winter, as none are found at that season within the limits of the United States. The Red-Eyed Vireo arrives in Pennsylvania late in April, and in New England about the beginning of May. It inhabits the 
shady forests or tall trees near gardens and the suburbs of villages, where its loud, lively, and energetic song is often continued, with little intermission, for several hours at a time, as it darts and pries among the thick foliage in quest of insects and small caterpillars. From its first arrival until August it is the most distinguished warbler of the forest, and when almost all the other birds have become mute, its notes are yet heard with unabated vigor. Even to the $5^{\text {th }}$ of October, still enlivened by the feeble rays of the sun, the male faintly recalls his song, and plaintively tunes a farewell to his native woods. His summer notes are uttered in short, emphatical bars of 2 or 3 syllables, and have something in them like the simple lay of the Thrush or American Robin when he first earnestly and slowly commences his song. He often makes use, in fact, of the same expressions; but his tones are more monotonous as well as mellow and melodious, like the rest of the Vireos. In moist and dark summer weather his voice seems to be one continued, untiring warble of exquisite sweetness; and in the most populous and noisy streets of Boston his shrill and tender lay is commonly heard from the tall elms; and as the bustle of carts and carriages attempts to drown his voice, he elevates his pipe with more vigor and earnestness, as if determined to be heard in spite of every discord. The call of "Whip-Tomkelly," attributed to this species by Sloane and even Wilson, I have never heard; and common as the species is throughout the Union, the most lively or accidental fit of imagination never yet in this country conceived of such an association of sounds. I have already remarked, indeed, that this singular call is, in fact, sometimes uttered by the Tufted Titmouse. When our Vireo sings slow enough to be distinctly heard, the following sweetly warbled phrases, variously transposed and tuned, may often be caught by the attentive listener: 'tshoŏe perveе peeaì müsik 'du 'dü 'du, 'tshoŏve 'hëre 'hëre, hear hère, 'k'ing 'ritshard, 'p'shĕgru 'tshevŭ, 'tsheevoo 'tshürve peeaīt 'pèroì, - the whole delivered almost without any sensible interval, with earnest animation, in a pathetic, tender, and pleasing strain, well calculated to produce calm and thoughtful reflection in 
the sensitive mind. Yet while this heavenly revery strikes on the human ear with such peculiar effect, the humble musician himself seems but little concerned; for all the while, perhaps, that this flowing chorus enchants the hearer, he is casually hopping from spray to spray in quest of his active or crawling prey, and if a cessation occurs in his almost untiring lay, it is occasioned by the caterpillar or fly he has just fortunately captured. So unaffected are these delightful efforts of instinct, and so unconscious is the performer, apparently, of this pleasing faculty bestowed upon him by Nature, that he may truly be considered as a messenger of harmony to man alone. Wantonly to destroy these delightful aids to sentimental happiness ought therefore to be viewed, not only as an act of barbarity, but almost as a sacrilege.

The Red-Eyed Vireo is one of the most favorite of all the adopted nurses of the Cowbird; and the remarkable gentleness of its disposition and watchful affection for the safety of its young, or of the foundling confided to its care, amply justifies this selection of a foster-parent. The male, indeed, defends his nest while his mate is sitting, with as much spirit as the King Bird, driving away every intruder and complaining in a hoarse mewing tone when approached by any inquisitive observer. By accident the eggs were destroyed in a nest of this species in the Botanic Garden, in a sugar-maple about 20 feet from the ground. At this time no complaints were heard, and the male sang all day as cheerful as before. In a few days, unwilling to leave the neighborhood, they had made a second nest in a beech at the opposite side of the same premises; but now the male drove away every intruder with the greatest temerity. The young of this species are often hatched in about I 3 days, or 24 hours later than the parasitic Troopial; but for want of room the smaller young are usually stifled or neglected. I have, however, seen in one nest a surviving bird of each kind in a fair way for being reared; yet by a singular infatuation the supposititious bird appeared by far the most assiduously attended, and in this case the real young of the species seemed to be treated as puny foundlings. 
In the month of August the young fed greedily on the small berries of the bitter cornel and astringent Viburnum dentatum, as well as other kinds. One of these inexperienced birds hopped close round me in an adjoining bush, without any fearful apprehension; and as late as the 26th of October two young. birds of the Red-Eye were still lingering in this vicinity, and busily engaged in gleaning subsistence. Eager after flies, about the $25^{\text {th }}$ of August a young bird with hazel instead of red eyes entered a chamber in the neighborhood and became my inmate. I clipped his wing and left him at large in a room; he soon became very gentle, took grasshoppers and flics out of my hand, eat Viburnum berries with a good appetite, and in short seemed pleased with his quarters. A fly could not stir but it was instantly caught; his only difficulty was with a lame King Bird who occupied the same apartment. The King appeared very jealous of this little harmless companion; snapped his bill at him when he approached, and begrudged him subsistence when he perceived that he fed on the same food with himself. At length he would come to me for provision and for protection from his tyrannical associate. But the career of my interesting and lively companion was soon terminated by death, occasioned, in all probability, by a diarrhœa produced in consequence of swallowing a small lock of hair with his food, which was found in his stomach. This bird, very different from a Sylvia autumnalis which I afterwards had in my possession, regurgitated by the bill, like the King Bird, pellets of the indigestible parts of his food, such as the legs and wings of grasshoppers and flies, and the skins and seers of berries. Unlike the King Bird in one particular, however, he folded his head under his wing when at rest, and reposed with great soundness; whereas for eight months I was never able to detect the former asleep. 


\section{PHILADELPHIA VIREO.}

\section{VIREO PHILADELPHICUS.}

CHAR. Above, grayish olive, brighter on rump, shading to ashy on crown; beneath, very pale yellow, whiter on throat and belly; sides shaded with olive. Length about $43 / 4$ inches.

Nest. In a grove ; suspended from forked twigs of low branch; composed of grass and birch bark.

Eggs. 4-2; white, spotted with brown; - ?

This species was first described by $\mathrm{Mr}$. Cassin, in $185 \mathrm{I}$, from a specimen shot by him near Philadelphia in 1842. The bird's habits remain almost unknown. The only nest yet discovered was found by Mr. Ernest E. Thompson in Manitoba.

Of the bird's range very little is known. A few examples have been taken in New England, and in I 882 our party secured several at Edmundston, in New Brunswick, near the Quebec border. Dr. Wheaton considered it a regular spring and fall migrant through Ohio, but very few have been observed in Ontario.

Note. - Mr. Comeau has taken at Godbout, on the north shore of the Gulf of St. Lawrence, one example of the YeLLOW-GREEN VIreo ( $V$. favovirides), a bird of Mexico and Central America. 


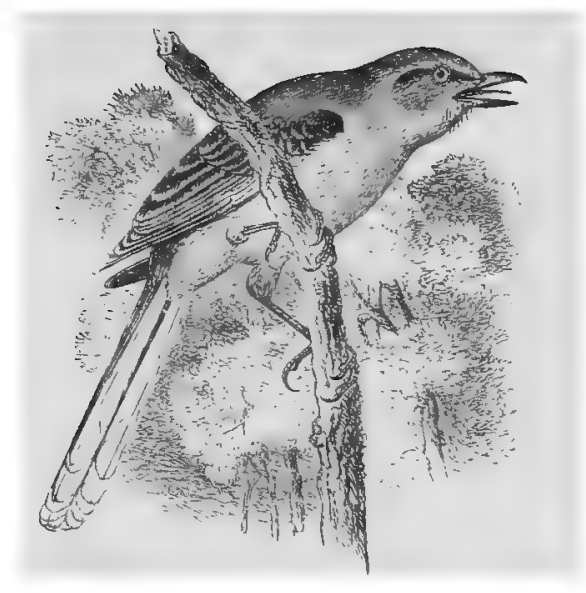

MOCKING BIRD.

Mimus polyglottus.

ChAR. Above, ashy gray, darker on wings and tail; wings with two white bars; outer tail-feathers white; beneath, white, tinged with gray on the breast; bill and feet black. Length 9 to I I inches.

Nest. In a thicket or bunch of low bushes; composed of twigs, roots, grass, etc.

Eggs. 4-6; greenish blue to pale buff, marked with reddish brown; $0.95 \times 0.70$.

This unrivalled Orpheus of the forest and natural wonder of America inhabits the whole continent, from the State of Rhode Island to the larger isles of the West Indies; and continuing through the equatorial regions, is found in the southern hemisphere as far as Brazil. Nor is it at all confined to the Eastern or Atlantic States. It also exists in the wild territory of Arkansas more than a thousand miles from the mouth of Red River; and I have since seen it in the scanty forests of Upper California. It breeds at the distant western sources of the Platte, near the base of the Rocky Mountains, as well as in Texas; and Mr. Bullock saw it in the table-land of Mexico. The Mocking Bird rears its young, and consequently displays its wonderful powers, in all the intermediate regions of its residence in the United States to the peninsula of Florida. It appears, in short, permanently to inhabit the milder regions of 
the western world in either hemisphere; and the individuals bred north of the Delaware, on this side the equator, are all that ever migrate from their summer residence. A still more partial migration takes place also, probably, from west to east, in quest of the food and shelter which the maritime districts afford. Though now so uncommon in that vicinity, 50 or 60 years ago, according to Bartram, it even wintered near Philadelphia, and made a temporary abode in the mantling ivy of his venerable mansion. In summer a few proceed as far as Rhode Island, following the mild temperature of the sea-coast; but farther north these birds are, I believe, nearly unknown, except rarely and occasionally in Massachusetts near the sea. With the advance of the season, also, in the country which it inhabits, varies the time of incubation. Early in April the nests are begun in the maritime parts of Georgia, but not before the middle of May in Pennsylvania.

In the winter these birds chiefly subsist on berries, particularly those of the Virginia juniper (called red cedar), waxmyrtle, holly, smilax, sumach, sour-gum, and a variety of others, which furnish them and many other birds with a plentiful repast. Insects, worms, grasshoppers, and larvæ are the food on which they principally subsist when so eminently vocal and engaged in the task of rearing their young. In the Southern States, where they are seldom molested, with ready sagacity they seem to court the society of man and fearlessly hop around the roof of the house or fly before the planter's door. When a dwelling is first settled in the wilderness, this bird is not seen sometimes in the vicinity for the first year; but at length he pays his welcome visit to the new-comer, gratified with the little advantages he discovers around him, and seeking out also the favor and fortuitous protection of human society. He becomes henceforth familiar, and only quarrels with the cat and dog, whose approach he instinctively dreads near his nest, and never ceases his complaints and attacks until they retreat from his sight.

None of the domestic animals, or man himself, but particularly the cat and dog, can approach during the period of incubation, without receiving an attack from these affectionate 
guardians of their brood. Their most insidious and deadly enemies, however, are reptiles, particularly the black snake, who spares neither the eggs nor young. As soon as his fatal approach is discovered by the male, he darts upon him without hesitation, eludes his bite, and striking him about the head, and particularly the eyes, where most vulnerable, he soon succeeds in causing him to retreat, and by redoubling his blows, in spite of all pretended fascination, the wily monster often falls a victim to his temerity; and the heroic bird, leaving his enemy dead on the field he provoked, mounts on the bush above his affectionate mate and brood, and in token of victory celebrates with his loudest song.

The Mocking Bird, like the Nightingale, is destitute of brilliant plumage ; but his form is beautiful, delicate, and symmetrical in its proportions. His motions are easy, rapid, and graceful, perpetually animated with a playful caprice and a look that appears full of shrewdness and intelligence. $\mathrm{He}$ listens with silent attention to each passing sound, treasures up lessons from everything vocal, and is capable of imitating with exactness, both in measure and accent, the notes of all the feathered race. And however wild and discordant the tones and calls may be, he contrives, with an Orphean talent peculiarly his own, to infuse into them that sweetness of expression and harmonious modulation which characterize this inimitable and wonderful composer. With the dawn of morning, while yet the sun lingers below the blushing horizon, our sublime songster, in his native wilds, mounted on the topmost branch of a tall bush or tree in the forest, pours out his admirable song, which, amidst the multitude of notes from all the warbling host, still rises pre-eminent, so that his solo is heard alone, and all the rest of the musical choir appear employed in mere accompaniments to this grand actor in the sublime opera of Nature. Nor is his talent confined to imitation; his native notes are also bold, full, and perpetually varied, consisting of short expressions of a few variable syllables, interspersed with imitations and uttered with great emphasis and volubility, sometimes for half an hour at a time, with undiminished ardor. These native strains bear a considerable resemblance to those 
of the Brown Thrush, to whom he is so nearly related in form, habits, and manners; but, like rude from cultivated genius, his notes are distinguished by the rapidity of their delivery, their variety, sweetness, and energy. As if conscious of his unrivalled powers of song, and animated by the harmony of his own voice, his music is, as it were, accompanied by chromatic dancing and expressive gestures; he spreads and closes his light and fanning wings, expands his silvered tail, and with buoyant gayety and enthusiastic ecstasy he sweeps around, and mounts and descends into the air from his lofty spray as his song swells to loudness or dies away in sinking whispers. While thus engaged, so various is his talent that it might be supposed a trial of skill from all the assembled birds of the country; and so perfect are his imitations that even the sportsman is at times deceived, and sent in quest of birds that have no existence around him. The feathered tribes themselves are decoyed by the fancied call of their mates, or dive with fear into the close thicket at the well-feigned scream of the Hawk.

Soon reconciled to the usurping fancy of man, the Mocking Bird often becomes familiar with his master; playfully attacks him through the bars of his cage, or at large in a room; restless and capricious, he seems to try every expedient of a lively imagination that may conduce to his amusement. Nothing escapes his discerning and intelligent eye or faithful ear. $\mathrm{He}$ whistles perhaps for the dog, who, deceived, runs to meet his master; the cries of the chicken in distress bring out the clucking mother to the protection of her brood. The barking of the dog, the piteous wailing of the puppy, the mewing of the cat, the action of a saw, or the creaking of a wheelbarrow, quickly follow with exactness. He repeats a tune of considerable length; imitates the warbling of the Canary, the lisping of the Indigo Bird, and the mellow whistle of the Cardinal, in a manner so superior to the originals that, mortified and astonished, they withdraw from his presence, or listen in silence as he continues to triumph by renewing his efforts.

In the cage also, nearly as in the woods, he is full of life and action while engaged in song, throwing himself round with in- 
spiring animation, and, as it were, moving in time to the melody of his own accents. Even the hours of night, which consign nearly all other birds to rest and silence, like the Nightingale he oft employs in song, serenading the houseless hunter and silent cottager to repose, as the rising moon illumines the darkness of the shadowy scene. His capricious fondness for contrast and perpetual variety appears to deteriorate his powers. His imitations of the Brown Thrush are perhaps interrupted by the crowing of the cock or the barking of the dog; the plaintive warblings of the Bluebird are then blended with the chatter of the Swallow or the cackling of the hen; amid the simple lay of the native Robin we are surprised with the vociferations of the Whip-poor-will; while the notes of the garrulous Jay, Wren, and many others succeed with such an appearance of reality that we almost imagine ourselves in the presence of the originals, and can scarcely realize the fact that the whole of this singular concert is the effort of a single bird. Indeed, it is impossible to listen to these Orphean strains, when delivered by a superior songster in his native woods, without being deeply affected and almost riveted to the spot 'by the complicated feelings of wonder and delight in which, from the graceful and sympathetic action, as well as enchanting voice of the performer, the eye is no less gratified than the ear. It is, however, painful to reflect that these extraordinary powers of nature, exercised with so much generous freedom in a state of confinement, are not calculated for long endurance, and after this most wonderful and interesting prisoner has survived for 6 or 7 years, blindness often terminates his gay career; and thus shut out from the cheering light, the solace of his lonely but active existence, he now after a time droops in silent sadness and dies.

The Mocking Bird is a rare but regular summer visitor to Rhode Island, Connecticut, and southern Massachusetts, and examples have been taken in Maine. Mr. McIlwraith reports that a pair spent the summer of 1883 near Hamilton, Ontario, and C. A. McLennan records in the O. \& O. the capture of one near Truro, N. S. The species is chiefly restricted to the Southern States. 


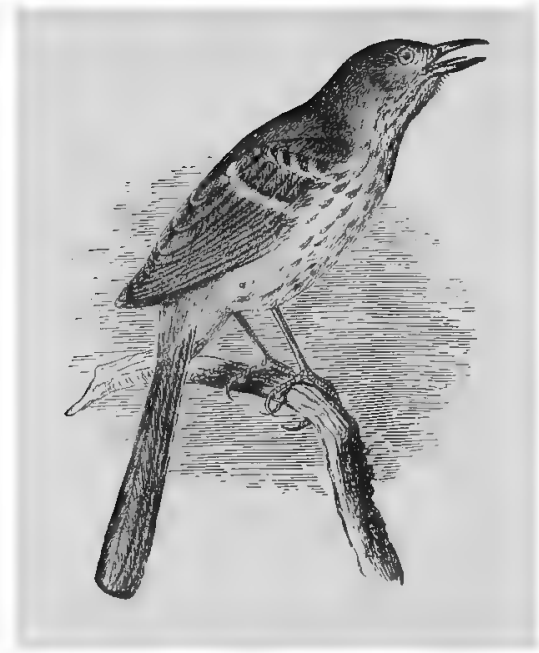

\section{BROWN THRASHER.}

BROWN THRUSH.

\section{HARPORHYNCHUS RUFUS.}

CHAR. Above, bright reddish brown or rufous; beneath, white, tinged with rufous or buff; breast and side spotted with brown; bill about as long as the head. Length $10 \% \frac{1}{2}$ to $I 2$ inches.

Nest. In a thicket or low bush, and sometimes on the ground; bulky, and loosely constructed of twigs, roots, and dried grass, sometimes lined with horse-hair or feathers.

Eggs. 3-6 (usually 4); cluli white with buff or green tint, marked with minute spots of reddish brown; $1.00 \times 0.80$.

This large and well-known songster, inferior to none but the Mocking Bird in musical talent, is found in every part of this continent, from Hudson's Bay to the shores of the Mexican Gulf, breeding in all the intermediate space, though more abundantly towards the North. It retires to the South early in October, in the States north of the Carolinas, and probably extends its migrations at this season through the warmer regions towards the borders of the tropics.

From the $\mathrm{r}_{5}$ th of April to early in May these birds begin to revisit the Middle and Northern States, keeping pace in some measure with the progress of vegetation and the comparative 
advancement of the season. They appear always to come in pairs, so that their mutual attachment is probably more durable than the season of incubation. Stationed on the top of some tall orchard or forest tree, the male, gay and animated, salutes the morn of his arrival with his loud and charming song. His voice, somewhat resembling that of the Thrush of Europe, but far more varied and powerful, rises pre-eminent amidst all the vocal choir of the forest. His music has the full charm of innate originality; he takes no delight in mimickry, and has therefore no title to the name of Mocking Bird. On his first appearance he falters in his song, like the Nightingale; but when his mate commences her cares and labors, his notes attain all their vigor and variety. The young birds, even of the first season, in a state of solitary domestication, without the aid of the parent's voice, already whisper forth in harmonious revery the pathetic and sweet warble instinctive to the species. In the month of May, while the blooming orchards perfume and decorate the landscape, the enchanting voice of the Thrasher in his affectionate lay seems to give grateful utterance for the bounty and teeming profusion of Nature, and falls in pleasing unison with the harmony and beauty of the season.

From the beginning to the middle of May the Thrashers are engaged in building their nest, selecting for this purpose usually a low, thick bush, in some retired thicket or swamp a few feet from the earth, and sometimes even on the ground in some sheltered tussuck, or near the root of a bush. They display the most ardent affection for their young, attacking snakes, dogs, and cats in their defence. One of the parents, usually the male, seems almost continually occupied in guarding against any dangerous intruder. The cat is attacked commonly at a considerable distance from the young, and the woods echo with his plaintive $y \dot{e}-\bar{o} w, y \dot{k}-\bar{o} w$, and the low, guttural, angry 'tsh 'tsh 'tsh 'tsh. The enemy is thus pursued off the field, commonly with success, as guilty grimalkin appears to understand the threatening gestures and complaints with which she is so incessantly assailed. Towards their more vOL. I. $-\mathrm{I} 3$ 
insidious enemies of the human species, when approaching the helpless or unfledged young, every art is displayed; threats, entreaties, and reproaches the most pathetic and powerful, are tried in no equivocal strain; they dart at the ravisher in wild despair, and lament, in the most touching strains of sorrow, the bereavement they suffer. I know of nothing equal to the burst of grief manifested by these affectionate parents excepting the afflicting accents of suffering humanity.

Their food consists of worms and insects generally; also caterpillars, beetles, and other coleopterous tribes, as well as various kinds of berries. In the month of January I observed this Thrush and the Mocking Bird feed on the berries of the sumach. Sometimes they raise up a few grains of planted corn, but this is more the effect of caprice than appetite, as the search for grubworms is what commonly induces this resort to scratching up the soil. The Thrasher is an active, watchful, shy, and vigorous species, generally flying low, dwelling among thickets, and skipping from bush to bush with his long tail sometimes spread out like a fan. About the first week in October, after moulting, they disappear for the season and pass the winter in the Southern States. By the middle of February, or early in March, they already display their vocal powers in the warmer parts of Georgia and West Florida. They are easily reared, and become very familiar and amusing companions, showing a strong attachment to the hand that feeds and protects them. In their manners, intelligence, song, and sagacity, they nearly approach to the Mocking Bird, being equally playful, capricious, petulant, and affectionate.

The Thrasher is abundant in Massachusetts, and is found in Vermont and New Hampshire, but near the Atlantic seaboard does not go farther north than southern Maine. It occurs regularly in the vicinity of Montreal, and is common in Ontario and Manitoba. It winters from about $37^{\circ}$ south ward. 


\section{CATBIRD.}

\section{Galeoscoptes Carolinensis.}

CHAR. General color dark slate, paler beneath ; top of head and tail black; under tail-coverts che:tnut. Length 8 to $9 \frac{1}{4}$ inches.

Nest. In thicket or orchard; bulky, and rudely constructed of twigs, leaves, and grass, lined with grass or fine roots.

Eggs. 4-6; deep bluish green; $0.95 \times 0.70$.

This quaint and familiar songster passes the winter in the southern extremities of the United States and along the coast of Mexico, whence as early as February it arrives in Georgia. About the middle of April it is first seen in Pennsylvania, and at length leisurely approaches this part of New England by the close of the first or beginning of the second week in May. These birds continue their migration also to Canada, where they proceed into the fur-countries as far as the $45^{\text {th }}$ parallel, arriving on the banks of the Saskatchewan about the close of May. Throughout this extent and to the territory of the Mississippi they likewise pass the period of incubation and rearing their young. They remain in New England till about the middle of October, at which time the young feed principally upon wild berries.

The Catbird often tunes his cheerful song before the break of day, hopping from bush to bush with great agility after his insect prey, while yet scarcely distinguishable amidst the dusky shadows of the dawn. The notes of different individuals vary considerably, so that sometimes his song in sweetness and compass is scarcely at all inferior to that of the Ferruginous Thrush. A quaintness, however, prevails in all his efforts, and his song is frequently made up of short and blended imitations of other birds, - given, however, with great emphasis, melody, and variety of tone, and, like the Nightingale, invading the hours of repose. In the late twilight of a summer's evening, when scarce another note is heard but the hum of the drowsy beetle, his music attains its full effect, and often rises and falls with all the swell and stidied cadence of finished harmony. 
During the heat of the day, or late in the morning, the variety of his song declines, or he pursues his employment in silence and retirement.

About the $25^{\text {th }}$ of May one of these familiar birds came into the Botanic Garden and took up his summer abode with us. Soon after his arrival he called up in low whisperings the notes of the Whip-poor-will, the Redbird, the peto peto of the Tufted Titmouse, and other imitations of Southern birds which he had collected on his leisurely route from the South. He also soon

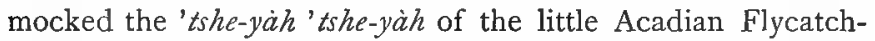
ers, with which the neighborhood now abounded. He frequently answered to my whistle in the garden, was very silent during the period of incubation, and expressed great anxiety and complaint on my approaching the young after their leaving the nest.

One of the most remarkable propensities of the Catbird, and to which it owes its name, is the unpleasant, loud, and grating cat-like meze ('pāy, 'pāy, 'pāy) which it often utters on being approached or offended. As the irritation increases, this note becomes more hoarse, reiterated, and vehement; and sometimes this petulance and anger are carried so far as to persecute every intruder who approaches the premises. This temper often prevails after the young are fledged; and though originating no doubt in parental anxiety, it sometimes appears to outlive that season, and occasionally becomes such an annoyance that a revengeful and fatal blow from a stick or stone. is but too often, with the thoughtless and prejudiced, the reward of this harmless and capricious provocation. At such times, with little apparent cause, the agitation of the bird is excessive; she hurries backward and forward with hanging wings and open mouth, mewing and screaming in a paroxysm of scolding anger, and alighting almost to peck the very hand that offers the insult. To touch a twig or branch in any part of the garden or wood is often amply sufficient to call down the amusing termagant. This harmless excess, and simulation of grimalkin's tone, - that wizard animal so much disliked by many, - are unfortunate associations in the cry of the Catbird; 
and thus, coupled with an ill name, this delightful and familiar songster, who seeks out the very society of man and reposes an unmerited confidence in his protection, is treated with undeserved obloquy and contempt. The flight of the Catbird is laborious, and usually continued only from bush to bush; his progress, however, is very wily, and his attitudes and jerks amusingly capricious. He appears to have very little fear of enemies, often descends to the ground in quest of insects, and though almost familiar, is very quick in his retreat from real danger.

The food of the Catbird is similar to that of the preceding " species, being insects and worms, particularly beetles, and various garden fruits; feeding his young often on cherries and various kinds of berries. Sometimes these birds are observed to attack snakes when they approach the vicinity of the nest, and commonly succeed in driving off the enemy; when bitten, however, by the poisonous kinds, it is probable, as related, that they may act in such a manner as to appear laboring under the influence of fascination. The Catbird, when raised from the nest, is easily domesticated, becomes a very amusing inmate, and seems attached to his cage, as to a dwelling or place of security. About dawn of day, if at large, he flirts about with affected wildness, repeatedly jerks his tail and wings with the noise almost of a whip, and stretching forth his head, opens his mouth and mews. Sometimes this curious cry is so guttural as to be uttered without opening the bill. $\mathrm{He}$ often also gives a squeal as he flies from one place to another, and is very tame, though pugnacious to all other birds which approach him for injury. When wanting food, he stirs round with great uneasiness, jerks everything about within his reach, and utters the feeble cry of the caged Mocking Bird. A very amusing individual, which I now describe, began his vocal powers by imitating the sweet and low warble of the Song Sparrow, as given in the autumn; and from his love of imitation on other occasions, I am inclined to believe that he possesses no original note of his own, but acquires and modulates the songs of other birds. Like the Robin, he is exceedingly 
fond of washing, and dashes about in the water till every feather appears drenched; he also, at times, basks in the gravel in fine weather. His food, in confinement, is almost everything vegetable except unbruised seeds, - as bread, fine pastry, cakes, scalded cornmeal, fruits, particularly those which are juicy, and now and then insects and minced flesh.

The Catbird occurs. regularly along the Annapolis valley in Nova Scotia, and in New Brunswick between the Maine border and the valley of the St. John, but it is rarely seen elsewhere in the Maritime Provinces. It is fairly common near the city of Quebec, and abundant about Montreal and in Ontario.

\section{ROBIN.}

\section{Merula migratoria.}

Char. Above, olive gray; head and neck darker, sometimes black; wings and tail dusky; outer tail-feathers broadly tipped with white; beneath, brownish red; throat white with clark streaks; under tail-coverts white; bill yellow. Length 9 to ro inches.

Nest. Usually in a tree, but often on fence-rail or window-ledge of house or barn; a bulky but compact structure of grass, twigs, etc., cemented with mud.

$E_{\text {strs }}$ s. 4-5; greenish blue (occasionally speckled); I.I $5 \times 0.80$.

The familiar and welcome Robins are found in summer throughout the North American continent from the desolate regions of Hudson's Bay, in the 53d degree, to the tableland of Mexico. In all this vast space the American Fieldfares rear their young, avoiding only the warmer maritime districts, to which, however, they flock for support during the inclemency of winter. The Robins have no fixed time for migration, nor any particular rendezvous; they retire from the higher latitudes only as their food begins to fail, and so leisurely and desultory are their movements that they make their appearance in straggling parties even in Massachusetts, feeding on winter berries till driven to the South by deep and inundating snows. At this season they swarm in the Southern States, though they never move in large bodies. The holly, prinos, 
sumach, smilax, candle-berry myrtle, and the Virginian juniper now afford them an ample repast in the winter, in the absence of the more juicy berries of autumn, and the insects and worms of the milder season. Even in the vicinity of Boston flocks of Robins are seen, in certain seasons, assembling round open springs in the depth of winter, having arrived probably from the colder interior of the State ; and in those situations they are consequently often trapped and killed in great numbers.

Towards the close of January in South Carolina the Robin at intervals still tuned his song; and about the second week of March, in the Middle States, before the snows of winter have wholly disappeared, a few desultory notes are already given. As soon as the Ioth of this month they may at times also be heard in this part of New England. Early in April, however, at the close of the jealous contests, which are waged with obstinacy, they are only seen in pairs; and now from the orchard or the edge of the forest, deliver their simple, thrilling lays in all the artless energy of true affection. This earnest song recalls to mind the mellow whistle of the Thrush, which in the charming month of May so sweetly rises in warbling echoes from the low copse and shady glen. Our American bird has not, however, the compass and variety of that familiar and much-loved songster; but his freedom and willingness to please, render him an universal favorite, and he now comes, as it were, with the welcome prelude to the general concert about to burst upon us from all the green woods and blooming orchards. With this pleasing association with the opening season, amidst the fragrance of flowers and the improving verdure of the fields, we listen with peculiar pleasure to the simple song of the Robin. The confidence he reposes in us by making his abode in our gardens and orchards, the frankness and innocence of his manners, besides his vocal powers to please, inspire respect and attachment even in the truant school-boy, and his exposed nest is but rarely molested. $\mathrm{He}$ owes, however, this immunity in no small degree to the fortunate name which he bears; as the favorite Robin Redbreast, said to have covered with a leafy shroud the lost and wander- 
ing " babes in the woods," is held in universal respect in every part of Europe, where he is known by endearing names, and so familiar in winter that he sometimes taps at the window or enters the house in search of crumbs, and like the domestic fowls, claims his welcome pittance at the farmer's door.

The nest of this species is often on the horizontal branch of an apple-tree, or in a bush or tree in the woods, and so large as to be scarcely ever wholly concealed. The parents show great affection, courage, and anxiety for the safety of their young, keeping up a noisy cackling chirp when the place is approached, sometimes even boldly pecking at the hand or flying in the face of the intruder; and they have often serious contests with the piratical Cuckoo, who slyly watches the absence of the parents to devour their eggs. To avoid these visits and the attacks of other enemies, the Robin has been known to build his nest within a few yards of the blacksmith's anvil; and in Portsmouth (New Hampshire) one was seen to employ for the same purpose the stern timbers of an unfinished vessel, in which the carpenters were constantly at work, the bird appearing by this adventurous association as if conscious of the protection of so singular and bold a situation. I have also seen a nest of the Robin bottomed with a mass of pine shavings taken without alarm from the bench of the carpenter. From the petulant and reiterated chirp so commonly uttered by the Robin when surprised or irritated, the Indians of Hudson's Bay call him, from this note, Pee-pee-tshu. They often also utter a loud echoing ' $k h$ ' $k h$ ' $k h$, and sometimes chirp in a high or slender tone when alarmed, and with an affectation of anger sharply flirt the tail and ends of the wings. They raise several broods in a season, and considerable numbers flock together in the latter end of summer and autumn. When feeding on cherries, poke, sassafras, and sour-gum berries, they are so intent as to be easily approached and shot down in numbers; and when fat are justly esteemed for food and often brought to market. In the spring they frequently descend to the ground in quest of worms and insects, which then constitute their principal support. 
They are commonly brought up in the cage, and seem very docile and content. They sing well, readily learn to imitate lively parts of tunes, and some have been taught to pipe forth psalms even to so dull and solemn a measure as that of "Old" Hundred" ! They acquire also a considerable taste for mimickry, imitating the notes of most of the birds around them, such as the Bluebird, Pewee, Whip-poor-will, and others. On being approached with the finger, they usually make some show of anger by cracking and snapping the bill. At times they become very tame, and will go in and out of the house with domestic confidence, feel uneasy when left alone, and on such occasions have sometimes the sagacity of calling attention by articulating endearing words, as pretty, pretty, etc., connecting, apparently with these expressions, their general import of attentive blandishment. They become almost naked in the moulting season, in which they appear to suffer considerably, yet have been known to survive for $\mathbf{I} 7$ years or upwards. The rufous color of the breast becomes deeper in those birds which thus live in confinement. Their principal song is in the morning, and commences before sunrise, at which time it is very loud, full, and emphatic.

The eastern form of this species is not found westward of the Great Plains excepting in the far North, where it has been traced to the Yukon district of Alaska. From the eastern base of the Rockies to the Pacific it is replaced by propinqua, a larger, grayer variety.

I have seen large flocks of Robins in New Brunswick during some winters, and every year they are more or less common during the cold months. These winter birds have much more white on their under parts than is seen on specimens taken in the summer, and their entire plumage is hoary. They doubtless spend the summer much farther north, - probably on the barren lands which border the Arctic Ocean, -- and are but the northernmost edge of that cloud of Robins which every autumn rises from their breedinggrounds and sails away southward until, when it has finally settled, its eastern margin is found stretched from the Gulf of St. Lawrence to the West Indies. Throughout this range, embracing as it does many variations of climate, Robins may be found in suitable localities during every winter, - rather rare, sometimes, at the north, but increasing in abundance towards the South. 
The habit of this species of assembling in large communities to roost at night, during the summer months, was unknown to naturalists until a few years ago, and no mention of this habit appeared in print until October, I890, when detailed accounts of several "roosts" that had been discovered in the vicinity of Boston were published in the "Atlantic Monthly" and "The Auk." They were written by Mr. Bradford Torrey and Mr. William Brewster respectively. The "roosts" are situated in Norton's Woods, on Beaver Brook, Belmont, in Longwood, and in Melrose.

The Robins assembling in these places are numbered by thousands.

Note. - A few examples of the VARIED THRUSH (Hesperocichla ncevia) have wandered from the Pacific coast to the Eastern States; and the RED-WINGED THRUSH (Turdus iliacus) occasionally wanders from Europe to Greenland.

\section{WOOD THRUSH.}

\section{TURDUS MUSTELINUS.}

Char. Above, tawny, brightest on head, shading to olive on rump and tail ; beneath, white; breast and sides spotted with dusky. Length $7 \frac{1}{2}$ to $8 \frac{1}{4}$ inches.

Nest. In a thicket or on low branch of small tree, usually in a moist place; of grass and leaves cemented with mud, lined with fine roots.

Eggs. 3-5; greenish blue; 1.05 $\times 0.75$.

This solitary and retiring songster during summer inhabits the whole continent from Hudson's Bay to Florida; and according to my friend Mr. Ware, breeds as far south as the vicinity of Natchez, in the territory of Mississippi. Whether it leaves the boundaries of the United States in the winter is not satisfactorily ascertained; as the species is then silent, and always difficult of access, its residence is rendered peculiarly doubtful. The lateness of the season in which it still lingers renders it probable that it may winter in the Southern States, as a young bird, gleaning insects and berries, has been caught in a garden in Boston on the 26 th of October.

From the southern parts of the Union, or wherever he may winter, the Wood Thrush arrives in the Middle States from the 
Ist to the I 5 th of April; though his appearance here, where the species is scarce, does not take place earlier than the beginning of May. At the dawn of morning he now announces his presence in the woods, and from the top of some tall tree, rising through the dark and shady forest, he pours out his few, clear, and harmonious notes in a pleasing revery, as if inspired by the enthusiasm of renovated Nature. The prelude to this song resembles almost the double tonguing of the flute, blended with a tinkling, shrill, and solemn warble which re-echoes from his solitary retreat like the dirge of some sad recluse who shuns the busy haunts of life. The whole air consists usually of 4 parts or bars, which succeed, in deliberate time, and finally blend together in impressive and soothing harmony, becoming more mellow and sweet at every repetition. Rival performers seem to challenge each other from various parts of the wood, vying for the favor of their mates with sympathetic responses and softer tones; and some, waging a jealous strife, terminate the warm dispute by an appeal to combat and violence. Like the Robin and the Thrasher, in dark and gloomy weather, when other birds are sheltered and silent, the clear notes of the Wood Thrush are heard through the dropping woods from dawn to dusk, so that the sadder the day, the sweeter and more constant is his song. His clear and interrupted whistle is likewise often nearly the only voice of melody heard by the traveller, to mid-day, in the heat of summer, as he traverses the silent, dark, and wooded wilderness, remote from the haunts of men. It is nearly impossible by words to convey any idea of the peculiar warble of this vocal hermit; but amongst his phrases the sound of 'airöee, peculiarly liquid, and followed by a trill repeated in two interrupted bars, is readily recognizable. At times the notes bear a considerable resemblance to those of Wilson's Thrush; such as eh rhehu 'vrhehu, then varied to 'eh villia villia, 'eh villia vrhehu, then 'eh velu villiu, high and shrill.

The Wood Thrush is always of a shy and retiring disposition, appearing alone or only in single pairs, and while he willingly charms us with his song, he is content and even soli- 
citous to remain concealed. His favorite haunts are low, shady glens by watercourses, often rendered dark with alder-bushes, mantled with the trailing grape-vine. In quest of his insect prey, he delights to follow the meanders of the rivulet, through whose leafy shades the sunbeams steal only in a few interrupted rays over the sparkling surface of the running brook. So partial is this bird to solitude that I have known one to sing almost uniformly in the same place, though nearly half a mile from his mate and nest. At times indeed he would venture a few faltering, low notes in an oak near his consort, but his mellowest morning and evening warble was always delivered from a tall hickory, overtopping a grove of hemlock firs, in which the dimness of twilight prevailed even at noon. The Wood Thrush, like the Nightingale, therefore feels inspired in darkness; but instead of waiting for the setting sun, he chooses a retreat where the beams of day can seldom "enter. These shady retreats have also an additional attraction to our Thrush; it is here that the most interesting scene of his instinctive labor begins and ends; here he first saw the light and breathed into existence; and here he now bestows his nest in a sapling oak, or in the next thick laurel or blooming alder, whose berries afford him ample repast in the coming autumn. Beetles, caterpillars, various insects, and in autumn, berries, constitute the principal food of the Wood Thrush. The young remain for weeks around gardens in quest of berries, and are particularly fond of those of the various species of cornel and viburnum. At this season they occasionally leave their favorite glens, and in their devious wanderings, previous to their departure, sometimes venture to visit the rural suburbs of the city. The young are easily raised, and sing nearly as well in the cage as in their native wilds.

Nuttall made a mistake in giving to the Wood Thrush so extended a range, and must have confused this species with the Olive-backed, of which he makes no mention. The Wood Thrush has not been seen farther north than Massachusetts, soutbern Ontario, and southern Michigan. It nests southward to Georgia and westward to eastern Kansas, and winters south to Guatemala and Cuba. 


\title{
HERMIT THRUSH.
}

\author{
SWAMP ROBIN.
}

\section{TURDUS AONALASCHKE PALLASII.}

Char. Above, olive, shading to rufous on rump and tail; beneath white or buffish, shaded with olive on sides; throat and breast spotted with dark olive. Length $6 \frac{1}{2}$ to $7^{1 / 2}$ inches.

Nest. On the ground, loosely made of leaves, grass, and moss.

$E_{\text {Sg }}$ s. 3-5; greenish blue; $0.85 \times 0.65$.

This species, so much like the Nightingale in color, is scarce inferior to that celebrated bird in its powers of song, and greatly exceeds the Wood Thrush in the melody and sweetness of its lay. It inhabits the United States from the lofty alpine mountains of New Hampshire to Florida. It is also met with on the tableland of Mexico and in the warmer climate of the Antilles. In Pennsylvania, New Jersey, and New England, at the close of autumn, it appears to migrate eastward to the seacoast in quest of the winter berries on which it now feeds; in spring and summer it lives chiefly on insects and their larvæ, and also collects the surviving berries of the Mitchella repens.

Like the preceding species, it appears to court solitude, and lives wholly in the woods. In the Southern States, where it inhabits the whole year, it frequents the dark and desolate shades of the cane swamps. In these almost Stygian regions, which, besides being cool, abound probably with its favorite insect food, we are nearly sure to meet our sweetly vocal hermit flitting through the settled gloom, which the brightest rays of noon scarcely illumine with more than twilight. In one of such swamps, in the Choctaw nation, Wilson examined a nest of this species which was fixed on the horizontal branch of a tree, formed with great neatness and without using any plastering of mud. The outside was made of a layer of coarse grass, having the roots attached, and intermixed with horsehair; the lining consisted of green filiform blades of dry grass very neatly wound about the interior.

In the Middle States these birds are only seen for a few 
weeks in the spring and fall. They arrive in this part of New England about the roth of April, and disperse to pass the summer in the seclusion of the forest. They are often seen on the ground in quest of their food, and frequent low and thick copses, into which they commonly fly for concealment when too attentively observed; though when in small companies, in the spring season, they do not appear very shy, but restless from the unsettled state of their circumstances. When dispersed, they utter a low, chirping call, and for some time continue to frequent the same secluded part of the forest in society. At times, like the Wagtail, they keep this part of their body in a slow, vertical motion. In manners they strongly resemble the following species, but their song seems to be unusually lively and varied.

The Hermit is a common bird in the Maritime Provinces and Quebec, and nests from about latitude $44^{\circ}$ northward. It is common on Anticosti and along the north shore of the Gulf of St. Lawrence, and has been taken at Lake Mistassini. In Ontario it occurs chiefly as a migrant, though breeding in the Muskoka district. In New England also it is principally known as a migrant, breeding in numbers only along the northern border and on the higher hills of Connecticut and Massachusetts. The nest has been taken in Ohio and in southern Michigan.

The opinions expressed by Nuttall that the Hermit Thrush is a peculiarly shy and solitary bird, and that its favorite resorts are amid the deep forests, are, I think, somewhat misleading; at least my observations in New Brunswick led me to form quite different opinions. I did find these birds courting retirement and apparently destitute of either vanity or curiosity; but they always displayed a calm self-possession that is inconsistent with shyness. Nor were they peculiarly solitary, for though it was unusual to see a number of them in close companionship, it was not unusual to meet with half a dozen in as many minutes, or to find as many nests within a small area.

Like all woodland birds, they prefer the groves to the open fields, and they enjoy a cool shade in a moist valley; but they build their nests near the settlements, and rarely go into the denser forests. This is their habit in New Brunswick, though of course when farther north they must resort to the timber districts; there are few settlements to attract them. 


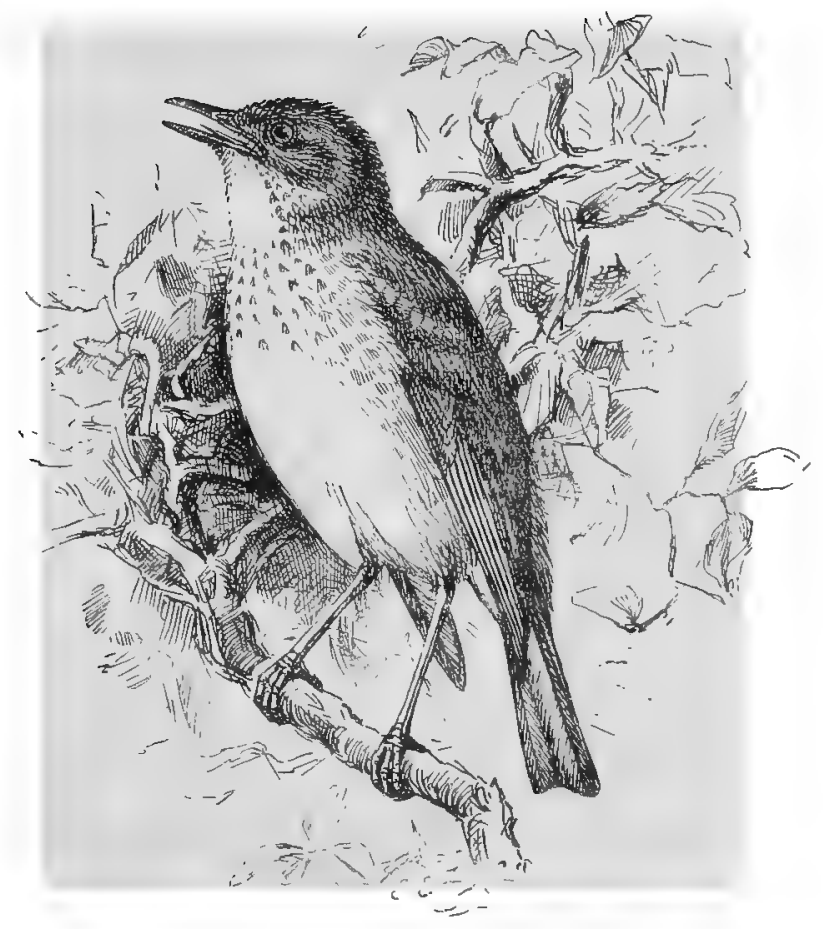

\section{WILSON'S THRUSH.}

\section{TAWNY THRUSH. VEERY.}

\section{TURDUS FUSCESCENS.}

Char. Above, light tawny or rufous; beneath, white, shaded with creamy buff on breast, and with olive on sides; breast spotted with tawny. Length $6 \frac{1}{2}$ to $7 \frac{3}{4}$ inches.

Nest. On the ground or near it, usually at the base of small tree or in tuft of old grass ; of leaves and grass, lined with fine roots.

Eggs. 3-5; pale greenish blue; $0.85 \times 0.65$.

This common Northern species arrives in Pennsylvania and New England about the beginning of May, and its northern range extends as far as Labrador. It appears to retire to the South early in October, and is more decidedly insectivorous than any other native species. According to Wilson, many of 
these birds winter in the myrtle-swamps of South Carolina. I have not, however, seen them in the Southern States at that season, and most part of the species pass on probably as far as the coast of the Mexican Gulf. They do not, according to Wilson, breed in the lower parts of Pennsylvania, though undoubtedly they do in the mountainous districts, where they are seen as late as the 2 oth of May. They propagate and are very common in Massachusetts.

In its retiring habits and love of concealment this Thrush resembles the preceding. It frequents the dark and shady borders of small brooks and woods, and sometimes the bushy and retired parts of the garden; from whence, without being often seen, in the morning and particularly the evening to the very approach of night, we often hear the singular, quaint, and musical note of this querulous species at short intervals, as one perches upon some low branch of a tree or bush. This curious whistling note sounds like 'vehu 'v'rehu 'v'rehu 'v'rehu, and sometimes 'veă veă 'vrehă 'vrehă vehu, running up the notes till they become shrill and quick at the close, in the first phrase, but from high to low, and terminating slender and slow, in the latter; another expression seems to be, 've 'veá vehurr, ascending like a whistle. The song of another individual was expressed in the following manner: 've'villill' 'villill 'tullüll'tullül. It was then repeated with variation, 've villillil villill villill; then villillill villillill, tullilill tullilill; the whole agreeably and singularly delivered in a shrill, hollow voice, almost like the sound of liquor passing through a tunnel into a bottle. I have also heard several of these sounds, sometimes occasionally prefaced by a mewing or chirping warble. These sounds, though monotonous, are possessed of greater variety than is at first imagined, the terminating tone or key changing through several repetitions, so as to constitute a harmony and melody in some degree approaching the song of the more musical Wood Thrush. From this habit of serenading into the night, the species is sometimes here dignified with the nickname of the Nightingale. Occasionally he utters an angry, rather plaintive mew, like the Catbird, or a quivering bleat 
almost similar to that of a lamb; and when approached, watches and follows the intruder with an angry or petulant queàh queàh; at other times a sort of mewing, melancholy, or complaining y'eow ' $y$ 'eow is heard, and then, perhaps, a hasty and impatient péŭt péŭt follows. The food of this species, at least during the early part of summer, appears to be shelly insects of various kinds, particularly Chrysomelas, or lady-bugs, and those many legged hard worms of the genus Iulus.

A good while after the commencement of the period of incubation $I$ have observed the males engaged in obstinate quarrels. On the $4^{\text {th }}$ of June, I830, I observed two of these petulant Thrushes thus fiercely and jealously contending; one of them used a plaintive and angry tone as he chased his antagonist up and down the tree. At length, however, a cousin Catbird, to which this species has some affinity, stepped in betwixt the combatants, and they soon parted. One of these birds had a nest and mate in the gooseberry bush of a neighboring garden; the second bird was thus a dissatisfied hermit, and spent many weeks in the Botanic Garden, where, though at times sad and solitary, yet he constantly amused us with his forlorn song, and seemed at last, as it were, acquainted with those who whistled for him, peeping out of the bushes with a sort of complaisant curiosity, and from his almost nocturnal habits became a great persecutor of the assassin Owl whenever he dared to make his appearance.

The nest of Wilson's Thrush (commenced about the close of the first week in May) is usually in a low and thorny bush in the darkest part of the forest, at no great distance from the ground ( $I$ to 3 feet), sometimes indeed on the earth, but raised by a bed of leaves, and greatly resembles that of the Catbird. This species seems, indeed, for security artfully to depend on the resemblance of itself and its leafy nest with the bosom of the forest on which it rests, and when approached it sits so close as nearly to admit of being taken up by the hand. The nest sometimes appears without any shelter but shade and association of colors with the place on which it rests. I have seen one placed on a mass of prostrated dead brambles, on a VOL. I. -14 
fallen heap of lilac twigs in a ravine, and also in a small withered branch of red oak which had fallen into a bush; below it was also bedded with exactly similar leaves, so as easily to deceive the eye. But with all these precautions they appear to lose many eggs and young by squirrels and other animals. The nest is usually bottomed with dry oak or beech leaves, coarse stalks of grass and weeds, and lined very generally with naturally dissected foliage, its stalks, some fine grass, and at other times a mixture of root-fibres; but no earth is employed in the fabric. The eggs, 4 or 5 , are of an emerald green without spots, and differ from those of the Catbird only in being a little smaller and more inclined to blue. So shy is the species that though $\mathrm{I}$ feigned a violent chirping near the nest containing their young, which brought Sparrows and a neighboring Baltimore to the rescue, the parents, peeping at a distance, did not venture to approach or even express any marked concern, though they prove very watchful guardians when their brood are fledged and with them in the woods. They have commonly two broods in the season; the second being raised about the middle of July, after which their musical notes are but seldom heard. I afterwards by an accident obtained a young fledged bird, which retained in the cage the unsocial and silent timidity peculiar to the species.

Wilson's Thrush breeds farther to the southward than the Hermit, but does not range quite so far north. It is common in the Maritime Provinces and near the city of Quebec, but has not been taken recently on the north shore of the Gulf of St. Lawrence. It breeds abundantly in Ontario and in northern Ohio.

In New Brunswick I have found the nest as frequently in an open pasture as in more obscure places. 


\section{OLIVE-BACKED THRUSH.}

\section{TuRdus USTUlatus SWAINSONII.}

Char. Above, olive; beneath, white, shaded with olive on the sides ; sides of head, neck, and breast tinged with buff; throat and breast spotted with olive; yellowish ring around the eye. Length $6 \frac{1}{2}$ to $7^{1 / 2}$ inches.

Nest. In a low tree or bush ; of twigs, leaves, grass, etc.

Eggs. 3-4; greenish blue speckled with brown; $0.90 \times 0.65$.

This species was omitted by Nuttall, though given by Wilson. It bas much the same range and similar habits as the Hermit, though differing in its song and the location of its nest. The tone of its voice is richer and rounder - more flute-like and less metallic than that of any other of the small Thrushes; but the song lacks that spiritual quality so conspicuous in the hymn-like melody of the Hermit.

The Olive-backed is found throughout the temperate region of eastern North America, and westward to the eastern base of the Rockies. It breeds in northern New England and northward, and in the elevated portions of Massachusetts and Connecticut, as well as in northern New York and Michigan, and winters in the Gulf States and southward to Panama.

It is common in the Maritime Provinces, but is reported rather rare between Montreal and Lake Huron, though it being an abundant migrant through Ohio, I should expect to find it plentiful in portions of Ontario.

\section{GRAY-CHEEKED THRUSH.}

\section{ALICE'S THRUSH.}

\section{TURDUS ALICLE.}

CHAR. Above, olive; cheeks grayish; beneath, white; sides tinged with olive; throat ancl breast tinged with buff and marked with large dark spots. Length 7 to $73 / 4$ inches.

Nest. In a low bush or on the ground; of grass and leaves, etc., lined with fine grass.

Eggs. 3-4; greenish blue spotted with brown; $0.90 \times 0.70$.

After much contention as to the validity of Alice's Thrush as a variety of the Olive-backed, the systematists have decided to give it 
specific rank. In appearance it differs from swainsonii chiefly in lacking the yellow around the eye, and in having gray instead of buff cheeks. Alicice is also a trifle the larger of the two.

The distribution of the present species has not yet been thoroughly worked out, for only a few years have passed since its discovery; but it is known to occur in the United States and the settled portions of Canada as a migrant only, breeding north to the Arctic, and wintering south to Costa Rica.

\section{BI C K N ELL'S THRUS'H.}

\section{TURDUS ALICIÆ BICKNELLI.}

CHAR. Above, olive, varying from a grayish to a russet tint; wings and tail slightly browner than back; distinct ring of pale buff around the eyes; cheeks buffish; beneath, white, tinged with olive on the sides; throat and breast tinged with buff and marked with large dark spots. Length 7 to $7 \frac{1}{2}$ inches.

Nest. On the ground, in a thicket; composed of twigs, grass, and moss, lined with grass.

Eggs. 3-4; pale blueish green speckled with brown; $0.85 \times 0.65$.

This variety of the Gray-cheeked Thrush was discovered by Mr. Eugene P. Bicknell amid the Catskill Mountains in I885. It has been found on all the higher ranges of Eastern America and in Illinois, and Mr. Langille claims to have discovered the nest on an island off the southern coast of Nova Scotia.

\section{WATER THRUSH. \\ WATER WAGTAIL. \\ SEIURUS NOVEBORACENSIS.}

Char. Above, deep olive brown; line over the eye whitish; beneath, white tinged with bright yellow, and spotted with olive. Length $5^{1 / 2}$ to 6 inches.

Nest. On the ground, in border of swamp or stream; bulky, and loosely made of moss, leaves, and grass, lined with roots. Sometimes deeply imbedded in moss, or covered with it.

Eggs. 4-6; white, spotted, most heavily near the larger end, with brown and lilac; $0.75 \times 0.55$. 
This shy and retiring sylvan species extends its summer migrations throughout the United States, breeding rarely in Pennsylvania, proceeding principally to the western and northern regions at the period of incubation. Mr. Townsend and myself observed this bird in Oregon, as well as in Missouri, where it was, no doubt, breeding, and sung in a very lively manner, keeping in a shady wood which bordered a small stream, often descending to the ground after aquatic insects or larvæ, and with the tail in a constant balancing motion, remincling us strongly of the Wagtail or Motacilla of Europe.

The Aquatic Thrush has, indeed, a particular partiality for the vicinity of waters, wading in the shallow streams in search of insects, moving its tail as it leisurely follows its pursuit, and chattering as it flies. During its transient migrating visits it is very timid, and darts into the thickets as soon as approached, uttering a sharp and rather plaintive tship' of alarm. About the beginning of May, these birds appear in Pennsylvania from the South, and stay around dark and solitary streams for ten or twelve days, and then disappear until about the middle of August, when, on their way to their tropical winter quarters, they leave the swamps and mountains of their summer retreat, and, after again gleaning a transient subsistence for a few days towards the sea-coast, depart for the season. In Massachusetts they are scarcely ever seen except in the autumn, and continue in shady gardens, probably feeding on small wild berries till nearly the close of September.

It appears, according to Wilson, that the favorite resort of this species is in the cane-brakes, swamps, river shores, and watery solitudes of Louisiana, Tennessee, and Mississippi. Here it is abundant, and is eminently distinguished by the loudness, sweetness, and expressive vivacity of its notes, which, beginning high and clear, flow and descend in a cadence so delicate as to terminate in sounds that are scarcely audible. At such times the singer sits perched on some branch which stretches impending over the flowing stream, and pours out his charming melody with such effect as to be heard at the distance of nearly half a mile, giving a peculiar charm to the dark 
and solitary wilds he inhabits. The silence of night is also, at times, relieved by the incessant warble of this Western Philomel, whose voice, breaking upon the ear of the lonely traveller in the wilderness, seems like the dulcet lay of something supernatural. His song is also heard in the winter when the weather proves mild. In this habit he appears considerably allied to the Reed Thrush or River Nightingale of Europe, which night and day almost ceaselessly sings, and soothes his sitting mate, among the reeds and marshes of his favorite resorts.

Since Nuttall's day the Water Thrush has been separated from the true Thrushes and classed with the Warblers. The birds seen by Wilson and Audubon in Louisiana, Tennessee, and Mississippi were doubtless referable to motacilla, for though the present species is found throughout this Eastern Province, west to Illinois and Manitoba, it seldom has been discovered breeding south of $45^{\circ}$. It is a rather common spring and autumn visitor to Massachusetts.

On the plains the type is replaced by the variety named notabilis, - Grinvell's Water Thrush, - which is larger and darker. Notabilis occurs occasionally in Illinois and Indiana.

\section{LOUISIANA WATER THRUSH.}

\section{SEIURUS MOTACILIA.}

ChaR. Similar to noveboracensis, but larger, and bill longer and stouter. Under parts tinged with buff, but never with bright yellow; throat free from spots. Length $53 / 4$ to $6 \mathrm{~J} / 2$ inches.

$N_{e s t}$. On the ground, hidden amid roots of fallen tree, or on a mossy bank; composed of leaves, grass, and moss, lined with grass and hair.

Eggs. 4-6; white, sometimes with creamy tint, speckled with brown and lilac; $0.75 \times 060$.

The range of this species extends from southern New England and the Great Lakes (in summer) to the Gulf States and Central America (in winter). A few pairs are seen every season in southern Ontario. Its habits do not differ from those of its congener. 


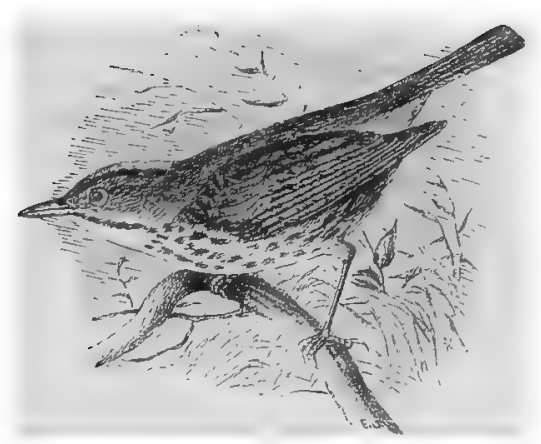

OVEN BIRD.

GOLDEN-CROWNED THRUSH.

\section{SEIURUS AUROCAPILLUS.}

Char. Above, olive; crown orange-brown, bordered with black stripes, white ring around the eyes; beneath, white, spotted with olive. Length $5 \frac{1}{2}$ to $61 / 2$ inches.

Nest. On the ground, at the foot of a tree or in the moss on a decayed $\log$; rather loosely made of twigs, grass, leaves, and moss, lined with fine grass and hair. The top is often completely roofed, sometimes arched or domed; the entrance on the side.

Eggs, 4-6; creamy white, spotted with brown and lilac; $0.80 \times 0.55$.

This rather common bird, so nearly allied to the true Thrushes, is found throughout the forests of the United States, Canada, and in the territory of Oregon during the summer, arriving in the Middle and Northern States about the beginning of May or close of April, and departing for tropical America, Mexico, and the larger West India islands early in September.

The Golden-crowned Thrush, shy and retiring, is never seen out of the shade of the woods, and sits and runs along the ground often like the Lark; it also frequents the branches of trees, and sometimes moves its tail in the manner of the Wagtails. It has few pretensions to song, and while perched in the deep and shady part of the forest, it utters, at intervals, a simple, long, reiterated note of 'tsh'e tshe tshe tshe tshe, rising from low to high and shrill, so as to give but little idea of the distance or place from whence the sound proceeds, and often appearing, from the loudness of the closing cadence, to be much 
nearer than it really is. As soon as discovered, like the Wood Thrush, it darts at once timidly into the depths of its sylvan retreat. During the period of incubation, the deliberate lay of the male, from some horizontal branch of the forest tree, where it often sits usually still, is a 'tshe te tshe tĕ tshe tĕ tshee, gradually rising and growing louder. Towards dusk in the evening, however, it now and then utters a sudden burst of notes with a short, agreeable warble, which terminates commonly in the usual 'tshe te tshe. Its curious oven-shaped nest is known to all the sportsmen who traverse the solitary wilds which it inhabits. This ingenious fabric is sunk a little into the ground, and generally situated on some dry and mossy bank contiguous to bushes, or on an uncleared surface ; it is formed, with great neatness, of dry blades of grass, and lined with the same; it is then surmounted by a thick inclined roof of similar materials, the surface scattered with leaves and twigs so as to match the rest of the ground, and an entrance is left at the side. Near Milton hills, in this vicinity, the situation chosen was among low whortleberry bushes, in a stunted cedar and oak grove. When surprised, the bird escapes, or runs from the nest with the silence and celerity of a mouse. If an attempt be made to discover the nest from which she is flushed, she stops, flutters, and pretends lameness, and watching the success of the manœuvre, at length, when the decoy seems complete, she takes to wing and disappears. The Oven Bird is another of the foster-parents sometimes chosen by the Cow Troopial; and she rears the foundling with her accustomed care and affection, and keeps up an incessant tship when her unfledged brood are even distantly approached. These birds have often two broods in a season in the Middle States. Their food is wholly insects and their larvæ, particularly small coleopterous kinds and ants, chiefly collected on the ground.

The Oven Bird, like the Water Thrush, has been removed by modern authorities from classification with the Thrush family and placed with the Warblers. It is now known to breed from Virginia and the Ohio valley to Labrador and Hudson Bay. It is abundant in Massachusetts and the Maritime Provinces, and common over its entire range. 


\section{MYRTLE WARBLER.}

YELLOW-RUMP WARBLER. YELLOW-CROWNED WARBLER.

Dendrotca coronata.

CHAR. Male: above, bluish gray streaked with black; sides of head black; breast and sides mostly black; patches of yellow on crown and rump and sides of breast; throat and belly white; wing-bars and patches on tail white. Female, young, and male in winter: similar, but the back with a tint of brown in place of blue, and all colors duller, and markings less distinct. Length 5 to 6 inches.

Nest. In a coniferous tree 5 to 10 feet from the ground, in a pasture or open grove of woodland; composed of twigs and grass, lined with fine grass, sometimes with feathers.

Egrss. 4-5; dull white or creamy white, spotted chiefly around the larger end with brown and lilac; $0.70 \times 0.50$.

The history of this rather common Warbler remains very imperfect. In the Middle and Northern States it is a bird of passage, arriving from the South about the close of April or beginning of May, and proceeding north as far as Canada and Labrador to pass the summer season in the cares of breeding and rearing the young. As early as the 3 oth of August, or after an absence of little more than three months, these birds again appear; and being hardy, passing parties continue with us in gardens and woods till about the close of November, feeding now almost exclusively on the myrtle-wax berries (Myrica cerifera), or on those of the Virginian juniper. These, other late and persisting berries, and occasional insects, constitute their winter food in the Southern States, where, in considerable numbers, in the swamps and sheltered groves of the sea-coast, they pass the cold season. In fine weather, in the early part of October, they may be seen, at times, collecting grasshoppers and moths from the meadows and pastures, and, like the Blue Bird, they often watch for the appearance of their prey from a neighboring stake, low bough, or fence-rail; and at this time are so familiar and unsuspicious, particularly the young, as fearlessly to approach almost within the reach of the silent spectator. At 
the period of migration, they appear in an altered and less brilliant dress. The bright yellow spot on the crown is now edged with brownish olive, so that the prevailing color of this beautiful mark is only seen on shedding the feathers with the hand; a brownish tint is also added to the whole plumage. But Wilson's figure of this supposed autumnal change only represents the young bird. The old is, in fact, but little less brilliant than in summer, and I have a well-founded suspicion that the wearing of the edges of the feathers, or some other secondary cause, alone produces this change in the livery of spring, particularly as it is not any sexual distinction.

While feeding they are very active, in the manner of Flycatchers, hovering among the cedars and myrtles with hanging wings, and only rest when satisfied with gleaning food. In spring they are still more timid, busy, and restless. According to Audubon, the nest and eggs are scarcely to be distinguished from those of Sylvia astiva; one which he examined from Nova Scotia was made in the extremity of the branch of a low fir-tree, about five feet from the ground. When approached, or while feeding, they only utter a feeble, plaintive tship of alarm. This beautiful species arrives here about the $7^{\text {th }}$ or 8 th of May, and now chiefly frequents the orchards, uttering at short intervals, in the morning, a sweet and varied, rather plaintive warble, resembling in part the song of the Summer Yellow Bird, but much more the farewell, solitary autumnal notes of the Robin Redbreast of Europe. The tones at times are also so ventriloquial and variable in elevation that it is not always easy to ascertain the spot whence they proceed. While thus engaged in quest of small caterpillars, the Myrtle seems almost insensible to obtrusion, and familiarly searches for its prey, however near we may approach.

The "Yellow-rump" - by which name this species is best known - breeds regularly in Vermont and New Hampshire, and northward to southern Labrador. It is an abundant summer resident of the Maritime Provinces, but elsewhere, in the settled portions of Canada, occurs as a migrant only. It winters regularly in Massachusetts and central Ohio, and thence southward as far as Central America. 


\section{YELLOW PALM WARBLER. \\ YELLOW RED-POLL WARBLER, \\ DENDROICA PALMARUM HYPOCHRYSEA.}

C'HAR. Above, brownish olive; rump yellowish, dusky streaks on the back; crown chestnut; line over eye and under parts rich yellow; breast and sides streaked with brown; no white wing bars; square patches of white on two pairs of outer tail-teathers. Length 5 to $5 \frac{3}{4}$ inches.

Nest. On the ground on border of swamp; loosely made of grass, weeds, and moss fastened with caterpillar's silk, lined with roots, hair, pine-needles, or feathers.

Eggs. 4-5; creamy white, sometimes with roseate tinge, marked on larger end with fine spots of brown and lilac; $0.65 \times 0.50$.

The Yellow Red-polls in small numbers arrive in the Middle and Northern States in the month of April ; many proceed as far as Labrador, where they were seen in summer by Audubon, and in the month of August the young were generally fledged. In the Southern States they are abundant in winter. While here, like many other transient passengers of the family, they appear extremely busy in quest of their restless insect prey. They frequent low, swampy thickets, are rare, and their few feeble notes are said scarcely to deserve the name of a song. These stragglers remain all summer in Pennsylvania, but the nest is unknown. They depart in September or early in October, and some probably winter in the southernmost States, as they were met with in February, by Wilson, near Savannah. This is a different species from the Palm Warbler, which probably does not exist in the United States.

This bird appears yet to be very little known. Pennant has most strangely blended up its description with that of the Ruby-crowned Wren! his supposed female being precisely that bird.

The Eastern form of the Palm Warbler is a common bird from the Atlantic to the Mississippi valley, where it is replaced by true palmarum. The Eastern bird is abundant in summer in northern Maine and New Brunswick, and Aububon considered it common in Labrador, though late observers there have rarely found it. 
Mr. Neilson thinks it uncommon near Dornald, Quebec, and says he never sees a specimen later than June Ist. Dr. Wheaton has reported it as a common migrant through Ohio, but it is reported rare in Ontario. Nuttall's statement, borrowed from Wilson, that some remained in Pennsylvania during the breeding season, has not been confirmed by more recent observations. It winters in the Southern and Gulf States.

In habits this species stands peculiar. Unlike other Dendroica, it nests on the ground, and unlike all other Warblers, it shows a strong preference for fields and road-sides, where it may be found hopping along with the Sparrows, and flirting its tail like a Titlark.

The song is a very simple affair, $-\mathrm{a}$ few sweet notes.

Note. - The Palm Warbler (Dendroica palmarum) differs from hypochrysea in being smaller and much duller colored. It is usually restricted to the Mississippi valley; but some winter in Florida, and occasionally a solitary straggler has been seen in the Atlantic States.

AUduBon's WARBLER (Dendroica auduboni), though a bird of the Western Plains, has a right to mention here through one example having been taken in Cambridge, Mass.

\section{YELLOW WARBLER.}

SUMMER YELLOW BIRD. SUMMER WARBLER.

DENDROICA FETIVA.

CHAR. General color golden yellow, upper parts tinged with olive; breast and sides streaked with orange brown. Length $4 \frac{1}{2}$ to $5 \frac{1}{4}$ inches.

Nest. On a bush or low tree, in a garden or open pasture; gracefully formed and compactly woven, of various vegetable fibres, - grass, stems, etc., - usually lined with hair or plant down, sometimes with feathers.

Eggs. 3-5; dull white or greenish white, marked chiefly around the larger end with brown and lilac; $0.65 \times 0.45$.

This very common and brilliant summer species is found in all parts of the American continent, from the confines of the Arctic circle to Florida and Texas, as well as Oregon and the Rocky Mountains, where it spends the mild season. About the middle of March I alrearly heard the song amidst the 
early blooming thickets and leafy woods of the Altamaha; but the birds do not arrive in Pennsylvania and this part of New England before the Ist of May. About the close of August in the Northern, and by the middle of September in the Central States of the Union, or as soon as their second brood are capable of joining the migrating host, they disappear, probably in the twilight, and wing their way by easy stages to their tropical destination, passing through Louisiana in October and appearing at length about Vera Cruz, whence they spread their numerous host through tropical America to Guiana, Cayenne, St. Domingo, and other of the larger contiguous islands of the West Indies.

This is a very lively, unsuspicious, and almost familiar little bird, and its bright golden color renders it very conspicuous, as in pursuit of flitting insects it pries and darts among the blooming shrubs and orchards. It is particularly attached to willow-trees and other kinds in moist and shady situations, that afford this and other species a variety of small larvæ and caterpillars, on which they delight to feed. While incessantly and busily employed it occasionally mounts the twig, and with a loud, shrill, and almost piercing voice it earnestly utters, at short and irregular intervals, - 'tsh' 'tsh' 'tsh' 'tsh' 'tshä̈a, or tshe tshe tsh tshayia tshe tshe; this last phrase rather plaintive and interrogatory, as if expecting the recognition of its mate. Sometimes, but particularly after the commencement of incubation, a more extended and pleasingly modulated song is heard, as se te te tshitshoo, or tsh' tsh' tsh' tsheetshoo, 'tshe 'tshe 'tshe 'tshoo 'peetshee, and 'tshe 'tshe 'tshe 'tshe 'tshaia 'tship or wäy; the termination tender, plaintive, and solicitous. I have heard this note also sometimes varied to 'soit 'soit'soit'soit 'tship ă wee. The female sometimes sings nearly as well as the male, particularly about the time she is engaged in fabricating her nest. Although the song of these birds may be heard, less vigorously, to the month of August, yet they do not here appear to raise more than a single brood.

The nest, in Massachusetts, is commonly fixed in the forks of a barberry bush, close shrub, or sapling, a few feet from the 
ground; at other times, I have known the nest placed upon the horizontal branch of a hornbeam, more than I5 feet from the ground, or even $5^{\circ}$ feet high in the forks of a thick sugarmaple or orchard tree. These lofty situations are, however, extraordinary; and the little architects, in instances of this kind, sometimes fail of giving the usual security to their habitation. The nest is extremely neat and durable; the exterior is formed of layers of Asclepias, or silk-weed lint, glutinously though slightly attached to the supporting twigs, mixed with some slender strips of fine bark and pine leaves, and thickly bedded with the down of willows, the nankeen-wool of the Virginian cotton-grass, the down of fern-stalks, the hair from the downy seeds of the buttonwood (Platanus), or the pappus of compound flowers; and then lined either with fine-bent grass (Agrostis), or down, and horse-hair, and rarely with a few accidental feathers. Circumstances sometimes require a variation from the usual habits of the species. In a garden in Roxbury, in the vicinity of Boston, I saw a nest built in a currant-bush, in a small garden very near to the house; and as the branch did not present the proper site of security, a large floor of dry grass and weeds was first made betwixt it and a contiguous board fence; in the midst of this mass of extraneous materials, the small nest was excavated, then lined with a considerable quantity of white horse-hair, and finished with an interior bed of soft cow-hair. The season proving wet and stormy, the nest in this novel situation fell over, but was carried, with the young to a safe situation near the piazza of the house, where the parents now fed and reared their brood. The labor of forming the nest seems often wholly to devolve on the female. On the roth of May I observed one of these industrious matrons busily engaged with her fabric in a low barberry bush, and by the evening of the second day the whole was completed, to the lining, which was made, at length, of hair and willow down, of which she collected and carried mouthfuls so large that she often appeared almost like a mass of flying cotton, and far exceeded in industry her active neighbor, the Baltimore, who was also engaged in collecting the same materials. Notwith- 
standing this industry, the completion of the nest, with this and other small birds, is sometimes strangely protracted or not immediately required. Yet occasionally I have found the eggs of this species improvidently laid on the ground. It is amusing to observe the sagacity of this little bird in disposing of the eggs of the vagrant and parasitic Cow Troopial. The egg, deposited before the laying of the rightful tenant, too large for ejectment, is ingeniously incarcerated in the bottom of the nest, and a new lining placed above it, so that it is never hatched to prove the dragon of the brood. Two instances of this kind occurred to the observation of my friend Mr. Charles Pickering; and in 1833 I obtained a nest with the adventitious egg about two thirds buried, the upper edge only being visible, so that in many instances it is probable that this species escapes from the unpleasant imposition of becoming a nurse to the sable orphan of the Cow Bird. She however acts faithfully the part of a foster-parent when the egg is laid after her own.

I have heard of two instances in which three of the Yellow Bird's own eggs were covered along with that of the Cow Blackbird. In a third, after a Blackbird's egg had been thus concealed, a second was laid, which was similarly treated, thus finally giving rise to a three-storied nest.

The Summer Yellow Bird, to attract attention from its nest, when sitting, or when the nest contains young, sometimes feigns lameness, hanging its tail and head, and fluttering feebly along, in the path of the spectator; at other times, when certain that the intrusion had proved harmless, the bird would only go off a few feet, utter a feeble complaint, or remain wholly silent, and almost instantly resume her seat. The male, as in many other species of the genus, precedes a little the arrival of his mate. Towards the latter end of summer the young and old feed much on juicy fruits, as mulberries, cornel berries, and other kinds.

The habitat of the present form is not extended beyond the eastern base of the Rockies ; westward from that line it is replaced by morcomi, a much paler race. 


\section{MAGNOLIA WARBLER. \\ BLACK-AND-YELLOW WARBLER. \\ DENDROICA MACULOSA.}

CHAR. Male : back black, the feathers edged with olive; rump yellow; crown ash, bordered by black and white; beneath, rich yellow, thickly spotted on breast and sides with black; wing-bars and tail-patches white. Female : similar, but colors duller, and back sometimes entirely olive.

Nest. On a horizontal branch of spruce or fir, usually 3 to 6 feet from the ground, but sometimes higher; made of twigs and grass, lined with fine black roots.

Eggs. 4-5; creamy white, spotted with lilac and several shades of brown; $0.60 \times 0.50$.

This rare and beautiful species is occasionally seen in very small numbers in the Southern, Middle, and Northern States, in the spring season, on its way to its Northern breeding-places. In Massachusetts I have seen it in this vicinity about the middle of May. Its return to the South is probably made through the western interior, - a route so generally travelled by most of our birds of passage at this season; in consequence of which they are not met with, or but very rarely, in the Atlantic States in autumn. In this season they have been seen at sea off the jsland of Jamaica, and have been met with also in Hispaniola, whither they retire to pass the winter. Like all the rest of the genus, stimulated by the unquiet propensity to migrate, they pass only a few days with us, and appear perpetually employed in pursuing or searching out their active insect prey or larvæ; and while thus engaged, utter only a few chirping notes. The Magnolia has a shrill song, more than usually protracted on the approach of wet weather, so that the Indians bestow upon it the name of Rain Bird. According to Audubon, many of these birds breed in Maine and the British Provinces, as well as in Labrador, and extend their summer residence to the banks of the Saskatchewan. They have also a clear and sweetly modulated song.

Although rare in the United States, it appears, according to Richardson, that this elegant species is a common bird on the 
banks of the Saskatchewan, where it is as familiar as the common Summer Yellow Bird ( $S$. cestiva), which it also resembles closely in its manners and in its breeding station, but is gifted with a more varied and agreeable song. It frequents the thickets of young spruce-trees and willows, flitting from branch to branch, at no great distance from the ground, actively engaged in the capture of winged insects, which now constitute its principal fare.

The Magnolia is not so rare a bird as Nuttall supposed, - indeed, it is common everywhere between the Atlantic and the eastern base of the Rockies, breeding in northern New England and in the northern portions of New York, Ohio, and Michigan, and thence to Labrador and Great Slave Lake.

In Massachusetts it is chiefly a spring and autumn visitor, though Mr. William Brewster found a few pairs nesting in the Berkshire Hills. It winters in Central America, Cuba, and the Bahamas.

In its habits this bird combines the Creeper and the Flycatcher in true Warbler fashion, picking insects and larvæ from the crannies of the bark and from the leaves, and capturing on the wing the flying mites. The favorite nesting site is the border of a wood or an open pasture, though I have found nests in the deep forest, usually on the margin of an open glade.

The song is Warbler-like in its simplicity, yet is an attractive melody, the tones sweet and musical.

Nuttall's idea that the autumn route of migration taken by more northern breeding birds lies somewhere to the westward of New England, is not consistent with more recent observation; for while it is true that large numbers follow the valley of the Mississippi, some of them crossing to the Atlantic when south of the Alleghanies, - it has also been ascertained that immense flights of birds that breed in the interior go southward along the coast-line. Many species that are not seen in New England during the spring migration are abundant in the autumn.

VOL. I. - I5 


\section{CAPE MAY WARBLER.}

\section{DENDROICA TIGRINA.}

Char. Male : back yellowish olive, with darker spots; crown blackish; ear-patch chestnut; line from bill around the eyes black; rump yellow, wing-bars white and fused into one large patch; white blotches on three pairs of tail-feathers; beneath, yellow tinged with orange on chin and throat, spotted with black on breast and sides. Female : similar, but back grayish, and lacking distinctive marking on head; under parts paler; spots on wings and tail smaller or obscure.

Nest. In a pasture or open woodland, on low branch of small tree; a neat, cup-shaped structure, partially pensile, composed of twigs and grass fastened with spider's webbing, lined with horse-hair.

Egys. 3-4; dull white or buffy, slightly specked, and wreathed around larger end with spots of brown and lilac; $0.70 \times 0.50$.

This very rare Warbler has only been seen near the swamps of Cape May by Edward Harris, Esq. ; near Moorestown, in New Jersey; and in the vicinity of Philadelphia, about the middle of May, - probably as a straggler on its way to some Northern breeding-place. Its notes and further history are yet unknown.

Since Nuttall wrote, we have learned a little more of the life history of this feathered beauty, though our knowledge of the bird's habits is still very limited. So rare is the bird that examples adorn but few collections; yet it has been seen occasionally throughout the Eastern States, and is reported by Thompson as "plentiful " along the Red River, in Manitoba. It has been traced north to Hudson Bay, and south (in winter) to the West Indies. The southern limit of its breeding area is probably about the $45^{\text {th }}$ parallel. The nest has been found by Mr. H. B. Bailey at Umbagog Lake, in Maine, and by Mr. James W. Banks near St. John, N. B.

Banks's nest, which I had the privilege of examining, was completely hidden amid the dense foliage of a clump of cedars, growing on an open hill-side, and quite close to a much-used thoroughfare. When first discovered it was unfinished, and the female was at work upon it. The male never appeared, nor was he heard in the vicinity, though the spot was visited frequently. After four eggs had been laid, female, nest, and eggs were "gathered."

The species had not been observed before near St. John, though Mr. Boardman had reported taking examples at St. Stephen's, and I had seen several at Edmundston, near the Quebec border. 
The Edmundston birds were seen in early June, and those secured proved to be males. As they sang with great frequency, they were easily discovered, and were invariably found amid the top branches of high spruce and fir trees on the crest of a hill. We were anxious to obtain a nest, and of course hunted through these high branches, little thinking that this coterie of Benedicts were making holiday while their industrious but neglected spouses were attending to housekeeping affairs down yonder in the valley. We learned the song, however, and discovered that its theme resembled somewhat the simple lay of the Nashville, though the voice is neither so full nor so sweet, recalling rather the thin, wiry tones of the Black and White Creeper.

\section{CANADIAN WARBLER.}

\section{Sylvania canadensis.}

CHAR. Above, bluish ash; crown marked with black; line from bill around the eyes, yellow; line from beneath the eyes to sides of breast black; under parts yellow spotted with black, the spots forming a line or crescent across the breast; throat unspotted. Length 5 to $5 \frac{3}{4}$ inches.

Nest. On the ground, sometimes near border of a stream or by a moist meadow, placed on side of mound or among upturned roots of a tree; composed of grass and stems, lined with hair.

Eggs. 4-5; white or creamy, spotted, chiefly around the larger end, with brown and lilac; $0.70 \times 0.50$.

This is a rare summer species in the Atlantic States, appearing singly, and for a few days only, on the passage north or south in the spring or autumn. These birds breed in Canada and Labrador, and are more abundant in mountainous interior, - the route by which they principally migrate. They winter in the tropical regions, are then silent, and, like the rest of their tribe, very active in darting through the branches after insects.

Audubon found this species breeding in the Great Pine Forest of the Pokono in Pennsylvania, as well as in Maine, the British Provinces, and Labrador. They have a short, unattractive note in the spring, and in the mountains where they dwell they have a predilection for the shady borders of streams where laurels grow. 
The Canadian Warbler is common during the migrations, from the Atlantic to the Mississippi, and though breeding chiefly north of $43^{\circ}$, some pairs nest in Massachusetts, New York, southern Ontario, and Illinois. It has been taken in Labrador and is common in Manitoba. It winters in Central America.

\section{YELLOW-THROATED WARBLER.}

\section{DENDROICA DOMINICA.}

ChAR. Above, grayish ash; forehead and sides of head, black; line from nostril to hind neck, yellow; wing-bars white; beneath, yellowish white; chin and throat rich yellow; sides of breast streaked with black. Length $4 \frac{3 / 4}{4}$ to $5 \frac{3}{4}$ inches.

Nest. In an open grove or the edge of heavy woods, on top of horizontal branch or at the forks of a limb, or "concealed in pendant moss," 20 to 90 feet from the ground; made of grass-weed stems, strips of bark, and moss, lined with vegetable fibre, horse-hair, or feathers.

Egys. 3-5; white, tinged with green, spotted around the larger end with brown and lilac; $0.70 \times 0.50$.

These elegant and remarkable birds reside in the West Indies, and also migrate in considerable numbers into the southern parts of the United States, particularly Louisiana and Georgia, whence indeed they only absent themselves in the two inclement months of December and January. They are seen in February in Georgia, but very rarely venture as far north as Pennsylvania. The song is pretty loud and agreeable, according to Latham and Wilson, resembling somewhat the notes of the Indigo Bird. In the tropical countries they inhabit, this delicate music is continued nearly throughout the year, and participated also by the female, though possessed of inferior vocal powers. The bird appears to have many of the habits of the Creeping Warbler ( $S$. varia), running spirally around the trunks of the pine-trees, on which it alights, and ascending or descending in the active search of its insect fare.

The sagacity displayed by this bird in the construction and situation of its nest is very remarkable. This curious fabric is 
suspended to a kind of rope which hangs from tree to tree, usually depending from branches that bend over rivers or ravines. The nest itself is made of dry blades of grass, the ribs of leaves, and slender root-fibres, the whole interwoven together with great art; it is also fastened to, or rather worked into, the pendant strings made of the tough silky fibres of some species of Echites, or other plant of that family. It is, in fact, a small circular bed, so thick and compact as to exclude the rain, left to rock in the wind without sustaining or being accessible to any injury. The more securely to defend this precious habitation from the attacks of numerous enemies, the opening, or entrance, is neither made on the top nor the side, but at the bottom; nor is the access direct, for after passing the vestibule, it is necessary to go over a kind of partition, and through another aperture, before it descends into the guarded abode of its eggs and young. This interior lodgment is round and soft, being lined with a kind of lichen, or the silky down of plants.

This species is confined chiefly to the South Atlantic States, though occasionally a few wander to New York, Connecticut, and Massachusetts.

Note. - The Sycamore WARBler ( $D$. dominica albilora) differs from the type in being smaller (length $4 \frac{1}{2}$ to $5 \frac{1 / 2}{2}$ inches) and in having the line over the eyes ruhite, instead of yellow. It occurs along the Mississippi valley and eastward to Ohio, where it is common. It has been taken also in South Carolina and Florida. 


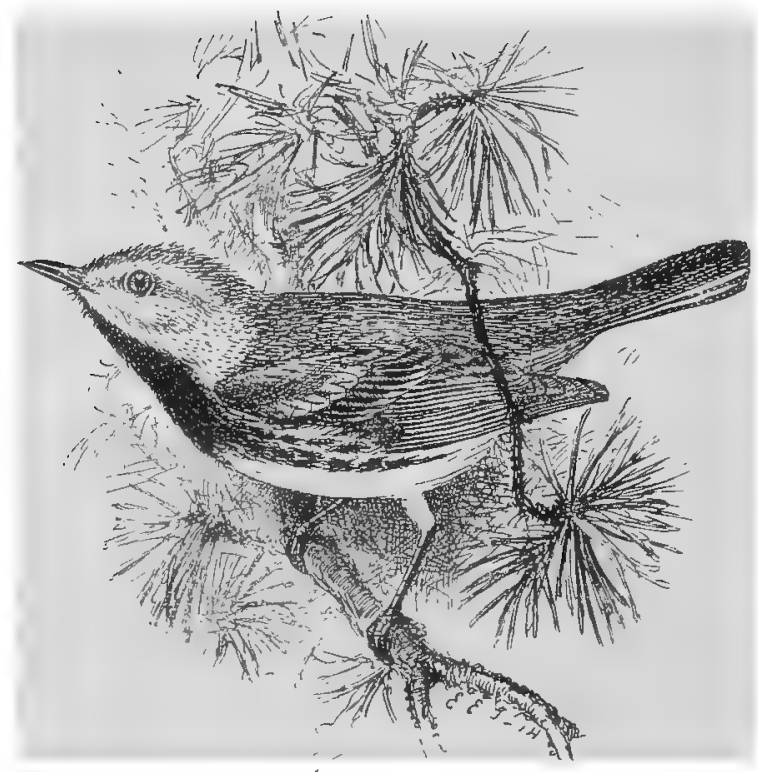

\section{BLACK-THROATED GREEN WARBLER.}

\section{DENDROTCA VIRENS.}

CHAR. Male in spring : above, bright olive; line on sides of head rich yellow; wings and tail dusky; wing-bars and outer tail-feathers white; beneath, white tinged with yellow; throat and chest rich black. Male in autumn, female, and young : similar, but black of throat mixed with yellow, sometimes obscured.

Nest. On the border of heavy woods, in fork of coniferous tree 30 to 5o feet from the ground; of twigs, grass, etc., lined with hair and down.

Eggs. 3-4; white or creamy white wreathed around larger end with spots of brown and lilac; $0.65 \times 0.50$.

This rather rare species arrives from its tropical winterquarters in Pennsylvania towards the close of April or beginning of May. About the $\mathbf{I} 2$ th of the latter month it is seen in this part of Massachusetts; but never more than a single pair are seen together. At this season a silent individual may be occasionally observed, for an hour at a time, carefully and ac- 
tively searching for small caterpillars and winged insects amidst the white blossoms of the shady apple-tree; and so inoffensive and unsuspicious is the little warbler that he pursues without alarm his busy occupation, as the spectator within a few feet of him watches at the foot of the tree. Early in October these birds are seen in small numbers roving restlessiy through the forest, preparatory to their departure for the South.

Though the greater part of the species probably proceed farther north to rear their young, a few spend the summer in the Middle and Northern States; but from their timorous and retiring habits it is not easy to trace out their retreats at the period of breeding. In the summer of 1830 , however, on the 8 th of June, I was so fortunate as to find a nest of this species in a perfectly solitary situation on the Blue Hills of Milton. The female was now sitting, and about to hatch. The nest was in a low, thick, and stunted Virginia juniper. When I approached near to the nest the female stood motionless on its edge and peeped down in such a manner that I imagined her to be a young bird. She then darted directly to the earth and ran; but when, deceived, I sought her on the ground, she had very expertly disappeared, and I now found the nest to contain 4 roundish eggs, white, inclining to flesh-color, variegated, more particularly at the great end, with pale, purplish points of various sizes, interspersed with other large spots of brown and blackish. The nest was formed of circularly entwined fine strips of the inner bark of the juniper and the tough white fibrous bark of some other plant, then bedded with soft feathers of the Robin, and lined with a few horse-hairs and some slender tops of bent-grass (Agrostis). The male was singing: his simple chant at the distance of a quarter of a mile from the nest, and was now nearly in the same dark wood of tall oaks and white pines in which I had first heard him a fortnight before. This simple, rather drawling, and somewhat plaintive song, uttered at short intervals, resembled the syllables 'te dé teritscá, sometimes te derisca, pronounced pretty loud and slow, and the tones proceeded from high to low. In the intervals he was perpetually busied in catching small cynips and 
other kinds of flies, keeping up a smart snapping of his bill, almost similar to the noise made by knocking pebbles together. This quaint and indolent ditty $I$ have often heard before in the dark and solitary woods of west Pennsylvania; and here, as there, it affords an agreeable relief in the dreary silence and gloom of the thick forest. This note is very much like the call of the Chicadee, and at times both are heard amidst the reigning silence of the summer noon. In the whole district of this extensive hill or mountain, in Milton, there appeared to exist no other pair of these lonely Warblers but the present. Another pair, however, had probably a nest in the vicinity of the woods of Mount Auburn in Cambridge, and in the spring of the present year ( $183 \mathrm{I}$ ) several pairs of these birds were seen for a transient period.

Nuttall was not the only one of the older writers who expressed the opinion that this and other species of the family were less abundant than more modern observers have found them. Wilson and Audubon made similar statements.

'This Warbler is now known to be a common bird throughout these Eastern States, and may be found, in summer, in any coniferous forest in Massachusetts, and thence northward to the furcountries and westward to the plains. It breeds also, sparingly, in southern New England, northern Ohio, Illinois, etc., and winters in the West Indies and Central America.

\section{BLACKBURNIAN WARBLER.}

\section{DENDROICA BLACKBURNIÆ.}

CHAR. Male : above, black, back streaked with whitish; sides of head black; crown patch, line over eye, and entire throat and breast rich orange or flame color; belly yellowish white; sides streaked with black; large white patches on wings; outer tail-feathers nearly all white. Female : similar, but black replaced by grayish brown, and orange by dull yellow; two white wing-bars. Length $5 \frac{1}{4}$ to $5 \frac{1}{2}$ inches.

Nest. Usually in coniferous woods, saddled on horizontal limb of pine or hemlock, zo to 40 feet from the ground; composed of twigs, roots, and shreds of bark mixed with vegetable down, lined with feathers, hair, and down.

Eggs. 4 ; white, often tinged with green, spotted, chiefly around larger end, with brown and lilac; $0.70 \times 0.50$. 
The Blackburnian Warbler is one of the rarest and most beautiful species of the genus, which from the ist to the I $5^{\text {th }}$ of May, or sometimes later, pays a transient visit to the Middle and Northern States, on its way to its remote boreal place of retirement for the breeding season. It is still more rarely seen in the autumn, about the month of September, in its passage to tropical America, where it winters, as may be presumed, from its occurrence late in autumn about Vera Cruz, according to Mr. Bullock. It is an exceedingly nimble insect-hunter, keeping towards the tops of trees, scarcely uttering even an audible chirp, and at this season no song as far as is yet known.

On the Magdalene Istands in the Gulf of St. Lawrence, in June, Audubon remarks that he heard the song of this beautiful warbler, consisting of five or six loud notes, which it uttered from the branches of a fir-tree while engaged in quest of its prey. The nest found in Nova Scotia was made externally of coarse materials and lined with silky fibres and delicate strips of bark, over which lay a thick bed of feathers and horse-hair. It was found in a small fork of a tree, 5 or 6 feet from the ground, near a brook. Dr. Brewer also found a nest of this species in Massachusetts.

The very rare adult of the Hemlock Warbler was found by Wilson in the Great Pine Swamp in Pennsylvania, and appeared to take up its residence in the dark hemlock-trees of that desolate region. It was very lively and active, climbing among the branches and hanging from the twigs like a Titmouse. It darted after flies to a considerable distance, and beginning with the lower branches, hunted with regularity upwards to the summit of the tree, and in this way it proceeded very industriously to forage through the forest till satisfied. At intervals it stopped an instant to warble out a few low and sweet notes, probably for the recognition or company of its mate, which the discoverer, however, did not see.

The nest of this species, according to Audubon, who discovered it in the Great Pine Swamp, was made in a hemlock or 
spruce tree at a considerable elevation. Lichens, dry leaves of the hemlock, and slender twigs formed the exterior; it was then lined with hair or fur and the feathers of the Ruffed Grouse. He afterwards met with this species in Maine and Newfoundland.

Nothing is more remarkable in the history of this species than the rarity of the adult and the abundance of the young birds; these last, which we have long known as the Autumnal Warbler, appear in gregarious flocks in the larger solitary forests of Massachusetts as early as the 2oth of July, assembled from the neighboring districts probably, in which they have been reared. They remain there usually until the middle of October, at which time they are also seen in the Middle States. They feed on small insects and berries. Late in the season, on a fine autumnal morning, troops of them may be seen in the fields and lanes, sometimes descending to the ground, and busily employed in turning over the new fallen leaves, or perambulating and searching the chinks of the bark of the trees, or the holes in the posts of the fence, in quest of lurking moths and spiders; and while thus eagerly engaged, they are occasionally molested or driven away by the more legitimate Creepers or Nuthatches, whose jealousy they thus arouse by their invasion. Earlier in the season they prey on cynips, flies, and more active game, in pursuit of which they may be seen fluttering and darting through the verdant boughs of the forest trees. One of these little visitors, which I obtained by its flying inadvertently into an open chamber, soon became reconciled to confinement, flew vigorously after houseflies, and fed greedily on grasshoppers and ivy berries (Cissus hederacea); at length it became so sociable as to court my acquaintance and eat from my hand. Before I restored it to liberty, its occasional tweet attracted several of its companions to the windows of its prison. At this time the bird is destitute of song, and only utters a plaintive call of recognition.

Nuttall followed Wilson and Audubon in considering the young Blackburnians a different species, naming it the "Hemlock Warbler." I have given above Nuttall's account of the two. 
The Blackburnian is rather common in the Atlantic States and westward to the Plains, breeding chiefly north of $45^{\circ}$, and sparingly in Massachusetts and Connecticut. It winters from the Bahamas and eastern Mexico southward.

Many Canadian observers have considered this Warbler rather rare, but the opinion has probably arisen from the secluded habits of the bird while in its summer home. It shows a preference for the higher branches, and its favorite haunts are amid the deeper forests' where the pine and hemlock flourish.

\section{CHESTNUT-SIDED WARBLER.}

\section{DENDROICA PENSYLVANICA.}

CHAR. Back black, streaked with olive of grayish or yellowish tint; crown yellow; sides of head white, enclosing a patch of black; sides of neck and entire under parts white; sides streaked with chestnut, which extends from neck to flanks ; wing-bars and blotches on tail white. Length $4 \frac{3}{4}$ to $5 \frac{1 / 4}{4}$ inches.

Nest. On the edge of an open woodland or the margin of a moist meadow, in low tree or bush; composed of grass and strips of bark fastened with insect silk, and lined with grass or leaves or hair.

Eggs. 4-5; white or creamy, spotted, chiefly around the larger end, which is sometimes wreathed, with reddish brown and lilac; $0.68 \times 0.50$.

This rare and beautiful Sylvia, which probably winters in tropical America, appears in the Middle and Northern States early in May on its way north to breed; it is also seen in the spring in Canada and around Hudson's Bay. A few pairs remain, no doubt, to rear their young in secluded mountainous situations in the Northern States, as on the $22 \mathrm{~d}$ of May, I 830 , a pair appeared to have fixed their summer abode near the summit of the Blue Hills of Milton. The note of the male was very similar to that of the Summer Yellow Bird, being only a little louder, and less whistling; it resembles 'tsh ' $t$ sh 'tsh 'tshyia, given at about an interval of half a minute, and answered by his mate at some distance, near which, it is probable, there was a nest. He appeared to be no way suspicious of our approach; his restlessness was subdued, and he quietly sat near the same low bushes, amusing himself and his consort, for an hour at a time, with the display of his lively and simple 
ditty. On their first arrival, previous to pairing, these birds are like the rest of the genus, restless, and intently engaged in the chase of insects amidst the blossoms and tender leaves; they likewise pursue common and green bottle flies with avidity and success. On the 27 th of June, I 831 , I observed a pair selecting food for their young, with their usual address and activity, by the margin of a bushy and secluded swamp on the west side of Fresh Pond, in this vicinity; but I had not the good fortune to discover the nest. I have, however, since, I believe, discovered the nest of this bird, in a hazel copse in a wood in Acton, in this State. It is fixed in the forked twigs of a hazel about breast high. The fabric is rather light and airy, being made externally of a few coarse blades and stalks of dead grass, then filled in with finer blades of the same, the whole matted and tied with caterpillar's silk, and lined with very slender strips of brown bark and similar white-pine leaves. It appeared to have been forsaken before its completion, and the eggs I have never seen.

In the woods around Farranville, on the Susquehanna, within the range of the Alleghany chain, in the month of May, I 83 , I saw and heard several males in full song, in the shady forest trees by a small stream, and have no doubt of their breeding in that situation, though I was not fortunate enough to find a nest.

This species is now a common summer resident of New England and the settled portions of Canada, and occurs westward to the Plains. It breeds in numbers as far south as the fortieth parallel, and regularly, though sparingly, on the elevated lands southward to Georgia, and I have found the nest in New Brunswick north of latitude $47^{\circ}$. It winters southward to the Bahamas and Central America. 


\section{BAY-BREASTED WARBLER.}

\section{DENDROICA CASTANEA.}

CHAR. Male : back grayish olive, streaked with black; forehead and sides of head black; sides of neck buffy; throat, breast, and sides chestnut ; remainder of under parts buffish; wing-bars and patches on tail white. Female : above, olive streaked with black; beneath, butfy, sides and breast tinged with dull rufous. Length $5 \frac{1}{2}$ to 6 inches.

Nest. In an open woodland, on horizontal branch of coniferous tree Io to 20 feet from the ground; of twigs, shreds of bark, grass roots, and moss, lined with fine roots, moss, or pine-needles.

Eggs. 3-6 (usually 4); white, with blue tint, or bluish green, spotted with reddish brown; $0.70 \times 0.50$.

This is a still rarer and more transient visitor than the last. It arrives in Pennsylvania from the South some time in April or about the beginning of May, and towards the 12 th or I 5 th of the same month it visits Massachusetts, but seldom stays more than a week or ten days, and is very rarely seen on its return in the autumn. Audubon once observed several in Louisiana late in June, so that it probably sometimes breeds in very secluded places without regularly proceeding to the northern regions. It is an active insect-hunter, and keeps much towards the tops of the highest trees, where it darts about with great activity, and hangs from the twigs with fluttering wings. One of these birds, which was wounded in the wing, soon became reconciled to confinement, and greedily caught and devoured the flies which I offered him; but from the extent of the injury, he did not long survive. In habits and manners, as well as markings, this species greatly resembles the preceding.

This Warbler is exceptional in being more abundant in New England in spring than in autumn. Mr. McIlwraith reports that the same rule obtains in Ontario, but Dr. Wheaton considered that in Ohio the birds were more numerous during the autumn; and these apparently conflicting statements suggest an interesting phase in the question of migration routes.

The bird is common as a summer resident in the northern portions of New England, New York, and Michigan, though rather rare 
in New Brunswick, Quebec, and Ontario. The most southern point at which it has been found breeding is Chicarua, N. H., in latitude $44^{\circ}$, where Mr. Frank Bolles obtained a nest in r89o. The species ranges north to Hudson Bay, and south to Central America.

\section{BLACK-POLL WARBLER.}

\section{DENDROICA STRIATA.}

CHAR. Above, grayish olive thickly streaked with black; top of head black; cheeks and entire under parts white; sides streaked with black; wing-bars and tail-patches white. Length $5^{\frac{1}{2}}$ to $5^{3 / 4}$ inches.

Nest. In an evergreen forest on low branch (sometimes on the ground); of grass, roots, twigs, and lichens; lined with grass covered with white feathers.

Eggs. 4-5; white, with various tints (usually pale pink or creamy), more or less spotted with reddish brown and lilac, - often dark brown and olive gray; $0.75 \times 0.55$.

This rather common and well-marked species is observed to arrive in Pennsylvania from the South about the 2 oth of April, but in Massachusetts hardly before the middle of May; it returns early in September, and appears to feed wholly on insects. In the Middle States it is confined chiefly to the woods, where, in the summits of the tallest trees, it is seen in busy pursuit of its favorite prey. On its first arrival it keeps usually in the tops of the maples, darting about amidst the blossoms. As the woods become clothed with leaves, it may be found pretty generally as a summer resident; it often also seeks the banks of creeks and swamps, in which situations it probably passes the breeding season. In this vicinity the Black-poll is a familiar visitor in the lowest orchard-trees, where it feeds on cankerworms and other small caterpillars, as well as flies of different kinds, etc. At this time, towards the month of June, it is no longer a restless wanderer, but having fixed upon its station for the summer, it now begins, in a humble way, to display its musical talents in the cherished and constant company of its faithful mate. This note, uttered at intervals of half a minute, is like the sound of $t s h$ 'tsh tsh tshé tshé, from low to high, but 
altogether so shrill and slender as to sound almost like the faint filing of a saw. This species extends its migrations to Newfoundland, according to Pennant. In the month of June, Audubon found the nest in Labrador placed about 3 feet from the ground, in the fork of a small branch, close to the main stem of a fir-tree. It was formed of green and white moss and lichens, intermixed with coarse dried grass; within this was a layer of bent-grass, the lining, of dark-colored dry moss, looked like horse-hair, and was arranged in a circular direction with great care; lastly was a thick bed of large soft feathers, - some of them were from Ducks, but most of them from the Willow Grouse. It contained 4 eggs.

The Black-poll breeds sparingly in northern New England, New Brunswick, and northern Michigan, building chiefly beyond the Laurentian hills, in Quebec and Ontario; though Dr. L. B. Bishop found it breeding in numbers on the Magdalen Islands, and Mr. J. P. Norris took a number of nests on Grand Menan. It ranges northward to the Barren Grounds and to Alaska, and winters in northern South America.

\section{PINE WARBLER.}

\section{DENDROICA VIGORSII.}

Char. Above, olive ; beneath, yellow, paler (or white) on belly ; wingbars and blotches on outer tail-feathers, white. Length $5 \frac{1}{4}$ to $5 \frac{3}{4}$ inches.

Nest. Usually in evergreen wonds, on horizontal bough of pine or cedar 30 or 40 feet from the ground; of weed stems, shreds of bark, and leaves fastened with insect silk, lined with hair and feathers.

Eggs. 4-5; dull white or gray, spotted with brown and lilac; 0.70 $\times 0.50$.

This common species, to the commencement of winter, inhabits all parts of the United States, and probably extends its northern migrations to the forests of Newfoundland. It arrives in Pennsylvania at the close of March and beginning of April, and soon after is seen in all parts of New England, amidst the pine and juniper forests, in which it principally 
resides. Both the old and young remain with us till nearly the close of October; stragglers have even been seen in mid-winter in the latitude of $43^{\circ}$. In winter they rove through the pine forests and barrens of the Southern States in companies of 20 to 50 or more, alighting at times on the trunks of the trees, and attentively searching them for lurking larvæ, but are most frequently employed in capturing the small insects which infest the opening buds of the pine, around which they may be seen perpetually hovering, springing, or creeping, with restless activity; in this way they proceed, from time to time, foraging through the forest; occasionally, also, they alight on the ground in quest of worms and grubs of various kinds, or dart irregularly after hovering flies, almost in the manner of the Flycatchers. In these states they are by far the most numerous of all the Warblers. In the month of March they already began to show indications for pairing, and jealous contests ensued perpetually among the males. The principal body of the species probably remain the year round in the Southern forests, where I saw them throughout the winter; great numbers are also bred in the Northern States. In summer their food is the eggs and larvæ of various insects, as well as flies or cynips, caterpillars, coleoptera, and ants. In autumn, the young frequent the gardens, groves, and orchards, feeding likewise on berries of various kinds, as on those of the cornel, wild grape, and five-leaved ivy; at this season they are very fat, and fly and forage in families. They now only utter a shrill and plaintive chip. I have had a male Pine Warbler, domesticated for a short time; he fed gratefully, from the instant he was caught, upon flies, small earthworms, and minced flesh, and was so tame and artless as to sit contented on every hand, and scarcely shift himself securely from my feet. On offering him drink he walked directly into the vessel, without using the slightest precaution or exhibiting any trace of fear. His tship and manner in all respects were those of the Autumnal Warbler.

The song of the Pine Warbler, though agreeable, amidst the dreary solitude of the boundless forests which he frequents, has 
but little compass or variety; sometimes it approaches the simplest trill of the Canary, but it is commonly a reverberating, gently rising, or murmuring sound, like $e r^{\prime} r^{\prime} r^{\prime} r^{\prime} r^{\prime} r{ }^{\prime} r a ́ h$; or, in the spring, 'twe 'twe 'twe 'tw' 'tw' twe 'tw', and sometimes like 'tsh'tsh'tsh'tw'tw'twe'twe 'tw; when harkened to some time, there is a variation in the cadence, which, though rather feeble at a distance, is not unpleasant, as the little minstrel tunes his pipe during the heat of the summer day, while he flits gently and innocently fearless through the shady boughs of the pine or cedar in perpetual quest of his untiring prey. This song is commonly heard at a considerable distance from his mate and nest, from whom he often widely strays, according to the success of his precarious pursuit. As the sound of the warble varies from slender to high or low, it is often difficult to discover the retreat of the little busy musician, which appears far. or near with the modulation of his almost ventriloquous note. The female likewise tunes, at times, her more slender lay in a wiry tone, almost like that of the S. varia, in early spring.

About the $7^{\text {th }}$ of June, I83o, I discovered a nest of this species in a Virginian juniper, near Mount Auburn, in this vicinity, at the height of about 40 feet from the ground. It was firmly fixed in the upright twigs of a close branch. The nest was thin, but very neat; the principal material was the wiry old stems of the slender knot-weed (Polygonum tenue), circularly interlaced, and connected externally with rough linty fibres of some species of Asclepias, and blended with caterpillar's webs. The lining was made of a few hog's bristles, slender root-fibres, a mat of the down of fern-stalks, and one or two feathers of the Robin's breast, - a curious medley, but all answering the pose of warmth and shelter for the expected brood. I saw several of these nests, which had at different times been thrown to the ground, and in all, the wiry grass and general material were the same as in the one now described; and this, of course, is entirely different from that given by Wilson on the authority of Mr. Abbot. The nest there mentioned is nothing more than the usual pendulous fabric of the Red-eyed Warbling Flycatcher. The eggs in ours were 4 , and, advanced towards VOL. I. -16 
hatching, they were white, with a slight tinge of green, very full of small pale brown spots, somewhat more numerous towards the larger end, where they appear connected or aggregated around a purplish ground. The female made some little complaint, but almost immediately resumed her seat, though 2 of the eggs were taken away; the male made off immediately, and was but seldom seen near the place.

The Pine Warbler is a common summer resident of New England, but I seldom saw it in New Brunswick, and can find no evidence of its occurrence in Nova Scotia. Mr. Neilson thinks it uncommon, and only a migrant in the vicinity of Quebec city, and Mr. McIlwraith makes a similar report for Ontario. It winters in the Southern States.

\section{PRAIRIE WARBLER.}

\section{DeNDROICA DISCOLOR.}

CHAR. Above, olive; back with patch of rect spots; forehead, line over the eyes, wing-bars, and entire under parts rich yellow; black streak on sides of head; sides spotted with black; 3 outer tail-feathers with broad patches of whitc. Length $4,1 / 2$ to 5 inches.

Nest. In open woodland or old meadow, on small tree or bush; neatly and compactly made of grass and vegetable fibre lined with hail or feathers.

Eggs. 4-5; white, spotted around larger end with brown; $0.63 \times$ 0.47 .

These birds, rare in the Atlantic States, appear to be somewhat more common in the solitary barrens of Kentucky and the open woods of the Choctaw country. Here they. prefer the open plains thinly covered with trees; and without betraying alarm at the visits of a spectator, leisurely pursue their search for caterpillars and small flies, examining among the leaves or hopping among the branches, and at times descending pretty near, and familiarly examining the observer, with a confidence and curiosity seldom witnessed in these shy and retiring species. Such was the conduct of a male bird in this vicinity, on the 4th of June, whom I discovered by his slender filing notes, which were uttered every half minute, and like those of 
the Black-poll Warbler resembled the suppressed syllables ' $t$ ' $h$ 'tsh 'tsh 'tshé $a$ ', beginning low, and gradually growing louder, haring nearly the same slender whistle as that species, though somewhat stronger. The pair were busily engaged collecting flies and larvæ from a clump of young locust-trees in the woods of Mount Auburn, and occasionally they flitted among the Virginian junipers; the familiar visit of the male appeared for the purpose of discovering my intentions near the nest, about which he was naturally solicitous, though he made his approaches with the appearance of accident. The female was more timid; yet while I was still engaged in viewing this little interesting and secluded pair, she, without any precaution or concealment, went directly to the nest in the forks of a low barberry bush near by, and when there, she sat and looked at me some time before she removed. She made, however, no pretences to draw me away from the spot, where she was sitting on 4 eggs, of which I took away 2 ; her approaches to the nest were now more cautious, and she came escorted and encouraged by the presence of her mate. Two eggs were again soon added, and the young brood, I believe, reared without any accident.

The nest was scarcely distinguishable from that of the Summer Yellow Bird, and quite different from the nests described by Wilson and Audubon. My opportunity for examination, so long continued, seemed to preclude the possibility of error in the investigation; neither can I compare the slender note of this species to any whirring sound, which would more nearly approach to the song of the Pine Warbler. The Prairie Warbler visits Cambridge about the first or second week in May, and according to the observations of my friend Mr. Cooper, is seen probably about the same time in the vicinity of New York in small numbers and in pairs, and retires to winter in the West Indies about the middle of September.

This species is now considered common in Massachusetts, though it has not been taken farther northward. It occurs in Ohio and in Michigan, but not in Ontario. It winters in southern Florida and the West Indies. 


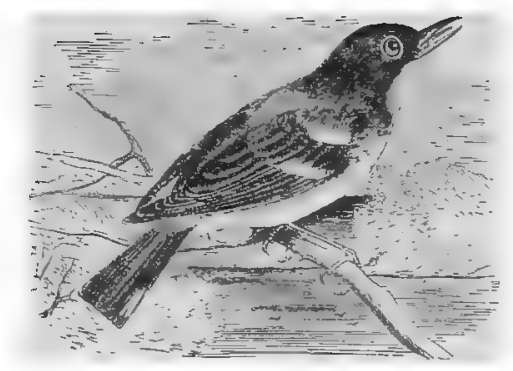

PARULA WARBLER.

BLUE-YELLOW-BACKED WARBLER.

COMPSOTHLYPIS AMERICANA.

Char. Male: above, bright ashy blue, an olive patch on the back; throat and breast yellow, a patch of rich brown on the breast; belly white; wings with 2 broad white bars; white patches on inner web of outer tail-feathers. Female : similar, but colors duller and the patches on back and breast obscure or absent. Length $4^{1 / 2}$ to $4 \frac{3}{4}$ inches.

Nest. In moist woodland or on border of swamp; usually in a bunch of "beard-moss" (usnea) hanging from the trunk or branch of a tree Io to 40 feet from the ground, and composed of threads of the moss and fine grass or hair compactly woven; sometimes lined with pine-needles or hair.

Eggs. 3-7 (usually 4); white or creamy, thickly spotted with several shades of reddish brown; $0.65 \times 0.45$.

This remarkable species visits the Middle and Northern States about the Ist to the I $5^{\text {th }}$ of May, and is seen again early in October on its way to the West Indies (St. Domingo and Porto Rico), whither it retires at the approach of winter. A few, according to Catesby, pass the whole year in South Carolina. It is very abundant in the summer in the woods of Kentucky, is active and restless on its first arrival, and frequents the summits of the highest trees, being particularly fond of the small caterpillars and flies of various kinds which are, in the early part of spring, attracted to the open blossoms and tender shoots. It also possesses in some degree the creeping and prying habits of the Titmouse, to which genus it it was referred by Linnæus and Pennant. Entering the south- 
ern extremity of the Union by the first approach of spring, it is now seen searching for its insect food on shrubs and plants in moist places, by the borders of lakes and streams. In this vicinity it is not common; but as it was singing as late as the $22 \mathrm{~d}$ of May in the woody solitude of the Blue Hills of Milton, it must undoubtedly breed there.

The notes of this species resemble those of the Prairie Warbler in some respects, though sufficiently different; the tones, rising from low to high, are rather weak and insignificant.

In Nuttall's day this dainty bird was named "Party-colored Warbler" and "Finch Creeper." It is now considered a rather common summer resident in Massachusetts and Connecticut, and breeds northward to the Gulf of St. Lawrence. The nests have been found also in northern Ohio and southern Illinois, and in winter the birds range through southern Florida and among the more northern West Indies.

The Parula is associated in my mind with secluded woods on cool and shaded hill-sides bordering a stream, and the song comes to me from amid the top branches of tall trees, - birch and poplar. It is an attractive song, though it has little theme, - merely a rapid trill of some twenty sibilant notes delivered with a rising inflection; but the tones are sweet, and the effect is pleasing. The song is clearly an outburst of joyous emotion.

\section{BLACK-THROATED BLUE WARBLER.}

\section{DENDROICA CAERULESCENS.}

CHAR. Male : above, dull blue, back sometimes streaked with black; sides of head, throat, and chest rich black; remainder of under parts white; white spot on wing; tail with large white blotches. Female: above, dull olive; beneath, dull greenish yellow; white spot on wing. Length 5 to $5^{1 / 2}$ inches.

Nest. In deep woods amid thick underbrush or on high branch; of grass, twigs, vines, and lichens, fastened with insect silk, lined with roots and hair.

Eggs. 3-5; white, with green or buff tint, often, when fresh, tinged with rosy, marked with large spots of reddish brown; $0.70 \times 0.50$.

Of this uncommon species we know very little. It appears only as a transient visitor in the month of April, in the Middle 
States, and after staying to feed for a week or ten days, it proceeds to its northern breeding-place in the wilds of Canada, of which we are wholly ignorant. In November I have observed a few on their return to the South, and according to Vieillot, they winter in St. Domingo and other of the larger West India islands.

Near Farranville, on the Susquehanna, within the range of the Alleghany Mountains, in the month of May, I saw and heard several pairs of this rare species in the shady hemlocktrees. The inales were uttering their slender, wiry, and very peculiar notes, while busily engaged in foraging for insects, and seemed, by being paired, to prepare for incubation.

The Pine Swamp Warbler (Syliza sphagnosa) is now considered only as the young of this species, of which, however, I think there yet remains some doubt.

The history of this species need no longer remain a mystery, for while not abundant, its nesting habits may be studied in any suitable locality in New England or northern New York, or along the higher altitudes of the Alleghanies as far down as Georgia ; though the major portion of the flocks pass on to the Canadian faunal area before stopping to build.

I did not meet with many examples in New Brunswick, and Mr. Neilson thinks it rare near Quebec city: but Mr. Wintle calls it common near Montreal, and the Ontario observers also regard it as common. It winters in Florida as well as in the West Indies.

\section{KENTUCKY WARBLER.}

\section{GEOTHLYPIS FORIOSA.}

CHAR. Above, olire; crown and sides of head and neck, black; line from nostril to and around the eye yellow; beneath, yellow, the sides shaded with olive. Length $5^{1 / 2}$ to $5^{3}+$ inches.

test. On the ground, in rather thick woods; a bulky affair of loosely laid leaves and grass, lined with vegetable down, roots, or hair.

Eggs. 4-6; white or creamy, spotted with lilac and sereral shades of brown; $0.73 \times 0.56$.

This beautiful species, first described by Wilson, frequents the dark forests of the southwestern parts of the Union, being 
particularly abundant in Louisiana, and not uncommon in Kentucky and Tennessee, and from thence inhabiting throughout the country to the estuaries of the Mississippi. It frequents low, damp woods and the desolate borders of the lagoons, cane-brakes, and swamps near the banks of the great rivers. It arrives in Kentucky about the middle of April, but enters the southern extremity of the Union from Mexico by the same time in March, and by the middle of September retires south of the United States. The males are very pugnacious in the pairing season of spring, and utter some loud notes, in threes, resembling the sound of 'tweedle tweedle tweedle. The nest is often attached to stems of stout weeds, or placed in a tuft of grass. It is made of the dry bark of herbaceous plants, mixed with downy substances, and lined with the cotton of the seed of the wild poplar. The species is scarcely known to the east of North Carolina.

In the A. O. U. check-list the habitat of this species is given as "Eastern United States, west to the Plains, and north to southern New England and southern Michigan. In winter, West Indies and Central America." It is most abundant along the Mississippi valley, and has been seen but rarely east of the Alleghanies. There is only one record of its occurrence in New England, - a pair taken in 1876 , at Suffield, Conn. Mr. John Neilson reports that a pair were frequently seen by him near the city of Quebec during the early part of July, I879.

Those who have heard the song pronounce it an attractive melody, the tones being loud and clear and the theme pleasing. $\mathrm{Mr}$. Wm. Brewster ranks it among the best of the Sylvicoline performances.

\section{CERULEAN WARBLER.}

BLUE WARBLER.

DENDROICA CAERULEA.

Char. Above, bright azure blue; back streaked with black; line of dusky blue through the eyes; wings with two white bars; all tailfeathers but inner pair spotted with white; beneath, white; breast and sides streaked with dusky blue. Length $4 \frac{1}{4}$ to 5 inches.

Nest. In open woodland, on horizontal bough 30 to 50 feet from the 
ground; of grass and lichens fastened with insect silk, lined with fine grass.

Eggs. 4; white with green or blue tint, spotted chiefly around the larger end with reddish brown and lilac; $0.70 \times 0.53$.

This very delicately colored species is among the rarest summer residents of the Atlantic States, and does not probably migrate or rather stray farther north than the State of New York. In the Southwestern States, particularly Tennessee and West Florida, it is one of the most abundant species; it is also found in the western wilderness beyond the Mississippi. It is only in the summer that it ventures into the Middle States, from which it retires almost before the first chills of autumn, or by the middle of August. It frequents the borders of streams and marshes, and possesses many of the habits of the Flycatchers, warbling also at times in a lively manner, and though its song be short, it is at the same time sweet and mellow.

The principal range of this daintily dressed songster is through the southwestern division of this Eastern Province, between the valley of the Mississippi and the Alleghanian hills, north to Ohio (where it is abundant), southern Ontario, Indiana, and Illinois. It occasionally wanders eastward to central New York, Rhode Island, and Connecticut. 


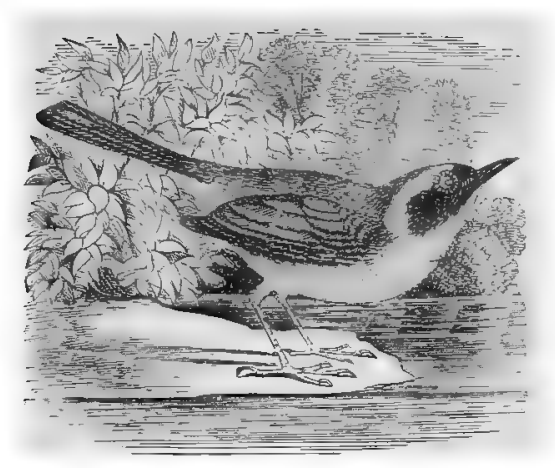

\section{MARYLAND YELLOW-THROAT.}

\section{GEOTHLYPIS TRICHAS.}

Char. Above, olive, duller on the head, brighter on rump; forehead and broad band on side of head black, with whitish border; beneatl rich yellow, paler on the belly. Length $43 / 4$ to $5^{\frac{1}{2}}$ inches.

Nest. Hidden by tuft of grass, or amid thicket of briers, usually in a moist woodland or on border of swamp ; composed exteriorly of loosely laid grass, twigs, etc., lined with fine grass compactly woven.

Eggs. 4-6; white, sometimes creamy, spotted around larger end with brown and lilac; often a few black spots and lines; $0.70 \times 0.52$.

This common and familiar species extends its summer migrations from Florida to Nova Scotia, arriving in Pennsylvania towards the middle of April, and in this part of New England about the first week in May. The majority return to the South in September; a few stragglers of the young, however, may be seen to the first week in October, and though some may remain and winter in the Southern States, it is more probable that the main body retire at this season into the interior of tropical America, as they were seen late in autumn around Vera Cruz by the naturalist and traveller Mr. Bullock. Early in the month of March, however, I heard this species singing in the forests of West Florida.

The Maryland Yellow-Throat, with cheerful devotedness to the great object of his summer migration, - the attachments and cares of his species, - passes his time near some shady rill of water, amidst briers, brambles, alders, and such other shrubbery as grows in low and watery situations. Unambitious to be seen, 
he seldom ascends above the tops of the underwood, where he dwells, busily employed in collecting the insects on which he feeds. After these, like the Wren, he darts into the deepest thicket, and threads his devious way through every opening; he searches around the stems, examines beneath the leaves, and raising himself on his peculiarly pale and slender legs, peeps into each crevice in order to seize by surprise his tiny lurking prey. While thus engaged, his affection to his neighboring mate is not forgotten, and with a simplicity, agreeable and characteristic, he twitters forth at short intervals his 'whititetee 'whititetee 'whititetee, but his more common song is 'whittitshee' whitittshee, or 'wetitshee wetitshee wee; and sometimes I have heard his note like, 'wetitshee wetitshee, 'wit'yu we. On this last syllable a plaintive sinking of the voice renders the lively, earnest ditty of the active minstrel peculiarly agreeable. Copying apparently from the Cardinal Bird, the song was, in one instance, which came to my notice, 'vitiyu 'vitiyu 'vitiyu. The whole is likewise often varied and lowered into a slender whisper, or tender revery of vocal instinct. Sometimes he calls out, teetshoo, teetshoo, and serwaidedit sewaiderdit sewaiditsewee, or sewaididit sewaiditsiwee, as he busily darts through the blooming and odor-breathing shrubs of the grove or garden, which he examines with minute attention, and sometimes springs perpendicularly after his retreating and discovered prey. He appears by no means shy or suspicious, as long as his nest is unapproached; but for the safety of that precious treasure he scolds, laments, and entreats with great anxiety.

The species generally nest in the recluse thickets of the forest, or the low bushy meadow; but sometimes they take up their abode in the garden, or the field contiguous to the house, and if undisturbed, show a predilection for the place which has afforded security to themselves and their young. They cornmence their labor of building about the middle of May, fixing the nest on or near the ground, among dry leaves, withered grass, or brush, and choose often for security the most intricate thicket of briers, so that the nest is often sheltered 
and concealed by projecting weeds and grass. Sometimes a mere tussuck of grass or accidental pile of brush is chosen. It is made of dry sedge-grass (Carex), and a few leaves loosely wound together and supported by the weeds or twigs where it rests; the lining consists entirely of fine bent-grass (Agrostis). The young leave the nest, here, about the middle of June, and a second brood is sometimes raised in the course of the season. 'The parents and young now rove about in restless prying troops, and take to the most secluded bushy marshes, where they pass their time in comparative security till the arrival of that period of scarcity which warns them to depart. As early as the close of July, the lively song of the male ceases to be heard, and the whole party now forage in silence.

This species is common throughout the settled portions of Canada, from the Atlantic to Lake Huron.

Note. - The Western form has lately been separated from true trichas and given varietal rank with the name $G$. trichas occidentalis. Its habitat is from the Mississippi valley to the Pacific. It is somewhat larger and more brightly colored than is the eastern race. Another geographical race, the FLORIDA YELLOW-THROAT ( $G$. trichas ignota), - lately described by Mr. Frank M. Chapman from specimens taken in Florida and Georgia, - differs from typical trichas in having the yellow of under parts of deeper shade and greater extent; the facial mask is wider also.

\section{MOURNING WARBLER.}

Geothlypis Philadelphia.

CHAR. Above, olive; head, neck, and breast ashy; breast mottled with black; remainder of under parts yellow. Length $5 \frac{1}{4}$ to $5 \frac{1}{2}$ inches.

$\Lambda_{c}^{t}$ ist. In open woodland or pasture, on the ground or in low tree or bush; of vegetable fibre, lined with hair.

Eggs. 3-5; white or creamy, with brown and lilac spots wreathed around the larger end; $0.70 \times 0.54$.

Wilson, the discoverer of this curious species, never met with more than a single individual, which in its habits of frequent- 
ing marshy ground, and filting through low bushes in quest of insects, appears very similar to the Maryland Yellow-throat. The discoverer, however, also distinguished it more importantly by the novelty of its sprightly and pleasant warble; we may therefore perhaps consider it as a solitary straggler from the main body in the western regions of this vast continent. It was shot in the early part of June near Philadelphia.

On the 2 oth of May, I83I, I saw, as I believe, the male of this species in the dark shrubbery of the Botanic Garden (Cambridge). It possessed all the manners of the common species, was equally busy in search of insects in the low bushes, and at little intervals warbled out some very pleasant notes, which though they resembled the lively chant of the Maryland Yellow-throat, even to the wetitshee, yet they were more agreeably varied, so as to approach in some degree the song of the Summer Yellow Bird (Syliia astiva). This remarkable note, indeed, set me in quest of the bird, which I followed for some time; but at last, perceiving himself watched, he left the garden. As far as I was able to observe this individual, he was above of a dark olive-green, very cinereous on the fore part of the head, with a band of black through the eyes, which descended from the side of the neck, where at length it joined with a crescent of dusky or black spots upon the breast; the throat was yellow and the under parts paler.

Mr. Townsend saw a specimen on the shady borders of the Schuylkill in the month of May last, and a second individual has been obtained by Mr. De Rham in the vicinity of New York. Two or three other specimens have also been obtained in the vicinity of Philadelphia and in New Jersey. It is, however, still a very rare species, and its proper habitation is yet to be discovered.

This is still a rare bird in many localities, and it is among the desiderata of most collectors; yet within the limits of its favorite breeding areas, - at the higher altitudes of the Alleghanies; on the Berkshire Hills; along the northern borders of Vermont and New Hampshire; in portions of New York; and elsewhere between the Atlantic coast and the Plains where suitable conditions of environ. 
ment are obtainable, - the Mourning Warbler is not at all rare, and in the West - in Minnesota, Dakota, and Manitoba - it is decidedly abundant. Evidently it has no special liking for the Maritime Provinces nor for any portion of Canada east of Lake Winnipeg, for Canadian observers in general report it rare or uncommon. Yet one of the few nests that have been discovered was secured by Mr. Kells, near Listowel, in Ontario. This nest was in a cedar swamp and placed on the horizontal branch of a small tree quite close to the ground.

The examples I saw in New Brunswick were in small flocks, and were a very busy and very merry company, - busy in searching for their food, moving in most sprightly and vivacious manner, and making merry with sweet voices. The song consists of a few simple notes, though sometimes, when hovering while on the wing, it is more elaborate.

\title{
CONNECTICUT WARBLER.
}

\author{
GRAY-HEADED WARBLER.
}

Geothlypis aGilis.

Char. Above, olive; head, neck, and breast ashy, darkest on breast and crown; white ring around the eyes; chest and belly yellow, sides shaded with olive. Length $5^{1 / 2}$ to 6 inches.

Nest. Hidden on a tuft of weeds, or sunk in mossy mound, in swampy woods; composed of dried grass.

Eggs. 4-?; creamy, spotted, chiefly around the larger end, with black, brown, and lilac; $0.75+0.55$.

This rare species, discovered by Wilson in Connecticut and afterwards in the neighborhood of Philadelphia, appears to frequent low thickets, and is exceedingly active in pursuit of its prey, scarcely remaining a moment in the same place. Wilson afterwards shot two specimens of a bird which in every particular agreed with the above, except in having the throat dull buff instead of pale ash. These were both females, as he supposed, of the present species.

The history of this bird is still interestingly obscure, so much has yet to be learned; but gleaning from records made by observers in various parts of the country, I am enabled to add a little to Nuttall's account. 
The bird has been taken throughout the greater part of this Eastern Province; but its distribution appears, from the evidence so far gathered, to be somewhat peculiar. It winters in Mexico and southward, and in the spring migrates wholly along the $\mathrm{M}$ ississippi valley, where it is more or less abundant north to Manitoba, though it is rarely seen at that season to the eastward of Illinois. It breeds in Minnesota, Dakota, and Manitoba, and in the au. tumn part of the flocks go south along the Mississippi, while others pass eastward along the shores of the Great Lakes, and thence to Massachusetts, the most northern limit of the bird's range on the Atlantic side, where it is common during the first half of September, after which the flocks continue on a gradual movement southward.

Dr. Wheaton considered the species very rare in Ohio, and it was thought to be rare in Ontario until 1884 , when my friend William Saunders found it common in the vicinity of London. The only nest yet taken was discovered by another friend and fellowworker Ernest Thompson. It was found near Carberry, Manitoba, in I883, sunk amid a mossy mound in a tamarack swamp, - "a dark, gray waste."

In the West, during the spring migrations, these birds are exceedingly active and very shy, moving incessantly among the branches in quest of insects, and when approached darting into the thickest covers; but those I saw on the Fresh Pond marsh at Cambridge fed chiefly on the ground, among the leaves, and when disturbed flew generally but a short distance to a low branch, and sat as composedly as a Thrush.

Thompson describes the song as similar to the Golden-crowned Thrush, and says it may be suggested by the syllables beecherbeecher-beecher-beecher-beecher-beecher, sung at the same pitch throughout. 


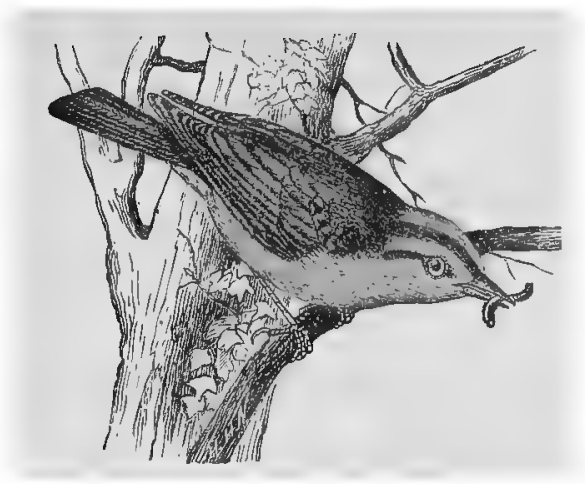

WORM-EATING WARBLER.

\section{Helmitherus vermivorus.}

CHAR. Above, olive; head buff, with four stripes of black; beneath, buff, paler on belly. Length $5 \frac{1 / 2}{2}$ to $5 \frac{3}{4} 4$ inches.

Nest. On the ground, often covered by a bush, or beside a fallen $10 g$; of leaves, moss, and grass, lined with moss. fine grass. or hair.

Eggs. 3-6 (usually 5); variable in shape and color; white, sometimes with buff or pink tint, marked with fine spots of reddish brown and lilac; $0.70 \times 0.55$.

These birds arrive in Pennsylvania about the middle of May, and migrate to the South towards the close of September; they were seen feeding their young in that State about the $25^{\text {th }}$ of June by Wilson, so that some pairs stay and breed there. They are very active and indefatigable insect-hunters, and have the note and many of the manners of the Marsh 'Titmouse or Chickadee. About the 4 th of October I have seen a pair of these birds roving through the branches of trees with restless agility, hanging on the twigs and examining the trunks, in quest probably of spiders and other lurking and dormant insects and their larvæ. One of them likewise kept up a constant complaining call, like the sound of tshe de de.

According to Richardson this species visits the fur countries, where a single specimen was procured at Cumberland House, on the banks of the Saskatchewan. It is found also in Maine and the British Provinces of New Brunswick and Nova Scotia. Dr. Bachman says that it breeds sparingly in the 
swamps of Carolina, as he observed a pair followed by three or four young ones nearly fledged, all of which already exhibited the markings on the head.

Richardson led Nuttall into a mistake regarding the distribution of this species. It is a Southern bird, breeding chiefly south of latitude $40^{\circ}$, and occurs but rarely along the northern limit of its range, - southern New England, the southern shores of Lake Erie, and northern Illinois. It has not been taken in the Provinces.

Usually these birds feed on the ground among the dead leaves, but sometimes rise amid the branches, as described by Nuttall. They are not "shy" birds, for they will remain on the nest until fairly driven off, and when feeding are apparently indifferent about being watched.

\section{SWAINSON'S WARBLER.}

\section{Helinaia swainsoni.}

CHAR. Above, dull olive, head and wings tinged with reddish brown; dark streak through the eyes; line over eyes and under parts white with yellow tint; sides tinged with olive. Length $5 \frac{1}{2}$ to 6 inches.

Nest. In a swamp, or near stagnant pool, or on dry upland; in canestalk or on bush, 4 to ro feet from the ground; a bulky and inartistic affair of dead leaves, lined with roots and pine-needles.

Eggs. 3-4; white with blue tint, unmarked; $0.75 \times 0.60$.

Dr. Bachman, who discovered this species near the banks of the Edisto River, in South Carolina, remarks: "I was first attracted by the novelty of its notes, four or five in number, repeated at intervals of five or six minutes apart. These notes. were loud, clear, and more. like a whistle than a song. They resembled the sound of some extraordinary ventriloquist in such a degree that I supposed the bird much farther off than it really was; for after some trouble caused by these fictitious notes, I observed it near me, and soon shot it." These birds appear to have a predilection for swampy, muddy places, usually more or less covered with water. They feed on coleopterous insects and the larvæ which infest the pond-lily. They usually keep in low bushes, and retire southward at the close of summer. They breed, it appears, in South Carolina. 
Until recently, naturalists knew nothing more of this species than Nuttall put into the above few lines; and for that information he was indebted to Audubon. Only three examples were taken between Audubon's time and 1873 , when Nathan C. Brown captured three more in Alabama; and eleven years afterwards, in 1884 , William Brewster collected fifty specimens in the vicinity of Charleston, and published in "The Auk" for January, 1885, an interesting account of the bird's habits.

He reports that he met with this bird in dry, scrubby woods or open orange-groves, though it prefers the ranker growth of the swamps, to which it appears to be confined during the breeding season. Its song is said to be "very loud, very rich, very beautiful, while it has an indescribable tender quality that thrills the senses after the sound has ceased."

The distribution of the species has not yet been very satisfactorily determined, but it probably occurs in all the South Atlantic and Gulf States, and along the Mississippi valley north to Illinois and Indiana.

\section{PROTHONOTARY WARBLER.}

\section{Protonotaria citrea.}

CHAR. Head, neck, and under parts golden yellow; back bright olive; wings, tail, and rump, bluish ash; inner webs of tail-feathers white. Length about $5^{\mathrm{T}} / 2$ inches.

Nest. On the margin of a stream or pond or in a swamp; a cavity in dead tree, often a deserted nest of Woodpecker or Chickadee, generally near the ground; lined with leaves and moss.

Eggs. 4-7 (usually 6); white, or with buff tint, thickly spotted with brownish red; $0.70 \times 0.55$.

This beautiful species inhabits the Southern States commonly in summer, being plentiful in the low, dark, and swampy forests of the Mississippi near New Orleans, as well as in Louisiana and the wilds of Florida. In these solitary retreats individuals are seen nimbly flitting in search of insects, caterpillars, larvæ, and small land shells, every now and then uttering a few creaking notes scarcely deserving the name of song. They sometimes, though very rarely, proceed as far north as Pennsylvania. They appear to affect watery places in swamps which abound with lagoons, and are seldom seen in the woods. According to

VOL. I. - I 7 
Dr. Bachman, these birds breed in South Carolina, as he saw a pair and their young near Charleston.

This species is common in the Gulf States, and ranges along the Mississippi valley, being peculiarly abundant in southern Illinois and southwestern Indiana, but near the Atlantic is rarely seen north of Georgia. A few stragglers have been encountered in New England, while one has been taken at St. Stephen, New Brunswick, by Mr. George A. Boardman, and another near Hamilton, Ontario, by H. C. McIlwraith.

It is said to be more deliberate and thrushlike in its movements than are its sprightly congeners, the Dendroica. The song most frequently heard is described as a simple but pleasing whistle, like that of the solitary Sandpiper, though when the singer is near at hand, almost startling in its intensity. Mr. Brewster mentions hearing another song delivered on the wing, and intended for the ear of the mate alone. It is generally heard only after incubation has commenced, and is low, but very sweet, and resembles somewhat the song of a Canary, delivered in an undertone.

\section{BLUE-WINGED IVARBLER.}

\section{HELMINTHOPHILA PINUS.}

Char. Above, bright olive; wings and tail dull blue; wings with two white bars; tail with several white blotches; black line through the eye ; crown and under parts yellow. Length about 5 inches.

Nest. In a tuft of grass amid thicket of underbrush or along margin of woods; bulky, and loosely made of dried leaves and vegetable fibre, lined with fine grass.

Eggs. 4-5; white, faintly speckled with brown; $0.60 \times 0.50$.

About the beginning of May this species enters Pennsylvania from the South, and frequents thickets and shrubberies in quest of the usual insect food of its tribe. At the approach of winter, very different from the Pine Warbler, with which it has sometimes been confounded, it retires to pass the winter in tropical America, having been seen around Vera Cruz in autumn by Mr. Bullock. On its arrival it frequents gardens, orchards, and willow trees, gleaning among the blossoms, but at length withdraws into the silent woods remote, from the 
haunts of men, to pass the period of breeding and rearing its young in more security.

The apparent distribution of this species, judged by the records of recent observations, is somewhat peculiar. It seems to be abundant in the southwestern portion of this Eastern Province, and rarely ranges east of the Alleghanian hills until north of $40^{\circ}$, when it spreads off to the shores of the Atlantic, though seldom going beyond latitude $42^{\circ}$. A few examples only have been taken in Massachusetts, and though common in Ohio it has not been seen in Ontario. Farther west it is found north to the southern portions of Michigan, Wisconsin, and Minnesota. It winters south to eastern Mexico and Guatemala.

The nests that have been discovered in recent years are not fashioned like that described by Wilson, for instead of being funnel-shaped, they have the ordinary cup-like form.

Opinions differ regarding the song, but I am inclined to believe that it is a rapid trill of strong, sweet tones, limited in compass and executed with little art, - a merry whistle rather than an artistic melody. 


\title{
GOLDEN-WINGED WARBLER.
}

\author{
HELMINTHOPHILA CHRYSOPTERA.
}

Char. Above, bluish gray; crown yellow; side of head yellowish white, with broad patch of black from bill through eyes; two wing-bars, yellow; blotches on tail white; beneath, white tinged with yellow; throat black; sides tinged with gray. Length about 5 inches.

Nest. Amid a tuft of long grass, in moist meadow or damp margin of woods ; constructed of shreds of bark, roots, etc., lined with fine grass.

Eggs. 4-6; white spotted with brown and lilac; $0.65 \times 0.50$.

This scarce species appears only a few days in Pennsylvania about the last of April or beginning of May. It darts actively through the leafy branches, and like the Titmouse examines the stems for insects, and often walks with the head downwards; its notes and actions are also a good deal similar, in common with the Worm-eating Warbler. I have never yet seen it in Massachusetts, and if it really does proceed north to breed, it must follow a western route.

The Golden-wing still remains a somewhat "scarce" bird, but it occurs regularly in Connecticut and southern Massachusetts, and in some few localities is often quite numerous. Its general breeding area lies north of latitude $40^{\circ}$, though nests have been found among the hills of Georgia and North Carolina. To the westward it breeds in Ohio, southern Michigan, Wisconsin, and Minnesota, and in the vicinity of London, Ontario, where Saunders reports it quite common. It winters south to Central America. 


\section{B A C H MA N'S WARBLER.}

\section{HELMINTHOPHILA BACHMANT.}

Char. Above, olive; head dull ashy; black band across crown; forehead and underparts yellow, with large patch of black on the breast; yellow band on wing. Length $4 \frac{1}{2}$ inches.

Nest. In a low tree.

Eggs. 4; dull white, heavily wreathed around larger end with dark brown and spotted with lilac; $0.74 \times 0.60$.

This species was first obtained a few miles from Charleston, S. C., in July 1833 , by Dr. Bachman, after whom it is named. It appears to be a lively, active species, frequenting thick bushes, through which it glides after insects, or occasionally, mounting on wing, it seizes them in the air. Several individuals were seen in the same neighborhood.

Nothing more was heard of this interesting bird than the little told by Audubon and Nuttall, until r 883 , when Mr. H. B. Bailey described the nest and eggs from examples collected in Georgia, by Dr. S. W. Wilson, somewhere between 1853 and 1865 . The male and female secured by Dr. Bachınan were the only specimens taken until 1886, when a third was shot by Charles S. Galbraith, in Louisiana, and announced by Mr. George N. Lawrence in "The Auk " of January, 1887. A fourth, taken in Florida in March, 1887 , was announced by Dr. Merriam, and during that year others were reported. Since then the bird has been discovered to be fairly common in the South Atlantic and Gulf States.

It is described as an active, quarrelsome bird, wary and difficult to approach. When searching for food, its manner is suggestive of the Parula. It frequents both shrubbery and high trees, but shows a preference for the latter and for a rather thick growth.

\section{TEN NESSEE WARBLER.}

\section{HeLminthophila PEREgRINA.}

Char. Above, olive, brightest on rump, shading to ashy on head; wings and tail dusky; beneath, white, with faint tint of yellow; sides tinged with gray. Length $4 \frac{1}{2}$ to $4 \frac{3}{4}$ inches.

Nest. On a low bush in open woodland; made of grass, moss, and vegetable fibre, lined with hair. 
Eggs, o-o (probably 4 or 5 ); white, wreathed around larger end with brown and purplish spots: $0.65 \times 0.50$ (?).

This rare and plain species was discovered by Wilson on the banks of Cumberland River, in the State of Tennessee. It was hunting with great agility among the opening leaves in spring, and like the rest of the section to which it appertains, possesses a good deal of the habits of the Titmouse. Its notes were few and weak, and its food, as usual, smooth caterpillars and winged insects. It is still so rare that Audubon never saw more than three individuals, - two in Louisiana, and one at Key West in East Florida, all of which were males.

Ornithologists of the present day do not consider this Warbler quite so rare as did Nuttall and his contemporaries, though it is somewhat local in its distribution, and is only met with occasionally at many places within its range. In the Eastern States it is rather rare, excepting on the northern border of New York and New England, where it breeds; but it is more numerous in the Mississippi valley, and Dr. Coues found it migrating in abundance along the Red River, through Minnesota and Dakota, while Thompson reports it as "a common summer resident" in parts of Manitoba. Dr. Wheaton considered it rare in Ohio, but Saunders reports it "common at times" in the southern peninsula of Ontario, while McIlwraith has seen it but twice near Hamilton. It is rare in the Ottawa valley and near the city of Quebec, while common near Montreal. Comeau says it breeds in numbers near Point de Monts, on the north shore of the Gulf of St. Lawrence, and Macoun reports it common around Lake Misstissini. It is not uncommon in some few localities in New Brunswick, where it remains all summer. Mr. Walter Faxon reports seeing an example on Graylock and another on the White Mountains. Very few nests have been discovered, and one of these was taken near Springfield, Mass.

It is an active bird and very wary, always on the alert, - darting rapidly from branch to branch. The song is a sweet-toned, cheery whistle, - somewhat similar to that of the Nashville. 


\section{NASH VILLE WARB LER.}

\section{HeLminthophila RUFicapilla.}

CHAR. Above, olive, brighter on rump; head ashy gray, with concealed patch of reddish brown; yellow ring around the eyes; beneath, bright yellow, paler on the belly; sides shaded with olive. Length $4 \frac{1}{2}$ to 5 inches.

Nest. Amid a tuft of weeds in pasture or open woodland; composed of leaves and vegetable fibre, lined with grass, pine-needles, or hair.

Eggs. 3-5 (usually 4); white or creamy, marked with fine spots of reddish brown and lilac; $0.60 \times 0.50$.

This rare species was discovered by Wilson in the vicinity of Nashville in Tennessee; it also exists in the neighboring States in summer, and occasionally proceeds as far north as Philadelphia, and even the neighborhood of Salem in this State [Massachusetts]. Its discoverer was first attracted to it by the singular noise which it made, resembling the breaking of small, dry twigs, or the striking together of pebbles, for six or seven times in succession, and loud enough to be heard at the distance of thirty or forty yards. A similar sound, produced, no doubt, by the smart snapping of the bill, is given by the Stonechat of Europe, - which hence, in fact, derives its name. Audubon says, the male, while standing in a still and erect posture, utters a few low, eagerly repeated, creaking notes. This species has all the active habits of the family to which it more particularly belongs. Audubon says that these birds are not in fact rare, as he saw them in considerable numbers in the month of April, towards Texas, on their way eastward; he also saw-them in Maine and the Provinces of New Brunswick and Nova Scotia. A few proceed to Labrador, and Dr. Richardson mentions the occurrence of a straggler in the fur countries.

However rare the Nashville may have been when Nuttall lived in Cambridge, it is not a rare bird here to-day. It is, indeed, a common summer resident throughout New England and the Maritine Provinces, and occurs in more or less abundance westward to Manitoba. It winters south to Mexico and Guatemala.

On the arrival of these birds in the spring they frequent the sub- 
urban gardens and orchards, but soon retire to a more secluded place to build; and hidden away amid the thicker bushes of their favorite haunts, are often overlooked by the collector, - the ornithological reporter, - and thus the species has acquired a reputation of being " uncommon."

The song is a typical Warbler-like performance, - a short trill of sweet notes, whistled with little variation in tone, and little effort at artistic execution; but I have not heard any of the "harsh" and "creaking" effects noted by some writers.

\section{ORANGE-CROWNED WARBLER.}

\section{Helminthophila CElata.}

CHAR. Above, olive, brightest on the rump; crown with concealed patch of brownish orange; line over and around the eyes, pale yellow; beneath, pale greenish yellow; sides shaded with olive. Length $4 \frac{\mathrm{T}}{2}$ to $5 \%$ inches.

Nest. On the ground among clumps of bushes; made of grass, moss, and plant stems, lined with hair.

Eggs. 4-6; white or creamy, marked, chiefly around the larger end, with spots of reddish brown and purplish slate; $0.65 \times 0.50$.

This species, first discovered, early in May, on the banks of the Missouri by my friend Mr. T. Say, appeared to be on its passage farther north. It is not uncommon in winter in the orange-groves of West Florida, where it proceeds to pass the season, around St. Augustine; and its note is described as a mere chirp and faint squeak, scarcely louder than that of a mouse.

According to Audubon, these birds breed in the eastern part of Maine and in New Brunswick and Nova Scotia. In the month of May we saw them abundant in the forests of the Oregon, where no doubt they breed. The song is weak, somewhat resembling that of most of the Sylvicolas.

Audubon must have gathered in all the New Brunswick Orange Crowns, for none have been seen there since his visit, nor can I learn of any having been observed elsewhere in eastern Canada, excepting the few discovered by McIlwraith and Saunders in 
southern Ontario, and one taken by Ernest D. Wintle near Montreal in $\mathbf{1} 890$.

Accidental stragglers have been taken in New England, but it is chiefly a Western bird, breeding in the far North, though it winters in the Southern and Gulf States.

\section{KIRTLAND'S WARBLER.}

\section{DENDROICA KIRTLANDI.}

Char. Above, slate blue, the feathers of head and back streaked with black; line across forehead and through the eyes, black; beneath, yellow, breast and sides spotted with black; two white wing-bars; white blotches on tail. Length $5^{1 / 2}$ to 6 inches.

Nest and Eggs. Unknown.

Only a few specimens of this bird, discovered by Dr. Kirtland, near Cleveland, in $185 \mathrm{r}$, have as yet been seen, and these few were captured in Ohio, Michigan, Wisconsin, and Missouri during the spring migrations. Mr. Charles B. Cory secured one in the Bahamas in winter. The habits of the bird are unknown, but $\mathrm{Mr}$. Chubb, who shot a male and female near Cleveland in I880, says: "I am inclined to think they are rather terrestrial in their habits, frequenting bushy fields near woods."

Note. - The Carbonated Warbler (Dendroica carbonata), mentioned by Nuttall on the authority of Audubon, who killed two specimens in Kentucky, has been placed on the "Hypothetical List" by the A.O. U. Committee, as has also the Blue Mountain Warbler (Dendroica montana) and the SMALL-HeAded WARBLER (Sylvania microcephala), mentioned by Wilson and Audubon. No specimens of either have been taken in recent years. On this same list has been placed the Cincinnati Warbler ( $\mathrm{Hel}$ minthophila cincinnatiensis), which is probably a hybrid of $H$. pinus and $G$. formosa; also LAwRENCE'S WARBLER (H. lawrenci) and BREwSTER'S WARBLER (H. leucobronchialis), both supposed to be hybrids of $H$.pinus and $H$. chrysoptera.

Mr. F. M. Chapman states that he saw a typical leucobronchialis in New Jersey in May, 1890.

TOWNSEND's WARBIER (Dendroica townsendi), described by Nuttall and named in honor of its discoverer, is a rare bird of the Far West, and its claim to mention here rests on the accidental occurrence of one example near Philadelphia in 1868. 


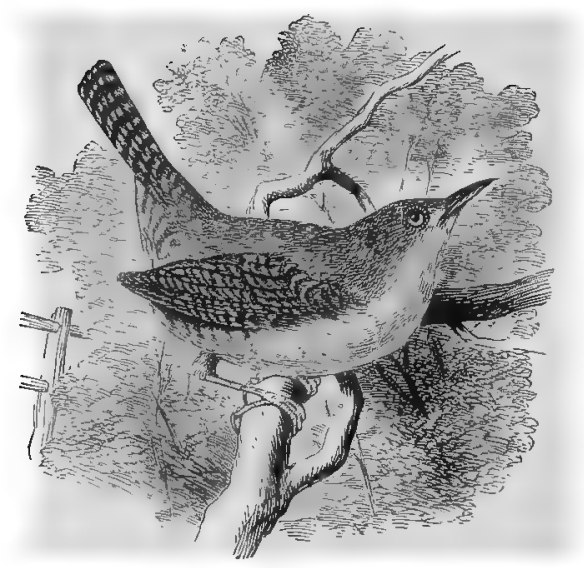

HOUSE WREN.

WOOD WREN.

TROGLODYTES AÉDON.

Char. Above, reddish brown (sometimes with dark bars), darker on the head; below, brownish white, marked irregularly with dark lines; wings and tail with fine waved lines. Length about 5 inches.

Nest. On the eaves of houses or in a barn or hollow tree, etc.; made of grass, twigs, etc.; the hole generally filled with rubbish and lined with feathers.

Eggs. 7-9; white tinted with pink, densely marked with reddish brown; $0.65 \times 0.50$.

This lively, cheerful, capricious, and well-known little minstrel is only a summer resident in the United States. Its northern migrations extend to Labrador, but it resides and rears its young principally in the Middle States. My friend $\dot{M}$ r. Say also observed this species near Pembino, beyond the sources of the Mississippi, in the Western wilderness of the $49^{\text {th }}$ degree of latitude. It is likewise said to be an inhabitant of Surinam, within the tropics, where its delightful melody has gained it the nickname of the Nightingale. This region, or the intermediate country of Mexico, is probably the winter quarters of our domestic favorite. In Louisiana it is unknown even as a transient visitor, migrating apparently to the east of 
the Mississippi, and sedulously avoiding the region generally inhabited by the Carolina Wren. It is a matter of surprise how this, and some other species, with wings so short and a flight so fluttering, are ever capable of arriving and returning from such distant countries. At any rate, come from where it may, it makes its appearance in the Middle States about the I 2 th or I $5^{\text {th }}$ of April, and is seen in New England in the latter end of that month or by the beginning of May. It takes its departure for the South towards the close of September or early in October, and is not known to winter within the limits of the Union.

Some time in the early part of May our little social visitor enters actively into the cares as well as pleasures which preside instinctively over the fiat of propagation. His nest, from preference, near the house, is placed beneath the eaves, in some remote corner under a shed, out-house, barn, or in a hollow orchard tree; also in the deserted cell of the Woodpecker, and when provided with the convenience, in a wooden box along with the Martins and Bluebirds. He will make his nest even in an old hat, nailed up, and perforated with a hole for entrance, or the skull of an ox stuck upon a pole; and Audubon saw one deposited in the pocket of a broken-down carriage. So pertinacious is the House Wren in thus claiming the convenience and protection of human society that, according to Wilson, an instance once occurred where a nest was made in the sleeve of a mower's coat, which, in the month of June, was hung up accidentally for two or three days in a shed near a barn.

The nest of this species, though less curious than that of some other kinds, is still constructed with considerable appearance of contrivance. The external approach is barricaded with a strong outwork of sticks, interlaced with much labor and ingenuity. When the nest, therefore, is placed beneath the eaves, or in some other situation contiguous to the roof of the building, the access to the inner fabric is so nearly closed by this formidable mass of twigs that a mere portion of the edge is alone left open for the female, 
just sufficient for her to creep in and out. Within this judicious fort is placed the proper nest, of the usual hemispherical figure, formed of layers of dried stalks of grass, and lined with feathers. The eggs, from 6 to 9, are of a reddish flesh-color, sprinkled all over with innumerable fine grains of a somewhat deeper tint. They generally rear two broods in the season: the first take to flight about the beginning of June, and the second in July or August. The young are early capable of providing for their own subsistence and twittering forth their petulant cry of alarm. It is both pleasant and amusing to observe the sociability and activity of these recent nurslings, who seem to move in a body, throwing themselves into antic attitudes, often crowding together into the old nests of other birds, and for some time roosting near their former cradle, under the affectionate eye of their busy parents, who have perhaps already begun to prepare the same nest for a new progeny. Indeed, so prospective and busy is the male that he frequently amuses himself with erecting another mansion even while his mate is still sitting on her eggs; and this curious habit of superfluous labor seems to be more or less common to the whole genus.

One of these Wrens, according to Wilson, happened to lose his mate by the sly and ravenous approaches of a cat, - an animal which they justly hold in abhorrence. The day after this important loss, our little widower had succeeded in introducing to his desolate mansion a second partner, whose welcome appeared by the ecstatic song which the bridegroom now uttered; after this they remained together, and reared their brood. In the summer of I 830 I found a female Wren who had expired on the nest in the abortive act of laying her first egg. I therefore took away the nest from under the edge of the shed in which it was built. The male, however, continued round the place as before, and still cheerfully uttered his accustomed song. Unwilling to leave the premises, he now went to work and made, unaided, another dwelling, and after a time brought a new mate to take possession; but less faithful than Wilson's bird, or suspecting some lurking danger, she 
forsook the nest after entering, and never laid in it. But still the happy warbler continued his uninterrupted lay, apparently in solitude.

The song of our familiar Wren is loud, sprightly, and tremulous, uttered with peculiar animation, and rapidly repeated; at first the voice seems ventriloquial and distant, and then bursts forth by efforts into a mellow and echoing warble. The trilling, hurried notes seem to reverberate from the leafy branches in which the musician sits obscured, or are heard from the low roof of the vine-mantled cottage like the shrill and unwearied pipe of some sylvan elf. The strain is continued even during the sultry noon of the summer's day, when most of the feathered songsters seek repose and shelter from the heat. His lively and querulous ditty is, however, still accompanied by the slower-measured, pathetic chant of the Red-eyed Flycatcher, the meandering, tender warble of the Musical Vireo, or the occasional loud mimicry of the Catbird; the whole forming an aërial, almost celestial concert, which never tires the ear. Though the general performance of our Wren bears no inconsiderable resemblance to that of the European species, yet his voice is louder, and his execution much more varied and delightful. He is rather a bold and insolent intruder upon those birds who reside near him or claim the same accommodation. He frequently causes the mild Bluebird or the Martin to relinquish their hereditary claims to the garden box, and has been accused also of sucking their eggs. Nor is he any better contented with neighbors of his own fraternity who settle near him, keeping up frequent squabbles, like other little busybodies, who are never happy but in mischief; so that upon the whole, though we may justly admire the fine talents of this petulant domestic, he is, like many other actors, merely a good performer. He is still upon the whole a real friend to the farmer and horticulturist, by the number of injurious insects and their destructive larvæ on which both he and his numerous family subsist. Bold and fearless, seeking out every advantageous association, and making up in activity what he may lack in strength, he does not confine his visits to the cottage or the 
country, but may often be heard on the tops of houses even in the midst of the city, warbling with his usual energy.

The House Wren is a common summer resident of Massachusetts, but is rarely seen north of this State.

The only instance of its occurrence in New Brunswick is that of a pair seen at Grand Falls by Mr. C. F. Batchelder. It is fairly common near Montreal and through southern Ontario, and is abundant in Manitoba. It winters in the Middle States and southward.

Note. - A Western form - distinguished from true aedon by the prevalence of gray on its upper parts and its more distinct bars on the back - occurs from Illinois and Manitoba westward. This is PARKMAN's WREN (T. aëdon parkmanii).

The WOOD WREN ( $T$. americanus), mentioned by Nuttall on the authority of Audubon, should have been referred to $T$. aëdon.

\section{WINTER WREN.}

\section{Troglodytes HIEMALIS.}

Char. Above, reddish brown, brightest on the rump, marked with dark waved lines; wings dusky, with dark bars and white spots; under parts paler brown, belly and under tail-coverts with dark bars. Length about 4 inches.

Nest. At the font of a moss covered stump, or under a fallen tree, or amid a pile of brush; composed of twigs and moss, lined with feathers.

Eggs. 4-6; white, spotted, chiefly near the larger end, with reddish brown and purple; $0.70 \times 0.50$.

This little winter visitor, which approaches the Middle States in the month of October, seems scarcely in any way distinguishable from the Common Wren of Europe. It sometimes passes the winter in Pennsylvania, and according to Audubon even breeds in the Great Pine Swamp in that State, as well as in New York. Early in the spring it is seen on its returning route to the Northwest. Mr. Say observed it in summer near the base of the Rocky Mountains; it was also seen, at the same season, on the White Mountains of New Hampshire by the scientific exploring party of Dr. Bigelow, Messrs. Boott 
and Gray, so that it must retire to the Western or mountainous solitudes to pass the period of incubation. Mr. Townsend obtained specimens of this bird in the forests of the Columbia. During its residence in the Middle States it frequents the broken banks of rivulets, old roots, and decayed logs near watery places in quest of its insect food. As in Europe, it also approaches the farm-house, examines the wood-pile, erecting its tail, and creeping into the interstices like a mouse. It frequently mounts on some projecting object and sings with great animation. In the gardens and outhouses of the city it appears equally familiar as the more common House Wren.

The Wren has a pleasing warble, and much louder than might be expected from its diminutive size. Its song likewise continues more or less throughout the year, - even during the prevalence of a snowstorm it has been heard as cheerful as ever; it likewise continues its note till very late in the evening, though not after dark.

This species is common throughout the Eastern States, breeding in northern New England and north to the Gulf of St. Lawrence, and westward through northern Ohio and Ontario to Manitoba. During the summer it occurs also, sparingly, on the Berkshire Hills in Massachusetts. It winters from about $40^{\circ}$ southward.

Had Nuttall ever met with the Winter Wren in its summer haunts; had he heard its wild melody break the stillness of the bird's forest home, or known of the power controlled by that tiny throstle and of its capacity for brilliant execution; had he but once listened to its sweet and impassioned tones, and the suggestive joyousness of its rapid trills; had Nuttall, in short, ever heard the bird sing, - he could not, surely, have damned it with such faint praise.

The song of this Wren is not well known, for the bird seldom sings beyond the nesting period, and then is rarely heard away from the woodland groves. But once heard, the song is not soon forgotten; it is so wild and sweet a lay, and is flung upon the woodland quiet with such energy, such hilarious abandon, that it commands attention. Its merits entitle it to rank among the best of our sylvan melodies. 


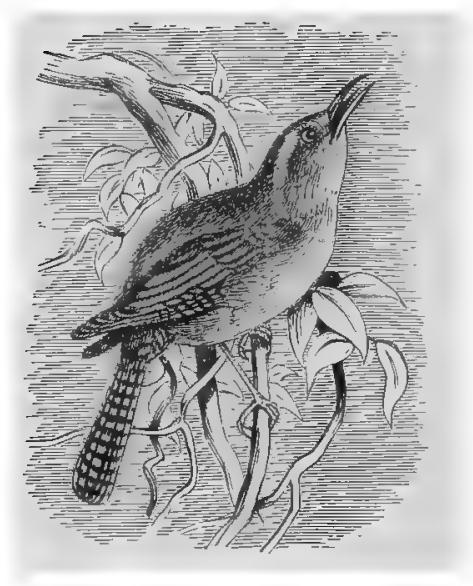

CAROLINA WREN.

MOCKING WREN.

THRYOTHORUS LUdOVICIANUS。

Char. Above, reddish brown, with fine black bars; below, tawny buff ; long line over the eye white or buff; wings and tail with dark bars. Length $5^{1 / 2}$ to 6 inches.

Nest. In any available hole, often in hollow tree, sometimes in brush heap, usually in the woods ; composed of grass, leaves, etc., sometimes fastened with corn-silk, lined with feathers, grass, or horse-hair.

Eggs. 3-6; white, with pink or buff tint, thickly speckled around larger end with reddish brown; $0.75 \times 0.60$.

This remarkable mimicking and Musical Wren is a constant resident in the Southern States from Virginia to Florida, but is rarely seen at any season north of the line of Maryland or Delaware, though, attracted by the great river-courses, it is abundant from Pittsburg to New Orleans. A few individuals stray, in the course of the spring, as far as the line of New York, and appear in New Jersey and the vicinity of Philadelphia early in the month of May. On the 17 th of April, returning from a Southern tour of great extent, I again recognized my old and pleasing acquaintance, by his usual note, near Chester, on the Delaware, where, I have little doubt, a few remain and pass the summer, retiring to the South only 
as the weather becomes inclement. On the banks of the Patapsco, near Baltimore, their song is still heard to the close of November.

Our bird has all the petulance, courage, industry, and familiarity of his particular tribe. He delights to survey the meanders of peaceful streams, and dwell amidst the shady trees which adorn their banks. His choice seems to convey a taste for the picturesque and beautiful in Nature, himself, in the foreground, forming one of the most pleasing attractions of the scene. Approaching the waterfall, he associates with its murmurs the presence of the Kingfisher, and modulating the hoarse rattle of his original into a low, varied, desponding note, he sits on some depending bough by the stream, and calls, at intervals, in a slow voice, tee-yùrh tee-yiurrh, or chr' $r^{\prime} r^{\prime} r^{\prime} r h$. In the tall trees by the silent stream, he recollects the lively, common note of the Tufted Titmouse, and repeats the peto peto peto peet, or his peevish katétédid, katétédid, katedid. While gleaning low, amidst fallen leaves and brushwood, for hiding and dormant insects and worms, he perhaps brings up the note of his industrious neighbor, the Ground Robin, and sets to his own sweet and liquids tones the simple toweet toweet toreet. The tremulous trill of the Pine Warbler is then recollected, and $t r^{\prime} r^{\prime} r^{\prime} r^{\prime} r^{\prime} r^{\prime} r h$ is whistled. In the next breath comes his imitation of the large Woodpecker, woity woity woity and wotchy wotchy wotchy, or tshovee tshovee tshof, and tshooădee tshooaldee tshooadeet, then varied to tshuvai tshuvai tshuvat, and toovaiiah toovaiiah toovaiiatoo. Next comes perhaps his more musical and pleasing version of the Blackbird's short song, wottitshee wottitshee wottitshee. To the same smart tune is now set a chosen part of the drawling song of the Meadow Lark, precĕdo precüdo preceet, then varied, recĕdo recĕdo receet and tecedo tecedo teceet; or changing to a bass key, he tunes sooteet sooteet soot. Once, I heard this indefatigable mimic attempt delightfully the warble of the Bluebird in the month of February. The bold whistle of the Cardinal Bird is another of the sounds he delights to imitate and repeat in his own quaint manner; such as vit-yì vit-yù vit-yù, and vishnu vishnu VOL. I. $-\mathrm{I} 8$ 
vishnu, then his woitee woitee woitee and wiltee wiltee wiltee. Soon after I first heard the note of the White-eyed Vireo in March, the Carolina Wren immediately mimicked the note of teeah wĕwá wittee weewá. Some of these notes would appear to be recollections of the past season, as imitations of the Maryland Yellow-Throat (wittisee wittisee wittisee wit, and shewaidit shewaidit shewaidit), not yet heard or arrived within the boundary of the United States. So also his tsherry tsherry tsherry tshup is one of the notes of the Baltimore Bird, yet in South America.

While at Tuscaloosa, about the 2oth of February, one of these Wrens, on the borders of a garden, sat and repeated for some time tshe-whiskee whiskee whiskee, then soolait soolait soolait; another of his phrases is tshukădee tshukădee tshukădeetshoo and chjoubrey chjubway chjôbway, uttered quick; the first of these expressions is in imitation of one of the notes of the Scarlet Tanager. Amidst these imitations and variations, which seem almost endless, and lead the stranger to imagine himself, even in the depth of winter, surrounded by all the quaint choristers of the summer, there is still, with our capricious and tuneful mimic, a favorite theme more constantly and regularly repeated than the rest. This was also the first sound that I heard from him, delivered with great spirit, though in the dreary month of January. This sweet and melodious ditty, tsee-toot tsee-toot tsee-toot, and sometimes tsee-toot tseetoot seet, was usually uttered in a somewhat plaintive or tender strain, varied at each repetition with the most delightful and delicate tones, of which no conception can be formed without experience. That this song has a sentimental air may be conceived from its interpretation by the youths of the country, who pretend to hear it say swĕet-heart swěet-heart swěet! Nor is the illusion more than the natural truth; for, usually, this affectionate ditty is answered by its mate, sometimes in the same note, at others, in a different call. In most cases it will be remarked that the phrases of our songster are uttered in 3's; by this means it will generally be practicable to distinguish its performance from that of other birds, and particularly from 
the Cardinal Grosbeak, whose expressions it often closely imitates both in power and delivery. I shall never, I believe, forget the soothing satisfaction and amusement I derived from this little constant and unwearied minstrel, my sole vocal companion through many weary miles of a vast, desolate, and otherwise cheerless wilderness. Yet with all his readiness to amuse by his Protean song, the epitome of all he had ever heard or recollected, he was still studious of concealment, keeping busily engaged near the ground, or in low thickets, in quest of his food; and when he mounted a log or brush pile, which he had just examined, his color, so similar to the fallen leaves and wintry livery of Nature, often prevented me from gaining a glimpse of this wonderful and interesting mimic.

Like the preceding species, he has restless activity and a love for prying into the darkest corners after his prey, and is particularly attached to the vicinity of rivers and wet places, when not surrounded by gloomy shade. His quick and capricious motions, antic jerks, and elevated tail resemble the actions of the House Wren. Eager and lively in his contracted flight, before shifting he quickly throws himself forward, so as nearly to touch his perch previous to springing from his legs. In Tuscaloosa and other towns in Alabama he appeared frequently upon the tops of the barns and out-houses, delivering with energy his varied and desultory lay. At Tallahassee, in West Florida, I observed one of these birds chanting near the door of a cottage, and occasionally imitating, in his way, the squalling of the crying child within, so that, like the Mocking Bird, all sounds, if novel, contribute to his amusement.

This species is common in the Southern States and north to $40^{\circ}$, being extremely abundant in southern Illinois, and it occasionally wanders to northern Ohio and to Massachusetts.

NOTE. - The FLORIDA WREN (T. ludovicianus miamensis) is a larger, darker form, which is restricted to southeastern Florida. 


\section{BEWICK'S WREN.}

\section{LONG-TAILED HOUSE WREN.}

\section{THRYOTHORUS BEWICKII.}

CHAR. Above, chestnut brown; wings and tail with dark bars; buff stripe over eye; below, dull white; flanks brown. Length 5 to $5^{3 / 2}$ inches.

Nest. Alnost anywhere. In settled districts it is usually built in a crevice of a house or barn; but in the woods a hollow tree or stump is selected, or a clump of bushes. Composed of a mass of leaves, grass, etc., roughly put together.

Eggs. 4-7; white or with pink tint, thickly marked with fine spots of reddish brown and purple; $0.65 \times 0.50$.

For the discovery of this beautiful species of Wren, appar. ently allied to the preceding, with which it seems nearly to agree in size, we are indebted to the indefatigable Audubon, in whose splendid work it is for the first time figured. It was observed by its discoverer, towards the approach of winter, in the lower part of Louisiana. Its manners are very similar to those of other species, but instead of a song, at this season it only uttered a low twitter.

Dr. Bachman found this species to be the most prevalent of any other in the mountains of Virginia, particularly about the Salt Sulphur Springs, where they breed and pass the season. The notes bear some resemblance to those of the Winter Wren, being scarcely louder or more connected. From their habit of prying into holes and hollow logs they are supposed to breed in such situations. Mr. Trudeau believes that they breed in Louisiana. In the marshy meadows of the Wahlamet Mr. Townsend and myself frequently saw this species, accompanied by the young, as early as the month of May. At this time they have much the habit and manners of the Marsh Wren, and probably nest in the tussocks of rank grass in which we so frequently saw them gleaning their prey. They were now shy, and rarely seen in the vicinity of our camp.

Bewick's Wren is abundant along the Mississippi valley, but is rarely seen east of the Alleghanies or north of latitude $40^{\circ}$. 


\section{SHORT-BILLED MARSH WREN.}

\section{Cistothorus STELlaRIS.}

CHAR. Above, brown, very dark on crown and back, and streaked everywhere with white; wings and tail with dark bars; below, buffy white, paler on throat and belly; breast and sides shaded with brown. Length $4 \frac{1}{2}$ inches.

Nest. On the ground, amid a tuft of high grass, in fresh-water marsh or swampy meadow; composed of grass, lined with vegetable down. Usually the tops of surrounding grass are weaved above the nest, leaving an entrance at the sicle.

Eggs. 6-8; white; $0.65 \times 0.50$.

This amusing and not unmusical little species inhabits the lowest marshy meadows, but does not frequent the reed-flats. It never visits cultivated grounds, and is at all times shy, timid, and suspicious. It arrives in this part of Massachusetts about the close of the first week in May, and retires to the South by the middle of September at farthest, probably by night, as it is never seen in progress, so that its northern residence is only prolonged about four months. In winter this bird is seen from South Carolina to Texas.

His presence is announced by his lively and quaint song of 'tsh'tship, ă dăay dăy dăy dăay, delivered in haste and earnest at short intervals, either when he is mounted on a tuft of sedge, or while perching on some low bush near the skirt of the marsh. The 'tsh 'tship is uttered with a strong aspiration, and the remainder with a guttural echo. While thus engaged, his head and tail are alternately depressed and elevated, as if the little odd performer were fixed on a pivot. Sometimes the note varies to 'tship 'tship 'tshia, $d h$ ' $d h$ ' $d h$ ' $d h$ ', the latter part being a pleasant trill. When approached too closely, which not often happened, as he never permitted me to come within two or three feet of his station, - his song became harsh and more hurried, like 'tship dă dă dă, and de de de de $d " d " d h$, or tshe de de de de, rising into an angry, petulant cry, sometimes also a low, hoarse, and scolding dargh daígh; then again on invading the nest the sound sank to a plaintive 'tsh 
tship, 'tsh tship. In the early part of the breeding season the male is very lively and musical, and in his best humor he tunes up a 'tship 'tship tship a dee, with a pleasantly warbled and reiterated $d e$. At a later period another male uttered little else than a hoarse and guttural daigh, hardly louder than the croaking of a frog. When approached, these birds repeatedly descend into the grass, where they spend much of their time in quest of insects, chiefly crustaceous, which with moths, constitute their principal food; here, unseen, they still sedulously utter their quaint warbling, and tship tship a day day day day may for about a month from their arrival be heard pleasantly echoing on a fine morning from the borders of every low marsh and wet meadow provided with tussocks of sedge-grass, in which they indispensably dwell, for a time engaged in the cares and gratification of raising and providing for their young.

The nest of the Short-billed Marsh Wren is made wholly of dry or partly green sedge, bent usually from the top of the grassy tuft in which the fabric is situated. With much ingenuity and labor these simple materials are loosely entwined together into a spherical form, with a small and rather obscure entrance left in the side; a thin lining is sometimes added to the whole, of the linty fibres of the silk-weed or some other similar material. The eggs, pure white and destitute of spots, are probably from 6 to 8 . In a nest containing 7 eggs there were 3 of them larger than the rest and perfectly fresh, while the 4 smaller were far advanced towards hatching; from this circumstance we may fairly infer that two different individuals had laid in the same nest, - a circumstance more common among wild birds than is generally imagined. This is also the more remarkable as the male of this species, like many other Wrens, is much employed in making nests, of which not more than one in three or four are ever occupied by the females.

The summer limits of this species, confounded with the ordinary Marsh-Wren, are yet unascertained; and it is singular to remark how near it approaches to another species inhabiting the temperate parts of the southern hemisphere in America, namely, the Syliva platensis, figured and indicated by 
Buffon. The time of arrival and departure in this species, agreeing exactly with the appearance of the Marsh Wren of Wilson, appears to prove that it also exists in Pennsylvania with the following, whose migration, according to Audubon, is more than a month earlier and later than that of our bird. Mr. Cooper, however, has not been able to meet with it in the vicinity of New York, but Dr. Trudeau found its nest in the marshes of the Delaware.

This Wren occurs throughout the Eastern Province north to Massachusetts on the Atlantic, and in the west to Manitoba, breeding generally north of $40^{\circ}$, and wintering in the Gulf States. It is found in eastern Canada only on the marshes near Lake St. Clair.

\section{LONG-BILLED MARSH WREN.}

\section{Cistothorus palustris.}

Char. Above, dull reddish brown, darker on crown; back black, streaked with white; white line over eyes; wings and tail with dark bars; below, buffy white, shaded on sides with brown. Length 5 inches.

Nest. In a salt marsh or reedy swamp of interior, fastened to reeds or cat-tails or a small bush; composed of grass and reeds, sometimes plastered with mud, lined with fine grass or feathers. It is bulky and spherical in form, the entrance at the side.

Eggs. 6-10; generally so thickly covered with dark-brown spots as to appear uniform chocolate with darker spots; $0.65 \times 0.50$.

This retiring inhabitant of marshes and the wet and sedgy borders of rivers arrives in the Middle States of the Union early in April, and retires to the South about the middle of October. It is scarcely found to the north of the State of New York, its place in New England being usually occupied by the preceding species, though a few individuals are known to breed in the marshes near Cambridge and Boston.

It is a remarkably active and quaint little bird, skipping and diving about with great activity after its insect food and their larvæ among the rank grass and rushes, near ponds and the low banks of rivers, where alone it affects to dwell, laying no claims to the immunities of the habitable circle of man, but content with its favorite marshes; neglected and seldom 
seen, it rears its young in security. The song, according to the observations of a friend, is very similar to that of the preceding, - a sort of short, tremulous, and hurried warble. Its notes were even yet heard in an island of the Delaware, opposite to Philadelphia, as late as the month of September, where they were still in plenty in this secluded asylum. Towards the close of the breeding season the song often falls off into a low, guttural, bubbling sound, which appears almost like an effort of ventriloquism.

The nest, according to Wilson, is generally suspended among the reeds and securely tied to them at a sufficient height above the access of the highest tides. It is formed of wet rushes well intertwisted together, mixed with mud, and fashioned into the form of a cocoa-nut, having a small orifice left in the side for entrance. The principal material of this nest, as in the preceding species, is, however, according to Audubon, the leaves of the sedge-grass, on a tussock of which it also occasionally rests. The young quit the nest about the 2oth of June, and they generally have a second brood in the course of the season. From the number of empty nests found in the vicinity of the residence of the Marsh Wren, it is pretty evident that it is also much employed in the usual superfluous or capricious labor of the genus. The pugnacious character of the males, indeed, forbids the possibility of so many nests being amicably occupied in the near neighborhood in which they are commonly found.

This Wren is common in suitable localities in Massachusetts, but has not been found farther northward. It occurs westward to the Pacific, and south (in winter) to the Gulf States. It appears on Canadian territory only in southern Ontario and Manitoba.

Note. - Mr. W. E. D. Scott discovered at Tarpon Springs, Florida, in I888, a Wren that resembles palustris, but differs in having bars on the upper and under tail-coverts; also the brown color has a more decided tinge of olive than of rufous. Mr. Scott has named the bird, in honor of his wife, MARIAN'S MARSH WREN (Cistothorus marianc). It is common along the southwestern coast of Florida. 


\section{RUBY-CROWNED KINGLET.}

\section{REGULUS CALENDULA.}

Char. Above, olive, brighter on rump; crown with a concealed patch of rich scarlet, white at the base, - wanting in female and young; white ring around the eyes; wings and tail dusky, the feathers edged with dull buff; wings with two white bars; below, dull white tinged with buff. Length about $4 \frac{1 / 4}{4}$ inches.

Nest. In woodland, usually partially pensile, suspended from extremity of branch, - often placed on top of branch, sometimes against the trunk, - on coniferous tree, Io to 30 feet from the ground; neatly and compactly made of shreds of bark, grass, and moss, lined with feathers or hair.

Eggs. 6-9; dull white or buff, spotted, chiefly around larger end, with bright reddish brown; $0.55 \times 0.43$.

These beautiful little birds pass the summer and breeding season in the colder parts of the North American continent, penetrating even to the dreary coasts of Greenland, where, as well as around Hudson's Bay and Labrador, they rear their young in solitude, and obtain abundance of the diminutive flying insects, gnats, and cynips, on which with small caterpillars they and their young delight to feed. In the months of October and November the approach of winter in their natal regions stimulates them to migrate towards the South, when they arrive in the Eastern and Middle States, and frequent in a familiar and unsuspicious manner the gardens and orchards; how far they proceed to the South is uncertain. On the I 2 th of January I observed them near Charleston, South Carolina, with companies of Sylvias busily darting through the evergreens in swampy situations in quest of food, probably minute larvæ. About the first week in March I again observed them in West Florida in great numbers, busily employed for hours together in the tallest trees, some of which were already unfolding their blossoms, such as the maples and oaks. About the beginning of April they are seen in Pennsylvania on their way to the dreary limits of the continent, where they only arrive towards the close of May, so that in the extremity of their range they do not stay more than three months. Wilson, 
it would appear, sometimes met with them in Pennsylvania even in summer; but as far as I can learn, they are never observed in Massachusetts at that season, and with their nest and habits of incubation we are unacquainted. In the fall they seek society apparently with the Titmouse and Golden-Crested Kinglet, with whom they are intimately related in habits, manners, and diet; the whole forming a busy, silent, roving company, with no object in view but that of incessantly gleaning their now scanty and retiring prey. So eagerly, indeed, are they engaged at this time that scarcely feeling sympathy for each other, or willing to die any death but that of famine, they continue almost uninterruptedly to hunt through the same tree from which their unfortunate companions have just fallen by the destructive gun. They only make at this time, occasionally, a feeble chirp, and take scarcely any alarm, however near they are observed. Audubon met with this species breeding in Labrador, but did not discover the nest; its song, he remarks, is fully as sonorous as that of the Canary, - as powerful and clear, and even more varied.

This species probably breeds from about latitude $45^{\circ}$ to the lower fur countries, and on the higher mountains to the southward. Few nests have been discovered. Rev. Frank Ritchie found one near Lennoxville, Quebec, and Harry Austen has taken another near Halifax, in which he found I I eggs.

The full song is much more elaborate and more beautiful than the bird has usually been credited with, for it has been described by writers who have heard only the thin, weak notes more generally uttered. Those who have compared it to the Skylark and the Canary have not grossly exaggerated.

Note. - CuvieR's KINGLET (Regulus cuvieri) was placed on the "Hypothetical List" by the A. O. U. Committee. The single bird shot by Audubon in Pennsylvania is the only specimen that has been obtained. 


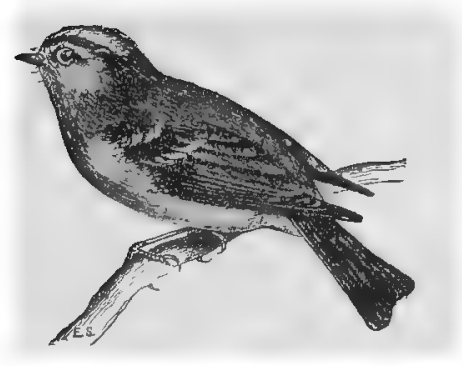

\section{GOLDEN-CROWNED KINGLET.}

\section{REgULUS SATRAPA.}

Char. Above, olive, brightest on the rump; crown with patch of orange red and yellow, bordered by black (female and young lacking the red); forehead and line over eyes and patch beneath, dull white; wings and tail dusky, the feathers edged with dull buff; two white bars on wings; below, dull white with buff tint. Length 4 inches.

Nest. In damp coniferous woods, often wholly or partially pendent from small twigs near end of branch (sometimes saddled upon the branch) ro to 50 feet from the ground; usually made of green moss and lichens, lined at bottom with shreds of soft bark and roots, and often with feathers fastened to inside of edge, and so arranged that the tips droop over and conceal the eggs; sometimes the nest is a spherical mass of moss and lichens, lined with vegetable down and wool; the entrance at the side.

Eggs. 6-1o; usually creamy or pale buff, sometimes white, unmarked, or dotted with pale reddish brown and lavender over entire surface, often merely a wreath, more or less distinct around larger end; 0.55 $\times 0.45$.

These diminutive birds are found, according to the season, not only throughout North America, but even in the West Indies. They appear to be associated only in pairs, and are seen on their southern route, in this part of Massachusetts, a few days in October, and about the middle of the month, or a little earlier or later according to the setting in of the season, as they appear to fly before the desolating storms of the northern regions, whither they retire about May to breed. Some few remain in Pennsylvania until December or January, proceeding probably but little farther south during the winter. They are not known to reside in any part of New England, retiring to the same remote and desolate limits of the farthest North with the preceding species, of which they have most of 
the habits. They are actively engaged during their transient visits to the South in gleaning up insects and their lurking larvæ, for which they perambulate the branches of trees of various kinds, frequenting gardens and orchards, and skipping and vaulting from the twigs, sometimes head downwards like the Chickadee, with whom they often keep company, making only now and then a feeble chirp. They appear at this time to search chiefly after spiders and dormant concealed coleopterous or shelly insects; they are also said to feed on small berries and some kinds of seeds, which they break open by pecking with the bill in the manner of the Titmouse. They likewise frequent the sheltered cedar and pine woods, in which they probably take up their roost at night. Early in April they are seen on their return to the North in Pennsylvania; at this time they dart among the blossoms of the maple and elm in company with the preceding species, and appear more volatile and actively engaged in seizing small flies on the wing, and collecting minute, lurking caterpillars from the opening leaves. On the 2 Ist of May, I835, I observed this species feeding its full-fledged young in a tall pine-tree on the banks of the Columbia River.

The range of this species is now set down as "Eastern North America west to the Rockies, breeding from the northern border of the United States northward, wintering in the Eastern States and south to Gautemala." Until quite recently it was supposed to be a migrant through Massachusetts, wintering in small numbers, but has been discovered breeding in both Berkshire and Worcester counties. Nests have been taken also on the Catskills. It is a resident of the settled portion of Canada, though not common west of the Georgian Bay, and rarely breeding south of latitude $45^{\circ}$

The song is a rather simple "twittered warble," shrill and highpitched. 


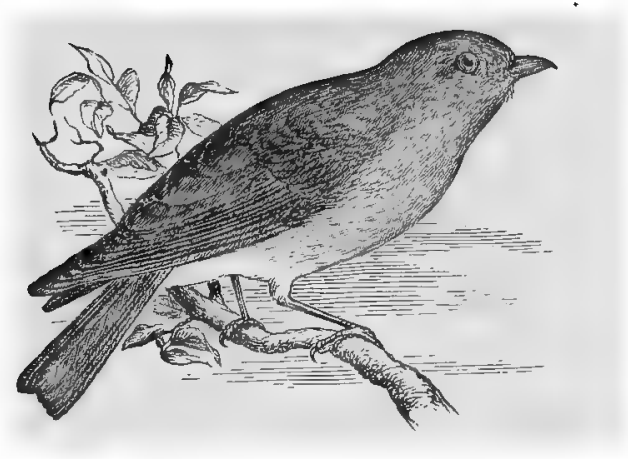

BLUEBIRD.

SIALIA SIALIS.

Char. Male : above, azure blue, duller on cheeks; throat, breast, and sides reddish brown; belly and under tail-coverts white; shafts of feathers in wing and tail, black. Female : duller, blue of back mixed-with grayish brown; breast with less of rufous tint. Length about $63 / 4$ inches.

Nest. In a hollow tree, deserted Woodpecker's hole, or other excavation or crevice, or in a bird-box; meagrely lined with grass or feathers.

Eggs. 4-6; usually pale blue, sometimes almost white; $0.85 \times 0.65$.

These well-known and familiar favorites inhabit almost the whole eastern side of the continent of America, from the 48 th parallel to the very line of the tropics. Some appear to migrate in winter to the Bermudas and Bahama islands, though most of those which pass the summer in the North only retire to the Southern States or the tableland of Mexico. In South Carolina and Georgia they were abundant in January and February, and even on the 12 th and 28 th of the former month, the weather being mild, a few of these wanderers warbled out their simple notes from the naked limbs of the long-leaved pines. Sometimes they even pass the winter in Pennsylvania, or at least make their appearance with almost every relenting of the severity of the winter or warm gleam of thawing sunshine. From this circumstance of their roving about in quest of their scanty food, like the hard-pressed and hungry Robin Redbreast, who by degrees gains such courage from necessity as to enter the cottage for his allowed crumbs, it has, without foundation, 
been supposed that our Bluebird, in the intervals of his absence, passes the tedious and stormy time in a state of dormancy; but it is more probable that he flies to some sheltered glade, some warm and more hospitable situation, to glean his frugal fare from the berries of the cedar or the wintry fruits which still remain ungathered in the swamps. Defended from the severity of the cold, he now also, in all probability, roosts in the hollows of decayed trees, - a situation which he generally chooses for the site of his nest. In the South, at this cheerless season, Bluebirds are seen to feed on the glutinous berries of the mistletoe, the green-brier, and the sumach. Content with their various fare, and little affected by the extremes of heat and cold, they breed and spend the summer from Labrador to Natches, if not to Mexico, where great elevation produces the most temperate and mild of climates. They are also abundant, at this season, to the west of the Mississippi, in the territories of the Missouri and Arkansas.

In the Middle and Northern States the return of the Bluebird to his old haunts round the barn and the orchard is hailed as the first agreeable presage of returning spring, and he is no less a messenger of grateful tidings to the farmer, than an agreeable, familiar, and useful companion to all. Though sometimes he makes a still earlier flitting visit, from the $3 \mathrm{~d}$ to the middle of March he comes hither as a permanent resident, and is now accompanied by his mate, who immediately visits the box in the garden, or the hollow in the decayed orchard tree, which has served as the cradle of preceding generations of his kindred. Affection and jealousy, as in the contending and related Thrushes, have considerable influence over the Bluebird. He seeks perpetually the company of his mate, caresses and soothes her with his amorous song, to which she faintly replies; and, like the faithful Rook, seeks occasion to show his gallantry by feeding her with some favorite insect. If a rival make his appearance, the attack is instantaneous, the intruder is driven with angry chattering from the precincts he has chosen, and he now returns to warble out his notes of triumph by the side of his cherished consort. The business of preparing and 
cleaning out the old nest or box now commences; and even in October, before they bid farewell to their favorite mansion, on fine days, influenced by the anticipation of the season, they are often observed to go in and out of the box, as if examining and planning out their future domicile. Little pains, however, are requisite for the protection of the hardy young, and a substantial lining of hay, and now and then a few feathers, is all that is prepared for the brood beyond the natural shelter of the chosen situation. As the Martin and House Wren seek out the favor and convenience of the box, contests are not unfrequent with the parties for exclusive possession; and the latter, in various clandestine ways, exhibits his envy and hostility to the favored Bluebird. As our birds are very prolific, and constantly paired, they often raise 2 and sometimes probably 3 broods in the season; the male taking the youngest under his affectionate charge, while the female is engaged in the act of incubation.

Their principal food consists of insects, particularly beetles and other shelly kinds; they are also fond of spiders and grasshoppers, for which they often, in company with their young, in autumn, descend to the earth, in open pasture fields or waste grounds. Like our Thrushes, they, early in spring, also collect the common wire-worm, or lubus, for food, as well as other kinds of insects, which they commonly watch for, while perched on the fences or low boughs of trees, and dart after them to the ground as soon as perceived. They are not, however, flycatchers, like the Sylnicolas and Muscicapas, but are rather industrious searchers for subsistence, like the Thrushes, whose habits they wholly resemble in their mode of feeding. In the autumn they regale themselves on various kinds of berries, as those of the sour-gum, wild-cherry, and others; and later in the season, as winter approaches, they frequent the red cedars and several species of sumach for their berries, eat persimmons in the Middle States, and many other kinds of fruits, and even seeds, - the last never entering into the diet of the proper Flycatchers. They have also, occasionally, in a state of confinement, been reared and fed 
on soaked bread and vegetable diet, on which they thrive as well as does the Robin.

The song of the Bluebird, which continues almost uninterruptedly from March to October, is a soft, rather feeble, but delicate and pleasing warble, often repeated at various times of the day, but most frequently in early spring when the sky is serene and the temperature mild and cheering. At this season, before the earnest Robin pours out his more energetic lay from the orchard tree or fence-rail, the simple song of this almost domestic favorite is heard nearly alone; and if at length he be rivalled, at the dawn of day, by superior and bolder songsters, he still relieves the silence of later hours by his unwearied and affectionate attempts to please and accompany his devoted mate. All his energy is poured out into this simple ditty, and with an ecstatic feeling of delight he often raises and quivers his wings like the Mocking Orpheus, and amidst his striving rivals in song, exerts his utmost powers to introduce variety into his unborrowed and simple strain. On hearkening some time to his notes, an evident similarity to the song of the Thrush is observable; but the accents are more weak, faltering, and inclining to the plaintive. As in many other instances, it is nearly impossible to give any approximating idea of the expression of warbled sounds by words; yet their resemblance to some quaint expressions, in part, may not be useless, as an attempt to recall to memory these pleasing associations with native harmony: so the Bluebird often at the commencement of his song seems tenderly to call in a whistled tone 'hear - héar büty, buty? or merely hear - büty, and instantly follows this interrogatory call with a soft and warbling trill. So much is this sound like that which these birds frequently utter that on whistling the syllables in their accent, even in the cool days of autumn, when they are nearly silent, they often resume the answer in sympathy. During the period of incubation, the male becomes much more silent, and utters his notes principally in the morning. More importantly engaged, in now occasionally feeding his mate as well as himself, and perhaps desirous of securing the interesting occupa- 
tion of his devoted consort, he avoids betraying the resort of his charge by a cautious and silent interest in their fate. Gentle, peaceable, and familiar when undisturbed, his society is courted by every lover of rural scenery; and it is not uncommon for the farmer to furnish the Bluebird with a box, as well as the Martin, in return for the pleasure of his company, the destruction he makes upon injurious insects, and the cheerfulness of his song. Confident in this protection, he shows but little alarm for his undisturbed tenement; while in the remote orchard, expecting no visitor but an enemy, in company with his anxious mate he bewails the approach of the intruder, and flying round his head and hands, appears by his actions to call down all danger upon himself rather than suffer any injury to arrive to his helpless brood.

Towards autumn, in the month of October, his cheerful song nearly ceases, or is now changed into a single plaintive note of $t \operatorname{sh} \bar{a} y$-zurt, while he passes with his flitting companions over the fading woods; and as his song first brought the welcome intelligence of spring, so now his melancholy plaint presages but too truly the silent and mournful decay of Nature. Even when the leaves have fallen, and the forest no longer affords a shelter from the blast, the faithful Bluebirds still linger over their native fields, and only take their departure in November, when at a considerable elevation, in the early twilight of the morning, till the opening of the day, they wing their way in small roving troops to some milder regions in the South. But yet, after this period, in the Middle States, with every return of moderate weather we hear their sad note in the fields or in the air, as if deploring the ravages of winter; and so frequent are their visits that they may be said to follow fair weather through all their wanderings till the permanent return of spring.

If the Bluebird ever tried the climate of Labrador, it evidently discovered that the weather there was not suitable, for now it rarely goes north of latitude $45^{\circ}$. A few pairs are seen every season about the farm-lands on the upper St. John, in New Brunswick, and Philip Cox has seen several at Newcastle, near the mouth of the Miramichi. Comeau found a pair breeding at Godbout, - the only occurrence reported recently from that latitude.

vOL. 1. - I9 


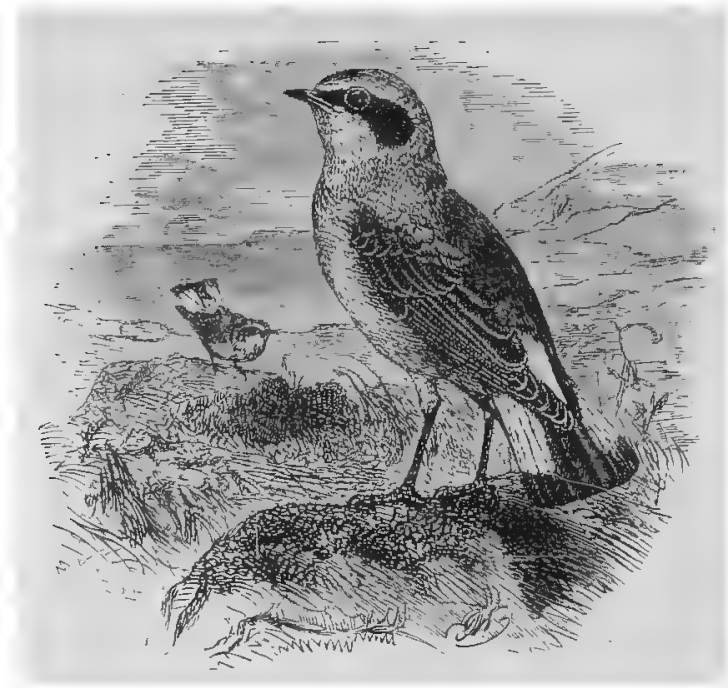

\section{WHEATEAR. \\ SAXICOLA GENANTHE.}

Char. Above, bluish gray; forehead and stripe over eyes white; patch on cheek and wings black ; rump white; middle tail-feathers black, rest white, broadly tipped with black; under parts white. In the female the upper parts are brown, and under parts buff. Length $61 / 2$ inches.

Nest. In a crevice of a stone wall or a stone heap; made of plant stems and grass, lined with feathers, hair, or rabbit's fur.

Eggs. 5-7; pale blue, sometimes spotted with pale tawny, or purple; $0.85 \times 0.65$.

The first mention of the occurrence of this species in eastern America appeared in Holböll's account of the birds of Greenland, issued in 1846; it had been reported previously from the Pacific coast by Vigors. In 1854 the name appeared in Cassin's work, and in Baird's "Report" of I859 it was recorded as "accidental in the northern part of North America."

It should not be termed accidental at the present day, for it occurs regularly in Greenland and Labrador and at Godbout, on the St. Lawrence, and has been taken in winter in Nova Scotia, Maine, New York, Long Island, Louisiana, and Bermuda.

American writers formerly gave the vernacular name as "Stonechat," or "Stone Chat," - Coues alone adding Wheatear (as a synonym). 
The Stonechat is a different bird, though Magillivray called the present species the "White-rumped Stonechat." Throughout Europe the bird is commonly known as the "White-rump," and Saunders considers the name "wheatear" a corruption of white and ars, - the Anglo-Saxon equivalent of the modern word "rump."

In Europe and Asia the species is abundant, breeding from central Europe far to the northward, and migrating in winter to north . ern Africa. A few winter in the British Islands, though these may be of the Greenland race, which some authors think is a distinct form, - larger than those that breed in Europe, - as the Greenland birds are known to migrate across Great Britain. Ridgway states that the examples taken on our western coast are smaller and more like those found in central Europe.

Formerly large numbers were trapped in the autumn on the Southdowns in England, and marketed, being considered little inferior in delicacy to the famous Ortolans.

The favorite resorts of the Wheatear at all seasons are the lonely moors or open meadows by the sea-shore. It is an active bird and always alert, keeping up a perpetual flitting. It is very terrrestrial, though the Greenland race is said to perch on trees more frequently than the European bird.

The song is sweet and sprightly, and the male often sings while hovering over his mate.

Mr. Hagerup writes to me that the birds in Greenland sing at times very similarly to the Snow Buntings, - a song that he never heard from the Wheatears of Denmark, - and this song is rendered by both females and males. 


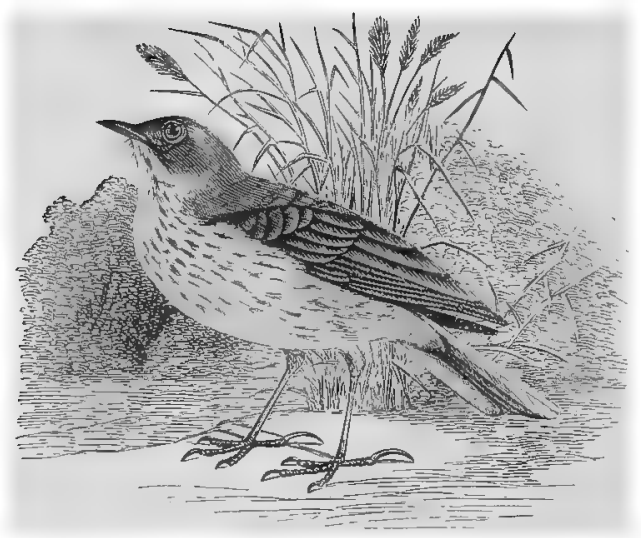

\section{AMERICAN PIPIT.}

TITLARK.

ANTHUS PENNSYLVANICUS.

Char. Above, olive brown, edges of the feathers paler; line over and around the eye pale buff; wings dusky, edges of feathers pale brown; tail dusky, middle feathers olive brown, large patches of white on outer feathers; below, dull buff, breast and sides spotted with brown. Length $6 \mathrm{~T} / 2$ inches.

Nest. On the ground, usually sheltered by stone or mound; a bulky affair of grass, stems, moss, and lichens, - sometimes only grass is used, - often loosely made, occasionally compact.

Eggs. 4-6; variable in color, usually dull white covered thickly with reddish brown and purplish brown; sometimes the markings so nearly conceal the ground color as to give appearance of a brown egg with gray streaks; $0.80 \times 0.60$.

This is a winter bird of passage in most parts of the United States, arriving in loose, scattered flocks from the North, in the Middle and Eastern States, about the second week in October. In the month of April we saw numerous flocks flitting over the prairies of Missouri, on their way, no doubt, to their breeding quarters in the interior. Andubon found these birds also in the summer on the dreary coast of Labrador. During the breeding season the male often rises on wing to the height of eight or ten yards, uttering a few clear and 
mellow notes, and then suddenly settles down near the nest or on some projecting rock. They leave Labrador and Newfoundland as soon as the young are able to fly, or about the middle of August. According to their well-known habits, they frequent open flats, commons, and ploughed fields, like a Lark, running rapidly along the ground, taking by surprise their - insect prey of flies, midges, and other kinds, and when resting for an instant, keeping the tail vibrating in the manner of the European Wagtail. They also frequent the river shores, particularly where gravelly, in quest of minute shell-fish, as well as aquatic insects and their larvæ. At this time they utter only a feeble note or call, like tweet tweet, with the final tone often plaintively prolonged; and when in flocks, wheel about and fly pretty high, and to a considerable distance before they alight. Sometimes families of these birds continue all winter in the Middle States, if the season prove moderate. In the Southern States, particularly North and South Carolina, they appear in great flocks in the depth of winter. On the shores of the Santee, in January, I observed them gleaning their food familiarly amidst the Vultures, drawn by the rubbish of the city conveyed to this quarter. They likewise frequent the cornfields and rice-grounds for the same purpose. They emigrate to the Bermudas, Cuba, and Jamaica, and penetrate in the course of the winter even to Mexico, Guiana, and Brazil. They also inhabit the plains of the Oregon. They are again seen on their return to the North, in Pennsylvania, about the beginning of May or close of April.

Nests of the Titlark have been found on the mountains of Colorado.

Note. - Two European congeners of the Titlark, the White Wagtail (Motacilla alba) and the Meadow PIPIT (Anthus pratensis) have been captured in Greenland, but should be considered merely as "accidentals" in that region. 


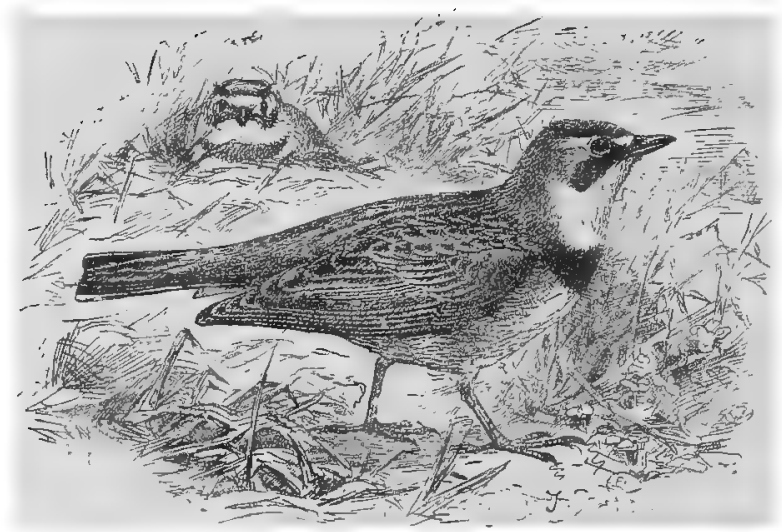

\section{HORNED LARK.}

SHORE LARK.

\section{OTOCORIS ALPESTRIS.}

CHAR. Above, dull grayish brown streaked with darker; nape, shoulders, and rump pink-vinaceous cinnamon; black bar across forehead and along sides of head, terminating in erectile horn-like tufts; throat and line over the eyes, yellow; black bar from nostril curving below the eyes; below, dull white, shaded on the sides with same color as back; breast tinged with yellow and bearing large black patch; middle tail-feathers like back, the rest black, with white patches on outer pair. Length about $71 / 2$ inches.

Nest. On the ground, amid a bed of moss; composed of grass, lined with feathers.

Eggs. 4-5; dull white with buff or purple tint spotted with purplish brown or olive brown and lilac; $0.93 \times 0.70$.

This beautiful species is common to the north of both the old and new continent; but, as in some other instances already remarked, the Shore Lark extends its migrations much farther over America than over Europe and Asia. Our bird has been met with in the Arctic regions by the numerous voyagers, and $\mathrm{Mr}$. Bullock saw it in the winter around the city of Mexico, so that in their -migrations over this continent these birds spread themselves across the whole habitable northern hemisphere to the very equator; while in Europe, according to the careful obser- 
vations of Temminck, they are unknown to the south of Germany. Pallas met with these birds round Lake Baikal and on the Volga, in the $53 \mathrm{~d}$ degree of latitude. Westward they have also been seen in the interior of the United States, along the shores of the Missouri.

They arrive in the Northern and Middle States late in the fall or commencement of winter. In New England they are seen early in October, and disappear generally on the approach of the deep storms of snow, though straggling parties are still found nearly throughout the winter. In the other States to the South they are more common at this season, and are particularly numerous in South Carolina and Georgia, frequenting open plains, old fields, common grounds, and the dry shores and banks of bays and rivers, keeping constantly on the ground, and roving about in families under the guidance of the older birds, who, watching for any approaching danger, give the alarm to the young in a plaintive call very similar to that which is uttered by the Skylark in the same circumstances. Inseparable in all their movements, like the hen and her fostered chickens, they roost together in a close ring or company, by the mere edge of some sheltering weed or tuft of grass on the dry and gravelly ground, and thickly and warmly clad, they abide the frost and the storm with hardy indifference. They fly rather high and loose, in scattered companies, and follow no regular time of migration, but move onward only as their present resources begin to fail. They are usually fat, esteemed as food, and are frequently seen exposed for sale in our markets. Their diet, as usual, consists of various kinds of seeds which still remain on the grass and weeds they frequent, and they swallow a considerable portion of gravel to assist their digestion. They also collect the eggs and dormant larvæ of insects when they fall in their way. About the middle of March they retire to the North, and are seen about the beginning of May round Hudson Bay, after which they are no more observed till the return of autumn. They arrive in the fur countries along with the Lapland Buntings, with which they associate; and being more shy, act the sentinel usually to 
the whole company in advertising them of the approach of danger. They soon after retire to the marshy and woody districts to breed, extending their summer range to the Arctic Sea. They are said to sing well, rising into the air and warbling as they ascend, in the manner of the Skylark of Europe. "The male," says Audubon, like the Common Lark, "soars into the air, sings with cheerfulness over the resort of his mate, and roosts beside her and his nest on the ground, having at this season a very remarkable appearance in the development of the black and horn-like egrets."

Happy Nuttall, to have died before "variety making" came into fashion! You had but one form of Horned Lark to deal with, while I am confronted with eleven. Fortunately a large number of these sub-species have never taken it into their horned heads to cross into the territory under present consideration, so I am saved from puzzling myself and my readers with their diagnosis.

The true alpestris is found during summer in the region between the Gulf of St. Lawrence and Greenland west to Hudson Bay, and in winter south to about latitude $35^{\circ}$. It is quite common along the New England shores while migrating and in winter.

The PRAIRIE HoRned LARK ( $O$. alpestris praticola) is a smaller bird with very gray back; line over eyes white; chin pale yellow.

This race is found in summer along the upper Mississippi valley and Great Lake region, eastward sparingly to Montreal, Vermont, and Long Island. It is resident over the greater portion of its range, but some few winter south to the Carolinas and Texas. 


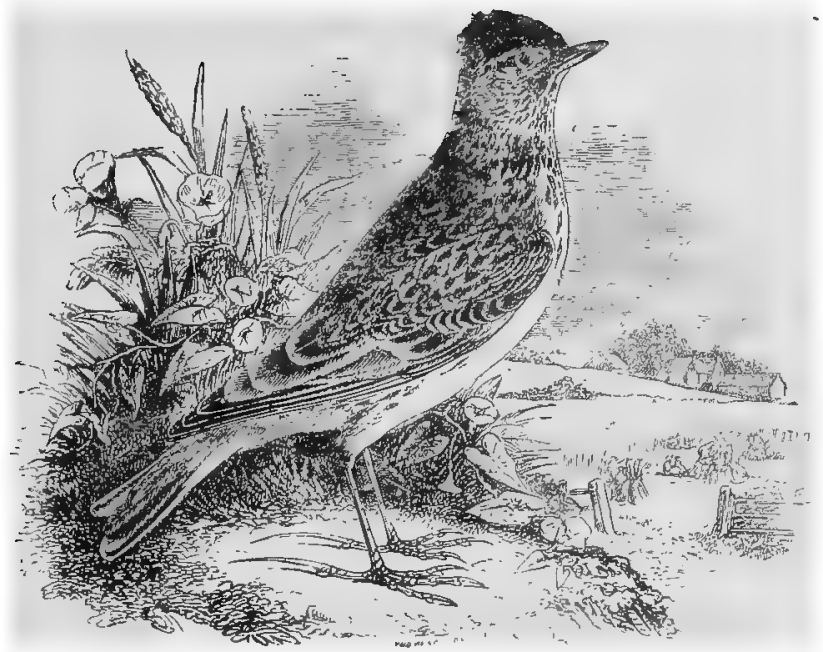

SKYLARK.

\section{Alauda ARVENSIS.}

Char. Above, yellowish brown streaked with dark brown, darkest on back and crown; buff streak over the eye; wings brown, margined with buff and tipped with white; outer tail-feathers mostly white; below, pale buff, spotted and streaked with brown. Length about 7 inches.

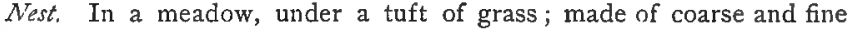
grass.

Egss, $3-5$; dull gray, marked with olive brown; $0.95 \times 0.70$.

Although not mentioned by Nuttall, this European bird becomes entitled to a place among the birds of America through its occurrence casually in Greenland and Bermuda. It also has been introduced lately into New York State and New Jersey; and though the success of the experiment is not yet assured, recent reports of the abundance and evident nesting of the birds on Long Island leave little doubt concerning it. 


\section{DICKCISSEL.}

\section{BLACK-THROATED BUNTING.}

SPIZA AMERICANA.

CHAR. Male: above, gray brown, middle of back streaked with black; nape and side of head ash, crown olive streaked with dusky; line over the eyes yellow; chin white; large patch of black on throat; two wing-bars chestnut; edge of wing yellow; below, white tinged with yellow; sides shaded with brown. Female: similar, somewhat smaller; throat without patch, but with black spots; less tinge of yellow on lower parts. Length 6 to 7 inches.

Nist. On the prairie or in a field or pasture or open scrubby woods; placed upon the ground or in a bush or low tree, sometimes io to 20 feet from ground; made of grass, weed-stalks, leaves, and roots, lined with fine grass or hair.

Eggs. 4-5; pale greenish blue, unspotted ; $0.80 \times 0.60$.

These birds arrive in Pennsylvania and New England from the South about the middle of May, and abound in the vicinity of Philadelphia, where they seem to prefer level fields, building their nests on the ground, chiefly of fine withered grass. They also inhabit the prairies of Missouri, the State of New York, the remote northern regions of Hudson's Bay, and are not uncommon in this part of New England, dwelling here, however, almost exclusively in the high, fresh meadows near the saltmarshes. Their song, simple and monotonous, according to Wilson consists only of five notes, or rather two, the first being repeated twice and slowly, the second thrice and rapidly, resembling tshsp tship, tshe tshe tshé. With us their call is 'tic 'tic - tshë tshĕ tshĕ tship, and tship tship, tshè tshè tshĕ tship. From their arrival nearly to their departure, or for two or three months, this note is perpetually heard from every level field of grain or grass; both sexes also often mount to the top of some low tree of the orchard or meadow, and there continue to chirp forth in unison their simple ditty for an hour at a time. While thus engaged they may be nearly approached without exhibiting any appearance of alarm or suspicion; and though the species appears to be numerous, they live in harmony, and 
rarely display any hostility to the birds around them, or amongst each other. In August they become mute, and about the beginning of September depart for the South, wintering as well as breeding in Texas and other parts of Mexico, but are not seen in the Southern States at any period of the winter. Their food consists of seeds, eggs of insects, and gravel, and in the early part of summer they subsist much upon caterpillars and small coleopterous insects; they are also among the many usual destroyers of the ruinous cankerworm.

This species occurs regularly in southern New England, but is rather rare in Massachusetts, and is merely accidental farther to the northward. The only examples that have been met with in Canada were the few that Mr. William E. Saunders found breeding at Point Pelee in southern Ontario.

Note. - Townsend's Bunting (Spiza townsendii) was placed on the "Hypothetical List" by the A. O. U. Committee. The type specimen taken by $\mathrm{Mr}$. Townsend in Pennsylvania remains unique.

The Lark Bunting (Calamospiza melinocorys) has been seen in Massachusetts, - the only instance of its occurrence east of the Great Plains. 


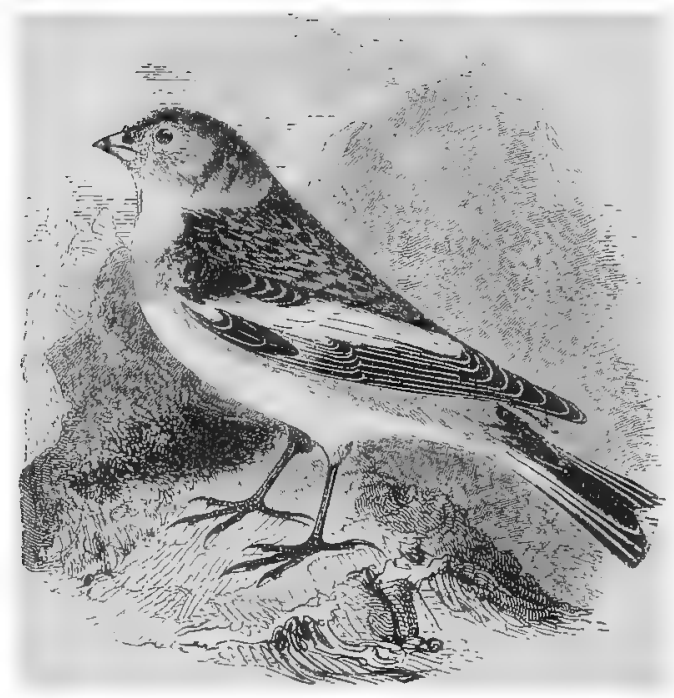

SNOWFLAKE.

\section{SNOW BUNTING. WHITE SNOW BIRD.}

\section{Plectrophenax nivalis.}

CHAR. In summer, prevailing color white; middle of back, wings, and tail mixed with black. In autumn the dark color is extended, the black being broadly margined with tawny brown, which gradually becomes white as winter advances. Length about $63 / 4$ inches.

Nest. On a barren hillside, under shelter of a rock or in a stone heap, sometimes in cavity of a sand-bank; compactly built of dry grass, plant stems, and moss, lined with feathers and hair.

$E_{g g s s}$. 4-6; dull white, with faint tint of blue or green, spotted, chiefly around larger end, with reddish brown and lavender; $0.90 \times 0.65$.

This messenger of cold and stormy weather chiefly inhabits the higher regions of the Arclic circle, whence, as the severity of the winter threatens, they migrate indifferently over Europe, eastern Asia, and the United States. On their way to the South they appear round Hudson Bay in September, and stay till the frosts of November again oblige them to seek out warmer quarters. Early in December they make their descent 
into the Northern States in whirling roving flocks, either immediately before or soon after an inundating fall of snow. Amidst the drifts, and as they accumulate with the blast, flocks of these illwars fogel, or bad-weather birds, of the Swedes, like the spirits of the storm are to be seen flitting about in restless and hungry troops, at times resting on the wooden fences, though but for an instant, as, like the congenial Tartar hordes of their natal regions, they appear now to have no other object in view but an escape from famine and to carry on a general system of forage. while they happen to stay in the vicinity. At times, pressed by hunger, they alight near the door of the cottage and approach the barn, or even venture into the out-houses in quest of dormant insects, seeds, or crumbs wherewith to allay their hunger; they are still, however, generally plump and fat, and in some countries much esteemed for the table. In fine weather they appear less restless, somewhat more familiar, and occasionally even at this season they chant out a few unconnected notes as they survey the happier face of Nature. At the period of incubation they are said to sing agreeably, but appear to seek out the most desolate regions of the cheerless North in which to waste the sweetness of their melody, unheard by any ear but that of their mates. In the dreary wastes of Greenland, the naked Lapland Alps, and the scarcely habitable Spitzbergen, bound with eternal ice, they pass the season of reproduction seeking out the fissures of rocks on the mountains in which to fix their nests about the month of May or June. A few are known to breed in the alpine declivities of the White Mountains of New Hampshire. The nest is here fixed on the ground in the shelter of low bushes, and formed nearly of the same materials as that of the Common Song Sparrow.

At times they proceed as far south in the United States as the State of Maryland. They are here generally known by the name of the White Snow Bird, to distinguish them from the more common dark-bluish Sparrow, so called. They vary in their color according to age and season, and have always a great predominance of white in their plumage. 
The Snow Buntings are seen in spring to assemble in Norway and its islands in great numbers; and after a stay of about three weeks they disappear for the season, and migrate across the Arctic Ocean to the farthest known land. On their return in winter to the Scottish Highlands their flocks are said to be immense, mingling, by an aggregating close flight, almost into the form of a ball, so as to present a very fatal and successful mark for the fowler. They arrive lean, but soon become fat. In Austria they are caught in snares or traps, and when fed with millet become equal to the Ortolan in value and flavor. When caged they show a very wakeful disposition, instantly hopping about in the night when a light is produced. Indulgence in this constant train of action and perpetual watchfulness may perhaps have its influence on this species, in the selection of their breeding places within the Arctic regions, where for months they continue to enjoy a perpetual day.

The food of these birds consists of various kinds of seeds and the larvæ of insects and minute shell-fish; the seeds of aquatic plants are also sometimes sought by them, and $I$ have found in their stomachs those of the Ruppia, species of Polygonum, and gravel. In a state of confinement they shell and eat oats, millet, hemp-seed, and green peas, which they split. They rarely perch, and, like Larks, live much on the ground.

This harbinger of winter breeds in the northernmost of the American islands and on all the shores of the continent from Chesterfield Inlet to Behring's Straits. The most southerly of its breeding stations in America, according to Richardson, is Southampton Island, in the $62 \mathrm{~d}$ parallel, where Captain Lyons found a nest, by a strange fatality, placed in the bosom of the exposed corpse of an Esquimaux child. Well clothed and hardy by nature, the Snow Bunting even lingers about the forts of the fur countries and open places, picking up grass-seeds, until the snow becomes deep. It is only during the months of December and January that it retires to the southward of Saskatchewan, and it is seen again there on its return as early as the middle of February, two months after which it arrives in the $65^{\text {th }}$ parallel, and by the beginning of May it 
has penetrated to the coast of the Polar Sea. At this period it feeds upon the buds of the purple saxifrage (Saxifraga oppositifolia), one of the most early of the Arctic plants.

As the Snow Bunting sometimes begins to visit the United States in October, it appears pretty certain that some of these birds breed almost, if not quite, within the northern limits of the Union; and as stated elsewhere, a nest has been found near the rocky summit of the White Mountains of New Hampshire.

The Snow Bunting is usually restricted in summer to the higher latitudes, - from Labrador and the Great Slave Lake region to the Arctic Ocean, - but an occasional flock is seen farther southward, and nests have been taken in the White Mountains and at Springfield, Mass.

Mr. A. Hagerup, who saw considerable of this bird when in Greenland, writes to me that the song is a sweet and pleasing melody, though rather disconnected, "delivered in short stanzas." "Warbling," he adds, "is perhaps the English word best suited to describe its character." 


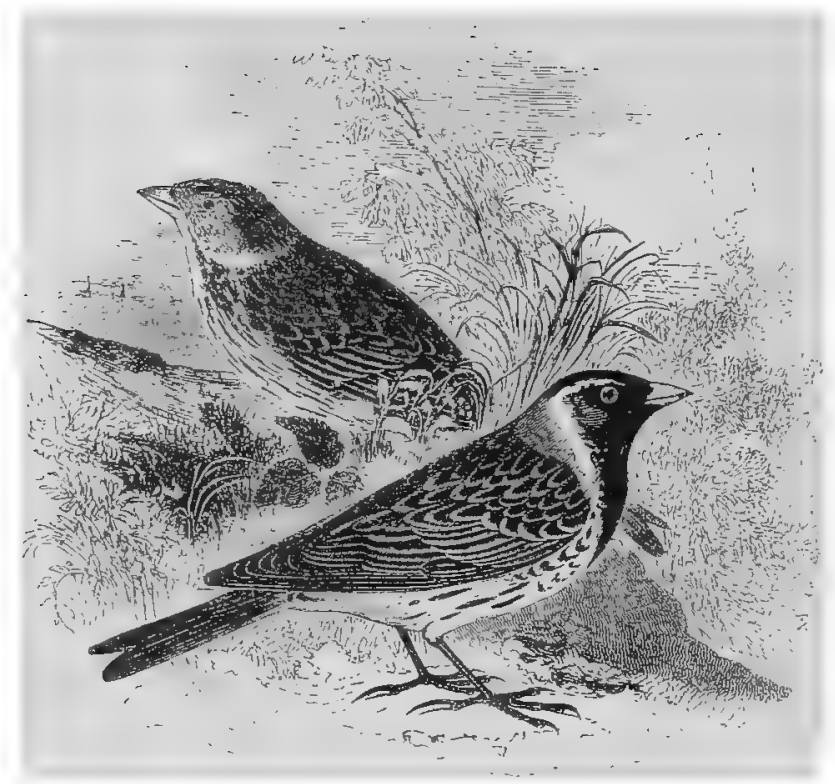

LAPLAND LONGSPUR.

\section{CaLCARIUS LAPPonicus.}

CHAR. Above, brownish black, the feathers edged with dull buff, wing-feathers with dull bay; head and throat rich black (female and young have the crown same as back); line from eyes and down side of throat, white; band of bright chestnut across hind-neck; tail with patches of white on outer feathers; below, dull white, breast and sides marked with black; bill yellow, tipped with black; legs and feet black. Length about $6 \%$ inches.

Nest. In swampy moorlands, amid deep moss or tuft of grass, or at the base of a mound; composed of grass, plant-stems, roots, and moss, lined with feathers or deer's hair.

Eggs. 4-7; pale grayish brown or reddish brown, marked with dark brown; $0.80 \times 0.60$.

This species generally inhabits the desolate Arctic regions of both continents. In the United States a few stragglers from the greater body show themselves in winter in the remote and 
unsettled parts of Maine, Michigan, and the Northwestern Territories. Large flocks also at times enter the Union, and contrary to their usual practice of resting and living wholly on the ground, occasionally alight on trees. They leave the colder Arctic deserts in the autumn, and are found around Hudson Bay on their way to the South in winter, not making their appearance there before November. Near Severn River they haunt the cedar-trees, upon whose berries they now principally feed. They live in large flocks, and are so gregarious that when separated from their own species, or in small parties, they usually, in Europe, associate with the common Larks, or, in America, they join the roving bands of Snow Birds. In the fur countries they extend their migrations in the spring as far as the $65^{\text {th }}$ parallel, where they were seen about Fort Franklin by the beginning of May; at this time they fed much upon the seeds of the Alpine arbutus. They feed principally on seeds, and also on grass, leaves, buds, and insects. They breed on small hillocks, among moss and stones, in open marshy fields, and the nest is thickly and loosely constructed of moss and grass, and lined with a few feathers and deer's hair. The Longspur, like the Lark, sings only as it rises in the air, in which, suspended aloft, it utters a few agreeable and melodious notes.

The Longspur occurs in winter in South Carolina, Kentucky, and Kansas, though it is not common south of about $40^{\circ}$.

Of its song $\mathrm{Mr}$. Hagerup writes to me: "It sounds best when the bird, after mounting up in the sky, drops slowly to the earth with extended wings. The song is not very long, but has a sweet, flute-like tone, and though the melody is attractive, it is almost melancholy in its wild plaintiveness, - as, indeed, all the notes of this species are."

Note. - One example of the Chestnut-collared Longspur (Calcarius ornatus) was captured in Massachusetts in 1876 . The usual range of this bird is limited to the Central Plains, - from Texas to the Saskatchewan.

Smith's Longspur (Calcarius pictus), which occurs in the interior, - breeding from the Great Slave Lake district to the Arctic Ocean, - is found, in winter, in Illinois.

VOL. I. -20 


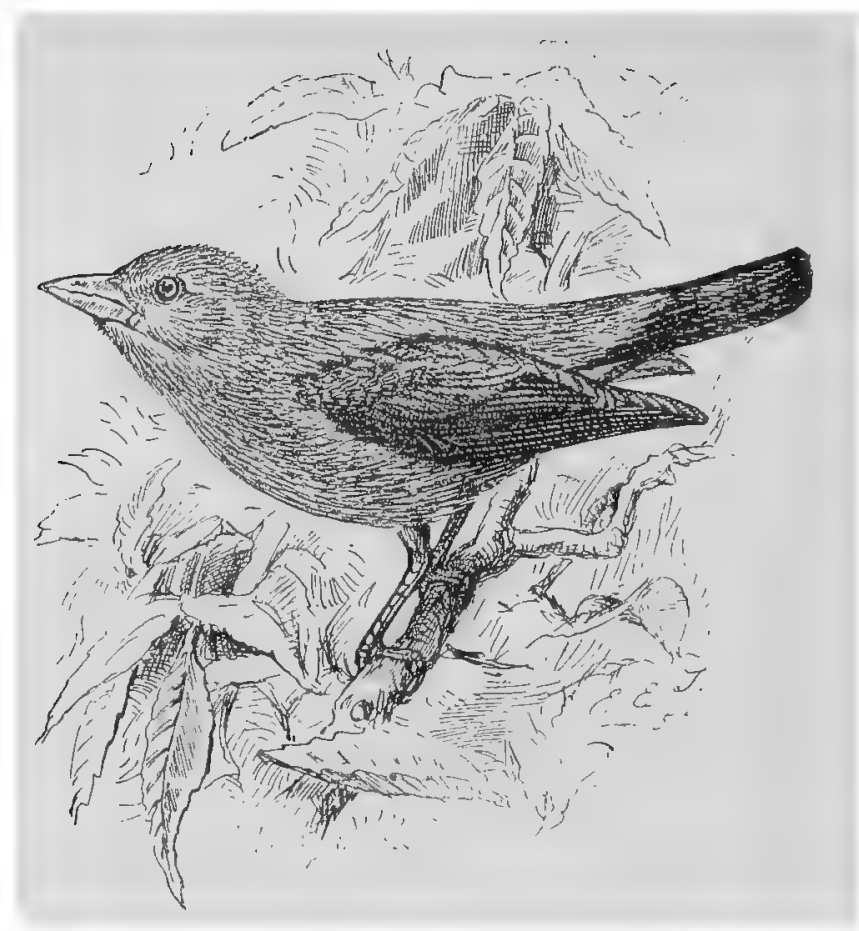

SCARLET TANAGER.

\section{Piranga erythromelas.}

CHAR. Male: scarlet, with black wings and tail. Female and young: above, olive; wings and tail dusky, the feathers edged with olive; below, greenish yellow. Length 7 to $7 \frac{1}{2}$ inches.

Nest. In a woodland grove, sometimes in an orchard, placed near the extremity of a horizontal limb ro to 20 feet from the ground; composed of twigs, roots, or shreds of bark, and lined with roots, sometimes with pine-needles.

Eggs. 3-5 (usually 4); dull white or with blue tinge, thickly marked, chiefly about larger end, with several shades of brown and lilac; 0.95 $\times 0.65$.

This splendid and transient resident, accompanying fine weather in all his wanderings, arrives from his winter station in tropical America from the beginning to the middle of May, and extends his migrations probably to Nova Scotia as well as Canada. With the shy, unsocial, and suspicious habits of his gaudy fraternity, he takes up his abode in the deepest recess 
of the forest, where, timidly flitting from observation, he darts from tree to tree like a flashing meteor. A gaudy sylph, conscious of his brilliance and the exposure to which it subjects him, he seems to avoid remark, and is only solicitous to be known to his humble mate, and hid from all besides. $\mathrm{He}$ therefore rarely approaches the habitations of men, unless perhaps the skirts of the orchard, where he sometimes, however, builds his nest, and takes a taste of the early and inviting, though forbidden, cherries.

Among the thick foliage of the tree in which he seeks support and shelter, from the lofty branches, at times we hear his almost monotonous tship wïtee, tship-ïdee, or tshükadee, tshükadee repeated at short intervals and in a pensive undertone, heightened by the solitude in which he delights to dwell. The same note is also uttered by the female when the retreat of herself and young is approached; and the male occasionally utters in recognition to his mate, as they perambulate the branches, a low whispering 'tait in a tone of caution and tenderness. But besides these calls on the female, he has also during the period of incubation, and for a considerable time after, a more musical strain, resembling somewhat in the mellowness of its tones the song of the fifing Baltimore. The syllables to which I have hearkened appear like 'tshoove 'wait 'wait 'vehöwit wait, and 'wait 'vehŏwit vea wait, with other additions of harmony for which no words are adequate. This pleasing and highly musical meandering ditty is delivered for hours, in a contemplative mood, in the same tree with his busy consort. If surprised, they fit together, but soon return to their favorite station in the spreading boughs of the shady oak or hickory. The song resembles that of the Red-eyed Vireo in its compass and strain, though much superior, the 'wait wait being whistled very sweetly in several tones and with emphasis, so that upon the whole, our Piranga may be considered as duly entitled to various excellence, being harmless to the farmer, brilliant in plumage, and harmonious in voice.

These birds only sojourn long enough to rear their single brood, which are here fledged early in July, leaving us already 
for the South about the middle or close of August, or as soon as the young are well able to endure the fatigue of an extensive migration in company with their parents. The female shows great solicitude for the safety of her only brood, and on an approach to the nest appears to be in great distress and apprehension. When they are released from her more immediate protection, the male, at first cautious and distant, now attends and feeds them with activity, being altogether indifferent to that concealment which his gaudy dress seems to require from his natural enemies. So attached to his now interesting brood is the Scarlet Tanager that he has been known, at all hazards, to follow for half a mile one of his young, submitting to feed it attentively through the bars of a cage, and, with a devotion which despair could not damp, roost by in the branches of the same tree with its prison; so strong, indeed, is this innate and heroic feeling that life itself is less cherished than the desire of aiding and supporting his endearing progeny (Wilson).

The food of the Scarlet Tanager while with us consists chiefly of winged insects, wasps, hornets, and wild bees, as well as smaller kinds of beetles and other shelly tribes; it probably also sometimes feeds on seeds, and is particularly partial to whortleberries and other kinds which the season affords.

About the beginning of August the male begins to moult, and then exchanges his nuptial scarlet for the greenish livery of the female. At this period these birds leave us; and having passed the winter in the celibacy indicated by this humble garb, they arrive again among us on its vernal renewal, and so soon after this change that individuals are at this time occasionally seen with the speckled livery of early autumn, or with a confused mixture of green and scarlet feathers in scattered patches.

The Scarlet Tanager is common throughout this Eastern Province north to about latitude $44^{\circ}$, and occurs sparingly along the Annapolis valley, in Nova Scotia and along the valley of the St. John in New Brunswick, also near the city of Quebec and in the vicinity of Lake Winnipeg. It winters in the West Indies and northern South America. 


\title{
SUMMER TANAGER.
}

\author{
SUMMER RED-BIRD.
}

Piranga RUBRA.

Char. Male: rich vermilion, duller above. Female and young: above, dull olive; below, dull buff. Length about $71 / 2$ inches.

Nest. On the edge of an open grove or by a roadside, placed near the extremity of a horizontal limb; composed of grass, leaves, and vegetable fibre, lined with grass.

Eggs. 3-4; bright green, sometimes with a tinge of blue, spotted, chiefly near the larger end, with various shades of brown and purple; $0.95 \times 0.65$.

This brilliant and transient resident, like the former species, passes the greatest part of the year in tropical America, whence in his gaudy nuptial suit he presents himself with his humble mate in the Southern States in the latter end of April or by the rst of May. In Pennsylvania these birds are but rarely seen, though in the warm and sandy barren forests of New Jersey several pairs may usually be observed in the course of every season; farther north they are unknown, ceding those regions apparently to the scarlet species. They are not confined to any particular soil, though often met with in bushy, barren tracts, and are consequently common even to the west of the Mississippi, in Louisiana and the Territory of Arkansas, as well as Mexico; they also breed near the banks of that river around Natchez.

The nest is built in the woods on the low, horizontal branch of a tree, often in an evergreen ro or $\mathrm{r} 2$ feet from the ground. Both parents assist in incubation, and the young are fledged by the middle or latter end of June. They only raise a single brood in the season, and towards the middle or close of August the whole party disappear on their way to the South, though the young remain later than the old and more restless birds.

The note of the male, like that of the Baltimore Bird, is said to be a strong and sonorous whistle, resembling the trill or 
musical shake on the fife, and is frequently repeated. The note of the female is a chattering, and appears almost like the

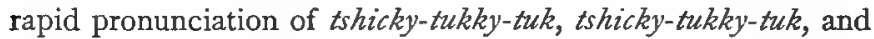
is chiefly uttered in alarm when any person approaches the vicinity of her nest. From the similarity of her color to the foliage of the trees, she is, however, rarely seen, and is usually mute; while the loquacity and brilliance of the male render him, as he flits timidly and wildly through the branches, a most distinguished and beautiful object.

The food of the Summer Red Bird is very similar to that of the preceding species; bugs, beetles, and stinging bees make part of his repast, as well as flies and cynips of various kinds, after which he often darts about until hindered by the approach of night. The late suppers are probably necessary, from the almost nocturnal habits of some of these insect tribes. After the period of incubation, and until their departure, whortleberries and other kinds of berries form no inconsiderable part of the food of these birds.

This species does not occur regularly north of New Jersey, southern Ohio, and southern Illinois. Occasionally stragglers are found in Connecticut and Massachusetts, and two examples have been taken in New Brunswick, one in Nova Scotia, four near Montreal, and one at Hamilton, Ontario.

Note. - One specimen of the Louisiaxa TANager (Piranga ludoviciana) - a Western species - has been taken in New England. It was shot near Lynn in 1878 .

\section{INDIGO BUNTING.}

\section{Passerina cyane.t.}

Char, Male: indigo blue, intense on head and throat, other parts tinged with green; black bar from bill to eyes; wings dull brown, the edge of feathers tinged with dull blue. Female: above, brown; below, much paler, with dark streaks. Length about $5 \frac{1}{2}$ inches.

Nest. On the margin of a meadow or country road, or in an orchard or garden, in a bush or low tree, placed in an upright crotch; a rather 
clumsy and bulky affair of twigs, stems, grass, etc., lined with fine grass, etc., sometimes with horse-hair.

Eggss. 4-5; white, sometimes with blue or green tint, occasionally with a few fine spots of purplish brown; $0.75 \times 0.55$.

This very beautiful and rather familiar messenger of summer, after passing the winter in tropical America, towards the $15^{\text {th }}$ of May, decked in his brilliant azure livery of the nuptial season, again joyfully visits his natal regions in the Middle States; and about a week or ten days later his lively trill in the garden, orchard, or on the top of the house, its chimney, or vane, is first heard in this part of New England. Still later, accompanied by his mate, he passes on to Nova Scotia, and probably to the precincts of Labrador. After raising and training their only brood in a uniform and more humble dress, the whole family, in color like so many common Sparrows, begin to retire to the South from the first to the middle of September. They are also known in Mexico, where, as well as in the Southern States to the peninsula of Florida, they breed and pass the summer as with us. There is reason, however, to believe that they are less abundant, if seen at all, to the west of the Mississippi ; but yet they are met with in the Western States up to the alluvial lands of that great natural boundary.

Their food in the early part of the season, as well as that of their young for a considerable time, is chiefly insects, worms, and caterpillars, as well as grasshoppers, of which they are particularly fond. They likewise eat seeds of various kinds, and are readily reared in a cage on the usual diet of the Canary.

Though naturally shy, active, and suspicious, particularly the brilliant male, they still at this interesting period of procreation resort chiefly to the precincts of habitations, around which they are far more common than in the solitary woods, seeking their borders or the thickets by the sides of the road; but their favorite resort is the garden, where, from the topmost bough of some tall tree which commands the whole wide landscape, the male regularly pours out his lively chant, and continues it for a considerable length of time. Nor is this song 
confined to the cool and animating dawn of morning, but it is renewed and still more vigorous during the noon-day heat of summer. This lively strain seems composed of a repetition of short notes; commencing loud and rapid, and then, slowly falling, they descend almost to a whisper, succeeded by a silent interval of about half a minute, when the song is again continued as before. The most common of these vocal expressions sounds like she tshe tshe-tshé tshéé tshéé-tshé tshé tshe. The middle syllables are uttered lispingly, in a very peculiar manner, and the three last gradually fall ; sometimes the song is varied and shortened into tshea tshea tshea tshrèn, the last sound being sometimes doubled. This shorter song is usually uttered at the time that the female is engaged in the cares of incubation, or as the brood already appear, and when too great a display of music might endanger the retiring security of the family. From a young or imperfectly moulted male, on the summit of a weeping-willow, I heard the following singularly lively syllables, 'tle 'tle 'tle tă lee, repeated at short intervals. While thus prominently exposed to view, the little airy minstrel is continually on the watch against any surprise, and if he be steadily looked at or hearkened to with visible attention, in the next instant he is off to seek out some securer elevation. In the village of Cambridge I have seen one of these azure, almost celestial musicians, regularly chant to the inmates of a tall dwelling-house from the summit of the chimney or the point of the forked lightning-rod. I have also heard a Canary, within hearing, repeat and imitate the slowly lisping trill of the Indigo Bird, whose warble indeed often greatly resembles that of this species. The female, before hatching her brood, is but seldom seen, and is then scarcely distinguishable from a common Sparrow; nor is she ever to be observed beyond the humble bushes and weeds in which she commonly resides.

The nest of our bird is usually built in a low bush partly concealed by rank grass or grain; at times in the forks of a young orchard tree Io or I 2 feet from the ground. I have also seen one suspended in a complicated manner in a trellised grape- 
vine. If left undisturbed, they often build in the same garden or orchard for several successive years. When in a bush, the nest is suspended betwixt two twigs, passing up on either side. Externally it is composed of coarse sedge-grass, some withered leaves, and lined with fine stalks of the same, and the slender hair-like tops of the bent-grass (Agrostis), with a very few cow-hairs; though sometimes they make a substantial lining of hair. The nest which I saw in the vine was composed outwardly of coarse strips of bass-mat, weeds, and some strings picked up in the garden, and lined with horse-hair and a few tops of bent-grass. The young here scarcely leave the nest before the end of July or the first week in August, and they raise usually but a single brood in the season. They appear to show great timidity about their nest, and often readily forsake it when touched, or when an egg is abstracted. Their usual note of alarm when themselves or their young are approached is a sharp tship, quickly and anxiously repeated, resembling almost the striking of two pebbles. They will not forsake their young, however ready they may be to relinquish their eggs; and they have been known to feed their brood very faithfully through the bars of a cage in which they were confined.

This species is a common summer resident from South Carolina to western Maine and the city of Quebec, and westward through Ontario and Illinois to the Great Plains. It also occurs occasionally in eastern Maine and the Maritime Provinces.

Note. - One example of the VARIED Bunting (Passerina versicolor) has been captured in southern Michigan. Its usual habitat is the valley of the Rio Grande and Lower California. 


\section{PAINTED BUNTING.}

NONPAREIL.

\section{PASSERINA CIRIS.}

CHAR. Male: head and neck purplish blue ; eyelids red; back yellowish green; rump purplish red; wings dusky, glossed with green and red; tail purplish brown; below, vermilion. Female : above, pale olive; below, dull buff. Length $5 \frac{1}{4}$ to $5 \frac{1}{2}$ inches.

Nest. In a thicket of low bushes; compactly made of twigs, roots, shreds of bark and grass, lined with fine grass or horse-hair, or fine roots.

Eggs. 4-5; dull white, or with blue tint, marked chiefly around larger end with purplish and reddish brown; $0.80 \times 0.60$.

This splendid, gay, and docile bird, known to the Americans as the Nonpareil, and to the French Louisianians as the Pape, inhabits the woods of the low countries of the Southern States, in the vicinity of the sea and along the borders of the larger rivers, from North Carolina to Mexico. It arrives from its tropical quarters in Louisiana and Georgia from the middle to the 2 oth of April ; but impatient of cold, retires to the South early in October, and is supposed to winter about Vera Cruz. For the sake of their song as well as beauty of plumage, these birds are commonly domesticated in the houses of the French inhabitants of New Orleans and its vicinity; and some have succeeded in raising them in captivity, where plenty of room was allowed in an aviary. They are familiar also in the gardens and orchards, where their warbling notes are almost perpetually heard throughout the summer. Their song much resembles that of the Indigo Bird, but their voice is more feeble and concise. Soon reconciled to the cage, they will sing even a few days after being caught. Their food consists of rice, insects, and various kinds of seeds; they collect also the grains of the ripe figs, and, frequenting gardens, build often within a few paces of the house, being particularly attached to the orangeries.

Their nests are usually made in the hedges of the orange, or on the lower branches of the same tree, likewise occasionally in a bramble or thorny bush. In the mildest climates in which 
they pass the surnmer, they raise two broods in the season. They are commonly caught in trap-cages, to which they are sometimes allured by a stuffed bird, which they descend to attack; and they have been known to survive in domestication for upwards of ten years.

This species is common in the South Atlantic and Gulf States, and has been taken north to southern Illinois and North Carolina.

Note. - The Grassquit (Euetheia bicolor) and the MeloDIOUS GRASSQUIT (Euetheia canora) - both West India birds have been taken in southern Florida, though they are merely accidental wanderers there.

\section{WHITE-CROWNED SPARROW.}

ZONOTRICHIA LEUCOPHRYS.

CHAR. Upper parts brown, streaked with brownish black, dull bay, and pale ash; crown white, bordered by bands of black; lines of black and white from eyes to hind neck; wings with two white bars; below, dark ash, whitening on throat and belly; flanks shaded with brown. Length about 7 inches.

Nest. In an open woodland, on the ground or in a low bush, usually concealed in grass at the foot of a bush; firmly made of dried grass lined with fine grass, - sometimes with deer's hair or feathers, or roots.

Eggs. 4-6; greenish white or bluish white thickly spotted with reddish brown; $0.90 \times 0.65$.

This rare and handsome species is very little known in any part of the United States, a few stragglers only being seen about the beginning of winter, and again in May or earlier, on their way back to their Northern breeding-places, in the fur countries and round Hudson's Bay, which they visit from the South in May, and construct their nests in June in the vicinity of Albany Fort and Severn River. These are fixed on the ground, or near it, in the shelter of the willow-trees which they glean, probably with many other birds, for the insects which frequent them. 
At this season the male sings in a loud, clear, musical, but rather plaintive tone, the song consisting of six or seven notes; these he repeats at short intervals during the whole day. On the I $3^{\text {th }}$ of April, I835, I saw flocks of this species among the thickets in the vicinity of Santa Barbara, Upper California. They sung with a feeble, quaint note, to me unlike that of any other species, and almost similar to some of the notes of the Chickadee. As they depart from Hudson Bay in September, it is probable that they principally winter in the Canadian provinces, otherwise, as passengers farther south, they would be seen more abundantly in the United States than they are. Indeed, as they approach this part of New England only in small desultory parties in the winter, as in November and December, it is evident that they only migrate a short distance in quest of food, and return to the North at the approach of fine weather. While here they appear silent and solitary, and are not difficult to approach. Their food, as usual, is seeds of grasses, insects, and their larvæ.

This species is not so rare in our day as Nuttall evidently considered it, for it is now more or less abundant throughout this Eastern Province, though likely to appear in irregular numbers at any given locality. It breeds in northern Maine and New Brunswick, and north to sub-arctic regions. Nests have been found also in Vermont and New York. The birds are met with in winter from southern New England southward. 


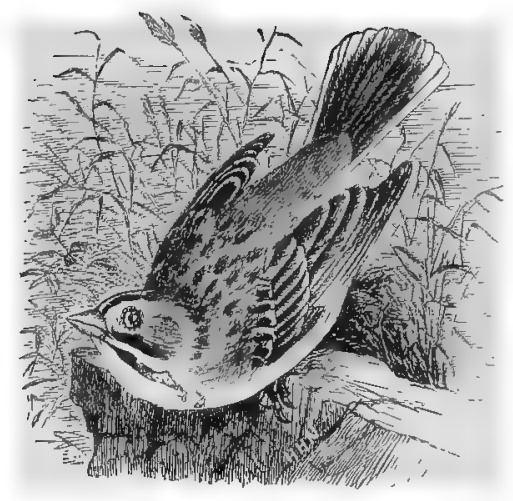

\section{LARK SPARROW.}

LARK FINCH.

\section{Chondestes gRammacus.}

CHAR. Above, grayish olive; the back brown, with fine streaks of black; tail black, - excepting central feathers, - tipped with white, outer web of outer pair entirely white; crown chestnut, with median line of dull white; line over the eye dull white; white crescent under the eyes bordered by black, and behind by chestnut; below white tinged with brown; breast with patch of black. Length $61 / 2$ to 7 inches.

Nest. Usually amid a tuft of grass, but sometimes in a tree or bush; composed of grass and vegetable fibre.

Eggs. 3-5 (usually 4); white or with blue or buff tint, marked with spots and lines of dark brown or black; $0,85 \times 0.65$.

For this species we are again indebted to Mr. Say, who observed it in abundance near the Council Bluffs and the neighboring country of the Missouri in the spring, as well as in the month of June. It appears to be wholly confined to the west side of the Mississippi, and probably extends into Mexico. These birds frequent the prairie grounds, and seldom if ever alight on trees; they sing sweetly, and, like the Larks, have the habit of continuing their notes while on the wing.

Mr. Townsend observes: "This species inhabits several hundred miles of the Platte plains in great numbers, as well as the banks of the Columbia River. It generally affects the low bushes of wormwood (Artemisia), from the summit of which 
it pours forth a variety of pretty notes." At the commencement of the pairing season the males are very pugnacious, fighting often on wing, and the conquering rival, repairing to the nearest bush, tunes his lively pipe in token of success.

The Lark Finch is common along the Mississippi valley north to Iowa and southern Michigan. It has been taken occasionally in Manitoba and in Ontario, and a few examples have appeared in New England. It is said to be the finest songster of the North American Sparrows.

\section{WHITE-THROATED SPARROW.}

PEABODY BIRD. OLD-TOM-PEABODY.

\section{ZONOTRICHIA ALBICOLLIS.}

Char. Back straked, reddish brown, black and dull buff; sides of head, breast, and rump ashy; crown with median stripe of white bordered by stripes of black; stripes of yellow from bill to eyes; stripes of white over eyes; stripes of black through eyes; throat white, bordered by black; belly white, the sides shaded with brown; wings with two white bars. Length $6 \frac{1}{2}$ to 7 inches.

Nest. In an old meadow or open woodland, or on the edge of a grove; placed on the ground upon a cushion of moss; composed of grass, stems, roots, etc., lined with fine grass or roots, - sometimes with hair or feathers.

Eggs. 4-5; pale greenish blue, thickly marked with several shades of reddish brown; $0.85 \times 0.60$.

These large and handsome Sparrows are seen in this part of Massachusetts only as transient visitors at the approach of winter, or in spring about the first week in May. In the Middle and Southern States they pass the inclement season, and appear there as a numerous species. A flock has been observed in the State of New York in the month of January. In their hibernal resorts they are seen in bands, and show a predilection for thickets, swamps, small streams, and the borders of ponds, where, among the tall and bleaching weeds, they continue to collect the seeds, and probably insect larvæ, which constitute their usual fare. While here they keep much on the ground, and seek out cool and shady situations, scratch- 
ing up the fallen leaves in quest of worms and other insects, and are at this time often very unsuspicious, allowing a near approach without betraying any alarm; but when in large flocks, they move about in timorous haste as soon as approached. About the $\mathbf{5}_{5}$ th of April they leave the Middle States, and retire to the high northern latitudes to breed, having been seen in Labrador, Newfoundland, and the fur countries up to the 66th parallel in summer. At the period of breeding the male sings with considerable energy and melody already in the early spring; also before their departure to the North, on fine mornings, they are heard to whisper forth a few sweet and clear notes, as in a revery of the approaching happiness of their more lively and interesting condition.

This Sparrow - known to the country people of the East as the "Peabody Bird" - breeds abundantly in the northern portions of New York and New England as well as in the Maritime Provinces; and at the west in northern Michigan and Manitoba. Two nests have been discovered in Massachusetts. The bird winters from southern New England southward.

The song, which is loud and sweet, is familiar in the district where the birds build, for they sing all day long, and are often heard during the night. It has been interpreted ped-pod-pedbodypeabody-peabody; hence the name. 


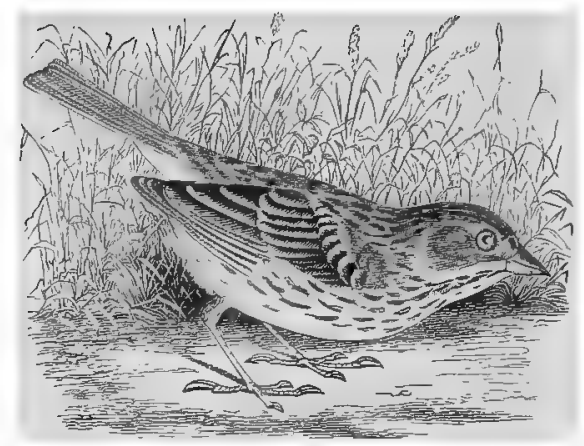

\section{VESPER SPARROW. \\ GRASS FINCH, BAY-WINGED BUNTING.}

POOCETES GRamineus.

CHAR. Above, yellowish brown, streaked with darker; line over and around eyes, white; shoulder chestnut or bay; two white bars on wing; two outer tail-feathers partly white; below, white with buffy tinge; breast and sides streaked with brown. Length about $6 / / 4$ inches.

Nest. In a field, old meadow, open pasture, or roadside, on the ground, - usually hidden by tuft of grass or under a low bush; composed of grass and roots, and lined with fine grass, sometimes with hair.

Eggs, 4-6; grayish white, sometimes with green or pink tint, thickly marked with several shades of brown; $0.80 \times 0.60$.

This plain-looking Finch chiefly frequents dry pastures and meadows, and is often seen perched on the fences and in orchard trees; it also often approaches the public roads and gathers its subsistence tamely from various sources. It is abundant in all the States east of the Alleghanies, where many pass the whole year; yet great numbers also winter in the southern parts of the Union, proceeding as far as the maritime districts of Georgia and Florida. From the beginning of April to the beginning of June, the males sing with a clear and agreeable note, scarcely inferior to that of the Canary, though less loud and varied. On their first arrival, as with the Song Sparrow, their notes are often given in an under-tone of considerable sweetness. Their song begins at early dawn, and is again peculiarly frequent after sunset until dark, when, from 
the fence of some elevated pasture-field, in the cool of the summer evening, when other songsters have retired to rest, the Grass Sparrow, more than usually wakeful, after a silence which has perhaps continued nearly through the warmer part of the day, pipes forth his clear and slender, though now almost monotonous song, near to the favorite spot where his mate hatches or fosters her tender brood; and from all the neighboring meadows, at this silent hour, as the last rays of the sun are reflected from the dusky horizon, we hear a constant repetition of an echoing and shrill tsh 'tsh 'tshé te tshête tshĕte, with warbling tones blended and varied, at the beginning and close of this simple, rather pensive, but agreeable ditty. They are more common in fields than thickets, and run along the ground in the manner of the Lark. They likewise frequent ploughing fields, searching on the ground for insects, and are very fond of dusting themselves and basking in dry places.

Being nearly sedentary, they raise probably several broods in the season. Sometimes when started from the nest, the female simulates lameness with remarkable dexterity, so as very readily to draw off the attention of her enemies or intruders. The young are easily raised from the nest, and become very tame, clean, and domestic, but readily quarrel with each other.

The "Bay-winged Bunting" of earlier writers was named "Vesper Sparrow" by Wilson Flagg, from its habit of singing during the early evening. It breeds from Virginia and Kentucky to Manitoba and the Maritime Provinces, and is one of the most abundant Sparrows in New England and Ontario.

VOL. I. - 2 I 


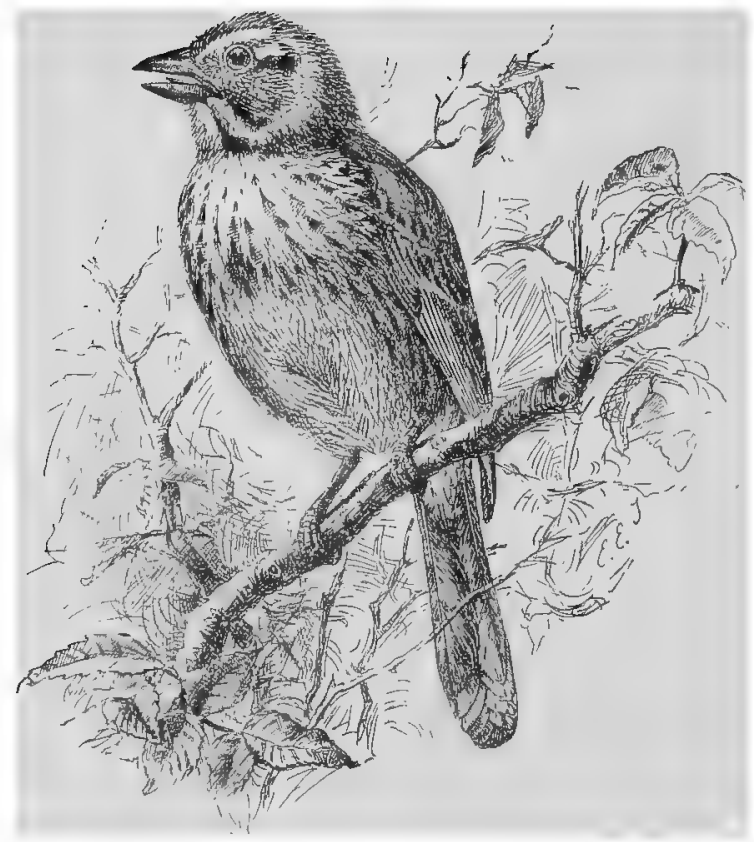

\section{SONG SPARROW.}

\section{Melospiza fasciata.}

CHAR. Back streaked with black, bay, and ash; crown bay, streaked with black and with two stripes of ash; wings grayish brown edged with dull rufous; tail grayish brown, with dark wavy cross-bars, below, white ; breast, sides of throat, and sides of body spotted with brown, the spots forming a "patch" on the breast. Length 6 to $6 \frac{1}{2} 2$ inches.

Nest. In a field or open pasture, amid a tuft of grass or under a low bush, sometimes fastened to bush or vine, occasionally placed in a cavity in a tree ; composed of twigs, grass, roots, and leaves, lined with grass and roots, or hair.

Eggs. 3-7 (usually 4 or 5); dull white or with tint of green, blue, or pink, thickly marked with several shades of brown occasionally unspotted; $0.80 \times 0.60$.

This familiar and almost domestic bird is one of the most common and numerous Sparrows in the United States; it is also, with the Bluebird, which it seems to accompany, one of the two earliest, sweetest, and most enduring warblers. 
Though many pass on to the Southern States at the commencement of winter, yet a few seem to brave the colds of New England as long as the snowy waste does not conceal their last resource of nutriment. When the inundating storm at length arrives, they no longer, in the sheltering swamps and borders of bushy streams, spend their time in gleaning an insufficient subsistence, but in the month of November begin to retire to the warmer States; and here, on fine days, even in January, whisper forth their usual strains. As early as the $4^{\text {th }}$ of March, the weather being mild, the Song Sparrow and the Bluebird here jointly arrive, and cheer the yet dreary face of Nature with their familiar songs. The latter flits restlessly through the orchard or neighboring fields; the Sparrow, more social, frequents the garden, barn-yard, or road-side in quest of support, and from the top of some humble bush, stake, or taller bough tunes forth his cheering lay, in frequent repetitions, for half an hour or more at a time. These notes have some resemblance to parts of the Canary's song, and are almost uninterruptedly and daily delivered, from his coming to the commencement of winter. When the birds first arrive, while the weather is yet doubtful and unsettled, the strain appears contemplative, and is often delivered in a peculiarly low and tender whisper, which, when hearkened to for some time, will be found more than usually melodious, seeming as a sort of revery, or innate hope of improving seasons, which are recalled with a grateful, calm, and tender delight. At the approach of winter, this vocal thrill, sounding like an Orphean farewell to the scene and season, is still more exquisite, and softened by the sadness which seems to breathe almost with sentiment, from the decaying and now silent face of Nature. Our songster, never remarkable for sprightliness, as the spring advances delivers his lay louder and more earnestly. He usually begins with a tsh' tsh' tshé te tshĕte tshète, and blends in a good deal of quivering notes. Individuals also excel, and vary their song from time to time with very agreeable effect; and it is only because our familiar vocalist is so constantly heard and seen that so little value is set upon his agreeable, cheerful, and faithful perform- 
ance. When not attached to the garden, our Sparrow seems fond of frequenting low bushy meadows, streams, swamps, and watery situations, which afford him ready shelter, and his usual food of worms, insects, larvæ, and seeds. Such situations are also their favorite resorts when, in gregarious and miscellaneous flocks with other congeneric kinds, they are seen to crowd the sheltered marshes of the Southern States. They are also commonly seen nimbly running along the ground, and gliding through low thickets in quest of their insect fare; and in fine weather they dust themselves, and bask in the sun. They often likewise frequent the water, being fond of washing ; and sometimes are seen to swim across small streams, particularly when disabled from flying by a gunshot wound.

The nest is usually formed of a considerable portion of fine dry grass neatly put together, and mostly lined with horse-hair. These birds are very prolific, raising as many as three broods in a season, the young being occasionally hatched, in the Middle States, from the close of April to the end of August. They are very solicitous for the safety of their young, keeping up at this time often a tiresome chirping; and on the destruction of the female and most of her young, I have known the remaining male, with unceasing and anxious attention, raise a solitary survivor of his ruined family with the most devoted affection. As they keep the young and their habitation so very clean, and are so prolific, it is a matter of surprise that they do not reoccupy the premises; instances are, however, not wanting in which they have been known to raise two broods in the same nest. Both parents join in the duty of incubation, and alternately feed each other while so engaged.

This species nests from South Carolina to Lake Mistassini, and from central Ohio and northern Illinois to Lake Winnipeg. It arrives at St. John, N. B., during the second week in April in immense flocks, and is usually accompanied by similar flocks of Robins and Juncos. Occasionally a few winter in the Maritime Provinces and in Quebec, as well as in New England. 


\title{
SAVANNA SPARROW.
}

\author{
GROUND SPARROW.
}

\section{AMMODRAMUS SANDWICHENSIS SAVANNA.}

CHAR. Above, streaked with grayish brown, black, rufous, and gray; line over the eyes and edges of wings yellow; crown with median stripe of yellowish white; line from lower mandible yellowish white bordered by brown; below, white tinged with buff, breast and sides streaked with brown and black. Length $51 / 2$ inches.

Nest. In a salt-marsh or along a river bank, sometimes in a dry inland meadow, concealed by tall grass or tuft of weeds ; composed of grass, sometimes mixed with fine roots, and occasionally lined with horse-hair.

Eggs. 3-6; variable in shape, size, and markings, usually dull white or with green tint, thickly spotted with dark brown, rich brown, and lilac; $0.70 \times 0.55$

This Sparrow, allied to the preceding, but far less familiar, is commonly seen in this part of New England from April to October, migrating towards the South in severe weather, though many pass the whole winter in the Middle States. In Georgia and West Florida these birds are rather numerous in the cold season, migrating in quest of food probably from the West; and the whole species generally show a predilection for the warm and sheltered vicinage of the sea, where the seeds and insects they feed on are most abundant. On their first arrival in Massachusetts they frequent the sandy beaches and shores of the bays in quest of Cicindelce and other coleopterous insects which frequent such situations; and they are at this time exceedingly fat, though their moult is not yet completed. In summer this shy and timid species lives wholly in pastures or grass fields, and often descends to the ground in quest of food. Its nest, also laid in the grass and made of the dry blades of the same, very similar to that of the Song Sparrow, is usually built about the close of April.

In the month of March, in Georgia, I observed these Sparrows in the open grassy pine woods on the margins of small swamps or "galls." At times they utter a note almost exactly similar to the chirpings of a cricket, so that it might be easily mistaken for that insect. At other times they utter a few 
pleasant notes somewhat similar to the song of the Song Sparrow, but sufficiently distinct.

The Savanna Sparrow breeds more abundantly along the coast of Massachusetts than in the interior, and perhaps this may apply to all localities; but the opinion expressed by many writers that it is almost exclusively a bird of the sea-shore - of the salt-marshes - is far from correct. I traced it up the valley of the St. John as far as there were cleared fields or marshy meadows, and in no locality was it more abundant than at Fort Kent, - the most northern point of Maine. It occurs throughout the southern portions of Canada.

These birds are rarely seen off the ground; an occasional perch on a stone heap or a fence being the only deviation from this rule.

\section{IPSWICH SPARROW.}

\section{AMMODRAMUS PRINCEPS.}

CHAR. General appearance of a large pale Savanna Sparrok: Above, grayish brown, each feather streaked with black and rufous; crown stripe dull buff or buffy white; stripe over eyes similar but paler; wings blackish brown, edged with rufous; tail blackish brown tipped with white; beneath, dull white tinged with buff; chest and sides streaked with brown. Length 6 to $63 / 4$ inches.

Nest and Eggs. Unknown.

This interesting bird was first described by Mr. C. J. Maynard from a specimen taken by him at Ipswich, Mass., in I868. For two years the type remained unique, and for several years later the species was supposed to be rare. It has since been found all along the Atlantic coast from Georgia to the Gulf of St. Lawrence. It usually frequents the sea-shore or salt-meadows near by, though $\mathrm{Mr}$. N. C. Brown reports that he has seen it at Lake Umbagog, in the interior of Maine. I met with it in New Brunswick only for a few days during the early spring; its breeding place is farther north. When feeding on the sandy shore in company with other Sparrows (the snow still covered the fields), it was not difficult to distinguish the Ipswich from their congeners, but it is difficult to define the distinguishing characteristics.

A nest and eggs supposed to be of this species are in the National Museum at Washington. They were taken on Sable Island, off the coast of Nova Scotia; but the identification is too doubtful to permit of their being accepted without question. The nest and eggs are described as similar to those of the Savanna Sparrow, the eggs being somewhat larger. 


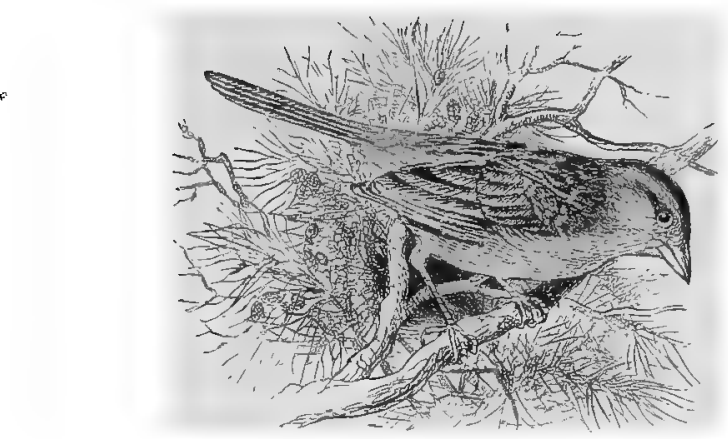

\section{BACHMAN'S SPARROW.}

SUMMER FINCH.

\section{PEUCFA ESTIVALIS BaCHMANII.}

CHAR. Above, rufous streaked with black and ash; lines over the eyes ash; edge of wing yellow; below, buff, sides shaded with ash, breast with brown. Length $6 \% / 4$ inches.

Nest. In open grassy woodland, half-cleared field, or old meadow; placed on the ground; made of dry grass or mixed with roots; sometimes the top is roofed, the entrance at the side.

Eggs. 4-5; white; $0.75 \times 0.60$.

This interesting species was first made known to Audubon by Dr. Bachman, who found it near the Edisto River, and afterwards breeding in the vicinity of Charleston, South Carolina, in the pine barrens. The discoverer remarks of this bird: "When I first heard its notes they so nearly resembled those of the Towee Bunting that I took it to be that bird. As soon as it is seen in the tall pine-trees where it usually sits to warble out its melodious notes, it darts down and conceals itself in the rank grass, through which it runs off like a mouse, and is flushed with difficulty." It is believed to breed on the ground. It is said to be the finest songster of the Sparrow family in the United States. Its notes are loud for the size of the bird, and heard nearly alone in the region it frequents. About the month of November it proceeds to migrate farther south, though a few stragglers still remain throughout the winter. According to Latham, its nest is usually on the ground among the grass, under small bushes; it is composed of dry 
grass for the most part, and the eggs are dusky white. $\mathrm{He}_{\text {* }}$ also adds that these birds inhabit Georgia the whole year, frequenting fences, brushwood, and thickets.

Some years ago in Georgia in the month of March I observed these Sparrows in the open grassy pine woods, on the margins of small swamps or galls. On being suddenly surprised, they often flew off a little distance, and then, if followed, descended to the ground, and ran and hid closely in the tall tufts of grass.

Their notes at this time were very long, piping, and elevated, and resembling often tshé tship tship tship tship tship $t s h i p$, then $t s h e c h^{\prime} t h^{\prime} t s h^{\prime} t s^{\prime} h t s^{\prime} h$. Some of these notes were as fine and lively as those of the Canary, - loud, echoing, and cheerful.

The food of this species consists of grass seeds, coleoptera, and a variety of small berries as they come in season. The sexes are nearly alike in plumage.

This species occurs in the Gulf States and north to South Carolina and southern Illinois, but the vicinity of Charleston, S. C., is the only locality in which it has been found in abundance. Very little is known of its habits or of its distribution.

Note. - The type of this species is larger and darker than bachmaniz. It is restricted to southern Georgia and Florida, and has been named the Pine Woods Sparrow (Peucaa astivalis).

\section{LINCOLN'S SPARROW.}

LINCOLN'S FINCH.

MElosPiza LINCOLNI.

Char. Above, streaked with brown, gray, and black; below, white; band across the breast and on sides brownish yellow. Length about $5 \frac{1}{2}$ inches.

Nest. On the ground, amid low bushes, along the skirts of marshy meadow, or on a dry grassy hillock in an open woodland; composed of grass.

Eggs. 4-5; pale green or buffish, - sometimes almost white, - thickly spotted and blotched with reddish brown and lilac; $0.80 \times 0.60$. 
The habits of this boreal species, discovered by Audubon in Labrador, are very similar to those of the Song Sparrow. Like it, mounted on the topmost twig of some tree or tall shrub, it chants for hours together; or, diving into the thicket, it hops from branch to branch until it reaches the ground in quest of its usual fare of insects and berries. It moves off swiftly when watched, and if forced to take wing flies low and with rapidity to some considerable distance. It is met with usually near streams, in the sheltered valleys of that cold and desolate region. By the $4^{\text {th }}$ of. July the young had left the nest, and in August they had begun their migrations to the South. Specimens have been obtained by Mr. W. Cooper near New York city.

Lincoln's Finch is now considered less "boreal "in its distribution than Nuttall and his contemporaries supposed, for though it has been found in Labrador and in the high Arctic regions of the West, yet nests have been discovered in Nova Scotia, northern New York, and Wisconsin, as well as on the higher mountains of the West down nearly to the Mexican border. It is a rare bird near the Atlantic, but is abundant along the Mississippi valley.

\section{GRASSHOPPER SPARROW.}

YELLOW-WINGED SPARROW. YELLOW-WINGED BUNTING.

\section{AMMODRAMUS SAVANNARUM PASSERINUS.}

CHAR. Above, streaked with bay, black, buff, and ash ; crown blackish, with median line of buff ; lines over the eye buff; bend of wing bright yellow; below, buff, shading to white on the belly. Length about 5 inches.

Nest. In a field, concealed by long grass; composed of grass, lined with horse-hair.

Eggs. 4-5; white, spotted with rich brown and lilac; $0.75 \times 0.60$.

This small Sparrow is a summer resident in the United States, in the distant territory of the Oregon, and is likewise, according to Sloane, a common species in the savannas or open glades of the island of Jamaica. From what little is known of it as a bird of the United States, it appears to 
remain in the sheltered plains of the sea-coast of New York and New Jersey until the very commencement of winter. It is also observed in the lower parts of Pennsylvania; and about the middle of May, or later, they are occasionally seen in the gardens in Cambridge, Mass., on their way apparently to some other breeding-station. On these occasions they perch in sheltered trees in pairs, and sing in an agreeable voice somewhat like that of the Purple Finch, though less vigorously. In the West Indies they live much on the ground, and run like Larks, flying low when flushed, and soon alighting. Their nest is likewise fixed on the ground, among the grass, where they collect their usual fare of seeds and insects.

The majority of local students of bird life to-day consider this species more or less common in Massachusetts and Connecticut, and it is known to occur in parts of the more northern New Eng. land States, and in New York, Ohio, Ontario, and Michigan. One example has been taken in New Brunswick. Its supposed rarity by earlier observers was probably due to its usual concealment amid the tall grass and to its lack of an attractive song; for in spite of Nuttall's assurance to the contrary, modern observers have indorsed the opinion expressed by one of their leaders that " its best vocalization is scarcely stronger or more musical than the stridulation of a grasshopper."

\section{HENSLOW'S SPARROW.}

\section{HENSLOW'S BUNTING.}

\section{AMMODRAMUS HENSLOWII.}

CHAR. Above, streaked with olive brown, bay, and gray; crown olive gray, with two blackish stripes; edge of wing yellow; below, buff, paler on throat and belly; sides of throat and sides of body streaked with black. Length about 5 inches.

Nest. In a field, concealed amid long grass; made of grass with a lining of hair.

Eggs. 4-5; dull white, sometimes tinged with green, spotted with brown and lilac; $0.75 \times 0.60$.

This species, so much allied to the Yellow-winged Finch discovered by Audubon, is known to breed in New Jersey. 
As a winter bird of passage it is common in South Carolina, and equally abundant in the pine forests of Florida, seeking out by choice the light sandy soils overgrown with pines, though it keeps on the ground wholly, running with celerity, and threading its way through the grass with the nimbleness of a mouse.

Henslow's Sparrow breeds from southern New England to South Carolina, and from Ontario and Hllinois southward. One nest has been discovered in New Hampshire. It is more abundant to the westward than near the Atlantic seaboard.

\section{LE CONTE'S SPARROW.}

LE CONTE'S BUNTING.

AMMODRAMUS LECONTEII.

Char. General color reddish brown, streaked with brownish black, the feathers margined with pale buff ; crown with two black stripes separated by a narrow stripe of pale buffish gray; cheeks and stripes over the eyes buff; hind neck rufous; under parts buff, paler on the belly; no streaks on the breast. Bill small and slencler; tail-feathers narrow, tapering, and extremely pointed. Length about 5 inches.

Nest. In a marsh or wet meadow, raised from the ground by tangled grass; made of fine grass.

Eggs. 3-?; delicate pink, with a few spots of brownish and of black towards the larger end; $0.75 \times 0.50$.

This interesting bird was first described by Audubon in the 1843 edition of his work, - issued after Nuttall had written. Audubon secured but one specimen, and only one other was discovered unti] 1873, when Dr. Coues took several examples on the Dakota plains. Since then the species has been found by a number of naturalists, and it is now known to breed on the plains of Dakota, Minnesota, and Manitoba, migrating in the autumn through Illinois, Iowa, Kansas, etc., to South Carolina and Florida. It is by no means a rare bird, - Ridgeway thinks it abundant in Illinois, and Thompson reports it common in Manitoba; but, as Dr. Coues suggests, its retiring habits and the nature of its resorts have doubtless caused it to be overlooked.

The birds resemble Henslow's Sparrow, and the habits of the two species are similar. Only one nest and set of eggs have been discovered, and they were taken by Mr. Ernest Thompson on the Manitoba plains. 


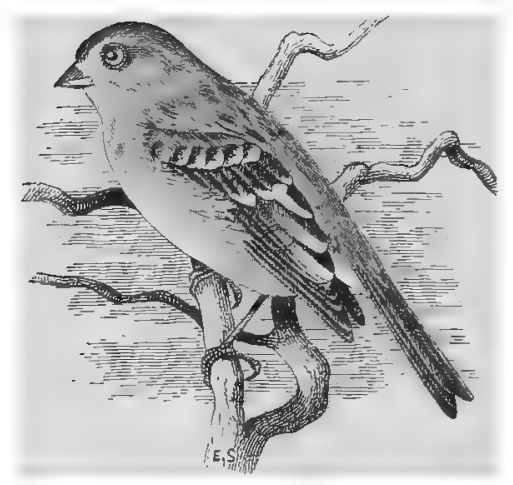

\section{TREE SPARROW.}

\section{SPIZELLA MONTICOLA.}

Char. Above, streaked with black, bay, and buff; crown chestnut, sometimes the feathers edged with ashy; sides of head and neck ashy; line from behind eyes chestnut; wings with two white bars; edges of tailfeathers white; below, dull white, breast and throat tinged with ash ; spot of brown on the breast; flanks shaded with brown. Length $6 \frac{1}{4}$ inches.

Nest. On the ground or in a low bush; made of grass, twigs, and roots, - sometimes cemented with mud, - lined with hair or feathers.

Eggs. 4-5; pale green or greenish blue, spotted with reddish brown; $0.75 \times 0.60$.

This handsome winter Sparrow arrives from the northern regions in New England about the close of October, withdrawing from Hudson Bay and the neighboring countries sometime in the month of September. The species consequently, like many more of our Fringillas, only measures its speed by the resources of subsistence it is able to obtain, and thus straggling southward as the winter advances, it enters Penusylvania only about the beginning of November; there, as well as in the maritime parts of Massachusetts, and perhaps as far south as Virginia, the Tree Sparrow is often associated with the hardy Snow Birds, gleaning a similar kind of subsistence ; and when the severity of winter commences, leaving the woods, gardens, and uplands in which it is an occasional visitor, it seeks in company the shelter of some bushy swamp, thickly shaded brook, or spring. Near Fresh Pond, in this vicinity, 
these birds are at that season numerous, and roost together near the margin of the reeds, almost in the society of the Blackbirds, who seek out a similar place of warmth and shelter as the chilling frosts begin to prevail.

At this cool and gloomy season, and down to the close of the first week in November, as they pass from branch to branch and play capriciously round each other, they keep up almost perpetually a low and pleasant liquid warble, not much unlike that of the Yellow Bird (Fringilla tristis), but less varied. Sometimes two or three at the same time will tune up s'weedit s'weedit weet, and s'waidit s'waidit weet, accompanied by some tremulous trilling and variation, which, though rather sad and querulous, is heard at this silent season with peculiar delight. In summer, during the breeding-time, they express considerable melody.

According to Mr. Hutchins they breed around the Hudson Bay settlements, making a nest in the herbage, formed externally of dry grass, and lined with soft hair or down, probably from vegetables, in the manner of the Yellow Bird. About the beginning of April they leave the Middle States for their summer quarters, and arrive around Severn River in May; they also probably propagate in Newfoundland, where they have been observed. With us they are still seen in numbers to the I 9 th of April.

Numbers of the Tree Sparrow winter regularly in the Maritime Provinces of Canada. Macoun reports the species common in summer at Lake Mistassini, which lies a little to the southward of Hudson Bay.

\section{CHIPPING SPARROW.}

CHIPPY, HAIR-BIRD.

\section{SPIZELla soctalis.}

CHAR. Above, streaked with grayish brown, black, and bay; crown chestnut; forehead black; sides of head and neck ashy; dull white line over eyes; dusky stripe from bill through eyes; tail forked and dusky with pale edgings; wings with two white bars; below, dull white, tinged with ash on breast and sides. Length about $5^{\mathrm{I} / 2}$ inches. 
Nest. In a pasture, orchard, or garden, placed in a bush or low tree; composed of grass, - sometimes mixed with roots, - thickly lined with horse-hair.

Eggs. 4-5; bluish green, spotted, chiefly about the larger end, with brown, black, and lilac; $0.70 \times 0.50$.

This species, with the Song Sparrow, is probably the most numerous, common, and familiar bird in the United States, inhabiting from Nova Scotia to Florida, westward to the banks of the Missouri, and Mr. Townsend found it to be a common species in the Territory of Oregon. Aware of the many parasitic enemies of the feathered race which it has to encounter, who prowl incessantly, and particularly in quest of its eggs, it approaches almost instinctively the precincts of houses, barns, and stables, and frequently ventures into the centre of the noisy and bustling city, to seek in the cultivated court an asylum for its expected progeny. Soon sensible of favor or immunity, it often occupies with its nest the thick shrubs of the garden within a few yards of the neighboring habitation, by the side perhaps of a frequented walk, in the low rose-bush, the lilac, or any other familiar plant affording any degree of shelter or security, and will at times regularly visit the threshold, the piazza, or farm-yard for the crumbs which intention or accident may afford it. On other occasions the orchard trees are chosen for its habitation, or in the lonely woods an evergreen, cedar, or fir is selected for the purpose. It makes no pretensions to song, but merely chips in complaint when molested, or mounting the low boughs of some orchard tree or shrub, utters a quickly articulated ascending 'tsh 'tsh ' $t s h$ 'tsh 'tsh tshe tshe, almost like the jingling of farthings, and a little resembling the faint warble of the Canary, but without any of its variety or loudness. This note, such as it is, is continued often for half an hour at a time, but is little louder than the chirping of a cricket, and uttered by the male while attending his brooding mate. For many weeks through the summer and during fine weather this note is often given from time to time in the night, like the revery of a dream.

The nest of the Chipping Bird varies sometimes considerably in its materials and composition. The external layer, 
seldom so thick but that it may be readily seen through, is composed of dry stalks of withered grass, and lined more or less with horse or cow hair. The Cuckoo destroys many eggs of this timid, harmless, and sociable little bird, as the nests are readily discovered and numerous; on such occasions the little sufferer expresses great and unusual anxiety for the security of her charge, and after being repeatedly robbed, the female sits closely sometimes upon perhaps only two eggs, desirous at any rate to escape if possible with some of her little offspring. Two or more broods are raised in the season.

Towards the close of summer the parents and their brood are seen busily engaged collecting seeds and insects in the neighboring fields and lanes, and now become so numerous, as the autumn advances, that flitting before the path on either side as the passenger proceeds, they almost resemble the falling leaves of the season rustling before the cheerless blast; and finally, as their food fails and the first snows begin to appear, advertised of the threatening famine, they disappear and winter in the Southern States. In the month of January, in Georgia, during the continuance of the cool weather and frosty nights, I frequently heard at dusk a confused chirping or piping like that of frogs, and at length discovered the noise to proceed from dense flocks of the Chipping Sparrows roosting or huddling near together in a pile of thick brush, where, with the Song Sparrow also, they find means to pass the cool nights. The Chipping Sparrow occurs throughout the Maritime Provinces and westward to the Rockies and northward to the Great Slave Lake region. It is abundant in Quebec and Ontario.

NOTE. - One example of BREWER's SPARRow (Spizella breweri), a bird that dwells chiefly on the western slopes of the Rockies, has been taken in Massachusetts. 


\section{FIELD SPARROW.}

\section{SpIZELLA PUSILLA.}

Char. Above, streaked rufous, black, and buff; crown chestnut, with obscure median line of ash; hind neck, sides of head and neck ash ; cheek shaded with brown; wings with two white bars; below, white; breast and throat tinged with yellow. Length $5 \frac{3}{4}$ inches.

Nest. In a field, pasture, or open woodland, amid a tuft of grass or in a tangled thicket, sometimes placed on a low bush or vine; composed of grass, twigs, and straw, lined with hair, fine roots, or fur.

Egrgs. 3-5; dull white or with buff or green tint, usually thickly spotted with reddish brown; $0.70 \times 0.55$.

The Small Brown Sparrow arrives in Pennsylvania and New England from the Southern States, where it passes the winter, in the beginning of April. It is with us a shy, wild, and retiring species, partial to dry hills and pastures, and open, bushy, secluded woods, living much in trees. In autumn, indeed, the pair, accompanied by their brood, in small flitting flocks leave their native wilds, and glean at times in the garden or orchard; yet but little is now seen of them, as they only approach cultivated grounds a few weeks before their departure. These Sparrows, if indeed they are the same as those described by Wilson, in winter flock together in great numbers in the Southern States, and mingling with the Chipping Birds and other species, they now line the roads, fences, and straggling bushes near the plantations in such numbers as, with their sober and brown livery, to resemble almost a shower of rustling and falling leaves, continually haunting the advancing steps of the traveller in hungry, active flocks, driven by the storms of winter into this temporary and irksome exile. But no sooner does the return of early spring arrive than they flit entirely from the Southern wilds to disperse in pairs and seek out again their favorite natal regions of the North.

Our little bird has a pretty loud and shrill note, which may be heard at a considerable distance, and possesses some variety of tone and expression. Sometimes it is something like twe twee twai, tw 'tw' 'tw' 'tw 'tw' 'tw' 'tw, beginning loud and 
slow, and going up and down, shrill and quick, with a reverberating tone almost as rapid as the drumming of the Ruffed Grouse. At other times the sound appears like te de de de de $d^{\prime \prime} d^{\prime \prime} d^{\prime} d^{\prime \prime} d^{\prime \prime} d^{\prime \prime} d r^{\prime}$, rapid and echoing; then weet weet weed wat te ' $d$ ' $d$ ' $d$ ' $d$ ' $d$ ' $d$, also weet weet weet weet' wt' wt' wt' wt' trr; the whole of these notes rising and running together into a short trill something like the song of the Canary, but less varied, and usually in a querulous or somewhat plaintive tone, though towards the close of summer I have heard individuals nearly as musical and warbling as the common Yellow Bird. These tones are also somewhat similar to the reverberations of the Chipping Bird, but quite loud and sonorous, and without the changeless monotony of that species. In fact, our bird would be worthy a place in a cage as a songster of some merit. Like most of the Sparrows, the food of this species consists of seeds and insects; and they also search the leaves and branches at times in quest of moths, of which they appear fond.

The Field Sparrow is rather rare north of Massachusetts. It has not been taken in the Maritime Provinces, though Mr. Neilson thinks it not uncommon near the city of Quebec, and it is common throughout Ontario and in Manitoba.

Note. - A few examples of the Clay-Colored Sparrow (Spizella pallida) wander every year from their usual habitat on the Great Plains to Iowa and Illinois.

VOL. I. -22 


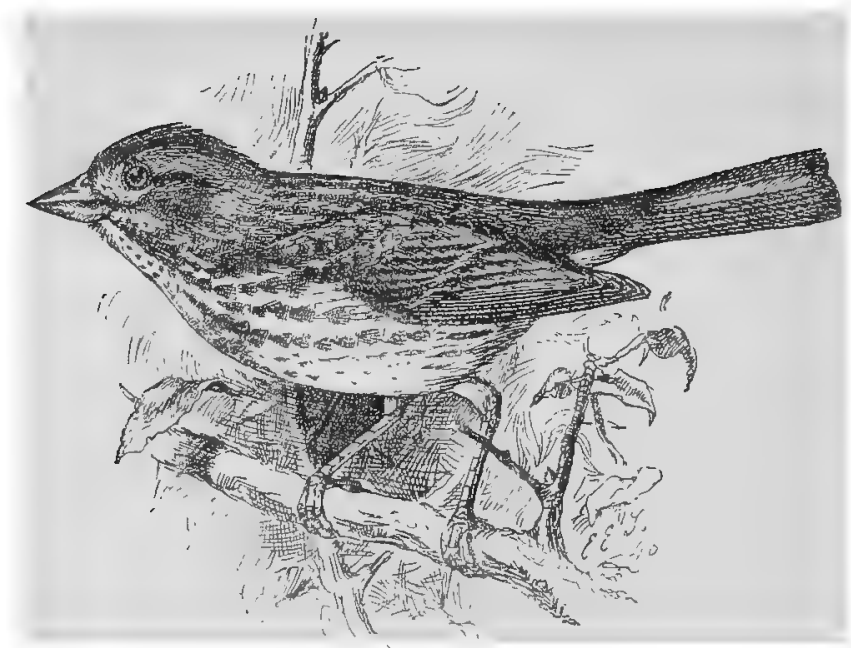

\section{FOX SPARROW.}

\section{PASSERELLA ILIACA.}

ChaR. Above, foxy red (brightest on wings and rump) streaked with ash (in winter the ash is sometimes obscure); head and tail without streaks; wings with two white bars; below, white spotted with red. Length about 7 inches.

Nest. Amid moss, or on a low bush ; composed of grass and moss, lined with grass, roots, and feathers.

Egg's. 4-5; white with green or blue tinge, spotted and blotched with brown of several shades (sometimes the brown almost conceals the ground color); great variation in size, average about $0.80 \times 065$ -

This large and handsome Sparrow, after passing the summer and breeding-season in the northern regions of the continent around Hudson Bay, and farther north and west perhaps to the shores of the Pacific, visits us in straggling parties or pairs from the middle of October to November. At this time it frequents low, sheltered thickets in moist and watery situations, where it usually descends to the ground and is busily employed in scratching up the earth and rustling among the fallen leaves in quest of seeds, worms, and insects, but more particularly the last. It migrates in a desultory manner, and sometimes arrives 
as far south as Georgia, passing the winter in the Southern States and retiring early in the spring to its favorite boreal retreats. These Sparrows are silent birds, rather tame and unsuspicious; when alarmed or separated their call is simply shep, shep; yet at times in the spring, a little before their departure, they whisper forth a few low and sweet notes indicative of the existence of vocal powers in the pairing season.

According to Richardson this species breeds in the woody districts of the fur countries up to the 68th parallel.

Nuttall was correct in his conjecture that the Fox Sparrow is a vocalist. It ranks as a peer of the best songsters of the entire Sparrow-Finch tribe.

I have heard the song frequently in New Brunswick, when cold storms have detained the birds on their journey north until the approach of their mating season. Sometimes they arrive there early in March, and pass on in a couple of weeks, without uttering any other note than a metallic cheep. But when they tarry until after the first week in April they then burst into full song, and sing almost continuously. It is a "fervent, sensuous, and withal perfectly rounded carol," writes William Brewster; and he adds: "It expresses careless joy and exultant masculine vigor rather than the finer shades of sentiment." The voice is strong, of wide com. pass, and sweet, rich tone.

Nests of this species have been found on the Magdalen Islands and in Newfoundland, where it is called the Hedge Sparrow, and Thompson reports it breeding in numbers on Duck Mountain in Manitoba.

\section{SLATE-COLORED JUNCO.}

\section{SNOW BIRD. WHITE BILL.}

\section{JUNCO HYEMALIS.}

CHAR. Upper parts, neck, and breast dark slate or blackish ash; below - from breast backward - white; outer tail-feathers and bill, white. Length $6 \frac{1}{4}$ to $6 \frac{1}{2}$ inches.

Nest. In grassy woodland, or old meadow, or by the roadside, sometimes in the garden of a farm-house; placed under the shelter of a mound or stump, or amid long grass, composed, usually, of grass, sometimes mixed with roots or moss; lining usually of feathers, but sometimes hair, fur, or moss is used. 
Eggs. 4-5; dull white, or tinted with green or buff, spotted chiefly around larger end with reddish-brown and lilac; $0.80 \times 0.60$.

This hardy and very numerous species, common to both continents, pours in flocks from the northern regions into the United States about the middle of October, where their appearance is looked upon as the presage of approaching winter. At this season they migrate into the Southern States in great numbers, and seem to arrive in augmenting hosts with the progress of the wintry storms and driving snows, before which they fly for food rather than shelter; for even during the descent of the whitening inundation, and while the tempest still rages without abatement, these hardy and lonely wanderers are often seen flitting before the blast, and, seeking advantage from the sweeping current, descend to collect a scanty pittance from the frozen and exposed ground, or stop to collect the seeds which still remain upon the unshorn weeds rising through the dreary waste. At such times they are also frequently accompanied by the Snow Bunting, the humbly dressed Yellow Bird, and the querulous Chickadee. Driven to straits, however, by hunger, they at length become more familiar, and are now seen about the barns and out-houses, spreading themselves in busy groups over the yard, and even approaching the steps of the door in towns and cities, and gleaning thankfully from the threshold any crumbs or accidental fragments of provision. Amidst all this threatening and starving weather, which they encounter almost alone, they are still lively, active, and familiar. The roads, presenting an accidental resource of food for these northern swarms, are consequently more frequented by them than the fields. Before the severity of the season commences, they are usually only seen moving in families; and the parents, watchful for the common safety, still continue by reiterated chirpings to warn their fullgrown brood of every approach of danger, and, withdrawing them from any suspicious observation, wander off to securer ground. At this time they frequent the borders of woods, seek through the thickets and among the fallen leaves for their usual food of seeds and dormant insects or their larvæ. Their 
caution is not unnecessary, for on the skirts of the larger flocks the famished Hawk prowls for his fated prey, and descending with a sudden and successful sweep, carries terror through all the wandering and retreating ranks.

In the latter end of March or beginning of April, as the weather begins to be mild, they re-appear in flocks from the South, frequenting the orchard trees, or retreating to the shelter of the woods, and seem now to prefer the shade of thickets or the sides of hills, and frequently utter a few sweet, clear, and tender notes, almost similar to the touching warble of the European Robin Redbreast. The jealous contest for the selection of mates already also takes place, soon after which they retire to the northern regions to breed; though, according to Wilson, many remove only to the high ranges of the Alleghany Mountains, where, in the interior of Virginia, and towards the western sources of the Susquehanna, they also breed in great numbers, fixing their nests on the ground or among the grass, the pairs still associating in near communion with each other. In the fur countries they were not observed by Richardson beyond the $57^{\text {th }}$ parallel.

The Junco breeds from northern New England northward, and on the higher hills south to North Carolina. It is an abundant summer resident of the Maritime Provinces, and winters there in small numbers. It also winters sparsely in northern New England, and from Massachusetts southward it is a common winter bird.

The song is very similar to that of the Chipping Sparrow. Though usually building its nest on the ground, a few have been found in other situations. Sheriff Bishop, of Kentville, N. S., recorded in the O. \& O. for September, 1888, finding nests on branch .s of low trees, in holes in apple-trees, etc.

Note. - Examples of the OREGON JUNCO (J.hyemalis oregonus), which was discovered by Nuttall and Richardson in the forests of Oregon, have wandered into Michigan and Massachusetts.

Another species, the Carolina Junco (Junco carolinensis), was first described by Mr. William Brewster from specimens obtained by him on the mountains of North Carolina in June, I885. It is much larger and lighter colored than hyemalis, and has a horn-colored bill. 


\section{SWAMP SPARROW.}

\section{MELOSPIZA GEORGIANA.}

CHAR. Alove, streaked with brown, black, and buff; crown bay, sometimes with indistinct median line of ash and streaks of black; forehead black; brown stripe behind eyes; sides of head and neck ash; below, dull white, breast shaded with ash, sides shaded with brown; wings and tail tinged with bay. Length about $5^{3 / 4}$ inches.

Nest. Under cover of long grass, in a swamp or wet meadow; usually made entirely of grass, though sometimes weed-stems are added to the exterior, and hair is used in lining.

Eggs. 4-6; dull white, tinted with green, blue, or pink, blotched, often clouded, with lilac and several shades of brown; $0.80 \times 0.60$.

The aquatic habits of these common, though little known, birds is one of their most remarkable peculiarities. In New England they arrive from the Southern States, where they winter, about the middle of April, and take up their summer residence in the swamps and marshy meadows through which, often without flying, they thread their devious way with the same alacrity as the Rail, with whom they are indeed often associated in neighborhood. In consequence of this perpetual brushing through sedge and bushes, their feathers are frequently so worn that their tails appear almost like those of rats, and are very often flirted in the manner of the Wagtail. Occasionally, however, they mount to the tops of low bushes or willow-trees and chant forth a few trilling, rather monotonous minor notes, resembling, in some measure, the song of the Field Sparrow, and appearing like twé $t w w^{\prime} t w w^{\prime} t w w^{\prime} t w w^{\prime} t w{ }^{\prime}$ twé, and twl' tw'l 'tw tw' twé, uttered in a pleasant and somewhat varied warble. These notes are made with considerable effort, and sometimes with a spreading of the tail. In the spring, on their first arrival, this song is delivered with much spirit, and echoes through the marshes like the trill of the Canary. The sound now resembles the syllables 'twe 'tw 'tw 'twee 'twee 'twe 'twe 'twe, or 'tshp 'tshp 'tshe 'tsh 'tsh 'tsh 'tsh, beginning loud, sweet, and somewhat plaintive; and the song is continued till late in the morning, and after sunset in the evening. This reverberating tone is again somewhat similar 
to that of the Chipping Sparrow, but far louder and more musical. In the intervals the Swamp Sparrow descends into the grassy tussocks and low bushes in quest of his insect food, as well as to repose out of sight; and while here his movements are as silent and secret as those of a mouse. The rice plantations and river swamps are the favorite hibernal resorts of these birds in Louisiana, Georgia, and the Carolinas; here they are very numerous, and skulk among the canes, reeds, and rank grass, solicitous of concealment, and always exhibiting their predilection for watery places. In the breeding season, before the ripening of many seeds, they live much on the insects of the marshes in which they are found, particularly the smaller coleopterous kinds, Carabi and Curculiones. They extend their northern migrations as far as the coasts of Labrador and Newfoundland.

They probably raise two or three broods in a season, being equally prolific with our other Sparrows. They express extreme solicitude for their young even after they are fully fledged and able to provide for themselves; the young also, in their turn, possess uncommon cunning and agility, running and concealing themselves in the sedge of the wet meadows. They are quite as difficult to catch as field-mice, and seldom on these emergencies attempt to take wing. We have observed one of these sagacious birds dart from one tussock to another, and at last dive into the grassy tuft in such a manner, or elude the grasp so well, as seemingly to disappear or burrow into the earth. Their robust legs and feet, as well as long claws, seem purposely provided to accelerate this clinging and running on the uneven ground.

This species is common throughout the settled portions of eastern Canada, and abundant on the St. Clair Flats and in Manitoba. 


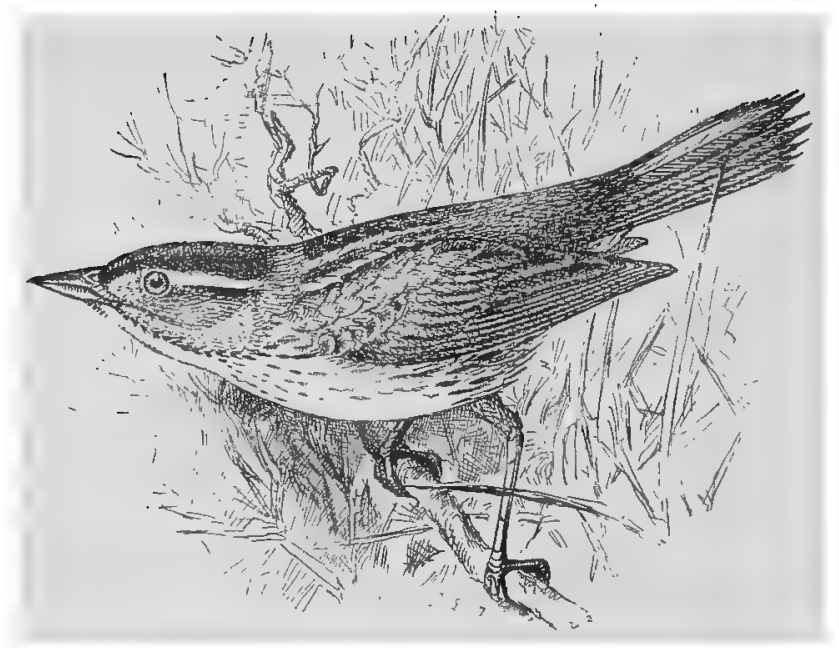

\section{SHARP-TAILED SPARROW.}

SHORE FINCH.

\section{Ammodramus CAUdACUTUS.}

CHAR. Above, brownish gray tinged with olive; crown darker, with median stripe of ashy gray and two stripes of black; back streaked with black; stripes of buff above and below eyes meeting behind ear-coverts; wings edged with yellow; tail-feathers narrow, with acutely pointed tips; below, dull white, breast and sides tinged with buff and streaked with black. Length about $5 \frac{1}{4}$ inches.

Nest. In a salt-marsh or wet meadow, amid a cluster of reeds or tuft of sedges, to the stems of which it is sometimes fastened; a somewhat bulky structure of grass and weed-stems, lined with fine grass.

Eggs. 4-5; dull white or tinged with buff or green, thickly spotted with brown and lilac; $0.75 \times 0.55$.

The Shore Finch is an inhabitant of the low islands and marshy sea-coasts from Massachusetts to Texas, living on small shrimps, marine insects, and probably grass seeds, moving through the rank herbage nearly with the same agility and timidity as a Swamp Sparrow, to which in structure of the feet and stoutness of the bill it bears considerable affinity. 
These birds are not rare, though not so numerous as the Seaside Sparrow, with which they commonly associate.

These Finches frequent the water, and walk on the floating weeds as if on the land; throughout the winter they remain gregarious till spring, when they separate for the purpose of breeding. They are almost silent, a single tweet being now all they are heard to utter; and even in the spring, so defective are they in melody that their notes are scarcely worthy the name of a song. They nest on the ground, amid the short marsh-grass near the line of high-water mark; a slight hollow is made, and then lined with delicate grass. They raise two broods in the season in the Middle States.

"Sharp-tails" have been traced north to Prince Edward's Island, but in $1887 \mathrm{Mr}$. Jonathan Dwight, Jr., discovered that true caudacutus had not been taken beyond Portsmouth, N. H., the birds found to the northward of that point being a distinct variety, which he named subvirgatus.

\section{ACADIAN SHARP-TAILED SPARROW.}

\section{AMmodRamUS CAUDACUTUS SUBVIRGATUS.}

Char. "Similar in size and coloring to $A$. caudacutus, but paler and much less conspicuously streaked beneath with pale greenish gray instead of black or deep brown. Bill averages smaller. Compared with nelsoni it is much paler and grayer, generally larger, and with a longer bill" (Dwight).

Nest and Eggs are not known to differ from those of true caudacutus.

The habitat of this newly discovered sub-species, or, rather, the limit of its range, has not yet been determined. Mr. Dwight gives it as "Marshes of southern New Brunswick, Prince Edward's Island, and probably Nova Scotia, and southward in migration along the Atlantic coast." In habits the present bird differs from caudacutus in frequenting fresh-water marshes and dry meadows on the margins of inland streams.

The song of this bird - if its few wheezy notes deserve such recognition - is a rather ludicrous effort, and suggests a bad cold in the head. Mr. Dwight represents it by the syllables $l \breve{c} c-s \bar{e}-\bar{e}-$ $\bar{e}-\bar{e}-o o p$. All I remember having heard from the specimens I encountered is the $s \bar{e} \bar{e}-\bar{e}-\bar{e}-\bar{e}-o o p$, delivered with apparent effort, as if choking. 


\section{NELSON'S SPARROW.}

\section{AMMODRAMUS CAUDACUTUS NELSONI.}

CHAR. Differs from the type by the colors of the back being very sharply defined, the white a clearer shade, and the brown a richer and more decided umber; chest and sides deep buff. Size larger than true caudacutus.

Nest and Eggs similar to caudacutus.

Nelson's Sharp-tail was described by Mr. J. A. Allen in 1875 . It is found in summer on the marshes of the Mississippi valley, and in winter on the Atlantic coast from Massachusetts (sparingly) to North Carolina, and possibly to the Gulf States.

\section{SEASIDE SPARROW.}

\section{SEASIDE FINCH.}

AMMODRAMUS MARITIMUS.

CHAR. Above, dull olive brown, back and head with indistinct streaks of ashy; superciliary line and edge of wing yellow; below, dull white, the breast and sides with dark streaks. Length about 6 inches.

Nest. Hidden amid a tuft of grass or coarse sedges in a salt marsh or wet meadow; sometimes placed on the ground, often a few inches above it ; composed of dry grass.

Eggs. 4-6; dull white with green or buff tint, spotted with brown; $0.80 \times 0.60$.

This species is not uncommon in the maritime marshy grounds and in the sea islands along the Atlantic coast from Massachusetts to the Southern States. It confines its excursions almost wholly within the bounds of the tide-water, leaving its favorite retreats for more inland situations only after the prevalence of violent easterly storms. In quest of marine insects, crustacea, shrimps, and minute shell-fish, it courses along the borders of the strand with all the nimbleness of a Sandpiper, examining the sea-weeds and other exuviæ for its fare; it seeks out its prey also at dusk, as well as at other times, and usually roosts on the ground like a Lark. In short, it derives its whole subsistence from the margin of the ocean, 
and its flesh is even imbued with the rank or fishy taste to be expected from the nature of its food. At other times it remains amidst the thickest of the sea-grass, and climbs upon the herbage with as much dexterity as it runs on the ground. Its feet and legs for this purpose are robust, as in the Swamp Sparrow. It appears to rear two broods in the season. In May and June the Seaside Finch may be seen almost at all hours perched on the top of some rank weed near the saltmarsh, singing with much emphasis the few notes which compose its monotonous song. When approached it seeks refuge in the rank grass by descending down the stalks, or flies off to a distance, flirting its wings, and then, alighting suddenly, runs off with great nimbleness.

The Seaside Finch is now considered a rare bird in Massachusetts, though common, if not abundant, in Connecticut. It is not quite so exclusively maritime as Nuttall supposed, as it is found on the margins of rivers so far inland that the water is scarcely brackish.

Note. - Scot'T'S Seaside SParrow (A. maritimus peninsula) was first described from specimens taken by Mr. W. E. D. Scott at Tarpon Springs, Florida, in I888. It is intermediate in coloration between $A$.nigrescens and $A$. maritimus.

This race has been found only along the southwestern coast of Florida and on Grand Isle, off Louisiana.

The DUSKy SEASIDE SPARRow (Ammodramus nigrescens) which differs from maritimus in being black above, streaked with olive and gray, beneath white, streaked with black - occurs in southern Florida. 


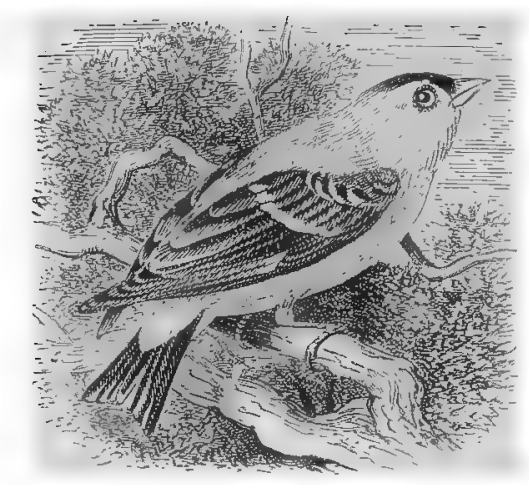

\section{AMERICAN GOLDFINCH.}

YELLOW BIRD. THISTLE BIRD. THISTLE FINCH. WILD CANARY.

SPINUS TRISTIS.

CHAR. Male in summer: bright gamboge yellow; crown, wings, and tail black; upper and under tail-coverts, wing and tail markings, white. In winter the male resembles the female, though with less olive tint. Female : above, olive brown; below, paler or yellowish; forehead without black; wings and tail much the same as in the male. Length about $43 / 4$ inches.

Nest. In a pasture or orchard; usually placed in a crotch of a deciduous tree 10 to 20 feet from the ground; a compact and gracefully formed cup, made of grass and vegetable fibre, lined with grass and plant down, and often with hair.

Eggs. 3-6; white with tint of green or greenish blue, occasionally marked with faint spots of brown; $0.65 \times 0.50$.

This common, active, and gregarious Goldfinch is a very general inhabitant of the United States. It is also found in summer in the remote interior of Canada, in the fur countries and near Lake Winnipique, in the $49^{\text {th }}$ degree of latitude, as well as in the remote territory of Oregon and the Rocky Mountains, on the banks of Lewis's River, where I found the nest as usual with white eggs. On the other hand, it is also met with in Mexico, and even in Guiana and Surinam in tropical America, where it frequents the savannas. Although many of these birds which spend the summer here leave at the approach of winter, yet hungry flocks are seen to arrive in 
this part of New England throughout that season; and sometimes, in company with the Snow Buntings, in the inclement months of January and February, they may be seen busily employed in gleaning a scanty pittance from the seeds of the taller weeds, which rise above the deep and drifted snows. As late as the $15^{\text {th }}$ of September I have observed a nest of the Yellow Bird with the young still unfledged. Their migrations are very desultory, and do not probably extend very far, their progress being apparently governed principally by the scarcity or abundance of food with which they happen to be supplied. Thus, though they may be numerous in the depth of winter, as soon as the weather relaxes in the month of March, scarcely any more of them are to be seen, having at this time, in quest of sustenance, proceeded probably to the southern extremity of the United States. Those observed in tropical America may be hibernal wanderers from the cooler parts of Mexico. At all events they select the milder climates of the Union in which to pass the breeding season, as at this time they are but rarely seen in the Southern States, Kentucky being about the boundary of their summer residence.

Naturally vagrant and wandering, they continue to live in flocks or in near vicinage, even throughout the greatest part of the selective season. As the fine weather of spring approaches they put off their humble winter dress, and the males, now appearing in their temporary golden livery, are heard tuning their lively songs as it were in concert, several sitting on the same tree enjoying the exhilarating scene, basking and pluming themselves, and vying with each other in the delivery of their varied, soft, and cheerful warble. They have also the faculty of sinking and raising their voices in such a delightful cadence that their music at times seems to float on the distant breeze, scarcely louder than the hum of bees; it then breaks out as it were into a crescendo, which rings like the loud song of the Canary. In cages, to which they soon become familiar and reconciled, their song is nearly as sonorous and animated as that of the latter. When engaged in quarrel they sometimes hurl about in a whole flock, some, as it were, interfering to 
make peace, others amused by the fray, all uttering loud and discordant chirpings. One of their most common whining calls while engaged in collecting seeds in gardens, where they seem to be sensible of their delinquency, is 'măy bé, 'măy bé. They have also a common cry like 'tsheveet'tshevee, uttered in a slender, complaining accent. These and some other twittering notes are frequently uttered at every impulse while pursuing their desultory waving flight, rising and falling as they shut or expand their laboring wings. They are partial to gardens and domestic premises in the latter end of summer and autumn, collecting oily seeds of various kinds and shelling them with great address and familiarity, if undisturbed often hanging and moving about head downwards, to suit their convenience while thus busily and craftily employed. They have a particular fondness for thistle seeds, spreading the down in clouds around them, and at this time feeding very silently and intently; nor are they very easily disturbed while thus engaged in the useful labor of destroying the germs of these noxious weeds. They do some damage occasionally in gardens by their indiscriminate destruction of lettuce and flower seeds, and are therefore often disliked by gardeners; but their usefulness in other respects far counterbalances the trifling injuries they produce. They are very fond, also, of washing and bathing themselves in mild weather; and as well as tender buds of trees they sometimes collect the Conferyas of springs and brooks as a variety to their usual fare.

They raise sometimes two broods in the season, as their nests are found from the first week in July to the middle of September. In 1831 I examined several nests, and from the late period at which they begin to breed it is impossible that they can ever act in the capacity of nurses to the Cow Troopial. This procrastination appears to be occasioned by the lack of sufficiently nutritive diet, the seeds on which they principally feed not ripening usually before July.

Note. - The Black-HeAded Goldfinch (Spinus notatus), a Mexican bird, is credited with an accidental occurrence in Kentucky. 


\section{PINE SISKIN.}

\section{PINE FINCH. PINE LINNET.}

SPINUS PINUS.

Char. Above, olive brown or dark flaxen, streaked with dusky; wings and tail black, the feathers edged with yellow; wings with two buffish bars; below streaked with dusky and yellowish white. Length about $43 / 4$ inches.

Nest. Usually in a deep forest, on a horizontal branch of an evergreen tree 20 to 40 feet from the ground. It is fairly well built, as a rule, but is neither as compact nor graceful as the Thistle Bird's, and is composed of various materials, though generally grass, twigs, and pine-needles form the exterior, while the lining is either feathers or hair, or both.

Eggs. 3-5; pale green or greenish blue spotted with light reddish brown and lilac; $0.70 \times 0.50$.

Our acquaintance with this little northern Goldfinch is very unsatisfactory. It visits the Middle States in November, frequents the shady, sheltered borders of creeks and rivulets, and is particularly fond of the seeds of the hemlock-tree. Among the woods, where these trees abound, these birds assemble in flocks, and contentedly pass away the winter. Migrating for no other purpose but subsistence, their visits are necessarily desultory and uncertain. My friend Mr. Oakes, of Ipswich, has seen them in large flocks in that vicinity in winter. With us they are rare, though their favorite food is abundant. They are by no means shy, and permit a near approach without taking alarm, often fluttering among the branches in which they feed, hanging sometimes by. the cones, and occasionally uttering notes very similar to those of the American Goldfinch. Early in March they proceed to the North, and my friend Audubon observed them in families, accompanied by their young, in Labrador in the month of July. They frequented low thickets in the vicinity of water, and were extremely fearless and gentle. Their summer plumage, as we have since also found in the Oregon Territory, where they abound and breed, is entirely similar to the garb in which they visit us in the winter, with the sole exception that the yellow of the wings is brighter. 
They sing on the wing in the manner of the Goldfinch. Their notes are clear, lively, and mellow, like as in that bird, but still sufficiently distinct; they fly out in the same graceful, deep curves, emitting also the common call-note at every effort to proceed.

The history of this interesting bird is but little better known today than when Nuttall wrote. Our ignorance is partly due to the irregular, nomadic habits of the bird, but chiefly because its favorite haunts are in out-of-the-way places, amid the deeper recesses of the forests, where few observers penetrate. At intervals large flocks visit the outskirts of settlements, and even look in upon the villages; but these are merely excursions by the way introduced into the migration programme. Its habitat is now given as "North America in general, breeding mostly north of the United States." In the east, nests have been found in New York State by Dr. C. Hart Merriam and Dr. A. K. Fisher, and a few pairs are known to breed yearly in Massachusetts; but the major portion of the eastern flocks go to the more northern portions of New England and beyond before settling down for the summer.

The dates usually given for the nesting are early in May; but a much earlier time is given by Dr. A. Leith Adams, an English naturalist who met with the species in New Brunswick. In his "Field and Forest Rambles," he writes: "It breeds early, and has its young flying before the first summer migrants arrive in April, when large flocks may be observed feeding on the buds of the hawthorn preparatory to their departure northward." He adds that it is a choice cage-bird, and is easily tamed. He kept some for several months, and when liberated they all returned to their cages after an absence of several days.

The biography of this species forms an interesting chapter in that interesting book, "The Land Birds and Game Birds of New England," by H. D. Minot, - a book, by the way, that has not received the recognition its merit deserves. 


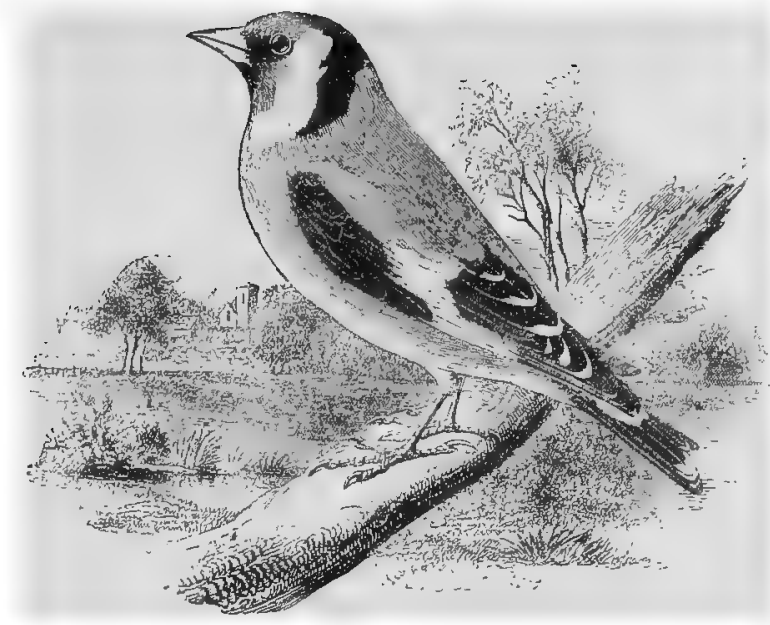

\section{GOLDFINCH.}

\section{Carduelis carduelis.}

Char. Forehead and throat crimson; cheeks and lower throat white; crown and nape black, the latter being bordered by a narrow line of white; back brown; wings black, tipped with white and barred with yellow; tail-coverts white with black bases; three outer tail-feathers black, with white central spots, the remainder black, tipped with white; breast white, banded with brownish buff; flanks buffy; belly and under tail-coverts white. Length about 5 inches.

Nest. In an orchard or garden, placed in a fork of a tree or bush; a compact and neatly made structure of fine grass and moss, lined with grass and plant down, etc.

Eggs. 4-6; dull white tinged with blue or green, spotted and streaked with purplish brown; $0.70 \times 0.50$.

This European songster has been introduced within recent years, and though increasing slowly, appears to be thoroughly naturalized.

It is most abundant near Hoboken, N. J., where a number were set at liberty in 1878 , but examples have been taken in other States. A nest and eggs were discovered in Cambridge some ten years ago, and during the summer of 1890 a nest was taken near Worcester, Mass.

In Great Britain it is very common, and breeds north to Caithness, and one nest has been taken on the south side of Skye.

The young are fed on insects and larvæ; but Mr. Saunclers says "the principal food of the Goldfinch consists of seeds of the thistle, knapweed, groundsel, dock, and other plants."

VOL. I. -23 


\title{
HOUSE SPARROW.
}

\author{
ENGLISH SPARROW.
}

PASSER DOMESTTCUS.

CHAR. General color grayish brown, the back streaked with black; a narrow stripe of white over the eyes; cheeks with patches of chestnut and white; sides and neck white; throat and breast black, sometimes washed with chestnut; wings brown with white bar; tail brown; belly dull white. Female: paler, without the black throat-patch. Length about 6 inches.

Nest. Anywhere and of any material, - usually a bulky affair, roughly made of dry grass and feathers.

Eggs. 4-7; grayish white speckled with rich brown and pale lavender; $0.85 \times 0.60$.

This is another introduced species; but about its naturalization there is, unfortunately, no doubt.

The history of the introduction of this bird, and its relation to American agriculture, is exhaustively treated in a volume prepared by Mr. Walter B. Barrows, under the direction of Dr. C. Hart Merriam, ornithologist to the Department of Agriculture, and issued from the Government Printing Office at Washington in 1889. From it we learn that the first importation of this Sparrow was made by Hon. Nicholas Pike, and the birds were liberated in Brooklyn, N. Y., in $185 \mathrm{I}$. The first batch did not thrive, so others - about a hundred - were brought over during 1852 and I 853 . In I854 Colonel Rhodes, of Quebec, brought a number from England and liberated some in Portland, Me., the remainder being taken to Quebec. During the following ten years a few hundred were brought from Europe and scattered between Portland and New York, some thirty being turned out on Boston Common. About I869 a thousand were taken to Philadelphia, and several cities in the interior received each a few pairs.

From these imported birds have sprung the hosts of "ruffians in feathers" that have taken possession of every town and village, from Cape Breton to Florida, and west to Kansas.

A few pairs were taken to southern Greenland, and though some lived through several winters, the entire flock at last perished.

Note. - The European Tree Sparrow (Passer montanus) has also been introduced. A few years ago a number were liberated in St. Louis, and have become thoroughly naturalized there. This bird is closely related to the House Sparrow, which it resembles in appearance and in habits. The Tree Sparrow has not, however, increased so rapidly as its congener, nor proved so great a pest. 


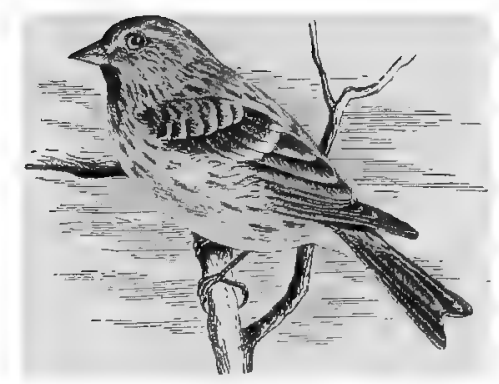

\section{REDPOLL.}

\section{LESSER REDPOLI. REDPOLI LINNET.}

\section{ACANTHIS LINARIA.}

Char. Above, brownish gray streaked with dusky; rump white, tinged with rose pink and streaked with dusky; forehead with patch of deep carmine; wings dusky brown with two white bars; below, white, sides heavily streaked with dusky; chin and throat dusky; breast deep rose pink. Bill extremely acute; in winter its color is yellow tipped with black, but in summer the color is dull blackish. (Female differs from male only in lacking the red tints on rump and breast.) Length $4 \frac{1}{2}$ to 5 inches.

Nest. In a low tree or amid a tuft of grass; composed of dry grass and moss lined with hair or feathers or plant down.

Ergs. 4-6; white tinged with green or b]ue, spotted with reddish brown; $0.65 \times 0.50$.

These elegant birds, which only pay us occasional and transient visits at distant intervals, are inhabitants of the whole Arctic circle to the confines of Siberia, and are found in Kamtschatka and Greenland as well as the colder parts of Europe. Arriving in roving flocks from the northern wilds of Canada, they are seen at times in the western parts of the State of New York with the fall of the first deep snow, and occasionally proceed eastward to the very city of New York, where in the depth of winter, and for several weeks, they have been seen gleaning their scanty food of various kinds of seeds in the gardens of the town and suburbs. Flocks are likewise sometimes seen in the vicinity of Philadelphia in severe winters, though at remote periods; as according to Mr. Ord they have not visited that part of Pennsylvania since the winter of 
I8I3-I4. They appear very unsuspicious while feeding in the gardens, or on the seeds of the alder-bush, one of their favorite repasts, and thus engaged allow a near approach while searching for their food in every posture, and sometimes head downwards. They are also fond of the seeds of the pine, the linden, and rape, and in the winter sometimes content themselves even with the buds of the alder. Wilson believed he heard this species utter a few interrupted notes, but nothing satisfactory is known of its vocal powers. Mr. Ord remarks that their call much resembles that of the common Yellow Bird, to which, indeed, they are allied. They are said to breed in the Highlands of Scotland, and to select the heath and furze for the situation of their nests, though they more commonly choose alder-bushes and the branches of the pine.

According to Richardson, these birds are among the few hardy and permanent residents in the fur countries, where they may be seen in the coldest weather on the banks of lakes and rivers, hopping among the reeds and carices or clinging to their stalks. They are numerous throughout the year even in the most northern districts, and from the rarity of their migrations into the United States it is obvious that they are influenced by no ordinary causes to evacuate the regions in which they are bred. Famine, in all probability, or the scarcity of food, urges them to advance towards the South. It is certain that they do not forsake their natal regions to seek shelter from the cold. This season, by the 7 th or 8 th $^{-1}$ of November ( 1833 ), before the occurrence of any extraordinary cold weather, they arrived in this vicinity (Cambridge, Mass.) in considerable flocks, and have not paid a visit to this quarter before to my knowledge for 10 or 12 years. They now regularly assemble in the birchtrees every morning to feed on their seeds, in which employment they are so intent that it is possible to advance to the slender trees in which they are engaged and shake them off by surprise before they think of taking wing. They hang upon the twigs with great tenacity, and move about while feeding in reversed postures, like the Chickadees. After being shot at they only pass on to the next tree and resume their feeding as 
before. They have a quailing call perfectly similar to that of the Yellow Bird (Fringilla tristis), tweée tweée, or tshe-veé; and when crowding together in flight make a confused chirping 'twit' itwit' twit' 'twit' 'twit, with a rattling noise, and sometimes go off with a simultaneous twitter. Occasionally they descend from their favorite birches and pick up sunflower seeds and those of the various weedy Chenopodiums growing in wastes. At length they seemed attracted to the pines by the example of the Crossbills, and were busily employed in collecting their seeds. As the weather becomes colder they also roost in these sheltering evergreens; and confused flocks are seen whirling about capriciously in quest of fare, sometimes descending on the fruit-trees to feed on their buds by way of variety. Though thus urged from their favorite regions in the north, there appeared no obvious reason for their movements, as we found them fat and not driven to migrate from any imminent necessity.

In Nuttall's day but two forms of Redpoll were recognized by naturalists, - linaria and canescens (=exilipes); but now there are five, - or six, if we count the hypothetical brewesteriz. Similar as these appear to the casual observer, an expert can readily divide them when examples of the different races are compared, though it is sometimes difficult to refer a specimen with accuracy unless so compared.

The habitat of true linaria is now given as "northern portions of northern hemisphere, excepting Greenland, in North America; migrating south in winter to about $40^{\circ} . "$

Note. - Holbell's Redpoll (Acanthis linaria holboellii) is larger than the type, - length 5 to $5 \frac{1}{4}$ inches, -- with a proportionately larger bill. It is usually restricted to the northern coasts of Europe and Asia, but examples have been taken in Alaska and at Quebec.

The Greater Redpoll (Acanthis linaria rostrata) is still larger, - length $5 \frac{1 / 4}{4}$ to $53 / 4$ inches, - and the colors are darker, with the under parts more broadly striped. It is found in southern Greenland in summer, and in winter migrates sparingly south to New England, and west to Manitoba and northern Illinois. 


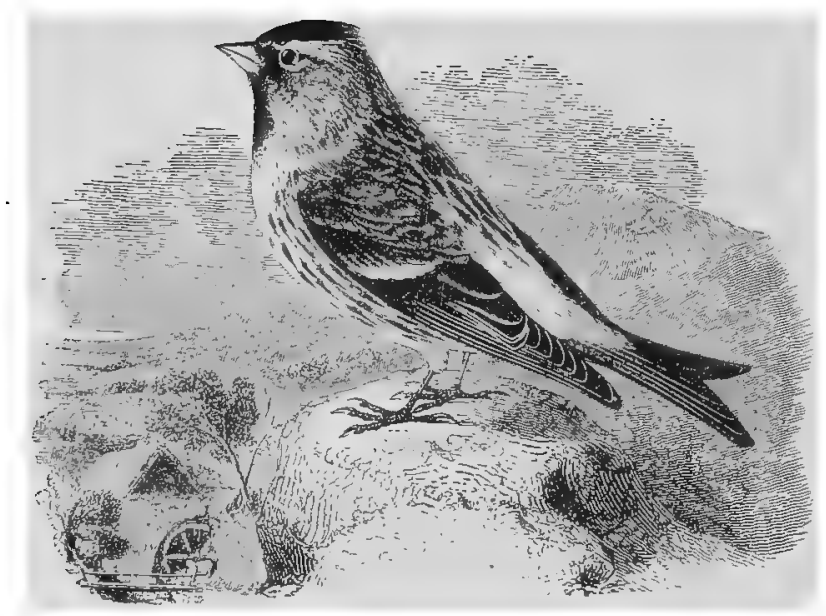

\section{HOARY REDPOLL.}

MEALY REDPOLL.

ACANTHIS HORNEMANII EXILIPES.

CHAR. A bove, dull white or pale brownish white, streaked with dusky brown; rump white unstreaked, - in the male usually washed with pink; wings dusky brown with two white bars; below, dull white sparsely streaked with dusky; chin and throat dusky; breast delicate rose pink. Length $4 \frac{\mathrm{t}}{2}$ to 5 inches.

Similar to $A$. linaria, but colors paler, - the brown largely replaced by gray, and the red of a paler shade and more restricted.

Nest. In a low tree or on the ground; composed of grass and twigs lined with feathers.

Eggs. 3-5; white tinged with blue or green, spotted with reddish brown; $0.65 \times 0.50$.

This species, so nearly allied to the last, is met with partly in the same remote boreal regions in the summer, but is of much more rare occurrence; it is also found in the territory of Oregon, and stragglers have been obtained as far south as New Jersey and New York. In Maine it is less rare. These birds have a note very similar to the last species, but distinct. They are full of activity and caprice while engaged in feeding, making wide circles and deep undulations in their flight. Like 
Titmice also, they frequently feed and hang to the twigs in reversed postures.

This form summers in the Arctic regions, and in winter migrates southward, a few examples reaching the northern border of the United States.

Note. - The GREenland Redpoll (Acanthis hornemannii) is larger than exilipes, - length $53 / 2$ to $61 / 2$ inches. It breeds in Greenland and the eastern part of Arctic America, and in winter ranges as far south as Labrador.

Brewster's LinNet (Acanthis brezesteriz) is a "Redpoll" without any red on its poll; it differs also from the other forms in lacking the dusky spot on the throat and in having a portion of its plumage tinged with yellow. The type specimen was taken at Waltham, Mass., in I870, and remains unique. The A. O. U. have placed the name in that "lock-up" for suspicious characters, the " hypothetical list."

\section{TOWHEE.}

\section{GROUND ROBIN. CHEWINK.}

\section{PIPILO ERYTHROPHTHALMUS.}

CHAR. Black with white belly and bay sides and vent; outer tailfeathers partly white; white spot on wing; iris red. Female and young tawny brown where the adult male is black.

Nest. Near the margin of woodland or in an overgrown pasture; usually placed on the ground and concealed in a tuft of grass or brushheap, or under a $\log$ or bush, - sometimes fastened to a low bush; loosely made of dry leaves, grape-vines, weed-stems, and grass, lined with fine grass, roots, or pine-needles.

Eggs. 4-6; dull white thickly marked with fine spots of warm, reddish brown and lilac; sometimes the marks are bolder; $0.95 \times 0.75$

This is a very common, humble, and unsuspicious bird, dwelling commonly in thick dark woods and their borders, flying low, and frequenting thickets near streams of water, where it spends much time in scratching up the withered leaves for worms and their larvæ, and is particularly fond of wire-worms (or Iuli), as well as various kinds of seeds and gravel. Its rustling scratch among the leafy carpet of the forest is often the only indication of its presence, excepting 
now and then a call upon its mate (tŏw-quee, tŏw-wee, tŏwweet), with which it is almost constantly associated. While thus busily engaged in foraging for subsistence, it may be watched and approached without showing any alarm; and taking a look often at the observer, without suspicion, it scratches up the leaves as before. This call of recognition is uttered in a low and somewhat sad tone, and if not soon answered it becomes louder and interrogatory, tow-wee towee? and terminates often with toweet. These birds are accused of sometimes visiting the pea-fields to feed, but occasion no sensible damage.

In the pairing season and throughout the period of incubation the male frequently mounts to the top of some bush amidst the thickets where he usually passes the time, and from hence in a clear and sonorous voice chants forth his simple guttural and monotonous notes for an hour or so at a time, while his faithful mate is confined to her nest. This quaint and somewhat pensive song often sounds like $t$ 'sh' $d$ zeñtée tê tê ť́ $t \breve{e} t \breve{e}$, or ' $b \breve{\imath} d \dot{d}-w \breve{t} t e \dot{e}$, tr tr 'tr 'tr, — the latter part a sort of quaint and deliberate quivering trill; sometimes it sounds like 'büd tsherr ' $r h$ ' $r h$, rrh 'wt, then ' $t$ 'wee twee $t$ ' tsher' $r$ ' $r$, also et se ya, ya 'ya 'ya 'ya 'ya; the latter notes, attempted to be expressed by whistled and contracted consonant syllables, are trilled with this sound.

Ground Robins, sometimes also called Tshe-ruink and Peewink, from another of their notes, are general inhabitants of Canada and the United States even to the base of the Rocky Mountains and the peninsula of Florida, in all of which regions, except the last, with Louisiana and the contiguous countries, they pass the summer and rear their young, migrating, however, from the Northern and Middle States in October, and returning again about the middle or close of April, according to the advancement of the season, at which time also the males usually precede the arrival of their mates. They pass the winter generally to the south of Pennsylvania, and are then very abundant in all the milder States in the Union.

They are said to show some address at times in concealing 
their nest, which is fixed on the ground in a dry and elevated situation and sunk beneath the surface among the fallen leaves, sometimes under the shelter of a small bush, thicket, or brier. According to the convenience of the site, it is formed of different materials, sometimes, according to Wilson, being made of leaves, strips of grape-vine bark, lined with fine stalks of dry grass, and occasionally in part hidden with hay or herbage. Most of the nests in this vicinity are made in solitary dry pine woods without any other protection than some small bush or accidental fallen leaves; and the external materials, rather substantial, are usually slightly agglutinated strips of red-cedar bark, or withered grass with a neat lining of the same and fallen pine leaves; the lining sometimes made wholly of the latter. The nest is also at times elevated from the ground by a layer of coarse leaf-stalks such as those of the hickory. The first brood are raised early in June, and a second is often observed in the month of July; but in this part of New England they seldom raise more than one. The pair show great solicitude for the safety of their young, fluttering in the path and pretending lameness with loud chirping when their nest is too closely examined.

The eastern form of the Towhee is not found west of Minnesota, Kansas, and Texas. In the more northern and unsettled portions of New England it is very rare or absent. It is common in Man. itoba and southern Ontario, but rare in Quebec; and one example, captured near St. John, N. B., in $188 \mathrm{I}$, is the only known instance of its occurrence in the Maritime Provinces.

NOTE. - The WhITE-EYED TOWHEE (Pipilo erythrophthalmus alleni) differs from the northern race chiefly in being of somewhat smaller size, and in the iris being white instead of red.

It was discovered during the spring of 1879 by Mr. C. J. May. nard in Florida, to which State it is restricted. 


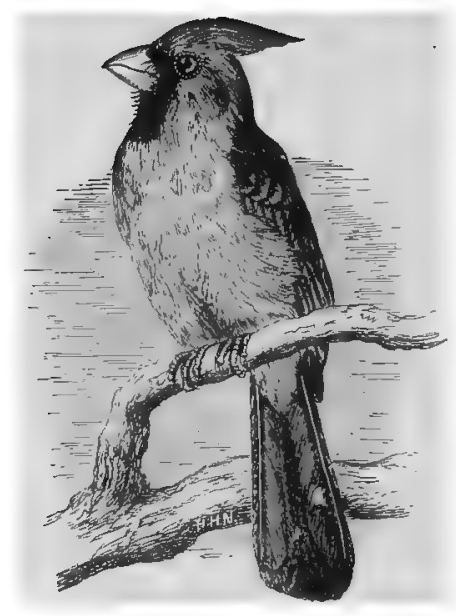

CARDINAL.

REDBIRD.

\section{CaRdinalis CARDINALIS.}

Char. Head with conspicuous crest. Male: above, bright vermilion, shaded with gray on the back; beneath, paler; forehead and throat black. Female: above, olive gray; beneath, buffy. Young similar to female, but duller. Length about 8 to $85 / 2$ inches.

Nest. In a variety of situations, most frequently amid a thicket of brambles or in a low tree; loosely made of twigs, strips of grape-vine, dry grass, weed-stems, lined with fine grass or roots, sometimes with hair.

Eggs. 3-5; dull white or tinged with blue, green, or buff; spotted with reddish brown and lilac; $1.00 \times 0.75$.

These splendid and not uncommon songsters chiefly reside in the warmer and more temperate parts of the United States from New York to Florida, and a few stragglers even proceed as far to the north as Salem in Massachusetts. They also inhabit the Mexican provinces, and are met with south as far as Carthagena; adventurously crossing the intervening ocean, they are likewise numerous in the little temperate Bermuda islands, but do not apparently exist in any of the West Indies. As might be supposed, from the range already stated, the Redbirds are not uncommon throughout Louisiana, Missouri, and Arkansas Territory. Most of those which pass the summer in 
the cooler and Middle States retire to the South at the commencement of winter; though a few linger in the sheltered swamps of Pennsylvania and near the shores of the Delaware almost through the winter. They also, at this season, probably assemble towards the sea-coast from the west, in most of the Southern States, where roving and skulking timid families are now seen flitting silently through thickets and swampy woods, eager alone to glean a scanty subsistence, and defend themselves from prowling enemies. At all times, however, they appear to have a predilection for watery groves and shaded running streams, abounding with evergreens and fragrant magnolias, in which they are so frequent as to be almost concomitant with the scene. But though they usually live only in families or pairs, and at all times disperse into these selective groups, yet in severe weather, at sunset, in South Carolina, I observed a flock passing to a roost in a neighboring swamp and bushy lagoon, which continued, in lengthened file, to fly over my head at a considerable height for more than twenty minutes together. The beautiful procession, illumined by the last rays of the setting sun, was incomparably splendid as the shifting shadowy light at quick intervals flashed upon their brilliant livery. They had been observed to pass in this manner to their roost for a considerable time, and, at daybreak, they were seen again to proceed and disperse for subsistence. How long this timid and gregarious habit continues, I cannot pretend to say; but by the first week in February the song of the Redbird was almost daily heard. As the season advances, roving pairs, living, as it were, only with and for each other, flit from place to place; and following also their favorite insect or vegetable fare, many proceed back to the same cool region in which they were bred, and from which they were reluctantly driven; while others, impelled by interest, caprice, and adventure, seek to establish new families in the most remote limits of their migration. Some of these more restless wanderers occasionally, though rarely, favor this part of New England with a visit. After listening with so much delight to the lively fife of the splendid Cardinal, as I travelled alone through the deep and 
wild solitudes which prevail over the Southern States, and bid, as I thought, perhaps an eternal adieu to the sweet voice of my charming companions, what was my surprise and pleasure, on the $7^{\text {th }}$ of May, to hear, for the first time in this State, and in the Botanic Garden, above an hour together, the lively and loud song of this exquisite vocalist, whose voice rose above every rival of the feathered race, and rung almost in echoes through the blooming grove in which he had chosen his retreat. In the Southern States, where these birds everywhere breed, they become familiarly attached to gardens, which, as well as cornfields, afford them a ready means of subsistence; they are also fond of the seeds of most of the orchard fruits, and are said occasionally to prey upon bees.

The lay of the Cardinal is a loud, mellow, and pleasingly varied whistle, delivered with ease and energy for a considerable time together. To give it full effect, he chooses the summit of some lofty branch, and elevating his melodious voice in powerful as well as soothing and touching tones, he listens, delighted as it were, with the powers of his own music, at intervals answered and encouraged by the tender responses of his mate. It is thus the gilded hours of his existence pass away in primeval delight, until care and necessity break in upon his contemplative reveries, and urge him again to pursue the sober walks of active life.

The song of the Redbird, like that of so many others, though possessed of great originality, often consists in part of favorite borrowed and slightly altered phrases. It would be a difficult and fruitless task to enumerate all the native notes delivered by this interesting songster; a few may be perhaps excused by those who wish, in their rural walks, to be made, in any way, acquainted with the language of the feathered vocalists that surround them. All the tones of the Cardinal are whistled much in the manner of the human voice. Late in February, while travelling in Alabama, I heard one crying woolit, wolit wolit wolit, then in a quicker tone butsh butsh bütsh bütsh, and 'tshooway tshooway tshooway. At another time the song was 'wit a'wit, 'teu'; then tshevi tsheve 'teru, 
'whoit 'whoit 'whoit' teu' (the 'whoit an exact human whistle, and the teiu tenderly emphatic). Another bird called téo téo téo, tshooe tshooe tshooe tshooe, then teo teo teo teo alone, or 'wóit 'wóit' 'wóit 'wóit, with the last word delivered slower, and in a sinking, delicately plaintive tone. These phrases were also answered in sympathy by the female, at a little distance up the meandering brook where they were engaged in collecting their food. In Florida, about the 12 th of March, I heard a very fine Redbird singing 'whĭttoo wüttoo wr̆doo 'wŭddoo. $\mathrm{He}$ began low, almost in a whisper, but very clearly articulated, and gradually raised his voice to loudness, in the manner of the Nightingale. He now changed the strain into 'victu, wilt wilt wilt wilt; then 'victue tshooe 'tshŏoe tshŏoe tshöoe, afterwards tu' tu' 'victu, and 'victu tu tu, then varying 'tshooee, etc., in a lower key. On approaching this bird, to see and hear him more distinctly, he exhibited his anger by scolding in a hoarse tone almost like that of a squirrel, and from the season, and absence of respondence in the female, I imagine he already had a nest in the neighboring thicket. The bird, which frequented the Botanic Garden for several days, in the morning sang fearlessly and loudly, but at other times the pair hid themselves amongst the thickest bushes, or descended to the ground to feed among the grass and collect insects and worms; now and then however, in an undertone, as if afraid of attracting notice, he whispered to his mate teu's teu' tế, woit, 'woit 'woit, elevating his tone of recognition a little at the close of the call, and going over other of the usual phrases in the same whispering and slenderly rising voice. About the 4 th of July, the same pair, apparently, paid us a parting visit, and the male sang with great energy, 'tv' twe', 'wétŏ 'wètŏ 'wetŏ 'wetŏ 'wetŏ wait, then waitüр waйtŭp waйtüp wă̌tŭp, tshow tshow tshŏw tshow tshow. On whistling any of these notes within hearing of the Cardinal, a response is almost certain, as this affectionate recognition is frequently answered by the female. His phrase may also be altered at will, by whistling some other than that which he repeats, as he often immediately answers in the call he hears, supposing it to be that of his approaching mate. 
On their arrival in the Middle States, in spring, violent contests sometimes ensue between the unmated and jealous males. When the dispute is for the present closed, the pair, probably for greater security, and dreading a recurring quarrel of doubtful issue, wander off to a remote distance from their usual, abode, and in this way, no doubt, occasionally visit countries but little frequented by the rest of their species. Early in May, it seems, in Pennsylvania, according to Wilson, they begin to prepare their nests, which are often placed in an evergreen bush, cedar, laurel, or holly. They usually raise two broods in the season. As they are so easily domesticated immediately after being caught in trap cages, it is unnecessary to raise them from the nest. By this kind of unnatural confinement, the brilliant color of the male is found sometimes to fade until it becomes of a pale whitish red. They live, however, long in confinement, and an instance is known of one which had survived for 2 I years. In the cage, they have not that variety of song which they exhibit in their native wilds; and this, judging from the frequent repetition of the same phrase, would appear to be a monotonous performance, if the variety of expression, tone, and key did not perpetually relieve and enhance the character of the lay. His song also continues for 6 or 8 months in the year, and is, even, as among the Thrushes, more lively in wet weather, the sadness of Nature, softening and soothing the tender vocalist into a lively, pathetic, and harmonious revery. So highly were these birds esteemed for their melody that, according to Gemelli Careri, the Spaniards of Havanna, in a time of public distress and scarcity, bought so many of these birds, with which a vessel was partly freighted, from Florida, that the sum expended, at Io dollars apiece, amounted to no less than 18,000 dollars! Indeed, Latham admits that the notes of our Cardinal "are almost equal to those of the Nightingale," the sweetest feathered minstrel of Europe. The style of their performance is, however, wholly different. The bold, martial strains of the Redbird, though relieved by tender and exquisite touches, possess not the enchanting pathos, the elevated and varied 
expression of the far-famed Philomel, nor yet those contrasted tones, which, in the solemn stillness of the growing night, fall at times into a soothing whisper, or slowly rise and quicken into a loud and cheering warble. A strain of almost sentimental tenderness and sadness pervades by turns the song of the Nightingale; it flows like a torrent, or dies away like an echo; his varied ecstasies poured to the pale moonbeams, now meet with no response but the sighing zephyr or the evermurmuring brook. The notes of our Cardinal are as full of hilarity as of tender expression; his whistling call is uttered in the broad glare of day, and is heard predominant over most of the feathered choir by which he is surrounded. His responding mate is the perpetual companion of all his joys and cares; simple and content in his attachment, he is a stranger to capricious romance of feeling, and the shades of melancholy, however feeble and transient, find no harbor in his preoccupied affections.

The Cardinal occurs regularly but sparingly in southern New England, and it has been occasionally seen in Massachusetts and northward. Two examples visited Halifax, N. S, in 1871 . It is quite common in Ohio, and has been taken, across the lake, in Ontario.

\section{EVENING GROSBEAK.}

\section{COCCOTHRAUSTES VESPERTTNA.}

Char. Dusky olivaceous, shading to yellowish on the rump; forehead, line over the eyes, and under tail-coverts, yellow; crown, wings, and tail black; secondaries mostly white; bill greenish yellow, conspicuously large. Female differs slightly from the male, but is readily identified. Length about $7 \frac{1}{2}$ to 8 inches.

Nest. In the deep forest, usually on a branch of a tall tree, sometimes in low bush; composed of twigs and roots, lined with roots or hair.

Eggs. 4-?; pale dull green, marked with pale brown spots.

This beautiful species inhabits the solitudes of the Northwestern interior, being met with from the extremity of the Michigan Territory to the Rocky Mountains. It is not uncommon towards the upper extremity of Lake Superior and 
the borders of Athabasca Lake; to the east of these limits these birds appear to be only transient visitors in spring and fall. They are common inhabitants of the fur countries, and particularly of the maple woods of the Saskatchewan, where they do not arrive from the South before the commencement of the month of June. In the pine woods of Oregon (according to Mr. Townsend) numerous flocks are seen about the middle of May, and at this time they are very tame and unsuspicious, moving about in considerable numbers throughout the whole of the day, and seem no way given to retiring before sunset. Their ordinary note while feeding consists of a single rather screaming call. At other times, particularly about mid-day, the male from the branches of some tall pine-tree utters a single warbling note much like the interrupted beginning of the Robin's song, but not so sweet. They feed upon the seeds of the pine and other trees, alighting upon the large limbs, and proceed by a series of hops to the very extremities of the branches. They also occasionally devour the larvæ of ants, and probably other kinds of insects.

The Evening Grosbeak occurs regularly in winter in Wisconsin, Illinois, Iowa, and Michigan, and occasionally in Ohio and Ontario. During the latter part of the winter of $1889-90$ numbers were seen eastward to Montreal and the New England States.

Its nesting habits are almost unknown. 


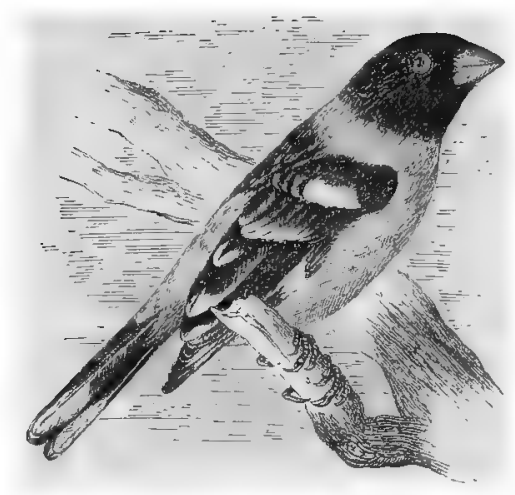

ROSE-BREASTED GROSBEAK.

\section{Habia ludoviciana.}

CHAR. Male: above, black; rump white; wings and tail black with white markings; below, white; breast and under tail-coverts deep rose pink. Female : above, streaked blackish and olive; crown with central stripe of white; rump white; under parts dull white, streaked with brown; no red on the breast. Length $7 \frac{1 / 2}{2}$ to $8 \pi / 2$ inches.

Nest. Usually on the margin of woods, or in a dense alder-swamp, occasionally in a garden or open pasture ; composed of grass, usnea moss, roots, stalks, and twigs, lined with fine grass, roots, or pine-needles.

Eggs. 3-5; dull green or bluish green variously marked with spots and blotches of reddish brown, lilac, and pale lavender; $1.00 \times 0.70$.

The remote Northwestern Territories of the Union, Canada, and the cool regions towards the Rocky Mountains appear to be the general residence of the Rose-breasted Grosbeak. A few pairs breed on the banks of the Mohawk, and probably in the interior of Pennsylvania. Mr. Say met with it in the spring, on the lower part of the Missouri; and at Pembino, on the $5^{\text {th }}$ of August, in the $49^{\text {th }}$ parallel. Dr. Richardson also observed it in the latitude of $53^{\circ}$, and Audubon found it breeding in Newfoundland. It has likewise been seen in Mexico and Texas. These are, no doubt, its proper natal regions, and the course of its migrations, from which it only ventures accidentally in severe winters, and is then transiently seen in pairs east of the Atlantic mountains, which constitute the general boundary of its range. It is thus seen occasionally in the

VOL. I. -24 
vicinity of Philadelphia, in the State of New York, particularly along the borders of Lake Ontario, and in Connecticut, but rarely in this part of New England. Pennant speaks of its arrival in the State of New York in May, where it has a nest of 5 eggs, and then retires in August. It is also unknown in the Southern States.

My friend Mr. Cooper remarks that though this species is rare in the vicinity of New York, a few probably breed in the woods of the Hudson, as at Tappan, 30 miles up that river, it is frequently seen in the cherry-trees in the month of June, and is said to be common in the forests along the south shore of Lake Erie, and usually breeds there. It thrives very well in a cage, is a most melodious and indefatigable warbler, frequently in fine weather, as in its state of freedom, passing a great part of the night in singing, with all the varied and touching tones of the Nightingale.

While thus earnestly engaged, it seems to mount on tiptoe in an ecstasy of enthusiasm and delight at the unrivalled harmony of its own voice. The notes are wholly warbled, now loud, clear, and vaulting with a querulous air ; then perhaps sprightly; and finally lower, tender, and pathetic. In short, I am not acquainted with any of our birds superior in song to the present, with the solitary exception of our Orphean Mocking Bird.

The Louisiana Grosbeak is fed with the usual kinds of birdseed, and in its wild state seems to be particularly fond of the kernels of the sour-gum berries; it probably also feeds upon the berries of the juniper, which abound in the regions it usually inhabits.

Though somewhat local in its distribution, this attractive bird occurs regularly throughout the Eastern States, but is uncommon in Maine, New Hampshire, and Vermont. It is found in some parts of New Brunswick, Nova Scotia, and Quebec, and is quite common in Ontario, and abundant in Manitoba.

Though generally selecting a secluded spot for nesting, a pair will occasionally wander away from the forest and thicket, and even build in the heart of a town. In 1890 a nest was built and a brood raised not a hundred yards from where I am penning these words, 
- almost within the shadow of Memorial Hall. The nest was laid upon a branch that hung over the sidewalk of Oxford Street, not more than ten or twelve feet from the ground, the tree being in the garden adjoining the residence of Mr. Francis Foster.

\section{BLUE GROSBEAK.}

\section{Guiraca Cerulea.}

ChaR. Male: general plumage rich blue, darker on the back; feathers around base of bill, wings, and tail black; two bright rufous bands on the wings. Female: smaller; above, yellowish brown; below, dark buff. Length $6 \frac{1}{2}$ to 7 inches.

Nest. On a low branch of a tree or bush, situated along the margin of a wood, or in an open pasture or orchard, or by a roadside, - sometimes in an alder swamp or blackberry thicket; composed of leaves, weedstems, and grass, lined with horse-hair, roots, or fine grass ; occasionally pieces of snake skin or newspaper are worked into the exterior.

Eggs. 3-4; light blue; $0.85 \times 0.65$.

This shy and almost solitary species chiefly inhabits the warmer parts of America from Brazil to Virginia; stragglers occasionally also visit the lower parts of Pennsylvania and New Jersey, and Bullock observed them on the tableland of Mexico. According to Wilson, it is nearly a silent bird, seldom singing in the cage, its usual note of alarm being merely a loud chuck; though at times its musical capacity under more favorable circumstances is suggested by a few low and sweettoned notes. It may be fed on Indian corn, hemp-seed, millet, and the kernels of several kinds of berries.

According to Audubon, these birds arrive in Louisiana about the middle of March. They proceed through Alabama, Georgia, and the Carolinas, in all which districts they breed; and although rarely seen in the Western States, Mr. Townsend and myself met with them in May on the borders of the Platte, near Scott's Bluffs, where they were already mated and breeding. They are sometimes met with along the Atlantic coast as far as New Jersey, and Audubon found a nest in that State within a few miles of Philadelphia. Their food consists 
principally of different sorts of seeds; they are also fond of those of rice, and grass of all kinds. At the period of breeding they sing with great sweetness and melody.

This species is still considered a Southern bird; but it regularly visits Pennsylvania, Kentucky, and Kansas, and has been taken in Massachusetts and New Brunswick.

\section{PURPLE FINCH.}

\section{LINNET.}

\section{CARPODACUS PURPUREUS.}

CHAR. Male : no "purple;" body rosy crimson, brightest on the head, darkest on the back, palest on the breast; belly white; wings and tail dusky; everywhere streaked more or less with brown and gray. Female and young: without red; streaked brown and gray, sometimes with olive tint.

Nest. Near a settlement and in some old pasture, open grove, park, or orchard; composed of twigs, weed-stems, roots, and bark, lined with fine grass or hair.

Egss. 4-5; pale dull bluish green, variously marked with dark brown and lilac; $0.85 \times 0.60$

These brilliant and cheerful songsters inhabit the Northern and Western States during the summer, where they rear their young. They appear to have a great predilection for resinous evergreens, pine, and spruce, and feed upon the berries of the juniper and red cedar as well as the seeds of the tulip-tree and others; they likewise frequent gardens for the same purpose, and are particularly pleased with sunflower seeds and other oily kinds. When reduced to necessity they are observed to eat the buds of the beech and those of the fruit-trees, - probably for the sake of the stamens contained in them, of which they are greedy when displayed in the opening blossoms. The stipules of the expanding buds of the elm, which are sweet and mucilaginous, as well as the young capsules of the willow in the spring, also make a common part of their fare. Their food in summer, however, consists principally of insects and juicy berries, as those of the honeysuckle and others. 
Although the Purple Finch breeds and passes the season in this vicinity, yet as early as the close of September they leave us for the South; about which time and nearly to the close of October, small, hungry, roving flocks arrive from the more northern States and Canada or Newfoundland. At the same time likewise great numbers visit Pennsylvania, the maritime parts of New York and New Jersey, and many pass the winter in the Middle States, while others proceed as far south as the States of Louisiana, Florida, and Texas, returning north in the latter end of March or early in April, and arriving with us in the month of May to pass the most important period of their existence. Roving flocks are also seen here as early as the $24^{\text {th }}$ of March, singing while they stay with great energy and cheerfulness; these in all probability proceed to Labrador or Newfoundland to breed. The males now have many bitter contests for the choice of their mates, and are very bold and pugnacious in confinement, attempting to destroy every other bird introduced into the same cage. They also bite severely when taken up wounded, but are directly reconciled to the cage, finding their most important wants so amply supplied; yet in this state they often refuse to sing, and after moulting into the humble plumage of the female, frequently remain so, without ever renewing their crimson dress. They are here exposed in cages for sale at high prices (by the name of Linnets), and sing pretty commonly in confinement. Their notes are very similar to those of the Warbling Vireo, but louder, and more agreeably diversified. From the tops of our lofty and spreading elms or shadowy spruce trees, where they delight to pass the time, their varied and very cheerful melody is often continued for hours almost without interval, and poured forth like a torrent. After a combat with a rival, his towering notes of victory burst out into rapture, and he now seems to triumph with loud and petulant hilarity. The song of this beautiful Finch is indeed much finer than that of the Canary; the notes are remarkably clear and mellow, and the trilling sweet and various, particularly on their first arrival. At times the warble is scarcely audible, and appears at a distance; 
it then, by a fine crescendo, bursts into loudness and falls into an ecstasy of ardent and overpowering expression; at such times the usual pauses of the song are forgotten, and like the varied lay of the Nightingale, the ravishing performer, as if in serious emulation, seems to study every art to produce the effect of brilliant and well-contrasted harmony. As he sits on the topmost bough of some tall sapling or more lofty tree, surveying the wide landscape, his proud voice and elevated action seem to bid defiance to competition; and while thus earnestly engaged, he seems to fear no spectator, however near may be his approaches. The rapidity of his performance and the preeminent execution with which it is delivered seem almost like the effort of a musical-box or fine-toned, quickly moving, delicate strain on the organ. While feeding in the month of March these birds also utter a querulous tshippee tshee, in nearly the same sad and liquid tone as that uttered by the Yellow Birds while thus engaged. The dull-colored birds, in the attire of the female, do not sing either so well or in the same manner as the crimson-colored individuals.

The nest of this species is, as I have observed in two instances in Cambridge, made in the horizontal branches of the balsam-fir. In the first, which I saw in the garden of Professor Farrar, it was made in a young tree about 6 feet from the ground. On approaching it the female sat still until I nearly touched her, and made very little complaint when off. The nest was coarse and substantial, very much like that of the Song Sparrow, composed of coarse grass and lined with fine root-fibres. From this nest was raised in a cage one of the young, which became exceedingly docile and affectionate, but was not remarkable for its song.

In winter the Purple Finch is found regularly, though sparingly, through the southern and central portions of New England and in Ontario, and I have heard its song in mid-winter in a New Brunswick forest. 


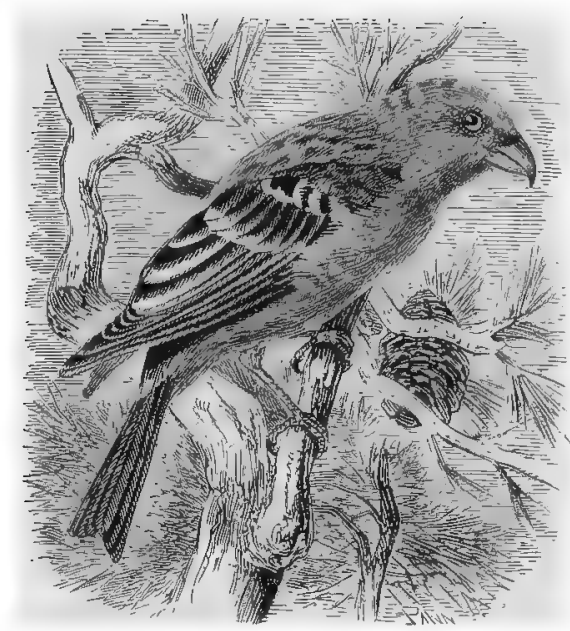

\section{PINE GROSBEAK.}

\section{Pinicola enUCleator.}

Char. Male: dark brown and ash washed with rosy carmine; wings with two white bands. Female and young male have no red; head and rump bronze. Length $8 / 4$ to 9 inches.

Nest. On the border of a swamp or the margin of a stream running through an evergreen forest; saddled on a low branch or in a crotch of a low bush, or placed in a crevice of a rock. A bulky, ill-made affair of moss, or twigs and roots or strips of bark, and lined with fine grass, roots, or vegetable fibre.

Eggs. 4-?; pale greenish blue marked with dark brown and lilac; $1.05 \times 0.75$.

These splendid and very hardy birds appear to dwell almost wholly within the cold and Arctic regions of both continents, whence, only in severe winters, a few migrate into Canada and the United States, where they are consequently of rare and uncertain occurrence. They have been seen in winter in the lower part of Missouri, and at the same season, occasionally, in the maritime parts of Massachusetts and Pennsylvania, and are observed to return to Hudson Bay as early as April. According to Mr. Pennant, they frequent the woods of pine and juniper, and are now possessed of musical talents; 
but as the period of incubation approaches they grow silent. Suited to the sterile climates they inhabit, their fare, besides the seeds of the pine, alpine plants, and berries, often consists of the buds of the poplar, willow, and other northern trees and shrubs; so that they are generally secure of the means of subsistence as long as the snows are not too overwhelming. The individuals as yet seen in the United States are wholly young birds, which, it seems, naturally seek out warmer climates than the adult and more hardy individuals.

According to Mr. T. McCulloch, of Pictou, Nova Scotia, in very severe winters flocks of these birds, driven from the pine forests by famine and cold, collect about the barns, and even enter the streets of Pictou, alighting in quest of food. A male bird at this season, caught in a trap, became very familiar, and as the spring approached he resumed his song in the mornings, and his notes, like those of the Rose-breasted Grosbeak, were exceedingly rich and full. As, however, the period for migration approached, his familiarity disappeared, and the desire of liberty seemed to overcome every other feeling. For four days in succession his food remained untouched, and his piteous wailing excited so much commiseration that at length he was released. The Pine Grosbeak is said to breed in Maine as well as in Newfoundland and Labrador.

The visits of this handsome bird to New England and the more southern portions of Canada are decidedly irregular. During an occasional winter the flocks are large and numerous, while again for several seasons but a few stragglers may appear.

Dr. Coues thinks that there is no question but that the bird is a "resident" in northern New England, breeding in some parts of Maine, New Hampshire, and Vermont; but I am much inclined to question it. Very possibly a few pairs may pass an occasional summer in that region, but I can find no evidence of the birds having been seen there with sufficient frequency to warrant their being termed residents.

The only known instances of this species having built in the vicinity of northern New England nust be credited to New Brunswick. These are Boardman's hypothetical nest, found near -St. Stephen; the unfinished nest which Banks discovered the parents at work upon, near St. John; and the nest with three 
young and one egg taken by Cox on the Restigouche, in latitude $47^{\circ}$ But excepting in these three instances, and a fourth where young birds were seen on the Tobique River, the species has been unknown as a summer resident in New Brunswick. Cox saw several examples along the Restigouche in July, I888, but I have hunted for them up and down the same river, from the Wagan to the Metapedia, both in July and September, without seeing or hearing so much as one.

Some years ago I kept a male in confinement, and found him a delightful pet. He was healthy and happy in his cage, was easily tamed, being confiding and affectionate, and added to his other good qualities a sweet voice and pretty melody.

The song differs with the season. In winter it is strong and cheery, as befits a stalwart fellow who laughs at Jack Frost and makes merry when the north wind blows. But when the springtime comes he tells the old, old story in most gentle tones, - a whispered love song, sweet and tender, yet with a wild plaintiveness that makes it peculiarly pleasing. 


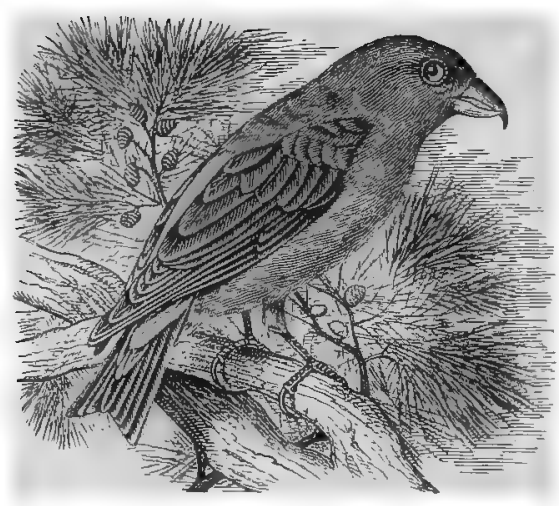

\section{AMERICAN CROSSBILL.}

\section{COMMON CROSSBILL. RED CROSSBILL.}

LOXIA CURVIROSTRA MINOR.

ChAR. Bill long and compressed, mandibles curved at the points, which cross or overlap. In young birds the bill is straight. Adult males: dull red, variable in shade; wings and tail blackish brown. Young males : yellowish olive. In changing plumage they display great variety of combinations of yellow, olive, and red. Females: above, dull olive; rump and crown yellow; wings and tail as male; below, grayish. Length $5^{\mathrm{I} / 2}$ to 6 inches.

Nest. Usually in a dense wood, on a branch of an evergreen tree i 5 to 30 feet from the ground; made of twigs, strips of bark, weed-stems, and roots, lined thickly with grass, roots, hair, and feathers.

Eggs. 3-4; pale green dotted, near larger end, with brown and lavender; $0.75 \times 0.57$.

This more common species, like the preceding, inhabits the high northern and arctic regions of both continents, where it breeds, and is met with from Greenland to Pennsylvania, or farther south, according to the season and the success in obtaining food when driven to make a southern descent or migration. From September to April these birds are found inhabiting the extensive pine forests in the mountainous and interior districts of Pennsylvania and other States to the north; they also extend their winter migrations into the lower parts of the State of Missouri. They have occasionally been seen in the maritime parts of Massachusetts, but are less common 
here than the following species, generally taking, in their irregular incursions, a more interior and mountainous route. In the eastern chain of the Alleghanies, in Pennsylvania, according to Wilson, they appear to be at times very abundant visitors, feeding so steadily on the seeds of the white pine and hemlock spruce as to be approached without taking alarm. They have also a loud, sharp, and not unmusical note, chattering as they fly, and during the prevalence of deep snows become so tamed by hunger as to alight round the mountain cabins, even settling on the roofs when disturbed, and, like pigeons, descending in the next moment to feed as if they had never been molested. They are then easily trapped, and so eager and unsuspicious as to allow an approach so near that they may be knocked down with sticks. In these very familiar visits they are observed even to pick off the clay from the logs of the house, and to swallow the mere earth to allay the cravings of hunger. In cages they show many of the habits of the Parrot, climbing up the sides and holding the pine-cones given them in one claw while they extract the seeds. Like the same bird in Louisiana, they also do considerable damage at times in the orchard by tearing apples to pieces for the sake of getting at the seeds only. They feed likewise on the seeds of the alder, as well as the kernels of other fruits and the buds of trees. Scarcely any of these birds have yet been observed to breed within the United States, as they retire for this purpose to their favorite pine forests in high and more cool latitudes, where in security and solitude they pursue the duties of procreation. Dr. Brewer, of Boston, however, obtained eggs of these birds from Coventry, in Vermont. Like the preceding species, they often breed in winter in more temperate countries, as in January and February, and the young fly in March.

This bird was not observed by the naturalists of the northern expeditions in any part of the fur countries. It is, however, described by Forster. In the winter of 1832 , during or soon after a severe snow-storm, a large flock of these uncertain winter visitors were seen in a red-cedar grove near to Mount Auburn, in this vicinity. In 1833 , accompanied by the 
White-winged species, a flock of the same birds made their appearance as early as the IIth of November in some tall pine-trees in the same place they visited the last year in the depth of winter. They are very busy and unsuspicious, having very much the manners of Parrots in their feeding. At some distance beneath the trees where they are engaged, we can hear them forcing open the scales of the rigid pine cones with a considerable crackling, and the wings of the seeds fly about in all directions. Sometimes the little Redpolls also attend to snatch a seed or two as they are spread to the winds. They fly somewhat like the Yellow Birds, by repeated jerks and sinkings and risings in their course, but proceed more swiftly and directly to their destination; they also utter a rather loud and almost barking or fifing chirp, particularly the females, like 'tsh'tship 'tsh 'tship. Their enemies seem also to follow them into this distant and unusual retreat. One evening, as they were uttering their quailing chirp, and about to roost in the pines, we heard an unusual cry, and found that the alarm was justly occasioned by the insidious and daring attack of a bold Butcher Bird (Lanius borealis), who had taken advantage of their bewildered confusion at the moment of retiring to repose. Besides their call and ordinary plaints, we hear, as I have thought, now and then, in the warmer part of the day, a rather agreeable, but somewhat monotonous, song. We found these birds, as well as the Redpolls, very fat and plump; and they devour a great quantity of pine-seeds, with which the œsophagus is perpetually gorged as full as in the gluttonous and tuneless Cedar Birđss (Bombycilla).

The Red Crossbill is still known to be chiefly a winter visitor to New England and the Middle States, though every summer a small number may be met with in the more northern districts and on the higher hills, and nests have been taken in Maine, Vermont, Massachusetts, and New York. In April, I889, Mr. G. S. Miller, Jr., found a flock on Cape Cod, and upon dissecting several, he discovered evidence that they were nesting.

In northern Maine and New Brunswick numbers have been seen during the summer months; but even in these regions it is chiefly a winter visitor. 


\section{WHITE-WINGED CROSSBILL.}

\section{LOXIA LEUCOPTERA.}

CHAR. Bill long and compressed, mandibles curved at the points, which cross or overlap. Male: dull rosy, clouded with dull dark brown on the back; wings and tail black; two broad white bars on the wings; belly dull white streaked with brown. Female : dull olive, paler beneath; rump buffy. Young similar to female, but paler olive above, and more decided yellow beneath, streaked everywhere with dark brown. Length about 6 to $6 \frac{1}{2}$ inches.

Nest. In the deep forest, usually saddled on a fork of an evergreen, amid the denser foliage near the centre of the tree; made of twigs and strips of birch bark, covered exteriorly with moss (usnea), and lined with soft moss and hair.

Egys. 3-?; pale blue, spotted and streaked near larger end with reddish brown and lilac; $0.80 \times 0.55$.

This beautiful and well-distinguished species inhabits the northern regions of the American continent only, whence, at irregular intervals, on the approach of winter, it arrives in the Northern and Middle States, and, as usual with the rest of this curious family, seeks out the pine and hemlock-spruce forests. Its visits to this State [Massachusetts] are very irregular. About two years ago, large, gregarious, famished flocks were seen near Newburyport and other neighboring towns in the vicinity of the sea-coast, at which time many were caught, killed, and caged. The habits of this bird are almost entirely similar to those of the preceding species. Its song -is said to be mellow and agreeable, and in captivity it becomes gentle and familiar.

According to Mr. Hutchins, it arrives around Hudson Bay in March, and in May builds a nest of grass, mud, and feathers, fixed generally about half way up a pine-tree, and lays 5 white eggs marked with yellowish spots. The young fly about the end of June. It remains in this country till the close of November, after which it retires, probably to the South; and Wilson's bird was obtained in the Great Pine Swamp or forest of the Pokono (Pennsylvania), in the month of September, so that it may be possible that some few pairs breed in this situation. 
This species, according to Richardson, inhabits the dense white spruce forests of the fur countries, feeding principally on the seeds of the cones. It ranges through the whole breadth of the continent, and probably up to the 68th parallel, where the forests terminate. It is usually seen in the upper branches of trees, and when wounded still clings so fast as to remain suspended after death. In September, collecting in small flocks, they fly from tree to tree in a restless manner and make a chattering noise; and in the depth of winter they retire from the coast to seek shelter in the thick woods of the interior.

This interesting bird must still be written "irregular" in its occurrence in this State, though usually more or less abundant in winter down to the 4oth parallel.

It is partially sedentary in northern New England and the Maritime Provinces of Canada, though much more abundant in winter than during the warm weather. The nest is built in January and February, - I have known of numerous nests being discovered in New Brunswick in those months, - and it is probable that both young and old retire farther northward after the young birds are able to fly. 


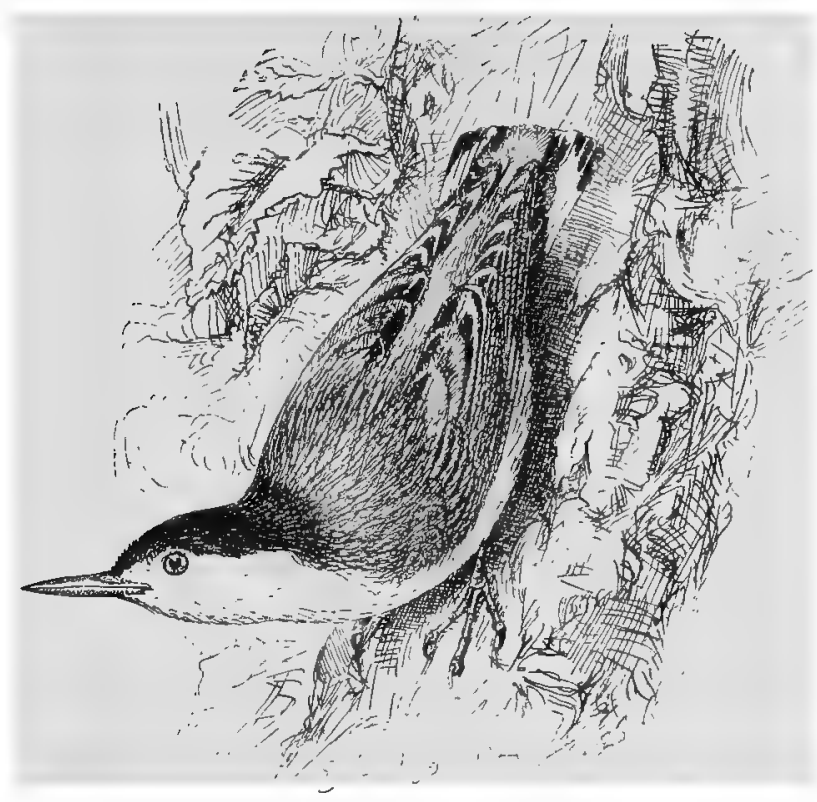

WHITE-BREASTED NUTHATCH.

SitTA CAROLINENSIS.

CHar. Above, bluish ash; top of head and neck black; wings black, blue, and white; tail black, marked with white; beneath, white; under tail-coverts reddish brown. Bill long and acute. Female and young similar, but black of head tinged with ashy or wanting. Length $53 / 4$ inches.

Nest. In open woodland, placed at the bottom of a cavity excavated in a dead tree or stump, - sometimes an old woodpecker's nest is used; made of leaves, grass, feathers, and hair.

- Eggs. 4-8 (occasionally as many as 10, usually 5); white tinged with rose pink, and spotted with reddish brown and lilac; $0.80 \times 0.60$.

This species, so nearly allied to the European Nuthatch, resides permanently throughout North America, from Hudson Bay and Oregon to the tableland of Mexico, appearing only more common and familiar at the approach of winter in consequence of the failure of its food in its favorite sylvan retreats, which it now often forsakes for the open fields, orchards, or gardens, where, in pairs or small and sometimes contending 
parties, they cautiously glean a transient means of subsistence, and wander from place to place as the supply diminishes. At the welcome return, however, of the month of April, with the revival and renewal of its insect fare the Nuthatch becomes more domestic; and retiring into the forest with its mate, it prepares for its progeny in some hollow tree, or even in a rail of the neighboring fence. The male is now assiduously attentive to his sitting mate, supplying her regularly with food; on which occasion he affectionately calls her from the mouth of her dark and voluntary prison, where sometimes, in mere sociability, he attempts in his rude way to soothe her with his complaisant chatter. He is too affectionate to ramble from this favorite spot, where he not only accompanies his consort, but, sentinel-like, watches and informs her of every threatening danger. When the pair are feeding on the trunk of the same tree, or near to each other in the same wood, the faithful male is heard perpetually calling upon his companion at short intervals as he circumambulates the trunk. His approach is announced usually at a distance by his nasal $k \bar{a} n k k \bar{a} n k$, frequently repeated, as in spiral circles round the trunk of some tree he probes, searches, and shells off the bark in quest of his lurking prey of spiders, ants, insects, and their larvæ in general. So tight and secure is his hold that he is known to roost indifferently with his head up or down from the tree; and when wounded, while any spark of life remains, his convulsive and instinctive grasp is still firmly and obstinately maintained. Sometimes, with a sort of complaisant curiosity, one of the birds, when there is a pair, will silently descend nearly to the foot of the tree, where the spectator happens to stand, stopping, head downwards, and stretching out his neck, as it were, to reconnoitre your appearance and motives; and after an interval of silence, wheeling round, he again ascends to his usual station, trumpeting his notes as before. He seldom wholly quits the forest, but when baffled by the slippery sleet which denies him a foothold, he is sometimes driven to the necessity of approaching the barnyard and stables, or the precincts of the dwelling, where, occasionally mixing among 
the common fowls, entering the barn, examining its beams and rafters, he seems to leave no means untried to secure a subsistence.

This species is doubtless a resident in Ontario and New England, becoming more abundant during the winter months; but in the Maritime Provinces it is only a summer visitor.

\section{RED-BREASTED NUTHATCH.}

\section{SitTa CANADENSIS.}

Char. Above, ashy blue; top and side of head black; broad stripe of white over the eyes; wings blackish, with ashy and white markings; outer tail-feathers black and white; beneath, reddish brown, - paler in the female; chin white; bill long and acute. Length $4 \frac{1}{2}$ inches.

Nest. In open woodland; an excavation in a decayed stub, lined with grass and roots, - sometimes with feathers. Often the entrance is surrounded with fir balsam.

Eggs. 4-6; white with pale roseate tint and thickly spotted with brown and lilac; $0.60 \times 0.50$.

The habits of these smaller birds are almost similar to the preceding; they have, however, a predilection for pine forests, feeding much on the oily seeds of these evergreens. In these barren solitudes they are almost certain to be found in busy employment, associating in pairs with the Chickadees and smaller Woodpeckers, the whole forming a hungry, active, and noisy group, skipping from tree to tree with petulant chatter, probing and rattling the dead or leafless branches, prying in every posture for their scanty food, and, like a horde of Tartars, proceed through the forest and leisurely overrun the whole of the continent to the very confines of the tropics, retiring north in the same manner with the advance of the spring.

The notes of this species of Nuthatch, though similar, are sharper than those of the preceding, resembling day day dait, and sounding almost like a child's trumpet. Its motions are also quicker. They cling to the bark of the tree and roost commonly with the head downwards, in the manner of their whole tribe.

VOL. I. -25 
This species has a more extended range than carolinensis, being found farther west and farther north. It breeds in northern New England and northward to about $50^{\circ}$. It occurs sparingly in winter in New Brunswick. A good account of its nesting habits, written by Mr. Manly Hardy, appeared in the Bulletin of the Nuttall Club for October, 1878 .

\section{BROWN-HEADED NUTHATCH.}

\section{SiTTA PUSILLA.}

Char. Above, ashy blue; top of head and neck brown; white spot on back of neck; wings black and bluish; middle tail-feathers like back, others black tipped with bluish; beneath, dull brownish white tinged with pale ash behind; throat white. Bill long, slender, and acute. Length $3 \frac{3}{4}$ to $4 \frac{1}{4}$ inches.

Nest. In open woodland; an excavation in a dead stump, lined with grass, leaves, and feathers.

Eggs. 4-6; white, thickly marked with fine spots of reddish brown and pale lilac; $0.60 \times 0.50$.

This small species is seldom seen to the north of the State of Virginia. In the Southern States it is rather common, and is also met with in the island of Jamaica. Like the last, which it resembles in manners, it is very fond of pine-trees, and utters a similar note, but more shrill and chirping. Its food, besides the seeds of the pine, is usually the insects which infest the forest trees. In winter families of this species of 8 or Io individuals may be seen busily hunting in company, and keeping up a perpetual and monotonous screeping. It is less suspicious than most other sylvan birds, sometimes descending down the trunk of a tree watching the motions of the bystander; and if the intrusion happens to be near the nest, or while engaged in digging it out, the little harmless mechanic utters a sort of complaining note, and very unwillingly relinquishes his employment, which is instantly renewed on the removal of the observer.

This species is restricted to the Southern and Gulf States, rarely wandering north of Virginia and Maryland; but examples have been taken in Missouri, Ohio, and Michigan. 


\section{BROWN CREEPER.}

\section{CERTHIA FAMILIARIS AMERICANA.}

CHAR. Above, grayish brown, each feather streaked with dull white; rump rufous; wings with two bars of dull or reddish white; beneath, dull white or pale gray. Length about $5^{\frac{1}{2}}$ inches.

Nest. In deep woods, placed behind a sliver of loose bark on a decayed tree or stub; made of shreds of bark and usnea moss firmly interwoven and set on a platform of twigs. It is sometimes lined with feathers.

Eggs. 4-8; white or creamy, - when freshly laid, tinted with pale roseate, - spotted with reddish brown; $0.60 \times 0.50$.

This industrious forager for insects, chiefly dwelling in the seclusion of the forest, is but seldom seen in the summer; but on the approach of winter, with other hungry wanderers of similar habits such as the small Woodpeckers and Nuthatches, it makes its appearance on the wooded skirts of the village, particularly among the pine-trees, and occasionally becomes familiar enough to pay a passing visit to the orchard. In this country, however, the species is neither common nor familiar, nor is it more abundant in the Northern than the Middle States, though its breeding range extends from Pennsylvania to Newfoundland.

The bill of the Creeper not being of sufficient strength to probe the wood, it rests contented with examining the crevices of the bark for insects and their eggs, proceeding leisurely upwards or downwards in straight or spiral lines towards the top of the tree, dodging dexterously to the opposite side from the observer, and only resuming its occupation when assured of solitude and safety. While thus employed it utters at short intervals a sharp, quick, rather grating note, by which its resort may be discovered, though it requires some time and a good eye to perceive it if on the upper branches of a tall tree. Though it lives chiefly on insects, it also, according to Wilson, collects the seeds of the pine for food, and is particularly fond of the vermin which prey on those kinds of trees. In the thick forests which it inhabits in the Northern and Western 
States about the middle of April, it commences the nest in the hollow trunk or branch of a tree which has been exposed to decay by injury or accident. Here in the accidental cavities or deserted holes of the squirrel or Woodpecker the Creeper deposits her eggs. The young creep about with great caution previous to taking to their wings.

The Brown Creeper is a common bird in New England, though in the southern portions it is less numerous in the breeding season than during the colder months. It is common in Ontario and Quebec, but less abundant in the Maritime Provinces. An interesting account of the breeding habits of this bird, written by Mr. William Brewster, appeared in the Nuttall Bulletin for July, I879.

\section{BAHAMA HONEY CREEPER.}

\section{Certhiola bahamensis.}

ChAR. Above, dark brown; rump yellow; stripe over eyes and underparts dull white; breast and edge of wing pale yellow; tail broadly tipped with white. Length $4 \frac{1}{2}$ inches.

Nest. In a low tree or bush; a large, pensile, dome-shaped structure, the entrance at the side; made of weed-stems and grass, and lined with plant down.

Eggs. 2-4; white, tinged with green and speckled with rufous: 0.65 $\times 0.50$.

The home of this species is on the Bahamas, but it is found regularly along the southeastern coast of Florida. Mr. Gosse in his "Birds of Jamaica" gives an interesting account of its habits. He describes it as obtaining its food in much the same manner as Humming Birds, - by probing the flowers; but instead of hovering in front of a flower, the Creeper alights on the tree. When examining a flower for the insects which are at the bottom of the cup, the bird throws its body into a variety of positions, sometimes with the back downward, the better to reach the interior of a blossom with its curved bill and peculiar tongue. The bird is unsuspecting and familiar, and freely resorts to the blossoming shrubs of a garden. 


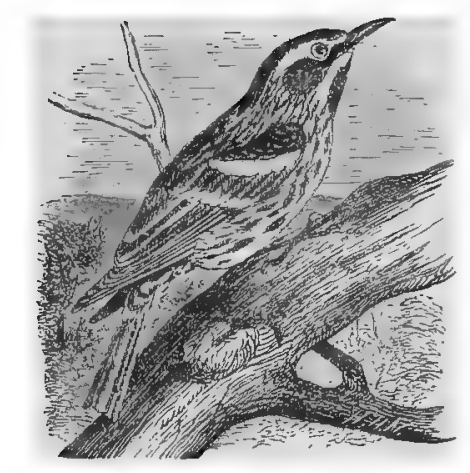

BLACK AND WHITE WARBLER.

BLACK AND WHITE CREEPER.

\section{MNIOTILTA VARIA.}

Char. Above, black striped with white, head, wings, and tail mostly black; beneath, white, more or less striped with black. Female and young without stripes on the throat. Length $4^{\mathrm{T}} / 2$ to $5^{1 / 2}$ inches.

Nest. In open woodland or pasture; placed at the foot of a tree or stump, or at the base of a moss-covered rock, sometimes in a hole; made of grass, moss, and shreds of bark, and lined with grass, hair, roots, and vegetable down.

Eggs. 4-5; creamy white, thickly spotted with pale reddish brown; $0.65 \times 0.50$.

This remarkable bird, allied to the Creepers, is another rather common summer resident in most parts of the United States, and probably migrates pretty far to the north. It arrives in Louisiana by the middle of February, visits Pennsylvania about the second week in April, and a week later appears in the woods of New England, protracting its stay in those countries till the beginning of October, and lingering on the southern limits of the Union a month later, so that it does not appear to be much affected by the commencement of frost, and probably at this season occasionally feeds on berries. As numbers are observed round Vera Cruz toward the commencement of winter, and are described as inhabiting the West India islands, it is probable they pass the extremity of the winter beyond the southern boundary of the Union. 
Like the Creepers and Nuthatches, these birds are seldom seen to perch upon the branches of trees, but creep spirally around the trunk and larger boughs up and down, in quest of insects which alight upon or hide within the crevices of the bark. In this employment they display all the dexterity of the more regular climbers. For this purpose the hind toe is rather stout, and extends backward so as to balance with the anterior part of the foot, and allow a motion like that of the Creepers, from which genus they are at the same time wholly distinct.

At the period of breeding, the male scrapes out a little monotonous ditty in recognition of his mate, resembling somewhat the syllables te tshe tshe tshe tsh' tsheté, proceeding from high to low in a tolerably strong and shrill, but somewhat filing tone. As the season of incubation advances, this note, however, becomes more mellow and warbling, and though feeble, is very pleasing, bearing at this time some resemblance to that of the Redstart (Setophaga ruticilla). This song is like the ascending call of 'twee 'twee 'twee 'twee 'tweet. At the romantic estate of the Cold Spring place in Roxbury the proprietor, Mr. Newman, pointed out to me the nest of this bird, which on the $27^{\text {th }}$ of June contained four young about a week old. Other birds of this species I had seen fledged this year about the $I 7$ th of the same month, and as Wilson remarks the flight of the young in July, we may suppose that they raise two broods in the season. The nest was niched in the shelving of a rock on the surface of the ground, and was externally composed of coarse strips of the inner bark of the hemlock-trees, which overshadowed the situation. With these were mixed soft, dissected old leaves and a few stalks of dead grass; the lining was made of a thin layer of black hair. According to Audubon, these birds nest in Louisiana in some small hole in a tree, and employ dry moss and a lining of downy substances. The pair fed the young before us with affectionate attention, and did not seem more uneasy at our presence than the common and familiar summer Yellow Bird. They crept about the trunks of the neighboring trees, often head downwards, like the Sittas, and carried large smooth caterpillars to their young. This is, 
in fact, at all times a familiar, active, and unsuspicious little visitor of the shady gardens and orchards, as well as woods and solitudes.

The Black and White Creeper, as this species is usually called, occurs west to the Mississippi valley, and is abundant in Manitoba. It is a common summer resident of the Maritime Provinces.

It was first classed with the Warblers by Spencer Baird in 1859 , and has been retained there by all later authorities. Nuttall considered that there were two species, one of which he named borealis; but it has not been considered valid, though Ridgway, in his "Manual," suggests the name $M$. varia borealis for a supposed Mississippi valley and Middle American race, which he describes as somewhat smaller than true varia; but he thinks the material at band insufficient to warrant a positive decision, so we are saved the infliction of this much "hair-splitting."

\section{PURPLE MARTIN.}

Progne subis.

CHAR. Male: lustrous black with purple tint, wings and tail with brownish tint. Female and young: browner above, and beneath grayish. Length $71 / 2$ inches.

Nest. In a box, or attached to the eave of a house; sometimes in a decayed tree; made of grass, leaves, etc.

Eggs. 4-6; white and glossy; $0.95 \times 0.75$.

According to the progress of the season in the very different climates of the United States, is measured the arrival of this welcome messenger of spring. Around the city of New Orleans, for example, the Purple Martin is seen from the ist to the 9th of February. At the Falls of the Ohio, it is not seen before the middle of March, and representatives do not arrive in the vicinity of Philadelphia until the first week in April ; on the $25^{\text {th }}$ of that month, or later, they visit the vicinity of Boston, and penetrate even to the cold regions of Hudson Bay, where they arrive in May and retire in August; about the 2 oth of the same month they also leave the State of Pennsylvania. The migrations of these birds are remarkably extensive, as they were seen by Mr. Swainson in great numbers around Per- 
nambuco. Mr. Townsend met with them on the Rocky Mountains, and Audubon observed them breeding in Texas. In Oregon we found them nesting in the knot-holes of the oaks, and they did not appear to court the society of man, as we seldom saw them near the fort. In their haste to return to their natal climes, they sometimes expose themselves to fatal accidents from changeable and unfavorable weather. In the maritime parts of Massachusetts, and probably throughout the State, a few years ago after a rainy midsummer, many were found dead in their boxes, and they have since been far less numerous than formerly.

This beautiful species, like many others of the family, seeks out the dwellings of man, associating itself equally with the master and the slave, the colonist and the aboriginal. To the Martin it is indifferent whether its mansion be carved and painted, or humbled into the hospitable shell of the calabash or gourd. Secure of an asylum for its mate and young, while under the protection of man it twitters forth its gratitude, and is everywhere welcomed to a home. So eager is it to claim this kind of protection that sometimes it ventures hostilities with the Bluebirds and domestic Pigeons, who are often forced to abandon their hereditary claims. Satisfied with the reception and success, like so many contented and faithful domestics, it returns year after year to the same station. The services of the Martin in driving away Hawks and Crows from the premises he claims, are also important inducements for favor; he has even the courage to attack the redoubtable Kingbird, when its visits are too familiar near the nest.

At the approaching dawn the merry Martin begins a lively twitter, which, continuing for half a minute, subsides until the twilight is fairly broken. To this prelude succeeds an animated and incessant musical chattering, sufficient, near the dwelling, to awaken the soundest sleeper. His early vigils are scarcely exceeded by the domestic Cock; the industrious farmer hears the pleasing call to labor, and associates with this favorite bird the idea of an economical, cheerful, and useful guest. 
In the Middle States, from the $5_{5}$ th to the 2 oth of April, the Martins begin to prepare their nest, which is usually made of small green or dry leaves, straws, hay, and feathers, laid in considerable quantities. They rear two broods in the season. Several pairs also dwell harmoniously in the same box. The male, very attentive to his sitting mate, also takes part in the task of incubation; and his notes at this time have apparently a peculiar and expressive tenderness.

The food of the Martin is usually the larger winged insects, as wasps, bees, large beetles, such as the common Cetonias, or goldsmiths, which are swallowed whole. His flight possesses all the swiftness, ease, and grace of the tribe. Like the Swift, he glides along, as it were, without exertion. Sometimes he is seen passing through the crowded streets, eluding the passengers with the rapidity of thought; at others he sails among the clouds at a dizzy height like something almost ethereal.

The Purple Martin occurs throughout the Maritime Provinces, though nowhere common, and is extremely local in its distribution. It is rather rare near Quebec, but common at Montreal and throughout Ontario. Observers in Winnipeg consider the bird abundant there, and it is said to range north to the Saskatchewan valley.

Small colonies of these Martins are found scattered through New England at widely separated localities, accepting, usually, the proffered hospitality of friendly villagers who provide them with homes, though an occasional coterie may be found nesting in the primitive manner of their ancestors, - rearing their broods in natural cavities of trees or in crevices of rocks, as was the custom of their race before the European led them into more Sybaritic habits. 


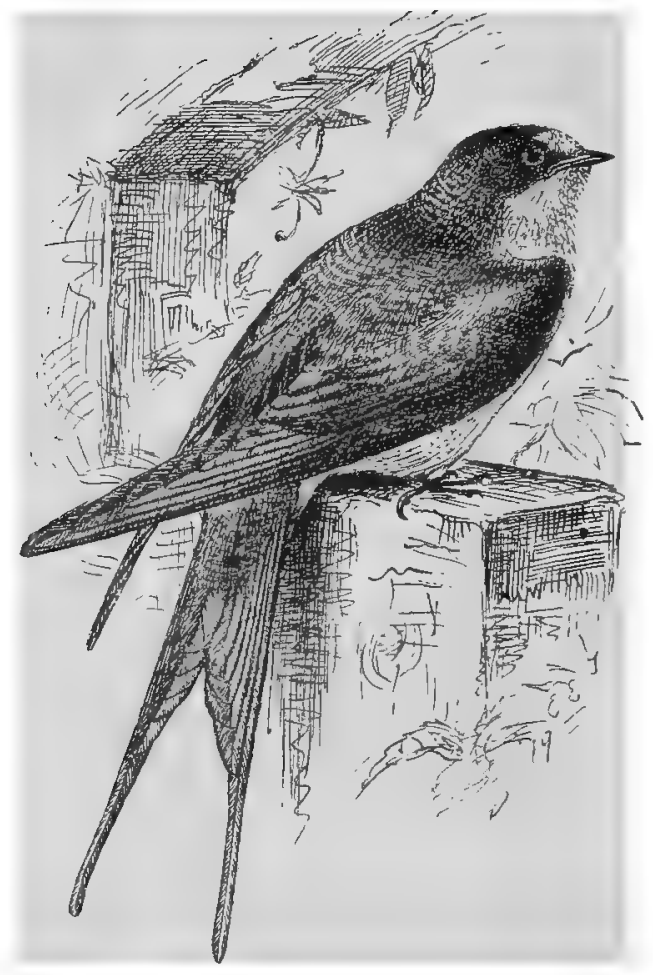

\section{BARN SWALLOW. \\ CHELIDON ERYTHROGASTER.}

Char. Upper parts steel blue; breast rich chestnut; belly paler; tail deeply forked, - outer feathers several inches longer than the inner. Length $5 \frac{1}{2}$ to $7 \frac{1}{2}$ inches.

Nest. Attached to a rafter of a barn or the side of a cave; cup shaped; made of pellets of mud bound with grass, and lined with grass and feathers.

Eggs. 3-6; white, variously marked with dark brown, reddish brown, or purplish brown and lilac; $0.75 \times 0.55$.

The Barn Swallows arrive in Florida and the maritime parts of Georgia about the middle of March, but are not seen in the Middle States before the last of that month or the beginning 
of April. Their northern migration extends to the sources of the Mississippi, the Rocky Mountains, and the fur countries, where, distant from the habitations of man, they inhabit caves, particularly those in the limestone rocks. They retire from Massachusetts about the I8th of September, and are observed in the same month and in October passing over the peninsula of Florida on their way to tropical America, where they probably pass the winter. I have seen a straggling pair in this vicinity even on the $\mathrm{r} 5$ th of October. The fleetness with which they move, and the peculiarity of their insect fare, are circumstances which would impel a prompt transition to more favorable climates. Accidental fits of torpidity, like those which occasionally and transiently take place with the Humming Bird, have undoubtedly happened to Swallows, without proving anything against the general migrating instinct of the species, which as long back as the time of Anacreon has been generally observed.

Early in May they begin to build against a beam or rafter, usually in the barn. The external and rounding shell is made of pellets of mud tempered with fine hay and rendered more adhesive by the glutinous saliva of the bird; within is laid a bed of fine hay, and the lining is made of loosely arranged feathers. They have usually two broods in the season, and the last leave the nest about the first week in August. Twenty or thirty nests may sometimes be seen in the same barn, and two or three in a cluster, where each pursues his busy avocation in the most perfect harmony. When the young are fledged, the parents, by their actions and twitterings, entice them out of the nest, to exercise their wings within the barn, where they sit in rows amid the timbers of the roof, or huddle closely together in cool or rainy weather for mutual warmth. At length they venture out with their parents, and, incapable of constant exercise, may now be seen on trees, bushes, or fence-rails, near some pond or creek convenient to their food; and their diet is disgorged from the stomachs or crops of their attentive parents. When able to provide for themselves, they are still often fed on the wing, without either party alighting; so aërial 
and light are all their motions that the atmosphere alone seems to be their favorite element. In the latter end of summer, parties of these social birds may be often seen by the sides of dusty roads, in which they seem pleased to bask.

About the middle of August they leave the barns, and begin to prepare for their departure, assembling in great numbers on the roofs, still twittering with great cheerfulness. Their song is very sprightly, and sometimes a good while continued. Some of these sounds seem like 't'le 't'le 't'letalit, uttered with rapidity and great animation. A while before their departure, they are observed skimming along the rivers and ponds after insects in great numbers, till the approach of sunset, when they assemble to roost in the reeds.

The Barn Swallow is a common bird throughout this Eastern Province, and northward to the lower fur countries.

It winters in the West Indies and Central America.

\section{CLIFF SWALLOW.}

EAVE SWALLOW.

\section{Petrochelidon Lunifrons.}

CHAR. Above, dark steel blue; forehead dull white; wings and tail brownish black; rump rufous; chin, throat, and collar around neck deep chestnut; patch of blue black on breast; remaining under-parts pale gray tinged with rufous. Length about $5 \frac{1}{4} /$ inches.

Nest. Fastened to the side of a cliff or the eave of a building; made of pellets of mud and lined with grass and feathers. Usually gourdshaped, the entrance at the mouth of the gourd, - sometimes open on top.

Eggs. 4-6; white, variously marked with shades of brown and purple; $0.80 \times 0.55$.

The Cliff Swallows have but recently come to the notice of naturalists. Their summer residence in the temperate parts of America is singularly scattered. They have long occupied the regions of the Rocky Mountains, extending to the banks of the Columbia, and the cliffs of the Missouri, and are probably to be found on other large Western rivers. According to 
Richardson they are extremely abundant in the fur countries. In 1815 they were observed for the first time at Henderson, on the banks of the Ohio, and at Newport in Kentucky. In I 8I 7 they made their appearance at Whitehall, near Lake Champlain, in the western part of the State of New York. In these places their increase seems to have kept pace with the time since their arrival, augmenting their nests from a single cluster to several hundreds in the course of four or five years. Vieillot observed one at sea off Nova Scotia, and they have, in fact, long been commonly known in that Province. In 1818 , as I learn from J. W. Boott, Esq., they began to build at Crawford's, near the base of the White Mountains of New Hampshire. In the summer of 1830 a few nests were seen by General Dearborn at Winthrop in Maine; he had also heard of one at Gardiner in the same State. The hibernal retreat of these birds would appear to be in the West Indies, as they were seen in Porto Rico by Vieillot, and one was also observed in St. Domingo by the same author.

In the Western States they arrive from the South early in April, and almost immediately begin to construct their nests. They commence their labor at the dawn, and continue their operations until near mid-day. The nests are made of pellets of sandy mud, disposed in layers until the fabric, with its entrance, assumes the form of a projecting retort, agglutinated to cliffs or the walls of buildings as convenience may offer. From the nature of the friable materials employed, the whole is frail, and would crumble in the possession of any but the airy owners. The internal lining is of "straw and dried grass negligently disposed for the reception of the eggs. They raise but a single brood, who, with their parents, after several attempts at mustering, finally disappear in August as suddenly as they came. Mr. Townsend says: "In the neighborhood of the Columbia River the Cliff Swallow attaches its nest to the trunks of trees, making it of the same form and materials as elsewhere." The face of Pillar Rock, an isolated columnar mass of basalt near Chinhook, at the estuary of the Columbia, was rendered still more fantastic and picturesque by the nests 
of the Cliff Swallow with which it was faced; a small colony having taken up their abode here. These were, as usual, made of pellets of mud, enclosed at the top, but without the retort necks.

Like the rest of their congeners, these birds are almost perpetually on the wing in quest of flies and other small insects which constitute their ordinary food. Their note does not appear to resemble a twitter, and according to Audubon it may be imitated by rubbing a moistened cork round in the neck of a bottle. In Kentucky, until the commencement of incubation, the whole party resorted to roost in the hollow limbs of the buttonwood-trees. However curious, it is certain that the birds have but recently discovered the advantage of associating round the habitations of men.

Numerous colonies of this species are found throughout New England and the Maritime Provinces, and a few pairs have been seen at Point de Monts, on the north shore of the Gulf of St. Lawrence, which is the limit of its northward range near the Atlantic.

It is highly probable that the habit of breeding in large communities, and thus becoming "local" in distribution, will account for the report of their having moved eastward during the first half of the present century. As a matter of fact, Audubon discovered the species in Kentucky five years before Say found it among the Rockies. That the older writers knew so little about the bird should not be taken as evidence of its absence, - they failed to learn the history of several equally common species; and after the added years we are still ignorant of the breeding habits of some of these birds. 


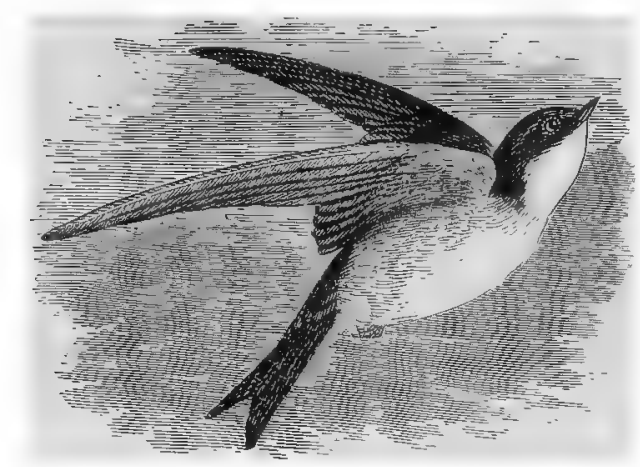

TREE SWALLOW.

WHITE-BELLIED SWALLOW. SINGING SWALLOW.

TACHYCINETA BICOLOR.

Char. Above, rich steel blue, wings and tail with green reflections; beneath, white. Length about 6 inches.

Nest. In a cavity of a tall dead tree, - often a deserted Woodpecker's hole, - sometimes in a bird box; made of grass and straw, lined with feathers.

Eggs. 4-9 (usually 5); white ; $0.75 \times 0.55$.

This species, less common than the Barn Swallow and nearly allied to the common Martin, arrives in Pennsylvania and New England about the middle of April, and extends its migrations over the continent nearly to the Arctic circle, having been seen by Dr. Richardson in the latitude of $53^{\circ}$; it is also abundantly dispersed over the Rocky Mountains and the Columbia River, where it breeds, as well as around Hudson Bay and throughout the Northern and Middle States. On its arrival, like many other species, it seeks out the society of man and frequently takes possession of the mansion of the Martin. When these advantages are unattainable it will be content with the eaves of some deserted dwelling, a hollow tree, its ancient residence, or even an horizontal branch when large and convenient.

The note of these birds is a shrill, lively, warbling twitter; but they are more quarrelsome and less sociable in the breed- 
ing season that the Barn Swallow. In the spring their protracted, angry contentions, and rapid chatter are often heard in the air. Their food is similar to that of the species above mentioned, and they make a snapping sound with the bill in the act of seizing their prey. They proceed to the South in September, and according to the observations of Audubon pass nearly, if not quite, the whole winter in the cypress swamps near to New Orleans, and probably in the Mexican vicinity. He observed them about the middle of December, and also near to the close of January. "During the whole winter many retired to the holes around houses, but the greater number resorted to the lakes, and spent the night among the branches of the wax-myrtle," whose berries at this season afford them a support on which they fatten, and are then considered as excellent food. About sunset they usually began to flock together at a peculiar call, and were then seen almost in clouds moving towards the neighboring lagoons or the estuaries of the Mississippi. Before alighting they perform their aërial evolutions to reconnoitre the place of roosting, soon after which they rapidly descend as it were in a spiral vortex almost like the fall of a water-spout, and when within a few feet of the waxmyrtles they disperse and settle at leisure; but their twittering and the motions of their wings are heard throughout the night. At dawn they rise, at first flying low over the waters which they almost touch, and then rising gradually separate in quest of food. During their low flight numbers of them are often killed by canoe-men with the mere aid of their paddles (Aububon). This predilection for the borders of lakes and ponds led some of the ancient writers to believe that Swallows retired to the bottom of the water during the winter; and some fishermen on the coast of the Baltic pretended to have taken them up in their nets in large knots, clinging together by their bills and claws in a state of torpidity. 


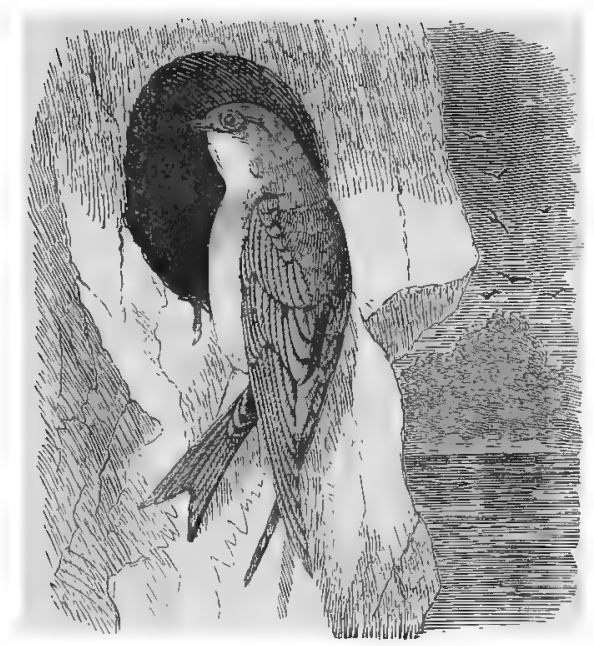

BANK SWALLOW.

SAND MARTIN.

Clivicola riparla.

ChAR. Above, dull grayish brown, which extends around the neck and across the breast; beneath, white. Length about 5 inches.

Nest. At the end of a burrow excavated in a bank of sand or gravel, - usually within a few feet of the top; the bank generally near a stream of water ; the excavation is 2 to 4 feet deep, and widens at the inner end, where a little dry grass and a few feathers are loosely placed, and on this cushion the eggs are laid.

Eggs. 4-6; white; $0.70 \times 0.50$.

These plain-looking and smaller birds, though equally gregarious with other kinds, do not court the protection or society of man, - at least their habitations are remote from his. They commonly take possession for this purpose of the sandy bank or bluff of a river, quarry, or gravel pit, 2 or 3 feet below the upper surface of the bank. In such places, in the month of April, they may be observed burrowing horizontally with their awl-like bills, when at length, having obtained a foot-hold in the cliff, they also use their feet and continue this labor to the depth of 2 or 3 feet. Many of these holes may be often seen within a few inches of each other. This species has genervOL. I. -26 
ally two broods in the season, and on the egress of the young in the latter end of May the piratical Crows often await their opportunity to destroy them as they issue from the nest. In rocky countries the birds often take possession of the clefts on the banks of rivers for their dwelling, and sometimes they content themselves with the holes of trees.

Their voice is only a low twitter of short lisping notes; and while busily passing backwards and forwards in the air around their numerous burrows, they seem at a distance almost similar to hiving bees. As they arrive earlier than other species, the cold and unsettled weather often drives them for refuge in their holes, where they cluster together for warmth, and have thus been found almost reduced to a state of torpidity. Dwelling thus shut up, they are often troubled with swarms of infesting insects, resembling fleas, which assemble in great numbers around their holes. They begin to depart to the South from the close of September to the middle of October. Although they avoid dwelling near houses, they do not fly from settled vicinities; and parties of six or more, several miles from their nests, have been seen skimming through the streets of adjacent villages in the province of Normandy.

They are found on both sides of North America, from the shores of the Atlantic to the borders of the Columbia, and in all the intermediate region suited to their manner of breeding. According to Audubon, they winter in great numbers in Florida, and breed from Labrador to Louisiana.

If the Bank Swallow was found in Labrador by Audubon it has since changed its habitat to the extent of deserting that country, for during recent years only one example has been seen on the northern side of the Gulf of St. Lawrence, though colonies have been found on Anticosti and the Magdalen Islands.

In the Far West these birds range to much higher latitudes, a few having been met with along the valley of the Mackenzie River. The winter resorts of the species are in South America. 


\section{ROUGH-WINGED SWALLOW.}

\section{STELGIDOPTERYX SERRIPENNIS.}

CHAR. Above, grayish brown; beneath, brownish gray, whitening on the belly. Edge of wings rough to the touch. Length 5 to $5 \frac{1}{4} / 4$ inches.

Nest. In a cavity of a bank or in a crevice of a stone wall or bridge, usually near a stream; made of dry grass lined with feathers.

Eggs. 4-7; white; $0.75 \times 0.50$.

We are indebted to Audubon for the discovery of this species so much allied to the preceding, who first observed it near Bayou Sara, and afterwards in South Carolina. Of its habits he says nothing; but it is rarer, and he thinks its habitual residence may prove to be far to the westward, perhaps the valleys of the Columbia.

This species is more common in the Western Faunal Province than in the East; it is abundant in British Columbia. It occurs regularly, however, throughout the Eastern States north to New York, Ohio, and Illinois, and sparingly in Connecticut. It has also been found in parts of Ontario.

In appearance and habits it so closely resembles the Bank Swallow that it may be overlooked by the casual observer; it does not, however, confine its choice of a nesting site to a sand-bank, but will place its nest amid the stones of a wall or bridge, in a crevice of a building, or even in a knot-hole.

Note. - The Cuban Cliff Swallow (Petrochelidon fulva) and the BaHAma Swallow (Calichelidon cyaneovirides) have been added to the United States fauna by Mr. W. E. D. Scott, who captured examples on Dry Tortugas island during March and April, I8go. 


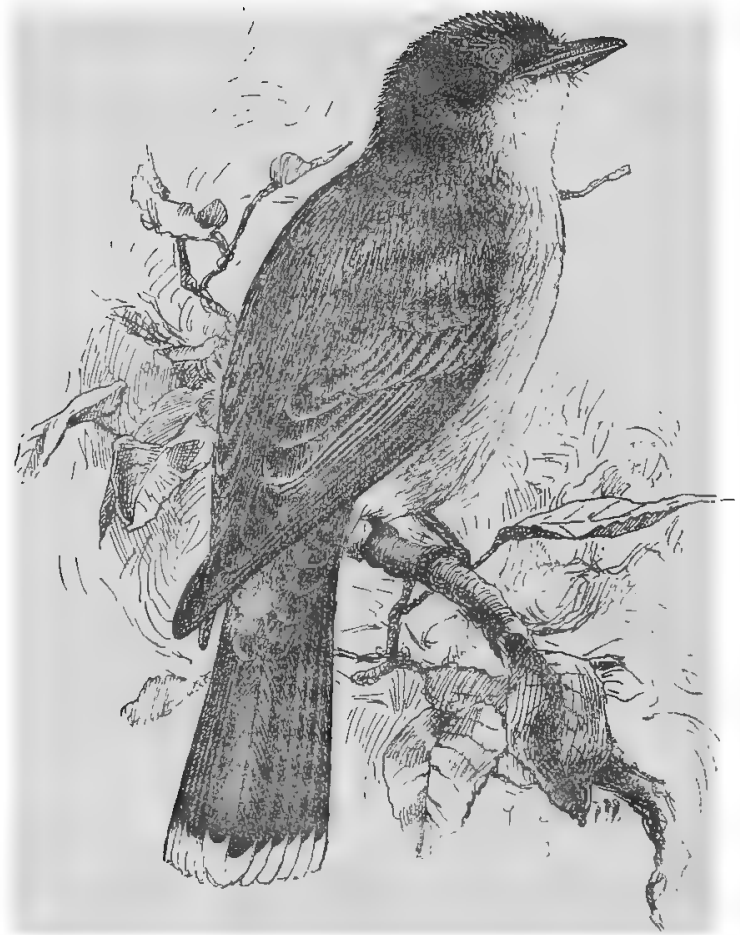

K I N G B I R D.

BEE MARTIN.

\section{TYRANNUS TYRANNUS.}

CHAR. Above, blackish ash, darker on the head; beneath, white; breast tinged with gray; tail black, tipped with broad band of white. Crown with concealed patch of yellow or orange red. Length 8 to 9 inches.

Nest. On a branch or in fork of a tree, in garden or pasture; composed of twigs, roots, and moss, lined with roots, horse-hair, and feathers. The exterior is loosely laid, but the interior is neat and compact.

Eggs. 4-5; creamy white, spotted with light and dark brown; 0.95 $\times 0.70$. 
This well-known, remarkable, and pugnacious bird takes up his summer residence in all the intermediate region from the temperate parts of Mexico to the uninhabited and remote interior of Canada. In all this vast geographical range the Kingbird seeks his food and rears his young. According to Audubon they appear in Louisiana by the middle of March; and about the 2oth of April Wilson remarked their arrival in Pennsylvania in small parties of five or six ; but they are seldom seen in this part of New England before the middle of May. They are now silent and peaceable, until they begin to pair, and form their nests, which takes place from the first to the last week in May or early in June, according to the advancement of the season in the latitudes of 40 and 43 degrees. The nest is usually built in the orchard, on the horizontal branch of an apple or pear tree, sometimes in an oak, in the adjoining forest, at various heights from the ground, seldom carefully concealed, and firmly fixed at the bottom to the supporting twigs of the branch. The outside consists of coarse stalks of dead grass and wiry weeds, the whole well connected and bedded with cut-weed down, tow, or an occasional ropeyarn and wool; it is then lined with dry, slender grass, root fibres, and horse-hair. The eggs are generally 3 to 5 , yellowish white, and marked with a few large, well-defined spots of deep and bright brown. They often build and hatch twice in the season.

The Kingbird has no song, only a shrill, guttural twitter, somewhat like that of the Martin, but no way musical. At times, as he sits watching his prey, he calls to his mate with a harsh tshéúp, rather quickly pronounced, and attended with some action. As insects approach him, or as he darts after them, the snapping of his bill is heard like the shutting of a watch-case, and is the certain grave of his prey. Beetles, grasshoppers, crickets, and winged insects of all descriptions form his principal summer food. I have also seen him collecting the canker-worms from the Elm. Towards autumn, as various kinds of berries ripen, they constitute a very considerable and favorite part of his subsistence; but with the excep- 
tion of currants (of which he only eats perhaps when confined), he refuses all exotic productions, contenting himself with blackberries, whortle-berries, the berries of the sassafras, cornel, viburnum, elder, poke, and five-leaved ivy. Raisins, foreign currants, grapes, cherries, peaches, pears, and apples were never even tasted when offered to a bird of this kind, which I had many months as my pensioner; of the last, when roasted, sometimes, however, a few mouthfuls were relished in the absence of other more agreeable diet. Berries he always swallowed whole, grasshoppers, if too large, were pounded and broken on the floor as he held them in his bill. To manage the larger beetles was not so easy; these he struck repeatedly against the ground, and then turned them from side to side, by throwing them dexterously into the air, after the manner of the Toucan, and the insect was uniformly caught reversed, as it descended, with the agility of a practised cup-and-ball player. At length the pieces of the beetle were swallowed, and he remained still to digest his morsel, tasting it distinctly soon after it entered the stomach, as became obvious by the ruminating motion of his mandibles. When the soluble portion was taken up, large pellets of the indigestible legs, wings, and shells, as likewise the skins and seeds of berries, were, in half an hour or less, brought up and ejected from the mouth in the manner of the Hawks and Owls. When other food failed he appeared very well satisfied with fresh minced meat, and drank water frequently, even during the severe frosts of January, which he endured without much difficulty; basking, however, like Diogenes, in the feeble beams of the sun, which he followed round the room of his confinement, well satisfied when no intruder or companion threw him into the shade. Some very cold evenings he had the sagacity to retire under the shelter of a depending bed-quilt, was very much pleased with the warmth and brilliancy of lamp-light, and would eat freely at any hour of the night. Unacquainted with the deceptive nature of shadows, he sometimes snatched at them for the substances they resembled. Unlike the Vieros, he retired to rest without hiding his head in the wing, and was extremely watchful, 
though not abroad till after sunrise. His taciturnity and disinclination to friendship, and familiarity in confinement, were striking traits. His restless, quick, and side-glancing eye enabled him to follow the motions of his flying insect prey, and to ascertain precisely the infallible instant of attack. He readily caught morsels of food in his bill before they reached the ground, when thrown across the room, and on these occasions seemed pleased with making the necessary exertion. He had also a praçtice of cautiously stretching out his neck, like a snake, and peeping about either to obtain sight of his food, to watch any approach of danger, or to examine anything that appeared strange. At length we became so well acquainted that when very hungry he would express his gratitude on being fed by a shrill twitter and a lively look, which was the more remarkable as at nearly all other times he was entirely silent.

In a natural state he takes his station on the top of an apple-tree, a stake, or a tall weed, and betwixt the amusement of his squeaking twitter, employs himself in darting after his insect food. Occasionally he is seen hovering over the field, with beating wing, almost like a Hawk, surveying the ground or herbage for grasshoppers, which are a favorite diet. At other times these birds may be observed in companies flickering over still waters in the same employment, - the gratification of appetite. Now and then, during the heat of summer, they are seen to dip and bathe in the watery mirror; and with this washing, drying, and pluming, they appear to be both gratified and amused. During the season of their sojourn the pair are often seen moving about in company, with a rapid quivering of the wings and a continued tremulous, shrieking twitter. Their energetic and amusing motions are most commonly performed in warm and fine weather, and continue, with little interruption, until towards the close of August.

One of the most remarkable traits in the character of the Kingbird is the courage and affection which he displays for his mate and young; for on his first arrival he is rather timid, and readily dodges before the Swallow and Purple Martin. Indeed 
at this season I have seen the Spotted Sandpiper drive away a pair of Kingbirds because they happened to approach the premises of her nest. But he now becomes, on this important occasion, so tenacious of his rights as readily to commence the attack against all his feathered enemies, and he passes several months of the summer in a scene of almost perpetual contest; and not overrating his hostile powers, he generally finds means to come off with impunity. Eagles, Hawks, Crows, Jays, and in short every bird which excites his suspicion by its intentional or accidental approach, are attacked with skill and courage; he dives upon the heads and backs of the larger intruders, who become so annoyed and tormented as willingly to make a precipitate retreat. He pursues his foes sometimes for a mile; and at length, assured of conquest, he returns to his prominent watch-ground, again quivering his wings in gratulation, and rapidly uttering his shrill and triumphant notes. $\mathrm{He}$ is therefore the friend of the farmer, as the scourge of the pilferers and plunderers of his crop and barn-yard. But that he might not be perfectly harmless, he has sometimes a propensity for feeding on the valuable tenants of the bee-hive; for these he watches, and exultingly twitters at the prospect of success as they wing their way engaged in busy employment; his quicksighted eyes now follow them, until one, more suitable than the rest, becomes his favorite mark. This selected victim is by some farmers believed to be a drone rather than the stinging neutral worker. The selective discernment of the eyes of this bird has often amused me; berries of different kinds, held to my domestic Kingbird, however similar, were rejected or snatched as they suited his instinct, with the nicest discrimination.

As the young acquire strength for their distant journey, they may be seen in August and September assembling together in almost silent, greedy, and watchful parties of a dozen or more, feeding on various berries, particularly those of the sassafras and cornel, from whence they sometimes drive away smaller birds, and likewise spar and chase each other as the supply diminishes. Indeed, my domestic allowed no other bird to 
live in peace near him when feeding on similar food; and though lame of a wing, he often watched his opportunity for reprisal and revenge, and became so jealous that, instead of being amused by companions, sometimes he caught hold of them with his bill, and seemed inclined to destroy them for invading his usurped privileges. In September the Kingbird begins to leave the United States and proceeds to pass the winter in tropical America. During the period of migration southward, Audubon remarks that they fly and sail through the air with great ease at a considerable elevation; and they thus continue their silent retreat throughout the night until about the first of October, when they are no longer to be seen within the limits of the Middle States.

All lovers of birds and of justice will thank Mrs. Olive Thorne Miller for her noble defence of this chivalrous and much maligned bird, which appeared in the "Atlantic Monthly" for August, I890. The systematists have dubbed him "tyrant of the tyrants," but his friends know him to be a true knight, the real "king of the air."

Note. - The Arkansas KingBird ( $T$. verticalis) differs from tyrannus in being light ashy gray on head, neck, and breast, and other lower parts yellow. In size the two birds are much the same, some examples of the Western form being slightly larger.

Its habitat is the Western plains; but specimens have been taken in the Middle and Northern States. 


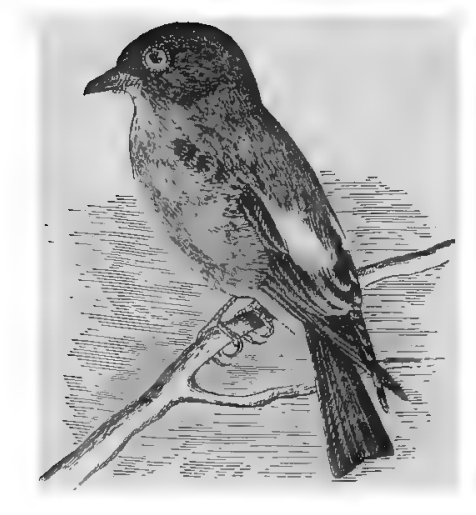

\section{OLIVE-SIDED FLYCATCHER.}

CONTOPUS BOREALIS.

CHAR. Above, dull olive brown, darker on head, paler on rump; tail dusky, tipped with gray; wings dusky, with gray band; lower parts yellowish white; flanks pale olive. Length $7^{1 / 4}$ to 8 inches.

Nest. Saddled on horizontal limb of tall tree; of twigs and grass lined with grass and moss.

Eggs. 3-5; creamy white, spotted near larger end with reddish brown and pale purple; $0.85 \times 0.65$.

This remarkable species, which appertains to the group of Pewees, was obtained in the woods of Mount Auburn, in this vicinity, by Mr. John Bethune, of Cambridge, on the 7 th of June, I83o. This, and a second specimen acquired soon afterwards, were females on the point of incubation. A third individual of the same sex was killed on the 2 Ist of June, I83 $\mathrm{x}$. They were all of them fat, and had their stomachs filled with torn fragments of wild bees, wasps, and other similar insects. I have watched the motions of two other living individuals who appeared tyrannical and quarrelsome even with each other; the attack was always accompanied with a whirring, querulous twitter. Their dispute was apparently, like that of savages, about the rights of their respective huntinggrounds. One of the birds, the female, whom I usually saw alone, was uncommonly sedentary. The territory she seemed 
determined to claim was circumscribed by the tops of a cluster of tall Virginia junipers or red cedars, and an adjoining elm and decayed cherry-tree. From this sovereign station, in the solitude of a barren and sandy piece of forest adjoining Mount Auburn, she kept a sharp lookout for passing insects, and pursued them with great vigor and success as soon as they appeared, sometimes chasing them to the ground, and generally resuming her perch with an additional mouthful, which she swallowed at leisure. On descending to her station she occasionally quivered her wings and tail, erected her blowsy cap, and kept up a whistling, oft-repeated, whining call of ' $p \breve{u}$ ' $p \breve{u}$,

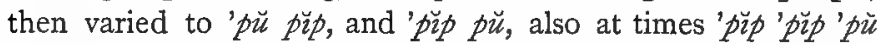

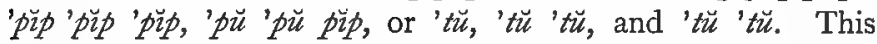
shrill, pensive, and quick whistle sometimes dropped almost to a. whisper or merely ' $p \breve{u}$. The tone was in fact much like that of the 'phü 'phü 'phü of the Fish Hawk. The male, however, besides this note, at long intervals had a call of 'eh'phèbeze or ' $h$ 'phebéa, almost exactly in the tone of the circular tin whistle, or bird-call, being loud, shrill, and guttural at the commencement. The nest of this pair I at length discovered in the horizontal branch of a tall red cedar 40 or 50 feet from the ground. It was formed much in the manner of the Kingbird, externally made of interlaced dead twigs of the cedar, internally of the wiry stolons of the common cinquefoil, dry grass, and some fragments of branching Lichen or Usnea. It contained 3 young and had probably 4 eggs. The eggs had been hatched about the 2 oth of June, so that the pair had arrived in this vicinity about the close of May.

The young remained in the nest no less than 23 days, and were fed from the first on beetles and perfect insects, which appeared to have been wholly digested, without any regurgitation. Towards the close of this protracted period the young could fly with all the celerity of the parents; and they probably went to and from the nest repeatedly before abandoning it. The male was at this time extremely watchful, and frequently followed me from his usual residence, after my paying him a visit, nearly half a mile. These birds, which I watched 
on several successive days, were no way timid, and allowed me for some time previous to visiting their nest to investigate them and the premises they had chosen, without showing any sign of alarm or particular observation.

This bird appears to have been discovered in the fur countries about the same time as in the United States. According to Dr. Richardson, the specimen, figured so spiritedly in the "Northern Zoology of Canada," was shot on the banks of the Saskatchewan as it was flying near the ground.

In 1832 , about the middle of June, the same pair apparently had again taken possession of a small juniper not more than 300 yards from the tree they had occupied the preceding year, about 14 or 15 feet up which they had fixed their thin twiggy nest as in the preceding year. It contained 4 eggs, on which the female had commenced sitting; these, except in their superior size, were precisely similar with those of the Wood Pewee, - yellowish-cream color, with dark-brown and lavender-purple spots, rather thinly dispersed. Being unfortunate enough to shake out the two eggs I intended to leave in the nest, the pair had to commence their labors of preparing for a progeny anew; and a few days after, a second nest was made in another Virginian juniper at a very short distance from the preceding. The present year, however, they did not return to their accustomed retreat, and no individual was seen in this vicinity. In all places it appears, in fact, a scarce and widely dispersed species. Audubon has since observed this bird in other parts of Massachusetts, Maine, the Magdalen Islands, and the coast of Labrador. He has also seen it in Georgia and in Texas. This species is a common inhabitant of the dark fir-woods of the Columbia, where it arrives towards the close of May. We again heard, at intervals, the same curious call, like ' $g h$-phebéa, and sometimes like the guttural sound 'egh-phebee', commencing with a sort of suppressed chuck; at other times the note varied into a lively and sometimes quick p't-detoway. This, no doubt, is the note attributed by Wilson to the Wood Pewee. When approached, or when calling, we heard the $p u p u p u$. 
The Olive-sided Flycatcher is a rare summer resident in the southern portions of New England, but is quite common in Maine and New Brunswick, and ranges north to about the 5oth parallel. In the region of the Great Lakes it occurs but rarely.

\section{CRESTED FLYCATCHER.}

\section{MYIARCHUS CRINITUS.}

CHAR. Upper parts olive, inclined to brown on the head; lower parts bright yellow, excepting throat and cheek, which are dark ash; wings and tail clusky, marked with rufous. Head crested. Length $81 / 2$ to 9 inches.

Nest. In a cavity of a tree; of twigs, grass-roots, feathers, and usually a cast-off snake-skin.

Egos. 4-6; light buffy brown, marked with lines of brown and purple; $0.85 \times 0.65$.

This species, nearly unknown in New England, arrives in Pennsylvania early in May, and builds his nest in the deserted holes of the Woodpecker or Bluebird. He also frequents the orchard, and is equally fond of bees with the Kingbird. $\mathrm{He}$ has no other note than a harsh squeak, which sounds like 'păp, 'paip, payüp, 'payzeip, with a strong accent on the first syllable. He preys actively on insects, which he collects from his stand, and, in short, has most of the manners and physiognomy of the whole section or family to which he belongs. The note of the male appears often delivered in anger and impatience, and he defends his retreat from the access of all other birds with the tyrannic insolence characteristic of the Kingbird.

Towards the and of summer these birds feed on berries of various kinds, being particularly partial to pokeberries and whortleberries, which for a time seem to constitute the principal food of the young. They remain in Pennsylvania till about the middle of September, when they retire to tropical America. In July, r83 r, I observed a pair in an orchard at Acton, in this State (Massachusetts). They had reared a brood in the vicinity, and still appeared very stationary on the premises; their harsh 
payup, and sometimes a slender twittering, as they took the perch, were heard almost from morn to night, and resembled at first the chirp of a young Robin. They fed on the caterpillars or vermin of some kind which happened to infest the apple-trees. I was told that they utter a different and more musical note about sunrise ; but of this I cannot speak from my own knowledge. They are unknown in the vicinity of the sea-coast of Massachusetts. According to Audubon, they are found on the upper Missouri during summer. Many also pass the winter in the warmer parts of Florida. They also breed in Texas.

This species is common in the Eastern States north to Connecticut and northern Ohio and in southern Ontario. It is rare in Massachusetts, but examples have been observed in Maine and New Brunswick.

Those who know the bird best say it has the courage of the Kingbird, and a knack of quarrelling that is all its own.

\section{GRAY KINGBIRD.}

\section{TyRanNus DOMINICENSIS.}

CHAR. Very similar to the Kingbird, but of paler color ; the upper parts, including the head, being ashy gray. Its size is somewhat larger, about an inch in length.

Nest. In a tree; composed of twigs, lined with roots or moss.

Eggs. 3-4; white, tinged with pale buff or salmon pink and spotted with brown and purple; $1.00 \times 0.75$.

This fine tropical species was discovered by Audubon on the Florida Keys, where it arrives about the first of April, and spreads over the peninsula as far as Cape Florida. It is common in Cuba and several other of the West India islands. Stragglers, however, appear to wander at times as far to the north as South Carolina; a pair and their nest having been found in a college yard, where they continued to return for several years in succession, rearing two broods in a season. Its whole demeanor so much resembles that of the common 
Kingbird that but for its superior size and note it might be mistaken for that species.

These birds flutter while flying, and sometimes during the breeding season the pair, crossing each other's path, rise in spiral evolutions, loudly twittering as they ascend. When interrupted, alarmed by pursuit, or in quest of insects, they dart off with great velocity. If a large bird, as a Heron or Crow, or indeed any intruder, pass near their station, they immediately pursue it, and that often to a considerable distance. At the same time they appear careless of the approach of man except when the nest is invaded, when they fly about in great anger, snapping their bills and loudly chattering; but when relieved from their unwelcome visitors, they return to their stand with notes of exultation.

Nuttall, following Audubon, named this species the Pipiry Flycatcher. It is abundant in the West Indies and is quite common in parts of Florida, but occurs at no other locality within the limits of the United States except as an accidental wanderer. Examples have been taken on Long Island and at Lynn, in Massachusetts.

\section{PHCEBE.}

PEWEE. PEWIT.

\section{- SAYORNIS PHEBE.}

ChaR. Upper parts dull olive brown, darker on head; under parts whitish, changing to pale yellow on belly, and brownish on flanks; wings and tail dusky, outer tail feathers and wing bar whitish; white ring around the eyes; bill and feet black. Head with inconspicuous crest. Length $6 \frac{1}{4}$ to 7 inches.

Nest. Attached to the under-side of a bridge, or to a rock, or the side of a cave; of twigs, roots, and moss, cemented with mud, lined with grass and feathers.

Eggs. 4-5; white, sometimes speckled with pale brown; $080 \times 0.55$.

This familiar species inhabits the continent of North America from Canada and Labrador to Texas, retiring from the Northern and Middle States at the approach of winter. How 
far they proceed to the South at this season is not satisfactorily ascertained; a few, no doubt, winter in the milder parts of the Union, as Wilson saw them in February in the swamps of North and South Carolina, where they were feeding on smilax berries, and occasionally even giving their well-known notes; but in the winter and early spring of $183^{\circ}$, while employed in an extensive pedestrian journey from South Carolina to Florida and Alabama, I never heard or met with an individ. ual of the species. Audubon found them abundant in the Floridas in winter.

These faithful messengers of spring return to Pennsylvania as early as the first week in March, remain till October, and sometimes nearly to the middle of November. In Massachusetts they arrive about the beginning of April, and at first chiefly frequent the woods.

Their favorite resort is near streams, ponds, or stagnant waters, about bridges, caves, and barns, where they choose to breed; and, in short, wherever there is a good prospect for obtaining their insect food. Near such places our little hunter sits on the roof of some out-building, on a stake of the fence, or a projecting branch, calling out at short intervals and in a rapid manner pheb̀e phebè, and at times in a more plaintive tone phee-bè-ee. This quaint and querulous note, occasionally approaching to a warble, sometimes also sounds like perwait pewait, and then pĕ-wai-ee, also phebè phü-bè-ee, twice alternated; the latter phrase somewhat soft and twittering. In the spring this not unpleasing guttural warble is kept up for hours together until late in the morning, and though not loud, may be heard to a considerable distance. From a roof I have heard these notes full half a mile across the water of a small lake; and this cheerful, though monotonous, ditty is only interrupted for a few seconds as the performer darts and sweeps after his retreating prey of flies, frequently flirting and quivering his tail and elevating his feathery cap, while sharply watching the motions of his fickle game.

In the Middle States he begins to construct his nest about the latter end of March, in Massachusetts not before the first 
week in April. The nest is situated under a bridge, in a cave, the side of a well 5 or 6 feet down, under a shed, or in the shelter of the low eaves of a cottage, and even in an empty kitchen; sometimes it rests on a beam, though it is frequently attached to the side of a piece of roofing timber in the manner of the Swallow.

According to the touching relation of Wilson, this humble and inoffensive bird forms conjugal attachments which probably continue through life; for, like the faithful Bluebirds, a pair continued for several years to frequent and build in a romantic cave in the forest which made part of the estate of the venerable naturalist, William Bartram. Here our unfortunate birds had again taken up their welcome lease for the summer, again chanted forth their simple lay of affection, and cheered my aged friend with the certain news of spring; when unexpectedly a party of idle boys, one fatal Saturday, destroyed with the gun the parents of this old and peaceful settlement; and from that time forward no other pair were ever seen around this once happy, now desolate spot.

Their attachment to particular places is indeed remarkable. About the middle of April, I831, at the Fresh Pond Hotel, in this vicinity, three different nests were begun in the public boat-house, which may be here considered almost as a thoroughfare. Only one nest, however, was completed; and we could not help admiring the courage and devotedness with which the parents fed their young, and took their alternate station by the side of the nest, undaunted in our presence, only now and then uttering a 'tship when observed too narrowly. Some ruffian at length tore down the nest and carried off the brood; but our Pewit immediately commenced a new fabric, laid 5 additional eggs in the same place with the first, and, in haste to finish her habitation, lined it with the silvery shreds of a Manilla rope which she discovered in the contiguous loft over the boat-house. For several previous seasons the parents had taken up their abode in this vicinity, and seemed unwilling to remove from the neighborhood they had once chosen, in spite of the most untoward circumstances. In two other VOL. I. -27 
instances I have known a pair, when the nest and eggs were taken by some mischievous boys, commence a new nest in the same place, and laying a smaller number of eggs, raised a second brood. In one of those nests, under a bridge, the insidious Cowbird had also dropped her parasitic egg.

Towards the time of their departure for the South, which is about the middle of October, they are silent, and previously utter their notes more seldom, as if mourning the decay of Nature, and anticipating the approaching famine which now urges their migration. In the Middle States they raise two broods in the season; but in Massachusetts the Pewit rarely raises more than a single brood, unless, as in the instance related, they have had the misfortune to lose the first hatch. The young, dispersed through the woods in small numbers, may now and then be heard to the close of September exercising their feeble voices in a guttural phébé. But the old birds are almost wholly silent, or but little heard, as they flit timidly through the woods, when once released from the cares of rearing their infant brood; so that here the Phobe's note is almost a concomitant of spring and the mildest opening of summer, it is, indeed, much more vigorous in April and May than at any succeeding period.

The Phœbe is an uncommon bird in the Maritime Provinces, but more common in the vicinity of Montreal and westward to Western Ontario, and in all the Eastern States. It winters in the Gulf States as well as in Cuba and Mexico.

Note. - Mr. G. S. Miller, Jr., captured on Cape Cod, in September, I889, an example of SAY'S PHळBE (Sayornis saya), the first that has been taken to the eastward of the Great Plains. 


\section{WOOD PEWEE.}

CONTOPUS VIRENS.

CHAR. Upper parts olive brown, darker on the head; lower parts whitish, with dull yellow tinge; sides pale olive, extending across the breast; tail and wings dusky; wings with bars of whitish. Head with inconspicuous crest. Length 6 to $61 / 2$ inches.

Nest. On branch of a tree; of twigs and grass, covered exteriorly with lichens and lined with moss.

Eggs. 3-4; creamy white with spots of brown and lilac wreathed about the larger end; $0.75 \times 7.55$.

This species has much the appearance of the common Pewit Flycatcher, but differs essentially by its note and habits. The Wood Pewee appears generally to winter south of the United States, and scarcely arrives in Pennsylvania or New England before the middle of May; its migrations, in all probability, extend to Canada. According to Audubon, many of them winter in the southern extremity of the United States, and Mr. Townsend and myself frequently saw them in the dark forests of the Oregon. It is a solitary species, frequenting gloomy forests and dark orchards, where, watching on some dead and projecting branch for its insect prey, it sweeps at intervals amidst the shade, and the occasional snapping of its bill announces the success of its flight. It then again alights as before, sometimes uttering a sort of gratulatory low twitter, accompanied by a quivering of the wings and tail; and in the lapse of its employment, in a feeble, sighing tone, often cries pee-wée or pee-é, and sometimes pe-twee pervittitee or pervittee $p \vec{e}$-wee. This note is continued often till quite late in the evening, at which time many of the insect brood and moths are abundant. Most of these birds, indeed, appear capable of collecting their food by the feeblest light, the only season when some of their favorite prey ever stir abroad. This species also appears particularly fond of small wild bees. From June to September, its solitary notes are heard in the field and forest; after which time, preparing for its departure, and intently gleaning food in every situation, it sometimes approaches the city, 
often examines the courts and gardens, at the same time feeding and training its young to the habits of their subsistence, and about the first week in October it retires south to pass the winter.

The Pewee is a very expert and cautious flycatcher; and as if aware of the drowsiness of insects in the absence of the sun's broad light, he is on the alert at day-dawn after his prey. At this early period, and often in the dusk of evening, for the most part of summer till the middle of August, he serenades the neighborhood of his mansion from 3 to 4 or 5 o'clock in the morning, with an almost uninterrupted chanting ditty, sweet, but monotonous, like $p \dot{e}-a y$ pāy-zeree, pé-ay pày-zuěe, then in a little higher and less sing-song tone, his usual and more serious pee-ä-zee. In dark and damp mornings this curious warble is sometimes continued nearly to 8 o'clock; and the effect of this tender, lulling lay in the gray dawn, before the awakening of other birds, and their mingling chorus, is singular and peculiarly pleasing. It is a gratulatory feeling of unmixed and placid delight, concomitant with the mild reviving light of the opening day and the perfect joy of the mated male, satisfied in every reasonable desire, - in short, a hymn of praise to the benevolent Author and Supporter of existence!

Towards the period of departure, they become wholly silent; and driven to extremity, they may now be seen watching the stagnant pools and ponds, dipping occasionally into the still surface after their drowsy and languid prey. Like the Kingbird, this species at times displays a tyrannical disposition; and I have observed one to chase a harmless Sparrow to the ground for safety, who merely by inadvertence happened to approach the station he had temporarily chosen for collecting his insect game.

The notes of peto-wāy peto-wāy pee-way are never uttered by this species; but on the I 2 th of February, 1830 , in Alabama, I heard, at that season, a bird uttering this note, and several times afterwards I saw a rather large and dark Flycatcher in the pine woods, to which I attributed this call, and which must be a distinct species, as its notes bear no resem- 
blance to those of the Wood Pewee, - at this season probably in South America.

The Pewee, I believe, raises here but a single brood, which are not abroad before the middle of July. The nest is extremely neat and curious, almost universally saddled upon an old moss-grown and decayed limb in an horizontal position, and is so remarkably shallow, and incorporated upon the branch, as to be very easily overlooked. The body of the fabric consists of wiry grass or root-fibres, often blended with small branching lichens, held together with cobwebs and caterpillar's silk, moistened with saliva; externally it is so coated over with bluish crustaceous lichens as to be hardly discernible from the moss upon the tree. It is lined with finer root-fibres or slender grass stalks. Some nests are, however, scarcely lined at all, being so thin as readily to admit the light through them, and are often very lousy, with a species of acarus which probably infests the old birds.

The plaintive and almost pathetic note of the Wood Pewee is a familiar sound amid the orchards of New Brunswick, and the bird is of common occurrence through Quebec and Ontario. It winters southward to Mexico and Guatemala.

\section{LEAST FLYCATCHER.}

CHEBEC.

EMPIDONAX MINIMUS.

ChaR. Upper parts olive; lower parts white, tinged with yellow; wings with two bars of grayish white. Length 5 to $5^{I / 2}$ inches.

Nest. On fork of a tree; of twigs and grass, lined with grass or feathers.

Eggs. 3-5; creamy white, usually unspotted; $0.65 \times 0.50$.

This is one of our most common summer birds in this part of New England, arriving from the South about the last week in April, and leaving us to retire probably to tropical America about the beginning of September or sometimes a little later. It also extends its migrations to Labrador and the Oregon 
Territory, and seems most abundant in the Northern and Eastern States. Though, like the preceding, these are solitary, retiring birds, and fond of the shade of the forest, yet in this vicinity their nests are numerous. On their first arrival, previous to pairing, they are engaged in constant quarrels about their mates, and often molest other birds whom they happen to see employed in pursuit of the same kind of food with themselves. Like the preceding species, they take their station on a low branch to reconnoitre the passing insects on which they feed, and from time to time make a circular sweep for their prey. When seated, they utter very frequently a sharp, unpleasant squeak, somewhat resembling that of the Kingbird, sounding like quedh, and sometimes 'tsh'ah, or tshedh, tshedh, and tshoo', with a guttural, snapping sound, succeeded by a kind of querulous, low twitter uttered as they fly from tree to tree, and chiefly at the instant of alighting. At other times they have a recognizing, rather low call of 'whit, 'whit, repeated at short intervals; again, in the warmest weather, I have heard one of these Pewees call something like the whistling of 'weet, 'weet, 'weet, 'will. Occasionally, when fighting or in flying, it also makes an echoing tshirr. It possesses all the habits of the Kingbird, catches bees, flies, and moths, exhibits a variety of quivering motions, and defends its nest with great courage against the approach of larger birds.

The nest of the Small Pewee is usually fixed in the slender, upright forks of a young forest tree from 6 to 20 or 30 feet from the ground. I have also found the nests on the horizontal branch of an apple-tree or forest tree. In most instances in the woods a gloomy, solitary situation is chosen. The materials of this fabric vary according to circumstances; for the first brood a very soft and warm nest is usually made of dry grass, willow, and cud-weed down in large quantities, partly felted or matted together externally with the saliva of the bird. Common tow, if convenient, is also occasionally employed when the nest is in an apple-tree, for which some neighboring graft is probably unravelled. The interior is usually formed of slender, narrow strips of bark, bass, and dry grass; 
the lining is commonly of fine root-fibres, slender tops of bent grass, and at times a few hairs and feathers. Occasionally the principal external material consists of strips or strings of silkweed lint and the bark of the common virgin's bower. The nest is extremely neat and uniform, resembling a complete hemisphere. As nests may be found late in July, it is probable they have a second brood in the course of the season. They are extremely attached to their offspring, and keep up an incessant, almost choking tsheàh tsheàh when any person approaches the tree where they have their brood. The young and old now move about in company, and at this time feed on various kinds of berries, particularly those of the cornel and whortleberry. At length the young are seen to select each other's society, and rove about without any fixed resort, previous to their gradual departure. A pair, probably of the same brood, still lingered here in September, and like the little Parrots called Inseparable, appeared fondly to cherish each other's company. It was toward evening when I saw them, and at first they appeared inclined to roost in the shady willow-tree in which they had alighted. They nestled close to each other with looks and notes of tenderness and affection; wherever one went, the other instantly followed, and the same branch contained the same contented pair.

Nuttall followed Wilson in the mistake of supposing this species and acadicus to be identical, and in his account has mingled the biographies of the two. The latter is more southern in its distribution. "Chebec" is a common summer resident from southern New England to the Gulf of St. Lawrence, and westward to the prairies. It winters south to Panama: 


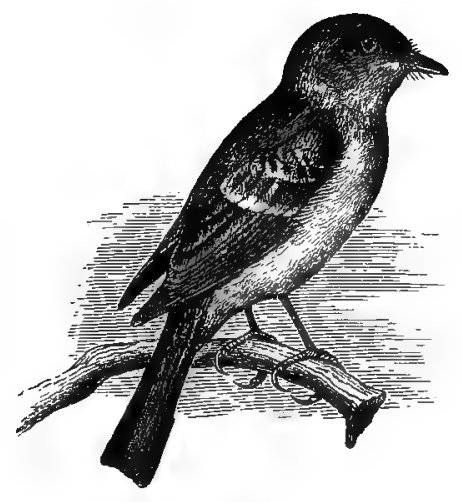

\section{TRAILL'S FLYCATCHER.}

\section{EMPIDONAX PUSILLUS TRAILLII.}

Char. Upper parts olive brown, darker on the head, lighter on the rump ; under parts whitish, the sides tinged with pale olive, which extends nearly across the breast, the belly tinged with yellow; wings dusky, with yellowish white bars. Length $5 \frac{1}{2}$ to 6 inches.

Nest. On an upright fork in a clump of alders or low deciduous tree, I to 8 feet from the ground; composed of grass roots or hempen fibre, lined usually with fine grass, sometimes with horse-hair or thistle-down.

Eggs. 3-4; creamy white or buff, boldly spotted with light and dark brown chiefly about the larger end; $0.70 \times 0.53$.

This species, so nearly allied to the last, was first distinguished by Audubon. Its note resembles the syllable 'wheet, 'wheet, articulated clearly while in the act of flying. It was first observed on the wooded skirts of the prairies along the banks of the Arkansas. Mr. Townsend and myself observed it in various places in the skirts of the forests of the Columbia and Wahlamet during the summer, when it was breeding, but we could not discover the nest. Its motions are thus described by Audubon: "When leaving the top branches of a low tree this bird takes long flights, skimming in zig-zag lines, passing close over the tops of the tall grasses, snapping at and seizing different species of winged insects, and returning to the same trees to alight."

Traill's Flycatcher is chiefly a spring and autumn migrant througb southern New England, though a few pairs breed as far 
south as Long Island. It is a common summer resident of Maine and of the northern part of Vermont and New Hampshire. It is common also in New Brunswick. West of this region it breeds farther to the southward, being common in the middle of Ohio and in southern Illinois and Missouri. Mr. Mcllwraith considers it uncommon in Ontario.

There has been considerable discussion over the breeding habits of this species, caused by the difference in habits of the Western birds from those which breed near the Atlantic. Here the favorite site is a clump of alders near a running stream, and the nest is placed within a foot or two of the ground; while in the West a small tree is generally selected, - sometimes an oak, - and the nest is placed as high as ten feet. The nest, in the West, is not so compactly or neatly made, and the materials are coarser. The note of this bird - for while the Flycatchers are not classed with the Oscines, or Singing-Birds, they add not a little to our forest melodies - is peculiar, though strictly of the family type. It sounds something like $k e$-wink delivered with a rising inflection and the accent on the final sound, which is prolonged, - quite a different note from the abrupt chebec of minimus. I have never heard the song uttered on the wing; but when the bird is perching, the head is tossed back and the note is flung out with a decided emphasis of manner as well as of voice.

\section{ACADIAN FLYCATCHER.}

\section{EMPIDONAX ACADICUS.}

CHAR. Upper parts olive, slightly darker on crown; under parts whitish, the sides tinged with pale olive, which reaches almost across the breast; belly tinged with pale yellow; wings and tail dusky; wing-bars byffy. Length $5^{1 / 2}$ to 6 inches.

Nest. In a tree, suspended on fork of twigs at the extremity of a low limb; rather loosely made of moss or grasses and shreds of bark bouncl with spider's webbing.

Eggs. 2-4; buff or creamy white, spotted, chiefly about the larger end, with reddish brown; $0.75 \times 0.55$.

The older writers had rather confused ideas regarding these small Flycatchers, and Nuttall supposed he was writing of the present species, when the bird be had in mind was minimus.

The Acadian Flycatcher belongs to the Middle States rather than to New England, and has never been taken north of the 
Connecticut valley. It is abundant in Ohio and Illinois, but has not been observed in Ontario.

I have not met with this species in the field, but those who have been so fortunate describe it as a shy bird, seeking the low, moist thicket and shaded groves rather than the open pastures. Dr. Coues thinks the nest "may be compared to a light hammock swung between forks." It is shallow and saucer-shaped, and so loosely made that the eggs may be seen from below. Dr. Wheaton states that so much loose grass is left on the outside of the nest "that it looks like a tuft of hay caught by the limb from a load driven under it."

\section{YELLOW-BELLIED FLYCATCHER.}

\section{EMPIDONAX FLAVIVENTRIS.}

ChaR. Upper parts dull olive, darker on the crown; under parts bright yellow, shaded with olive on the breast; wing-bars pale yellow; a yellow ring around the eye. Length $5 \frac{1}{2}$ to 6 inches.

Nest. Anid moss-covered roots of upturned tree or mossy log; of twigs, or vegetable fibre, or moss, lined with roots, or fine grass, or moss.

Eggs. 4; pale buff, sparingly spotted, mostly about larger end, with reddish brown; $0.70 \times 0.50$.

This species was discovered about I 843 , and for many years - as late as 1880 - was considered a rare bird. Even now comparatively few persons are familiar with it, though it occurs throughout this Eastern Province. It is common in New England, breeding in the northern portion, and occurs on the higher hills elsewhere. I found it abundant in New Brunswick, and it has been traced northward to the lower Hudson Bay region. Macoun reports it common at Lake Mistissini.

Dr. Wheaton considered it a common migrant through Ohio, but observers in Ontario have met with it so seldom as to think it rare. It is common in Illinois and in portions of Manitoba.

The notes of this species have caused much discussion, - some writers claiming for it an individuality, and others insisting that it utters nothing different from the notes of traillii or minimus. The kil-lic of faviventris seems, to my ear, quite different from the ke-wink of Traill's, - which is rather sibilant, and is delivered with a rising inflection, - as also from the che-bec of the Least Flycatcher. While the latter delivers his two notes in rapid stac- 
cato, and makes more or less pause after each couplet, the Yellowbellied whistles four notes, kil-lic kil-iic, with but a short pause a mere rest - between each pair, and delivers the notes with a trifle less abruptness.

Other notes of the present species resemble pea and pe-we-yea. These are heard when a pair are in close companionship. They are soft, sweet, cooing-notes, delivered in a plaintive tone that suggests the tender pathos of the Pewee's.

Note. - The Fork-TAILEd Flycatcher (Milvulus tyrannus), a bird of Central and South America, has occasionally wandered north, and been taken in Mississippi, Kentucky, and New Jersey.

Also a few examples of the SCISSOR-TAILED FLYCATCHER (Milvulus forficatus), which rarely appears north or east of Texas, have been seen in Virginia, New Jersey, Connecticut, Ontario, and Manitoba, and one wandered to the shores of Hudson Bay. 


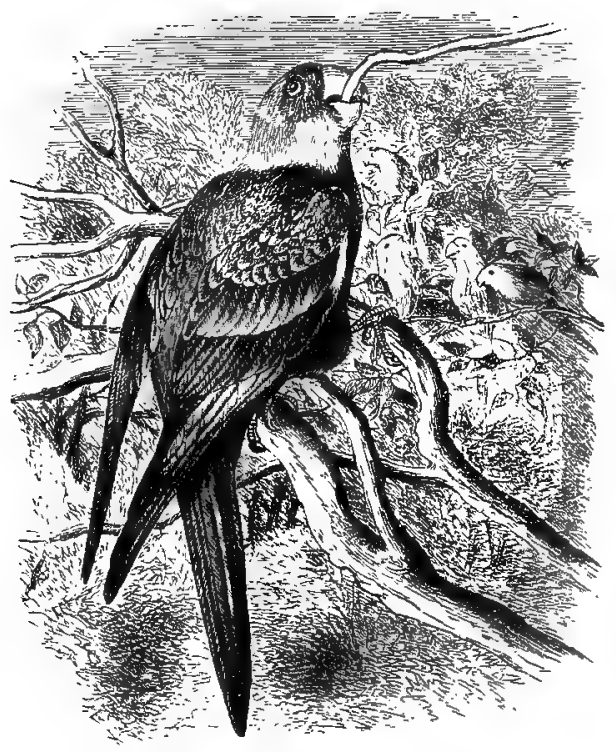

\section{CAROLINA PAROQUET.}

CAROLINA PARROT. PARAKEET.

\section{CONURUS CAROLINENSIS.}

CHAR. Head and neck yellow; forehead and sides of head orange red; body and tail green, the belly linged with yellow; wings green and yellow, the edges tinged with orange red. In immature specimens the yellow of head and neck is replaced by green. Length about 13 inches.

Nest. In clense woods or cypress swamp; placed on a fork near the end of a branch or in a hole in a tree. When on a branch it is made of cypress twigs loosely woven, and a nest in a hole is usually lined with cypress twigs. When abundant the birds gencrally build in large colonies.

$E_{g g s .} \quad 2-5$ (?) ; greenish white or creamy; $1.40 \times 1.05$.

Of more than 200 species now known to belong to this remarkable and brilliant genus, the present is the only one found inhabiting the United States; it is also restricted to the warmer parts, rarely venturing beyond the State of Virginia. West of the Alleghanies, however, circumstances induce these birds commonly to visit much higher latitudes; so that, fol- 
lowing the great valley of the Mississippi, they are seen to frequent the banks of the Illinois, and occasionally to approach the southern shores of Lake Michigan. Straggling parties even have sometimes been seen in the valley of the Juniata in Pennsylvania, and a flock, to the great surprise of the Dutch inhabitants of Albany, are said to have appeared in that vicinity. They constantly inhabit and breed in the Southern States, and are so far hardy as to make their appearance, commonly in the depth of winter, along the woody banks of the Ohio, the interior of Alabama, the banks of the Mississippi and Missouri around St. Louis, and other places, when nearly all other birds have migrated before the storms of the season.

The Carolina Parrakeets in all their movements, which are uniformly gregarious, show a peculiar predilection for the alluvial, rich, and dark forests bordering the principal rivers and larger streams, in which the towering cypress and gigantic sycamore spread their vast summits, or stretch their innumerable arms over a wide waste of moving or stagnant waters. From these, the beech, and the hack-berry, they derive an important supply of food. The flocks, moving in the manner of wild Pigeons, dart in swift and airy phalanx through the green boughs of the forest; screaming in a general concert, they wheel in wide and descending circles round the tall buttonwood, and all alight at the same instant, their green vesture, like the fairy mantle, rendering them nearly invisible beneath the shady branches, where they sit perhaps arranging their plumage and shuffling side by side, seeming to caress and scratch each other's heads with all the fondness and unvarying friendship of affectionate Doves. If the gun thin their ranks they hover over the screaming, wounded, or dying, and returning and flying around the place where they miss their companions, in their sympathy seem to lose all idea of impending danger. When more fortunate in their excursions, they next proceed to gratify the calls of hunger, and descend to the banks of the river or the neighboring fields in quest of the inviting kernels of the cockle-burr, and probably of the bitterweed, which they extract from their husks with great dexterity. 
In the depth of winter, when other resources begin to fail, they, in common with the Yellow Bird and some other Finches, assemble among the tall sycamores, and hanging from the extreme twigs in the most airy and graceful postures, scatter around them a cloud of down from the pendant balls in quest of the seeds, which now afford them an ample repast. With that peculiar caprice, or perhaps appetite, which characterizes them, they are also observed to frequent the saline springs or licks to gratify their uncommon taste for salt. Out of mere wantonness they often frequent the orchards, and appear delighted with the fruitless frolic of plucking apples from the trees and strewing them on the ground untasted. So common is this practice among them in Arkansas Territory that no apples are ever suffered to ripen. They are also fond of some sorts of berries, and particularly of mulberries, which they eat piecemeal in their usual manner as they hold them by the foot. According to Audubon, they likewise attack the outstanding stacks of grain in flocks, committing great waste; and on these occasions, as well as the former, they are so bold or incautious as readily to become the prey of the sportsman in great numbers. Peculiarity of food appears wholly to influence the visits and residence of this bird, and in plain, champaign, or mountainous countries they are wholly strangers, though common along the banks of all the intermediate watercourses and lagoons.

Of their manners at the interesting period of propagation and incubation we are not yet satisfactorily informed. They nest in hollow trees and take little if any pains to provide more than a simple hollow in which to lay their eggs, like the Woodpeckers. They are at all times particularly attached to the large sycamores, in the hollow trunks of which they roost in close community, and enter at the same aperture into which they climb. They are said to cling close to the sides of the tree, holding fast by the claws and bill; and into these hollows they often retire during the day, either in very warm or inclement weather, to sleep or pass away the time in indolent and social security, like the Rupicolas of the Peruvian caves, at 
length only hastily aroused to forage at the calls of hunger. Indeed, from the swiftness and celerity of their aërial movements, darting through the gleaming sunshine like so many sylvan cherubs decked in green and gold, it is obvious that their actions as well as their manners are not calculated for any long endurance; and shy and retiring from all society but that to which they are inseparably wedded, they rove abroad with incessant activity until their wants are gratified, when, hid from sight, they again relapse into that indolence which seems a relief to their exertions.

The Carolina Parrot is readily tamed, and early shows an attachment to those around who bestow any attention on its wants; it soon learns to recollect its name and to answer and come when called on. It does not, however, evince much, if any, capacity for mimicking human speech or sounds of any kind, and as a domestic is very peaceable and rather taciturn. It is extremely fond of nuts and almonds, and may be supported on the vegetable food usually given to other species. One which I saw at Tuscaloosa, a week after being disabled in the wing, seemed perfectly reconciled to its domestic condition; and as the weather was rather cold, it remained the greater part of the time in the house, climbing up the sides of the wire fender to enjoy the warmth of the fire. I was informed that when first caught it scaled the side of the room at night, and rocsted in a hanging posture by the bill and claws; but finding the labor difficult and fruitless, having no companion near which to nestle, it soon submitted to pass the night on the back of a chair.

I fear that the story of this gorgeously apparalled bird is nearly finished. It is not quite exterminated yet, but of the large fiocks that were once to be seen all over the Southern States, only a mere remnant can be found, and these are hidden amid the dense swamps of central Florida and along the lower valley of the Mississippi. The farmers and fruit-growers were obliged to kill large numbers, and later woman's vanity and man's greed have joined hands to carry on the slaughter. From the combined attack of such foes the remnant has but slight chance for escape. 


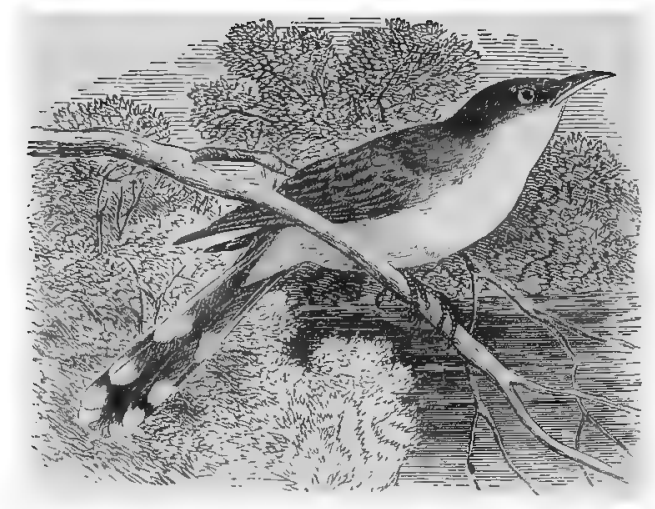

YELLOW-BILLED CUCKOO.

RAIN CROW.

\section{COCCYZUS AMERICANUS.}

CHAR. Upper mandible and tip of lower, black; rest of lower mandible and cutting edges of upper, yellow. Upper parts olive, with a slight metallic gloss, tinged with ash toward the bill; wings tinged with rufous; middle feathers of tail like back, remainder black tipped with white; beneath, white or creamy. Length about $\mathrm{I} 2$ inches.

Nest. In a thicket by the side of a stream or on the border of a swamp ; placed in a bush or Jow tree. A flat, frail affair made of twigs loosely laid, sometimes lined with bark strips or grass.

Eggs. 2-6 (usually 4); pale dull green or bluish green; $1.25 \times 0.90$.

The American Cuckoo arrives in the middle and colder States of the Union about the close of April or the first week of May, and proceeds to the north as far as Nova Scotia. It probably winters in Mexico, and individuals pass no farther than the forests of Louisiana. We also met with it in the remote Territory of Oregon. Latham speaks of these birds also as inhabitants of the tropical island of Jamaica. They delight in the shady retirement of the forest, and are equally common in tall thickets and orchards, where, like piratical prowlers, they skulk and hide among the thickest boughs; and although, unlike the European Cuckoo, they are faithfully paired, yet the pair are seldom seen in the same tree, but, shy and watchful, endeavor to elude everything like close observation. 
The male, however, frequently betrays his snug retreat by his monotonous and guttural kówe kówe kówe kówe, or koo koo koo koo, and kó kük, kó kük, koo koo koo kuk, koo kŏ koo, koo $k \breve{o} k o o$, uttered rather low and plaintively, like the call of the Dove. At other times the kow kow kow, and 'tk' $t k{ }^{\prime} t k$ ' $t k$ 'tăk, or 'kh 'kh' 'kh ' $k h$ ' $k a h$ kow kow kow kow, beginning slow, rises, and becomes so quick as almost to resemble the grating of a watchman's rattle, or else, commencing with this call, terminates in the distant cry of kowe kowe kowe. From this note, supposed to be most clamorous at the approach of rain, it has received in Virginia and other States the name of RainCrone and Coze-Bird. At various seasons during the continuance of warm weather the vigil kow kŏw kŏw koze of the faithful male is uttered for hours at intervals throughout the night. The same notes, but delivered in a slower and rather tender strain, are given with great regularity likewise in the day as long as the period of incubation continues. He often steadfastly watches any approach to the nest, going to it occasionally to assure himself that it is unmolested; and at times he may be observed darting even at the dormant bat, who accidentally seeks repose beneath the shady leaves of some contiguous tree, so that he is no less vigilant in seeking the security of his own progeny than in piratically robbing the nests of his neighbors. There are two or three other species in Jamaica and other parts of tropical America possessing a note very similar to that of our bird, which also frequently approaches, when delivered in the plaintive mood, koo koo and $k o o k o o k o ́ o$, the usual sound of the European Cuckoo. There is a Mexican species (Cuculus ridibundus) which so simulates laughter as to have excited the superstition of the natives, by whom it is hated as a messenger of evil, its accidental note of risibility being construed into an ominous delight in misfortune.

The whole tribe of Cuckoos are in disgrace for the unnatural conduct of the European and some other foreign species, who, making no nests nor engaging in conjugal cares parasitically deposit their eggs one by one in the nests of other small birds, VOL. I. -28 
to whom the care of rearing the vagrant foundling is uniformly consigned.

But we may turn with satisfaction to the conjugal history of our own subject, which, early in May or soon after its arrival, may be at times observed obstinately engaged in the quarrels of selective attachment. The dispute being settled, the nest is commenced, and usually fixed either in the horizontal branches of an apple-tree or in a thicket, a thorn-bush, crab, cedar, or other small tree in some retired part of the woods. The fabric is usually very slovenly and hastily put together, and possesses scarcely any concavity for the reception of the young, who in consequence often fall out of their uncomfortable cradle. The nest is a mere flooring of twigs put together in a zig-zag form, then blended with green weeds or leaves and withered blossoms of the maple, apple, or hickory catkins. A nest near the Botanic Garden had, besides twigs, fragments of bass-mat, and was very uncomfortably heated, and damp with the fermentation of the green tops of a species of maple introduced into it, and the whole swarmed with thrush-lice or millipedes. The eggs are of a bluish-green color, often pale, varying in the shade and without spots; they are somewhat round and rather large. If they are handled before the commencement of incubation, the owner generally forsakes the nest, but is very tenacious and affectionate towards her young, and sits so close as almost to allow of being taken off by the hand. She then frequently precipitates herself to the ground, fluttering, tumbling, and feigning lameness, in the manner of many other affectionate and artful birds, to draw the intruder away from the premises of her brood. At such times the mother also adds to the contrivance by uttering most uncouth and almost alarming guttural sounds, like quà quàh gwaih, as if choking, as she runs along the ground. While the female is thus dutifully engaged in sitting on her charge, the male takes his station at no great distance, and gives alarm by his notes at the approach of any intruder; and when the young are hatched, both unite in the labor of providing them with food, which, like their own, consists chiefly of the hairy caterpillars, rejected by other birds, 
that so commonly infest the apple-trees, and live in communities within a common silky web. They also devour the large yellow cockchafer, Carabi, and other kinds of insects, as well as various sorts of berries; but their worst propensity is the parasitic habit of sucking the eggs of other birds, thus spreading ruin and dismay wherever they approach. They hatch several broods in a season, and I have seen a nest with eggs in it as late as the 28 th of August ! - though they usually take their departure in some part of the month of September. Considering the time they are engaged in breeding, they raise but few young, appearing to be improvident nurses and bad nestmakers, so that a considerable part of their progeny are either never hatched, or perish soon after. These birds are greatly attached to places where small birds resort, for the sake of sucking their eggs; and I have found it difficult at times to eject them, as when their nests are robbed, without much concern they commence again in the same vicinity, but adding caution to their operations in proportion to the persecution they meet with. In this way, instead of their exposing the nest in some low bush, I have with difficulty met with one at least in a tall larch, more than fifty feet from the ground. When wholly routed, the male kept up a mournful kóze kow kow for several days, appearing now sensible by experience of his own predatory practices.

Careless in providing comfort for her progeny, the American Cuckoo, like that of Europe, seems at times inclined to throw the charge of her offspring on other birds. Approaching to this habit, I have found an egg of the Cuckoo in the nest of a Catbird; yet though the habitation was usurped, the intruder probably intended to hatch her own eggs. At another time, on the I 5 th of June, I830, I saw a Robin's nest with two eggs in it indented and penetrated by the bill of a bird, and the egg of a Cuckoo deposited in the same nest. Both birds forsook the premises, so that the object of this forcible entry was not ascertained, - though the mere appropriation of the nest would seem to have been the intention of the Cuckoo. 
This Cuckoo is common in southern Ontario, but elsewhere in the Dominion it is rather rare. Nuttall has not mentioned one peculiar habit of this bird, - that of laying eggs at such long intervals that young in very different stages of maturity are frequently found in the same nest, as also young birds and partially incubated eggs. The practice of laying its eggs in the nests of other birds is seldom indulged in, - indeed, the known instances are extremely rare.

\section{BLACK-BILLED CUCKOO.}

RAIN CROW.

\section{COCCYZUS ERYTHROPHTHALMUS.}

CHAR. Above, olive brown with a slight metallic gloss, tinged with ash toward the bill; wings slightly tinged with rufous; tail similar to back, outer feathers slightly tinged with gray, narrowly tipped with white. Beneath, white, tinged on the throat with pale buff. Bill black. Length about 12 inches.

Nest. On the edge of a swampy wood, usually in a retired situation placed generally in a low bush; made of twigs, strips of bark, moss, and catkins. Similar to the nest of the Yellow-billed, but somewhat firmer and more artistic.

Eggs. 2-6 (usually 4); deep glaucous green; 1.10 $\times 0.80$.

This species, so nearly related to the preceding, is also equally common throughout the United States in summer, and extends its migrations about as far as the line of Nova Scotia or Newfoundland. This kind also exists in the island of St. Domingo and Guiana, and the birds which visit us probably retire to pass the winter in the nearest parts of tropical America. They arrive in Massachusetts later than the Yellowbilled Cuckoo, and the first brood are hatched here about the $4^{\text {th }}$ of June. In Georgia they begin to lay towards the close of April. Their food, like that of the preceding species, also consists of hairy caterpillars, beetles, and other insects, and even minute shell-fish. They also, like many birds of other orders, swallow gravel to assist digestion.

They usually retire into the woods to breed, being less familiar than the former, choosing an evergreen bush or sapling for the site of the nest, which is made of twigs pretty well 
put together, but still littie more than a concave flooring, and lined with moss occasionally, and withered catkins of the hickory. The female sits very close on the nest, admitting a near approach before flying; the young, before acquiring their feathers, are of a uniform bright grayish blue; at a little distance from the nest the male keeps up the usual rattling call of kow kow kow kow, the note increasing in loudness and quickness; sometimes the call seems like $k h$ ' $k h$ ' $k h$ ' $k h$ ' ' $k h$ ' $k a h$, the notes growing louder, and running together like those of the Yellow-winged Woodpecker. This species has also, before rain, a peculiar call, in a raucous, guttural voice, like orrattotoo or worrattotoo. It is less timorous than the Yellowbilled kind; and near the nest with young, I have observed the parent composedly sit and plume itself for a considerable time without showing any alarm at my presence. It is equally addicted to the practice of sucking the eggs of other birds. Indeed, one that I saw last summer, kept up for hours a constant watch after the eggs of a Robin sitting in an apple-tree, which, with her mate, kept up at intervals a running fight with the Cuckoo for two days in succession.

This species is considered less abundant than the Yellow-billed, but it has much the same general distribution; it goes, however, farther north, having been taken in Newfoundland and Labrador, and is common in Manitoba, where the Yellow-billed is not found. The Black-billed is rather common in New Brunswick and Nova Scotia.

\section{MANGROVE CUCKOO.}

COCCYZUS MrNor.

Char. Above, olive; head, ashy; below, buff with tawny tinge, paler towards the chi.; middle tail-feather olive, rest black, broadly tipped with white. Length 12 inches.

Nest. In a low tree or bush; loosely made of twigs.

Eggs. 3-4; pale green or bluish green; 1.25 $\times 0.90$.

The Mangrove Cuckoo is especially a West Indian bird, but is a resident also of the Florida Keys, though not common there. A few examples have been met with in Louisiana. 
NOTE. - MAYNARD'S CuCKOo (C. minor maynardi), a smaller race, with paler lower parts, is found in the Bahama islands and in Southern Florida.

Note. - Nuttall made no mention in his book of the ANI (Grotophaga ani), a South American bird that had been found in Louisiana and Florida. It was but a straggler within the borders of the United States in his day, and is still considered a rare bird here. A few years ago one was taken near Philadelphia by Mr. John Krider.

\section{FLICKER.}

\section{GOLDEN-WINGED WOODPECKER, PIGEON WOODPECKER.} HIGH-HOLDER.

\section{Colaptes auratus.}

Char. Above, olive brown barred with black; crown and sides of neck bluish gray; red crescent on nape; male with black "moustache;" rump white; beneath, pale brown with pink and yellow tints, each feather bearing a spot of black; shafts and under surface of wings and tail golden yellow. Length about $12 \mathrm{~T} / 2$ inches.

Nest. In open woodland, pasture, or orchard; a cavity excavated in dead trunk, and unlined save for the fine chips made by the boring.

Eggs. 6-io (usually 2 or 7); snow white, with surface like highly polished ivory; 1 . $10 \times 0.90$.

This beautiful and well-known bird breeds and inhabits throughout North America, from Labrador and the remotest wooded regions of the fur countries to Florida, being partially migratory only from Canada and the Northern States, proceeding to the South in October, and returning North in April. From the great numbers seen in the Southern States in winter it is evident that the major part migrate thither from the North and West to pass the inclement season, which naturally deprives them of the means of acquiring their usual sustenance. At this time also they feed much on winter berries, such as those of the sumach, smilax, and mistletoe. In the Middle States some of these birds find the means of support through the most inclement months of the winter. In New England they reappear about the beginning of April, soon after which 
they commence to pair and build; for this purpose they often make choice of the trunk of a decayed apple or forest tree, at different heights from the ground. When an accidental cavity is not conveniently found, confident in the formidable means provided them by nature, with no other aid than the bill, they have been known to make a winding burrow through a solid oak for $I_{5}$ inches in length. At this labor, for greater security and privacy, they continue till late in the evening, and may be heard dealing blows as loud and successive as if aided by the tools of the carpenter. My friend Mr. Gambel observed the present spring ( 1840 ) a burrow of this kind in Cambridge, excavated out of the living trunk of a sassafras about I 5 feet from the ground. It was about 8 inches in diameter and 18 inches deep, dug with a shelving inclination; and was continued at intervals for more than 4 weeks before it was completed. The eggs, about 6 , and pure white, are deposited merely upon the fragments of wood which line the natural or artificial cavity thus forming the nest. This cell, before the young are fledged, acquires a rank and disagreeable smell; and on inserting the hand into it, the brood unite in producing a hissing, like so many hidden snakes. They at length escape from this fetid den in which they are hatched; and climbing sometimes into the higher branches of the tree, are there fed until able to fly. At other times the young cling to their protecting cell with great pertinacity, so that the female will often call upon them for hours together (queà queàh), trying every art to induce them to quit their cradle, punishing them by fasting, till at length they are forced to come out and answer to her incessant plaint. If not disturbed, they will occasionally approach the farm-house; and I have known a pair, like the Bluebirds, repair to the same hole in a poplar-tree for several years in succession, merely cleaning out the old bed for the reception of their eggs and young. They incubate by turns, feeding each other while thus confined to the nest, and are both likewise equally solicitous in feeding and protecting their young; the food on this occasion is raised often from the throat, where it has undergone a preparatory 
process for digestion. In the month of March, in Florida and Alabama, I observed them already pairing, on which occasion many petulant quarrels daily ensued from a host of rival suitors, accompanied by their ordinary cackling and squealing. One of their usual complaisant recognitions, often delivered on a fine morning from the summit of some lofty dead limb, is 'wit a 'wit 'wit' wit 'wit 'wit 'wit weet and woit a woit, woit woit woit woit, commencing loud, and slowly rising and quickening till the tones run together into a noise almost like that of a watchman's rattle. They have also a sort of complaining call, from which they have probably derived their name of pee itt, pee iut; and at times a plaintive quéàh quéàh. Occasionally they also utter in a squealing tone, when surprised, or engaged in amusing rivalry with their fellows, we-cŏgh wee-coggh we-cŏgh we-cogh or wecŭp wecŭp wecüp.

The food of these birds varies with the season. They are at all times exceedingly fond of wood-lice, ants, and their larvæ; and as the fruits become mature, they also add to their ample fare common cherries, bird cherries, winter grapes, gumberries, the berries of the red-cedar, as well as of the sumach, smilax, and other kinds. As the maize too ripens, the Flicker pays frequent visits to the field; and the farmer, readily forgetful of its past services, only remembers its present faults, and closing its career with the gun, unthinkingly does to himself and the public an essential injury in saving a few unimportant ears of corn. In this part of New England it is known by the name of Pigeon Woodpecker, from its general bulk and appearance; and, to the disgrace of our paltry fowlers, it is in the autumn but too frequently seen exposed for sale in the markets, though its flesh is neither fat nor delicate. It is exceedingly to be regretted that ignorance and wantonness in these particulars should be so productive of cruelty, devastation, and injurious policy in regard to the animals with whose amusing and useful company Nature has so wonderfully and beneficently favored us. 


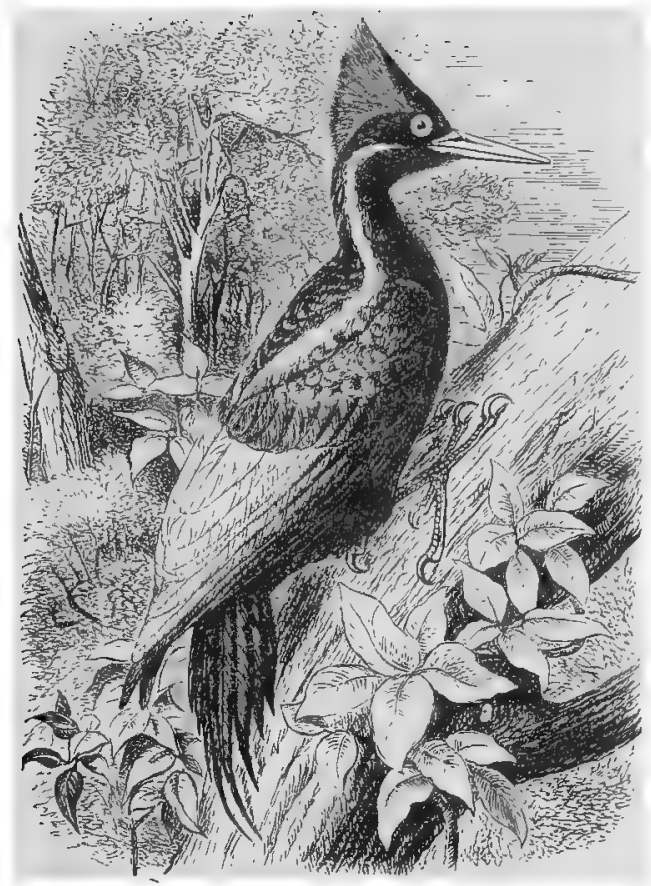

\section{IVORY-BILLED WOODPECKER.}

\section{Campephilus PRINCIPALIS.}

Char. Glossy black; white stripe from bill down sides of neck; scapulars and secondaries white; bill ivory white. Male with crest of scarlet and black ; female with crest of black. Length $2 I$ inches.

Nest. In a cypress-swamp or deep forest; a cavity excavated in a live tree.

Eggs, 4-6; white ; $1.40 \times$ I.00.

This large and splendid bird is a native of Brazil, Mexico, and the Southern States, being seldom seen to the north of Virginia, and but rarely in that State. $\mathrm{He}$ is a constant resident in the countries where he is found, breeding in the rainy season, and the pair are believed to be united for life. More vagrant, retiring, and independent than the rest of his family, he is never found in the precincts of 
cultivated tracts; the scene of his dominion is the lonely forest, amidst trees of the greatest magnitude. His reiterated trumpeting note, somewhat similar to the high tones of the clarinet (pait pait pait pait), is heard soon after day, and until a late morning hour, echoing loudly from the recesses of the dark cypress-swamps, where he dwells in domestic security without showing any impertinent or necessary desire to quit his native solitary abodes. Upon the giant trunk and mossgrown arms of this colossus of the forest, and amidst almost inaccessible and ruinous piles of mouldering logs, the high, rattling clarion and rapid strokes of this princely Woodpecker are often the only sounds which vibrate through and communicate an air of life to these dismal wilds. His stridulous, interrupted call, and loud, industrious blows may often be heard for more than half a mile, and become audible at various distances as the elevated mechanic raises or depresses his voice, or as he flags or exerts himself in his laborious employment. His retiring habits, loud notes, and singular occupation, amidst scenes so savage yet majestic, afford withal a peculiar scene of solemn grandeur on which the mind dwells for a moment with sublime contemplation, convinced that there is no scene in Nature devoid of harmonious consistence. Nor is the performance of this industrious hermit less remarkable than the peals of his sonorous voice or the loud choppings of his powerful bill. $\mathrm{He}$ is soon surrounded with striking monuments of his industry; like a real carpenter (a nick-name given him by the Spainards), he is seen surrounded with cartloads of chips and broad flakes of bark which rapidly accumulate round the roots of the tall pine and cypress where he has been a few hours employed; the work of half a dozen men felling trees for a whole morning would scarcely exceed the pile he has produced in quest of a single breakfast upon those insect larvæ which have already, perhaps, succeeded in deadening the tree preparatory to his repast. Many thousand acres of pine-trees in the Southern States have been destroyed in a single season by the insidious attacks of insects which in the dormant state are not larger than a grain of rice. It 
is in quest of these enemies of the most imposing part of the vegetable creation that the industrious and indefatigable Woodpecker exercises his peculiar labor. In the sound and healthy tree he finds nothing which serves him for food.

One of these birds, which Wilson wounded, survived with him nearly three days, but was so savage and unconquerable as to refuse all sustenance. When taken, he reiterated a loud and piteous complaint, almost exactly like the violent crying of a young child; and on being left alone in a tavern, in the course of an hour he had nearly succeeded in making his way through the side of the wooden house. He also cut the author severely in several places while engaged in drawing his portrait, and displayed, as long as he survived, the unconquerable spirit of a genuine son of the forest. From his magnanimous courage and ardent love of liberty, the head and bill are in high esteem among the amulets of the Southern Indians.

The nest of this species is usually made in the living trunk of the cypress-tree at a considerable height, both sexes alternately engaging in the labor. The excavation is said to be two or more feet in depth. The young are fledged and abroad about the middle of June. It is usually known by the name of "Large Log-cock." This species appears to live almost wholly upon insects, and chiefly those that bore into the wood, which never fail in the country he inhabits; nor is he ever known to taste of Indian corn or any sort of grain or orchard fruits, though he has a fondness for grapes and other kinds of. berries.

This species is now restricted to the Gulf States and lower Mississippi valley. 


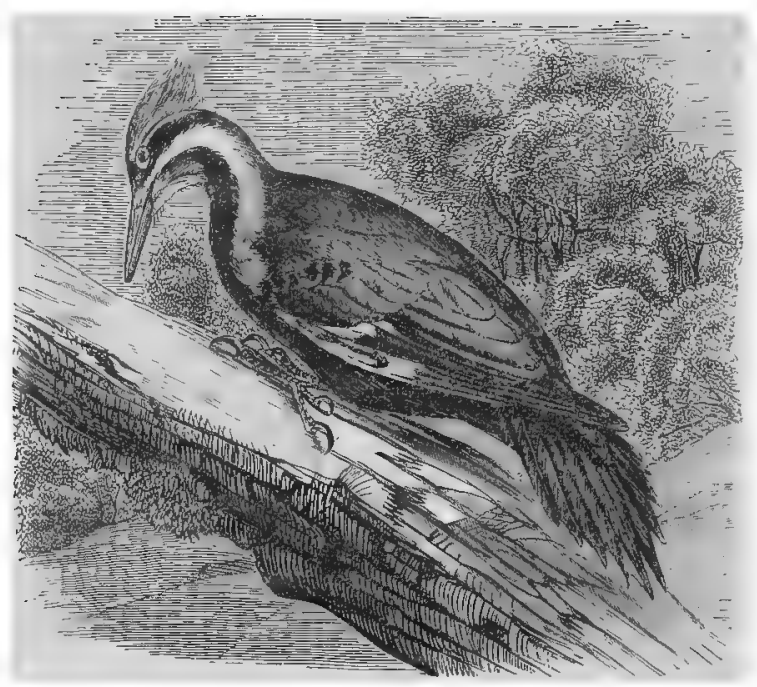

\section{PILEATED WOODPECKER.}

\section{LOG-COCK. BLACK WOODCOCK.}

\section{Ceophletus pileatus.}

Char. General color greenish black; wide stripe of white from the bill down the sides of the neck; chin, throat, and part of wings white or pale yellow. Male with scarlet crown, crest, and cheek patch. Female with crest partly black and no scarlet on cheek. Length about 18 inches.

Nest. In a deep forest or the seclusion of a swampy grove; excavated in high trees, and lined only with fine chips.

Eggs. 4-6; snow white and glossy; I.2 $5 \times 1.00$.

This large and common Woodpecker, considerably resembling the preceding species, is not unfrequent in well-timbered forests from Mexico and Oregon to the remote regions of Canada, as far as the $63 \mathrm{~d}$ degree of north latitude; and in all the intermediate region he resides, breeds, and passes most of the year, retiring in a desultory manner only into the Southern States for a few months in the most inclement season from the North and West. In Pennsylvania, however, he is seen as a resident more or less throughout the whole year; and $\mathrm{Mr}$. 
Hutchins met with him in the interior of Hudson Bay, near Albany River, in the month of January. It is, however, sufficiently singular, and shows perhaps the wild timidity of this northern chief of his tribe, that though an inhabitant towards the savage and desolate sources of the Mississippi, he is unknown at this time in all the maritime parts of the populous and long-settled State of Massachusetts. In the western parts of the State of New York he is sufficiently common in the uncleared forests, which have been the perpetual residence of his remotest ancestry. From the tall trees which cast their giant arms over all the uncleared river lands, may often be heard his loud, echoing, and incessant cackle as he flies restlessly from tree to tree, presaging the approach of rainy weather. These notes resemble ekerek rek rek rek rek rek rek uttered in a loud cadence which gradually rises and falls. The marks of his industry are also abundantly visible on the decaying trees, which he probes and chisels with great dexterity, stripping off wide flakes of loosened bark to come at the burrowing insects which chiefly compose his food. In whatever engaged, haste and wildness seem to govern all his motions, and by dodging and flying from place to place as soon as observed, he continues to escape every appearance of danger. Even in the event of a fatal wound he still struggles with unconquerable resolution to maintain his grasp on the trunk to which he trusts for safety to the very instant of death. When caught by a disabling wound, he still holds his ground against a tree, and strikes with bitterness the suspicious hand which attempts to grasp him, and, resolute for his native liberty, rarely submits to live in confinement. Without much foundation, he is charged at times with tasting maize. I have observed one occasionally making a hearty repast on holly and smilax berries.

This species is being driven back by "civilization," and is now found only in the deeper forests. Mr. William Brewster reports that a few pairs still linger in the northern part of Worcester County, Mass. 


\section{RED-HEADED WOODPECKER.}

\section{MELANERPES ERYTHROCEPHALUS.}

C HAR. Back, tail, and primaries blue black; head, neck, and breast crimson; belly, rump, and secondaries white. Length 9 to $91 / 2$ inches.

Nest. In woodland, pasture, or orchard; usually a cavity in a decayed tree.

Eggs. 4-6; glossy white; $1.00 \times 0.80$.

This common and well-known species is met with along the coast from Nova Scotia to the Gulf of Mexico, and inland in the region of the Rocky Mountains and about the sources of the Mississippi. In all the intermediate country, however extensive, it probably resides and breeds. At the approach of winter, or about the middle of October, these birds migrate from the North and West, and consequently appear very numerous in the Southern States at that season. Many of them also probably pass into the adjoining provinces of Mexico, and they reappear in Pennsylvania (according to Wilson) about the first of May. According to Audubon, they effect their migration in the night, flying high above the trees in a straggling file, at which time they are heard to emit a sharp and peculiar note, easily heard from the ground, although the birds themselves are elevated beyond the sight. Like the Log-cock, the present species is but rarely seen in the maritime parts of Massachusetts; this region is only occasionally visited by solitary stragglers, yet in the western parts of the State it is said to be as common as in the Middle States.

These birds live principally in old forests of tall trees, but are much less shy than most of the genus, frequently visiting the orchards in quest of ripe fruits, particularly cherries and juicy pears and apples, with which they likewise occasionally feed their young. They also at times eat acorns, of which they are said to lay up a store, and visit the maize-fields, being partial to the corn while in its juicy or milky state. In consequence of these dependent habits of subsistence, the Red-headed Woodpecker is a very familiar species, and even sometimes 
not only nests in the orchard which supplies him with sustenance, but ventures to rear his brood within the boundaries of the most populous towns. In the latter end of summer its reiterated tappings and cackling screams are frequently heard from the shady forests which border the rivulets in more secluded and less fertile tracts. It is also not uncommon to observe them on the fence-rails and posts near the public roads, flitting before the passenger with the familiarity of Sparrows. In the Southern States, where the mildness of the climate prevents the necessity of migration, this brilliant bird seems half domestic. The ancient live-oak, his cradle and residence, is cherished as a domicile; he creeps around its ponderous weathered arms, views the passing scene with complacence, turns every insect visit to his advantage, and for hours together placidly reconnoitres the surrounding fields. At times he leaves his lofty citadel to examine the rails of the fence or the boards of the adjoining barn; striking terror into his lurking prey by the stridulous tappings of his bill, he hearkens to their almost inaudible movements, and discovering their retreat, dislodges them from their burrows by quickly and dexterously chiselling out the decaying wood in which they are hid, and transfixing them with his sharp and barbed tongue. But his favorite and most productive resort is to the adjoining fields of dead and girdled trees, amidst whose bleaching trunks and crumbling branches he long continues to find an ample repast of depredating and boring insects. When the cravings of appetite are satisfied, our busy hunter occasionally gives way to a playful or quarrelsome disposition, and with shrill and lively vociferations not unlike those of the neighboring tree-frog, he pursues in a graceful, curving flight his companions or rivals round the bare limbs of some dead tree to which they resort for combat or frolic.

About the middle of May, in Pennsylvania, they burrow out or prepare their nests in the large limbs of trees, adding no materials to the cavity which they smooth out for the purpose. As with the Bluebird, the same tree continues to be employed for several years in succession, and probably by the same undi- 
vided pair. The eggs and young of this and many other birds occasionally fall a prey to the attacks of the common black snake. The young are easily tamed for a while, and when left at large come for some time regularly to be fed, uttering a cry to call attention. I have seen them feed on corn-meal paste, a large piece of which the bird would carry off to a distance and eat at leisure.

This species is common in Ontario and near Montreal, but is only an accidental visitor to other portions of eastern Canada. It is usually a rare bird to the eastward of the Hudson River, though in the fall of I88I it was quite common in parts of Connecticut and Massachusetts.

The habit of this bird - in common with others of the family -to store nuts and grain for winter use, briefly alluded to by Nuttall, has been confirmed frequently by recent observers. An interesting paper on this subject by O. P. Hay appeared in the "Auk" for July, I 887 .

\section{RED-BELLIED WOODPECKER.}

\section{Melanerpes CAROLINUS.}

CHAR. Above, black and white in narrow bands; tail black and white; beneath, pale buff; belly rosy red. Male, with crown and back of head scarlet, which in the female is replaced by dull ash.

Nest. Usually in a secluded forest of tall trees; a cavity cut in a dead trunk or limb.

Eggs. 4-6; white and glossy; $1.00 \times 0.75$.

This species inhabits the whole North American continent, from the interior of Canada to Florida, and even the island of Jamaica, in all of which countries it probably rears its young, migrating only partially from the colder regions. This also, like the preceding, is unknown in all the eastern parts of Massachusetts, and probably New Hampshire.

The Red-bellied Woodpecker dwells in the solitude of the forest; amidst the tall and decayed trees only he seeks his less varied fare, and leads a life of roving wildness and independence, congenial with his attachment to freedom and liberty. Sometimes, however, on the invasion of his native haunts by 
the progress of agriculture, he may be seen prowling among the dead and girdled trees which now afford him an augmented source of support; and, as a chief of the soil, he sometimes claims his native rights by collecting a small tithe from the usurping field of maize. His loud and harsh call of 'tshoze 'tshow 'tshow 'tshow, reiterated like the barking of a cur, may often be heard, through the course of the day, to break the silence of the wilderness in which his congenial tribe are almost the only residents. On a fine spring morning I have observed his desultory ascent up some dead and lofty pine, tapping at intervals, and dodging from side to side, as he ascended in a spiral line ; at length, having gained the towering summit, while basking in the mild sunbeams, he surveys the extensive landscape, and almost with the same reverberating sound as his blows, at intervals he utters a loud and solitary 'cur'rh in a tone as solemn as the tolling of the Campanero. He thus hearkens, as it were, to the shrill echoes of his own voice, and for an hour at a time seems alone employed in contemplating, in cherished solitude and security, the beauties and blessings of the rising day.

The nest, early in April, is usually made in some lofty branch; and in this labor both the sexes unite to dig out a circular cavity for the purpose, sometimes out of the solid wood, but more commonly into a hollow limb. The young appear towards the close of May or early in June, climbing out upon the higher branches of the tree, where they are fed and reared until able to fly, though in the mean time from their exposure they often fall a prey to prowling Hawks. These birds usually raise but one brood in the season, and may be considered, like the rest of their insect-devouring fraternity, as useful scavengers for the protection of the forest; their attacks, as might be reasonably expected, being always confined to decaying trees, which alone afford the prey for which they probe.

This bird is common in parts of Ontario, but has not been taken elsewhere in Canada. It is common in Ohio, and ranges as far to the southward as Florida, but is very rare in New England.

VOL. 1. -29 


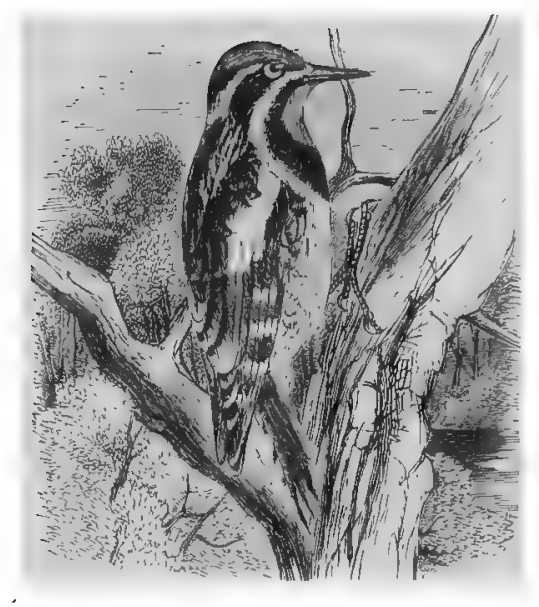

\section{YELLOW-BELLIED SAPSUCKER.}

\section{SPHYRAPICUS VARIUS.}

CHAR. Above, black and white, back tinged with yellow; crown and chin scarlet, bordered by black; cheeks black, bordered by white or pale yellow; breast black; belly pale yellow. In females the scarlet on chin is replaced by white. Length $8 \mathrm{z} / 2$ inches.

Nest. In woodland; a cavity in a dead trunk of large tree; sometimes excavated in a live tree.

Eggs. 4-7; white; $0.85 \times 0.60$.

This species, according to the season, extends over the whole American continent, from the 53 d degree to the tropics, where it is seen in Cayenne. With us it is most common in summer in the Northern and Middle States, and as far north as Nova Scotia. At this season it is seldom seen beyond the precincts of the forest, in which it selects the most solitary recesses, leaving its favorite haunts only at the approach of winter, and seeking, from necessity or caprice, at this roving season the boundaries of the orchard. The habits of this bird are but little different from those of the Hairy and Downy Woodpeckers, with which it is often associated in their foraging excursions. The nest, as usual, is made in the body of some decayed orchard or forest tree, the circular entrance to 
which is left only just sufficient for the passage of the parties. The depth of the cavity is about $I_{5}$ inches, and the eggs, 4 or upwards, are white. The principal food of these birds is insects, for they sometimes bore the trunks of the orchard trees.

The "sapsucking" habit of this species, denied by some of our most eminent naturalists, has been established by Mr. Frank Bolles, who published an interesting account of his observations in "The Auk" for July, I 89 I.

For several days Mr. Bolles almost continuously watched a number of these birds while they operated on trees in the vicinity of his summer home at Chicarua, N. H. The birds drilled holes in maple, oak, birch, and ash trees, and drank the sap as it dripped from these holes. When one set of holes became "dry," others were drilled, eight to sixteen on each tree, the new holes being made higher up than the old. Some of the birds spent about nine tenths of the time in drinking the sap. Mr. Bolles placed under the trees cups made of birch bark and filled with maple syrup, which the birds drank freely. Later brandy was added, with amusing consequences, the mixture finally acting as an emetic. He moreover states that the sap was not used as a trap for insects, as some writers have supposed; and while the birds caught insects occasionally, these did not appear to form a large part of their diet. An examination of the stomachs of a few birds revealed but little insect remains, and that little was composed chiefly of ants.

\section{HAIRY WOODPECKER.}

\section{Dryobates villosus.}

Char. Above, black and white, the back witl long, slender, loose hair-like feathers; beneath, white; outer tail-feathers white. Male with scarlet band at back of head, which in the female is black. In immature birds the crown is more or less tinged with red, or, sometimes with yellow. Length $8 \frac{1}{2}$ to 9 inches.

Nest. In open woodland, pasture, or orchard; a cavity in a dead trunk, without lining.

Eggs. 4-5; white and glossy; $1.00 \times 0.70$.

This common and almost familiar species is a resident in most parts of America, from Hudson Bay to Florida, fre- 
quently approaching the cottage or the skirts of the town as well as the forest. It is likewise much attached to orchards, an active borer of their trunks, and an eager hunter after insects and larvæ in all kinds of decayed wood, even to stumps and the rails of the fences. In autumn it also feeds on berries and other fruits. In the month of May, accompanied by his mate, the male seeks out the seclusion of the woods, and taking possession of a hollow branch, or cutting out a cavity anew, he forms his nest in a deep and secure cavern, though sometimes a mere stake of the fence answers the purpose. In the Southern States these birds have usually two broods in the season, and raise them both in the same nest, which is not infrequently at no great distance from habitations. Their call consists in a shrill and rattling whistle, heard to a considerable distance. They also give out a single querulous note of recognition while perambulating the trunks for food.

The habitat of true villosus is now considered as restricted to the middle portion of the Eastern States. At the North it is represented by $D$. villosus leucomelas, a larger variety (length Io to II inches), and at the South by $D$. villosus audubonii, which measures but 8 to $8 \frac{1}{2}$ inches in length.

\section{DOWNY WOODPECKER.}

\section{DRYOBATES PUBESCENS.}

Char. Similar to $D$. villosus, but smaller. Above, black and white, the back with long, slender, loose hair-like ("downy") feathers; beneath, white; outer tail-feathers barred. Male with scarlet band at back of head, which in the female is black. In immature birds the crown is more or less tinged with red, or, sometimes, with yellow. Length $61 / 2$ to 7 inches.

Nest. In open woodland, pasture, or orchard; a cavity in a dead trunk, without lining.

Egos. 4-6; white and glossy; $0.80 \times 0.60$.

This species, the smallest of American Woodpeckers, agrees almost exactly with the $P$. villosus in its colors and markings. It is likewise resident throughout the same countries. About 
the middle of May also, the pair begin to look out a suitable deposit for their eggs and young. The entrance is in the form of a perfect circle, and left only just large enough for an individual to pass in and out. Both sexes labor for about a week at this task with indefatigable diligence, carrying on the burrow in some orchard tree, in two different directions, to the depth of 16 to 20 inches down; and to prevent suspicion the chips are carried out and strewn at a distance. The male occasionally feeds his mate while sitting; and about the close of June the young are observed abroad, climbing up the tree with considerable address. Sometimes the crafty House Wren interferes, and, driving the industrious tenants from their hole, usurps possession. These birds have a shrill cackle and a reiterated call, which they frequently utter while engaged in quest of their prey. In the autumn they feed on various kinds of berries as well as insects. No species can exceed the present in industry and perseverance. While thus regularly probing the bark of the tree for insects, it continues so much engaged as to disregard the approaches of the observer, though immediately under the tree. These perforations, made by our Sapsuckers, - as the present and Hairy species are sometimes called, - are carried round the trunks and branches of the orchard trees in regular circles, so near to each other that, according to Wilson, eight or ten of them may be covered by a dollar. The object of this curious piece of industry is not satisfactorily ascertained; but whether it be done to taste the sap of the tree, or to dislodge vermin, it is certain that the plant escapes uninjured, and thrives as well or better than those which are unperforated.

This diminutive and very industrious species is a constant inhabitant of the fur countries up to the $5^{8 \text { th }}$ parallel, seeking its food principally on the maple, elm, and ash, and north of latitude 54 degrees, where the range of these trees terminates, on the aspen and birch. The circles of round holes which it makes with so much regularity round the trunks of living trees are no doubt made for the purpose of getting at the sweet sap which they contain. In the month of February, 1830, I 
observed these borers busy tapping the small live trunks of several wax-myrtles (Myrica cerifera); and these perforations were carried down into the alburnum, or sap-wood, but no farther : no insects could be expected, of course, in such situations, and at this season very few could be obtained anywhere. On examining the oozing sap, I found it to be exceedingly saccharine, but in some instances astringent or nearly tasteless. To a bird like the present, which relishes and devours also berries, I make no doubt but that this native nectar is sought after as agreeable and nutritious food, in the same manner as the Baltimore Bird collects the saccharine secretion of the fruit blossoms; and in fact I have observed the Woodpecker engaged in the act of sipping this sweet fluid, which so readily supplies it on all occasions with a temporary substitute for more substantial fare. Sometimes, however, on discovering insects in a tree, it forgets its taste for the sap, and in quest of its prey occasionally digs deep holes into the trees large enough to admit its whole body.

The Downy Woodpecker is found throughout the eastern and northern portions of North America, and like its congener, the Hairy, is a resident, rather than a migratory species, breeding usually wherever it is found. There is no such difference in the two birds as is represented by the names "hairy" and "downy;" the long feathers of the back from which the names are derived are exactly similar. The differentiation lies in the size of the birds and in some markings on the tail-feathers.

\section{THE RED-COCKADED WOODPECKER.}

\section{DRYOBATES BOREALIS.}

CHAR. Above, black and white, barred transversely; crown, black; sides of head with white patch, bordered, above, by red stripe ; beneath, white, sides streaked with black. Length $7 \frac{1}{2}$ to $81 / 2$ inches.

Nest. In pine woods; an excavation in a decayed trunk or living tree.

Eggs. 4-6; white, with but little gloss; $0.95 \times 0.70$.

This species, remarkable for the red stripe on the side of its head, was discovered by Wilson in the pine woods of 
North Carolina, whence it occurs to the coast of the Mexican Gulf, and as far to the north and west as New Jersey and Tennessee. It is a very active and noisy species, gliding with alertness along the trunks and branches of trees, principally those of oak and pine. At almost every move it utters a short, shrill, and clear note, audible at a considerable distance. In the breeding season its call, still more lively and petulant, is reiterated through the pine forests, where it now chiefly dwells. These birds are frequently seen by pairs in the company of the smaller Woodpeckers and Nuthatches in the winter season, and they now feed by choice principally upon ants and small coleoptera.

In Florida they are already mated in the month of January, and prepare their burrows in the following month. The nest is frequently in a decayed trunk 20 to 30 feet from the ground. In the winter season, and in cold and wet weather, this bird is in the habit of roosting in its old nests or in the holes of decayed trees, and frequently retreats to such places when wounded or pursued.

The habitat of this species as at present determined is the Southeastern States, including North Carolina and Tennessee, and the bird also occurs sparingly in New Jersey.

\section{ARCTIC THREE-TOED WOODPECKER.}

\section{BLACK-BACKED WOODPECKER.}

\section{PICOIDES ARCTICUS.}

Char. Only three toes. Above, black; white stripe on side of head; outer tail-feathers white; beneath, white barred with black. Adult male with square patch of yellow on the crown. Length $9^{1 / 2}$ to ro inches.

Nest. In a deep forest, an excavation in a dead tree.

Eggs, 4-6; white and glossy; $0.95 \times 0.75$.

This species is an inhabitant of the northern regions from Maine to the fur countries, dwelling among deep forests in mountainous regions. Its voice and habits are indeed precisely similar to those of the Spotted Woodpeckers, to which it 
is closely allied. Its food consists of insects, their eggs and larvæ, to which it sometimes adds, according to the season, seeds and berries. Audubon had the good fortune to meet with it in the pine forests of the Pokono Mountains in Pennsylvania. It is, however, sufficiently common in the dreary wilds around Hudson Bay and Severn River. It is remarkable that a third species, so nearly allied to the present as to have been confounded with it merely as a variety, is found to inhabit the woods of Guiana. In this (the Picus undulatus of Vieillot) the crown, however, is red instead of yellow; the tarsi are also naked, and the black of the back undulated with white.

This species occurs sparingly in winter in northern New England and southern Canada, and representatives have been taken in Massachusetts and Connecticut. Occasionally one is met in summer in northern Maine and New Brunswick.

\section{AMERICAN THREE-TOED WOODPECKER.}

BANDED-BACKED WOODPECKER.

\section{PicoIdes americanus.}

ChAR. Only three toes. Above, black, thickly spotted with white about the head and neck; back barred with white; beneath, white; sides barred with black. Adult male with yellow patch on the crown. Length about 9 inches.

Nest. In a deep forest; an excavation in a dead tree.

Eggs. 4- ?; cream white; $0.90 \times 0.70$.

According to Richardson, this bird exists as a permanent resident in all the spruce-forests between Lake Superior and the Arctic Sea, and is the most common Woodpecker north of Great Slave Lake. It resembles $P$. villosus in its habits, seeking its food, however, principally on decaying trees of the pine tribe, in which it frequently burrows holes large enough to bury itself.

This is only a rare winter visitor as far south as New Brunswick, though it has been taken in Massachusetts, and Dr. Merriam has found a nest in the Adirondacks. 


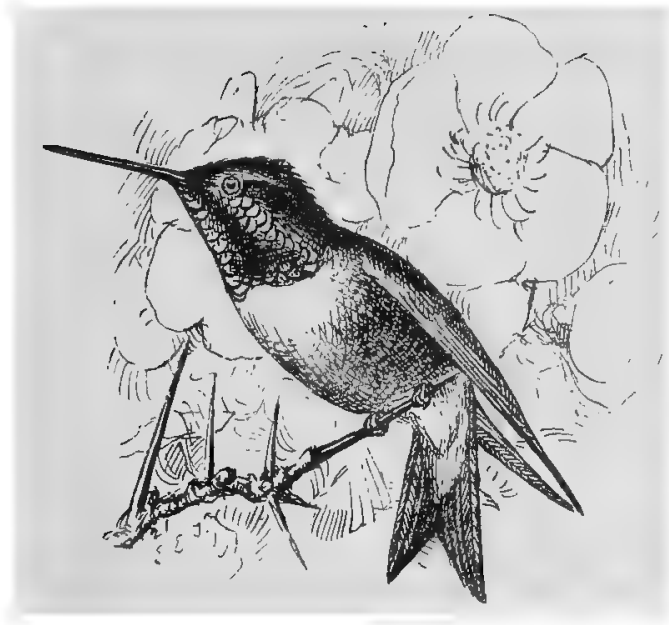

RUBY-THROATED HUMMING BIRD.

Trochilus COLUBRIS.

CHAR. Above, metallic green; wings and tail brownish violet or bronzy; chin velvety black; throat rich ruby, reflecting various hues from brownish black to bright crimson; belly whitish. Female and young without red on the throat, which is dull gray; tail-feathers barred with black and tipped with white. Length 3 to $3 \frac{1}{4}$ inches.

Nest. In an orchard or open woodland; placed on a horizontal branch or in a crotch; made of plant down firmly felted and covered exteriorly with lichens.

Eggs. 2-?; white, with rosy tint when fresh; $0.50 \times 0.30$.

This wonderfully diminutive and brilliant bird is the only one of an American genus of more than a hundred species, which ventures beyond the limit of tropical climates. Its approaches towards the north are regulated by the advances of the season. Fed on the honeyed sweets of flowers, it is an exclusive attendant on the varied bounties of Flora. By the roth to the 2oth of March, it is already seen in the mild forests of Louisiana and the warmer maritime districts of Georgia, where the embowering and fragrant Gelsemium, the twin-leaved Bignonia, with a host of daily expanding flowers, invite our little sylvan guest to the retreats it had reluctantly 
forsaken. Desultory in its movements, roving only through the region of blooming sweets, its visits to the Northern States are delayed till the month of May. Still later, as if determined that no flower shall "blush unseen, or waste its sweetness on the desert air," our little sylph, on wings as rapid as the wind, at once launches without hesitation into the flowery wilderness of the north.

The first cares of the little busy pair are now bestowed on their expected progeny. This instinct alone propelled them from their hibernal retreat within the tropics; strangers amidst their numerous and brilliant tribe, they seek only a transient asylum in the milder regions of their race. With the earliest dawn of the northern spring, in pairs, as it were with the celerity of thought, they dart at intervals through the dividing space, till they again arrive in the genial and more happy regions of their birth. The enraptured male is now assiduous in attention to his mate; forgetful of selfish wants, he feeds his companion with nectared sweets, and jealous of danger and interruption to the sole companion of his delights, he often almost seeks a quarrel with the giant birds which surround him : he attacks even the Kingbird, and drives the gliding Martin to the retreat of his box. The puny nest is now prepared in the long-accustomed orchard or neighboring forest. It is concealed by an artful imitation of the mossy branch to which it is firmly attached and incorporated. Bluish-gray lichens, agglutinated by saliva and matched with surrounding objects, instinctively form the deceiving external coat; portions of the cunning architecture, for further security, are even tied down to the supporting station. Within are laid copious quantities of the pappus or other down of plants; the inner layer of this exquisite bed is finished with the shortwood of the budding Platanus, the mullein, or the soft clothing of unfolding fernstalks. Incubation, so tedious to the volatile pair, is completed in the short space of ten days, and in the warmer States a second brood is raised. When the nest is approached, the parents dart around the intruder, within a few inches of his face; and the female, if the young are out, often resumes her 
seat, though no more than three or four feet from the observer. In a single week the young are on the wing, and in this situation still continue to be fed with their nursing sweets by the assiduous parents.

Creatures of such delicacy and uncommon circumstances, the wondrous sports of Nature, everything appcars provided for the security of their existence; the brood are introduced to life in the warmest season of the year : variation of temperature beyond a certain medium would prove destructive to these exquisite forms. The ardent heats of America have alone afforded them support; no region so cool as the United States produces a set of feathered beings so delicate and tender ; and, consequently, any sudden extremes, by producing chill and famine, are fatal to our Humming Birds. In the remarkably wet summer of I83 I very few of the young were raised in New England. In other seasons they comparatively swarm, and the numerous and almost gregarious young are then seen, till the close of September, eagerly engaged in sipping the nectar from various showy and tubular flowers, particularly those of the trumpet Bignonia and wild balsam, with many other conspicuous productions of the fields and gardens. Sometimes they may also be seen collecting dimunitive insects, or juices from the tender shoots of the pine-tree. While thus engaged in strife and employment, the scene is peculiarly amusing. Approaching a flower, and vibrating on the wing before it, with the rapidity of lightning the long, cleft, and tubular tongue is exerted to pump out the sweets, while the buzzing or humming of the wings reminds us of the approach of some larger sphinx or droning bee. No other sound or song is uttered, except occasionally a slender chirp while flitting from a flower, until some rival bird too nearly approaches the same plant; a quick, faint, and petulant squeak is then uttered, as the little glowing antagonists glide up in swift and angry gyrations into the air. The action at the same time is so sudden, and the flight so rapid, that the whole are only traced for an instant, like a gray line in the air. Sometimes, without any apparent provocation, the little pugnacious vixen will, for 
mere amusement, pursue larger birds, such as the Yellow Bird and Sparrows. To man they show but little either of fear or aversion, often quietly feeding on their favorite flowers when so nearly approached as to be caught. They likewise frequently enter the green houses and windows of dwellings where flowers are kept in sight. After feeding for a time, the individual settles on some small and often naked bough or slender twig, and dresses its feathers with great composure, particularly preening and clearing the plumes of the wing.

The old and young are soon reconciled to confinement. In an hour after the loss of liberty the cheerful little captive will often come and suck diluted honey, or sugar and water, from the flowers held out to it; and in a few hours more it becomes tame enough to sip its favorite beverage from a saucer, in the interval flying backwards and forwards in the room for mere exercise, and then resting on some neighboring elevated object. In dark or rainy weather it seems to pass the time chiefly dozing on the perch. It is also soon so familiar as to come to the hand that feeds it. In cold nights, or at the approach of frost, the pulsation of this little dweller in the sunbeam becomes nearly as low as in the torpid state of the dormouse; but on applying warmth, the almost stagnant circulation revives, and slowly increases to the usual state.

Near the Atlantic this frail creature nests regularly as far north as the Laurentian hills of Quebec. It is an abundant summer resident of the Maritime Provinces, but occurs in southern Ontario as a migrant only.

The fact that insects form a staple diet of these diminutive birds has been satisfactorily proved, though formerly they were supposed to feed entirely on honey. Honey doubtless forms a part of their food, and they also drink freely of the sweet sap which the Woodpeckers draw from the maple and birch.

Another mistake regarding the Humming Birds, - that they never alight while feeding, - has been rectified by several trustworthy observers. The birds have been seen to alight on the leaves of the trumpet-flower while gathering honey, and also to rest on the tapped trees while they leisurely drank of the fowing sap.

The young birds are fed by regurgitation. 


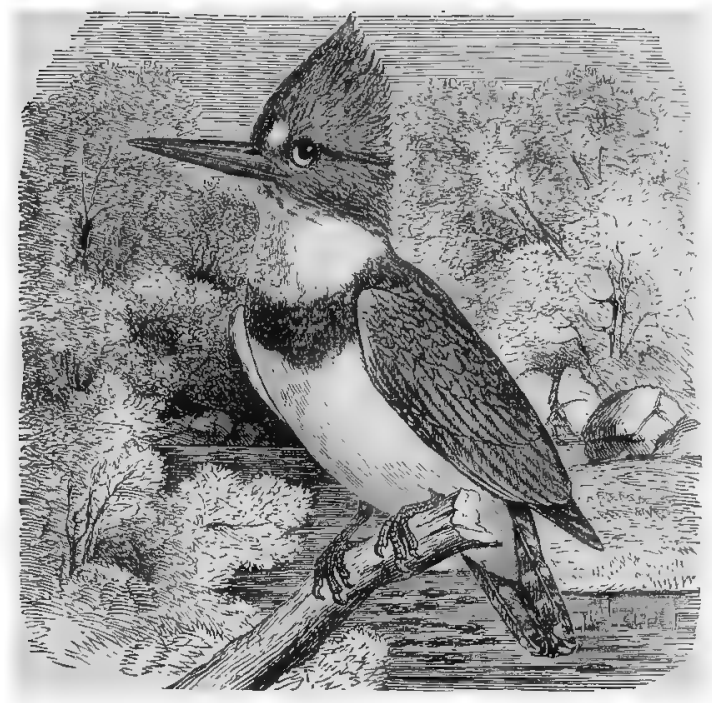

BELTED KINGFISHER.

\section{Ceryle alcyon.}

Char. Above, slaty blue; head with long crest; beneath, white. Male with blue band across breast. Female and young with breast-band and sides of belly pale chestnut. Length $\mathbf{I} 2$ to $\mathrm{I} 3$ inches.

Nest. An excavation in a sandbank, - usually by the side of a stream; lined with grass and feathers.

Eggs. 6-8; white and glossy; I. $35 \times$ 1.05.

This wild and grotesque-looking feathered angler is a wellknown inhabitant of the borders of fresh waters from the remote fur countries in the 67 th parallel to the tropics. Its delight is to dwell amidst the most sequestered scenes of uncultivated nature, by the borders of running rivulets, near the roar of the waterfall, or amidst the mountain streamlets which abound with the small fish and insects that constitute its accustomed fare. Mill-dams and the shelving and friable banks of watercourses, suited for the sylvan retreat of its brood, have also peculiar and necessary attractions for our retiring Kingfisher. By the broken, bushy, or rocky banks of 
its solitary and aquatic retreat, this bird may often be seen perched on some dead and projecting branch, scrutinizing the waters for its expected prey. If unsuccessful, it quickly courses the meanders of the streams or borders of ponds just above their surface, and occasionally hovers for an instant, with rapidly moving wings, over the spot where it perceives the gliding quarry; in the next instant, descending with a quick spiral sweep, a fish is seized from the timid fry, with which it returns to its post and swallows in an instant. When startled from the perch, on which it spends many vacant hours digesting its prey, it utters commonly a loud, harsh, and grating cry, very similar to the interrupted creakings of a watchman's rattle, and almost, as it were, the vocal counterpart to the watery tumult amidst which it usually resides.

The nest-a work of much labor - is now burrowed in some dry and sandy or more tenacious bank of earth, situated beyond the reach of inundation. At this task both the parties join with bill and claws, until they have horizontally perforated the bank to the depth of 5 or 6 feet. With necessary precaution, the entrance is only left sufficient for the access of a single bird. The extremity, however, is rounded like an oven, so as to allow the individuals and their brood a sufficiency of room. This important labor is indeed prospective, as the same hole is employed for a nest and roost for many succeeding years. Here the eggs are deposited. Incubation, in which both parents engage, continues for sixteen days; and they exhibit great solicitude for the safety of their brood. The mother, simulating lameness, sometimes drops on the water, fluttering as if wounded, and unable to rise from the stream. The male also, perched on the nearest bough, or edge of the projecting bank, jerks his tail, elevates his crest, and passing to and fro before the intruder, raises his angry and vehement rattle of complaint (Audubon). At the commencement of winter, the frost obliges our humble Fisher to seek more open streams, and even the vicinity of the sea; but it is seen to return to Pennsylvania by the commencement of April. 


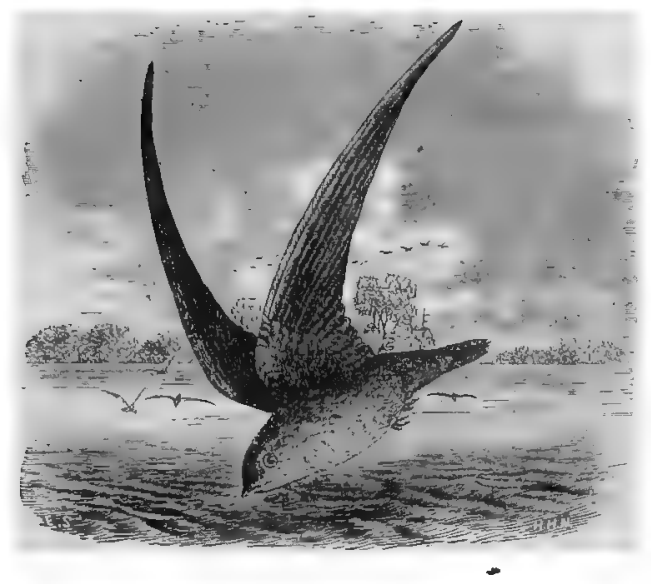

CHIM N E SWIFT.

CHIMNEY SWALLOW.

Cheetura pelagica.

CHAR. General color sooty brown, paler on the throat and breast, tinged with green above. Length about $5 / 4$ inches.

Nest. Usually in a chimney, sometimes in a hollow tree or a barn; made of twigs cemented with saliva.

Eggs. 4-5; white; $0.70 \times 0.50$.

This singular bird, after passing the winter in tropical America, arrives in the Middle and Northern States late in April or early in May. Its migrations extend at least to the sources of the Mississippi, where it was observed by Mr. Say. More social than the foreign species, which frequents rocks and ruins, our Swift takes advantage of unoccupied and lofty chimneys, the original roost and nesting situation being tall, gigantic hollow trees such as the elm and buttonwood (Platanus). The nest is formed of slender twigs neatly interlaced, somewhat like a basket, and connected sufficiently together by a copious quantity of adhesive gum or mucilage secreted by the stomach of the curious architect. This rude cradle of the young is small and shallow, and attached at the sides to the wall of some chimney or the inner surface of a hollow 
tree; it is wholly destitute of lining. 'They have commonly two broods in the season. So assiduous are the parents that they feed the young through the greater part of the night; their habits, however, are nearly nocturnal, as they fly abroad most at and before sunrise, and in the twilight of evening. The noise which they. make while passing up and down the chimney resembles almost the rumbling of distant thunder. When the nests get loosened by rains so as to fall down, the young, though blind, find means to escape, by creeping up and clinging to the sides of the chimney walls; in this situation they continue to be fed for a week or more. Soon tired of their hard cradle, they generally leave it long before they are capable of flying.

On their first arwival, and for a considerable time after, the males, particularly, associate to roost in a general resort. 'This situation, in the remote and unsettled parts of the country, is usually a large hollow tree, open at top. These well-known Swallow trees are ignorantly supposed to be the winter quarters of the species, where, in heaps, they doze away the cold season in a state of torpidity; but no proof of the fact is ever adduced. The length of time such trees have been resorted to by particular flocks may be conceived, perhaps, by the account of a hollow tree of this kind described by the Rev. Dr. Harris in his Journal. The Platanus alluded to, grew in the upper part of Waterford, in Ohio, two miles from the Muskingum, and its hollow trunk, now fallen, of the diameter of $5 \mathrm{~T} / 2$ feet, and for nearly i 5 feet upwards, contained an entire mass of decayed Swallow feathers, mixed with brownish dust and the exuviæ of insects. In inland towns these birds have been known to make their general roost in the chimney of the court-house. Before descending, they fly in large flocks, making many ample and circuitous sweeps in the air; and as the point of the vortex falls, individuals drop into the chimney by degrees, until the whole have descended, which generally takes place in the dusk of the evening. They all, however, disappear about the first week in August. Like the rest of the tribe, the Chimney Swift flies very quick, and with but slight 
vibrations of its wings, appearing as it were to swim in the air in widening circles, shooting backwards and forwards through the ambient space at great elevations; and yet scarcely moving its wings. Now and then it is heard to utter, in a hurried manner, a sound like tsip tstp tsip tsee tsee. It is never seen to alight but in hollow trees or chimneys, and appears always most gay and active in wet and gloomy weather.

Near the Atlantic border this species is found north to $50^{\circ}$, but in the West it ranges still farther northward.

\section{H UCK - W I L L'S-W I D O W.}

\section{ANTROSTOMUS CAROLINENSIS.}

CHAR. Gape extremely wide, the rictal bristles with lateral filaments. General color reddish brown mottled with black, white, and tawny; throat with collar of pale tawny, terminal third of outer tail-feathers white or buffy; under parts tawny white. Length II to I 2 inches.

Nest. In open woods or dense thicket. No attempt is made at building a receptacle for the eggs, which are laid on the bare ground or upon fallen leaves.

Eggs. 2; white or buffish, marked with brown and lavender; 1.40 $\times$ r.o.

The Carolina Goatsucker is seldom seen to the north of Virginia, though in the interior its migrations extend up the shores of the Mississippi to the 38 th degree. After wintering in some part of the tropical continent of America, it arrives in Georgia and Louisiana about the middle of March, and in Virginia early in April. Like the following species, it commences its singular serenade of 'chuck-'will's-widow in the evening soon after sunset, and continues it with short interruptions for several hours. Towards morning the note is also renewed until the opening dawn. In the day, like some wandering spirit, it retires to secrecy and silence, as if the whole had only been a disturbed dream. In a still evening this singular call may be heard for half a mile, its tones being slower, louder, and more full than those of the Whip-poor-will. The species is particularly numerous in the vast forests of the Mississippi, VOL. I. $-3^{\circ}$ 
where throughout the evening its echoing notes are heard in the solitary glens and from the surrounding and silent hills, becoming almost incessant during the shining of the moon; and at the boding sound of its elfin voice, when familiar and strongly reiterated, the thoughtful, superstitious savage becomes sad and pensive. Its flight is low, and it skims only a few feet above the surface of the ground, frequently settling on logs and fences, whence it often sweeps around in pursuit of flying moths and insects, which constitute its food. Sometimes these birds are seen sailing near the ground, and occasionally descend to pick up a beetle, or flutter lightly around the trunk of a tree in quest of some insect crawling upon the bark. In rainy and gloomy weather they remain silent in the hollow log which affords them and the bats a common roost and refuge by day. When discovered in this critical situation, and without the means of escape, they ruffle up their feathers, spread open their enormous mouths, and utter a murmur almost like the hissing of a snake, thus endeavoring, apparently, to intimidate their enemy when cut off from the means of escape.

This species also lays its eggs, two in number, merely on the ground, and usually in the woods; if they be handled, or even the young, the parents, suspicious of danger, remove them to some other place. As early as the middle of August, according to Audubon, these birds retire from the United States; though some winter in the central parts of East Florida.

The general habitat of this species is the South Atlantic and Gulf States and the lower Mississippi valley. The bird ranges to North Carolina, and Mr. Ridgeway reports it not uncommon in southern Illinois. 


\section{W H I P-P O R - W I L L.}

\section{ANTROSTOMUS VOCIFERUS.}

Char. Gape extremely wide; rictal bristles without lateral filaments. General color dull gray brown, mottled with black, white, and tawny; throat with collar of white or tawny; outer tail-feathers partly white; under parts gray mottled with black. Length $9^{1 / 2}$ to ro inches.

Nest. In dense woods or shady dells; eggs laid on the ground or amid dry leaves.

Eggs. 2; white or buffy marked brown and lavender; I.I2 $\times 0.85$.

This remarkable and well-known nocturnal bird arrives in the Southern States in March, and in the Middle States about the close of April or the beginning of May, and proceeds in its vernal migrations along the Atlantic States to the centre of Massachusetts, being seldom seen beyond the latitude of $43^{\circ}$; and yet in the interior of the continent, according to Vieillot, it continues as far as Hudson Bay, and was heard, as usual, by Mr. Say at Pembino, in the high latitude of $49^{\circ}$. In all this vast intermediate space, as far south as Natchez on the Mississippi, and the interior of Arkansas, these birds familiarly breed and take up their temporary residence. Some also pass the winter in the interior of East Florida, according to Audubon. In the eastern part of Massachusetts, however, they are uncommon, and always affect sheltered, wild, and hilly situations, for which they have in general a preference. About the same time that the sweetly echoing voice of the Cuckoo is first heard in the north of Europe, issuing from the leafy groves as the sure harbinger of the flowery month of May, arrives amongst us, in the shades of night, the mysterious Whip-poor-zeill. The well-known saddening sound is first only heard in the distant forest, re-echoing from the lonely glen or rocky cliff; at length the oft-told solitary tale is uttered from the fence of the adjoining field or garden, and sometimes the slumbering inmates of the cottage are serenaded from the low roof or from some distant shed. Superstition, gathering terror from every extraordinary feature of nature, has not suffered this harmless nocturnal babbler to escape suspicion, and his 
familiar approaches are sometimes dreaded as an omen of misfortune.

In the lower part of the State of Delaware, I have found these birds troublesomely abundant in the breeding season, so that the reiterated echoes of 'whip-'whip-pǒor-will, 'whip-pĕriwill, issuing from several birds at the same time, occasioned such a confused vociferation as at first to banish sleep. This call, except in moonlight nights, is continued usually till midnight, when they cease until again aroused, for a while, at the commencement of twilight. The first and last syllables of this brief ditty receive the strongest emphasis, and now and then a sort of guttural cluck is heard between the repetitions; but the whole phrase is uttered in little more than a second of time.

Although our Whip-poor-will seems to speak out in such plain English, to the ears of the aboriginal Delaware its call was wecoális, though this was probably some favorite phrase or interpretation, which served it for a name. The Whip-poorwill, when engaged in these nocturnal rambles, is seen to fly within a few feet of the surface in quest of moths and other insects, frequently, where abundant, alighting around the house. During the day the birds retire into the darkest woods, usually on high ground, where they pass the time in silence and repose, the weakness of their sight by day compelling them to avoid the glare of the light.

The female commences laying about the second week in May in the Middle States, considerably later in Massachusetts; she is at no pains to form a nest, though she selects for her deposit some unfrequented part of the forest near a pile of brush, a heap of leaves, or the low shelving of a hollow rock, and always in a dry situation; here she lays two eggs, without any appearance of an artificial bed. This deficiency of nest is amply made up by the provision of nature, for, like Partridges, the young are soon able to run about after their parents; and until the growth of their feathers they seem such shapeless lumps of clay-colored down that it becomes nearly impossible to distinguish them from the ground on which they repose. 
Were a nest present in the exposed places where we find the young, none would escape detection. The mother also, faithful to her charge, deceives the passenger by prostrating herself along the ground with beating wings, as if in her dying agony. The activity of the young and old in walking, and the absence of a nest, widely distinguishes these birds from the Swallows, with which they are associated. A young fledged bird of this species, presented to me, ran about with great celerity, but refused to eat, and kept continually calling out at short intervals pé-ügh in a low, mournful note.

After the period of incubation, or about the middle of June, the vociferations of the males cease, or are but rarely given. Towards the close of summer, previously to their departure, they are again occasionally heard, but their note is now languid and seldom uttered; and early in September they leave us for the more genial climate of tropical America, being there found giving their usual lively cry in the wilds of Cayenne and Demerara. They enter the United States early in March, but are some weeks probably in attaining their utmost northern limit.

Their food appears to be large moths, beetles, grasshoppers, ants, and such insects as frequent the bark of decaying timber. Sometimes, in the dusk, they will skim within a few feet of a person, making a low chatter as they pass. They also, in common with other species, flutter occasionally around the domestic cattle to catch any insects which approach or rest upon them; and hence the mistaken notion of their sucking goats, while they only cleared them of molesting vermin.

The Whip-poor-will is a common summer resident throughout New England, and is not uncommon in the Maritime Provinces. It is common also in Ontario, and Dr. Robert Bell reports finding it in the southern parts of the Hudson Bay region. 


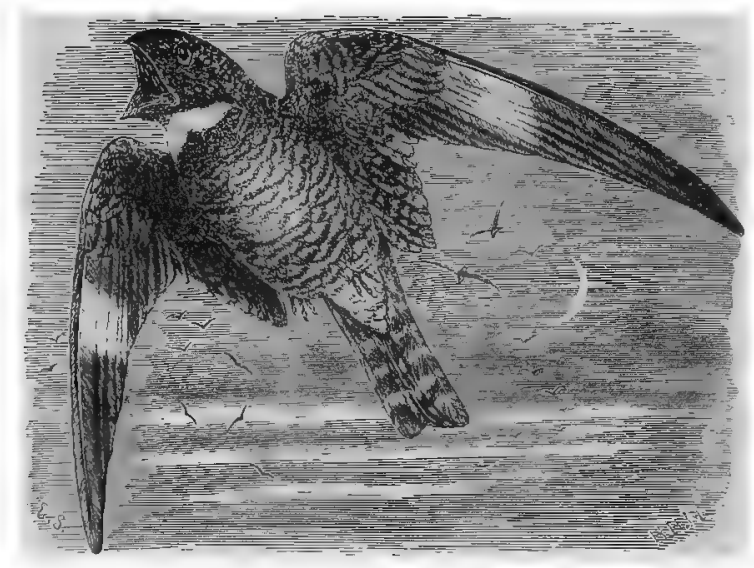

NIGHTHAWK.

GOATSUCKER. BULL BAT.

Chordeiles virginlanus.

Char. Gape wide; bill extremely small; no rictal bristles. Above, dull black mottled with brown and gray; wings brown, a patch of white on five outer primaries; tail dusky, with bars of gray and a patch of white near the extremity; lower parts reddish white with bars of brown; throat with patch of white. Length about $9 \frac{1}{2}$ inches.

Nest. Usually in open woods; the eggs generally laid upon a rock or on the turf, - sometimes they are laid on a gravel roof in a city.

$E_{\text {Sgs. }} 2$; dull white or buff, thickly mottled with brown, slate, and lilac: $1.25 \times 0.85$.

Towards the close of April the Nighthawks arrive in the Middle States, and early in May they are first seen near the sea-coast of Massachusetts, which at all times appears to be a favorite resort. In the interior of the continent they penetrate as far as the sources of the Mississippi, the Rocky Mountains, and the Territory of Oregon; they are likewise observed around the dreary coasts of Hudson Bay and the remotest Arctic islands, breeding in the whole intermediate region to the more temperate and elevated parts of Georgia. They are now commonly seen towards evening, in pairs, saling round in sweeping circles high in the air, occasionally descending lower 
to capture flying insects, chiefly of the larger kind, such as wasps, beetles, and moths. About the middle of May, or later, the female selects some open spot in the woods, the corner of a corn-field or dry gravelly knoll, on which to deposit her eggs, which are only two, and committed to the bare ground, where, however, from the similarity of their tint with the soil, they are, in fact, more secure from observation than if placed in a nest. Here the male and his mate reside during the period of incubation, roosting at a distance from each other on the ground or in the neighboring trees; and in consequence of the particular formation of their feet, like the rest of the genus, they roost or sit lengthwise on the branch. During the progress of incubation the female is seen frequently, for some hours before nightfall, playing about in the air over the favorite spot, mounting in wide circles, occasionally propelled by alternate quick and slow vibrations of the wings, until at times he nearly ascends beyond the reach of sight, and is only known by his sharp and sudden squeak, which greatly resembles the flying shriek of the towering Swift. At other times he is seen suddenly to precipitate himself downwards for 60 or 80 feet, and wheeling up again as rapidly; at which instant a hollow whirr, like the rapid turning of a spinning-wheel or a strong blowing into the bung-hole of an empty hogshead, is heard, and supposed to be produced by the action of the air on the wings or in the open mouth of the bird. He then again mounts as before, playing about in his ascent and giving out his harsh squeak till in a few moments the hovering is renewed as before; and at this occupation the male solely continues till the close of twilight. The European Goatsucker is heard to utter the hollow whirr when perched and while holding it head downwards, so that it does not appear to be produced by the rushing of the air. The female, if disturbed while sitting on her charge, will suffer the spectator to advance within a foot or two of her before she leaves the nest; she then tumbles about and flutters with an appearance of lameness to draw off the observer, when at length she mounts into the air and disappears. On other 
occasions the parent, probably the attending male, puffs himself up as it were into a ball of feathers; at the same time striking his wings on the ground and opening his capacious mouth to its full extent, he stares wildly and utters a blowing hiss like that of the Barn Owl when surprised in his hole. On observing this grotesque manouvre, and this appearance so unlike that of a volatile bird, we are struck with the propriety of the metaphorical French name of Crapaud volans, or Flying Toad, which this bird indeed much resembles while thus shapelessly tumbling before the astonished spectator. The same feint is also made when he is wounded, on being approached. Like some of the other species, instinctively vigilant for the safety of their misshapen and tender brood, these birds also probably convey them or the eggs from the scrutiny of the meddling observer. In our climate they have no more than a single brood.

Sometimes the Nighthawk, before his departure, is seen to visit the towns and cities, sailing in circles and uttering his squeak as he flies high and securely over the busy streets, occasionally sweeping down, as usual, with his whirring notes; and at times he may be observed, even on the tops of chimneys, uttering his harsh call. In gloomy weather these birds are abroad nearly the whole day, but are most commonly in motion an hour or two before dusk. Sometimes indeed they. are seen out in the brightest and hottest weather, and occasionally, while basking in the sun, find means to give chase to the Cicindeli, Carabi, and other entirely diurnal insects, as well as grasshoppers, with which they often gorge themselves in a surprising manner; but they probably seldom feed more than an hour or two in the course of the day. On Wappatoo Island, at the estuary of the Wahlamet, they were till the roth of September numerous and familiar, alighting often close to the dwellings, in quest probably of crawling insects which come out in the dark.

About the middle of August they begin their migrations towards the south, on which occasion they may be seen in the evening moving in scattered flocks consisting of several hun- 
dreds together, and darting after insects or feeding leisurely as they advance towards more congenial climes. For two or three weeks these processions along the rivers and their banks, tending towards their destination, are still continued. Mingled with the wandering host are sometimes also seen the different species of Swallow, - a family to which they are so much allied in habits and character; but by the 2 oth of September the whole busy troop have disappeared for the season.

I have observed Nighthawks flying over the city of St. John, in New Brunswick, during most of the summer months, and have known of the eggs being found frequently on gravel roofs in that city.

Note. - The Florida Nighthawk (C. virginianus chapmani), a smaller race, has been discovered breeding at Tarpon Springs, Florida. 
STONY BROOK NATURE CENTER AND WILD LIFE SANCTUARY
NORTH STRECT NORFOLK, MASSACHUSETTS 02056 


$$
\bullet
$$




